\title{
MATERIALS FOR THE STUDY OF LATE ANTIQUE AND MEDIEVAL GREEK AND LATIN INSCRIPTIONS IN ISTANBUL
}

\author{
A REVISED AND EXPANDED BOOKLET
}

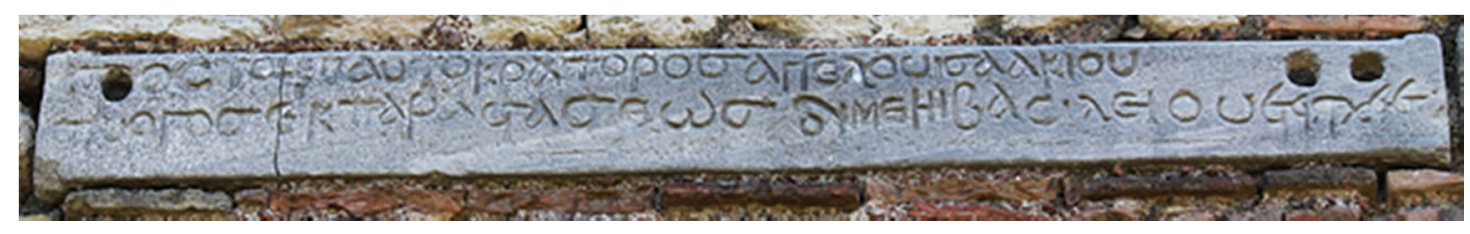

The Summer Programme in ByZANTine EPIgraphy

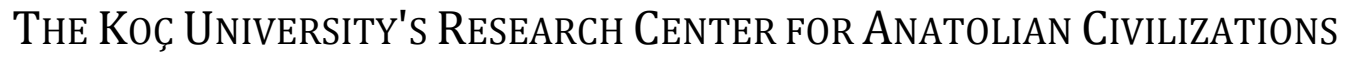
ISTANBUL, 3-9 SEPTEMBER 2018

PREPARED BY IDA TOTH AND ANDREAS RHOBY 
THE SUMMER PROGRAMME IN BYZANTINE EPIGRAPHY WAS FUNDED BY KOÇ UNIVERSITY'S STAVROS NIARCHOS FOUNDATION CENTER FOR LATE ANTIQUE AND BYZANTINE STUDIES (GABAM). IT WAS HOSTED BY KOÇ UNIVERSITY'S RESEARCH CENTER FOR ANATOLIAN CIVILIZATIONS (ANAMED)

\author{
ORGANISED IN PARTNERSHIP WITH: \\ THE INTER-FACULTY OF LATE ANTIQUE AND BYZANTINE STUDIES \\ THE OXFORD CENTRE FOR BYZANTINE RESEARCH \\ (OXFORD UNIVERSITY) \\ THE INSTITUTE FOR MEDIEVAL RESEARCH, THE DIVISION OF BYZANTINE \\ RESEARCH (THE AUSTRIAN ACADEMY OF SCIENCES)
}

FOR THE FULL SCHEDULE OF THE PROGRAMME, CLICK ON

Byzantine Epigraphy Programme

\begin{abstract}
With our special thanks to
Engin Akyürek and Chris Roosevelt for their encouragement and generous support; Mustafa Sayar and Ivana Jevtić, our fellow-concepteurs, for their judicious guidance and good humour; Buket Coşkuner and her team at ANAMED, for providing a welcoming home to us all during our stay in Istanbul; David Hendrix, Ingela Nilsson, Meriç Öztürk, Brigitte Pitarakis, Alessandra Ricci, and Roman Shliakhtin, for their insights, hospitality, and, when necessary, presbeia, which secured access to some rare and unpublished inscriptional material; all our participants - our colleagues and friends - for the memorable week of inspiring seminar presentations, lively discussions, and vigorous walking-and-talking site visits. We look forward to our next epigraphic venture!
\end{abstract}


How to cite:

N.N. (2020), Title of contribution, in: Materials for the Study of Late Antique and Medieval Greek and Latin Inscriptions in Istanbul. A Revised and Expanded Booklet. Prepared by I. Toth and A. Rhoby, Oxford and Vienna, ppp-ppp: https://doi.org/10.1553/Inscriptions_in_Istanbul

Cover image: Inscription on Tower 13, Blachernai walls ((C) Andreas Rhoby) 



\section{Table of Contents}

1 Ida Toth and Andreas Rhoby, Preface 9

Map of Late Antique and Byzantine Constantinople 11

\section{Epigraphic Landmarks}

2 Ine Jacobs, The Theodosian Obelisk in Constantinople 15

3 Anna M. Sitz, The Masonry Obelisk in Constantinople 19

4 Canan Arıkan and Andreas Rhoby, The Church of Saints Sergios and Bakchos 23

5 Antonio Felle, Hagia Eirene in Constantinople 29

6 Paul Magdalino, Monumental Inscriptions and Their Stories 39

7 Ida Toth, The Column of Constantine 43

\section{Inscriptions Displayed: The Istanbul Archaeological Museum}

8 Paweł Nowakowski, Epigraphy and the Cult of Saints in Constantinople: The Case of Anicia Juliana $\mathbf{5 1}$

9 Maria Xenaki, The Epigraphy of Commemoration: Late Antique Epitaphs from Constantinople $\mathbf{6 5}$

10 Mirela Ivanova, Bardas - Ninth-Century Building Inscription on

Constantinopolitan Sea Walls 73

11 Matthew Kinloch, An Inscription of John VIII Palaiologos and the Late Palaiologan Repairs 7

12 Ida Toth, A Fifteenth-Century Building Inscription of George Branković 79

13 Maria Tomadaki, Epigrams on Charioteers: Themes and Function 83

\section{Latin Inscriptions in Constantinople}

14 Andreas Rhoby, Latin Inscriptions in Late Antique Constantinople 91

15 Estelle Ingrand-Varenne, Medieval Latin Inscriptions in Constantinople 97 
16 Desi Marangon, Latin Inscriptions in the Arap Camii 107

\section{The Epigraphy of Small Finds}

17 Nikos Tsivikis, Epigraphical finds from Amorion: A View from the Excavations $\mathbf{1 1 3}$

18 Nikos Tsivikis, The Epigraphy of Small Finds from the Theodosian Harbor/ Yenikapi 121

19 Deniz Sever Georgousakis, Byzantine Amulets in the Eastern Mediterranean and Constantinople 127

\section{The Epigraphy of the Sea and Land Walls}

Map of the Walls of Constantinople 135

20 Roman Shliakhtin, The Land Walls of Constantinople: An Introduction 137

21 Nicholas Melvani, The Epigraphy of the Land Walls of Constantinople 143

22 Roman Shliakhtin, The Walls Project 151

23 Efthymios Rizos, The Epigraphy of The Sea Walls (Including the Marmara Sea and the Golden Horn) 153

\section{Inscriptions in the Lips, St Euphemia, and the Chora}

24 Andreas, Rhoby, The Dedicatory Inscription of the Lips Monastery 167

25 Ivana Jevtić, The Church of Saint Euphemia 171

26 Nectarios Zarras, Remarks on Donor and other Narrative Inscriptions of the Chora Monastery 175

27 Brad Hostetler, The Funerary Inscriptions at the Chora Monastery: Display, Function, and Meaning 179

26-27 Consolidated Bibliography and Figures of the contributions by N. Zarras and B. Hostetler 183

28 Filiz Yașar, Some Remarks on Post-Byzantine/Ottoman History of the Chora Monastery 195 


\section{The Epigraphy of St Sophia}

29 Georgios Pallis, Architecture and Epigraphy in St Sophia 199

30 Maria Lidova, Hagia Sophia: Word and Image in Byzantine Church Decoration 203

31 Alex Rodriguez Suarez, The Conciliar Edict of 1166 in Hagia Sophia 211

32 Ida Toth, Maria Xenaki, and Andreas Rhoby, Graffiti in St Sophia 217

\section{The Longue Durée: The Pammakaristos and The Ecumenical Patriarchate}

33 Meriç T. Öztürk, The Architecture of the Church of the Theotokos Pammakaristos in Constantinople 225

34 Ivan Drpić, The South Parekklēsion of the Church of the Theotokos Pammakaristos (Fethiye Camii): Inscriptions 231

35 Ariel Fein, The Post-Byzantine and Ottoman Afterlives of the Pammakaristos (Fethiye Camii) Parekklesion: Epigraphy 239

36 Pınar Serdar Dinçer, The Ecumenical Patriarchate and Its Inscriptions 245

\section{Field Archaeology and Epigraphy}

37 Alessandra Ricci, A Middle Byzantine Patriarchal Monastery and Its Long Durée: The Contribution of Inscribed Finds from The Küçükyalı, Istanbul 255

\section{Photo Archive: Site Visits 263}





\section{Preface \\ IDA TOTH and ANDREAS RHOBY}

The inscriptional heritage of Istanbul spans multiple periods, habits, and traditions. Countless examples survive, both in situ and in various museum collections, and these provide a rich source for the study of the city's world of writing in any phase of its history, not least the medieval. Moreover, although great portion of this epigraphic trove remains hidden underneath the modern urban layer, recent findings - such as those emerging during the Yenikapı excavations -confirm that Istanbul still holds considerable promise of new and surprising discoveries.

The centrality of Constantinople to both the existence of the Byzantine Empire and the development of Byzantine Studies needs no explanation; neither does the fact that Byzantine Epigraphy, a discipline concerned with the inscriptions of the Byzantine world, looks to Constantinopolitan evidence for essential insights into the realities of public writing. And yet Byzantinists have been slow to engage with the diversity and wealth of Constantinople's epigraphic remains. The extant scholarship, where it has been forthcoming, has been predominantly interested in exploiting these epigraphs as historical sources, thus leaving a somewhat distorted view of the range and character of inscriptions in the Byzantine capital.

In convening a week-long Summer Programme in Byzantine Epigraphy, our agendas were rather different. We set out with the idea of examining both Istanbul's well known and some of its newly discovered epigraphic evidence, including inscriptions displayed in formal (and predominantly monumental) settings, and those that have often been described as casual, unofficial, and at any rate, insignificant. Such a holistic focus also benefited from a wide range of creative approaches - to context, display, taxonomy, ideology, materiality, transformation and performance - all of which have lately become part of the scholarly discourse in the field of Byzantine Epigraphy.

The present booklet was commissioned in preparation for the Summer Programme to provide work materials for the busy schedule of daily seminars, practical sessions in Istanbul's museums, and guided visits to Byzantine monuments and excavation sites. Our intention was to explore inscriptions from different viewpoints, and to open communication lines between experts in different fields. Responding to our brief to review extant epigraphic scholarship, all participants contributed chapters approaching their chosen topics from the direction of their own interests and expertise. As the week unfolded, and our group confronted an ever-greater quantity of diverse epigraphic material, new insights inevitably started to challenge many of our initial - as well as some of the traditional and long-established - assumptions. Our daily sessions also made it clear that any initiative aiming to propel the study of Constantinopolitan epigraphy forward must commit to being interdisciplinary, involving collaborations between textual and literary scholars, and between historians and specialists in visual and material cultures. Most pressingly, such an initiative requires a vigorous (re-)assessment of epigraphic evidence in situ.

The present volume, which we have renamed Materials for the Study of Late Antique and Medieval Greek and Latin Inscriptions in Istanbul, represents a revised and updated version of the original booklet. It has been prepared in the year following the Programme, and incorporates updated notes and observations, a large number of additional images, and new chapters on the Column of Constantine, amulets, late antique Latin epigraphy, the Lips Monastery and small finds from the Yenikapı excavations. We have also made 
several (conscious) omissions: although we were fortunate enough to get access to some new finds from the Theodosian Harbour and to the restorations of St Euphemia, the unpublished materials from these sites - as has been requested - have not been included in the booklet.

In every other sense, our approach has been comprehensive. We have tried to create a resource whose relevance extends beyond the scope of the Summer Programme in Byzantine Epigraphy. Our hope is that this collection of essays can serve as a teaching tool and perhaps also as a dependable vademecum to the extant traces of Istanbul's rich late antique and medieval epigraphic legacy.

Oxford and Vienna, April 2020 


\section{Map of Constantinople}

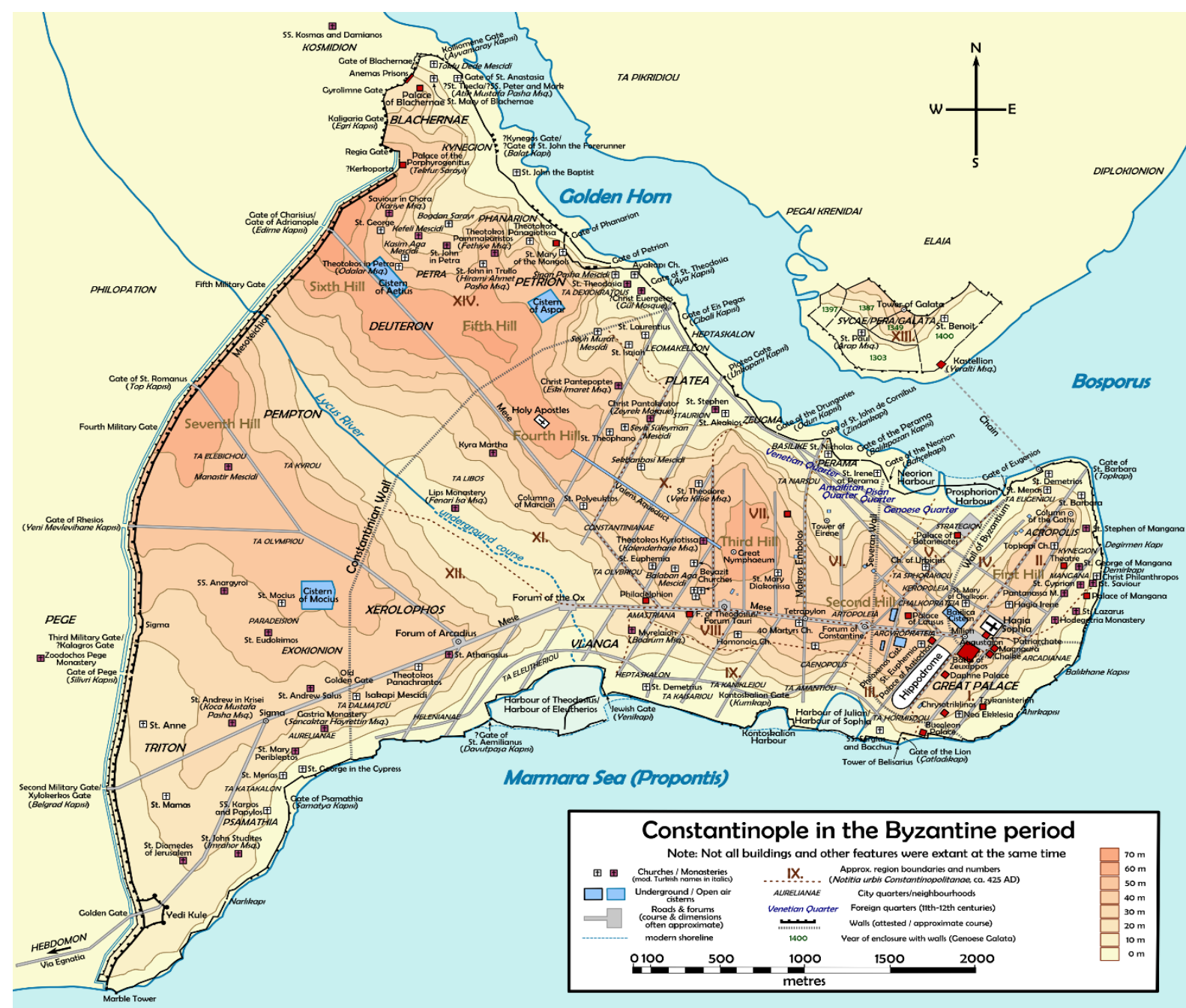

(C) https://de.wikipedia.org/wiki/Datei:Byzantine Constantinople-en.png 



\section{EPIGRAPHIC LANDMARKS}





\section{The Theodosian Obelisk in Constantinople}

INE JACOBS

\section{Hippodrome}

- Located to the west of the palace area

- Inheritance from the Severan era of the city's history, finished under Constantine

- Capacity of $100.000 \rightarrow$ vital "stage"

- Accumulation of statuary displays

- Two obelisks (one authentic, one imitation) like the Circus Maximus

- The (eventual) presence of two obelisks may not have been as symbolic as is has often been suggested in publications: considering that we do not know the building date of the masonry obelisk, which may well be much earlier and already dedicated under Constantine, it becomes more difficult to maintain that the reference to Rome, the only other location in the world that had two obelisks, was intentional. (See, Anna Sitz, Chapter 3)

The Theodosian Obelisk

- Erected in the Hippodrome in 390 under Theodosius I (378-392), $c f$. the erasure of the name of Proclus

- Motivation = the celebration of the victory over "the tyrants"

- = Obelisk of Thutmose III (1490-1436 BC); one of a pair from the Temple of in Thebes, removed from the temple under Constantine; raised in the Hippodrome by Theodosius I $\rightarrow$ intermittent period unclear

- Newly created base underneath with reliefs (originally coloured) and two inscriptions (one Latin, one Greek), carved in situ surrounding audiences should be taken into account

o SE: Emperor in the kathisma awarding a wreath + the Latin inscription (fig. 1):

DIFFICILIS QVONDAM, DOMINIS PARERE SERENIS

IVSSVS ET EXTINCTIS PALMAM PORTARE TYRANNIS.

OMNIA THEODOSIO CEDVNT SVBOLIQVE PERENNI.

TER DENIS SIC VICTVS EGO DOMITVSQVE DIEBVS.

IUDICE SVB PROCLO SUPERAS ELATVS AD AVRAS

'Once it was difficult to conquer me, but I was ordered to obey mild masters and to carry the subdued tyrants' palm. Everything cedes to Theodosius and his eternal descendants. Thus conquered I was tamed in thrice ten days. When Proclus was judge, I was erected to the skies.'

o NW: The emperor and imperial family, surrounded by officials and courtiers, subordinated barbarians in the zone below + the Greek inscription (fig. 2):

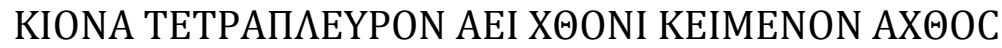

MOYNOC ANACTHCAI $\Theta E Y \triangle O C I O C$ BACIAEYC

ТО $\Lambda$ МНСАС ПРОК $О С$ ЕПЕКЕКАЕТО КАI ТОСОС ЕСТН

KI $\Omega$ N HEAIOIC EN TPIAKONTA $\triangle \mathrm{YO}$ 
'It was only the Emperor Theodosius who succeeded in raising the foursided column which had ever lain as a burden to the earth. He committed the task to Proclus, and so great a column stood erect in thirty-two days.'

- SW: The emperor depicted with his family in the kathisma + the races

- NE: The emperor in the kathisma surrounded by officials + the representation of the erection of the obelisk

The iconography takes the viewers into account on all four sides of the obelisk:

- SE: Side facing the emperor: clearest depiction of the imperial family with the most central depiction of the emperor himself

- NW: Side of the militia: addition of guards to the sides of the imperial box; depiction of the conquered enemies

- SW and NE: The architecture of the surrounding building is mirrored in the reliefs

\section{Inscriptions, further observations}

- The inscription in Latin, the traditional language of imperial power, faced the imperial box, whereas the Greek text would have been visible from the grandstands of the circus factions

- Slightly different content (e.g., discrepancy in the number of days); Latin text is generalized, Greek text is specific $\sim$ intended audiences

- Lack of inscriptions on SW and NE explained by the illiteracy of the spectators/their multilinguism/distance between spectators and base?

- 'Proclus' has been erased and restored (See, Andreas Rhoby, Chapter 14)

The Theodosian inscriptions, as important as they may be, are the least visible element of the monument. The original obelisk and hieroglyphs remain by far the most visible, followed by the reliefs and only in a final place by the inscriptions. They are, moreover, placed at the very bottom of the monument.

Assessment on site suggested that the texts would not have been readable from most of the seating area, even when still painted.

The readability and overall visibility of both text and reliefs would have changed dramatically during the day. With oblique sun light, the visibility is much better than when the reliefs/inscriptions are entirely in the sun or shade.

It is unclear whether or not the hieroglyphs would still have been understandable to anyone in the Theodosian period. There is very little evidence that they were. The last active usage can be dated to 394 in Egypt. It is far more likely that they were understood as powerful signs, and that they were also used as such. 


\section{Selected Bibliography}

\section{Hippodrome}

Bassett, S. G. (1991) The Antiquities in the Hippodrome of Constantinople, Dumbarton Oaks Papers 45, 87-96.

Bardill, J. (2010) The Architecture and the Archaeology of the Hippodrome in Costantinople, in Hippodrom/Atmeydani-A Stage for İstanbul's History I, 91-148.

Dagron, G. (2011) L'hippodrome de Constantinople: jeux, peuple et politique, Paris.

Pitarakis, B. (ed.) (2010) Hippodrome/Atmeydani: Istanbul'un Tarih Sahnesi: A stage for Istanbul's history, Istanbul.

Vespignani, G. (2010) Ippodromos: il circo di Costantinopoli nuova Roma dalla realtà alla storiografia, Spoleto.

Theodosian Obelisk

Safran L. (1993) Points of View: The Theodosian Obelisk Base in Context, Greek, Roman and Byzantine Studies 34, 409-435.

Kiilerich, B. (1998) The obelisk base in Constantinople: court art and imperial ideology, Rome.

Kazan, G. (2017) What's in a Name? Constantinople's Lost 'Golden Gate' Reconsidered, in T. Papacostas and M. Parani (eds) DISCIPULI DONA FERENTES. Glimpses of Byzantium in honour of Marlia Mundell Mango (Studies in Byzantine History and Civilization, 11), Turnhout, 291-320.

\section{Inscriptions}

Corpus Inscriptionum Latinarum III/1, no. 737 (the Greek version at Corpus Inscriptionum Graecarum IV, no. 8612, also preserved in the Anthologia Palatina: 9, 682).

Cugusi, P. (2010) Carmina Latina epigraphica Constantinopolitana, Rivista di Filologia e di Istruzione Classica, 138, 445-461: 452-453 (no. 2).

Mango, C. (1993) The Byzantine Inscriptions of Constantinople: A Bibliographical Survey, American Journal of Archaeology 55 (1951) 52-66: 62. 


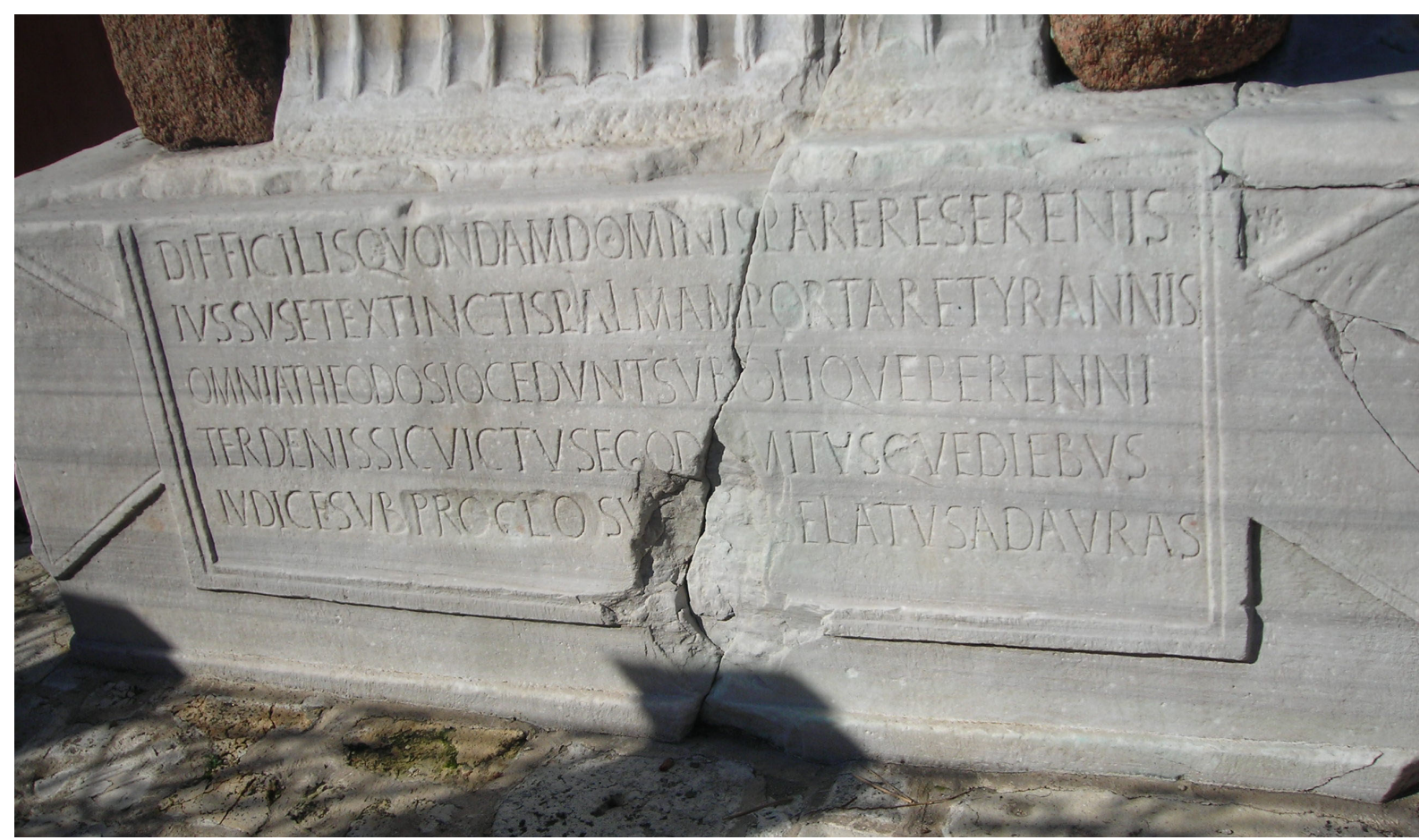

Fig. 1 Latin inscription on the base of the Theodosian Obelisk (C) Ine Jacobs)

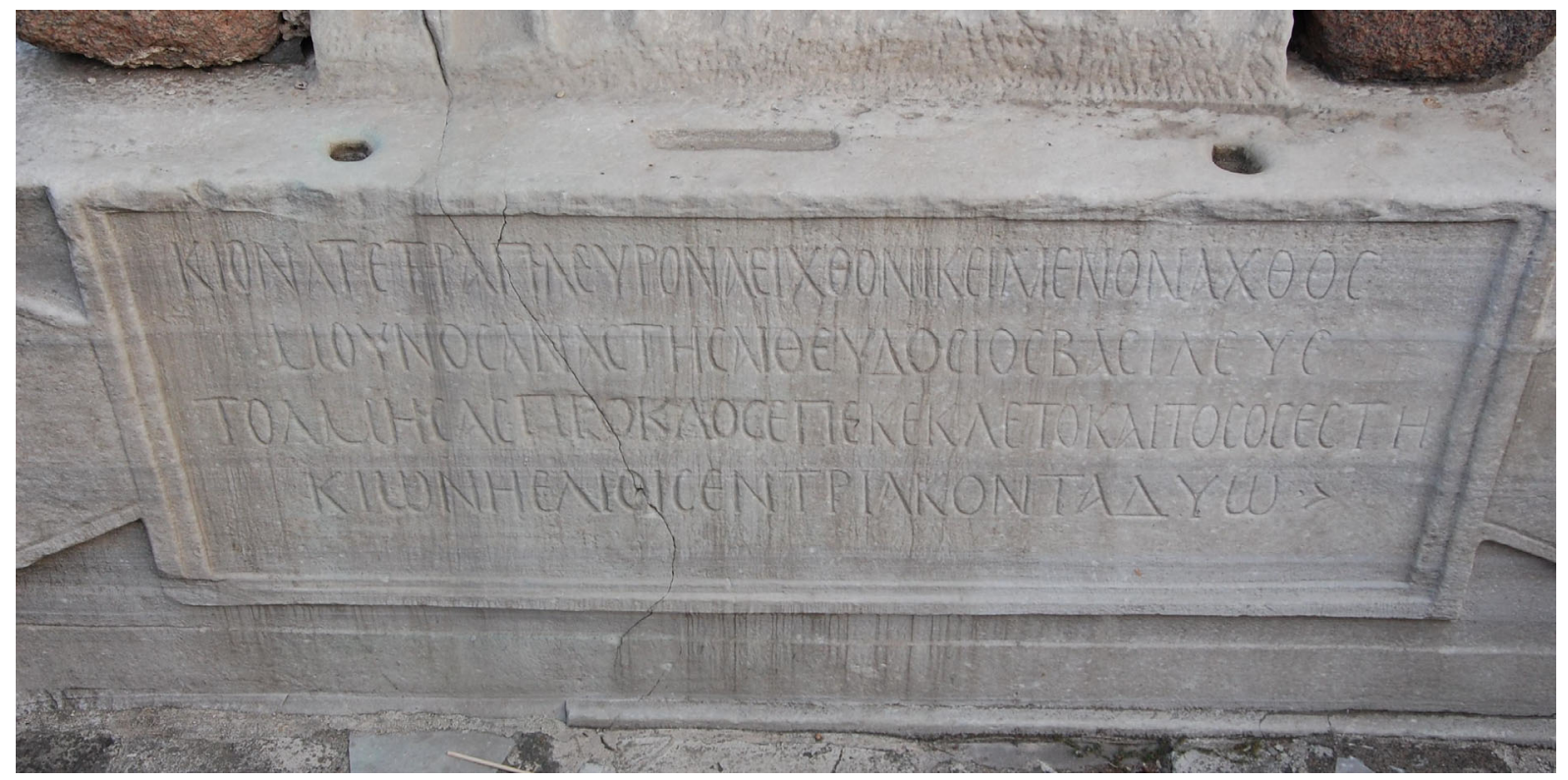

Fig. 2 Greek inscription on the base of the Theodosian Obelisk (C) Ine Jacobs) 


\title{
3. The Masonry Obelisk in Constantinople
}

\author{
ANNA M. SiTZ
}

Tò $\tau \varepsilon \tau \rho[\alpha ́ \pi \lambda \varepsilon v \rho o v] \theta \alpha \tilde{u} \mu \alpha \tau \tilde{\omega} v \mu \varepsilon \tau \alpha \rho \sigma i ́ \omega v$

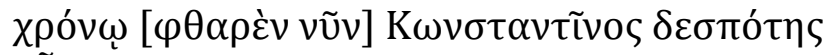

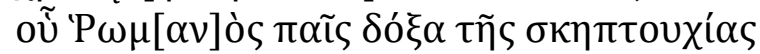

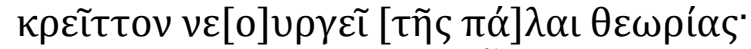

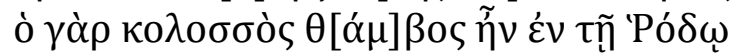

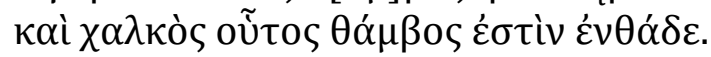

(Rhoby 2014, no. TR53)

The four-sided marvel on high,

wasted by time, now the lord Constantine,

whose child Romanos is the glory of the crown,

has renewed better than the spectacle of old.

For the Colossus was an awe-inspiring sight on Rhodes,

but this bronze is here and now an awe-inspiring sight.

(Translated by A. Sitz)

This six-line dodecasyllable epigram is inscribed on the east face of the base of the Masonry Obelisk (Built Obelisk) in the Hippodrome in Constantinople (fig. 1). It is still in situ, although damaged; it is also recorded in several surviving manuscripts. The most recent edition of the text can be found in A. Rhoby, Epigramme auf Stein, no. TR 53, with previous bibliography.

The Masonry Obelisk was likely constructed in the fourth century CE, perhaps as an Ersatz-monument for a monolithic Egyptian Obelisk that had been delayed in transport (possibly the one later erected as the Theodosian Obelisk in the Hippodrome) (See, Ine Jacobs, Chapter 2). The Masonry Obelisk is said to be 32 meters high, the same height as the Lateran Obelisk in Rome, which was erected under Constantius II in the Circus Maximus in 357.

Whatever the date of the original construction of the Masonry Obelisk in Constantinople, it had apparently fallen into disrepair by the tenth century, when Constantine VII Porphyrogennetos (r. 913-959) had it renovated and covered with bronze platting (now lost). This activity was commemorated in the epigram inscribed on the obelisk's base. It is unclear how, or whether, the bronze platting was attached to the ashlar stones of the obelisk itself, or whether it covered only the obelisk's base, where numerous revetment holes are apparent on every side of the base (fig. 2), except for the east side, which bears the inscription. Written in majuscule letters without accents, with a regular layout, the epigram emphasizes the "wonder" and "spectacle" aspects of the obelisk. The top two lines of the inscription are badly abraded, although it is unclear whether it was intentionally damaged at some late date or it has simply been worn over time.

Constantine VII's son, Romanos, is mentioned in the text, which gives a date for the composition between 945-959, when Romanos was co-emperor with this father. The praise given to Romanos as Constantine's "child" may suggest the need to legitimize this Romanos in contrast with Constantine's deposed father-in-law, Romanos Lekapenos, or alternatively, it may indicate that the epigram was composed late in Constantine VII's reign by someone more closely affiliated with the young heir to the throne, as recently suggested by P. Magdalino. (See, Paul Magdalino, Chapter 6) 
The epigram furthermore draws a parallel between the Colossus of Rhodes, one of the seven wonders of the ancient world and Constantine VII's restored Masonry Obelisk (see, also Chapter 6 by Paul Magdalino and Chapter 7 by Ida Toth). This monumental statue of Helios, built of stone and iron covered with bronze, was constructed from 294-282 BCE and was also said to be $32 \mathrm{~m}$ high. It fell in an earthquake in 225/6 BCE but seems to have been restored in the imperial period. A story circulated in the Byzantine sources, including in Constantine Porphyrogennitos' own De administrando imperio, that the Arab conquerors of Rhodes around $650 \mathrm{CE}$ found the remains of the fallen Colossus and sold them as scrap metal to a Jew from Edessa (or Emesa); approximately 900 camels were needed to transport the metal. Although the story is surely apocryphal, it indicates the continued relevance of the Colossus as a sign of the monumentality of antiquity, of the supposed disregard of the Islamic invaders for the remains of the Greek and Roman past, and of the futility of worldly attempts at lasting greatness in general.

Constantine Porphyrogennitos' epigram on the Masonry Obelisk therefore elevates his own bronze monument to the level of the Seven Wonders of the ancient world, while also highlighting that this Constantinopolitan structure still stands while the Colossus had fallen. Nonetheless, the epigram, one of the few Byzantine examples in a secular setting, does not highlight religious aspects of the emperor or city. Instead, Constantine's link with his son Romanos is emphasized, perhaps in response to the Porphyrogennitos' own illegitimate birth and subsequent falling out with his father-in-law and co-emperor, Romanos I Lekapenos.

The inscription and obelisk stood on the spina of the Hippodrome, surrounded by many ancient statues, inscribed bases, columns and the Obelisk of Theodosios, which bore inscriptions in both Latin and Greek from its dedication in the fourth century. From the Constantinian period onwards, the Hippodrome functioned to display these assorted wonders of ancient culture, including the Serpent Column from Delphi, which commemorated the Greek victory over the Persians in 479/8 BCE. According to the seventh/eighth century Parastaseis, the ancient inscriptions found in the Hippodrome were difficult to decipher; the same source claims that they foretold the future. The Hippodrome functioned as far more than simply an arena for chariot races; it was also the site of important political events and uprisings, as well as a space to contemplate the empire's past and future.

\section{Selected Bibliography}

Bassett Guberti, S. (1991) The Antiquities in the Hippodrome of Constantinople, Dumbarton Oaks Papers 45, 87-96.

Conrad, L.I. (1996) The Arabs and the Colossus, Journal of the Royal Asiatic Society, third series 6.2, 165-187.

Lauxtermann, M.D. (1994) The Byzantine Epigram in the Ninth and Tenth Centuries: A Generic Study of Epigrams and Some Other Forms of Poetry, University of Amsterdam, 30.

- (2003) Byzantine Poetry from Pisides to Geometres: Texts and Contexts, vol. 1, Vienna, 342 (no. 38).

Magdalino, P. (2012) Cultural Change? The Context of Byzantine Poetry from Geometres to Prodromos, in Bernard, F. and Demoen, K. (eds) Poetry and its Contexts in EleventhCentury Byzantium, Farnham, 19-36. 
Mango, C. A. (1951) The Byzantine Inscriptions of Constantinople: A Bibliographic Survey, American Journal of Archaeology 55.1, 62-63.

- (1993) Studies on Constantinople, pt. X: The Columns of Justinian and His Successors, Aldershot, 1-20.

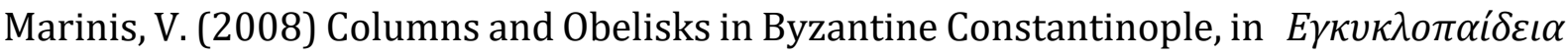

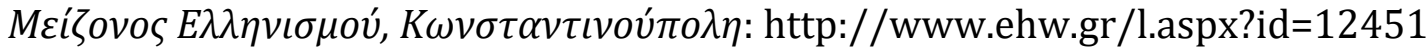

Müller-Wiener, W. (1997) Bildlexikon zur Topographie Istanbuls: Byzantion, Konstantinupolis, Istanbul bis zum Beginn des 17. Jahrhunderts, Tübingen, 65, 71.

Rhoby, A. (2014) Byzantinische Epigramme auf Stein, Vienna, no. TR53.

Safran, L. (1993) Points of View: The Theodosian Obelisk Base in Context," Greek, Roman, and Byzantine Studies 34.4, 409-435.

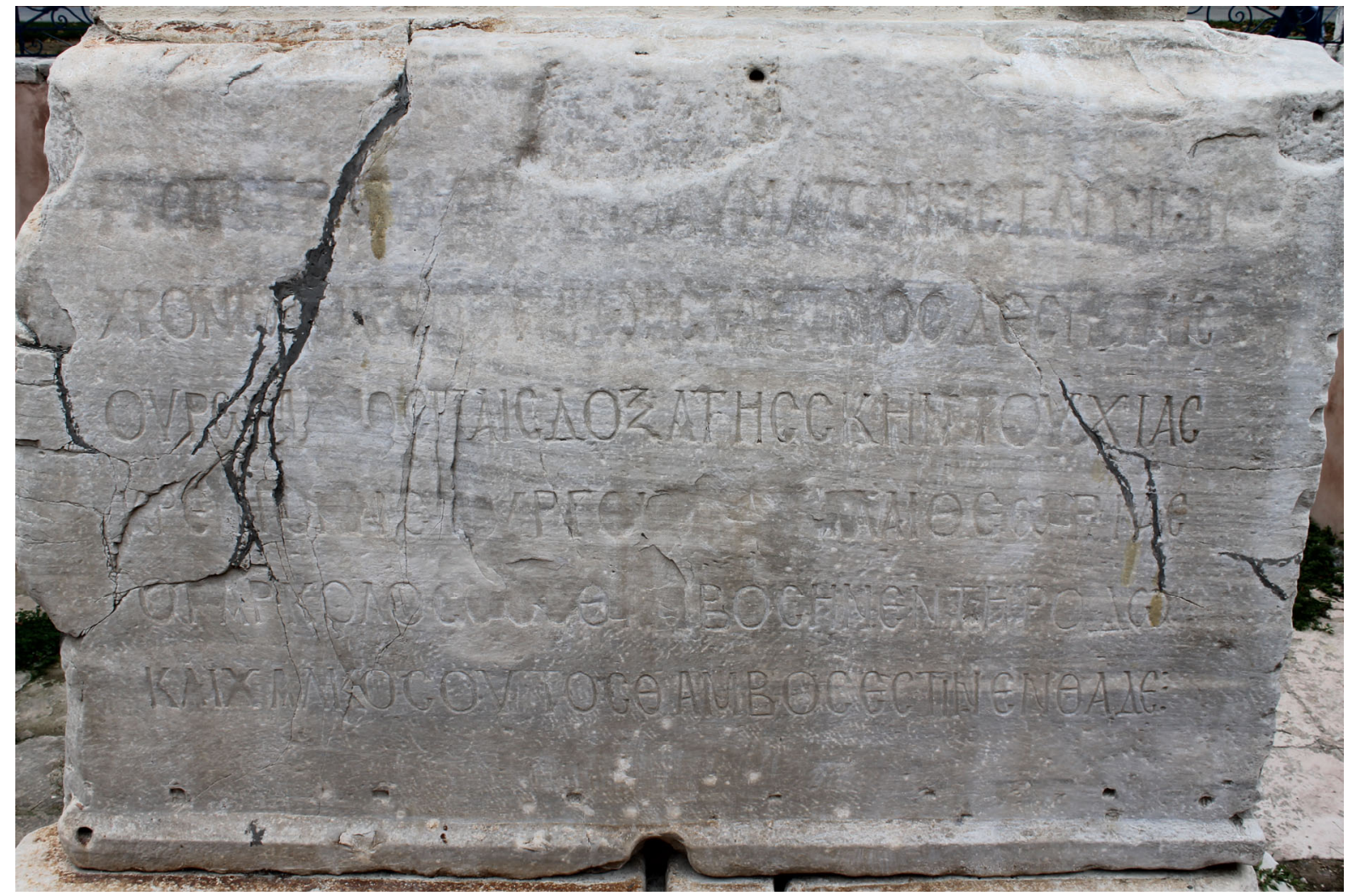

Fig. 1 Inscription on the base of the Masonry Obelisk (C) Andreas Rhoby) 


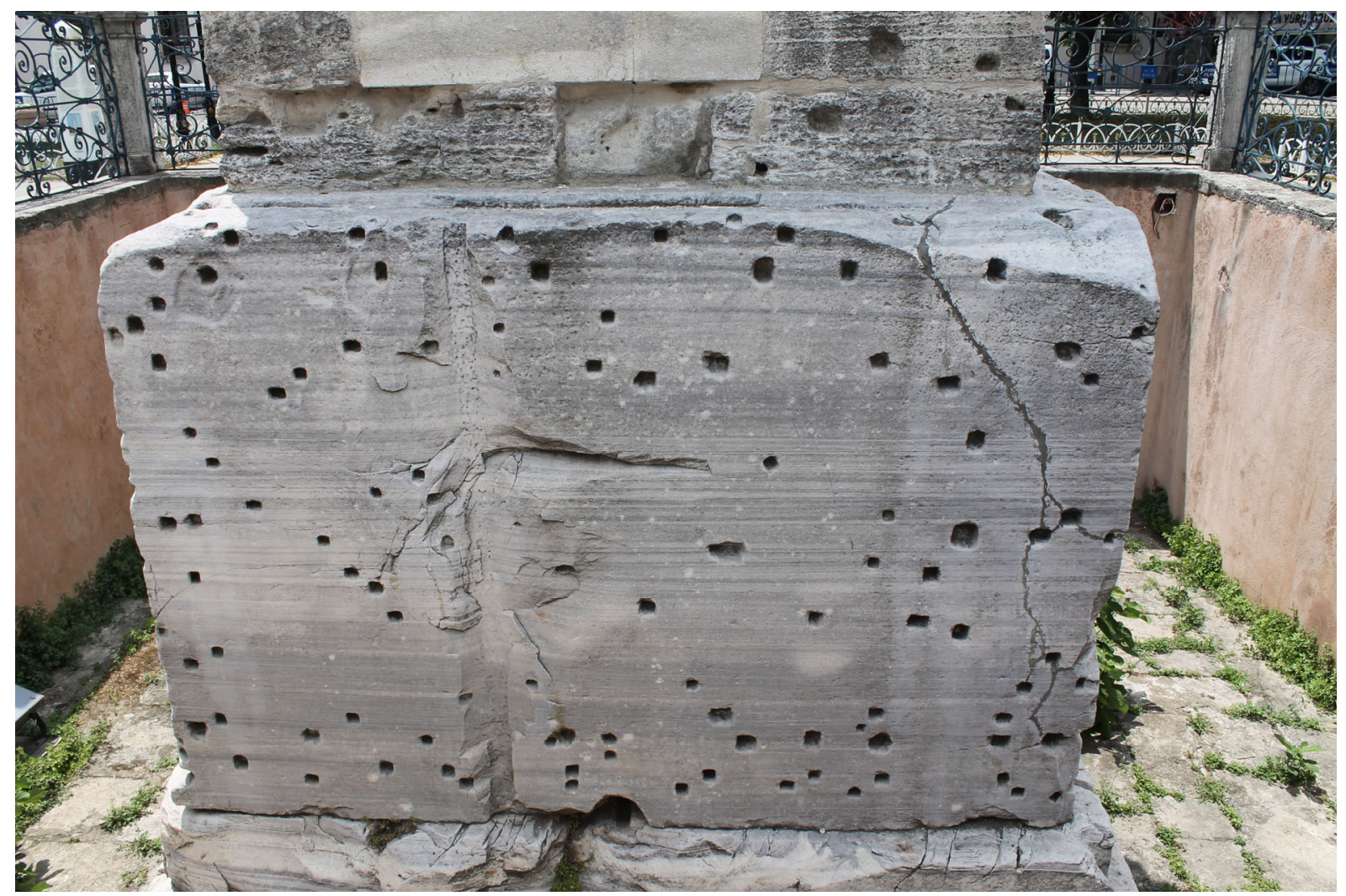

Fig. 2 Base of the Masonry Obelisk (C) Andreas Rhoby) 


\section{The Church of Saints Sergios and Bakchos \\ CANAN ARIKAN and ANDREAS RHOBY}

The church of SS. Sergios and Bakchos, today known as Küçükayasofya Camii, was built by Justinian, whose patronage is clearly stated in a dedicatory inscription on the upper part of the frieze around the nave (figs. 1-2). The relief inscription is an epigram consisting of twelve hexameters. Besides Justinian, the text also mentions Theodora as the protector of the destitute. In addition, carved monograms of the imperial couple are visible on the column capitals. Traditionally, the terminus post quem for the erection of the church was 527 , the year of the coronation of Justinian and Theodora. However, very recently, it has also been argued that the church should be dated between 532 and 536; this means that the church does not predate Hagia Sophia but that it was erected when the Great Church was rebuilt after the Nika revolt of 532. It has been suggested by scholars such as Cyril Mango and Jonathan Bardill that the church was founded for the liturgical needs of the Monophysite refugees, who were accommodated by Theodora in the Palace of Hormisdas.

In terms of paleography, the inscription shares the style and technique of the epigram in the church of St Polyeuktos, and it originally had the same bright blue background. The letters are nicely carved and quite large (ca. $17 \times 17 \mathrm{~cm}$ ); ivy leaves function as separators of the verses (fig. 3). Like in the case of so many other inscriptions, the letters are likely to have been painted so that the inscription was legible from the ground. Today, the first ten letters of the opening verse cannot be seen because they are hidden behind the Ottoman minbar (fig. 4), which was constructed, when the church was converted into a mosque at the beginning of the $16^{\text {th }}$ century.

In terms of historical context, the text of the inscription has been seen as Justinian's response to Anicia Juliana's commission of the Polyeuktos church. However, after Bardill's recent re-dating, this assumption has to be reconsidered. (See, Chapter 8 by Pawel Nowakowski)

Despite the fact that the inscription honors S. Sergios, the text has also to be seen in terms of Justinian's self-promotion and self-presentation as sole ruler and "unrivalled" benefactor of building projects in Constantinople.

The epigram is also transmitted in manuscripts because it was interpolated into the late eleventh-century Synopsis of Byzantine History by John Skylitzes (p. 162 in Thurn's edition) as part of a description of the repairs to the church under Basil I (867-886). The metrical system of the dactylic hexameters is very close to that used in the Polyeuktos inscription, which leaves the possibility of both texts having been composed by the same author. The use of the Nonnian hexameter, and of the Nonnian language and style are typical of the sixth century; they are also conspicuous in the inscription in SS. Sergios and Bakchos, which can be said to clearly reflect the dominant trends of the learned literature of the time.

Dedicatory relief inscription on the frieze

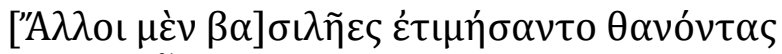

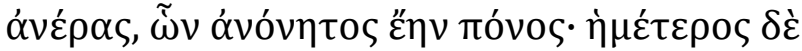

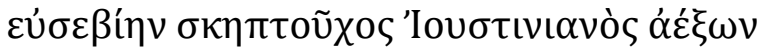

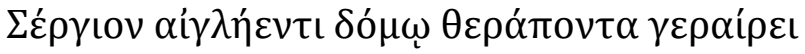

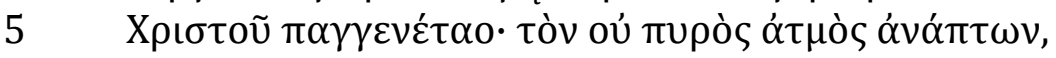

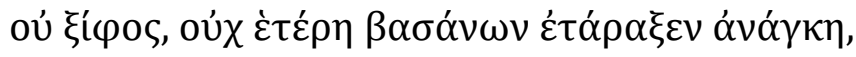




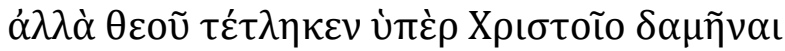

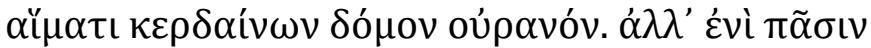

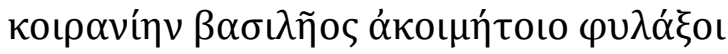

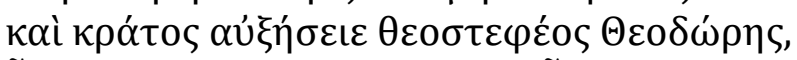

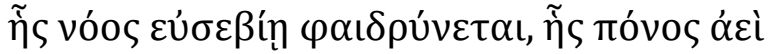

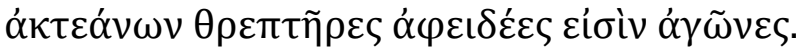

'Other sovereigns have honored dead men whose labor was unprofitable, but our sceptered Justinian, fostering piety, honours with a splendid abode the Servant of Christ, Begetter of all things, Sergius; whom not the burning breath of fire, nor the sword, nor any other constraint of torments disturbed; but who endured to be slain for the sake of Christ, the God, gaining by his blood heaven as his home. May he in all things guard the rule of the sleepless sovereign and increase the power of the God-crowned Theodora whose mind is adorned with piety, whose constant toil lies in unsparing efforts to nourish the destitute.' (Translated by C. Mango)

\section{Selected Bibliography}

$\mathrm{Du}$ Cange, Ch. Du Fresne (1680) Constantinopolis Christiana, seu descriptio urbis Constantinopolitanae, pars 4, Paris, 74.

Hammer-Purgstall, J. (1822) Constantinopolis und der Bosporus: örtlich und geschichtlich beschrieben; mit 120 griechischen, lateinischen, arabischen, persischen und türkischen Inschriften, dem Plane der Stadt Constantinopel und einer Karte des Bosporus, vol. 1, Pesth (reprint Osnabrück. 1967), XII (no. 31).

Salzenberg, W. (1854) Altchristliche Baudenkmale von Constantinopel vom V. bis XII. Jahrhundert, Berlin, 41-45.

Dethier, Ph. A. (1858) Fac-simile der Inschrift in der kleinen Hagia Sophia zu Konstantinopel zum ersten Male nach etwa 600 Jahren in der Kirche selbst kopiert, Sitzungsberichte der k. Akademie der Wissenschaften zu Wien, phil.-hist. Cl. 27, 164-173.

Swainson, H. (1895) Monograms on the Capitals of S. Sergius at Constantinople, Byzantinische Zeitschrift 4.2, 106-108.

Van Millingen, A. (1912), Byzantine Churches in Constantinople, London, 62-84.

Mercati, S. G. (1925) Sulla tradizione manoscritta dell'iscrizione nel fregio dei SS. Sergio e Bacco a Costantinpoli, Rendiconti della Pontificia Accademia Romana di Archeologia 3, 197-205 (= - [1970] Collectanea Byzantina, vol. II, Bari, 311-319).

Mango, C. (1951) Byzantine Inscriptions of Constantinople: A Bibliographical Survey, American Journal of Archaeology 55, 52-66: 59-60.

Mango, C. (1972) The Church of Saint Sergius and Bacchus at Constantinople and the Alleged Tradition of Octagonal Palatine Churches, Jahrbuch der Österreichischen Byzantinistik 21, 189-193.

Krautheimer, R. (1974) Again Saints Sergius and Bacchus at Constantinople, Jahrbuch der Österreichischen Byzantinistik 23, 251-253.

Mango, C. (1975) The Church of Sts. Sergius and Bacchus Once Again, Byzantinische Zeitschrift 68, 385-392.

Restle, M. (1976) Istanbul. Bursa, Edirne, Iznik. Baudenkmäler und Museen, Stuttgart, 184192.

Müller-Wiener, W. (1977) Bildlexikon Zur Topographie Istanbuls: Byzantion, Konstantinupolis, Istanbul bis zum Beginn des 17. Jahrhunderts, Tübingen, 177-183. 
(Turkish edition [ $\left.{ }^{4} 2016\right]$ Isstanbul'un tarihsel topografyası. Byzantion-KonstantinopolisIstanbul)

Connor, C. I. (1999) The Epigram in the Church of Hagios Polyeuktos in Constantinople and its Byzantine Response, Byzantion 69, 479-527.

Bardill, J. (2000) The Church of Sts. Sergius and Bacchus in Constantinople and the Monophysite Refugees, Dumbarton Oaks Papers 54, 1-11.

Feissel, D. (2000) Les édifices de Justinien au témoignage de Procope et de l'épigraphie, Antiquité tardive 8, 81-104: 89.

Shahîd, I. (2003) The Church of Sts Sergios and Bakhos in Constantinople and Some New

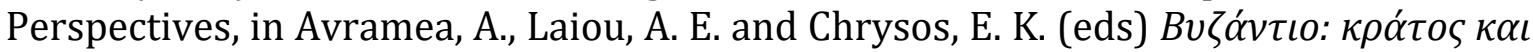

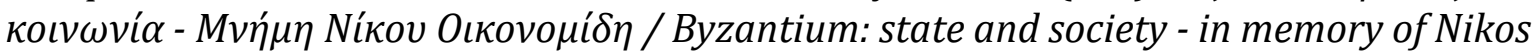
Oikonomides, Athens, 2003, 467-480.

Croke, B. (2006) Justinian, Theodora, and the Church of Saints Sergius and Bacchus, Dumbarton Oaks Papers 60, 25-63.

Whitby, M. (2006) The Polyeuktos Epigram (AP 1.10): A Literary Perspective, in Johnson, Sc. (ed) Greek Literature in Late Antiquity: Dynamism, Didactism, Classicism, Aldershot, 159-187: 183-184.

Eastmond, A. (2016) Monograms and the Art of Unhelpful Writing in Late Antiquity, in Bedos-Rezak, B. M. and Hamburger, J. F. (eds) Sign and Design. Script as Image in CrossCultural Perspective (300-1600 CE), Washington, 219-235: 224-225.

Asutay-Effenberger, N. and Effenberger, A. (2017) Byzanz. Weltreich der Kunst, Munich, 96-98 [German translation of the epigram].

Bardill, J. (2017) The Date, Dedication, and Design of Sts. Sergius and Bacchus in Constantinople, Journal of Late Antiquity 10.1, 62-130.

Agosti, G. (2017) Alcune iscrizioni greche in onore di San Sergio nel V e VI secolo e la diffusione della paideia classica in provincia, in Il Calamo della memoria VII. Raccolta delle relazioni discusse nell'incontro internazionale di Trieste, Biblioteca Statale, 29-30 settembre 2016, Trieste, 229-243: 238-239.

Rhoby, A. and Schreiner, P. (2018) Antiquitates Constantinopolitanae im Osmanischen Reich: Johannes Malaxos und seine Aufzeichnungen im Vat. Reg. gr. 166, Miscellanea Bibliothecae Apostolicae Vaticanae 24, 605-657: 613-617.

See also http://www.thebyzantinelegacy.com/sergius-bacchus 

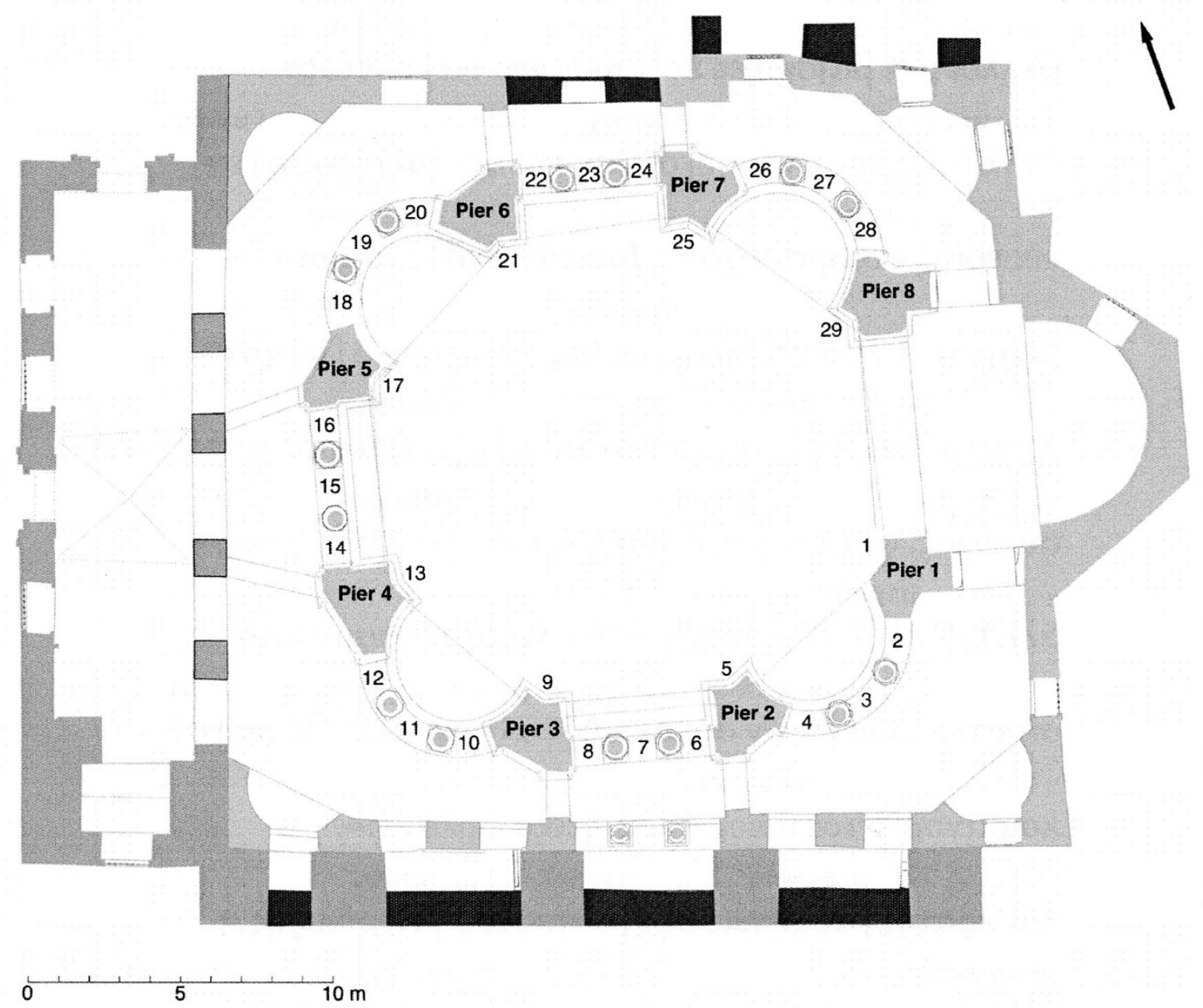

Fig. 6. Plan of Sts. Sergius and Bacchus at ground-floor level showing the positions of the twenty-nine inscribed entablature blocks and eight piers. (C) Jonathan Bardill

Fig. 1 (C) Bardill 2017)

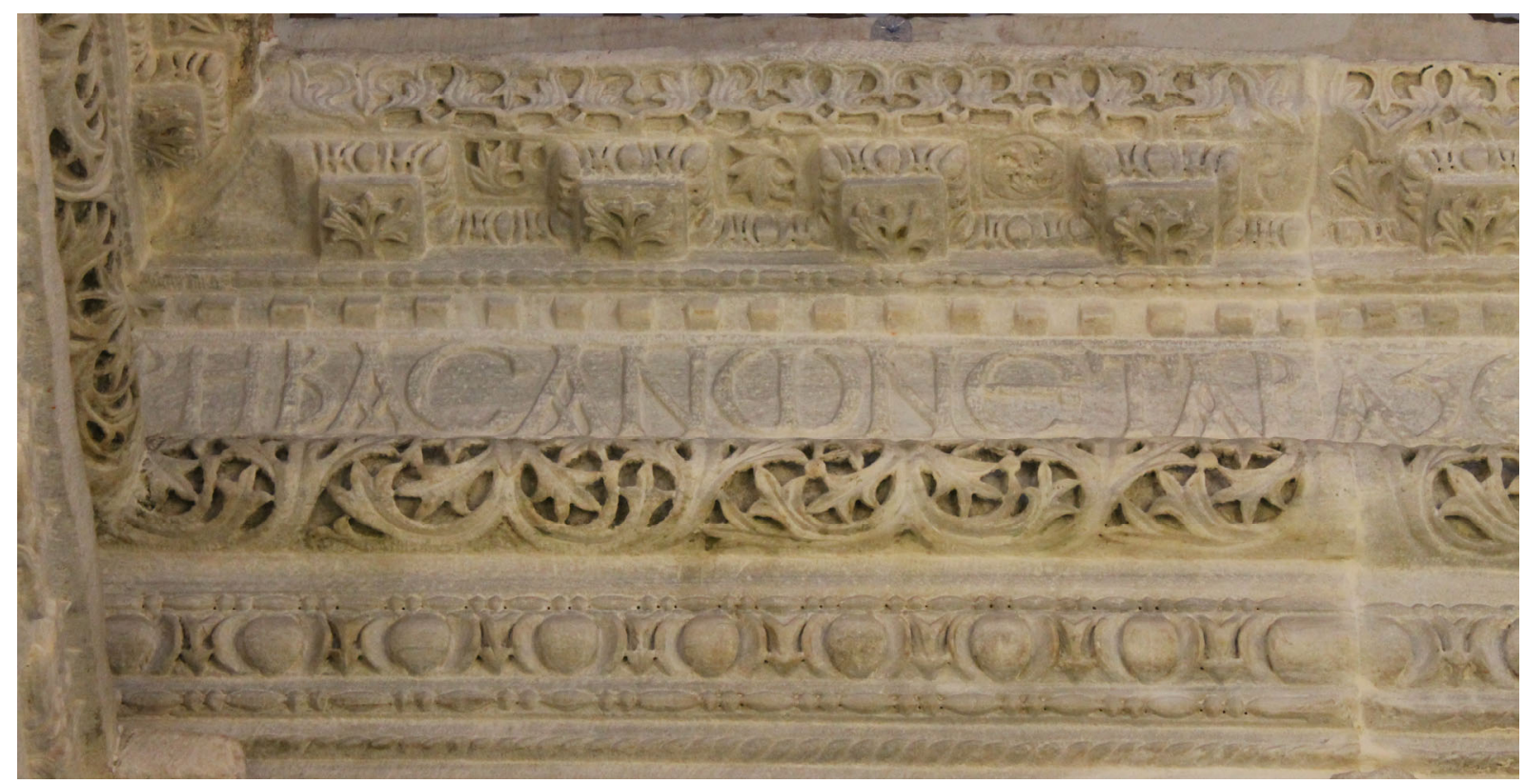

Fig. 2 Inscription on the inner frieze (part of v. 6) (C) Andreas Rhoby) 


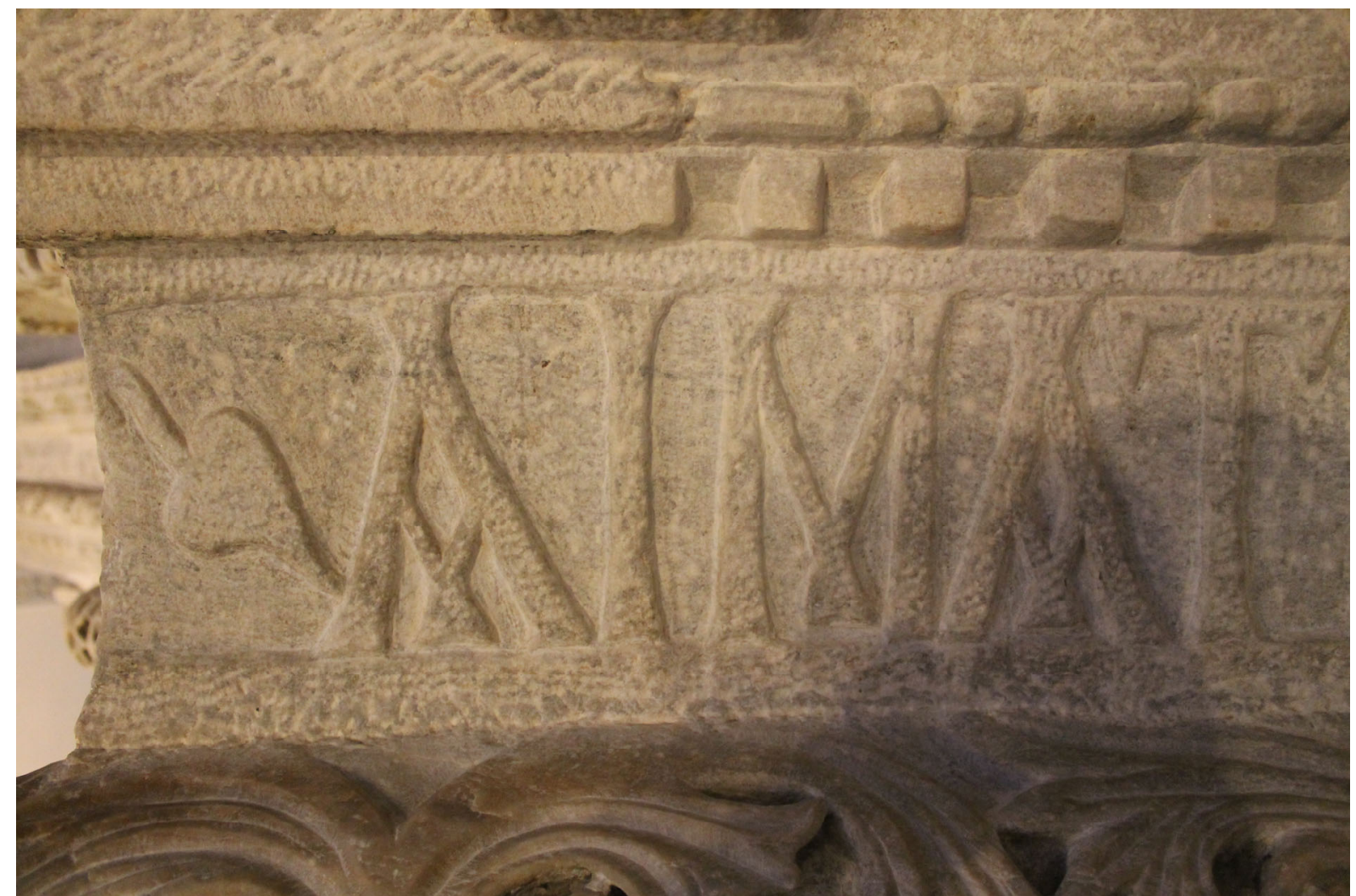

Fig. 3 Inscription on the inner frieze (part of v. 8) (C) Andreas Rhoby)

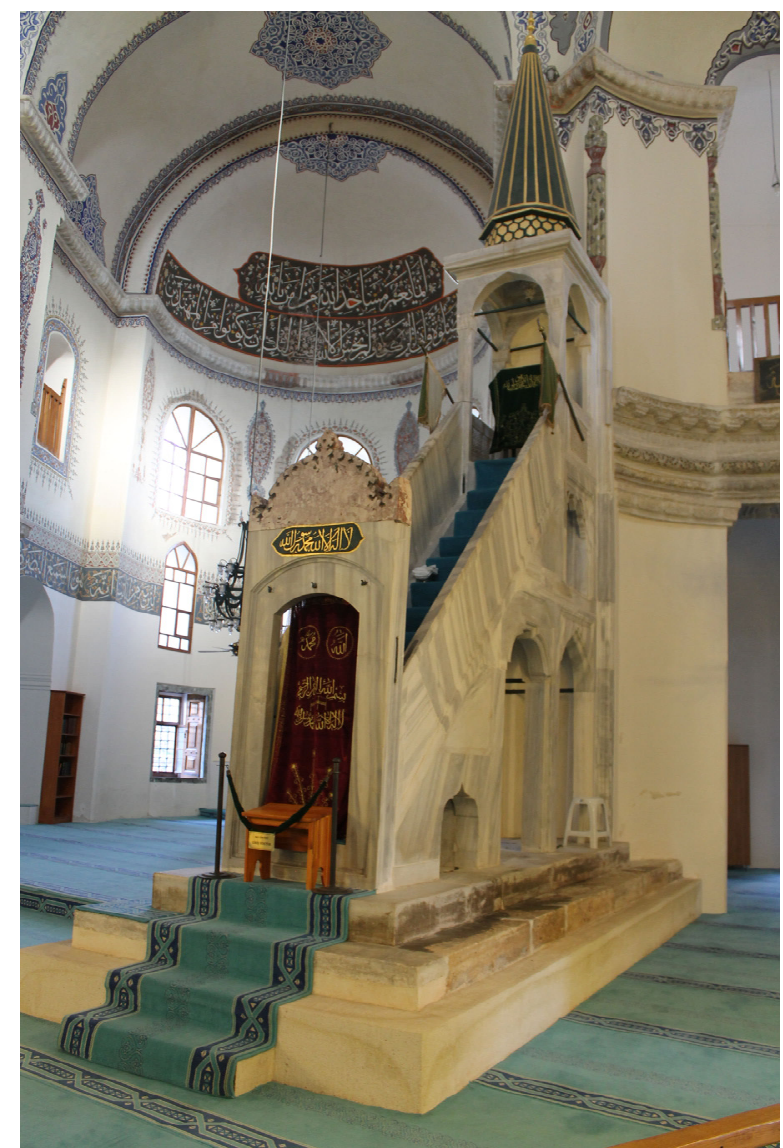

Fig. 4 Sergios and Bakchos church, interior, Ottoman minbar (C) Andreas Rhoby) 



\section{Hagia Eirene in Constantinople ANTONIO FELLE}

\section{Introduction}

The church of St. Eirene is the oldest Christian building in the city: probably a cathedral, it remained the seat of the bishop of Constantinople until 1453. The foundation of the church was traditionally ascribed to Constantine himself. However, two passages in the Historia Ecclesiastica by Socrates Scholasticus (see, the Appendix for the chronological list of primary sources on the history of the church) seem to suggest that St Eirene dated back to pre-Constantinian times. Its position, inside the Ottoman Topkapi Sarayi, preserved the building from being converted into a mosque, which was commonly the fate of Byzantine churches in Istanbul: instead, St Eirene was transformed into an armoury during the Ottoman period, and, more recently, it has been used as a museum. The building preserves the ground plan of Justinian's and Theodora's basilica, which was built by their order to replace and enlarge the earlier church, after it had been destroyed in the Nika Revolt of

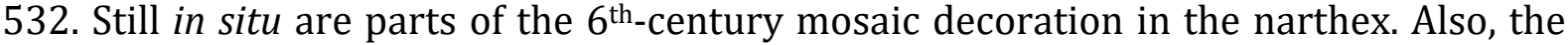
monograms of Justinian and Theodora are visible on some capitals in the central nave.

The upper sections of the building, the dome, the bema arch, and the apse, all collapsed during the earthquake of 740 . The mosaics of the apse preserve a rare example of Iconoclastic art and epigraphy, assigned usually to the reign of Constantine $\mathrm{V}$ Kopronymos. Very recently, Paul Magdalino in his Renaissances d'une capital, has suggested a different dating for the reconstruction of the church (and consequently of the mosaics and the inscriptions, too). Magdalino's suggestion is based on the results of dendrochronological analysis by Kuniholm (et al.), and on a recent reconsideration of The Short History by Nikephoros by Marjanović. According to Magdalino, the reconstruction can be ascribed to the patronage of the Empress Irene, at the very end of $8^{\text {th }}$ century.

In the apse above the altar, we see two inscriptions, one on the outer, the other on the inner edge of the arch (figs. 1-2). They have commonly been understood as belonging to the same period; however, there can be observed some palaeographical differences between them, which most certainly deserve further consideration. Both inscriptions quote the Bible, more precisely, the Book of Prophet Amos and the Psalter referring to the concept of a building created for God and by God. 
The Epigraphy of Hagia Eirene

I. The Mosaic Inscriptions in the Main Apse

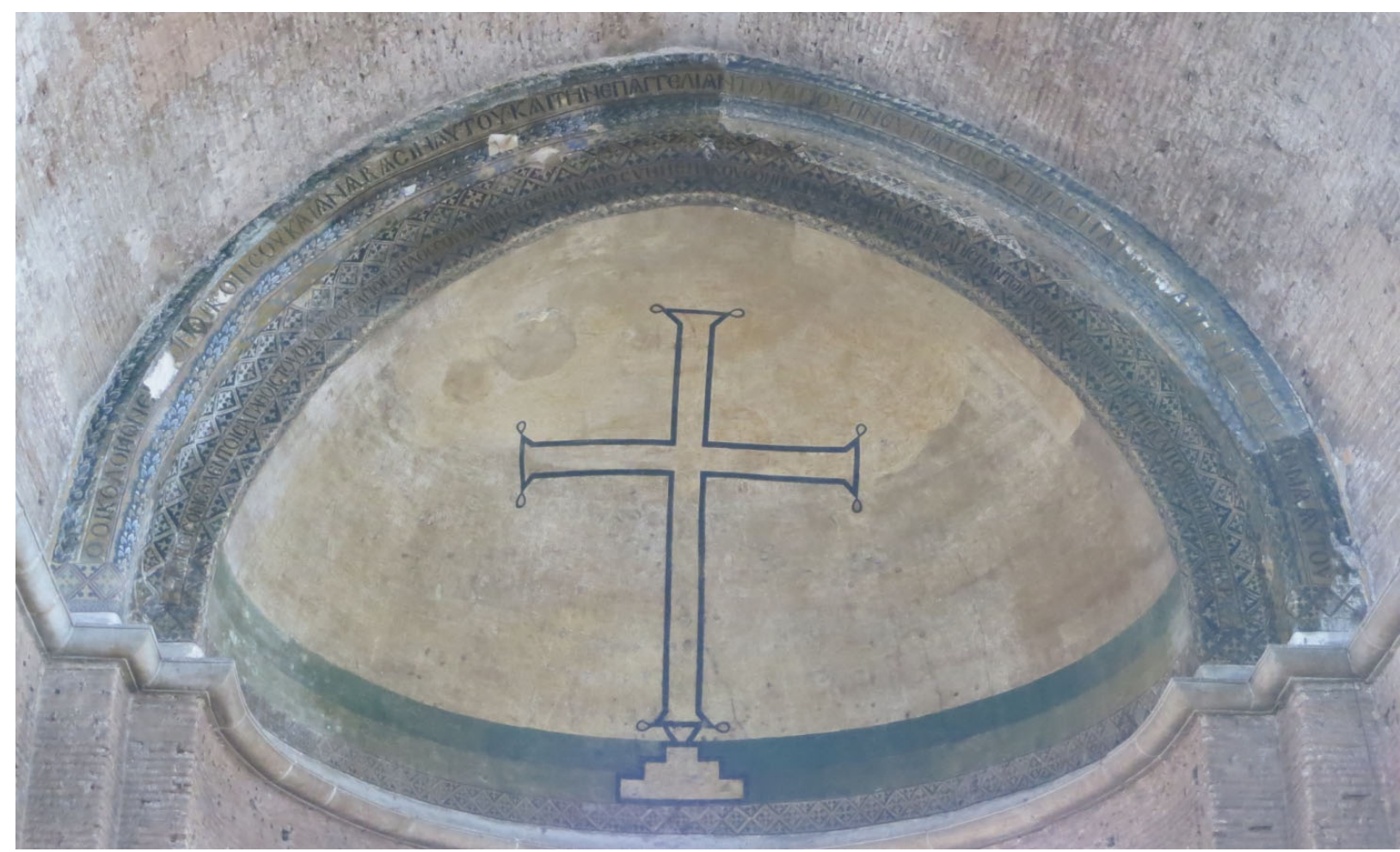

Fig. 1 St Eirene, the Conch of the Main Apse (C) Brad Hostetler)

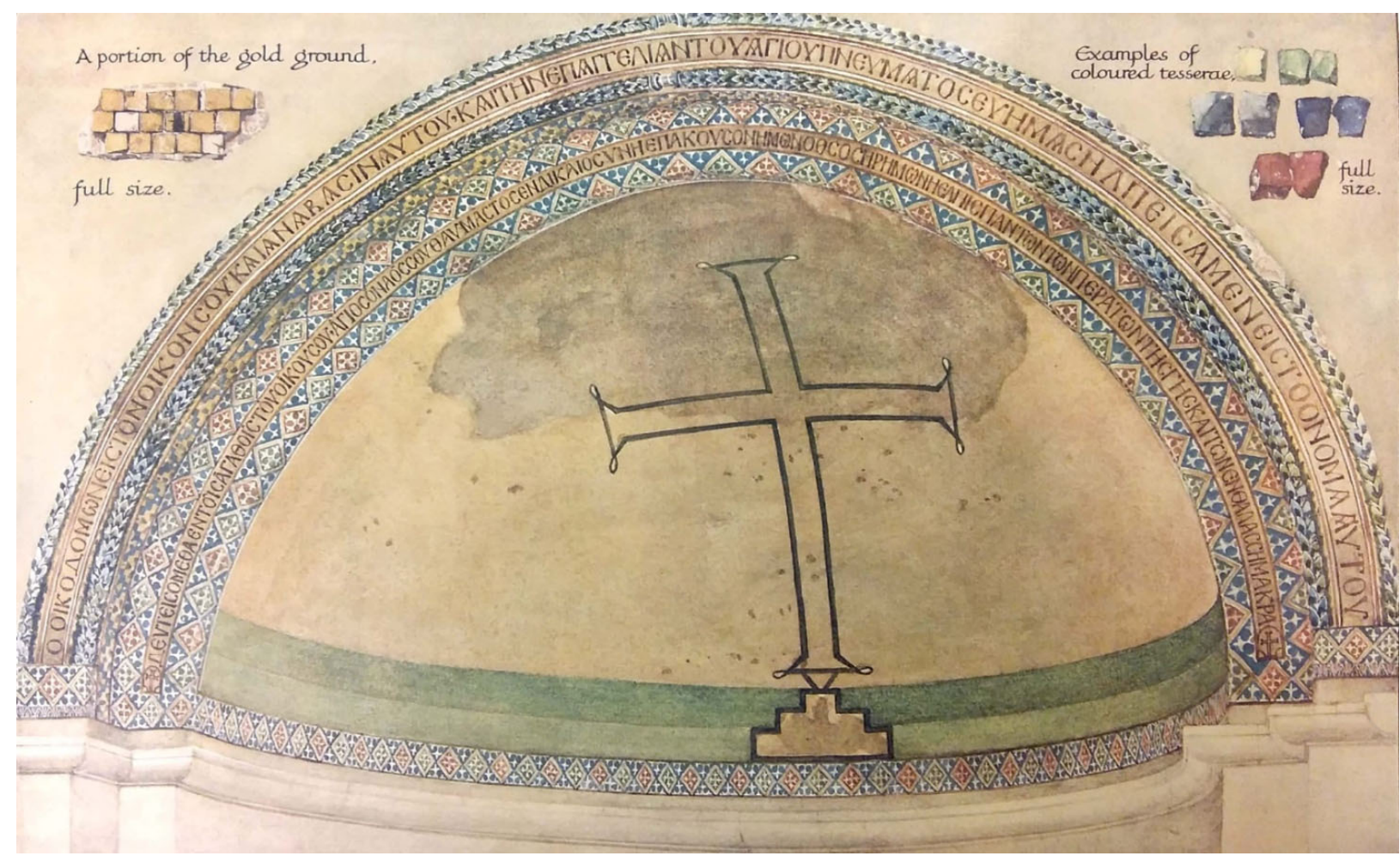

Fig. 2 St Eirene, the Conch of the Main Apse (Drawing by George 1912, fig. 17) 
I.1 The Outer Inscription Surrounding the Conch of the Main Apse

Editions: Van Millingen 1912, 94-96; George 1912, 48-50, pl. 17; Ebersolt - Thiers 1913, 68; Biblia epigraphica, 507. Also, Grabar 1957, 153 fig. 88; Mango 1951, 60, IV; Taddei 2011, 887.

A. Text extant today: reading from a picture by Brad Hostetler, published on Flickr on May 2018. Grey letters mark the painted sections (19th-century restoration), black letters mark the original mosaic layer:

O OIKO $\Delta O M \omega N$ EI[-c.2-]ON OIKON COY KAI ANABACIN AYTOY KAI THN EПАГГЕАIAN TOY AГIOY ПNEYMATOC EY HMAC HANEICAMEN EIC TO @NOMA AYTOY

B. Reading from the images previously published (Van Millingen 1912; George 1912)

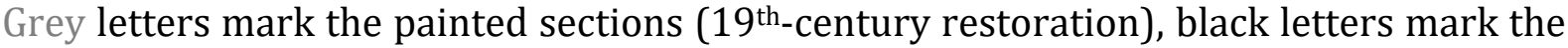
original mosaic layer:

\section{O OIKO $\Delta$ OM $\omega$ N EIC TON OIKON COY KAI ANABACIN AYTOY KAI THN ЕПAГГEAIAN TOY

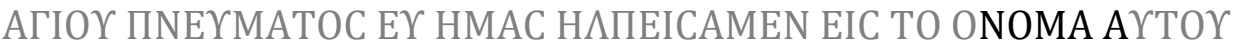

c. Transcription:

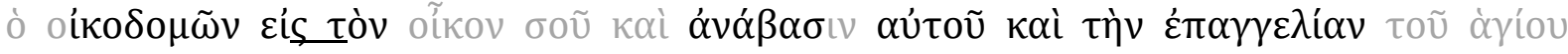

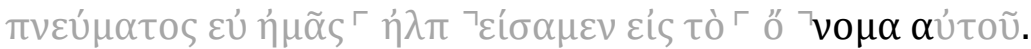

Painted: HAN; $\Theta$.

d. Bible quotation(s).

Judging by the surviving mosaic inscription, the original text (badly restored) quotes Amos 9,6 (the quoted passages are given in bold):

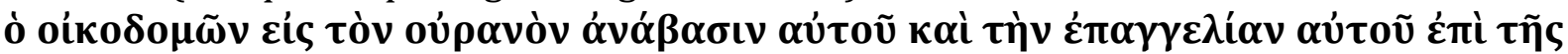

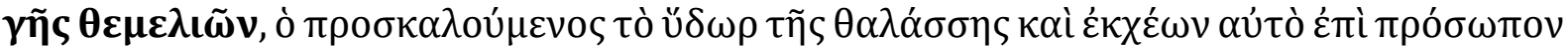

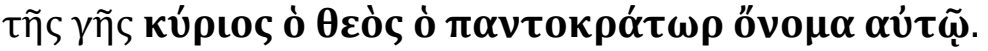

('he builds his lofty palace in the heavens and sets its foundation on the earth; he calls for the waters of the sea and pours them out over the face of the land-the Lord is his name': English translation from NIV)

In addition to the quotation of Am 9, 6, George $(1912,50)$ suggests a paraphrase of Ps 32,

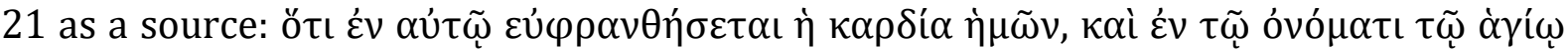
$\alpha u ́ \tau o \tilde{~} \dot{\eta} \lambda \pi i ́ \sigma \alpha \varepsilon v$ ('For in him our heart shall rejoice: and in his holy name we have trusted').

Mango 1951, 60 agrees with George and follows Van Millingen 1912, proposing also a

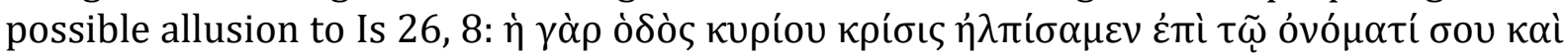

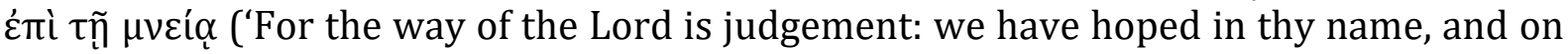
the remembrance [of thee'].

E. the transcription of the original inscription (where I underlined the lost letters that since the restoration are replaced by the painted letters: '... manifestly the work of a restorer who has disregarded the grammatical construction and obscured the meaning of the inscription' (George, 1912).

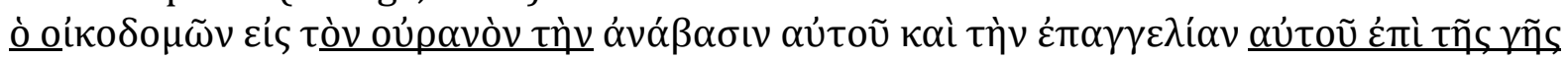

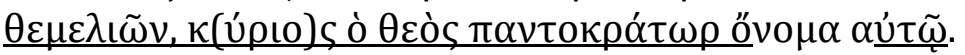


George $(1912,50)$ suggests that the text ends only with the word кúpıos; but, reading $\kappa($ úpıo)ৎ ò $\theta \varepsilon$ cò gives exactly the same length (of 105 letters) as the restored inscription surrounding the arch.

\section{I, 2 The Inner Inscription Surrounding the Conch of the Main Apse}

Editions: Van Millingen 1912, 94-96; George 1912, 50-51, pl. 17; Ebersolt - Thiers 1913, p. 68; Biblia epigraphica, 506. Mentioned by Grabar 1957, 153 fig. 88; Mango 1951, 60, IV; Taddei 2011, 887.

a. Text extant today: reading from a picture by Brad Hostetler, published on Flickr on May

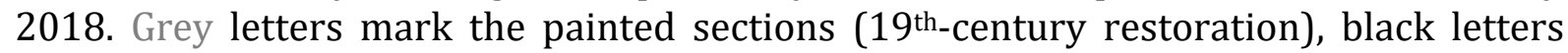
mark the original mosaic layer:

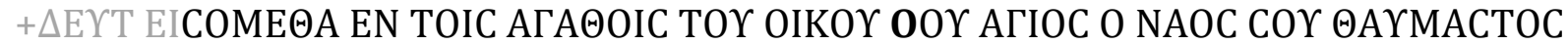

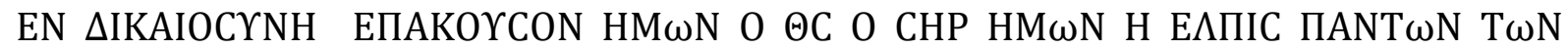

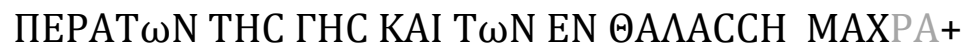

b. Reading from the images previously published (Van Millingen 1912; George 1912)

Grey letters mark the painted sections (19th-century restoration), black letters mark the original mosaic layer; the solutions of abbreviations are in square brackets, according to George 1912):

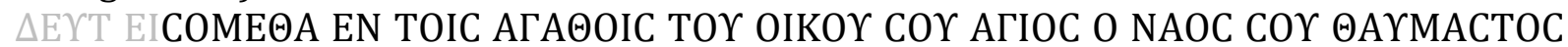

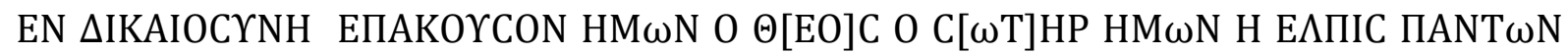

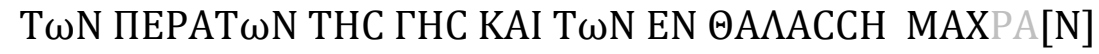

c. Transcription:

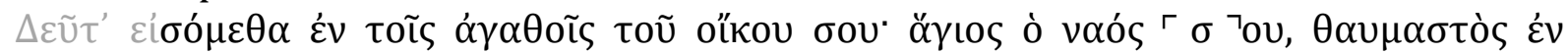

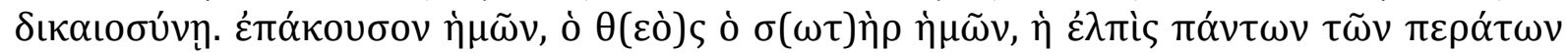

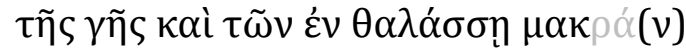

OOY, mosaic.

d. Bible quotation(s).

Judging by the surviving mosaic inscription, the original text (badly restored) quotes

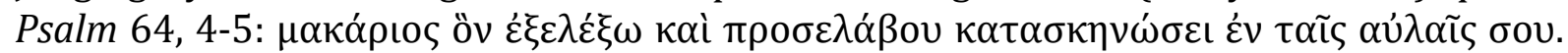

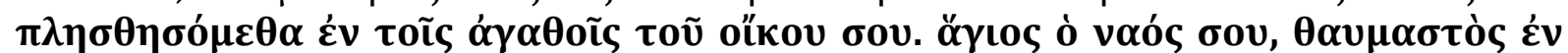

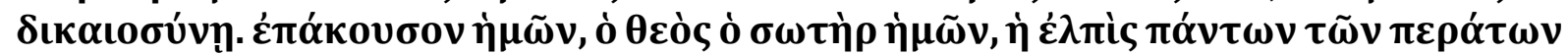

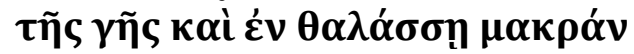

('Blessed [is he] whom thou hast chosen and adopted; he shall dwell in thy courts; we shall be filled with the good things of thy house; thy temple is holy, wonderful in righteousness. Hearken to us, 0 God our Saviour; the hope of all the ends of the earth, and of them [that are] on the sea afar off').

1in. The six painted letters $\triangle \mathrm{EYT} \mathrm{EI}$ at the beginning of the inscription are 'a mistake of the restorer' (Van Millingen 1912, p. 95), incorrectly replacing the six original letters $\Pi \Lambda \mathrm{HC} \Theta \mathrm{H}(\sigma o ́ \mu \varepsilon \theta \alpha)$.

1ex. The possible final $\mathrm{N}$ at the end of the inscription could be also not considered, reading $\mu \alpha \kappa \rho \tilde{\alpha}$, as adjective of the dative $\theta \alpha \lambda \alpha$ ó $\sigma \eta$ (but we have no testimonia of this variation). 
E. the transcription of the original inscription (where I underlined the lost letters that since the restoration are replaced by the painted letters:

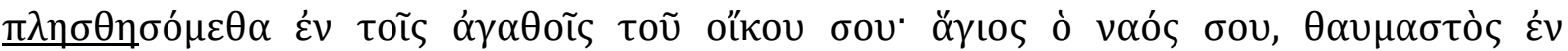

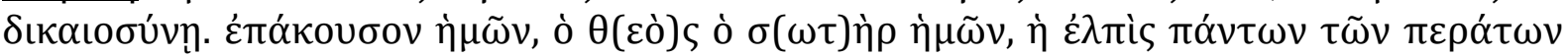

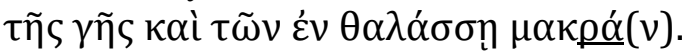

\section{Monograms on the capitals in the nave arcades}

Here are the monograms on the capitals in the nave arcades, according to their sequence (as displayed by George 1912, 21, fig. 7):

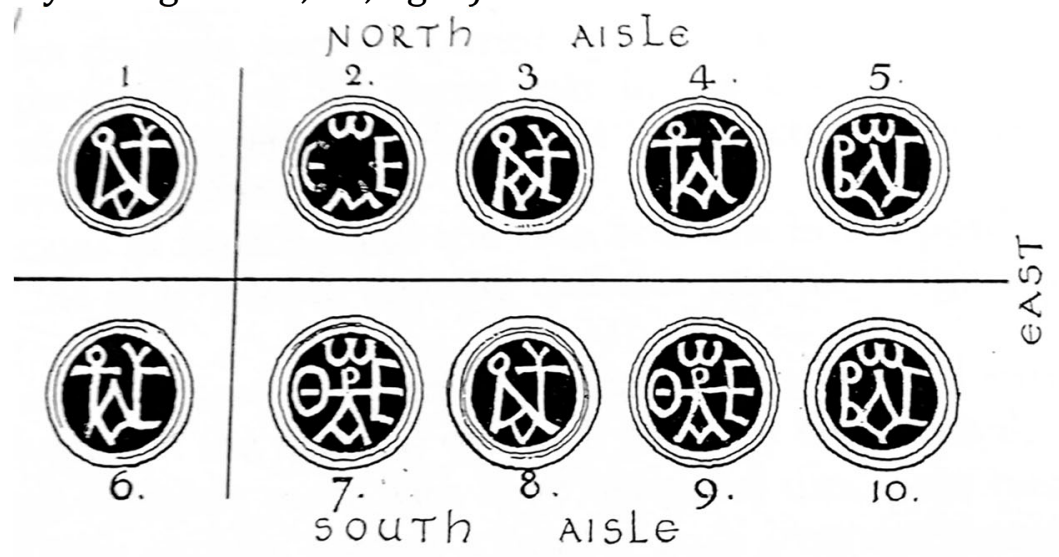

According to George 1912, we have four types of monograms:

II, 1 (monograms 1, 3, 8)

IOYCTINIANOY

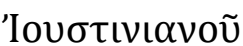

II, 2 (monograms 2, 7, 9)

$\Theta \mathrm{EO} \Delta \omega \mathrm{PAC}$

$\Theta \varepsilon o \delta \omega ́ \rho \alpha \varsigma$

II, 3 (monograms 4, 6)

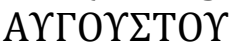

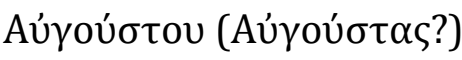
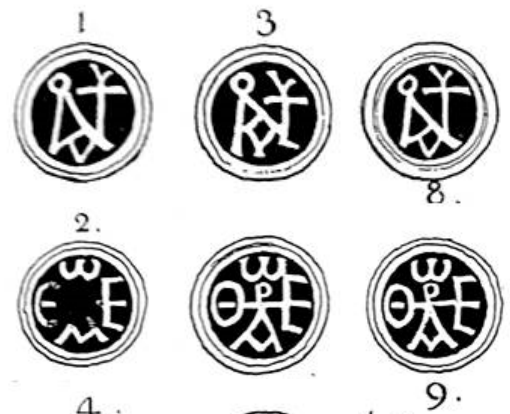

II. 4 (monograms 5, 10)

BACI $\Lambda \mathrm{E} \omega \mathrm{C}$

$\beta \alpha \sigma \iota \lambda \varepsilon^{\prime} \omega \varsigma$
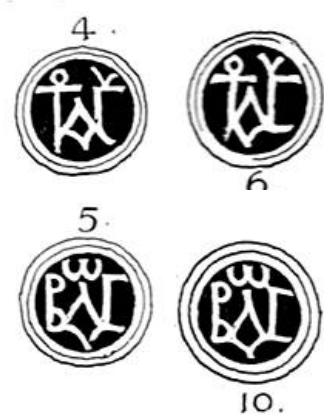

George 1912, 21: 'The evidence of these monograms fixes with certainty the period at which the capitals were made, but it must not be applied without caution to the whole of the structure of which they form a part, as the capitals may have been reset.' 


\section{Selected Bibliography}

Dirimtekin, F. (1962) Les fouilles faites en 1946-47 et en 1958-60 entre Sainte-Sophie et Sainte-Irène à Istanbul, Cahiers Archéologiques 13, 161-185.

Ebersolt, J. and Thiers, A. (1913) Les églises de Costantinople, Paris, 55-72.

Feissel, D. (2005) De Sainte-Irène au domaine de Rufin. Trois notes de toponymie constantinopolitaine, in Mélange Jean-Pierre Sodini (= Travaux et mémoires 15), Paris, 245-260.

Felle, A. (2020) Epigrafi e cattedrale. Note sulla Hagia Eirene di Costantinopoli, in Bisconti, F., Cresi Marrone, G., Mainardis, F. and Prenc, F. (eds) Legite, tenete, in cordo habete. Miscellanea in onore di Giuseppe Cuscito, Trieste, 189-204.

George, W. S. (1912) The Church of Saint Eirene at Constantinople, London.

Grabar, A. (1957) L'iconoclasme byzantin. Dossier archéologique, Paris, especially 153155, fig. 88.

Grossmann, P. (1965) Zum Atrium der Irenenkirche in Istanbul, Istanbuler Mitteilungen $15,186-207$.

Janin, R. (1953) La geographie ecclésiastique de l'Empire byzantine, Première partie. Le siège de Constantinople et le patriarcat oecuménique, tome III: Les églises et les monastères, Paris, 108-111.

Krautheimer, R. (1965), Early Christian and Byzantine Architecture, Harmondsworth (Italian translation [1991] Architettura paleocristiana e bizantina, Torino)

Kuniholm, P. I., Pearson, C. J., Wažny, T. I. and Briggs, C. B. (2015) Of harbors and trees: the Marmaray contribution to a 2367-year chronology for 97 sites for the Aegean, East Mediterranean and Black Sea, in Magdalino, P. and Ergin, N. (eds), Istanbul and water, Leuven, Paris and Bristol, 63-64.

Magdalino, P. (2018) Renaissances d'une capitale : l'urbanisme constantinopolitain des dynasties impériales, Travaux et mémoires 22, 1-24: especially 19-20.

Marjanović, D. (2017) Creating memories in late 8th-century Constantinople: The Short history of Nikephoros of Constantinople, Amsterdam.

Mathews, T. F. (1971), The Early Churches of Constantinople, University Park and London, 77-88.

Mathews, T.F. (1976), The Byzantine Churches of Istanbul. A Photographic Survey, University Park and London.

Peschlow, U. (1977) Die Irenenkirche in Istanbul: Untersuchungen zur Architektur, Tübingen.

Peschlow, U. (1996) Die Baugeschichte der Irenenkirche in Istanbul neu betrachtet, in Striker, C. L. (ed) Architectural Studies in Memory of Richard Krautheimer, 133-136.

Ramazanoğlu, M. (1946) Sentiren ve Ayasofyalar Manzumesi (L'ensemble de S.te Irène et les diverses S.te Sophie), Istanbul.

Ramazanoğlu, M. (1951) Neue Forschungen zur Architekturgeschichte der Irenenkirche und des Complexes der Sophienkirche, in Atti dell'VIII Congresso di Studi Bizantini, vol. 2, Palermo, 232-235.

Strube, C. (1973) Die westliche Eingangsseite der Kirchen von Konstantinopel in justinianischer Zeit, Wiesbaden, 106-117.

Taddei, A. (2011), Remarks on the Decorative Wall-mosaics of Saint Eirene at Constantinople, in Sahin M. (ed) 11 th International Colloquium on Ancient Mosaics (October $16^{\text {th }}-20^{\text {th }}, 2009$, Bursa Turkey). Mosaics of Turkey and Parallel Developments in the Rest of the Ancient and Medieval World, Istanbul, 883-896. 
Taddei, A. (2012) Il mosaico parietale aniconico da Tessalonica a Costantinopoli, in Acconcia Longo, A., Cavallo, G., Guiglia, A. and Iacobini, A. (eds) La Sapienza bizantina. Un secolo di ricerche sulla civiltà di Bisanzio all'Università di Roma (Atti della Giornata di Studi. Sapienza Università di Roma, 10 ottobre 2008), Rome, 153-182: 164-165, 174 (footnotes 48-55), 182 (figs. 23-24)

Tansuğ, S. (1962) First restoration of mosaics in the Church of Saint Eirene, Ayasofya Müzesi Yıllı̆̆ı 4, 66-67.

Van Millingen, A. (1912), Byzantine Churches in Constantinople, London, 84-105.

\section{Appendix}

Literary sources on the history of Hagia Eirene church $\left(4^{\text {th }}-8^{\text {th }}\right.$ centuries $)$

\section{0-337.}

Socrates Scholasticus, Historia ecclesiastica (around the year 425), I, 16.

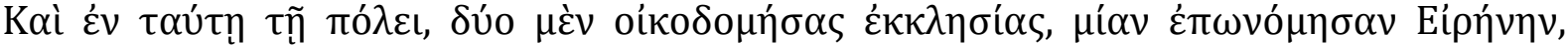

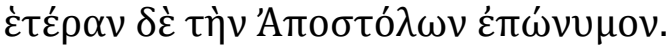

"He built also in the same city two churches, one of which he named "Irene", and the other "of The Apostles'

Theophanes, Chronographia, I, 24; Georgius Codinus (Patrologia Graeca 157, 457A:

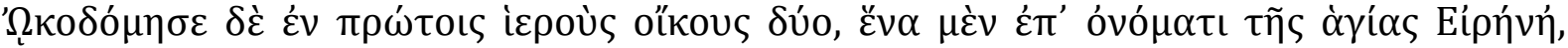

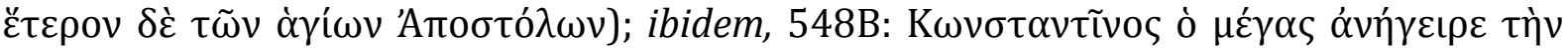

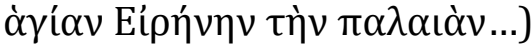

Cedrenus, Historiarum Compendium (Patrologia Graeca 121, 544A = Tartaglia, p. 502)

\section{5.}

Socrates, Historia ecclesiastica, I, 37.

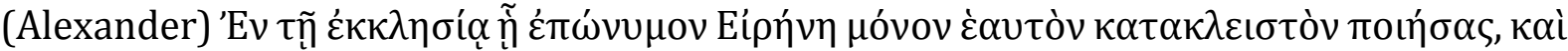

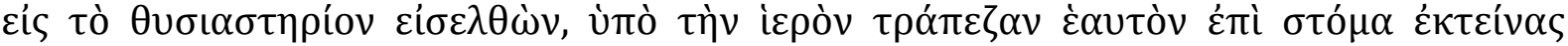

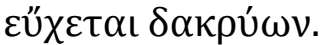

'Alexander... Communicating his purpose to no one, he shut himself up alone in the church called Irene: there going up to the altar, and prostrating himself on the ground beneath the holy communion table, he poured forth his fervent prayers weeping.'

340.

Socrates, Historia ecclesiastica, II, 6.

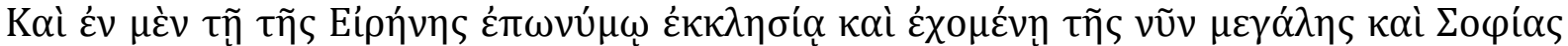

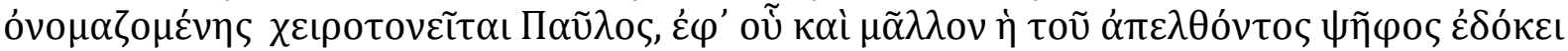
кр $\alpha \tau \varepsilon \tilde{\tau} v^{\sim}$

'Paul therefore was ordained bishop in the church called Irene, which is situated near the great church of Sophia.'

\section{Life of Saint Paul of Constantinople in Photius, Bibliotheca, 257}

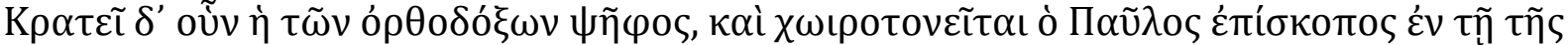

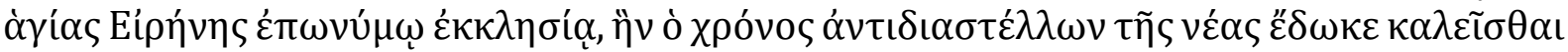
$\pi \alpha \lambda \alpha\llcorner\alpha \dot{\nu}$. 
'Le suffrage des orthodoxes l'emporta et Paul fut élu évêque dans l'église de saint Irène, celle qu'avec le temps, pour la distinguer de la nouvelle église, on appela l'Ancienne' (French translation in the edition of the Collection Byzantine, Budé, vol. 5, 8 [ed. Henry, R.] p. 9 [474b]).

\section{Life of Saint Paul of Constantinople in Photius, Bibliotheca, 257}

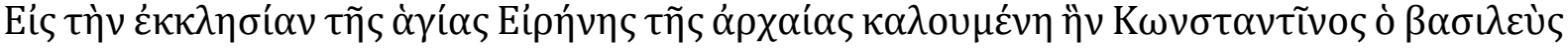

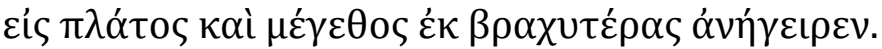

'Ils portèrent son corps à travers la ville et allèrent le déposer dans l'église de saint Irène dite l'ancienne que Paul avait desservie quelque temps; l'empereur Constance l'avait agrandie en longuer et en largeur' (French translation in the edition of the Collection Byzantine, Budé, vol. 5, 8 [ed. Henry, R.] p. 17 [477]).

Janin (1953, p. 108, footnote 7) writes that, according to this source, the church was enlarged not by Constantine, but by Constantius II. But, in the Greek text

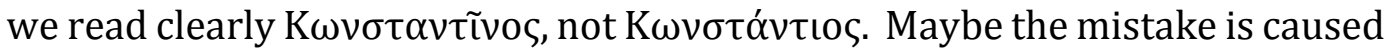
by the Latin translation in Migne edition: probat omnia imperator, et perferri curat magna cum reverentia reliquias sancti Pauli confessoris: et episcopi quotquot aderant una cum Nectario, longe extra Chalcedonem obviam procedunt, multoque cantu et comitato suscipiunt, et per mediam urbem corpus ferentes, collocarunt in ecclesia sanctae Irenes nomini antiqui, quam Constantius imperator in latitudinem et magnitudinem e parva excitavit, cui et Paulus aliquandio praefuerat....

This same mistake we read also in the French translation in the edition by R. Henry in the Collection Byzantine, Budé, vol. 5, 8, part. p. 17, [477b]: "L'empereur vota en accord avec tous et il accompagna très respecteusement la dépuille mortelle de Paul le Confesseur. Et tous les évèques qui étaient là, avec Nectaire lui-même, allèerent à sa rencontre très loi de Chalcédoine; ils l'accueillerent avec des chants et une très nombreuse escorte, ils portèrent son corps à travers la ville et allèrent le déposer dans l'église de saint Irène dite l'ancienne que Paul avait desservie quelque temps; l'empereur Constance l'avait agrandie en longuer et en largeur".

381.

Vita S. Stephani iunioris (Patr. Gr. 100, 1144D = 44, 76 Auzépy):

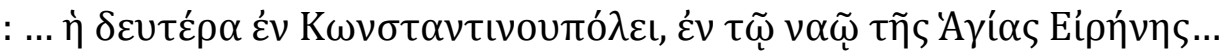

"... the second [council] was in Constantinople, in the church of St. Eirene..."

Hagia Eirene is there mentioned as the official place the Ecumenical Council in 381.

427.

Synaxaristes, January 20 (about the return of the remains of St. John Chrysostome in Constantinple, under Theodosius II)

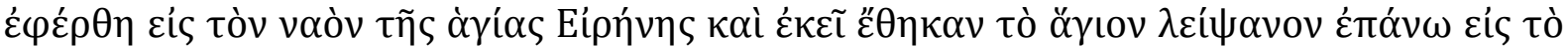

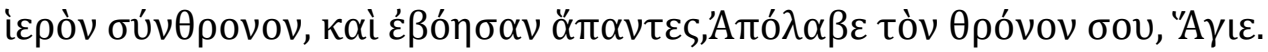

'The saint reliquary was brought to the church of the saint Eirene and there it was placed upon the episcopal seat in the synthronon; all shouted: 'O Saint, receive back your throne!" 
430ca.

Notitia urbis Constantinopolitanae (Ed. Seeck, p. 231; p. 235)

In the regio II an ecclesia antiqua was mentioned together with an ecclesia magna (respectively, Hagia Irene and Hagia Sophia). Another "Eirene" church (Irenen) was mentioned in the regio VIII.

\section{2, February $16^{\text {th }}$, Nika riot}

\section{Theophanes Confessor, Chronographia}

I, 181 ('A large part of the city was burned, including the Great Church, St. Eirene, the hospice of Sampson, the Augustaion, the portico of the Basilica and the Bronze House of the palace')

See also Cedrenus, Historiarum Compendium (Patrologia Graeca, 121, 705B = Tartaglia, p. 627).

\section{4-548.}

\section{Procopius, De aedificiis}

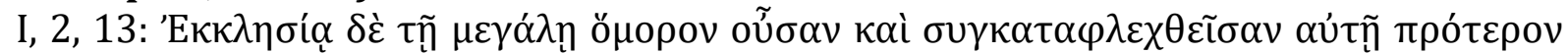

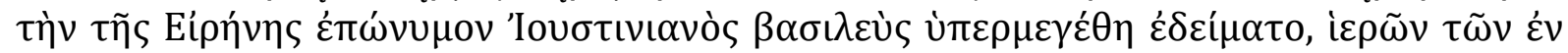

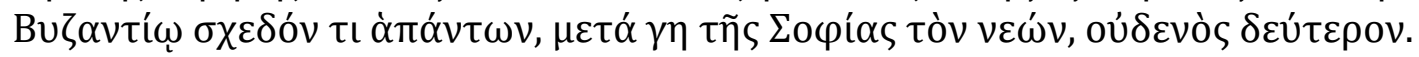

'The church called after Eirenê, which was next to the Great Church and had been burned down together with it, the Emperor Justinian rebuilt on a large scale, so that it was scarcely second to any of the churches in Byzantium, save that of Sophia.'

\section{5.}

\section{Iustinianus, Novellae,}

III, 1: ... erat autem etiam venerabilis domus sanctae Irenae, quae sanctissimae maiori ecclesiae copulata est...

Hagia Eirene and Hagia Sophia are considered together as one sanctuary, identified with

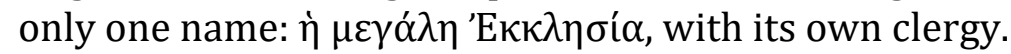

\section{3-564.}

\section{Theophanes (+ 817), Chronographia}

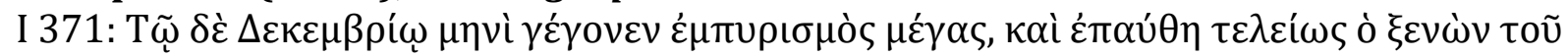

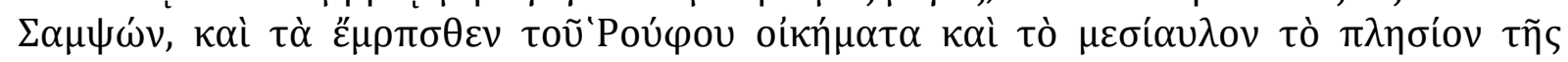

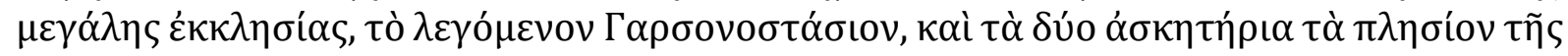

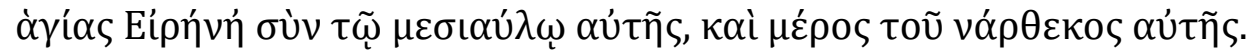

"In December a great fire broke out, and the hospice of Sampson was completely gutted as too were the buildings in front of the quarter of Rufus and also the middle court, near the Great Church (the one called Garsonostasion) and the two monasteries near St Eirene, along with its middle court and part of its narthex".

(Translation reprised by Mango C. and Scott R. with the assistance of Greatrex, G. [1997] The Chronicle of Theophanes Confessor. Byzantine and Near Eastern History AD 284-813, Oxford, 1997: here p. 353 ad AM 6056 = AD 563/4)

\section{0, 0ctober 26th.}

\section{Theophanes (+817), Chronographia}

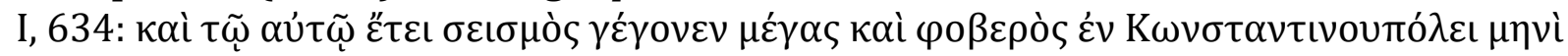

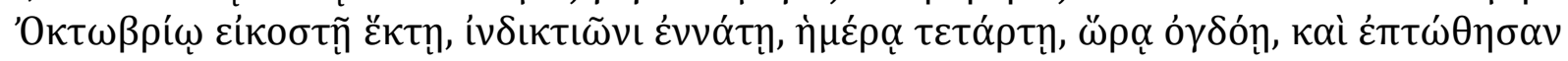




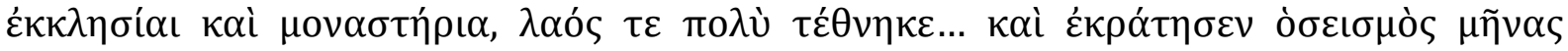
$\delta \omega ́ \delta \varepsilon \kappa \alpha$.

26 ottobre 740 , earthquake:

'In the same year a violent and fearful earthquake occurred at Constantinople on 26 October, indiction 9, a Wednesday, in the $8^{\text {th }}$ hour. Many churches and monasteries collapsed and many people died... The quakes continued for twelve months' (translation by Mango and Scott [1997], The Chronicle of Theophanes Confessor, 572 ad AM $6232=$ AD 740)

Nicephorus Patriarcha, Breviarium historicum ( $P G$ 100, col. $965=63$, 4-16 Mango):

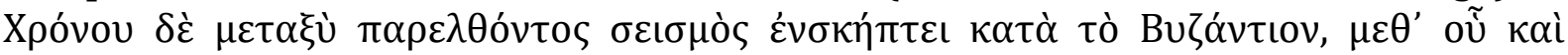

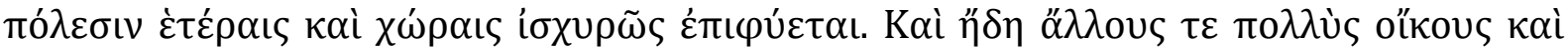

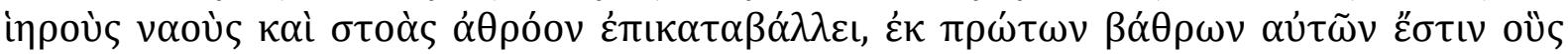

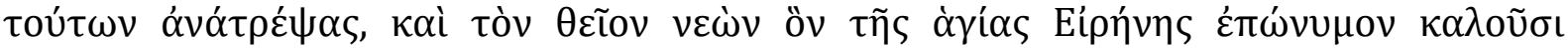

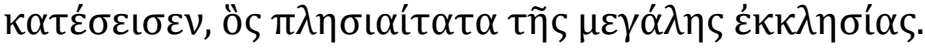

'After a lapse of time an earthquake occurred at Byzantium and likewise shook violently other towns and regions. In addition to many other buildings, holy churches, and porticoes which it cause to fall down at once, some of them being overturned from their very foundations, it also threw down the sacred church which bears the name of St. Eirene and stands very close to the Great Church... The quakes continued for a whole year.'

(English text by Nikephoros, Patriarch of Constantinople, ed. Mango C. [1990], Short History [= CFHB 13], Washington, 63, 4-16: St Eirene is mentioned as one of the churches destroyed by the earthquake). 


\section{Monumental Inscriptions and Their Stories \\ PAUL MAGDALINO}

Inscriptions have been of vital importance in identifying, dating and contextualizing the sites and monuments of Byzantine Constantinople. They both enable the monuments to tell their own stories, and give access to the stories surrounding the monuments. This summary presents three monumental inscriptions, all in situ, which in conjunction with other evidence provide valuable insights into the history, topography and aesthetics of the built environment:

1. The Latin inscription on the base of the Column of the Goths (figs. 1-2), which identifies this as a monument to 'Fortuna/Tyche returning on the defeat of the Goths'. This monument should be reconsidered in relation to the two late antique sources that refer to it: a set of epigrams by the poet Palladas (Anth. Pal. IX 180183), and a sixth-century commentary on the inscription by John Lydus ( $D e$ mensibus IV 32). The combined evidence of these texts strengthens the old hypothesis that the monument predated Constantine and was originally erected to commemorate the victories of Claudius Gothicus in 269 (see, also Andreas Rhoby, Chapter 14); it further allows us to conclude that the column was originally associated with a temple of Fortuna/Tyche that Constantine converted into a tavern. In contrast to the marginal and isolated location of the monument today, at the time of the foundation of Constantinople it stood at a major crossroads of routes linking the main cult and entertainment venues of ancient Byzantion. It was also a significant landmark in Constantine's city, since it completed the axis linking other monuments to Tyche at the Strategion (lower agora) and the Basilica (upper agora).

2. The Greek verse inscription on the base of the Masonry Obelisk in the Hippodrome, commemorating the restoration and bronze-cladding of the monument by Constantine VII Porphyrogennetos (945-959). (See, Anna Sitz, Chapter 3 ) The text is not only our unique source for the history of this prominent monument, but also an interesting addition to our evidence for the literary and artistic patronage of the 'Macedonian Renaissance'. It shows that Constantine VII's concern to renovate the ancient past was not confined to the Palace, to books and to sacred relics, but extended to the public space of the city. Two aspects of the text deserve attention: (1) the comparison of the obelisk with the Colossus of Rhodes, which implicitly makes it a wonder of the world as well as linking it with the Seven Wonders of Constantinople that Constantine the Rhodian celebrated in a contemporary poetic ekphrasis dedicated to Constantine VII (see, also Chapter 3 by Anna Sitz and Chapter 7 by Ida Toth); (2) the fulsome reference to the emperor's son and successor Romanos II, which suggests that the text was composed and inscribed after his accession.

3. The Latin inscription on the base of the Column of Marcian (450-457) identifying this monument as the centre of an imperial forum (fig. 3; see, also Andreas Rhoby, Chapter 14). The recent excavations for the construction of the metro station at Vezneciler uncovered remains of a paved street that is aligned with the forum in a way that allows us to reconstruct the line of the northern branch of the city's central avenue (Mese) as follows: the forum was laid out on the main line of the avenue, which continued as far as the Forum of Theodosius, although the main 
processional route branched off to the south before this, to join the southern branch of the Mese not at the Forum of Theodosius, but to the west of the latter at the Capitol. In this case, the Mese would not have passed close to the church of the Holy Apostles, but the main processional access to this would have been via a cross-street, in all probability the street that still today runs from an opening in the aqueduct to the Column of Marcian (Kız Taşı). It is notable that the line of this transverse street, if continued southwards, runs straight to the Forum and Column of Arcadius, thus placing the Forum of Marcian at the right angle of the triangle that it forms with the Fora of Theodosius and Arcadius.

\section{Selected Bibliography}

Bardill, J. (2010) The Monuments and Decoration of the Hippodrome in Constantinople, in Pitarakis, B. (ed) Hippodrome/Atmeydanı, Istanbul, vol. I, 149-184.

Croke, B. (2008) Poetry and Propaganda: Anastasius I as Pompey, Greek, Roman and Byzantine Studies 48, 447-466.

Łajtar, A. (2000) Die Inschriften von Byzantion, vol. I (= Inschriften griechischer Städte aus Kleinasien, vol. 58), Bonn.

Magdalino, P. (2012) The 'Columns' and the Acropolis Gate: a Contribution to the Study of the Ceremonial Topography of Constantinople, in Asutay-Effenberger, N. and Daim, F.

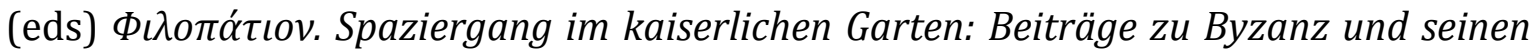
Nachbarn. Festschrift für Arne Effenberger zum 70. Geburtstag, Mainz, 147-56.

Mango, C. (1985) Le déevleoppement urbain de Constantinople (IVe-VIIe siècles), Paris.

Rhoby, A. (2019) Latin Inscriptions in (Early) Byzantium', in Garcea, A., Rosellini, M. and Silvano, L. (eds), Latin in Byzantium I. Late Antiquity and Beyond, Turnhout, 275-294.

Wilkinson, K. W. (2010) Palladas and the Foundation of Constantinople, Journal of Roman Studies 100, 179-194. 

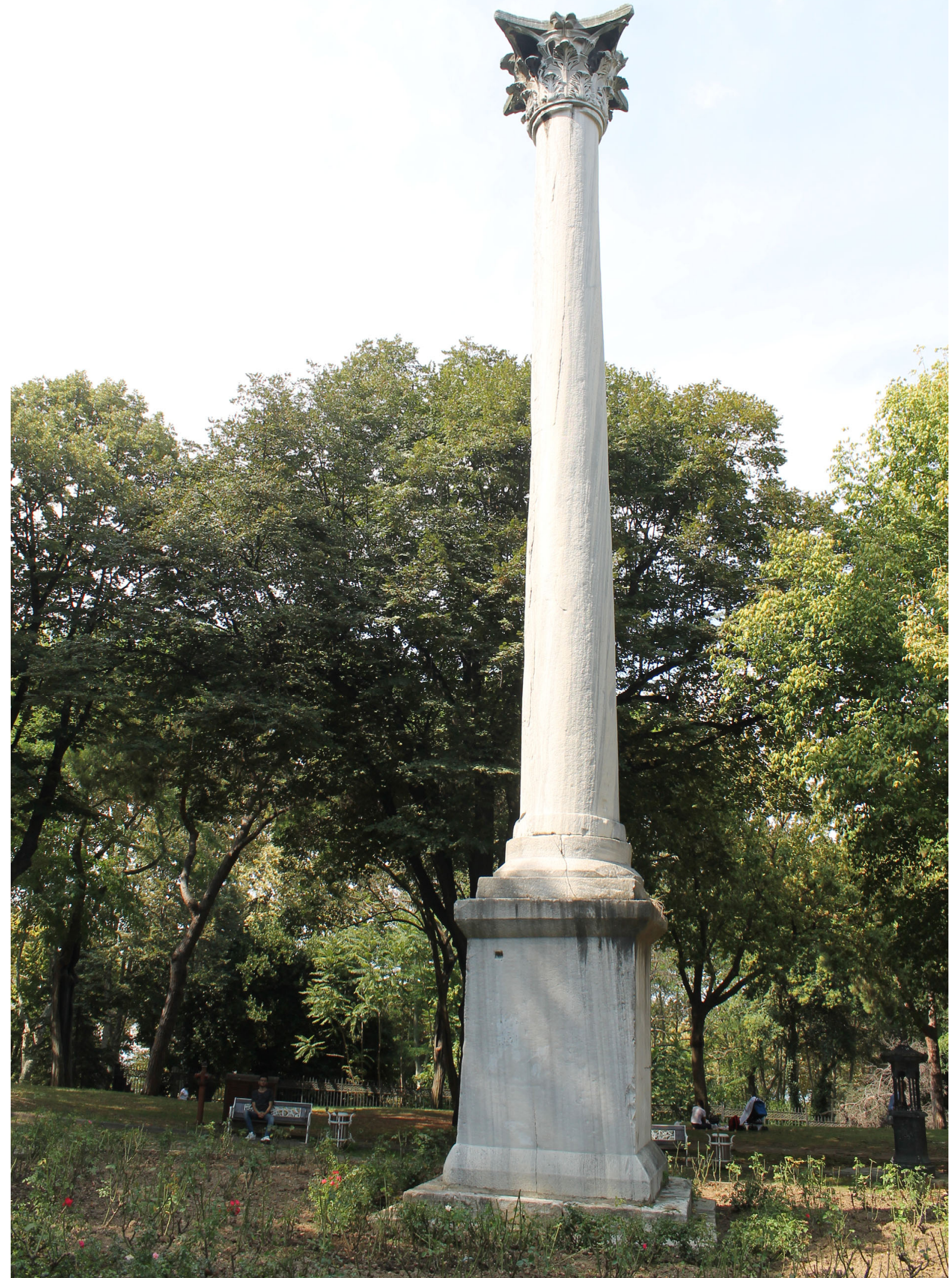

Fig. 1 The column of the Goths (C) Andreas Rhoby) 


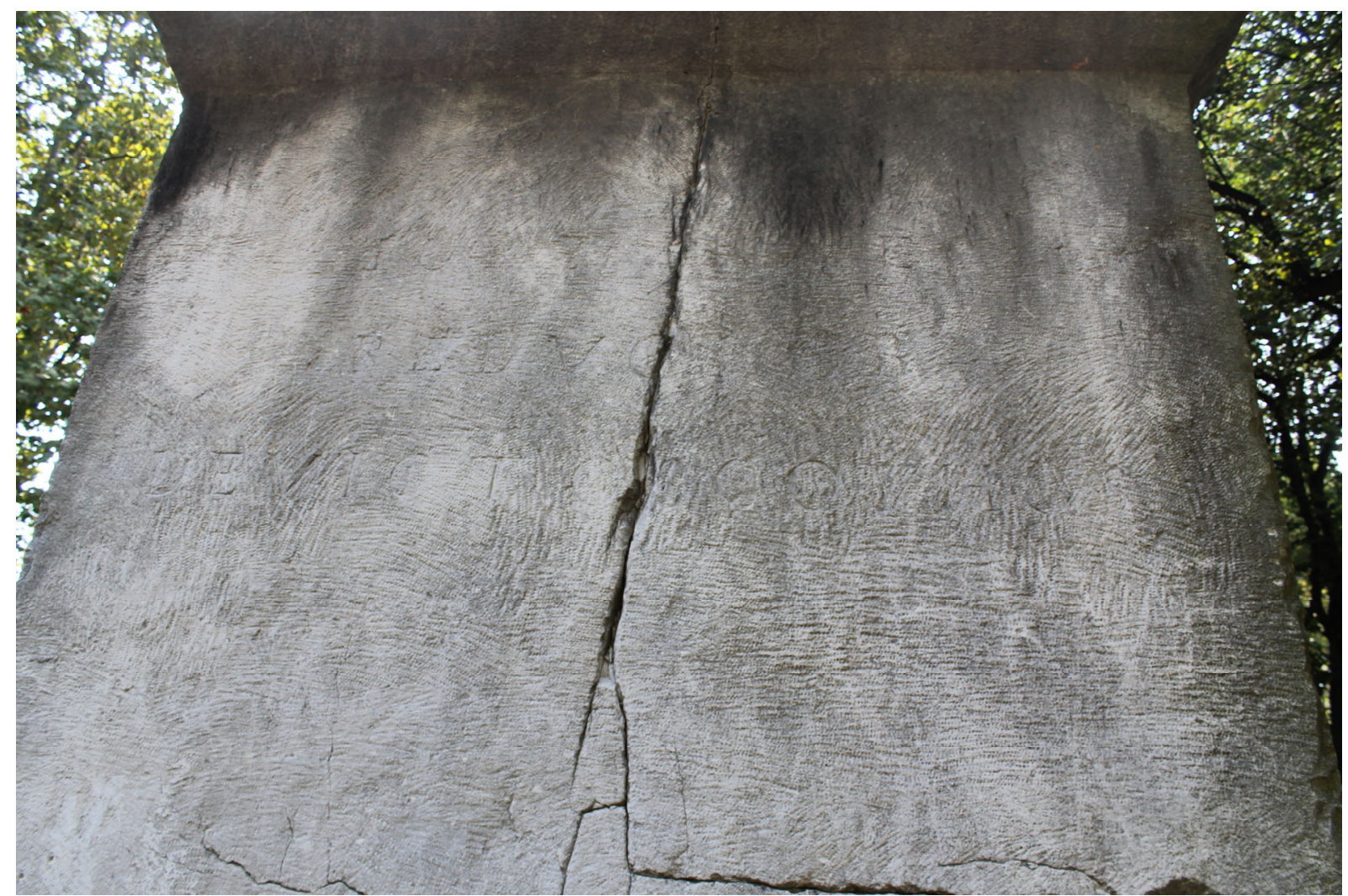

Fig. 2 The column of the Goths, Latin inscription (C) Andreas Rhoby)

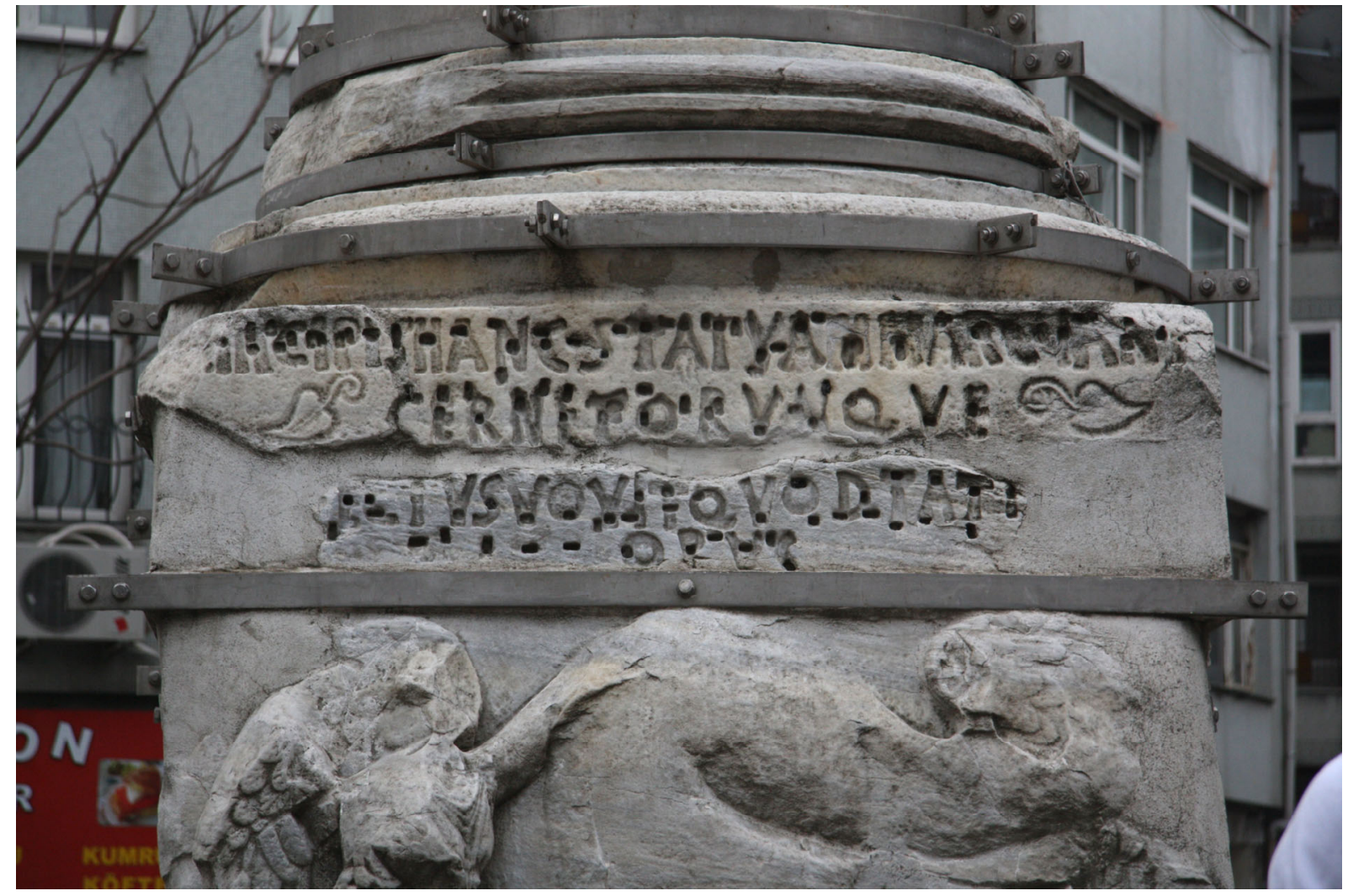

Fig. 3 Inscription on the base of the column of the Emperor Marcian (C) Ida Toth) 


\section{The Column of Constantine \\ IDA Tотн}

The Column of Constantine was the tallest and most visible monument in the early

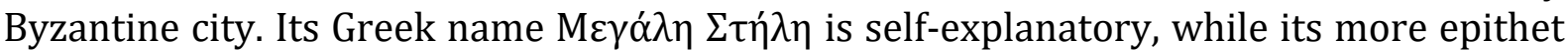
Çemberlitaş, Turkish for 'the Banded Stone', refers to the metal rings, which were added in the $5^{\text {th }}$ century to stabilize the monument. Rising some 36 meters above the ground level, it still stands as one of the most imposing landmarks of Istanbul's historic centre.

The Column of Constantine has received a fragmentary treatment in written sources. While many texts mention this monument, their reports tend to be vague and anecdotal. Some recount events taking place by, and around, the column, some record damage that it suffered over time, while the majority focus on the collection of relics that were supposedly buried under the column. These include: the famous Palladium of Rome, particles of the True Cross and of the crosses of the two thieves, a glass ampulla with the myrrh with which Christ was anointed, 12 baskets blessed by Christ, Noah's axe and the stone from which Moses brought forth water. This motley collection of foundation deposits gradually expanded creating ever more elaborate, and curious, stories and their interpretations.

Diaries and drawings by early modern visitors, and reports on more recent excavation and conservation works provide more conclusive evidence of the original state of the column, especially in its lower segments. They confirm that it once had a stepped stylobite and a platform, probably with some figural decoration (possibly replicating the iconography of the column itself), and that it consisted of seven porphyry drums banded with laurel wreaths at the joints. Six of these are still visible; the seventh is hidden behind the current $\left(18^{\text {th }}\right.$-century) base. It has been noted that the column repeats the measurements of the Colossus of Rome, and, by extension, of the Colossus of Rhodes. This connection creates a direct link to another renowned Constantinopolitan site: the Hippodrome's Masonry Obelisk, which is of the same height as Constantine's Column, and whose $10^{\text {th }}$-century inscription, likens this built structure to the Colossus of Rhodes. (See, Chapter 3 by Anna Sitz and Chapter 6 by Paul Magdalino, who associates this simile with Constantine of Rhodes' ekphrasis dedicated to Constantine VII).

The Column of Constantine originally had a Corinthian capital, above which stood a colossal statue of Constantine himself represented as Helios/Apollo, holding an orb and a spear, and wearing a crown with seven rays. Two eleventh-century historians mention dedications that were allegedly inscribed on the monument. According to Leo the Grammarian, the statue's epigraph addressed 'Constantine, who shines equal to the sun' (Chron., 87). In addition, George Kedrenos quotes an inscription on the column, spoken in the person of Constantine declaring: 'You, O Christ, are the Lord and Ruler of the World. I, your servant, dedicate this city to you. With this scepter and all the power of Rome. Guard it, save it from harm.' (Comp. Hist., 565)

Another middle Byzantine historian, Anna Komnene, informs us that Constanitine's statue was blown off its pedestal during a violent storm 1105/6 (Alexiad, 12.4.5). Some decades later, in the course of the second half of the $12^{\text {th }}$ century, the Emperor Manuel I Komnenos (1143-1180) replaced the statue with a cross. At that point, the capital of the column was also entirely reworked. Bob Ousterhout, who examined the monument during the conservation campaign in 2002, observes: 'The present capital [...] is particularly odd: rather than cap the column shaft, it extends as a cylinder of slightly decreased diameter and is squared off at the top. Its lower portion consist of 10 bands of 
Proconnesian marble, with an elegant dedicatory inscription on the third band, all the letters originally filled with lead. The inscription begins on the west side with a cross in an area now damaged, and then wraps around the capital; the final rho appears on the same damaged block as the cross and the first three letters of the inscription.' (Fig. 2)

The inscription commemorating Manuel I's renovation of the column is an epigram. It consists of two unprosodic dodecasyllable verses written in accentuated majuscule. The quality of execution is high: all letters, ligatures, and diacritical marks are beautifully executed and neatly laid out. (Fig. 3) The text was probably carved and inlaid with lead before the blocks were put in place. It reads as flows:

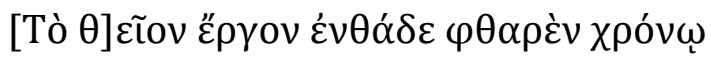

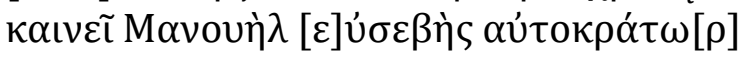
(Edition: Rhoby 2014, no. TR55, with previous bibliography)

This work of God, which had been destroyed by time, The pious Emperor Manuel restores here

The epigram is noticeably deictic: the adverb $\varepsilon^{\prime} v \theta \alpha \dot{\alpha} \delta \varepsilon$ (here) asks the reader to expand the

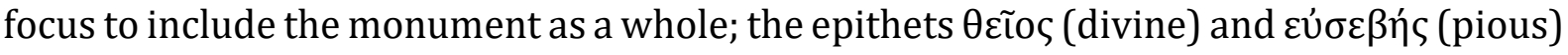
give a strong religious tone to the poem, which also makes effective use of another familiar motif, that of the destructive agency of time, a topos habitually employed to explain the motivation of patrons to fund restoration and rebuilding works.

Prominent public spaces were especially suitable for the display of imperial epigraphy. The elevated position of Manuel I's inscription is not unusual inasmuch as it replicates the placement of similarly worded messages on the city's walls and fortifications. It also reflects the aspects of the Byzantine imperial ceremonial, which involved the staging of the emperor's appearances to his subjects from a raised platform or a balcony. Moreover, the close proximity of the inscription to the large cross on top of the column adds an apotropaic quality to the whole composition intending to secure protection and stability to the emperor's monument and, by extension, to his entire capital city. Admittedly, the inscription was less visible than the cross - if visibility played any role in its desired efficacy - but it was probably legible with the help of the lead filling. Its most recognizable feature, in addition to the sign of the cross, was the emperor's name. The familiar shape of Manuel's signature would have stood out, not least for the stylistic features that it shared with another contemporary example of imperial monumental epigraphy: the Conciliar Edict of 1166 in Hagia Sophia. (See, fig. 4 and Chapter 31 by A. Rodrigez Suarez).

Manuel I's epigraphic self-presentation cannot be separated from its impressive physical surroundings. Both the inscription and the column were a centerpiece of a magnificent circular forum, which Constantine I built at the Gate of the ancient city of Byzantium. (Fig. 5) The entire area of this lavishly designed space was enclosed by a twostory colonnade, and it included two facing arches, a Senate House, and an impressive collection of ancient statues, many of which carried Latin and Greek. From the very beginning, the forum was used to exhibit the wonders of ancient culture and demonstrate Roman imperial power, but, over time, it acquired a more pronounced Christian character. The forum was the setting of Constantinople's inauguration as a new imperial capital on 11 May 330. Later on, a story appeared claiming that it was also the site of the ceremony of the dedication of the city to the Virgin. Irrespective of the veracity of this account, we know that the forum continued to be an important stop for liturgies and processions as well as the stage of the annual ceremony of the beginning of the administrative year on 1 
September. During the period of Iconoclasm, a small chapel of St Constantine was added to the platform of the column to be used in stational services, which regularly involved solemn participation of both the emperor and the patriarch. Even though much of the $4^{\text {th }}$ century splendor must have faded by the time Manuel I embarked on his renovation project, the Forum of Constantine still served as a symbolic link between the city and the emperor, and as an elaborate stage for public spectacles reinforcing the political and religious ideology of the Byzantine Empire.

\section{Selected Bibliography}

Bassett, S. (2004), The urban image of late antique Constantinople, Cambridge, 192-204. Bauer, F. A. (1996) Stadt, Platz und Denkmal in der Spätantike: Untersuchungen zur Ausstattung des öffentlichen Raums in den spätantiken Städten Rom, Konstantinopel und Ephesos, Mainz 1996, 167-187.

Bralewski, S. (2011) The Porphyry Column in Constantinople and the Relics of the True Cross, Studia Ceranea 1, 87-100.

Gehn, U. in: http://laststatues.classics.ox.ac.uk, LSA-2457 (accessed 30 March 2020).

Kaldellis, A. (2016) The Forum of Constantine in Constantinople: What do we know about its original architecture and adornment? Greek, Roman, and Byzantine Studies 56, 714739.

Mango, C. (1981) Constantine's Porphyry Column and the Chapel of St. Constantine,

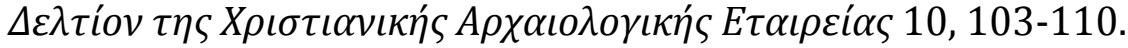

Mango, C. A. (1951) The Byzantine Inscriptions of Constantinople: A Bibliographic Survey, American Journal of Archaeology 55.1, 62.

Melvani, N. (2020) State, Strategy, and Ideology in Monumental Imperial Inscriptions, in M. Lauxtermann and I. Toth (eds), Inscribing Texts in Byzantium: Continuities and Transformations. Papers from the Forty-Ninth Spring Symposium of Byzantine Studies, Exeter College, Oxford, 18-20 March 2016, Abingdon and New York, 162-188.

Müller-Wiener, W. (1997) Bildlexikon zur Topographie Istanbuls: Byzantion, Konstantinupolis, Istanbul bis zum Beginn des 17. Jahrhunderts, Tübingen, 255.

Ousterhout, B. (2014) The Life and Afterlife of Constantine's Column, Journal of Roman Archaeology 27, 304-326.

Rhoby, A. (2014) Byzantinische Epigramme auf Stein (= Byzantinische Epigramme in inschriftlicher Überlieferung, vol. 3), Vienna, Nr. TR55

Rhoby, A. and Schreiner, P. (2018) Antiquitates Constantinopolitanae im Osmanischen Reich: Johannes Malaxos und seine Aufzeichnungen im Vat. Reg. gr. 166, Miscellanea Bibliothecae Apostolicae Vaticanae 24, 605-657, at 639-641

Yoncası Arslan, P. (2016) Towards a New Honorific Column: The Column of Constantine in Early Byzantine Urban Landscape (1), METU Journal of the Faculty of Architecture (Middle East Technical University) 33/1, 121-145. 


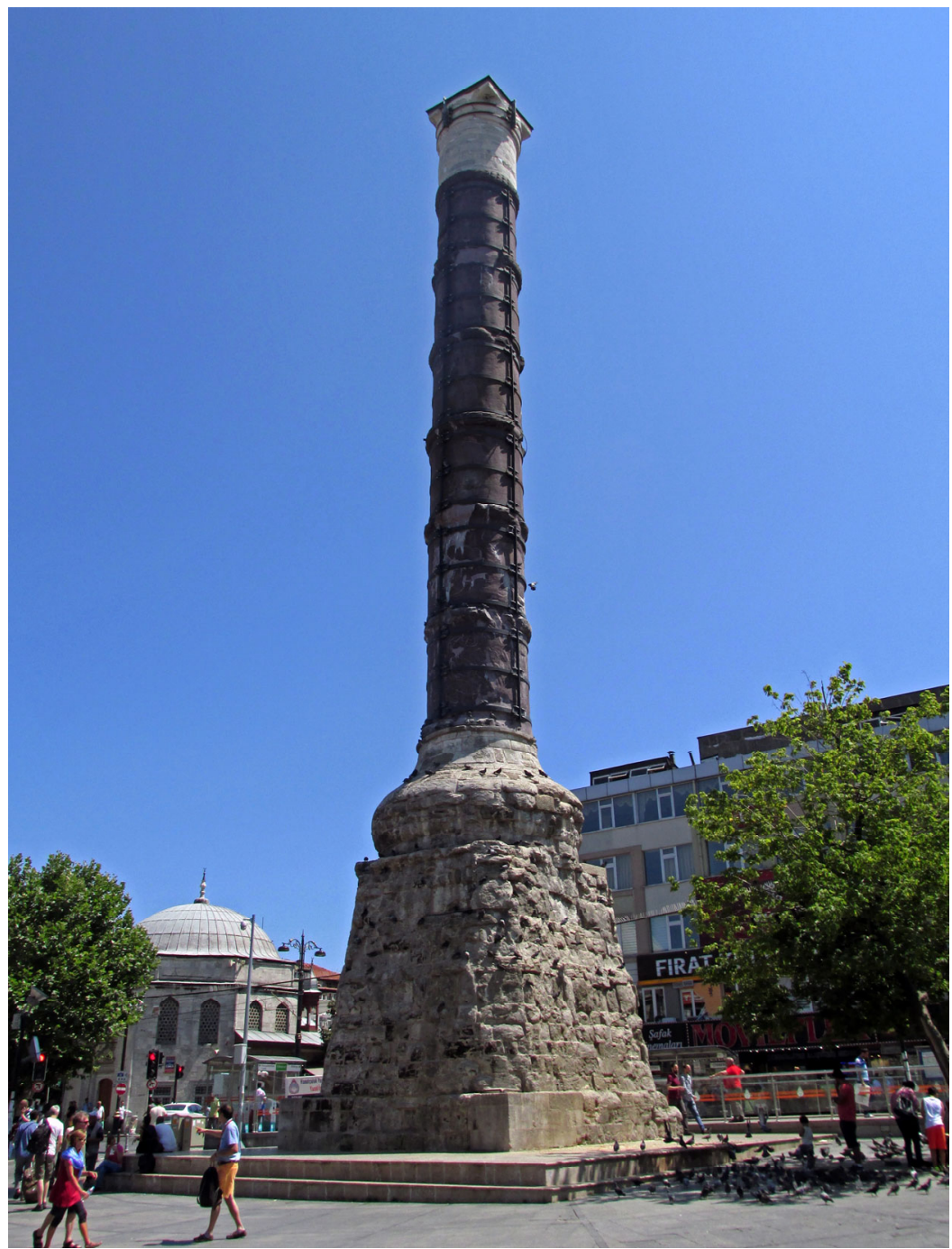

Fig. 1 The Column of Constantine (C) David Hendrix)

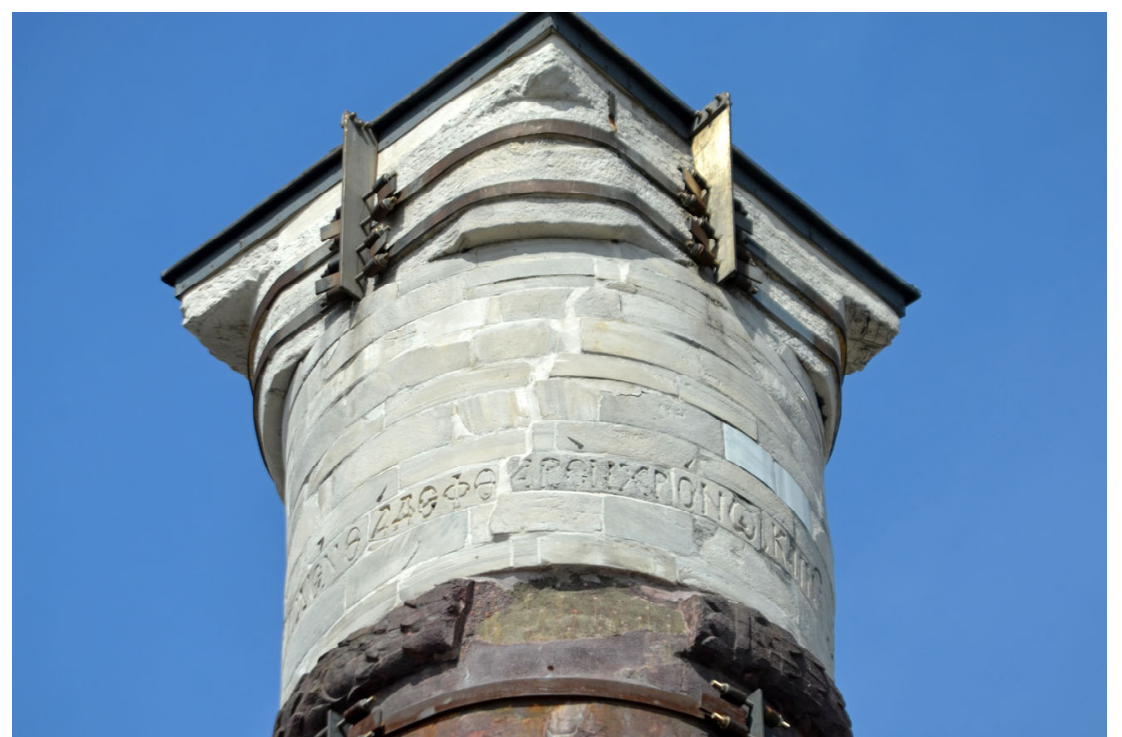

Fig. 2 Capital of the Column of Constantine (CDavid Hendrix) 


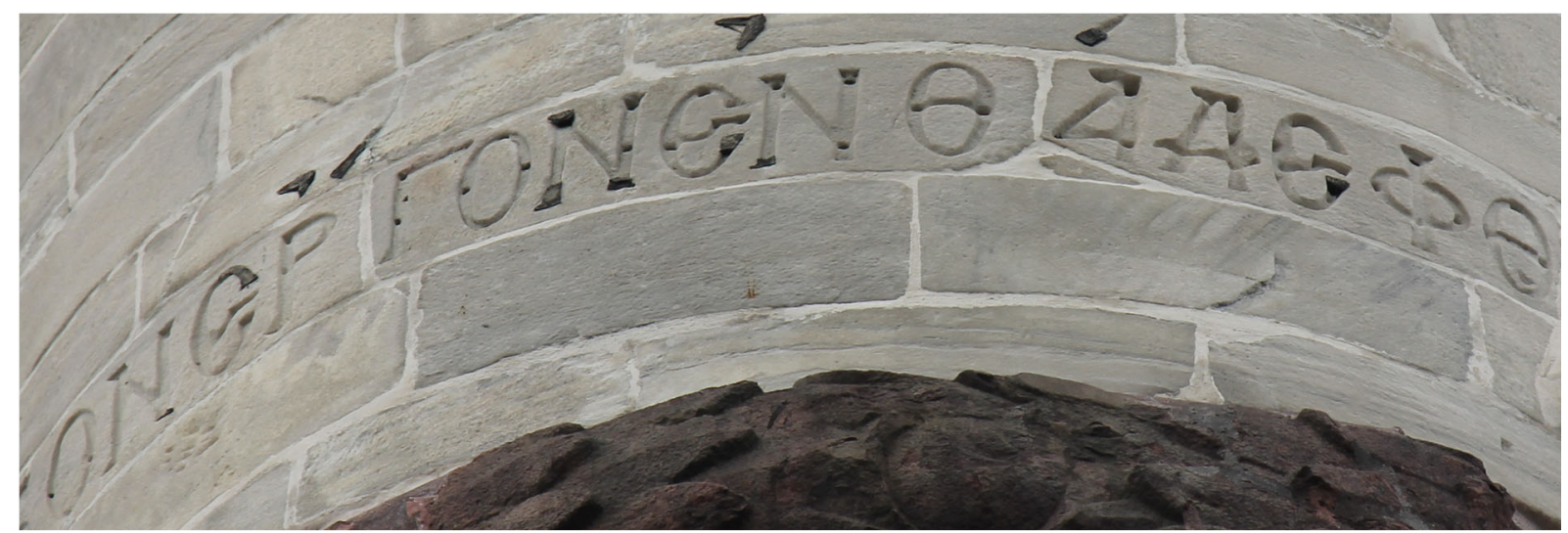

Fig. 3 Inscription by Manuel I, detail (@ Andreas Rhoby)
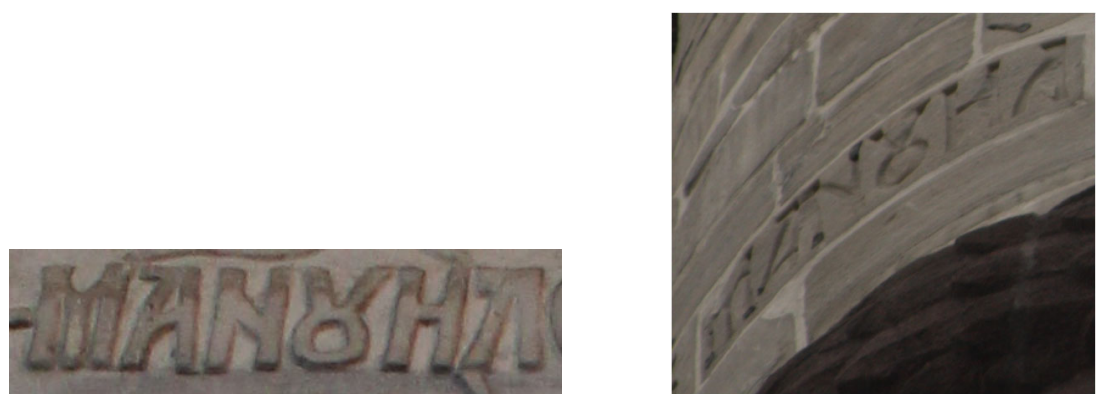

Fig. 4 Manuel I' name from St Sophia and the Column of Constantine

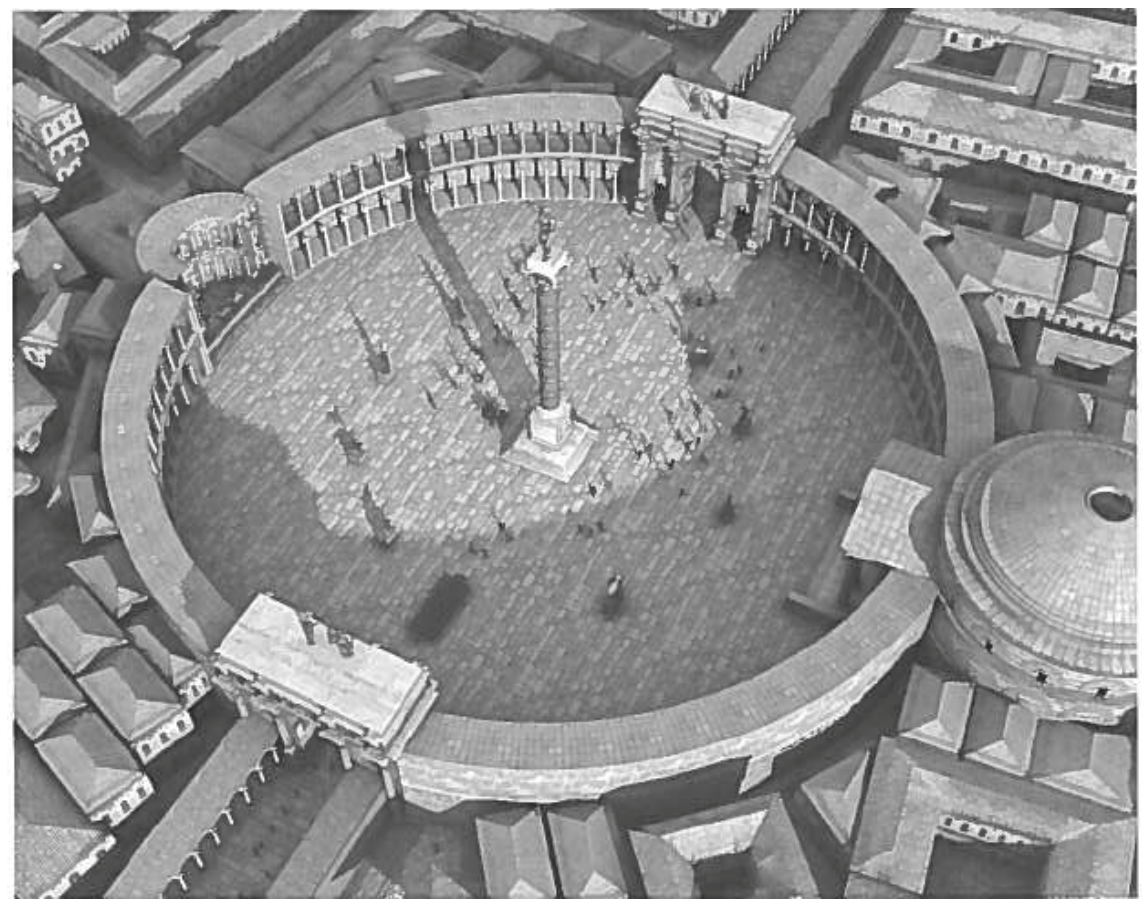

Fig. 5 Reconstructed aerial view of the Forum of Constantine (author: T. Öner, after Ousterhout 2014) 



\section{INSCRIPTIONS DISPLAYED: THE ISTANBUL ARCHAEOLOGICAL MUSEUM}





\section{Epigraphy and the Cult of Saints in Constantinople: \\ The Case of Anicia Juliana \\ PAWEŁ NOWAKOWSKI}

1) The family background of Anicia Juliana, and the political situation at the turn of the 6 th c.

- Anicia Juliana as the heir to the House of Theodosius

- Daughter of Fl. Anicius Olybrius, emperor in the West (472), and Galla Placidia the Younger

- Grand daughter of Valentinian III, emperor in the West (425-455) and Licinia Eudoxia

- Great-grand daughter of Theodosius II, emperor in the East (408-450) and Aelia Eudocia

- Descendant of Arcadius, emperor in the East (395-408)

- Descendant of Theodosius I, founder of the dynasty (389-395)

- Wife of Fl. Areobindus, consul in 506 (proclaimed emperor in 512, apparently against his will)

- Mother of Fl. Olybrius, consul in 491 (as a child)

- Mother-in-law of Irene, niece of the emperor Anastasius

- Imitating powerful women of the Theodosian dynasty: lavish building activity as a means of creating an alternative centre of power, and reclaiming the empire for her family in the troublesome later 5 th and early 6 th centuries

- Usurpers, and unstable situation in the East in the second half of the 5th c.

- 512 - Fl. Areobindus, Juliana's husband, is proclaimed emperor in an urban riot in Constantinople (but he rejects this opportunity)

- c.512 Juliana builds a church dedicated to the Theotokos en tois Honoratois

- 513-515 - the Vitalian rebellion

- 518 - the ascension of Justin I, followed by the end of the Acacian schism in 519

- c.507/508-511/512 or c.519 (?) Juliana embellishes the church of St Euphemia en tois Olybriou, built by her grandmother Licinia Eudoxia, and restored by her mother, Galla Placidia the Younger

- c.518-522 Juliana refurbishes the church of St Polyeuktos built by her greatgrand mother Eudocia

- Juliana builds a church of St Stephen (exact date unknown) in the Constantinianae, probably again imitating Eudocia's devotion to Stephen

- 527 - the ascension Justinian I 
2) The epigram from the church of Saint Polyeuktos in Constantinople, commissioned by Anicia Juliana (c.518-522).

The epigram consist of seventy-six hexameter verses originally displayed on walls, blocks, and entablatures in the nave and the narthex of the church of St. Polyeuktos. The text is preserved in extenso in the Palatine Anthology.

It praises Juliana as the person who completely refurbished the church of Polyeuktos, built by her great-grand mother Aelia Eudocia. The poem begins with a reference to Eudocia's glory. Then Juliana is presented as a benefactor equal to or even surpassing Constantine I, and king Solomon, founder of the Temple in Jerusalem. In the poem we read that 'inhabitants of the entire world praise Juliana's works', which is in a way reflected in a passage (ch. 102) in The Glory of the Martyrs by Gregory of Tours (Gaul, 582-593), giving an account of the restoration of the church of Polyeuktos, and containing an anecdote on how Juliana saved her gold from the emperor Justinian's greed by gilding the ceiling of the church (in 2006 Jonathan Bardill used this story to argue for the presence of a wooden ceiling gilded with gold at the church of Polyeuktos). The dating of Juliana's refurbishment is based on brick stamps found in situ, dated broadly to the period 507/508-511/512 and $517 / 518-521 / 522$; and on her death in 527 or 528 . In addition, the anecdote preserved by Gregory of Tours dates the refurbishment of this church to the early years of Justinian I (possibly the times when he still assisted Justin I).

A small number of Proconnesian marble fragments with phrases from verse 27 and 31 were found in 1960 during construction works near the Şehzade mosque, in the quarter of Saraçhane. They were identified by Ihor Ševčenko and first edited by him and Cyril Mango in Dumbarton Oaks Papers in 1961. The fragments became the basis for the identification of the remains of the church as being that of St Polyeuktos. Mango and Ševčenko list 'two kinds of cornices', each assembled of several fragments, 'a niche-head, and a rectangular block', but state that 'the total number of pieces found is at present difficult to determine.' Excavations directed by Martin Harrison followed, and, during six seasons (1964-1969), they brought to light more inscribed fragments, and a rich lot of capitals, columns, pillars, and other elements of architecture, all of them carvings of very high quality. Some were still bearing colour glass revetments, as, for example, one of the four columns from the canopy of the altar, which had its glass inlays preserved. However, one must remember that a number of objects from the church fell victim to looting by the Crusaders after the capture of the city in 1204. For example, two pillars and several capitals are now in Venice, in the church of San Marco.

To date, the total of seven inscribed fragments (two of them conjoining) from the first part of the poem have been identified (Figs. 1-6). Letter height 10-11.5 cm; estimated length of the complete inscription: $c .135$ running meters. Three inscribed fragments are now exhibited in the Archaeological Museum of Istanbul. More are kept in the Museum's storage (I thank Brad Hostetler for this information). According to a modern reconstruction, based on the lemmata from the Palatine Anthology and the shape of extant fragments, verses 141 were probably carved inside the nave, on six niches. Verses 42-61 were displayed on four slabs outside the narthex, and verses 62-76 on a slab to the right of the entrance (see the enclosed plan by Jonathan Bardill). Mary Whitby (2006) suggests that, in spite of the layout of the epigram as presented in the Palatine Anthology, lines 42-76 could be a separate epigram, or the first part of the poem. Exhibited in the narthex, they were 
first to be read by the visitors to the church. The two parts were perhaps even written by two different authors, because lines 42-76 seem to be less in accordance with the rules of Nonnian poetry.

A detailed analysis of the 'technical' quality of the epigram has been offered by Mary Whitby (2006). She suggests that the poem stood up to the highest poetical standards of the early 6 th c. It follows the Nonnian pattern regarding the preference for feminine caesuras, and the arrangement of accents at the ends of verses. As for the author, it has been suggested that the epigram could be composed by Juliana herself (if so, she did not imitate Eudocia in her literary tastes, as Eudocia's hexameters, for example, the eulogy of St Cyprian of Antioch of Pisidia, follow the Homeric, not the Nonnian model), or by Christodorus of Koptos, a contemporary Constantinopolitan poet using similar vocabulary, metaphors, and the structure of the metre (suggested by Francesco Tissoni in 2000).

Whitby, however, advises caution, as the similarities appear smaller than one would expect, and seventy-six verses are not enough to ensure a reliable stylistic analysis. Interestingly, the poems from the church of St Euphemia, also built by Juliana, are shorter and of slightly inferior quality compared to that of Polyeuktos (which by no means implies that they constitute bad poetry). Whitby rightly concludes that there was a good number of poets in Constantinople able to compose hexameters in the Nonnian manner, making it difficult to identify, who of them was the author of our poem.

Text after The Greek Anthology I 10, (transl. Paton, W. R.). The passages preserved on extant fragments are underlined below.

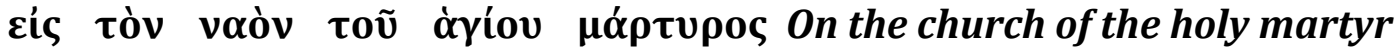

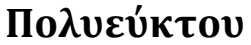 Polyeuktos}

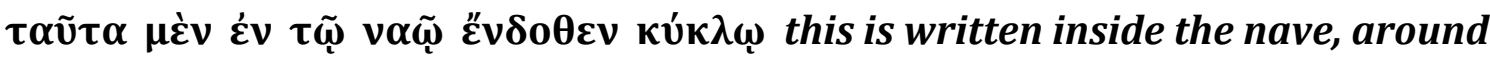

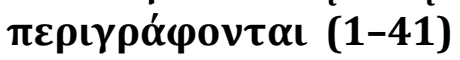

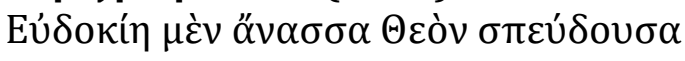

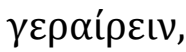

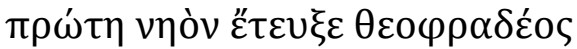

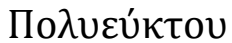

it, in a circle (1-41)

Eudocia the empress, eager to honour God, first

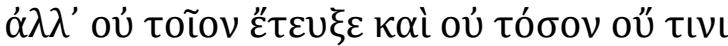
$\varphi \varepsilon เ \delta$ ог,

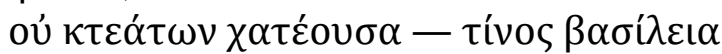

$\chi \alpha \tau i ́ \zeta \varepsilon l ;-$

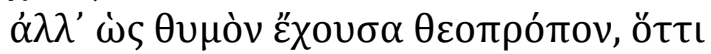

$\gamma \varepsilon v \varepsilon \dot{\varepsilon} \theta \lambda \eta$

built here a temple of Polyeuktos the

servant of

God. But she did not make it as great and beautiful

as it is, not from any economy or lack of

possessions - what doth a queen lack? -

but because her prophetic soul told her

that she should leave

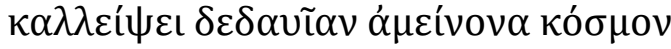

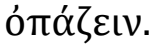

a family well knowing how better to adorn it.

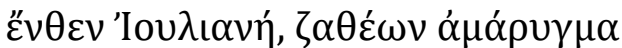

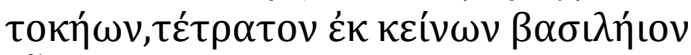

$\alpha \tilde{i} \mu \alpha \lambda \alpha \chi 0 \tilde{v} \sigma \alpha$,

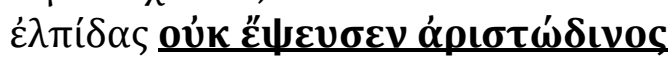

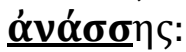

Whence Juliana,

the glory of her blessed parents, inheriting their royal blood in the fourth generation,

did not defeat the hopes of the Queen. the mother of a noble race but raised

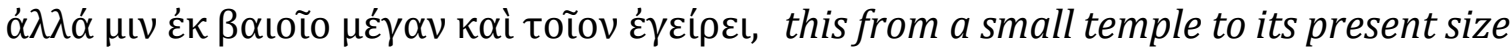




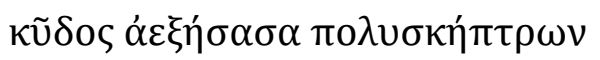

$\gamma \varepsilon v \varepsilon \tau \eta ́ \rho \omega \nu$

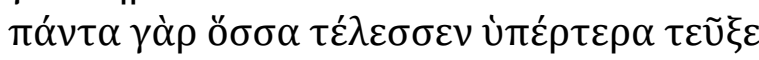

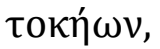

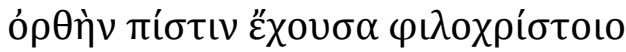

$\mu \varepsilon v o เ v \tilde{\eta} s$.

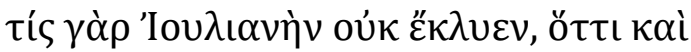

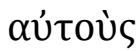

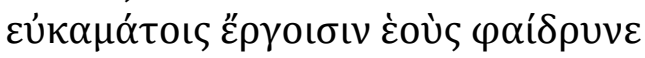

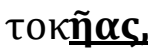

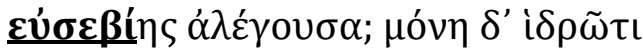

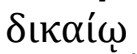

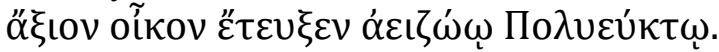

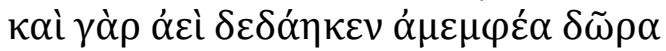

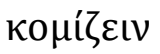

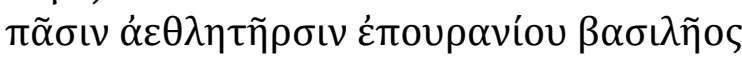

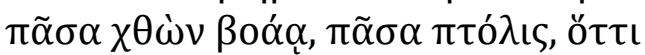

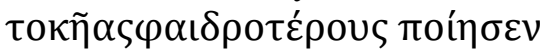

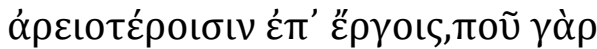

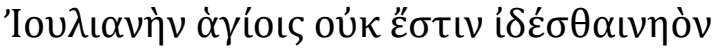

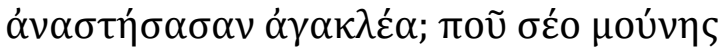

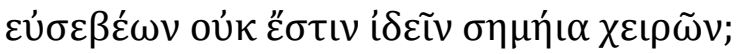

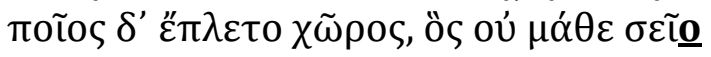



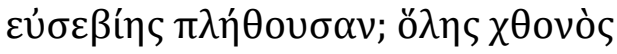

$\dot{\varepsilon} \nu \nu \alpha \varepsilon \tau \tilde{\eta} \rho \varepsilon S$

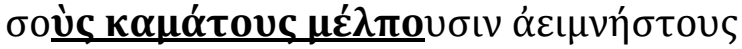
$\gamma \varepsilon \gamma \alpha \tilde{\omega} \tau \alpha \varsigma$.

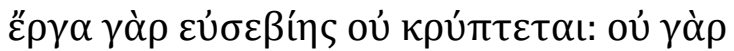

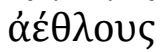

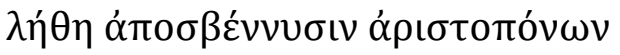

$\alpha \dot{\alpha} \rho \tau \tau \alpha \dot{\alpha} \omega v$.

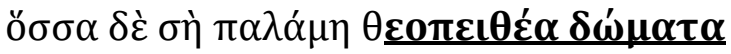

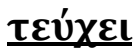

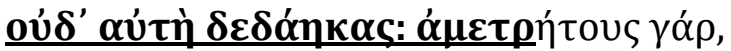

óíw,

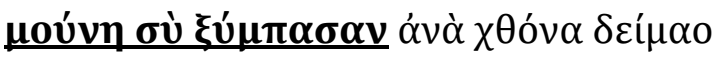

vaoús,

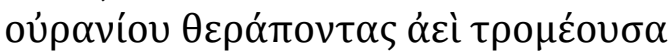

$\Theta \varepsilon$ во̃o.

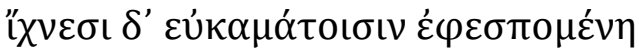

$\gamma \varepsilon v \varepsilon \tau \eta \dot{\rho} \rho \omega \nu$

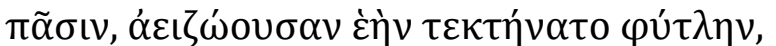

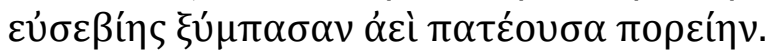

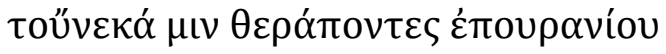

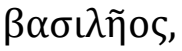

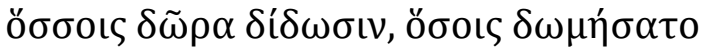

vๆoús, and beauty, increasing the glory of her

many-sceptred ancestors;

for all that she made,

she made more magnificent than they,

holding the true faith of a mind devoted to

Christ.

Who hath not heard

of Juliana,

how in her pious care

she glorified even her parents

by fair-fashioned works?

All alone by her righteous toil she built a worthy house to immortal Polyeuktos, for she had ever studied to give blameless gifts to all athletes of the Heavenly King.

Every country cries, every city,

that she made her parents more glorious by better works.

Where do we not find that Juliana hath raised splendid temples to the Saints?

Where do we not see the signs of the pious hand of thee alone?

What place hath not learnt that thy mind is full of piety?

The inhabitants of the whole world sing

\section{thy works,}

which are eternally remembered.

For the works of piety

are not hidden;

oblivion doth

not quench

the labours of beneficent virtue.

Not even thyself knoweth how many

houses dedicated to God

thy hand hath made; for thou alone,

I ween, didst build innumerable temples

all over the world, ever fearing the

servants of God in Heaven.

Following by her good works all the

footsteps of her parents

she made the fame

of her race immortal,

always walking

in the whole path of piety.

Therefore, all ye servants

of the Heavenly King

to whom she gave gifts or built temples, preserve her gladly with her son and his daughters, 


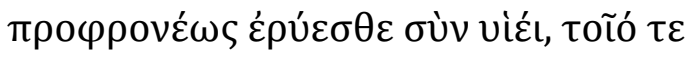
кoú $\rho \alpha \iota s:$

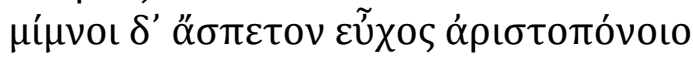
$\gamma \varepsilon v \varepsilon \dot{\theta} \theta \lambda \eta$,

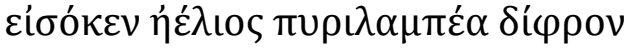

$\varepsilon \dot{\lambda} \alpha u ́ v \varepsilon t$.

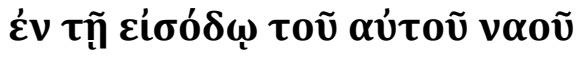 substituted by a different hand with

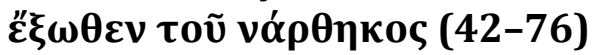

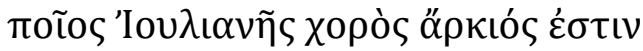

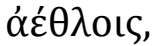

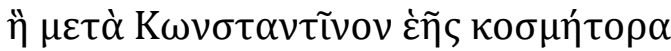

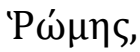

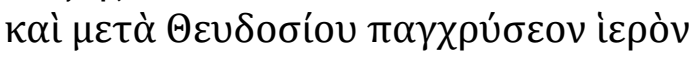

ő $\mu \mu \alpha$,

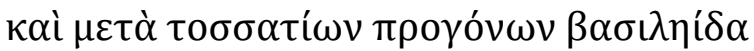

ṕí̧ $\alpha \nu$,

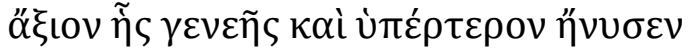

है $\rho \gamma o v$

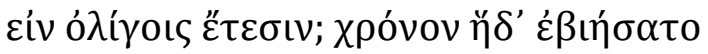

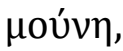

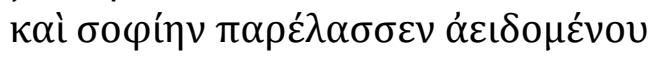

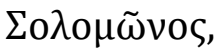

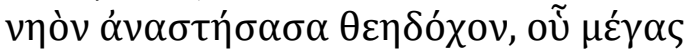

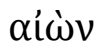

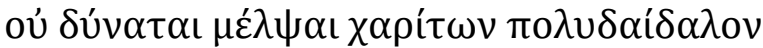

$\alpha " \gamma \lambda \eta \nu$

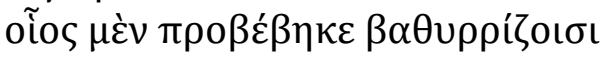

$\theta \varepsilon \mu \varepsilon \dot{\theta} \theta \lambda$ oเs,

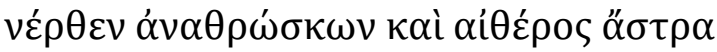

$\delta เ \omega ́ \kappa \omega \nu$

oĩos $\delta^{\prime} \alpha \dot{\alpha} v \tau o \lambda i ́ \eta \varsigma \mu \eta \kappa u ́ v \varepsilon \tau \alpha \iota ~ \varepsilon ́ \varsigma ~ \delta u ́ \sigma เ v$

है $\rho \omega \omega v$,

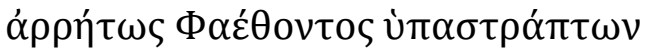

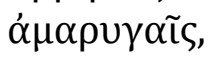

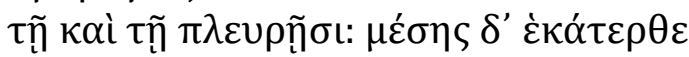

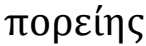

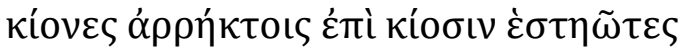

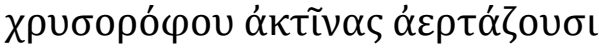

$\kappa \alpha \lambda u ́ \pi \tau \rho \eta \varsigma$.

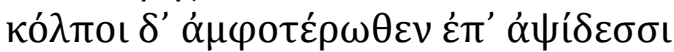

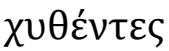

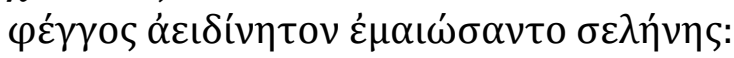

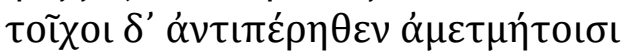

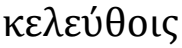

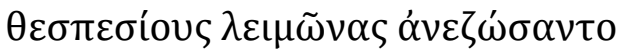

$\mu \varepsilon \tau \alpha \dot{\alpha} \lambda \lambda \omega \nu$, and may the immeasurable glory

of the most beneficent family

survive as long

as the Sun drives

his burning chariot.

at the entrance of the same church, substituted by a different hand with outside the narthex (42-76)

What quire is sufficient to chant the works of

Juliana, who after Constantine, the adorner of

his Rome, and after the holy golden light of Theodosius, and after so many royal

ancestors,

in a few years

accomplished a work worthy of her race, yea, more than worthy? She alone did violence to Time and surpassed the wisdom of renowned

Solomon by raising a habitation for God, whose

glittering and elaborate beauty the ages cannot

celebrate - how it rises from its deeprooted foundations, running up from the ground and aspiring to the stars of heaven, and how from east to west it extends itself glittering with unspeakable brightness in the sunlight on both its sides!

On either side of its aisle columns standing on firm columns support the rays of the golden dome, while on each side arched recesses scattered on the dome reproduce the ever-revolving light of the moon.

The opposite walls

in innumerable paths are clothed in marvellous metallic veins of colour, like flowery meadows which Nature made to flower in the depth of the rock, and hid their glory, keeping them for the

House of God, to be the gift of Juliana, so that she might produce a divine work, following in her toil 


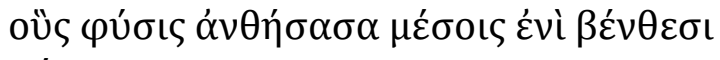

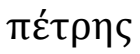

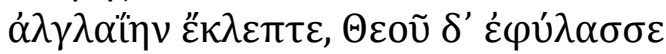
$\mu \varepsilon \lambda \alpha \dot{\theta} \theta \rho o เ \varsigma$,

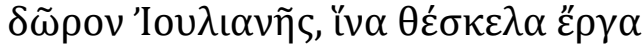
$\tau \varepsilon \lambda \varepsilon \dot{\varepsilon} \sigma \emptyset \eta$

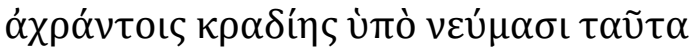
$\kappa \alpha \mu о \tilde{\sigma} \sigma$.

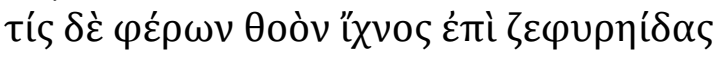
$\alpha u ̋ \rho \alpha$

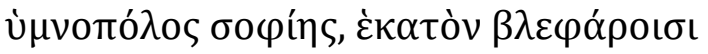

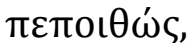

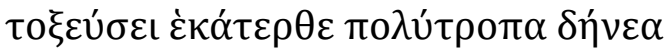

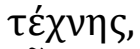

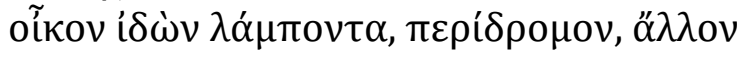

$\varepsilon \dot{\varepsilon} \pi^{\prime} \alpha \lambda \lambda \omega$,

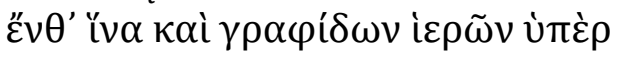

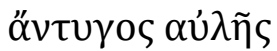

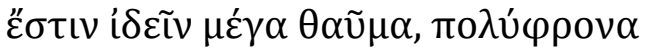

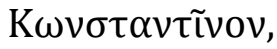

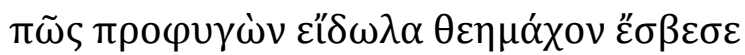

$\lambda u ́ \sigma \sigma \eta v$,

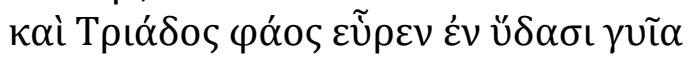

$\kappa \alpha \theta \dot{n} \rho \alpha \varsigma$.

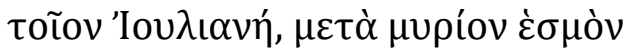

$\alpha \dot{\alpha} \theta \lambda \omega v$,

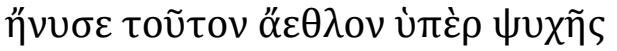

$\gamma \varepsilon v \varepsilon \tau \dot{p} \rho \omega v$,

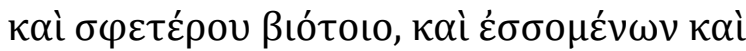

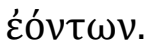

the stainless dictates of her heart. What singer of

skilful works shall now hasten to the west, armed

with a hundred eyes, and read aright the various

devices on the walls, gazing on the circle of

the

shining house, one story set on another?

There

you may see

a marvellous creation

of the holy pencils

above the centre

of the porch,

the wise Constantine,

how escaping

from the idols he quenched the impious

fury

of the heathen

and found the light of the Trinity

by cleansing his limbs in water.

Such is the labour that Juliana,

after a countless swarm of labours,

accomplished for the souls

of her parents,

and for her own life,

and for that of those

who are and shall be.

3) Polyeuktos, a martyr of Melitene

- A 4th/5th c. martyrdom account (BHG 1566-1567) presents Polyeuktos as a soldier, friend and companion of Nearchos, and son-in-law of Felix. Felix was reportedly commissioned to persecute Christians 'under Decius and Valerian'. He sentenced Polyeuktos to death for throwing pagan idols onto the ground, and destroying a copy of an imperial edict. Feasts celebrated on 9 January, and 25 December

Efthymios Rizos, Cult of Saints, E02836 -

http://csla.history.ox.ac.uk/record.php?recid=E02836

- Appendix to the martyrdom account describing the translation of relics of Polyeuktos to a certain Kana (in Lycaonia or Egypt) by Nearchos.

Efthymios Rizos, Cult of Saints, E02837 -

http://csla.history.ox.ac.uk/record.php?recid=E02837 
- The Syriac Martyrology: feast celebrated on 7 January, at Melitene Sergey Minov, Cult of Saints, E01406 http://csla.history.ox.ac.uk/record.php?recid=E01406

- Georgian Calendar of Jerusalem: 9 January Nikoloz Aleksidze, Cult of Saints, E02912 http://csla.history.ox.ac.uk/record.php?recid=E02912

- Gregory of Tours (Histories 7.6): in 584 the Frankish kings Gountram and Chilperic invoke Polyeuktos, Martin of Tours, and Hilary of Poitiers, as saints who would punish the person that would break a pact

Katarzyna Wojtalik, Cult of Saints, E06249 http://csla.history.ox.ac.uk/record.php?recid=E06249

Polyeuktos and Aelia Eudocia

- It could be that Polyeuktos's particular insight into the cases of perjury was the reason that Aelia Eudocia chose him as the patron of the church. She was accused of adultery in c.443 and may have taken an oath to prove her innocence. But in spite of that she was subsequently forced into exile (I thank Efthymios Rizos for these suggestions).

- For a different explanation, see Bardill 2006, 341 (after Pizzone 2003 and an earlier idea of Marlia Mundell Mango), who writes: 'Eudokia had been a monophysite but had converted to Chalcedonian orthodoxy in about 455, having been persuaded to do so by abbot Euthymius, whose birth had been foretold at the shrine of St. Polyeuktos in Melitene. It does not seem unreasonable to suggest that, in commemoration of her conversion, Eudokia had sent relics of St. Polyeuktos from her home in Jerusalem to Constantinople, for deposition in an existing church that was to be rededicated to that saint.'

4) The epigram in the church of Saints Sergios and Bakchos in Constantinople, commissioned by Justinian and Theodora (527-548). A direct response to Juliana's poem?

The epigram consists of 12 hexameter verses, running on the upper part of the frieze around the nave, in raised, ornamental letters. The letters were painted white on a blue background. They are preserved in situ. (See, also, Canan Arıkan and Andreas Rhoby, Chapter 4)

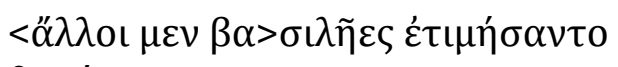
$\theta \alpha \nu o ́ v \tau \alpha \varsigma$

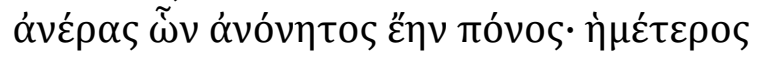
$\delta \grave{\varepsilon}$

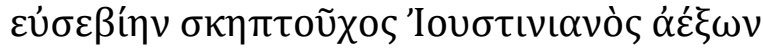

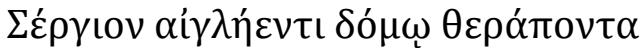

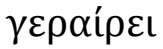

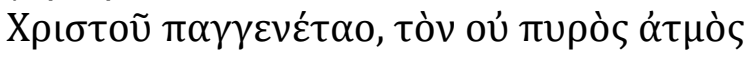
óvó $\pi \tau \omega \nu$
Other sovereigns have honoured dead men whose labour was unprofitable, but our sceptered Justinian, fostering piety, honours with a splendid abode the Servant of Christ, Begetter of all things, Sergios;

whom not the burning breath of fire, nor the sword, nor any other 


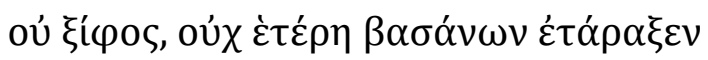

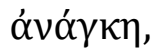

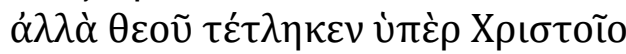
$\delta \alpha \mu \tilde{\eta} v \alpha \iota$

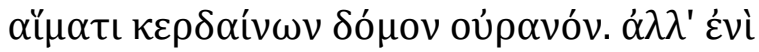
$\pi \tilde{\alpha} \sigma \mathrm{\iota \nu}$

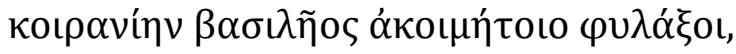

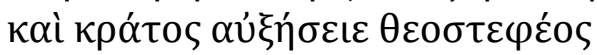

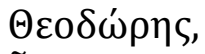

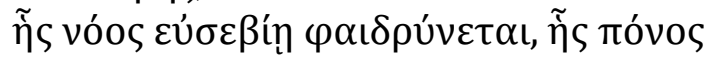

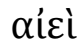

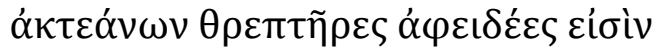
$\alpha \dot{\alpha} \gamma \tilde{\omega} v \varepsilon \varsigma$. constraint of torments disturbed; but who endured to be slain for the sake of Christ, the God, gaining by his blood heaven as his home.

May he in all things guard the rule of the sleepless sovereign and increase the power of the God-crowned Theodora whose mind is adorned with piety, whose constant toil lies in unsparing efforts to nourish the destitute.

Text: Shahîd 2003: 477, transl. Alexander van Millingen, modified by Cyril Mango.

Based on the evidence of the above mentioned anecdote by Gregory of Tours (Glory of the Martyrs 102) and of the contents of the Justinian and Theodora's poem, it has been suggested that the inscription from Saints Sergios and Bakchos was a direct response to Juliana's epigram, meant to discredit her hybris, and her trust in the glorious past of her dynasty, which seemed more important to her than Christian humility, and praising the martyr's deeds. As Justinian and Theodora could not claim an equally glorious ancestry, they place emphasis onto other virtues: moderation, humility, and an apt selection of the martyr they venerated (a famous saint instead of a marginal one).

The existing evidence is, however, insufficient to support this interpretation. The poem from the Church of Sergios and Bakchos probably vaguely refers to former emperors honouring mortal men, or possibly to all other rulers paying honours to pagan heroes. The author of the poem argues that their shedding of blood was futile while Christian martyrs died for the sake of salvation, and to bear witness to the true God, saviour of mankind. Therefore, they, not the heroes or aristocrats, represent the examples to be faithfully followed and commemorated.

5) Anicia Juliana's other foundations and dedications to saints

a) Juliana builds a church dedicated to the Virgin Mary (Theotokos) en tois Honoratois on the Asian shore of the Bosphorus. It is first mentioned in an illuminated medical manuscript, the Vienna Dioskorides, which preserves an image of Juliana next to an honorific inscription expressing the gratitude of inhabitants of the district to Juliana for constructing this church. Later, it is recorded by Theophanes' Chronographia under AM 6005. See Nathan 2006: 435-437, proposing that the dedication of the church to Mary Theotokos was aimed at discrediting Anastasius' non-Chalcedonian religious policy. Hence, Nathan also dates its construction to the Vitalian rebellion (c.513-515). The use of the term Theotokos as an anti-Miaphysite slogan is, however, not obvious, since it primarily denoted any opponent of the Nestorian dogma. 
b) Juliana embellishes the church of St Euphemia (a saint associated with the Chalcedonian creed) en tois Olybriou. The shrine was a foundation of her grandmother Licinia Eudoxia and underwent a former restoration under her mother Placidia the Younger. This work is commemorated by six epigrams preserved in the Palatine Anthology I 12-17. The foundation almost certainly postdates that of the church of Mary Theotokos. This dating is based on the assumption that some brick stamps found in the church of Polyeuktos, dated 507/508-511/512 (which may be too early for Polyeuktos), come from an earlier building by Juliana, probably the church of Euphemia. Another dating is to a period around 519: after the death of Anastasius and the reconciliation of the Constantinopolitan patriarchate with Rome. See NATHAN 2006: 437 n. 21, 438.

c) In 1903, Jules Pargoire (p. 489) argued the church of St Stephen in the Constantinianae was also a foundation of Juliana, possibly imitating Eudocia's church and monastery to Stephen in Jerusalem (dedicated in 439 and rededicated in 460), or her bringing of relics of Stephen to Constantinople in 439. This hypothesis was supported by Mango and Ševčenko (1961: 244), based on the fact the Church of Polyeuktos lay in the same quarter, which was probably the site of Anicii family estate, and of Juliana's residence, ta Ioulianes.

d) Provincial shrines of martyrs reportedly built by Juliana before 522 are mentioned in the poem from the church of St Polyeuktos.

\section{Selected bibliography}

Bardill, J. (2000) The church of Sts. Sergius and Bacchus in Constantinople and the Monophysite refugees, Dumbarton Oaks Papers 54, 1-11.

Bardill, J. (2006) A new temple for Byzantium: Anicia Juliana, King Solomon, and the gilded ceiling of the church of St Polyeuktos in Constantinople', in: Bowden, W., Gutteridge, A., and Machado, C. (eds) The Social and Political Archaeology of Late Antiquity [= Late Antique Archaeology 3/1], Leiden, 339-370.

Bardill, J. (2011) 'Église Saint-Polyeucte à Constantinople: nouvelle solution pour l'énigme de sa reconstruction', in Spieser, J.-M. (ed) Architecture paléochrétienne, Gollion, 77103 and 155-158 (see the comments in Bulletin épigraphique 2013, 510).

Capizzi, C. (1968) Anicia Giuliana (462 ca.-530 ca.): Ricerche sulla sua famiglia e la sua vita, Rivista di studi bizantini e neoellenici n. s. 5, 191-226.

Connor, C. (1999) The epigram in the church of Hagios Polyeuktos in Constantinople and its Byzantine response, Byzantion 59, 379-527.

Fowden, G. (1994) Constantine, Silvester and the church of S. Polyeuctus in Constantinople, Journal of Roman Archaeology 7, 274-284.

Harrison, R. M. (1989) A Temple for Byzantium: The Discovery and Excavation of Anicia Juliana's Palace-Church in Istanbul, London.

Harrison, R. M., and Hayes, J. W. (eds) (1986) Excavations at Saraçhane in Istanbul, Princeton and Washington, D. C.

Janin, R. (1969) La géographie ecclésiastique de l'empire byzantin, vol. 1: Les églises et les monastères de la ville de Constantinople (2 ${ }^{\text {nd }}$ ed.), Paris, 405-406.

Krautheimer, R. (1974) Again Saints Sergius and Bacchus at Constantinople, Jahrbuch der Österreichischen Byzantinistik 23, 251-253. 
Mango, C. (1972) The church of Saints Sergius and Bacchus at Constantinople and the alleged tradition of octagonal palatine churches, Jahrbuch der Österreichischen Byzantinistik 21, 189-193.

Mango, C. (1975) The church of Sts. Sergius and Bacchus once again, Byzantinische Zeitschrift 68, 385-392.

Mango, C., and Ševčenko, I. (1961) Remains of the church of St. Polyeuktos at Constantinople, Dumbarton Oaks Paper 15, 243-247.

Mathews, T. F. (1974) Architecture et liturgie dans les premières églises palatiales de Constantinople, Revue de l'art 24, 22-29.

Milner, Ch. (1994) The image of the rightful ruler: Anicia Juliana's Constantine mosaic in the church of Hagios Polyeuktos', in Magdalino, P. (ed) New Constantines: The Rhythm of Imperial Renewal in Byzantium, 4th-13th Centuries: Papers from the Twenty-sixth Spring Symposium of Byzantine Studies, St Andrews, March 1992, Aldershot, 73-81.

Nathan, G. (2006) Pothos tes philoktistou: Anicia Juliana's architectural narratology, in Burke, J., et alii (eds), Byzantine Narrative. Papers in Honour of Roger Scott, Melbourne, 433-443.

Pargoire, J. (1903) Constructions de Juliana Anicia, Byzantinische Zeitschrift 12, 486-490.

Pizzone, M. V. (2003) Da Melitene a Costantinopoli: S. Polieucto nella politica dinastica di Giuliana Anicia: alcune osservazione in margine ad A.P. I 10, Maia 55, 107-132.

Russo, E. (2004) La scultura di S. Polieucto e la presenza della Persia nella cultura artistica di Constantinopoli nel VI secolo, in La Persia e Bisanzio, Atti dei Convegni Lincei 201 (Roma, 14-18 ottobre 2002), Rome, 737-826.

Schachner, L. A. and Parpulov, G. R. (eds) (2011) From the Bosporus to Oxford: Unseen Photographs from Prof. Harrison's Byzantine Excavations in Istanbul. An Exhibition at the Ioannou Centre for Classical and Byzantine Studies, University of Oxford Hilary Term 2011.

Shahîd, I. (1996), Byzantine Studies Conference Abstracts 22, 84.

Shahîd, I. (2003) The church of Sts Sergios and Bakchos in Constantinople. Some new

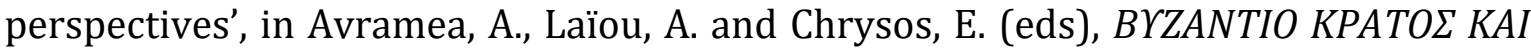
KOINSNIA. MNHMH NIKOY OIKONOMIAH - Byzantium, State and Society. In memory of Nikos Oikonomides, Athens, 467-480 (with further bibliography).

Speck, P. (1991) Juliana Anicia, Konstantin der Große und die Polyeuktoskirche in Konstantinopel, Poikila Byzantina 11, 133-147.

Strube, C. (1984) Polyeuktoskirche und Hagia Sophia: Umbildung und Auflösung antiker Formen, Entstehung des Kämpferkapitells, Munich.

Tissoni, Fr. (2000) Christodoro, un'introduzione e un commento, Alessandria.

Vikcers, M. J. (1986) A 'new' capital from St Polyeuktos, in Harrison, R. M., and Hayes, J. W. (eds) Excavations at Saraçhane in Istanbul, vol. 2, Princeton and Washington, D. C., 213216.

Vickers M. J. (1989) A 'new' capital from St Polyeuktos (Saraçhane) in Venice, Oxford Journal of Archaeology 8, 227-230.

Whitby, M. (2006) The St Polyeuktos epigram (AP 1.10): A literary perspective, in Johnson, S. F. (ed) Greek Literature in Late Antiquity: Dynamism, Didacticism, Classicism, Aldershot, 159-188.

See, also, the bibliography of the Church of Sts Sergios and Bakchos by Canan Arlkan and Andreas Rhoby (see Chapter 4) in this booklet. 
The Cult of Saints in Late Antiquity database records:

Efthymios Rizos, David Lambert, Cult of Saints, E00553 http://csla.history.ox.ac.uk/record.php?recid=E00553

Efthymios Rizos, David Lambert, Cult of Saints, E00555 -

http://csla.history.ox.ac.uk/record.php?recid=E00555

The Byzantine Legacy website:

David Hendrix http://www.thebyzantinelegacy.com/polyeuktos

The Qantara website (Patrimoine Méditerranéen)

https://www.qantara-med.org/public/show_document.php?do_id=656

Photographs of fragments with the epigram for Polyeuktos (from The Byzantine Legacy website):
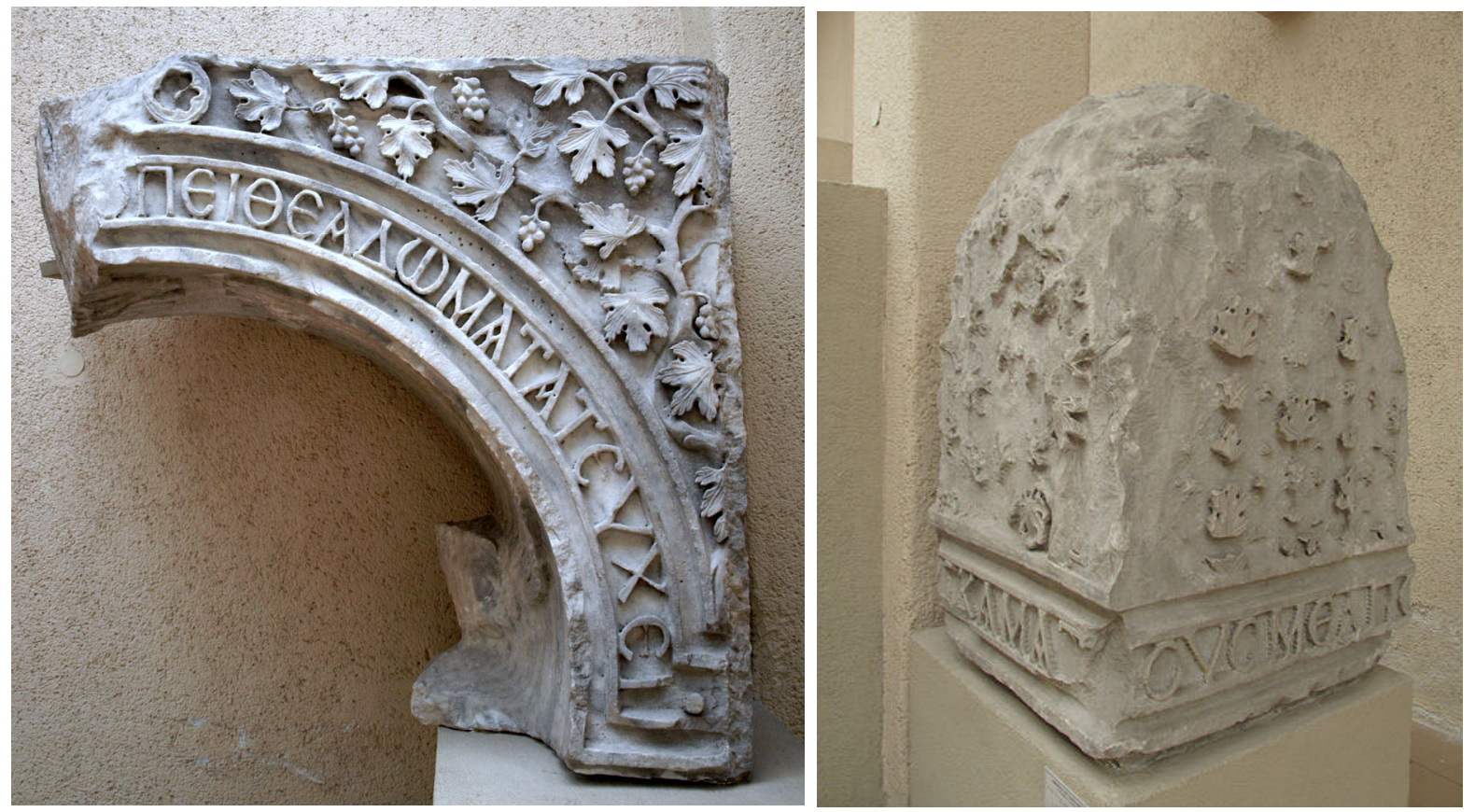

Figs. 1-2

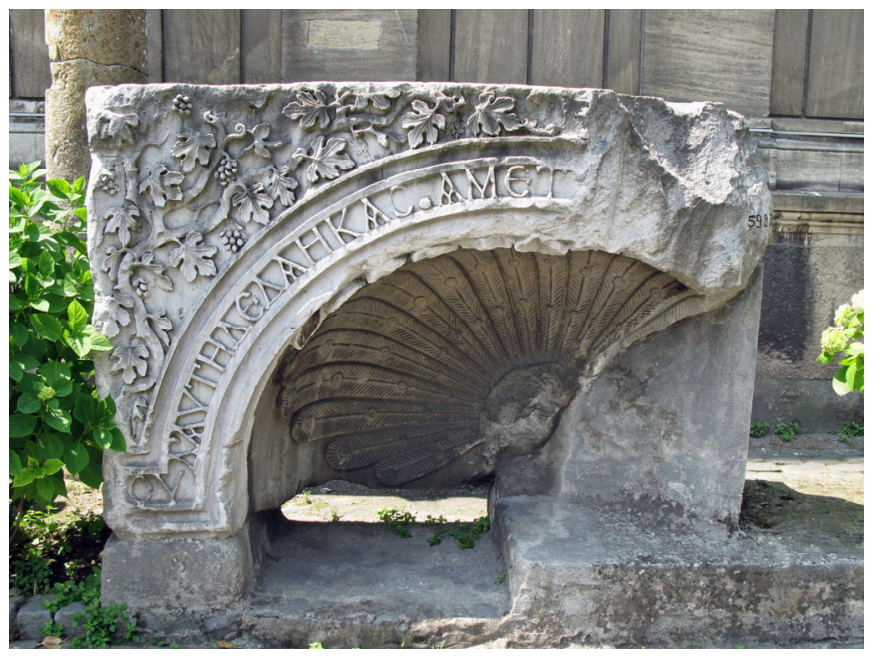

Fig. 3 
Photographs of fragments with the epigram for Polyeuktos (courtesy of Brad Hostetler):

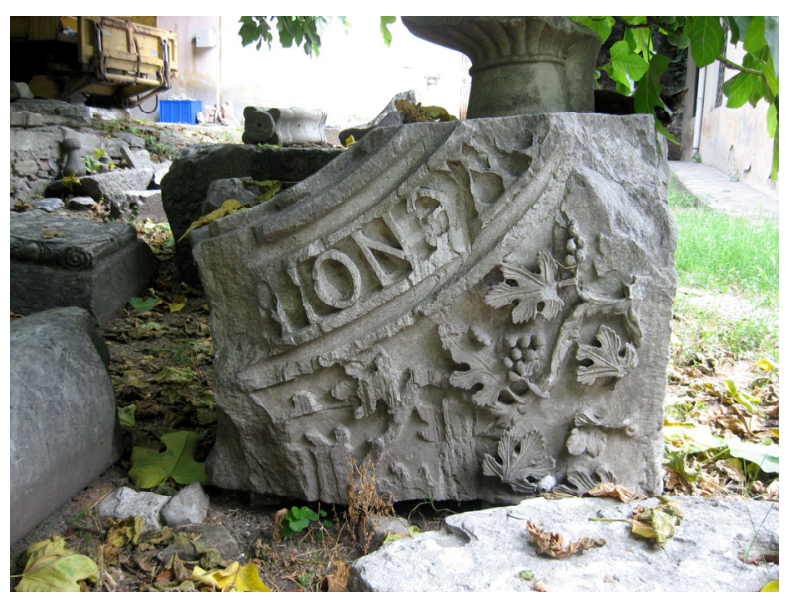

Fig. 4

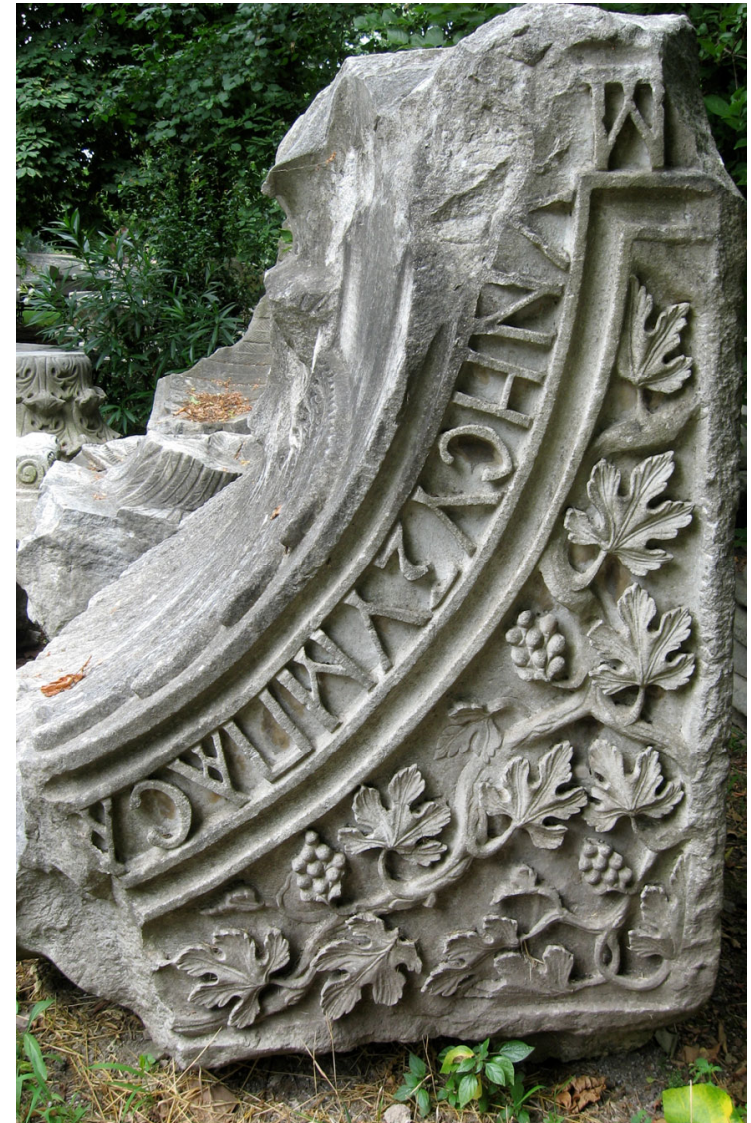

Fig. 6

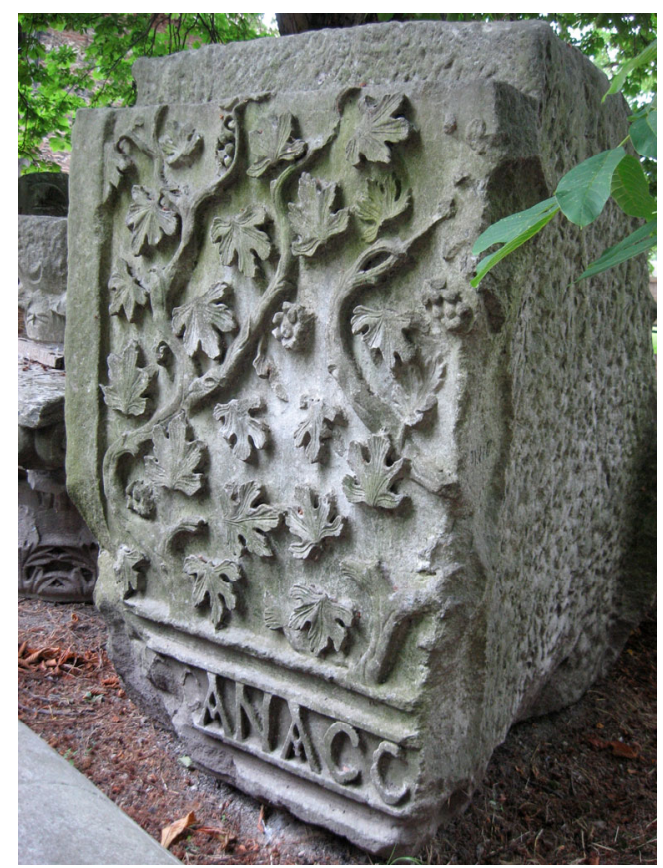

Fig. 5 
Proposed plan of the church (from The Byzantine Legacy website, after Harrison 1989):

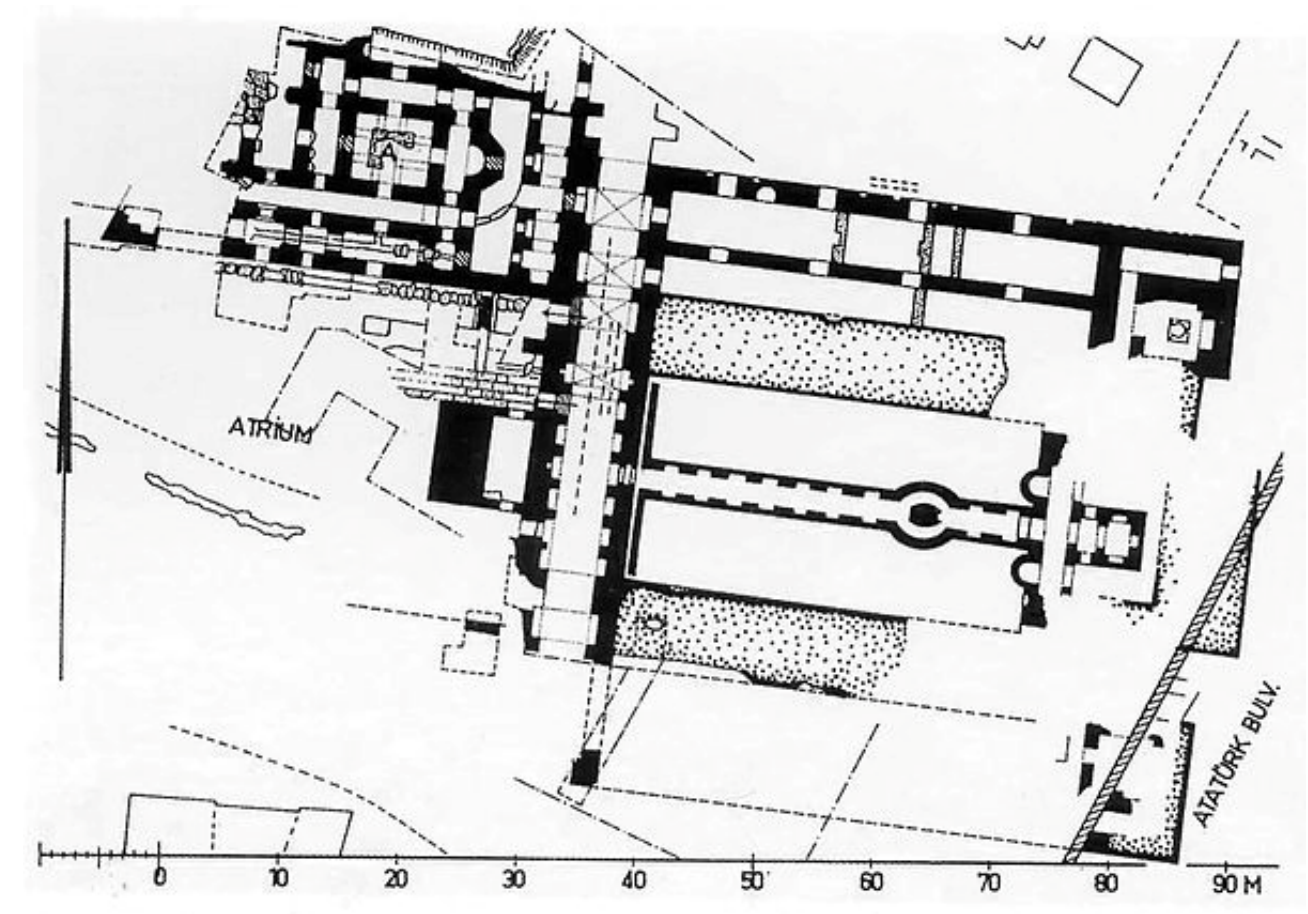

Proposed plan of the church with positions of verses 1-41 marked on six exedrae (from Bardill 2006)

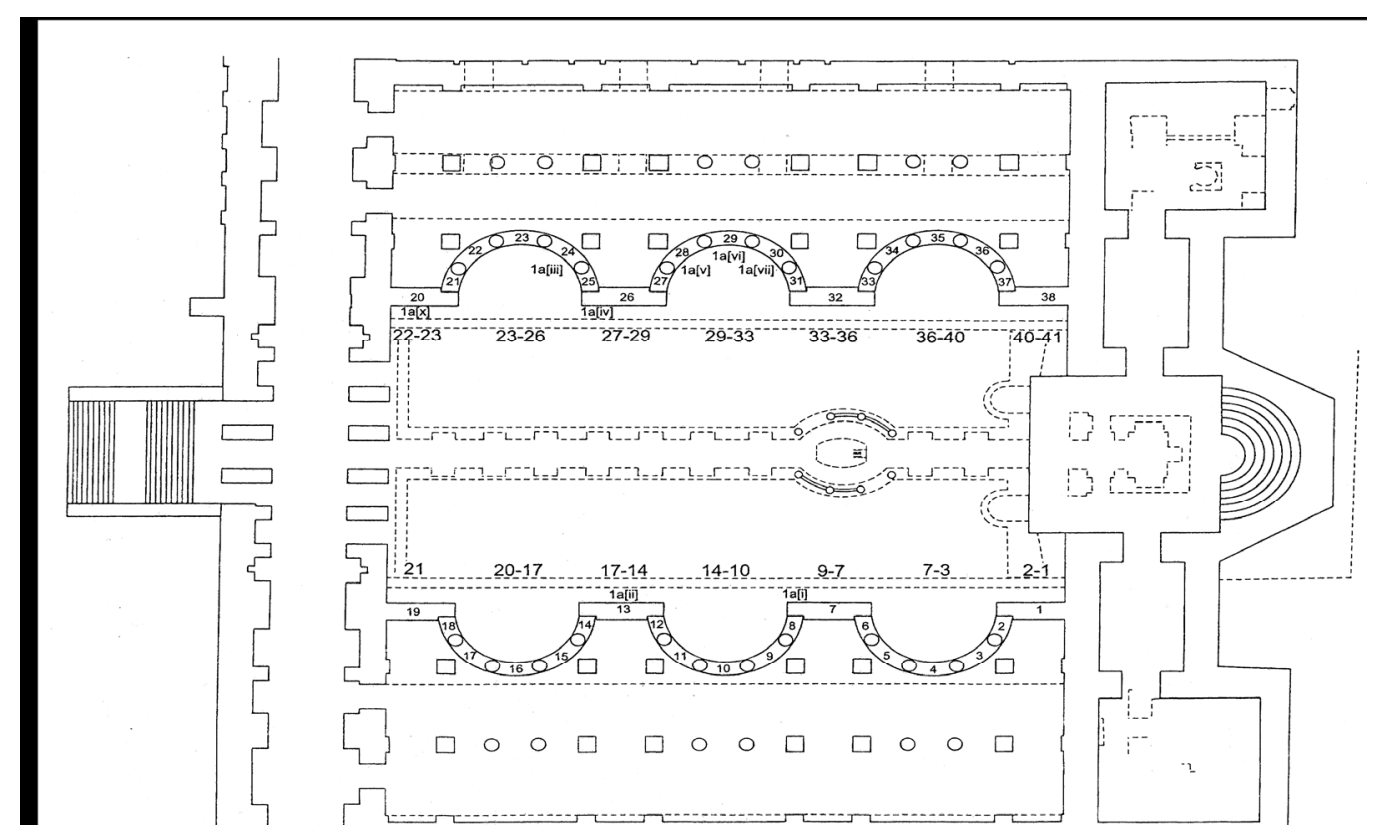





\section{The Epigraphy of Commemoration: Late Antique Epitaphs from Constantinople \\ MARIA XENAKI}

In his pioneering article published in 1951, Cyril Mango announced the beginning of a systematic study of the Byzantine inscriptions of Constantinople: he included about sixty epitaphs in this study, most of them having been scattered in obscure and often unobtainable publications. The critical edition of these epitaphs by Vitalien Laurent, to which Mango referred, has never been accomplished. In 1978, Mango together with his colleague and friend Ihor Ševčenko published twenty-five new epitaphs, discovered in the sixties and seventies in various places of Istanbul. This publication appeared in the framework of their joint project "A Corpus of the Dated Byzantine Inscriptions of Constantinople". Such a corpus is still a major desideratum in the field of Byzantine epigraphy, without which our knowledge of late antique epitaphs from Constantinople and its surroundings remains incomplete. This lack has been in part remedied by the recent work on Thracian and Bithynian inscriptions: for Thrace, we have the publication of Catherine Asdracha, which incorporates about twenty-three epitaphs dating back to the period between the third up and the seventh centuries. A series of epitaphs from Bithynia has benefited from the recent editions by Sencer Şahin, Reinhold Merkelbach, Thomas Corsten and Denis Feissel. In 1995, Sencer Şahin and Hatice Kalkan published eleven cruciform steles, most of them found near the gates of the capital's walls. This is an indication of the presence of cemeteries in these places, the location of which is otherwise poorly documented due to the lack of systematic excavations.

The formulae used in the late antique epitaphs of Constantinople are largely inherited from the pre-Christian burial tradition. Among the terms denoting the grave in GrecoRoman and then in Christian monuments, we find some Constantinopolitan examples of $\mu v \eta \dot{\mu} \eta$ and $\mu v \tilde{\eta} \mu \alpha$, of $\sigma \tau \eta \dot{\eta} \lambda \eta$, of $\tau \alpha \dot{\alpha} \varphi o \varsigma$, as well as formulations little attested elsewhere, such as vंró $\mu \nu \eta \mu \alpha$ and $\lambda \alpha \tau o ́ \mu ı v / \lambda \alpha \tau o ́ \mu เ v$. To my knowledge, the Christian term

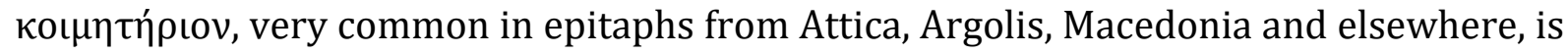
not attested in Constantinople. The most widely attested formula indicating the place of burial is $\varepsilon \nu \theta \alpha ́ \delta \varepsilon \kappa \varepsilon \tau \tau \tau \iota$ or more often $\kappa \alpha \tau \alpha ́ \kappa \varepsilon เ \tau \alpha \mathrm{l}$, used sometimes in the first person. The death is indicated in most cases by the well-known verb (in ancient epitaphs) $\tau \varepsilon \lambda \varepsilon v \tau \alpha \dot{\alpha} \omega$, and rarely by the verb $\alpha v \alpha \pi \alpha u ́ \rho \alpha$, typical in Christian inscriptions. In rare cases, the


Another verb, largely attested in the epitaphs of Egypt and Palestine, namely коцнóo $\mu \alpha$, commonly used in the passive aorist غ́коциं $\theta \eta$, is very rare in Constantinople. The deceased is often accompanied by the expression $\tau \tilde{\eta} \varsigma \mu \alpha \kappa \alpha \rho i \alpha \varsigma \mu \nu \eta \dot{\eta} \mu \varsigma$, or less frequently

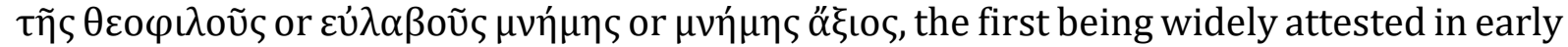

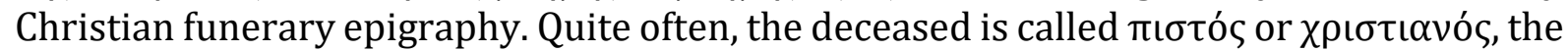
two epithets being used in late antique epigraphy to emphasize the affirmation of the Christian faith (reflecting probably an anti-heretic position). In more elaborate epitaphs, the office or occupation of the deceacsed, his nickname, his family ties, and even his place of origin can be specified.

Overall, we can identify two dominant features that belong in the broader context of epigraphic commemoration in the Christian East: one is the permanence of themes used in pagan epitaphs, especially in the epitaphs written in verse; the other, the use of formulas borrowed from liturgical prayers for the deceased. 


\section{Selected Bibliography}

Mango, C. (1951) The Byzantine Inscriptions of Constantinople: A Bibliographical Survey, American Journal of Archaeology 55, 52-66.

Mango, C., and Ševčenko, I. (1978) Some Recenlty Acquired Byzantine Inscriptions at the Istanbul Archaeological Museum, Dumbarton Oaks Papers 32, 1-27.

Asdracha, C. (2003) Inscriptions protobyzantines et byzantines de la Thrace orientale et de l'ile d'Imbros (IIIe-XVe siècles), Athens.

Şahin, S. (1978) Bithynische Studien (= Inschriften griechischer Städte aus Kleinasien, vol. 7), Bonn.

Şahin, S. (1979) Katalog der antiken Inschriften des Museums von Iznik (Nikaia), Teil I (= Inschriften griechischer Städte aus Kleinasien, vol. 9), Bonn.

Merkelbach, R. (1980) Die Inschriften von Kalchedon (= Inschriften griechischer Städte aus Kleinasien, vol. 20), Bonn.

Corsten, Th. (1987) Die Inschriften von Apameia (Bithynien) und Pylai (= Inschriften griechischer Städte aus Kleinasien, vol. 32), Bonn.

Feissel, D. (1987) De Chalcédoine à Nicomédie. Quelques inscriptions négligées, Travaux et Mémoires 10, 405-436.

Kalkan, H. and Şahin, S. (1995) Epigraphische Mitteilungen aus Istanbul, II. Kreuzförmige Grabstelen aus Konstantinupolis, Epigraphica Anatolica 24, 137-148. 


\section{Three Funerary Inscriptions in the Istanbul Archaeological Museum}

Funerary epigram for Poimenios, $5^{\text {th }} 6^{\text {th }}$ century (inv. no. 2793 T)

A marble rectangular stele, broken on the lower part, found at Kuruçeşme in Ortakoy; at the Archaeological Museum of Istanbul since 1915. The inscription is carved in majuscule letters. On the basis of paleography and content it can be dated to the $5^{\text {th }} 6^{\text {th }}$ centuries. The verse epitaph of Poimenios originally consisted of two distiches, of which only the first survives. The verses are written $\kappa \alpha \tau \alpha \lambda$ $\alpha \alpha \dot{\delta} \delta \nu$ due to the lack of space: neither a hexameter nor a pentameter could fit in a single line. The poetic language of the epitaph makes it difficult to understand the precise title or office that Poimenios held at the

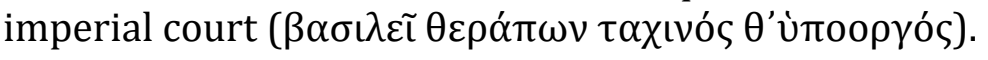

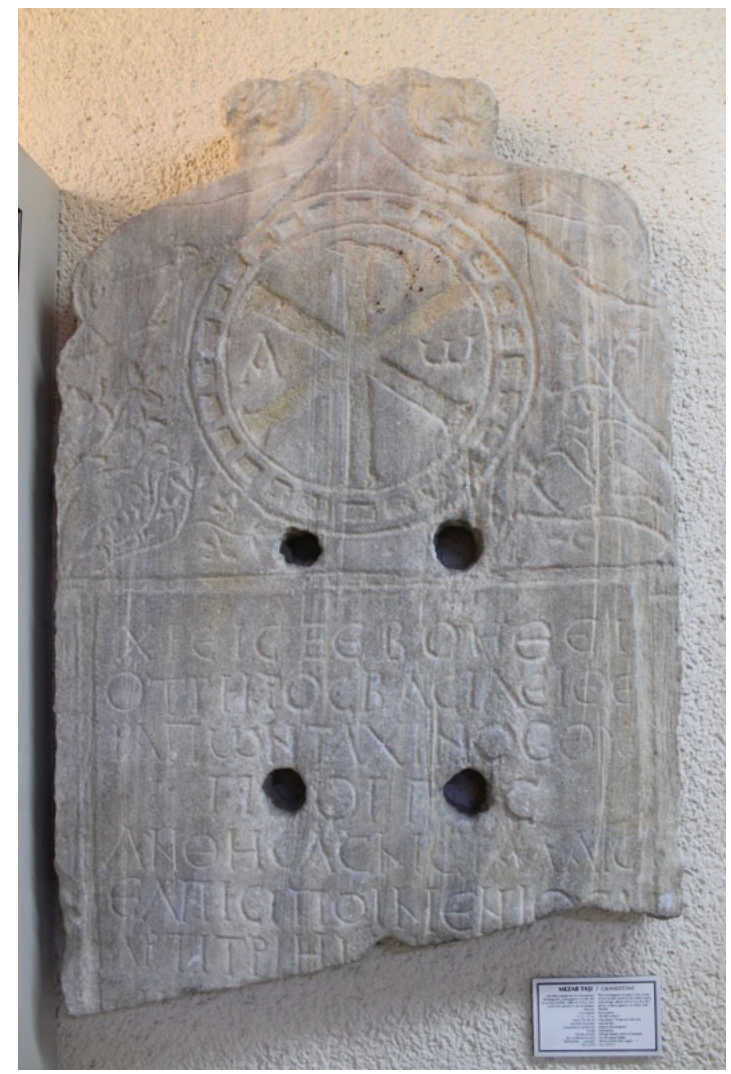

$$
\begin{aligned}
& \text { Х } \rho \varepsilon \iota \sigma<\tau>\grave{\varepsilon} \beta о \eta ́ \theta \varepsilon \iota .
\end{aligned}
$$

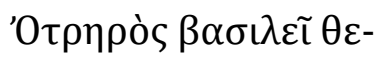

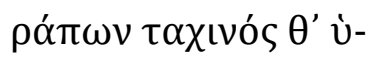

$$
\begin{aligned}
& \pi[0] o \rho \gamma[o ́] s,
\end{aligned}
$$

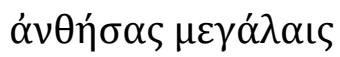

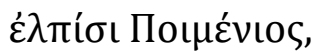

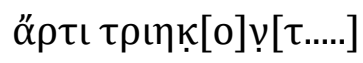

$$
\begin{aligned}
& \text { III[----------------------] }
\end{aligned}
$$

Fig. 1 (C) Andreas Rhoby)

\section{Ed.:}

Feissel, D. (1990) in Firatll, N. et alii (eds) La sculpture byzantine figurée au Musée archéologique d'Istanbul, Paris, 65-66, no 113 (cf. Supplementum Epigraphicum Graecum 56, 2006, n 824). 
Funerary epigram for Maria Palaiologina, $14^{\text {th }}$ century (inv. no. 4020 T)

The funerary stele of the nun Maria was found in 1917, at Atmeydan/Forum of Arcadius. Although its original provenance is unknown, it may have come from the South Church of the Lips Monastery, located to the north of the Forum of the Ox and the Mese. The church, dedicated to St John the Baptist, was founded towards the end of the 13th century as the mausoleum of the Palaiologan imperial family. The founder was the Empress Theodora, the widow of Michel VIII Palaiologos. Maria was probably Theodora's relative, but we cannot identify her with certainty with any of the Marias known to have belonged to the family of the Palaeologoi. More recently, it has been suggested that Maria was Michael VIII's sister, and that the stele could have come from the monastery of Kyra-Martha (Melvani, 2017). The stele survives in two fragments. It seems that the marble plaque, originally about one meter in height, had initially been built into a wall, probably next to the tomb of the nun Maria. An epigram of 14 verses is inscribed in majuscule letters (a rare use of the minuscule!) to the left of a carved standing female figure, in all probability that of Maria herself. The poem is composed in Byzantine dodecasyllables, with each verse corresponding to one line.

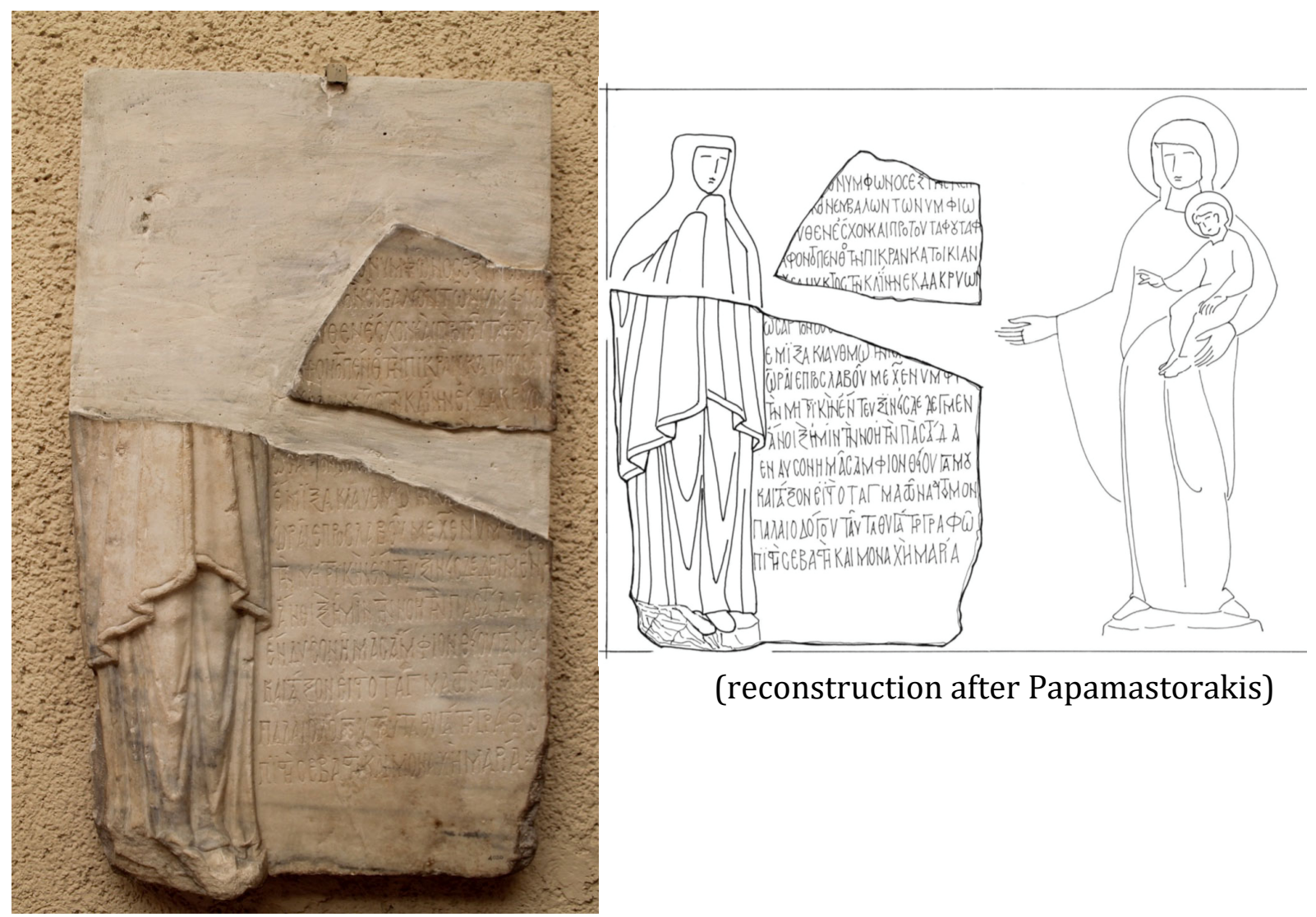

Fig. 2 (C) Andreas Rhoby)

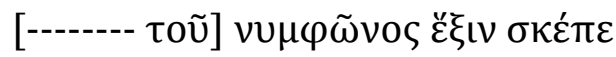

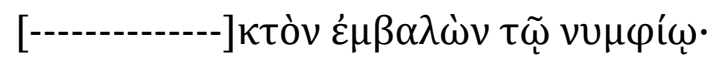

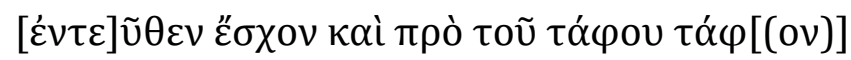




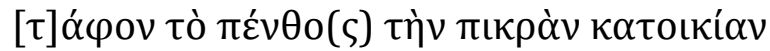

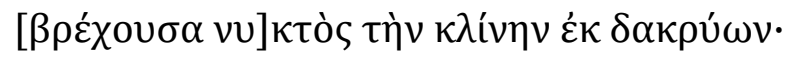

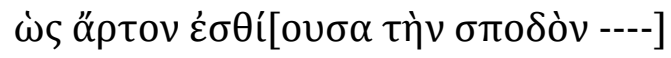

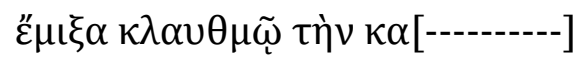

$\grave{\omega} \rho \alpha \tilde{\varepsilon} \varepsilon \pi \rho o \sigma \lambda \alpha \beta o \tilde{u} \mu \varepsilon \mathrm{X}(\rho เ \sigma \tau) \grave{\varepsilon} v u \mu \varphi \underline{\varepsilon} \varepsilon$

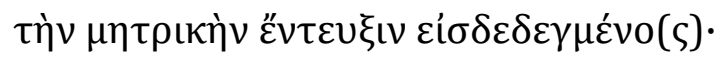

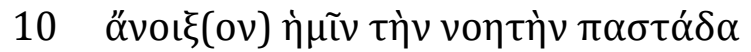

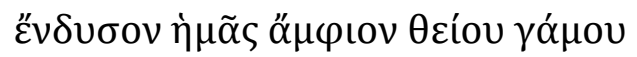

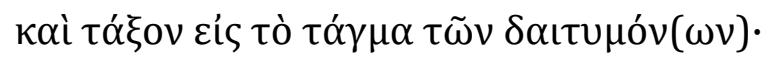

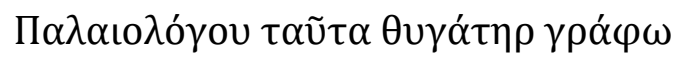

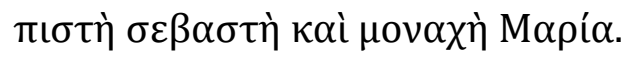

(text after Rhoby)

Ed.:

Buckler, W. (1924) The Monument of a Palaiologina, in Mélanges offerts à M. Gustave Schlumberger, Paris, 521-526.

Firatll, N. et alii (eds) (1990) La sculpture byzantine figurée au Musée archéologique d'Istanbul, Paris no 115.

Brooks, S. T. (2004) Two Fragments from a Tomb Monument for the Nun Maria Palaiologina, in Evans, H. C. (ed) Byzantium, Faith and Power (1261-1557), New Haven and London 2004, no 49.

Rhoby, A. (2014) Byzantinische Epigramme auf Stein. Nebst Addenda zu den Bänden 1 und 2 (= Byzantinische Epigramme in inschriftlicher Überlieferung, vol. 3), Vienna, no TR62.

Lit. (selection):

Mango, C. (1995) Sépultures et épitaphes aristocratiques à Byzance, in Cavallo, G. and Mango, C. (eds) Epigrafia medievale greca e latina. Ideologia e funzione, Spoleto, 106.

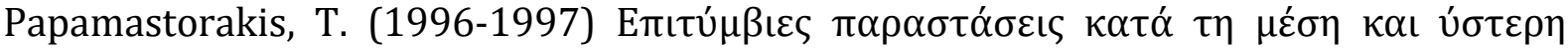

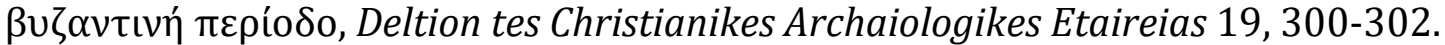

Talbot, A.-M. (1999) Epigrams in Context. Metrical Inscriptions on Art and Architecture of the Palaiologan Era, Dumbarton Oaks Papers 53, 75-90.

Brooks, S. T. (2014) Women's Authority in Death: The Patronage of Aristocratic Laywomen in Late Byzantium, in Theis., L., Mullett, M. and Grünbart, M. (eds) Female Founders in Byzantium and Beyond, Vienna 2014, 324.

Melvani, N. (2017) The monument of a Palaiologina and the monastery of Kyra-Martha in Constantinople, Arkeoloji ve Sanat Dergisi 155, 161-174. 
The fragmentary marble slab was found during the excavations of the Martyrion and the Church of St. Euphemia, on the east wall of the main entrance. The year of death of Stephanos is missing. Schneider lists the years corresponding to the sixth indiction: 858, $903,1188,1233,1323$. Naumann and Belting exclude a date before the $11^{\text {th }}$ century on palaeograpic grounds. They also exclude the year 1233, as no metropolitan see of Chalcedon existed at that time, as well as the year 1323, which coincides with the years of the Metropolitan Theodoulos (1315-1325). The invocation formula that Stephanos

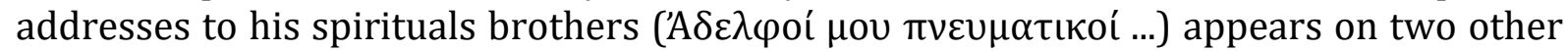
funerary slabs, that of John, the Abbot of Elegmi in the Bithynian Olympos, who died in 1196, and that of an Abbot Antony, found on the Seraglio Point (without a date). In my opinion, all three inscriptions, in addition to using the same invocation formula, also share palaeographic features (the form of letters, ligatures, abbreviations, accents and breathings). I believe that the epitaph of Stephanos (and that of Antony) can be dated to the $12^{\text {th }}$ century, in all probability to 1188 (6696) (thus being in concordance with the day, month and indiction mentioned in the text itself).

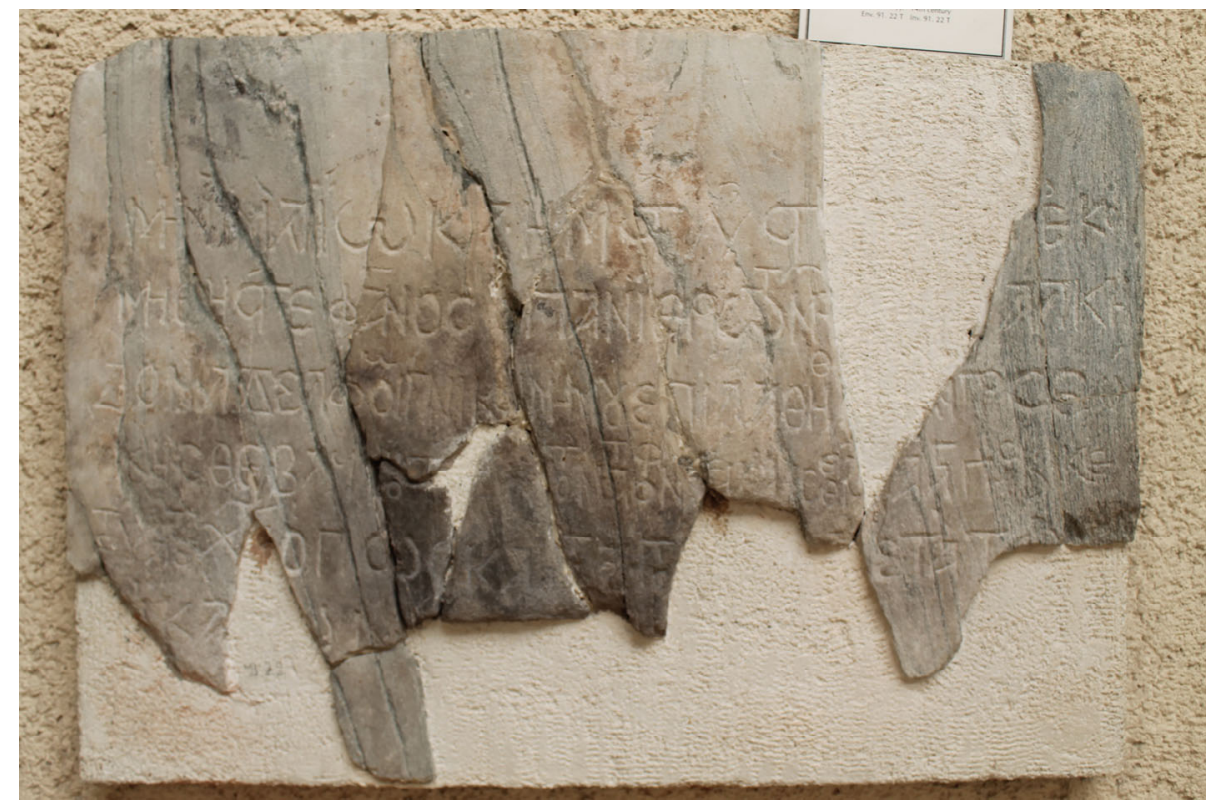

Fig. 3 (C) Andreas Rhoby)

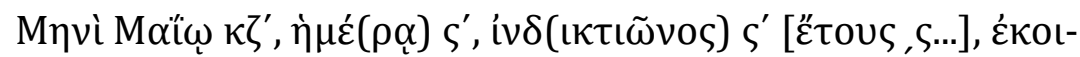

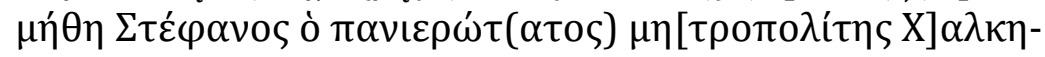

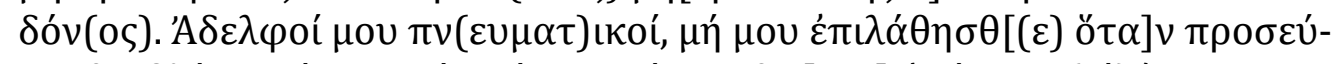

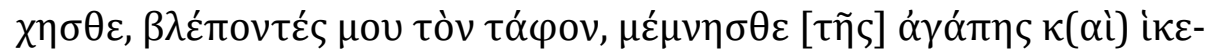

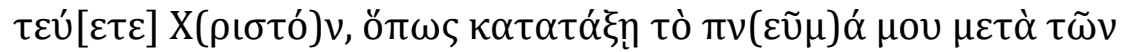

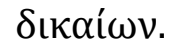

(text after Schneider with slight emendations)

Ed.:

Schneider, A. M. (1942) Das Martyrion der hl. Euphemia beim Hippodrom zu Konstantinopel, Byzantinische Zeitschrift 42, 183.

Naumann, R. and Belting, H. (1966) Die Euphemia-Kirche am Hippodrom zu Istanbul und ihre Fresken, Berlin, 87-88. 
For the epitaphs of John and Antony, see

Mango, C. (1978) The Monastery of St. Abercius at Kurşunlu (Elegmi) in Bithynia, Dumbarton Oaks Papers 22, 175, n. 43.

Corsten, Th. (1987) Die Inschriften von Apameia (Bithynien) und Pylai (= Inschriften griechischer Städte aus Kleinasien, vol. 32), Bonn.

Tunay, M. I., Erdoğan, E. G., Tekin, M. and Yılmaz, H. F. (1998) Recent Excavations in the Church of Hagios Aberkios, Kurşunlu, Province of Bursa (Turkey), Cahiers Archéologiques 46, 68, figs 8-9. 



\title{
10. Bardas - Ninth-Century Building Inscription on Constantinopolitan Sea Walls MiRELA IVANOVA
}

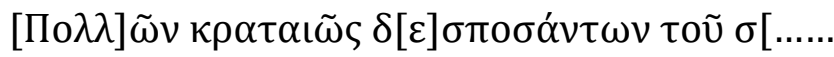

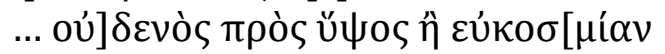

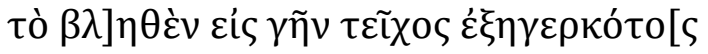

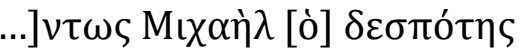

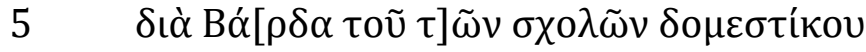

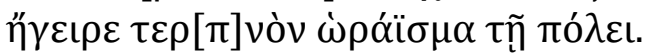

Rhoby (2014), 626, no. TR61

\author{
'Since many powerful [men] ruled over [...] \\ No one had raised to height or good order \\ The wall, which had fallen to the ground \\ [...] Michael the despot \\ Through Bardas the domestikos of the scholai \\ Raised a delightful embellishment for the city'
}

This text is found on two long and narrow stone slabs, now in Istanbul's Archeological Museum (Inv. 1654 T, 2476 T, 2363 T) (figs 1-2). (See, Efthymios Rizos, Chapter 23) At the time of Alexander Van Milligen's study, the inscription was still walled into a sea-wall tower. The slabs form an epigram of six verses, written across two lines, originally six verses per line. The epigram records the repairs of the Sea Walls by Michael III (c.842867) during the regency of his uncle Bardas (early 850s-866). Bardas is said to have been made Domestikos of the Scholai in 858, and to have received the title Caesar in 862 . The title's absence from this text allows us to date this inscription between 858-862, or 866 if we accept it possible that Bardas may chose not to use all of his titles. It must also be noted that the epigram is rather unusually specific for the otherwise formulaic and vague nature of epigrammatic epigraphy, on fortifications. As this was a period of relative peace, with no major attacks on Constantinople, it is likely that the repairs were required in the aftermath of the earthquake of 861.

The epigraphic material concerning Michael III is at odds with the historiographical record. The account of his reign in Theophanes Continuatus, Books I-IV, stresses his fiscal irresponsibility and general lavish spending. The chronicler notes that Michael had so depleted the imperial treasury that he had to melt golden monuments and imperial vestments in order to pay the army. In contrast, the epigraphic accounts of his reign show a sustained commitment to wall repair across a number of cities. Together with three inscriptions alongside his father Theophilos, two of which are on two sea towers in the immediate vicinity of the Topkapi, eight inscriptions on the walls of Nicaea, and evidence for his repairs in Smyrna and Ankara, it seems clear that Michael's spending cannot have been too disastrous. Rather, his practice of wall repair seems to continue what was a priority in the reign of his father, Theophilos.

The inscription offers scope for further consideration of the imperial rhetoric of (repair-)works on monuments associated with the state. In the absence of an attack or an enemy (as noted in late ninth-century Nessebar inscription by Basil, Leo and Alexander, 
who blame the destruction of the city on 'pagan hands') Michael III and Bardas accuse those who ruled beforehand of neglect and inertia.

The physical damage of the slabs prevents us from a definitive judgement, but it is possible that something more specific than 'many' was originally intended. The vagueness is perhaps intended to avoid laying the blame on his own father, but, rather, to accuse the iconoclast emperors of neglect. The association between good-order (eukosmia) and aesthetic beauty (terpnon horaisma) of the wall, reveals something of the intellectual climate after the end of iconoclasm, and points to a novel aesthetic discourse, attempting to assert a link between aesthetic delights and the ideas of good order.

\section{Selected Bibliography}

Featherstone, J. M. and Signes Codoñer, J. (2015) Chronographiae quae Theophanis Continuati nomine fertur libri I-IV, Berlin.

Foss, Cl. (1984) Anomalous Imperial Inscriptions of the Walls of Constantinople, in Studies presented to Sterling Dow on his eightieth birthday, Durham, NC, 77-87.

Lauxtermann, M. D. (2003) Byzantine Poetry from Pisides to Geometres, Texts and Contexts, vol. I, Vienna.

Melvani, N. (2020) State, Strategy and Ideology in Monumental Imperial Inscriptions in Lauxtermann, M. and Toth, I. (eds), Inscribing Texts in Byzantium. Continuities and Transformations. Papers from the Forty-Ninth Spring Symposium of Byzantine Studies, London and New York, 162-188.

Van Millingen, A. (1899) Byzantine Constantinople: the Walls of the City and Adjoining Historical Sites, London.

Rhoby, A. (2016) Tower, stablished by God, God is protecting you: Inscriptions on Byzantine Fortifications - Their Functions and their Display, in Stavrakos, Chr. (ed), Inscriptions in the Byzantine and Post-Byzantine History and History of Art, Wiesbaden, 341-369.

Rhoby, A. (2014) Byzantinische Epigramme auf Stein (= Byzantinische Epigramme in inschriftlicher Überlieferung, vol. 3), Vienna. 


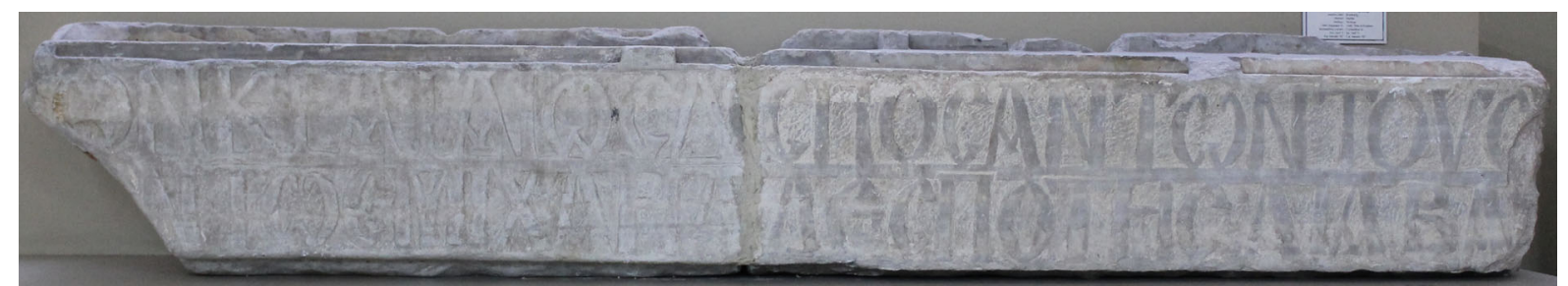

Fig. 1 (C) Andreas Rhoby)

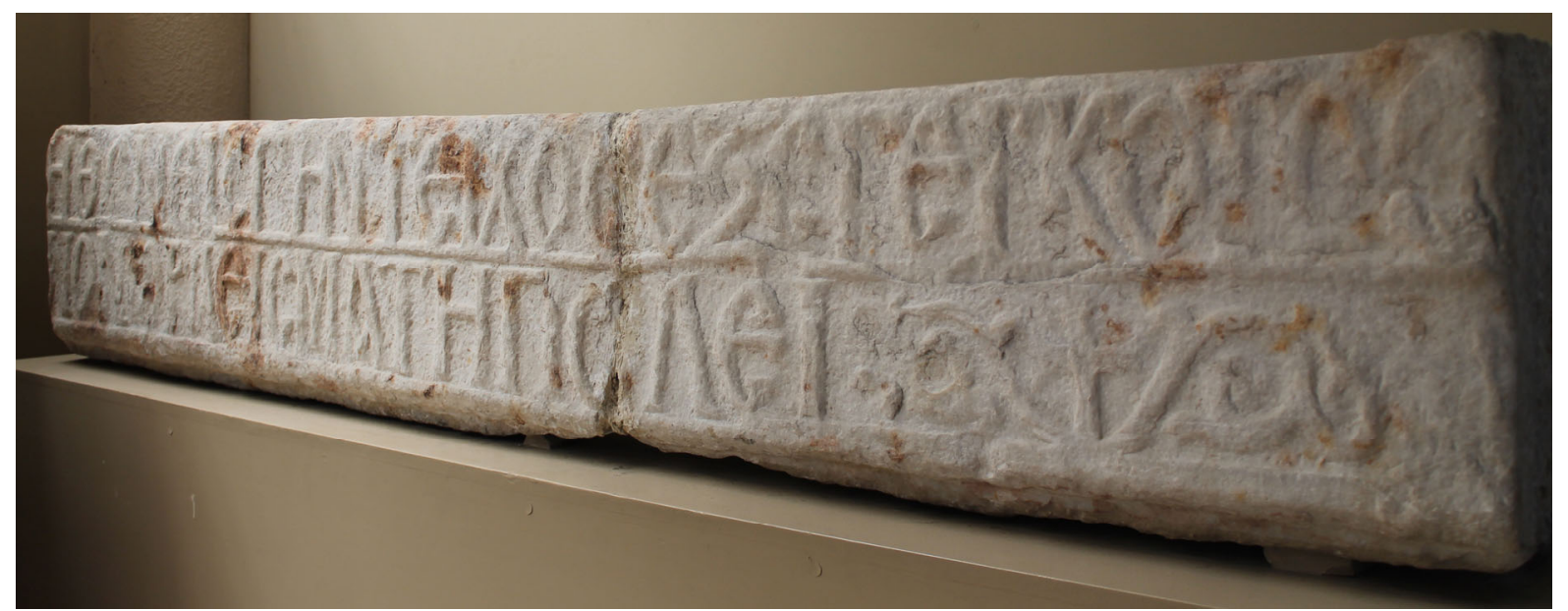

Fig. 2 (C) Andreas Rhoby) 



\section{An Inscription of John VIII Palaiologos and the Late Palaiologan Repairs \\ MATTHEW KINLOCH}

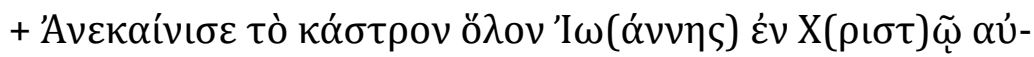

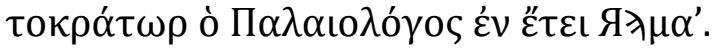

'John Palaiologos, autokrator in Christ, renewed the whole fortress in the year 6941' $(=1432 / 1433)$

This short inscription from Istanbul Archaeological Museum (inv. no. 1648 T) comes from

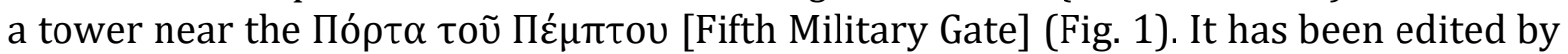
Meyer-Plath and Schneider in 1943 (no. 45), and by Van Milligen in 1899. The inscription claims that "John Palaiologos, autokrator in Christ, renewed the whole fortress in the year 6941", that is in 1432 or 1433. John VIII Palaiologos (r. 1425-1448) reigned during a period when the medieval Roman polity, under pressure from an increasingly expansionist Ottoman state, had shrunk to little more than the area encompassed by the Walls of Constantinople. As a consequence of the empire's new political position, the city walls had perhaps never been so important.

The last major restoration project carried out on the Theodosian walls, dates to the period between 1432 and 1444. The large number of inscriptions from this period testify to the continuing importance of fortifying this liminal space. Perhaps more than any other period, the fortification of the Land Walls in the fifteenth-century was a practical necessity, as well as being ideologically significant. Notably, the area around the Пó $\rho \tau \alpha$

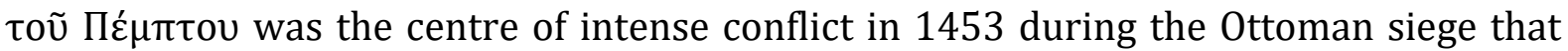
would end in the conquest of the city. However, the increased interest in fortification during this period was not just a Byzantine preoccupation and must be placed in the context of comparable developments throughout the Balkans in the face of the same Ottoman threat. Developments in the Serbian despotate, for example, suggest parallels. Here it is instructive to consider the massive building project undertaken in Smederevo, which created the largest late medieval fortress in the Balkans southeast of Belgrade on the Danube (between 1427 and 1430) or indeed the investment of Serbian rulers, such as George Branković (r. 1427-1456), in the fortifications of Constantinople, as discussed by Ida Toth in Chapter 12 .

The inscription under discussion is the first of twelve inscriptions that survive from the eleven-year period of John's restoration project (1432-1444). The long duration seems to suggest a slow and somewhat irregular series of repairs on the land walls, which Alexander van Millingen suggested was probably due to lack of funding, rather than the extensive scope of the work. Ten of these inscriptions have the same formula, albeit with different levels of detail given to their dating and a single example that slightly extends the emperor's title. (See, Nicholas Melvani, $\underline{\text { Chapter 21) }}$

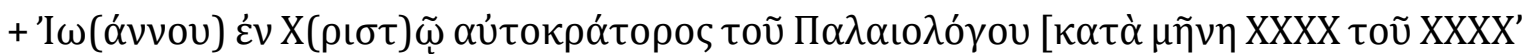
हैंous] (as noted in Meyer-Plath and Schneider (1943), nos. 3a, 11, 17, 19, 25, 27, 59, 66,68 , and 69)

Only two of the twelve inscriptions noticeably diverge from this formula. One is an inscription recording the repairs of the Gate of Pege, dating to 1438, which credits Manuel 
Bryennios Leontari with the renewal of 'the God-protected gate' (number 20 in MeyerPlath and Schneider). As such, it is the only inscription that attributes agency to anyone other than John, although the inscription does note at the end that it occurred in the rein of John and Maria Palaiologoi.

In contrast, the inscription under discussion here is closer to the standard formula of the other examples. However, it diverges in important ways. It presents John as the subject, actively renewing the whole kastron. Andreas Rhoby has argued that this use of 'kastron' implies the renewal of the whole fortified city rather than just the specific tower of the inscription. He has also noted that the syntax, which makes John the subject, emphasises his active role in the renewal, quite literally. This is notably the opposite of the passive used in the inscription attributing the building to Bryennios. The claim of John Palaiologos to renew the whole kastron is a significant gesture, but its significance is only really seen when placed in the context of the other inscriptions, from which it is noticeably more expansive.

\section{Selected Bibliography}

van Millingen, A. (1899) Byzantine Constantinople: The Walls of the City and Adjoining Historical Sites, London.

Meyer-Plath, B. and Schneider, M. (1943) Die Landmauer von Konstantinopel, Berlin, especially 136 (no. 45).

Nicol, D. (1993) The Last Centuries of Byzantium, 1261-1453, Cambridge, especially 339368.

Asutay-Effenberger, N. (2007) Die Landmauer von Konstantinopel-İstanbul. Historischtopographische und baugeschichtliche Untersuchungen, Berlin, especially 167, n. 716.

Rhoby, A. (2016) Tower, stablished by God, God is protecting you: Inscriptions on Byzantine Fortifications - Their Functions and their Display, in Stavrakos, Chr. (ed), Inscriptions in the Byzantine and Post-Byzantine History and History of Art, Wiesbaden, 341-369, especially 360-361.

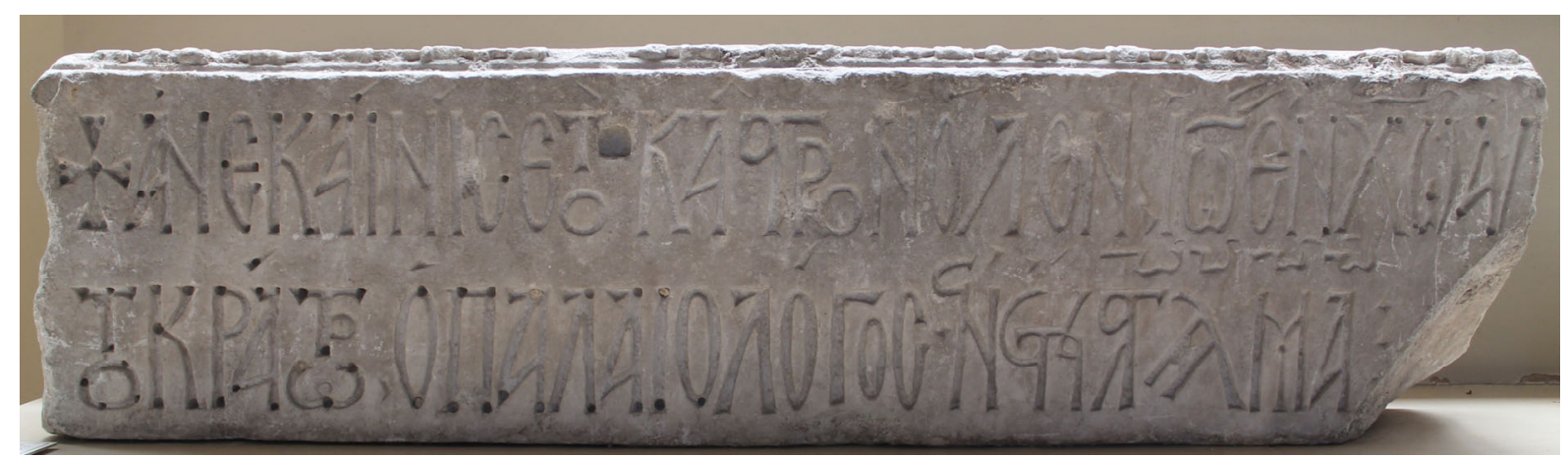

Fig. 1 (C) Andreas Rhoby) 


\title{
12. A Fifteenth-Century Building Inscription of George Branković IDA Tотн
}

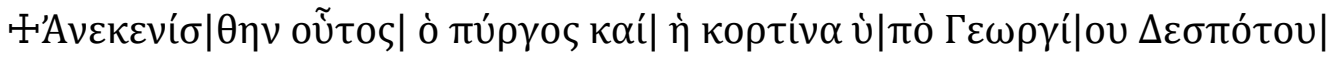

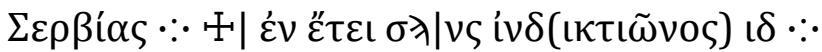 \\ 'This tower and the curtain wall was [scil. were] restored by George, Despot of \\ Serbia, in the year 6956 [scil. 1448], in the fourteenth indiction.'
}

The inscription was discovered in the area between modern Yenikapı and Kumkapı, and it presumably comes from a nearby sea-wall tower. It is on permanent display in Istanbul's Archaeological Museum, IAM Inv. 1647. (See, Fig. 1 and Efthymios Rizos, Chapter 23) It features a clearly legible text, neatly carved into a marble slab. The inscription has been damaged by the loss of most of its original led inlays. Executed in majuscule letters (with the exception of the cursive abbreviation of the word 'indiction'), it also preserves traces of all writing marks including crosses, punctuation, and accentuation. The wording of the inscription is simple and formulaic, but it shows certain peculiarities: against the prevailing practice visible in similar epigraphs on the Constantinople's fortifications, it makes no reference to the reigning Byzantine emperor.

The inscription commemorates the funding of the repairs of a tower and parts of a wall on the Sea of Marmara by George Branković, Despot of Serbia (1427-1456). He was one among the wealthy patrons, on whom the last Palaiologan emperors increasingly relied for financial support in their efforts to maintain the city's defence infrastructure. George Branković had forged strong links with Constantinople, both through his family ties (he married the great-grand daughter of John Kantakouzenos, Irene, and thus affiliated himself with the Kantakouzenoi and the Palaiologoi), and through his building patronage (according to Van Milligen, Branković also funded the repair of a section of the Land Walls). Branković's status as one of the richest monarchs in contemporary Europe was made manifest in his ambitious building projects. One of these, Mali Grad, the inner citadel of Brankovićs capital city, Smederevo, closely resembled the Mermerkule, a Constantinopolitan residence of his father-in-law, Theodore Kantakouzenos Palaiologos (S. Ćurčić). Even though it is difficult to ascertain whether the Mermerkule was built from the foundations by Theodore Kantakouzenos Palaiologos or it was part of the so-called Polichnion, a fortified palace constructed somewhat earlier, during the reign of the Emperor John V Palaiologos (Asutay-Effenberger), there is little doubt that the two fortified structures, Constantinople's Mermerkule and Smederevo's Mali Grad, have many architectural features in common. The findspot of George Branković's inscription in an area close to the Mermerkule and the lack of reference to the reigning Byzantine emperor in the text indicate that the patronage might have come about as a result of the Despot's private initiative to secure his in-laws' palace by restoring a stretch of the Sea Walls in its immediate vicinity.

Overall, George Branković seems to have used epigraphy as an effective (visual/verbal) means of conveying political power. The façade of one of the southern towers of his palace in Smederevo features the largest surviving building inscription in the fifteenth-century Balkans: executed in elaborate brickwork, it bears a close resemblance to some of the most striking monumental examples of Byzantine imperial epigraphy (figure 2). The marble slab with Branković's inscription from Istanbul's Archaeological Museum fades in comparison; neither do its size and style compare favourably with the contemporary 
examples of Constantinopolitan imperial epigraphy, whose decorative features show that the Byzantine capital still had skilled craftsmen capable of executing high-quality stonework, and that the imperial patronage continued to be epigraphically commemorated even in the decades immediately preceding the fall of the city in 1453. (See, Matthew Kinloch, Chapter 11)

\section{Selected Bibliography}

Asutay-Effenberger, N. (2002) Wer erbaute Mermer-Kule?, Byzantion 72, 270-274.

Ćurčić, S. (2013) Visible and Invisible Aspects of Building the Fortified Palace of Smederevo and its Historical Significance', Zbornik radova Vizantološkog instituta 50, 835-851.

Harris, J. (2010) The End of Byzantium, New Haven and London, 111-112.

van Millingen, A. (1899) Byzantine Constantinople: The Walls of the City and Adjoining Historical Sites, London, 107, 193.

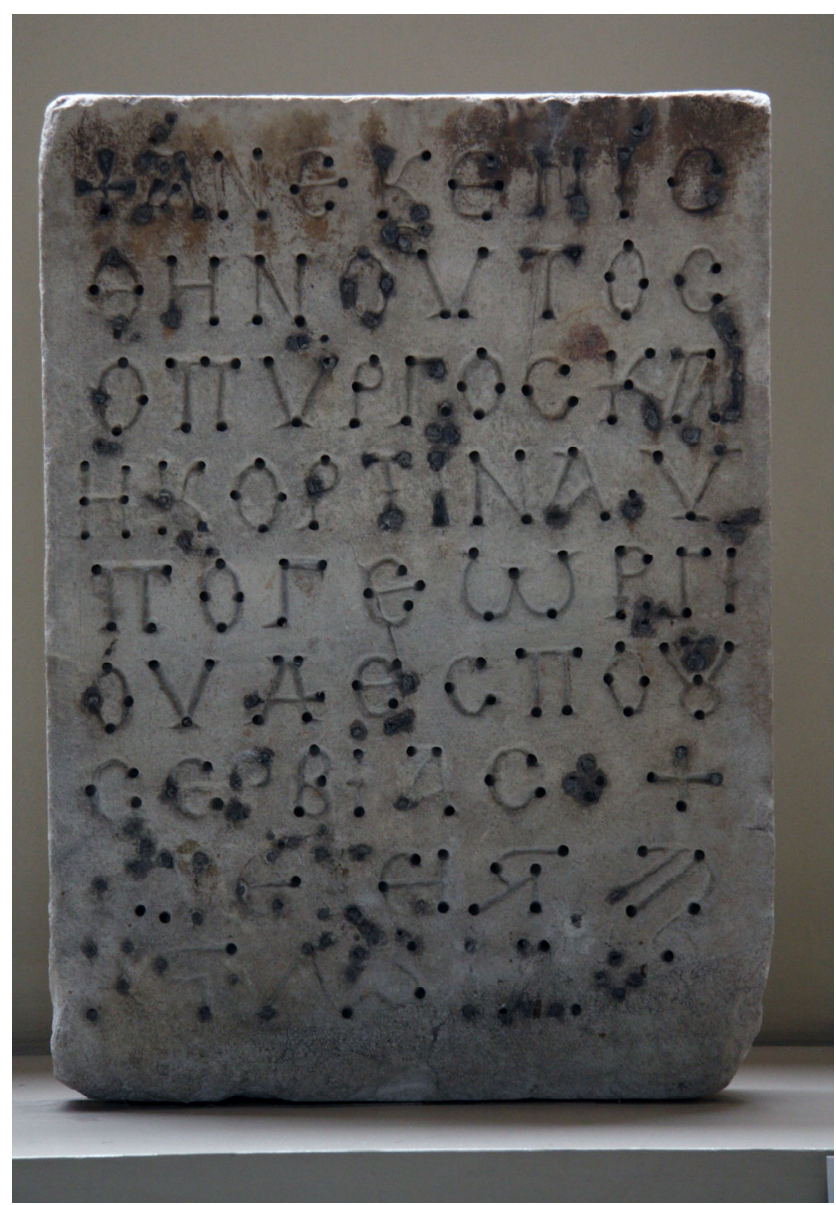

Fig. 1 (C) Ida Toth) 


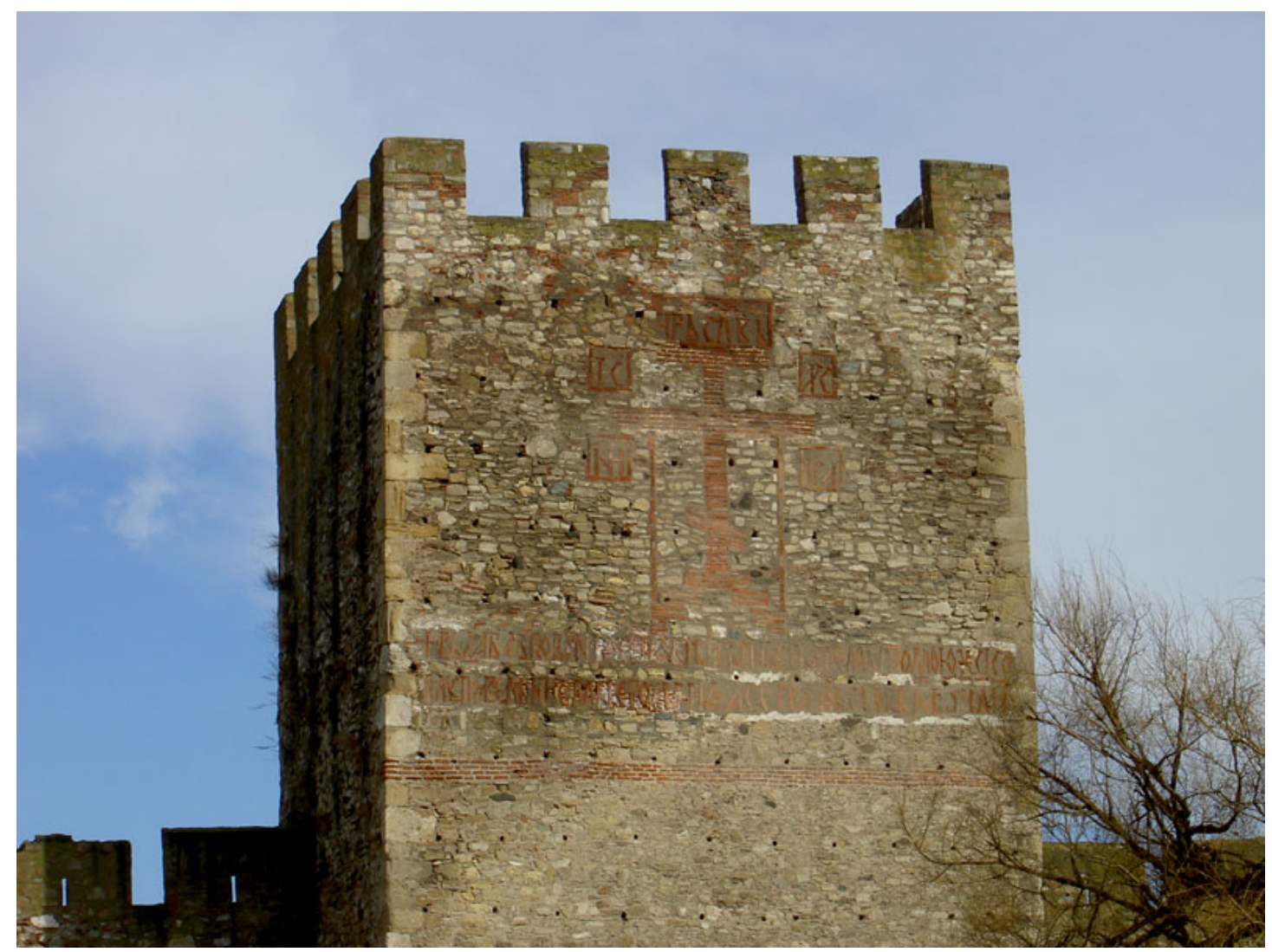

Fig. 2

Building inscription, Smederevo Fortress:

In Christ God Faithful Despot Gurg, the Lord of Serbia and Litoral Zeta.

By his order this fort was built, in the year 6938 [1430]

(C) Regionalni zavod za zaštitu spomenika culture Smederevo) 



\section{Epigrams on Charioteers: Themes and Function \\ MARIA TOMADAKI}

The Hippodrome of Constantinople was the principal place of athletic and ceremonial events and, therefore, an important center of social and political power in Byzantium. The circus factions of the Byzantine capital (e.g., the Greens, the Blues) had numerous devoted supporters, who expressed publicly not only their athletic preferences, but also their opposing views on political affairs (e.g. on the candidacy for the throne). Athletes, as representatives of the factions, participated in chariot races and their victories were honored in various ways both by their factions and emperors themselves.

The elegiac epigrams from the Greek Anthology (XV 41-50, XVI 335-379) offer an insight into the chariot races of Constantinople, on the most popular charioteers, and on the Hippodrome's monuments commemorating their victories. These epigrams were engraved on carved stone bases that were erected at the Hippodrome of Constantinople after the victories, the retirement or the death of popular charioteers, especially in the $6^{\text {th }}$ century. They provide valuable information about the commission, symbolism, and function of these richly decorated monuments. Additionally, they demonstrate the intense interest and participation of the Byzantines in Hippodrome's spectacles, and the ways they honored their victorious charioteers.

Six of the epigrams (Anthologia Graeca XVI 340, 342, 351-353, 356) (fig. 1) can be still found in situ, inscribed in two charioteer monuments, the so-called Old and New Base, which are today kept in the Istanbul Archaeological Museum. Both bases are dedicated to the famous charioteer Porphyrius (figs. 2-4), who lived in Constantinople between the end of the $5^{\text {th }}$ and the beginning of the $6^{\text {th }}$ centuries, and raced for the racing teams of the Greens and the Blues. The Old Base was erected by the Blues and the New Base by the Greens. The epigrams of these bases always mention Porphyrius, and they praise him highly by referring to his victories, awards, crowns and virtues. The poem AG XVI, 352 is

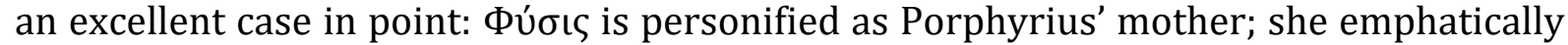
declares that she cannot give birth to another person as charismatic as Porphyrius, because she has already given all her graces exclusively to him.

As regards the display, the epigrams have been executed in a majuscule script, set into inscriptional panels situated above or under the ornamental reliefs. They constitute the decorative programme of the monuments together with the short prose inscriptions (e.g. acclamations, names of horses) and reliefs depicting Porphyrius in his chariot, wreathed and victorious, surrounded by spectators as well as other scenes taking place in the Hippodrome. Since the content of the epigrams is not closely related to the depictions of the reliefs, they cannot be characterized as purely ekphrastic texts; rather, they can de defined as honorific, commemorative, and dedicatory. However, the epigram 242 stresses the vividness of the representation of Porphyrius, referring to a lost bronze statue, which most probably stood on top of the old base.

The motivation behind, and the function of, the cycle of the charioteer epigrams from the Greek Anthology should be examined in the context of the so-called agonistic epigraphy, which commonly features poetic depictions of charioteers, praising them not only for their athletic accomplishments and victories, but also for their beauty, glory, wisdom and general excellence. Porphyrius' monuments and the epigrams in his honor keep his memory alive as well as providing a valuable insight into Hippodrome's spectacles and its glorious past for the benefit of their viewers and readers alike. 


\section{Selected Bibliography}

Beckby, H. (1958) Anthologia Graeca: Buch XII-XVI, vol. 4, Munich.

Cameron, Al. (1973) Porphyrius the Charioteer, Oxford.

Cameron, Al. (1976) Circus Factions: Blues and Greens at Rome and Byzantium, Oxford.

Christesen P. and Kyle, G. D. (2014) A Companion to Sport and Spectacle in Greek and Roman Antiquity, Malden, MA,Oxford and Chichester.

Mordtmann, A. (1880) Das Denkmal des Porphyrius", in Mittheilungen des deutschen archäologischen Institutes in Athen, vol. V, Athens, 295-308.

Paton, W. R. (1918), The Greek Anthology, vol. 5, London.

Pitarakis, B. (2010) Hippodrome. A Stage for Istanbul's History / Atmeydani. Istanbul'un Tarih Sahnesi, vol. I, Istanbul.

Vasiliev, A. (1948) The Monument of Porphyrius in the Hippodrome at Constantinople, Dumbarton Oaks Papers 4, 29-49.

\section{Appendix: epigrams on Charioteers - a selection}

1.

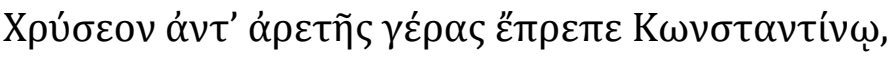

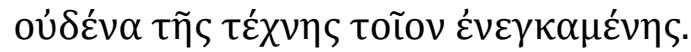

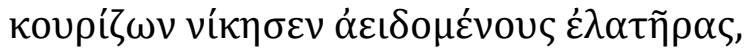

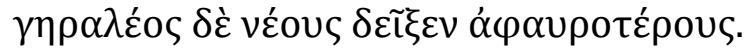

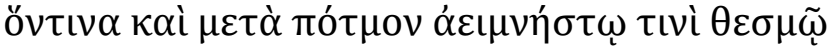

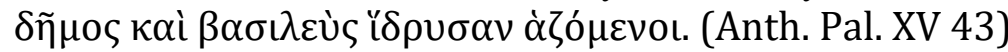

'Constantinus deserved a golden gift for his merit, for his art has produced none like to him. While yet a youth he overcame the celebrated drives, and in his old age showed that the young were his inferiors. The people and the Emperor, reverencing him even after his death, set up his statue by a degree that will ever be remembered.' (Translated by Paton 1918: 150-151)

2.

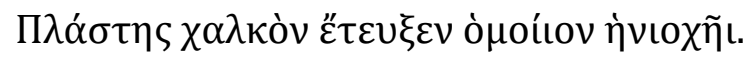

$\varepsilon^{\prime \prime} \theta \varepsilon \delta \varepsilon \dot{\varepsilon} \kappa \alpha \grave{~ \tau \varepsilon ́ \chi \nu \eta ~ o ̋ \gamma \kappa o v ~ \alpha ́ \pi \varepsilon เ \rho \gamma \alpha ́ \sigma \alpha \tau o, ~}$

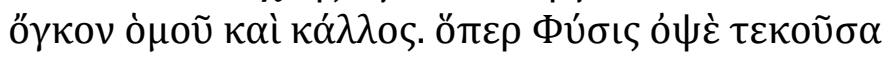

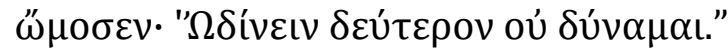

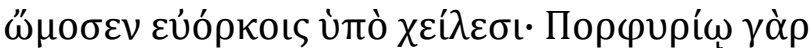

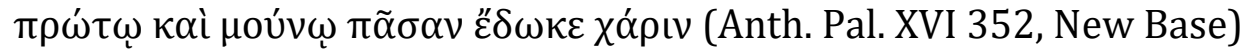

'The sculptor made the bronze like unto the charioteer, but would that he could have fashioned also the vastness of his skill, its vastness and beauty, a thing that when Nature brought forth late in her life she swore, "I cannot travail again". She swore it with truthful lips, for to Porphyrius first and alone she gave all her gifts.' (Translated by Paton 1918: 371) 
3.

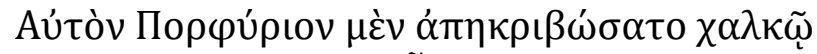

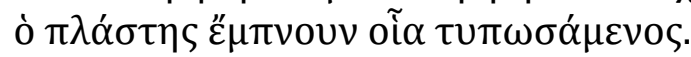

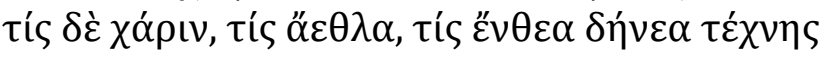

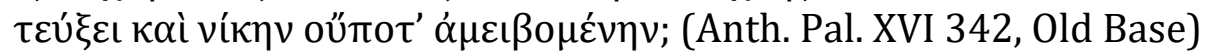

'Den Porphyrios selbst hat der Künstler zwar treulich gebildet, hat ihn im ehernen Bild gleichsam zum Leben geformt. Wer aber bildet sein Können, die Kämpfe, die hohen Gedanken seiner Kunst und den Sieg, der ihn noch niemals verließ?' (Translated by Beckby 1958: 487)

4.

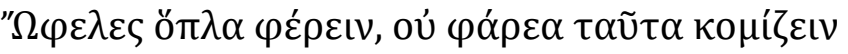

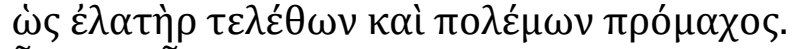

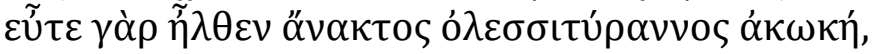

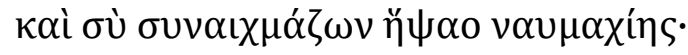

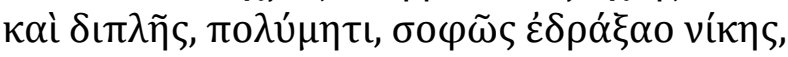

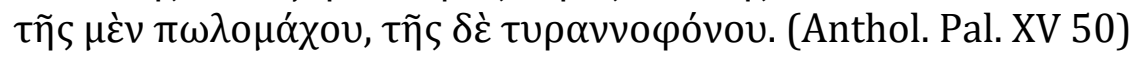

'Waffen müßtest du tragen, nicht diese Farbengewänder, Rennfahrer warest du wohl, aber ein Krieger zugleich. Als der Kaiser das Schwert zum Tod der Tyrannen gezückt hat, zogst als Kämpfer auch du fort in die Seeschlacht mit ihm. Weise hast du, o Kluger, dir doppelte Siege errungen: als du im Rennen gekämpft und du Tyrannen erschlugst.' (Translated by Beckby 1958: 298)

5.

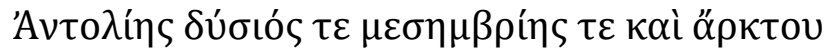

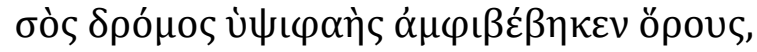

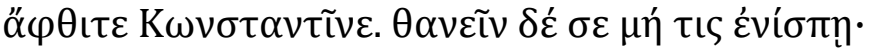

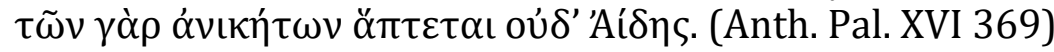

'Your course, shining afar, has traversed the bounds of east, west, south, and north, immortal Constantine. Let no man say you are dead. Hades himself cannot lay his hands on the unconquerable.' (Translated by Cameron 1973: 61) 


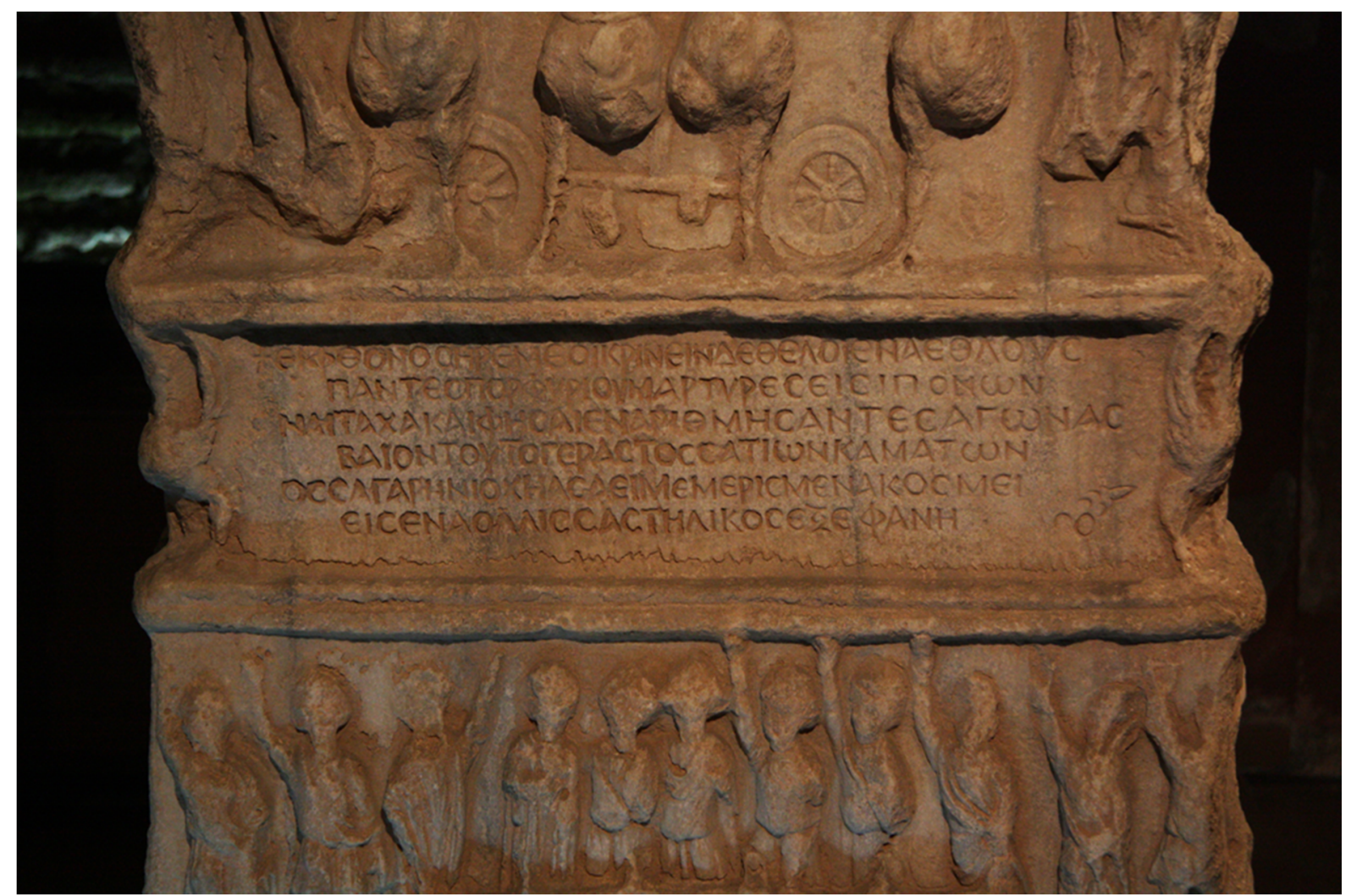

Fig. 1 Anth. Pal. XVI 353 (C) Ida Toth)

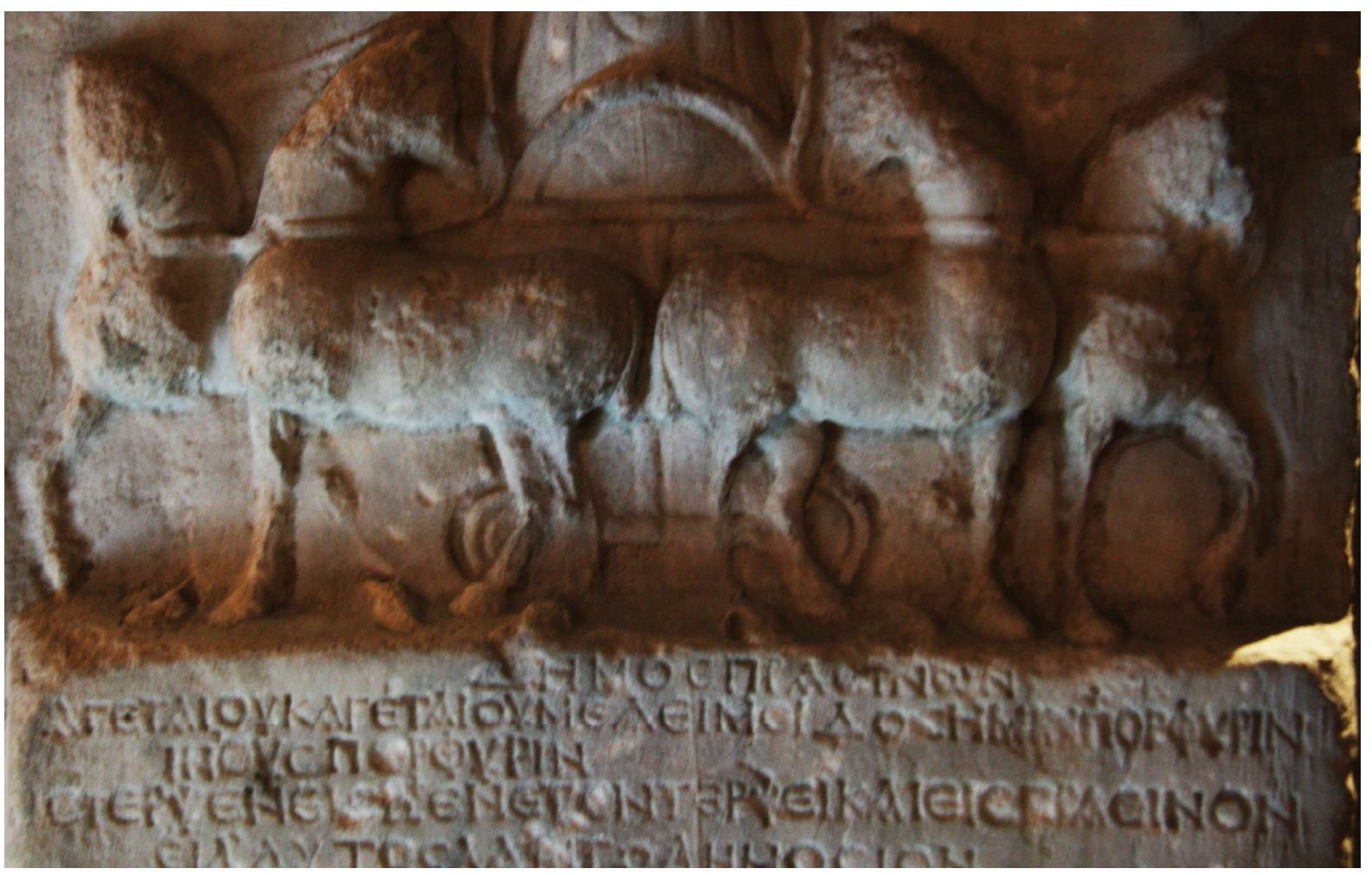

Fig. 2 The Old Base of Porphyrius, left face (prose inscription) (C Ida Toth) 


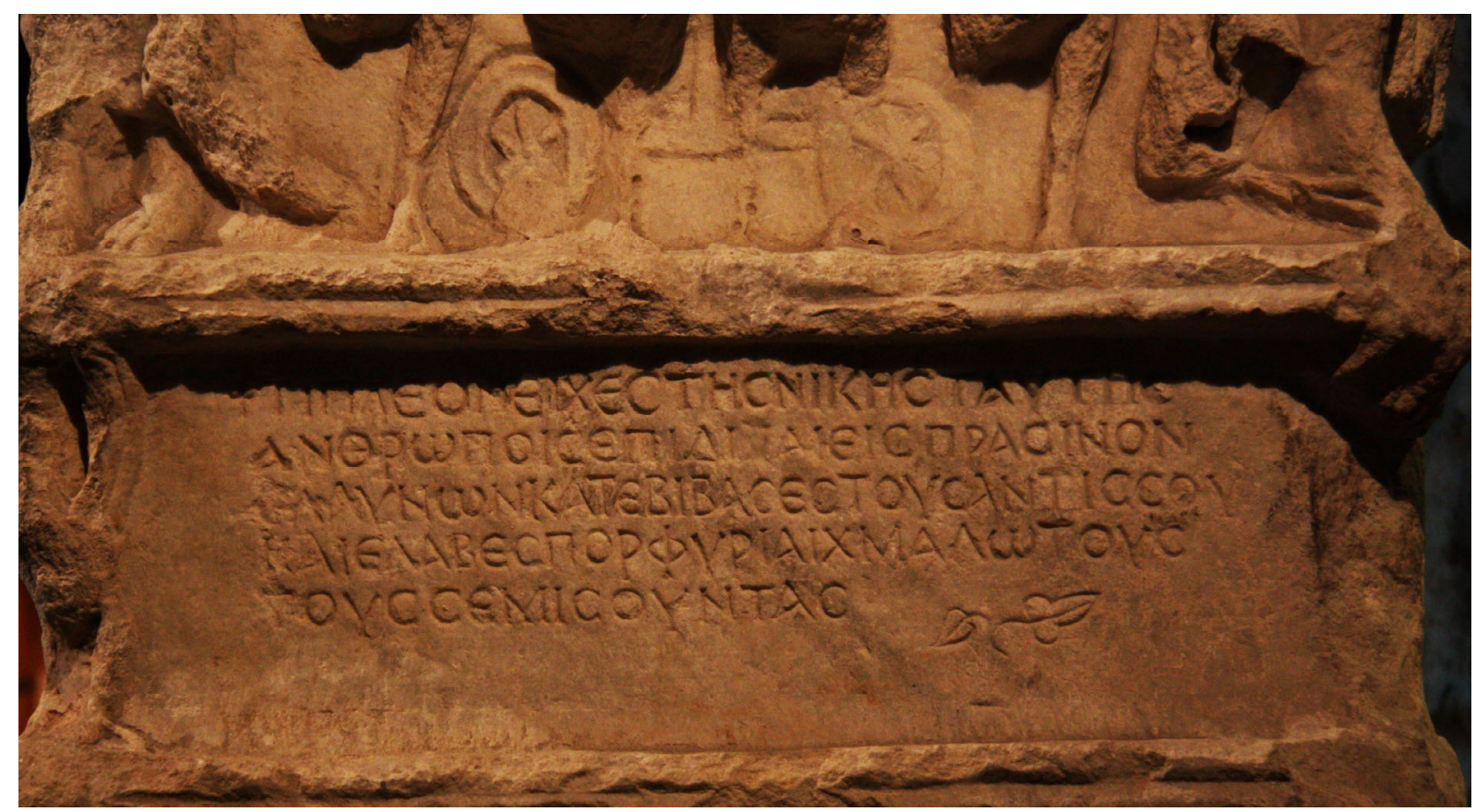

Fig. 3 The New Base of Porphyrius, left face (prose inscription) (C Ida Toth)

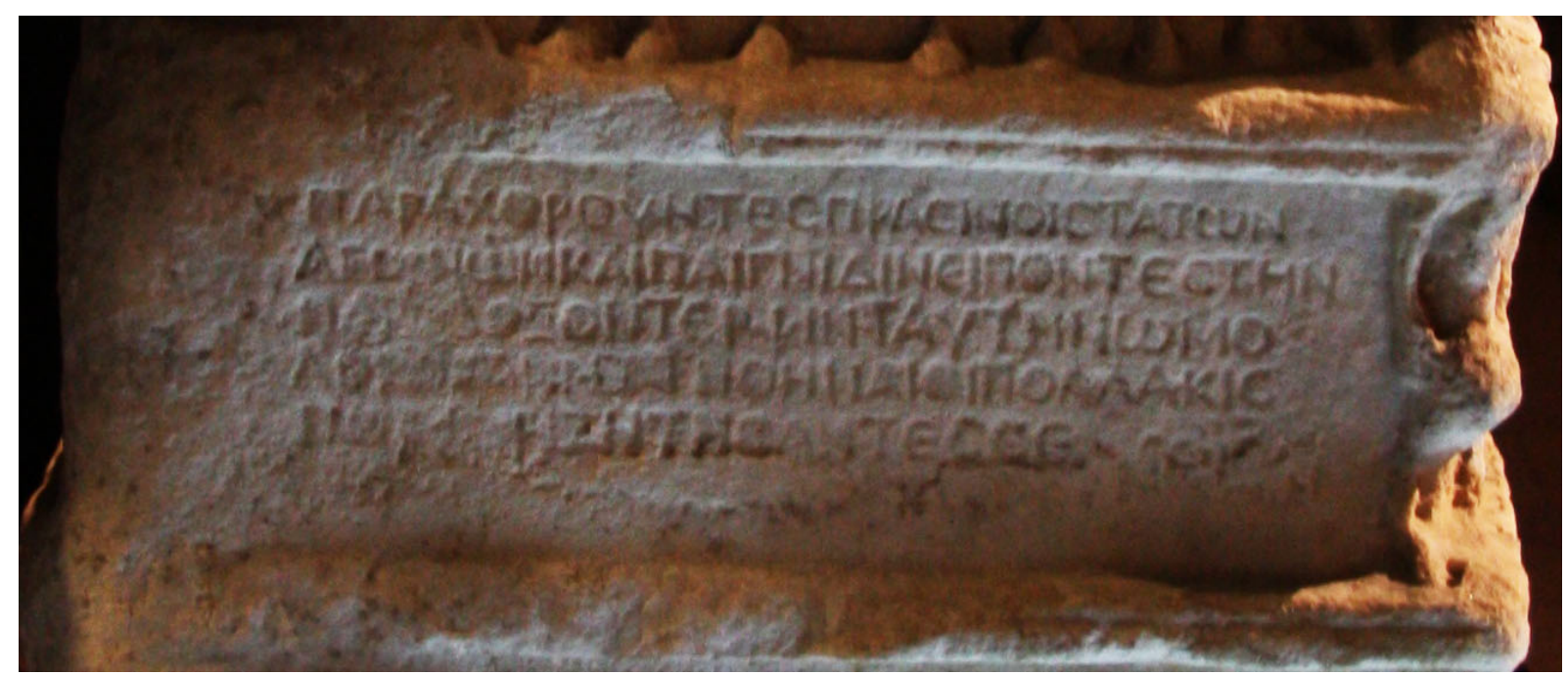

Fig. 4 The New Base of Porphyrius, right face (prose inscription) (C Ida Toth) 



\section{LATIN INSCRIPTIONS IN CONSTANTINOPLE}





\title{
14. Latin Inscriptions in Late Antique Constantinople ANDREAS RHOBY
}

\author{
Introduction
}

The production of Latin inscription in the Byzantine Empire was very limited due to the fact that the Roman East was always primarily a Greek-speaking territory. By the first half of the fifth century, Greek had become the principal administrative language. This explains the almost complete lack of any post $5^{\text {th }}$-century evidence, with the notable exception of Latin inscriptions produced by Latin rulers in the former Byzantine territories after 1204.

In Constantinople itself, the increasing number of Latin inscriptions in the fourth century was closely linked to the transfer and adoption of Roman administrative and ideological traditions. Imperial inscriptions as well as inscriptions issued by state officials (e.g. on statue bases and fortifications) were written in Latin, often in verse, although Rome and its representatives in the East never sought to impose the general use of Latin. After the fourth century, the number of bilingual Latin-Greek epigraphs increased. As Byzantium lost control over the West in the late fifth century, official Latin inscriptions became even less frequent, and, as a result, the overall production of Latin inscriptions decreased considerably.

Late Antique Latin inscriptions in Constantinople: the evidence of the Land Walls and imperial monuments

Latin inscriptions in Byzantium were rather scarce before the consecration of the city as the imperial capital and 'New Rome' in 330. One famous exception seems to be the inscription on the so-called Column of the Goths in the Seraglio Gardens, which very likely refers to the Emperor Claudius II Gothicus's (268-70) victory against the Goths at Naissus (today Niš) in 269 (see also Chapter 6 by Paul Magdalino) The inscription reads: Fortunae Reduci ob devictos Gothos ('To Fortuna Redux [i. e. the returning Fortune] because the Goths have been defeated'). There are, however, scholars, who date the column and the inscription to the time of Constantine the Great and his victory in 332.

The (Theodosian) Land Walls of Constantinople were always an ideal place for the display of imperial authority. (See Chapter 21 by Nicholas Melvani) One can easily imagine that the earlier, Constantinian Walls, which are no longer extant, had also been equipped with Latin inscriptions in keeping with the Roman tradition. Traces of evidence of Latin inscriptions are still visible on the Theodosian Walls:

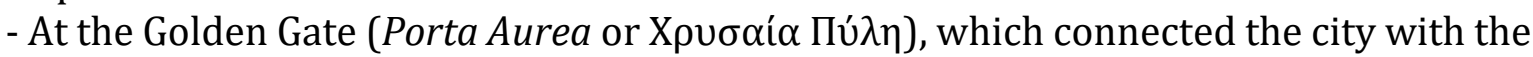
Via Egnatia, an inscription consisting of two dactylic hexameters was placed on both sides of the central entrance with the first verse inscribed on the city side and the second verse on the outer side. Today there remain only the holes, to which the letters had been attached. The inscription reads as follows:

Haec loca Theudosius decorat post fata tyranni. Aurea saecla gerit qui portam construit auro.

'Theodosius decorates this place after the death of a tyrant. He who builds the gate with gold rules the golden age'. 
Previous scholarship was undecided as to whether this inscription was set up by Theodosius I or Theodosius II. However, very recently, Adrastos Omissi has argued that the Golden Gate was not part of the Theodosian Walls, but that it was originally built as a triumphal arch for Theodosius I in order to celebrate his victory over the augustus Magnus Maximus in the year 388.

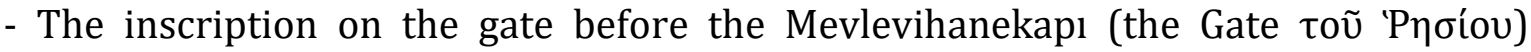
specifically states that this stretch of the wall was built under the Prefect (praefectus praetorio Orientis) Constantine in the year 447 (fig. 1). This information is conveyed in Greek and Latin hexameters: the Greek verses are incised on the vertical surface of the lintel of the stone block above the gate, while the Latin verses are incised into the north console, on the left side, and beneath the Greek inscription.

Theodosii iussis gemino nec mense peracto

Constantinus ovans haec moenia firma locavit.

Tam cito tam stabilem Pallas vis conderet arcem.

'On the order of Theodosius, within less than two months,

Constantine triumphantly placed these firm walls.

So fast not even Pallas [Athena] could found a fortress standing so strong'.

In the Latin epigram, the verses primarily praise the prefect Constantine (while paying very little homage to the emperor); by alluding to the ancient poet Virgil (Ecloga 2, 61: Pallas quas condidit arces), the poem even likens Constantine's deed to Athena's supernatural power to build fortresses, such as the Athenian Acropolis.

Another Latin elegiac distich can be found incised on both sides of the lower part of a cross, on a lintel of the Sulukulekapı, also known as the Porta Pempti, situated between Towers 77 and 78 (fig. 2):

Portarum valido firmavit limine muros

Pusaeus, magno non minor Anthemio.

'With a strong lintel Pusaeus strengthened the walls of the gates,

he, who is not second to the great Anthemius'.

This inscription is a very good example of how inscribed texts may relate to each other: this distich is undoubtedly connected to the aforementioned epigram at the Golden Gate. Although the Golden Gate inscription does not refer to Anthemios by his name - it mentions only the emperor - knowledge about the building works carried out under the supervision of the the praefectus praetorio Orientis Anthemios must have still been widespread in the second half of the fifth century. The verses of the Sulukulekapı clearly show that Pusaeus (pretorian prefect and hypatos between 465 and 467 and again in 473) compares himself with Anthemios.

\section{Other Latin inscriptions in public places in Constantinople}

The statue base of Eudoxia, the wife of the Emperor Arcadius and mother of the future Emperor Theodosius II, was erected in 403. It bears a bilingual inscription: however, the Greek part of the inscription is much more elaborate, as it consists of four hexameters, whereas the Latin text is composed in simple prose stating that the prefect of the city (praefectus urbis) Simplicius has dedicated the statue: D(ominae) n(ostrae) Ael(iae) Eudoxiae semper Augustae v(ir) c(larissimus) Simplicius praef(ectus) urb(is) dedicavit. 
The Column of the Emperor Marcian (450-57) (see also Chapter 6 by Paul Magdalino) is also inscribed with a Latin elegiac distich - a form, which is reminiscent of the epigraphs listed above (fig. 3). The verses mention the emperor, but they emphasise the name of the prefect responsible for the erection of the column:

[Pr]incipis hanc statuam Marciani cerne forumque, [prae]fectus vovit quod Tatianus opus.

'Behold this statue and the Forum of Marcian.

The prefect Tatianus dedicated this work'.

The famous inscription on the Egyptian Obelisk in the Hippodrome is displayed in two versions: Latin and Greek (see also Chapter 2 by Ine Jacobs). Both texts credit the Emperor Theodosius I and the Urban Prefect Proclus with raising the obelisk in the year AD 390. As can be clearly seen, the name Proclus was erased and then re-engraved due to Proclus's removal from office in 392 and to his reinstatement in 395. The Latin and the Greek versions are not exact translations of each other, but represent two different treatments of the same subject. Both are honorific building inscriptions addressing visitors of the Hippodrome, the Latin and Greek speakers of Constantinople of that time. It is noteworthy that the Latin text faced the - likely - place of the imperial kathisma, while the Greek version was oriented towards the seating area occupied by the circus factions. This placement indicates two distinct target audiences: Latin was still the language of power, the court, the bureaucracy and the army, whereas Greek was the lingua franca of Constantinople's population. And even if they could not be deciphered distinctly from the Hippodrome's seats, their mere existence had a symbolic (and most certainly evocative) meaning for the spectators, who gazed at them.

\section{Latin inscriptions on late antique artefacts from Constantinople}

Very rarely are Latin inscriptions preserved on media other than stone and mosaic. The last known Latin inscription issued by a Byzantine emperor is a dedicatory poem on the so-called Crux Vaticana (now kept in St Peter's Treasury), offered by Justin II (565-78) and his wife Sophia to the city of Rome, presumably presented to the Pope John III (fig. 4):

\section{Ligno quo Christus humanum subdidit hostem dat Romae Iustinus opem et socia decorem.}

'Justin and his consort give to Rome a glorious treasure in the wood by which Christ subdued the enemy of mankind'.

(Translation by A. Eastmond)

Justin II's name is mentioned in the middle of the second hexameter. However, on the object, the words, which precede the emperor's name, are squeezed in on the upper arm of the cross, so that IUSTINUS appears as the first word on the left arm.

Ivory consular diptychs constitute another set of evidence for artefacts with Latin inscriptions. These were serially-produced panels issued by consuls at the time of their accession to office; the series ends with the civil consulate in 541. The latest two preserved consular diptychs are those of Justin, the second cousin of the Emperor Justinian I. They were issued in 540 to celebrate the appointment of Justin as consul ordinarius, and of Basil, a member of a renowned Roman aristocratic family, who assumed the eastern consulship in 541, only a few months after the Byzantine re-establishment of power in Italy. 
Only one surviving diptych bears a metrical Latin inscription. It was issued when Justinian, the future emperor, became consul of the East in 521. The elegiac distich reads as follows:

Munera parva quidem pretio sed honoribus alma patribus ista meis offero cons(ul) ego.

'I, the consul, offer to my senators these gifts,

small indeed in value but affectionate with marks of respect'.

\section{Selected Bibliography}

Cugusi, P. (2010) Carmina Latina epigraphica Constantinopolitana, Rivista di Filologia e di Istruzione Classica, 138, 445-461

Feissel, D. (2006) Les inscriptions latines dans l'Orient protobyzantin, in Harreither, R., Pergola, Ph., Pillinger, R. and Pülz, A. (eds) Acta Congressus Internationalis XIV Archaeologiae Christianae, Vindobonae 19.-26. 9. 1999. Frühes Christentum zwischen Rom und Konstantinopel, Vatican City, I, 99-129, II, fig. 96-100.

Łajtar, A. (2000) Die Inschriften von Byzantion, vol. I (= Inschriften griechischer Städte aus Kleinasien, vol. 58), Bonn.

Mango, C. (1951) The Byzantine Inscriptions of Constantinople: A Bibliographical Survey, American Journal of Archaeology, 55, 52-66.

Mango, C. (1986) Epigrammes honorifiques, statues et portraits à Byzance', in

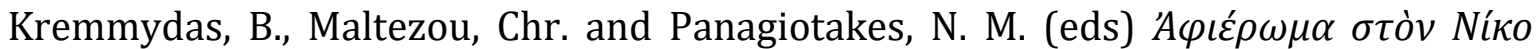
$\Sigma \beta o \rho \tilde{\omega} v o$, Rethymno, I, 23-35

Meyer-Plath, B. and Schneider, A. M. (1943) Die Landmauer von Konstantinopel. Zweiter Teil: Aufnahme, Beschreibung und Geschichte, Berlin.

Olovsdotter, C. (2005) The Consular Image. An Iconographical Study of the Consular Diptychs, Oxford.

Omissi, A. (2016) Damnatio Memoriae or Creatio Memoriae? Memory Sanctions as Creative Processes in the Fourth Century AD, The Cambridge Classical Journal 62, 170 199.

Rhoby, A. (2019) Latin Inscriptions in (Early) Byzantium, in Garcea, A., Rosellini, M. and Silvano, L. (eds), Latin in Byzantium I. Late Antiquity and Beyond, Turnhout, 275-294.

Schmidt, M. G. (2015) Carmina Latina epigraphica, in Bruun, Chr. and Edmondson, J. (eds) The Oxford Handbook of Roman Epigraphy, Oxford, 764-782. 


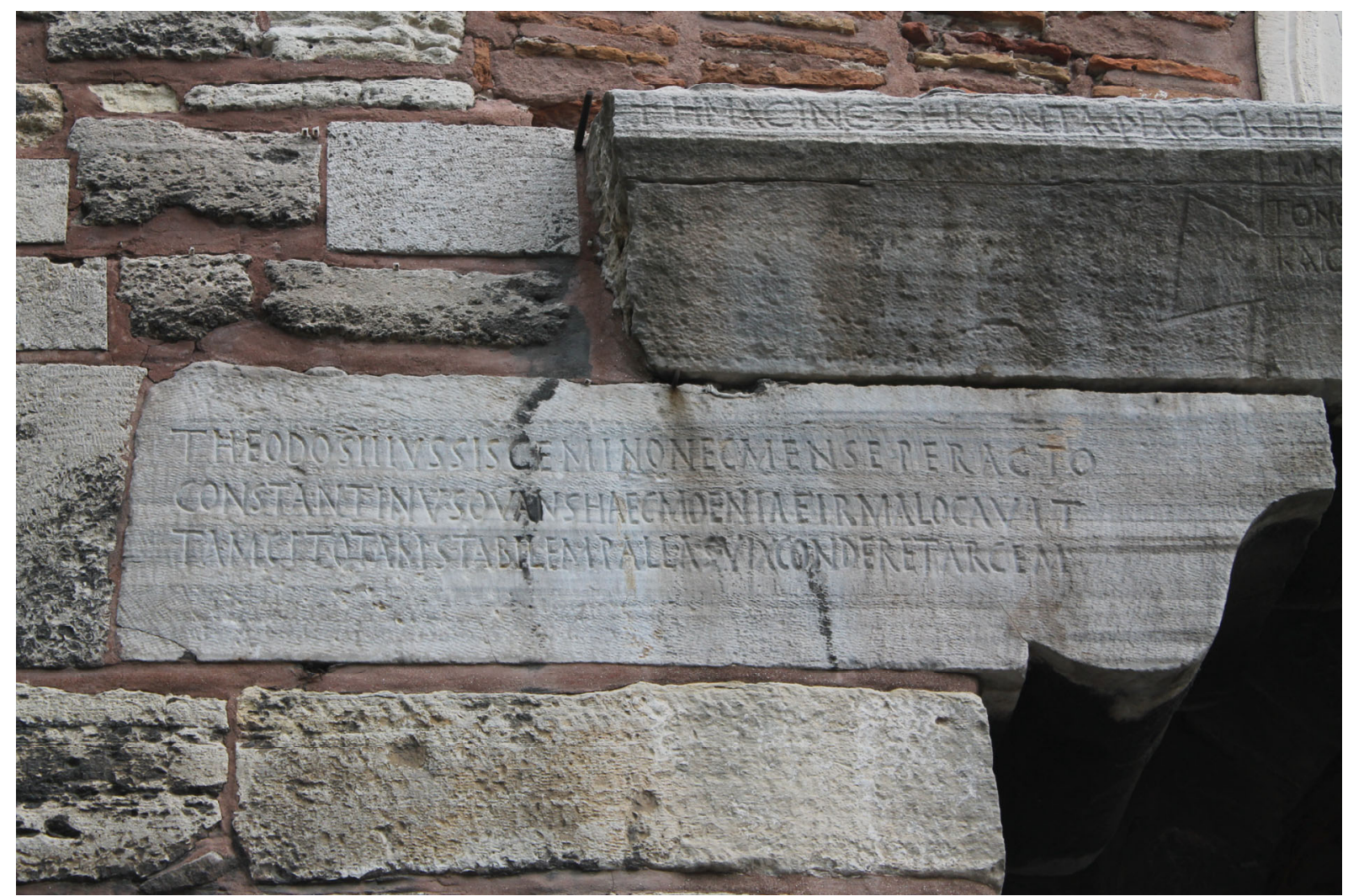

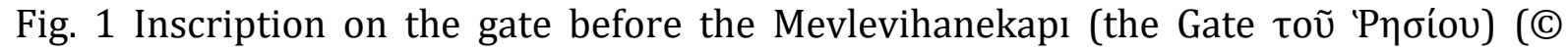
Andreas Rhoby)

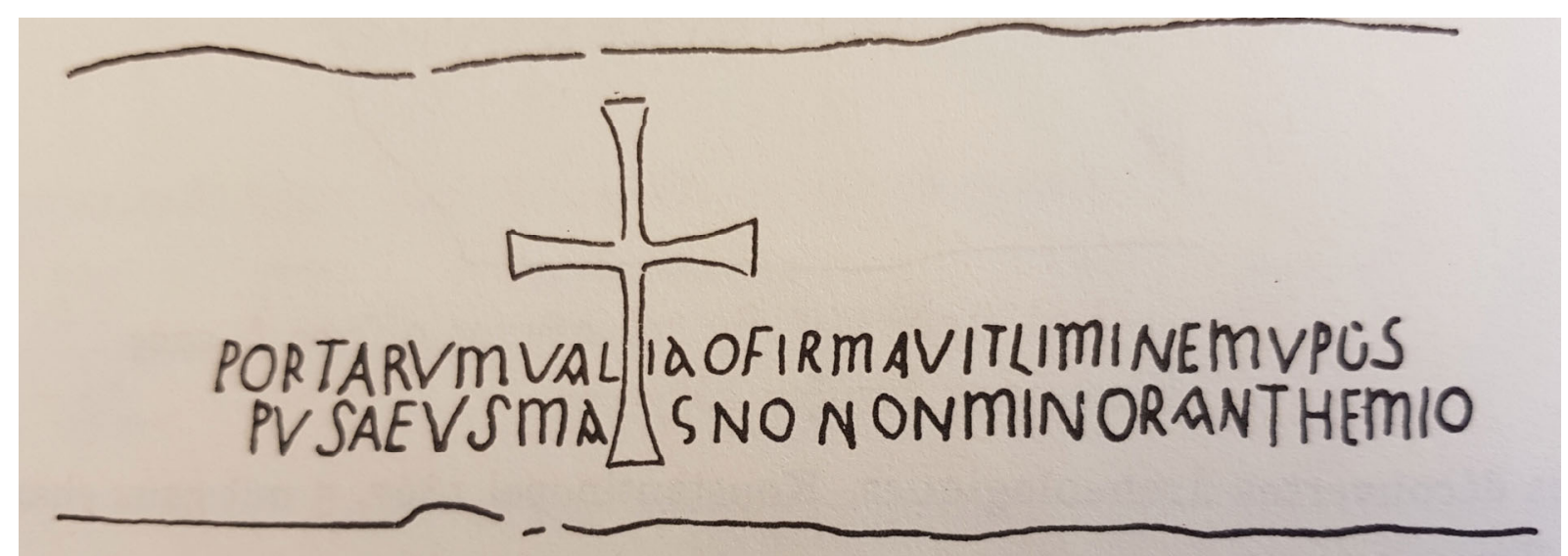

Fig. 2 Inscription on the lintel of the Sulukulekapı (Porta Pempti) (after Meyer-Plath and Schneider 1943, 136). 


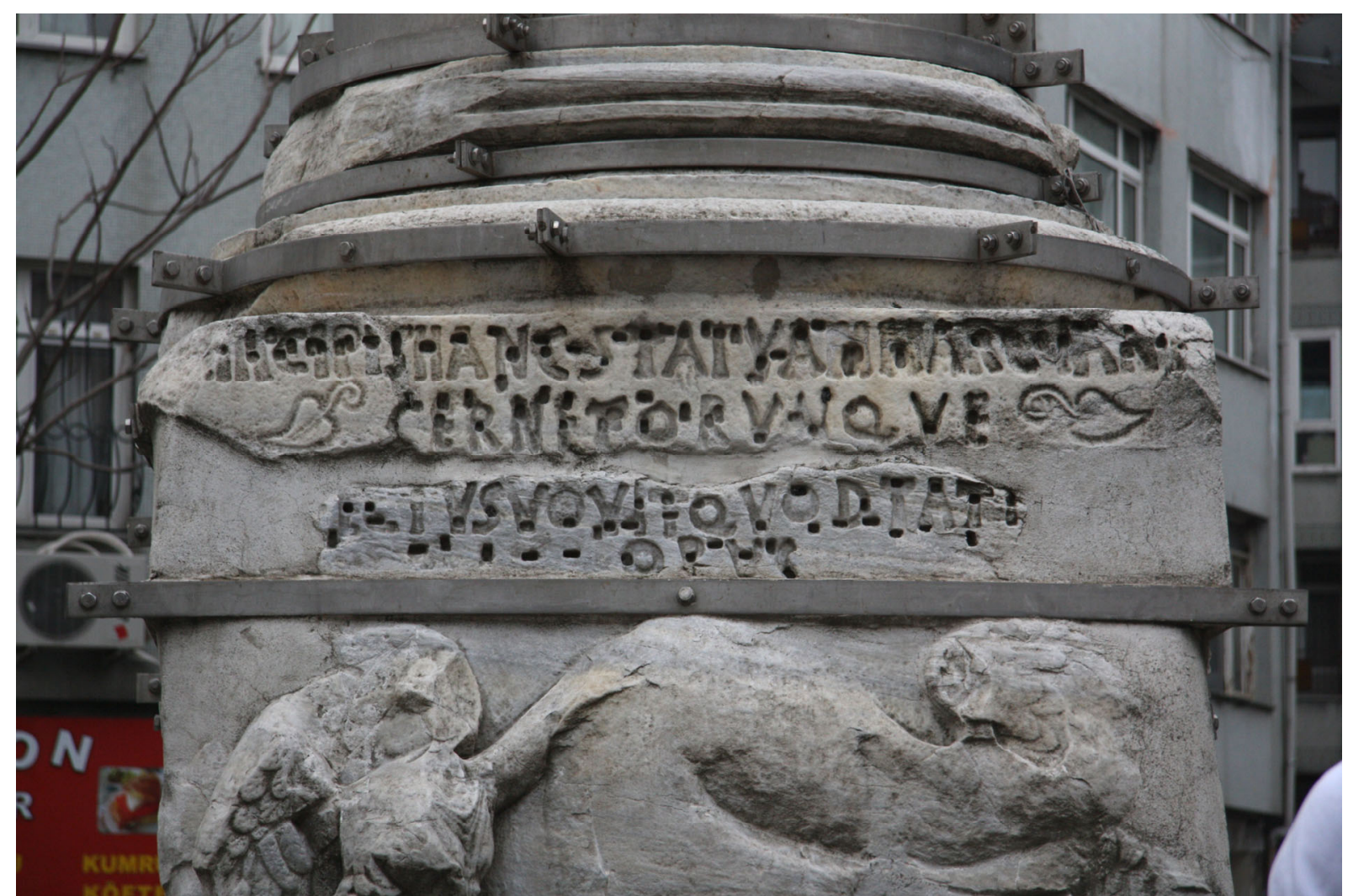

Fig. 3 Inscription on the base of the column of the Emperor Marcian (C) Ida Toth)

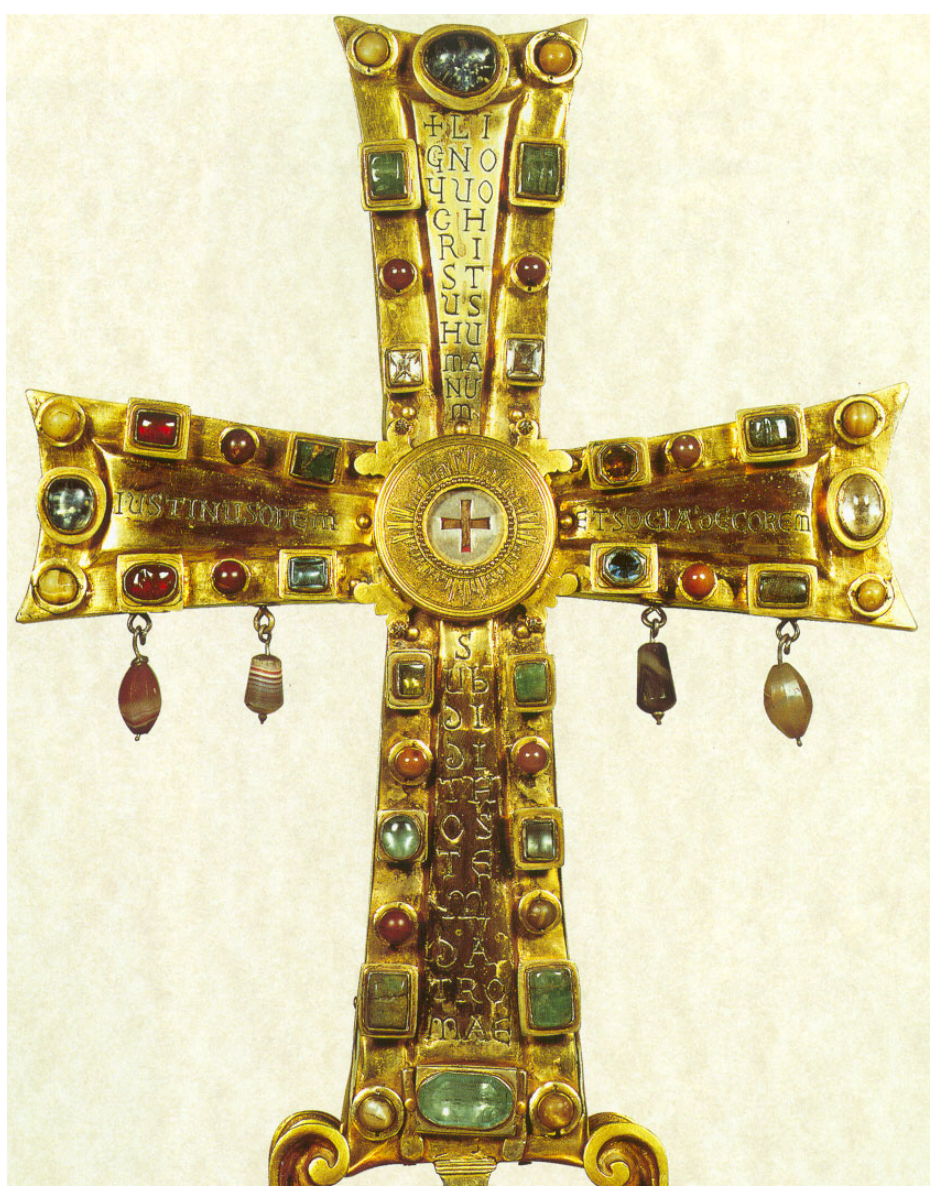

Fig. 4 Crux Vaticana (after

http://campus.belmont.edu/honors/Just/JustinianIIcrossgift.jpg) 


\title{
15. Medieval Latin Inscriptions in Constantinople
}

\author{
ESTELLE INGRAND-VARENNE
}

"Latin" in the title refers to the Latin language and the Latin alphabet (vs. Greek), but it is also a metonymy for the Western world (vs. the Byzantine world). In other words, the Latin epigraphy of Constantinople is an 'exogenous' epigraphic tradition in Byzantium, showing Western presence in the Second Rome. From the Fourth Crusade to the Ottoman period, the status of the Latins changed: from the position of supremacy, it was reduced to that of a colony. Moreover, the Latins were extremely divided between themselves (one needs only to mention the strong rivalry between Venice and Genoa); the Genoese did not take part in the Crusade, and they supported the restoration of Byzantine power (the Treaty of Nymphaeum, 1261).

After the fall of Constantinople in 1204, the new, Latin, emperors engaged in the reconstruction and the embellishment of their capital, perhaps also with inscriptions, but this cannot be verified: fewer than ten epigraphic texts are known from this period, and two of them are no longer in Istanbul. The reliquary for the True Cross is preserved in the Treasury of San Marco in Venice and bears an inscription explaining that the cross was executed by Gerard, the goldsmith for Henry of Flanders, the second Latin emperor of Constantinople. Another inscription was carved in 1260 for the Venetian palace of Constantinople. Following the palace's destruction in 1261, the inscription was transported to Genoa to adorn the new palace San Giorgio. Only one funerary text (1249?) has been found within the Byzantine city. Nevertheless, we know that other leaders or members of the Latin imperial family were buried in Hagia Sophia: the doge Enrico Dandolo (a $19^{\text {th }}$-century commemorative plaque is still visible in the church) and Mary, Baldwin I's wife (her exact burial place remains unknown). The most significant inscriptions dating back to the period of Latin rule are the frescoes discovered in 1967 in the Church of Theotokos Kyriotissa. They feature the cycle of the Life of St. Francis (ca. 1250) and are embellished with inscriptions including a quotation of the Psalm 25 (26):8 (commonly used in the liturgy of the consecration of a church), and a fragment of the name 'Chrysostom'. The first half of the $13^{\text {th }}$ century might not have produced a large number of Latin inscriptions, but they are nonetheless worthy of mention.

Under the Palaiologoi, the Genoese obtained the right to have their own district, and to construct their own buildings in Galata, but without any defensive structures. Despite this edict, in 1304 they began to build walls, and to expand their settlement by purchasing more land. 44 inscriptions and coats of arms discovered on the walls and the towers of Galata attest to this expansion (studied by H. S. Sağlam) and the power of the Genoese colony, playing the role of 'colonial milestones' (according to Siegrid Düll). Between 120 and 130 stone slabs have been discovered on the sites of the churches St Domenico and St Francesco, all dating back to the $14^{\text {th }}$ and $15^{\text {th }}$ centuries. They feature funerary inscriptions following the Genoese models, beginning with a cross, then the word 'sepulcrum', the name and the title(s) of the deceased in genitive, and often the expression 'et heredum ejus' (= 'and of his family'). In this regard, the large tomb slab of two English knights, probably brothers-in-arms, who died in 1391, is an exception. (See, Desi Marangon, Chapter 16) Overall, the inscriptions of Galata form a homogeneous group closely resembling the epigraphic production of Genoa: always in Latin (no vernacular), these prose texts commonly use elegant Gothic majuscules, clearly legible letters (no minuscule), and heraldic signs. 
The total number of nearly 180 inscriptions forms a significant source material for the story of the Latins in Constantinople, and not only of the Crusaders post 1204 but also of the Genoese: their podestàs, their noble families and merchants, and their relationship with the Greeks. Do these inscriptions provide any evidence of interactions between Latin and Byzantine art and written culture? The studies of the decoration of Constantinople's mendicant churches have shown artistic commonalities, and they have also posited Byzantine painters' involvement in the execution of the fresco programmes in these churches. The paintings of St Domenico, for example, betray Palaiologan style and artistic taste, even if their decorative program is Italian. We have seen how John Chrysostom could be perceived as a spiritual model for the Franciscans as a proponent of the Church Union. The inscribed slabs used in the construction of the walls in the Genoese quarter resemble Greek inscriptions on the Sea and Land Walls, even if their display is different. A further question remains open: did at any point Latin epigraphy influence Greek?

\section{Selected Bibliography}

Akyürek, E. (2011) Dominican Painting in Palaiologan Constantinople: The Frescoes of the Arap Camii (Church of S. Domenico) in Galata, in Klein, H. A., Ousterhout, R. G. and Pitarakis, B. (eds) The Kariye Camii Reconsidered, Istanbul, 327-341.

Çetinkaya, H. (2010), Arap Camii in Istanbul: Its Architecture and Frescoes, Anatolia antiqua. Eski Anadolu 18, 169-188.

Dallegio d'Alessio, E. (1928) Une nouvelle inscription génoise découverte à Galata, Échos d'Orient 27, 168-174.

Dallegio d'Alessio, E. (1929) Une inscription inédite d'Arab-Djami, Échos d'Orient 28, 407 413.

Dallegio d'Alessio, E. (1932), Les inscriptions latines funéraires de Constantinople en Moyen Âge, Échos d'Orient 31, 188-206.

Dallegio d'Alessio, E. (1933) Inscriptions latines funéraires de Constantinople au Moyen Âge. 2e série, Échos d'Orient 32, 340-347.

Dallegio d'Alessio, E. (1942) Le pietre sepolcrali di Arab Giamí (Antica Chiesa di S. Paolo a Galata) (= Atti della Società Ligure di Storia Patria, vol. 69), Genova.

Düll, S. (1982) Die lateinischen Inschriften aus Istanbul vor und nach der osmanischen Eroberung (Vorarbeiten für ein neues Inschriftenprojekt in der Türkei), in Koch, W. (ed) Epigraphik 1982 - Referate. Fachtagung für mittelalterliche und neuzeitliche Epigraphik, Klagenfurt, 30. September - 3. Oktober 1982, Wien 101-118.

Düll, S. (1983) Unbekannte Denkmäler der Genuesen aus Galata, Istanbuler Mitteilungen 33, 225-238.

Düll, S. (1986) Unbekannte Denkmäler der Genuesen aus Galata, II, Istanbuler Mitteilungen 36, 245-256.

Düll, S., Luttrell A., Keen M. (1991) Faithful Unto Death: the Tomb Slab of Sir William Neville and Sir John Clanvowe, Constantinople 1391, The Antiquaries Journal 71, 174190.

Gottwald, J. (1911) Une inscription latine à Galata de 1418, Échos d'Orient 14, 270-272.

Haug, H. (2016) Territory and the Tomb: Enrico Dandolo's. Final Resting Place in Hagia Sophia, in Paul B. (ed) The tombs of the Doges of Venice from the beginning of the Serenissima to 1907, Rome and Venice, 167-188.

Ivison, E. (1996) Latin Tombs Monuments in the Levant 1204-ca 1450, in Lock, P. and Sanders G. D. R. (eds) The Archaeology of Medieval Greece, Oxford, 91-106. 
Jolivet-Lévy, C. (2012), La peinture à Constantinople au XIIIe siècle. Contacts et échanges avec l'Occident, in Caillet J.-P. (ed) Orient et Occident méditerranéens au XIII ${ }^{e}$ s. Les programmes picturaux, Paris, 21-40.

Pantanella, C. (1990), I Francescani a Costantinopoli. Gli affreschi con le storie di S. Francesco d'Assisi alla Kalenderhane Camii, Studia Orientalia Christiana 23, 351-380.

Pistarino G. (1995) Les symboles de Gênes dans les établissements d'outre-mer, in Balard, M. and Ducellier, A (eds) Coloniser au Moyen Âge. Méthodes d'expansion et techniques de domination en Méditerranée du 11e au 16e siècle, Paris, 299-309.

Rossi E. (1928) Le lapidi genovesi delle mura di Galata, in Iscrizioni genovesi in Crimea ed in Costantinopoli (= Atti della Società Ligure di Storia Patria, vol. 56), Genova, 143-167.

Sağlam, H. S. (2018) Urban palimpsest at Galata and an architectural inventory study for the Genoese colonial territories in Asia Minor, PhD Politecnico di Milano.

Striker, C.L. and Kuban, Y.D. (1997) Kalenderhane in Istanbul: Final Reports on the Archaeological Exploration and Restoration at Kalenderhane Camii, 1966-1978, vol. 1: The buildings, their history, architecture, and decoration, Mainz.

Van Tricht, P. (2011) The Latin 'Renovatio' of Byzantium: the Empire of Constantinople, 1204-1228, Leiden and Boston.

\section{Medieval Latin Inscriptions in Constantinople: A Selection}

\section{Venice, Treasury of St Mark - Inscription on the staurotheke of Henry of Flanders.}

Inscription made by the goldsmith Gerard, in Constantinople. The text runs along the gold-plated border around the True Cross, and reveals who made the staurotheke, for whom, and when.

Date: before 1216 .

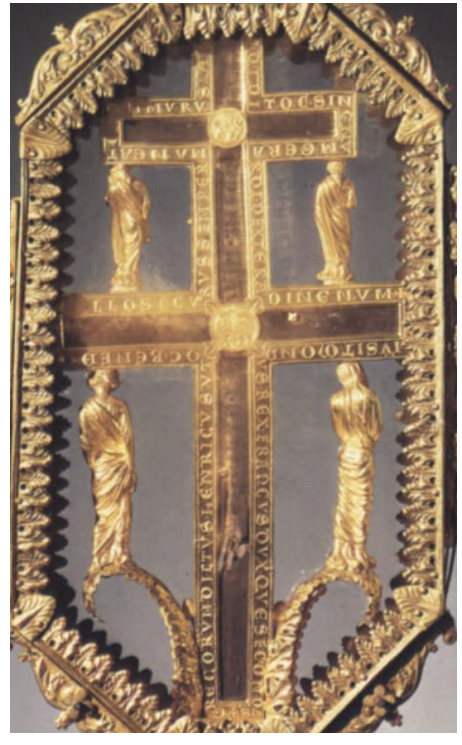

+ CONDIDIT OC SINGNVM GERARDI DEXTERA DINGNUM + QVOD IVSSIT MONDVS REX FRANCVS DVXQVE SECONDVS
+ GRECORVM DICTVS HENRICVS VT OC BENEDICTVS

+ BELLO SECVRVS SEMPER MANEAT QVASI MVRVS AMEN

Condidit oc singnum Gerardi dextera dingnum,

Quod jussit mondus rex Francus duxque secondus

Grecorum dictus Henricus ut oc benedictus Bello secures semper maneat quasi murus. Amen.

The hand of Gerard has made this venerable cross at the command of the free king with the pure heart and second leader of the Greeks, called Henry, so that, under its blessing, he will always be protected in war, as a wall. Amen. 


\section{Istanbul, ? - Funerary inscription for Bartholomew.}

The slab was found near the Sublime Porte, 7 meters under the ground level. It has since disappeared.

Date: 1249 ?

+ S(epulchrum) q[u]onda(m) mag(ist)ri Bartholomei d(ivinae a[rtis medici(na)e p(er)iti, q(u)i obiit a(nno) a[etatis quadragesimo nono, die ultimo Aug(usti)....

Grave of the deceased Bartholomeus once magistrus of the divine art of medicine, who died in the $49^{\text {th }}$ year, on the last day of August...

\section{Istanbul, Archaeological Museum - Biblical quotation, Ps 25 (26), 8.}

Fragmentary frescoes from the Church of Theotokos Kyriotissa/ Kalenderhane Camii, on the arch framing the apse of the St Francis chapel.

Date: ca. 1250.

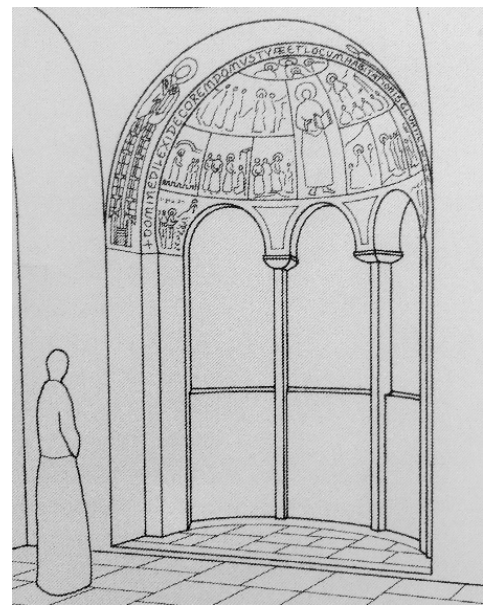

+ DOMINE DILEXI DECOREM DOMU[---] TUAE

+ Domine, dilexi decorem domu[s tuae et locum habitationis gloriae] tuae.

0 Lord, I love the house in which you dwell and the place where your glory abides.

\section{Istanbul, Archaeological Museum - Mention of the name Chrysostom.}

Fragmentary frescoes from the Church of Theotokos Kyriotissa/ Kalenderhane Camii, presenting the cycle of the Life of St Francis from the apse of one of the south chapels. 3 letters are legible in the soffit of the arch that frames the apse.

Date: ca. 1250.

$$
\text { [---]STO[--- }]
$$

[Johannes Chryso]sto[mos].

John Chrysostom. 
5. Istanbul, Archaeological Museum - Cycle of the Life of St Francis.

Fragmentary frescoes from the Church of Theotokos Kyriotissa/ Kalenderhane Camii, presenting the cycle of the Life of St Francis from the apse of one of the south chapels. Scene 6.

Date: ca. 1250.

S. FRANCISCI [---]V̄ I[.] AERA

S(aint) Francisci [---]um i[n] aera.

St. Francis ... in the air.

\section{Genoa, Palazzo San Giorgio - Mention of a date.}

Originally in the Venetian palace of Constantinople (demolished in 1261), and then reinstated in the Palazzo del Capitano del Popolo (later Palazzo San Giorgio) in Genoa. Date: 1260.
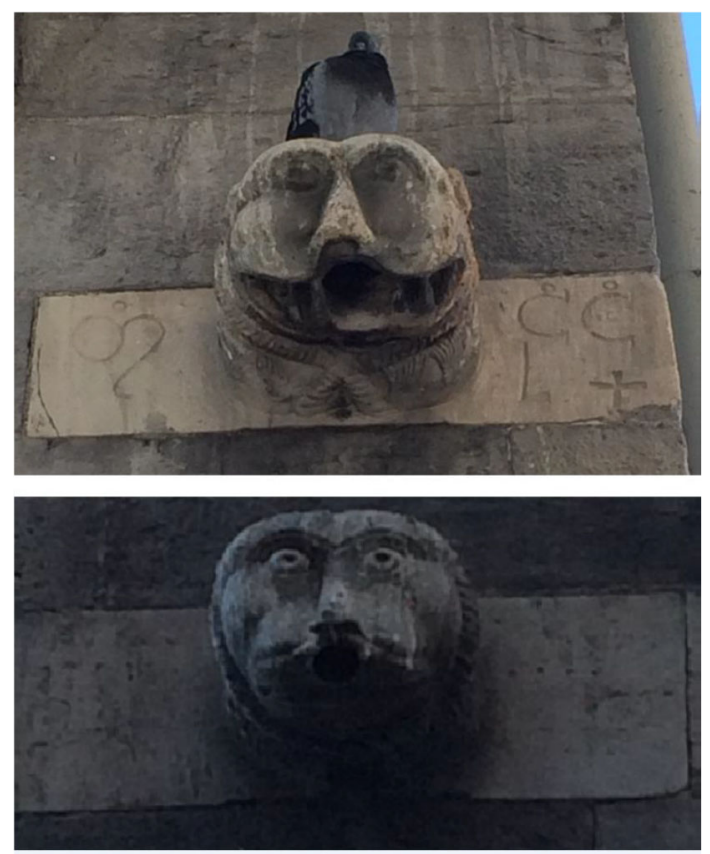

$\mathrm{M}^{\circ} \mathrm{C}^{\circ} \mathrm{C}{ }^{\circ} \mathrm{LX}$

Millesimo duecentesimo sexagesimo.

1260.

7. Istanbul, Arap Camii / S. Domenico in Galata - Identification of figures of saints and biblical quotations.

Wall paintings on the vault of the apse.

Date: first half of the 14th c. 


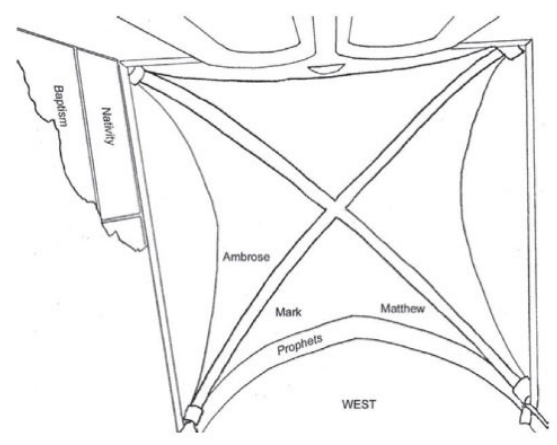

Şek. 5 Arap Camisi, İstanbul. Bemayı örten çapraz tonoz (çizim: E. Akyürek ve R. Ousterhout) Şek. 5 Arap Camisi, Istanbul. Bemayı orten çapraz tonoz (çizim: E. Akyurek ve R. Ousterhout)
Fig. 5 Arap Camii, Istanbul. Cross vault over bema (drawing by E. Akyürek and R. Ousterhout)
Western compartment - south half: MARCVS

[---]ARIAS

Western compartment - north half: S MATTEUS

LIBER GENER[---]

Southern compartment: AMBROSIUS

Marcus ; [Zach]arias; s(anctus) Matteus ; Liber gener(ationis); Ambrosius.

Mark; Zachary; Saint Mattew; the Book of the Generation; Ambrose.

\title{
8. Istanbul, Galata - Inscription relating the reconstruction of Pera after 1315.
}

Disappeared inscription, from Galata.

Date: 1316.

\author{
$[---]$ \\ MEN : IMPERANTE : SERENISSIMO : \\ DNNO $:$ DNO $\vdots$ ANDRONICO $\vdots$ PALEO \\ LOGO $:$ DEI $:$ GRA $:$ IMPERATORE $:$ RO \\ MEORU $\vdots \mathrm{M}^{\circ}: \mathrm{CCC}^{\circ} \vdots$ III $^{\circ}$ : EDIFICATA $\vdots$ FUIT $\vdots$ \\ PEYRA $\vdots$ ET $\vdots \mathrm{M}^{\circ} \vdots \mathrm{CCC}^{\circ} \vdots \mathrm{XV}^{\circ} \vdots$ COBBUSTA $\vdots$ FUIT $\vdots$ \\ MEDIETAS $:$ PEYRE $:$ CU $:$ ECCLITA $:$ PALA \\ CIO $\vdots$ COĪS $\vdots$ ET $\vdots \mathrm{M}^{\circ}: \mathrm{CCC}^{\circ} \vdots \mathrm{XVI}^{\circ} \vdots$ TPRE $\vdots$ PO \\ TESTACIE $\vdots$ DN I $\vdots$ MŌTANI $:$ Đ $\vdots$ MARINIS $\vdots$ \\ REDIFICATA : FUIT $:$ PEYRA $:$ QUI $\vdots$ DNS : \\ MONTAN $\vdots$ REDIFICARI $:$ FECIT $\vdots$ PALA \\ CIUM $:$ PLATEA $\overline{\text { }}$ LOGIE $\vdots$ HOSPITALE : \\ ET $\vdots$ DOMŪ $\vdots$ PONDERIS $\vdots$ COISS $\vdots$ ET $\vdots$ ECI \\ AM $:$ EXGRA $\bar{A}:$ SIBI $:$ CONCESSA $:$ A DIC \\ TO $\vdots$ SERENISSIMO $\vdots$ IMPATORE $\vdots$ DO \\ MOS : IUXTA $\vdots$ FOSSATA $\vdots$ CIRCA $\vdots$ TERRĀ \\ PEYRE $\vdots$ DILIGITE $\vdots$ IUSTICIĀ $\vdots$ QUI $\vdots$ IU \\ DICATIS : TERRA $\bar{A}:$ AUDI $:$ ADVERSAM : \\ PARTE $:$ ANTE $\vdots$ QUĀ $:$ FERAS $\vdots$ SETTECIAM :
}

[+ In nomine Domini a]men. Imperante serenissimo d(omi)no, d(omi)no Andronico Paleologo, Dei gra(tia) imperatore Romeoru(m), 1303 edificata fuit Peyra et 1315 co(m)busta fuit medietas Peyre cu(m) eccl(es)ia palacio co(mmun)is et 1316 t(em)p(o)re potestacie d(omi)ni Mo(n)tani De Marinis redificata fuit Peyra qui d(omi)nus Montan(i) redificarai fecit palacium platea $(m)$ logie hospitale et domu(s) ponderis co(mmun)is et ec(cles)iam exgra(tia) sibi concessa a dicto serenissimo imp(er)atore domos juxta fossata circa terra $(m)$ Peyre. Diligite justicia $(m)$ qui judicatis terra $(m)$, audi adversam parte $(m)$ ante qua $(m)$ feras se $(n)$ te $(n)$ ciam. 
In the name of the Lord amen. The most serene reigning ruler, Lord Andronikos Palaiologos, by the grace of God, Emperor of Rome has established Pera in 1303. The half of Pera was burnt in 1315 with the church and the communal palace. In 1316, during his podestàship, Lord Montano De Marini has rebuilt Pera; Lord Montano has rebuilt the palace, loggia square, hospital and the communal house of scales and the church. Furthermore, houses next to moats around the land of Pera were granted as a favor by the most serene emperor himself. Love justice, you judges of the earth! Listen to the opposite party before ratifying judgments!

\section{Istanbul Archaeological Museum - Inscription commemorating the work of Raffaele Doria on the Galata Tower.}

Slab located above the first tower in the northwest of Galata Tower (inventory number: 954T).

Date: 1387.

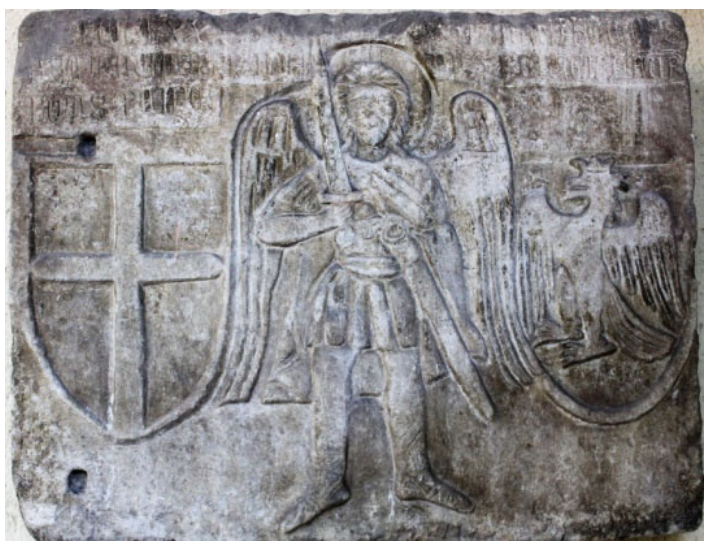

+ M CCC LXXX VII DIE XXV MARCII HOC OP FACT FUIT TPR NOB̄L/ DN̄S RAFAEL D AŪR POTTAS PEIRE

+ 1387 die 25 marcii hoc op(us) fact(um) fuit t(em)p(o)r(e) nob(i)l(is) d(omi)n(u)s Rafael D(e) Aur(ia) pot(est)as Peire.

25 March 1387. This work was done during the time of the noble lord Raffaele Doria, podestà of Pera.

10. Istanbul Archaeological Museum - Double epitaph for William Neville and John Clanvowe.

Tomb slab of two English knights, formerly located in S. Domenico in Galata (inventory number: 2894T).

Date: 1391.

$\begin{array}{ll}:^{*}: \text { HIC }: \text { IACET : } & \text { HIC : IACET : } \\ \text { NOBILIS : MILES } & \text { NOBILIS : MILES } \\ \text { DNS : GVLIELMVS } & \text { DNS IOHES C } \\ \text { NEVILE : ANGLIC' } & \text { [---] ANGL } \\ \text { QI : OBIIT : M : CCC } & \text { IC[..] QI : OBIIT } \\ \text { LXXXX }{ }^{\circ}: \text { DIE }: \text { X } & \text { M CCC LXXXXI } \\ \text { OCTOBRIS : + } & \text { DIE VI OCTOBRIS }\end{array}$

Hic jacet nobilis miles d(omi)n(u)s Gulielmus Nevile Anglic(us) q(u)i obiit 1391 die 10 octobris. Hic jacet nobilis miles d(omi)n(u)s Joh(ann)es C[lanvowe] anglic[us] q(u)i obit 1391 die 6 octobris. 
Here lies the noble knight Sir William Neville, Englishman, who died 10 October 1391. Here lies the noble knight Sir John Clanvowe, Englishman, who died 6 October 1391.

\section{Istanbul Archaeological Museum - Inscription commemorating the work of Nicolo Antonio Spinola on the Galata Tower.}

Slab discovered on the fourth tower to the northwest of Galata Tower (inventory number: 961T).

Date: 1442.

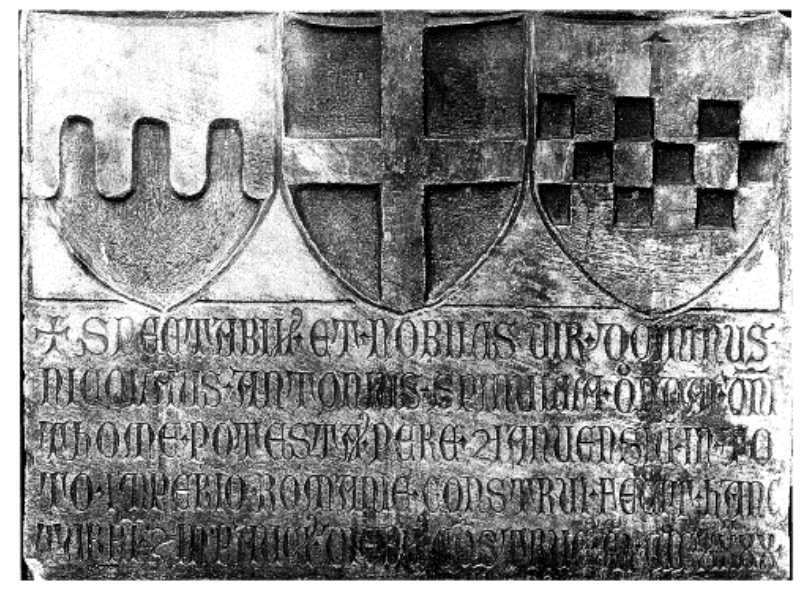

+ SPECTABIL'. ET. NOBILIS . VIR . DOMINUS. NICOLAUS. ANTONIUS. SPINULLA. Q ${ }^{\circ}$ NDAN : DN̄I THOME. POTESTA'. PERE. Z IANUENSIŪ. IN TO TO. IMPERIO. ROMANIE. CONSTRUI. FECIT. HANC TURRĪ. Z IN PAUCI'. DIEBU'. CŌSTRUC'. Mํ. CCCC. XXXX. DIE. VIIII. MAII

+ Spectabil(is) et nobilis vir, dominus Nicolaus Antonius Spinulla q(uo)ndan d(omi)ni Thome potesta(s) Pere (et) Januensiu(m) in toto imperio Romanie construi fecit hanc turri(m) (et) in pauci(s) diebu(s) co(Ostruc(ionis) 1442, die 9 maii.

Admirable and noble man Lord Nicolo Antonio Spinola, formerly Lord Tommaso, the podestà of Pera and Genoa in the whole Roman Empire has constructed this tower within a few days. 9 May 1442.

\section{Istanbul Archaeological Museum - Inscription on the construction of a tower.}

Slab discovered on the second/third tower to the northwest of Galata Tower (inventory number: 962T).

Date: 1443. 


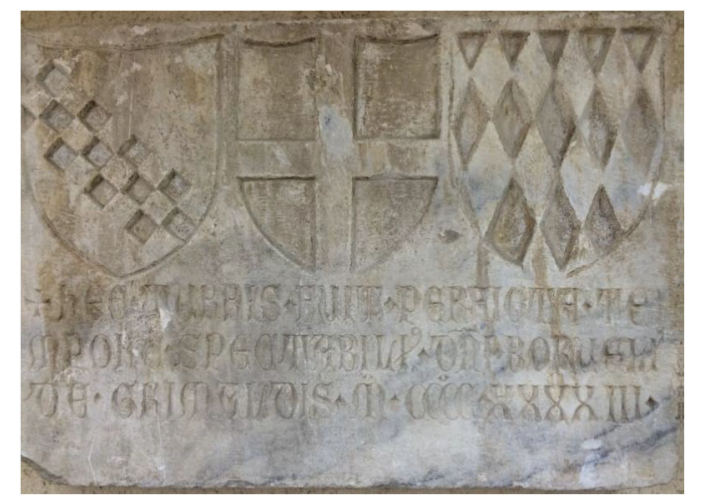

+ HEC . TURRIS . FUIT . PERFICTA . TE

MPORE . SPECTABILI' . DN̄I . BORUELI'

DE . GRIMALDIS . $\mathrm{M}^{\circ}$.CCCC ${ }^{\circ}$. XXXX III .

+ Hec turris fuit perficta tempore spectabili(s) d(omi)ni Borueli(s) de Grimaldis 1443.

This tower was completed in 1443 under the worthy administrator Boruel de Grimaldi.

\section{Istanbul Archaeological Museum - a mention of date.}

Slab discovered above the circular lower wall in front of Galata Tower (inventory number: 950T).

Date: 1452.

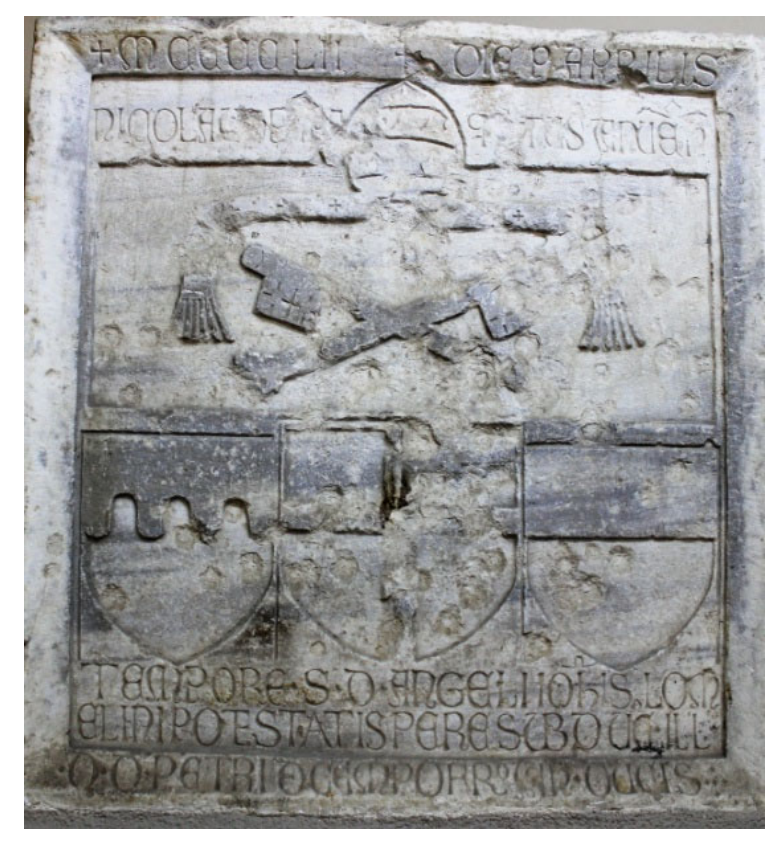

+ M CCCC LII + DIE PA APRILIS NICOLAU[.] P[..]A / Q[..]TUS JANUĒN TEMPORE . S . D . ANGELI IOḦIS LOM ELINI POTESTATIS PERE SUB DUC .ILL . . D. D. PETRI DE CAMPOFR ${ }^{\circ}$ IAN DUCIS +

+ 1452, die p(rim)a aprilis, Nicolau[s] Papa Q[uin]tus Januen(sis), tempore s(pectabilis) d(omini) Angeli Joh(ann)is Lomelini, potestatis Pere sub duc(atu) ill(ustris) d(omini), d(omini) Petri D(e) Campofr(egos)o, Jan(ue) ducis.

1 April 1452. Pope Nicholas V of Genoa. During the time of admirable lord Angelo Giovanni Lomellini, podestà of Pera under the duchy of the illustrious ruler, Lord Pietro de Campofregoso, the doge of Genoa. 



\section{Latin Inscriptions in the Arap Camii DESI MARANGON}

The history of Genova in the Middle Ages is closely connected with the growth of trade and with the development of its colonies in the East. For these reasons, historiography concerning the city has been focused mainly on three geographical areas: the crusader states, Constantinople and the Byzantine empire, and the Black Sea. As concerns the territories of the Byzantine Empire, the publications are numerous and epigraphic collections are considered an important complement to the existing archival material. Most of them are funerary inscriptions.

The most important burial church in the Genoese colony of Constantinople was the monastery of SS Paolo e Domenico in Galata, now called Arap Camii. It was erected during the thirteenth century, but became the most important Latin church only a century later, when it was enriched with numerous funerary inscriptions and floor slabs.

The epigraphs located in the monastery have many features in common: motifs linked to the western design, like coats of arms, the representation of Agnus Dei, depictions of the full length figures of the deceased, and, significantly, the exclusive use of Latin language. The brevity of the text is noteworthy. The opening words usually refer to the burial place (sepulcrum) and to the name of the patron expressed through the genitive case (Domini), followed by the common funerary formula hic iacet, and the date of death. (See, Estelle Ingrand-Varenne, Chapter 15)

These devices and the text structure evokes the Genoese tradition, but they at the same time include contemporary Greek features. These are detectable especially on their decorative elements, while the content of the text and the shape of letters conform to the western epigraphic habit. This intermingling of features should be understood in the context of a wider phenomenon whereby scripts and epigraphs composed in some of the Italian cities that formed close ties with Constantinople were similarly infused with elements borrowed from the Byzantine writing traditions and alphabet.

In conclusion, it should be noted that the funerary inscriptions of the Arap Camii, although open to Byzantine influence, nonetheless adopted the Latin alphabet. Thus, they represent the expression of a distinct identity.

\section{Selected bibliography}

Akyürek, E. (2011) Dominican Painting in Palaiologan Constantinople: The Frescoes of the Arap Camii (Church of S. Domenico) in Galata, in Klein, H. A., Ousterhout, R. G. and Pitarakis, B. (eds) The Kariye Camii Reconsidered, Istanbul, 327-341.

Çetinkaya, H. (2010), Arap Camii in Istanbul: Its Architecture and Frescoes, Anatolia antiqua. Eski Anadolu 18, 169-188.

Cramer, L. and Düll, S. (1985) Baubeobachtungen an der Arap Camii in Istanbul, Istanbuler Mitteilungen 35, 295-321.

Dallegio d'Alessio, E. (1942) Le pietre sepolcrali di Arab Giamí (Antica Chiesa di S. Paolo a Galata) (= Atti della Società Ligure di Storia Patria, vol. 69), Genova.

Düll, S. (1986) Unbekannte Denkmäler der Genuesen aus Galata, Istanbuler Mitteilungen 36, 245-257.

Ebersolt, J. (1921) Arab Djami et ses sculpures byzantines, in Ebersolt, J. (ed) Mission archéologique de Constantinople, Paris, 35-39.

Ivison, E. (1996) Latin Tombs Monuments in the Levant 1204-ca 1450, in Lock, P. and Sanders G. D. R. (eds) The Archaeology of Medieval Greece, Oxford, 91-106. 
Rossi E. (1928) Le lapidi genovesi delle mura di Galata, in Iscrizioni genovesi in Crimea ed in Costantinopoli (= Atti della Società Ligure di Storia Patria, vol. 56), Genova, 143-167.

Skrzinska, E. (1928) Inscriptions latines des colonies génoises en Crimée (Thédosie - Soudak Balaklava), in Iscrizioni genovesi in Crimea ed in Costantinopoli (= Atti della Società Ligure di Storia Patria, vol. 56), Genova, 1-140.

Westphalen, S. (2007) Pittori greci nella chiesa domenicana dei Genovesi a Pera (Arap Camii). Per la genesi di una cultura figurativa levantina nel Trecento, in Calderoni Masetti, A. R., Dufour Bozzo, C. and Wolf, G. (eds), Intorno al sacro Volto. Genova, Bisanzio e il Mediterraneo (secoli XI-XIV), Venice, 51-62.

Westphalen, S. (2008) Die Dominikanerkirche der Genuesen von Pera (Arap Camii). Griechische Maler - Lateinische Auftraggeber, in Wulff-Rheidt, U. and Pirson, F. (eds), Austausch und Inspiration. Kulturkontakt als Impuls architektonischer Innovation. Kolloquium vom 28.-30.4.2006 in Berlin anlässlich des 65. Geburtstages von Adolf Hoffmann, Mainz, 276291.

\section{Appendix: Latin Inscriptions in the Arap Camii: A Selection}

1.

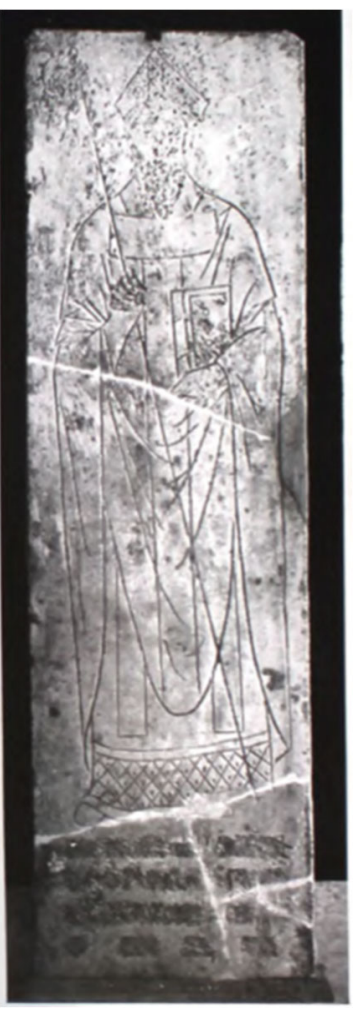

2.

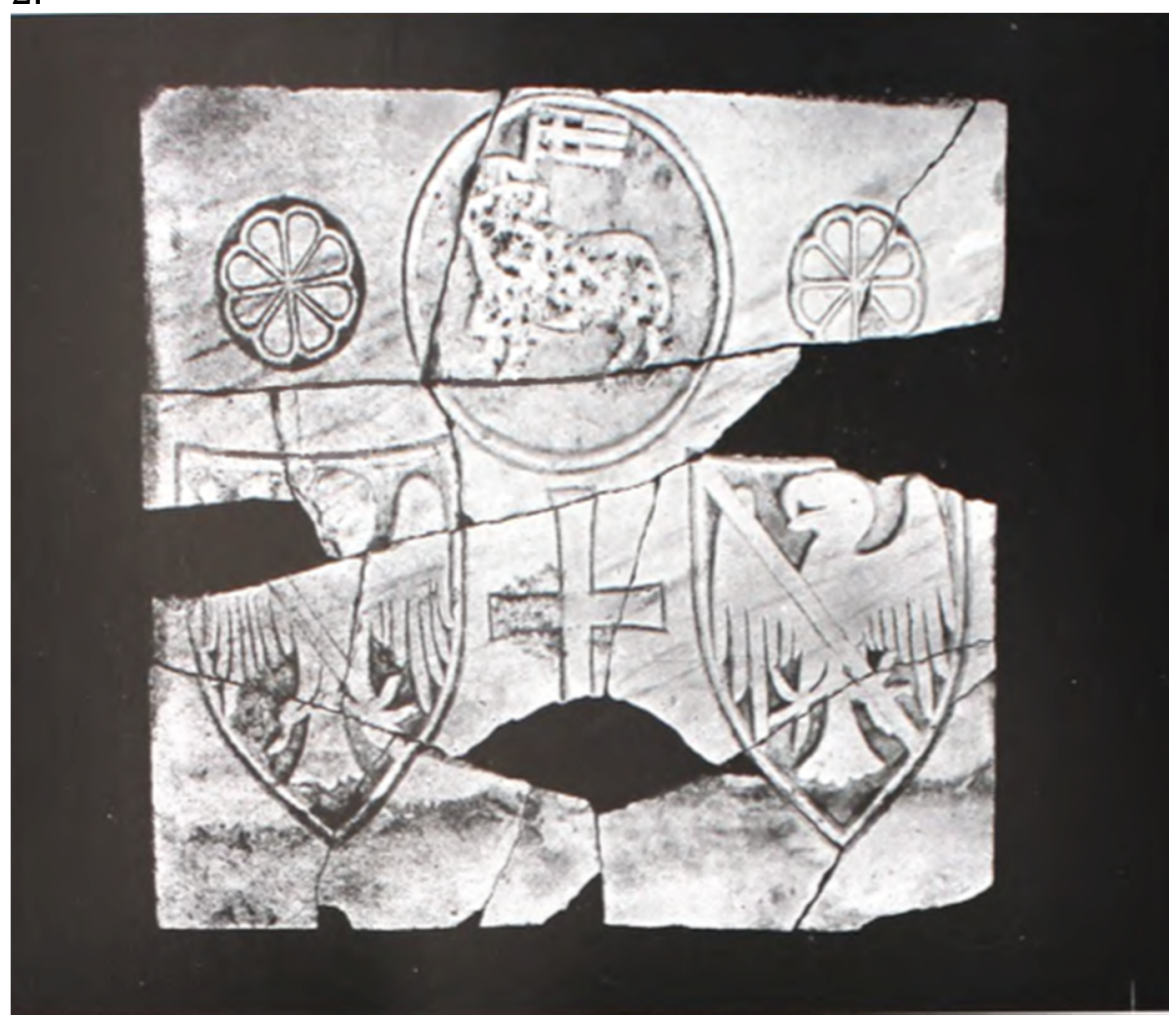


3.

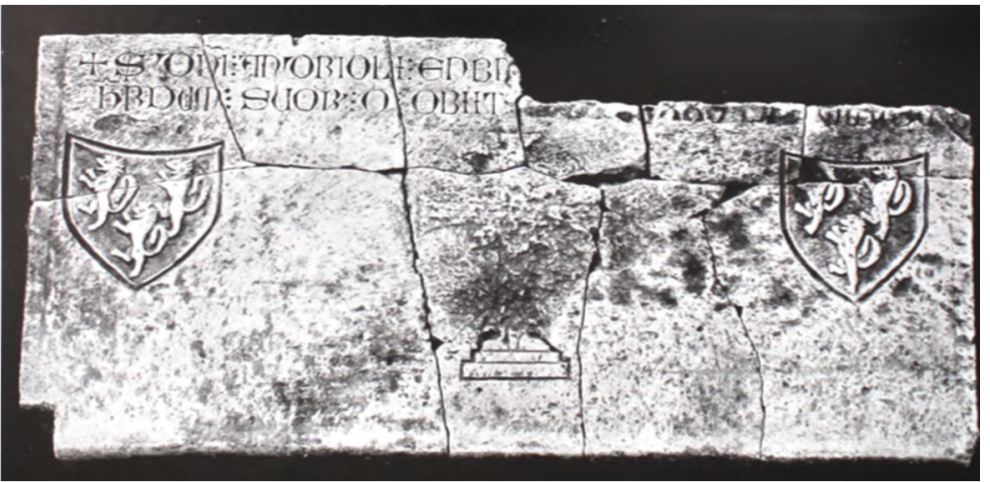

+ S(epulcrum) D(omi)ni Embr[iaco... et] /h(e)r(e)dum suor(um) q(ui) obiit [a(nno)] MCC [C] XXV di(e) p(ri)ma de(cembris)

4.

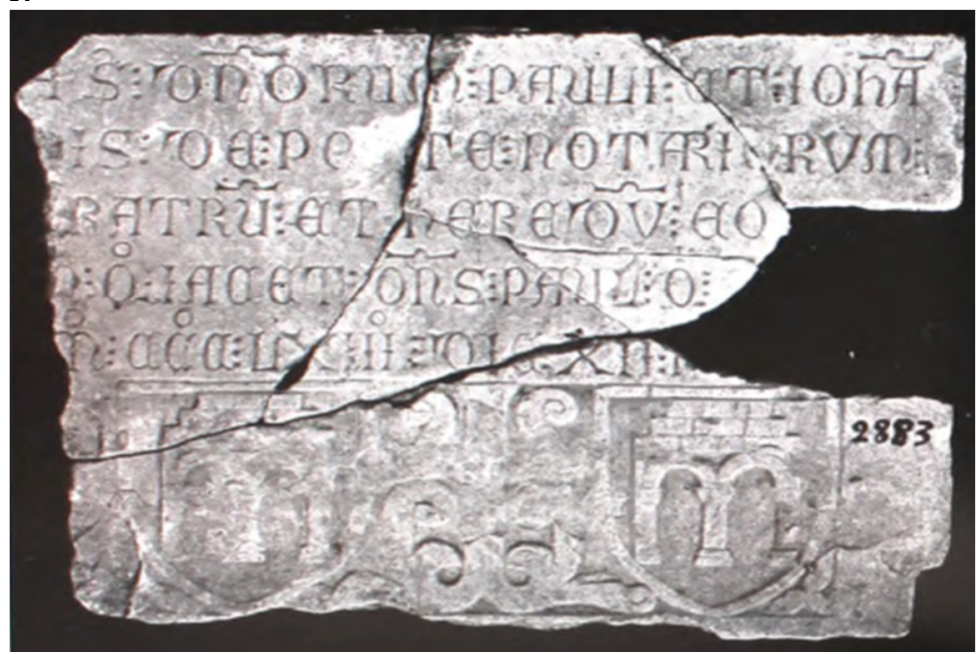

+ S(epulcrum) D(omi)norum Pauli et Ioha/[n] is de Po[n] te notariorum / [f] ratrum (m) et heredu(m) eo[rum] / [i]n $q(u)$ o iacet $D($ omi $) n(u) s$ Paulu(s) $q(u) i$ o[biit] / MCCCLXIII die XII

\section{5.}

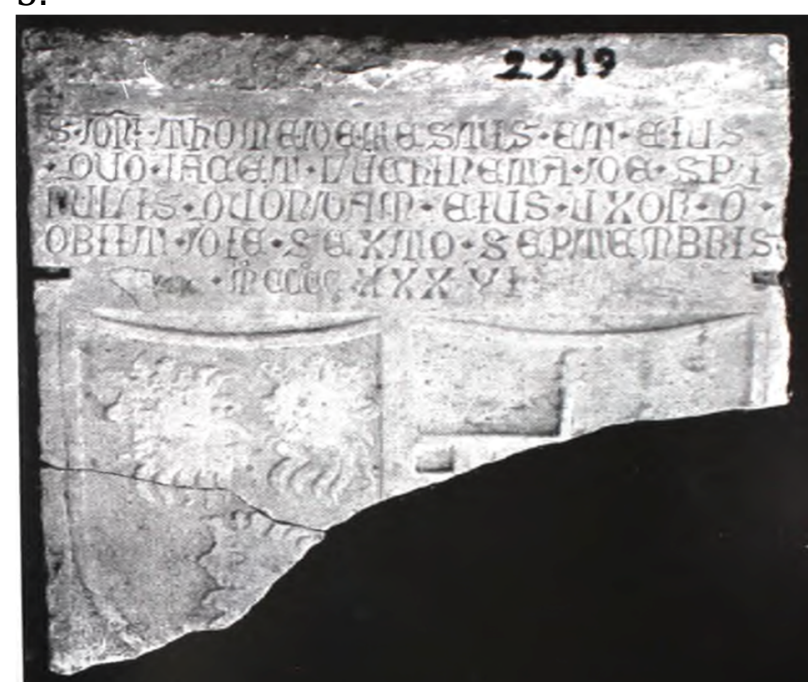

S(epulcrum) D(omi)ni Thome de Testis et eius / [i](n) quo iacet Luchineta de Spi/nulis quondam eius exor q(uae) / obiit die sexto septembris / MCCCCXXXVI) 
6.

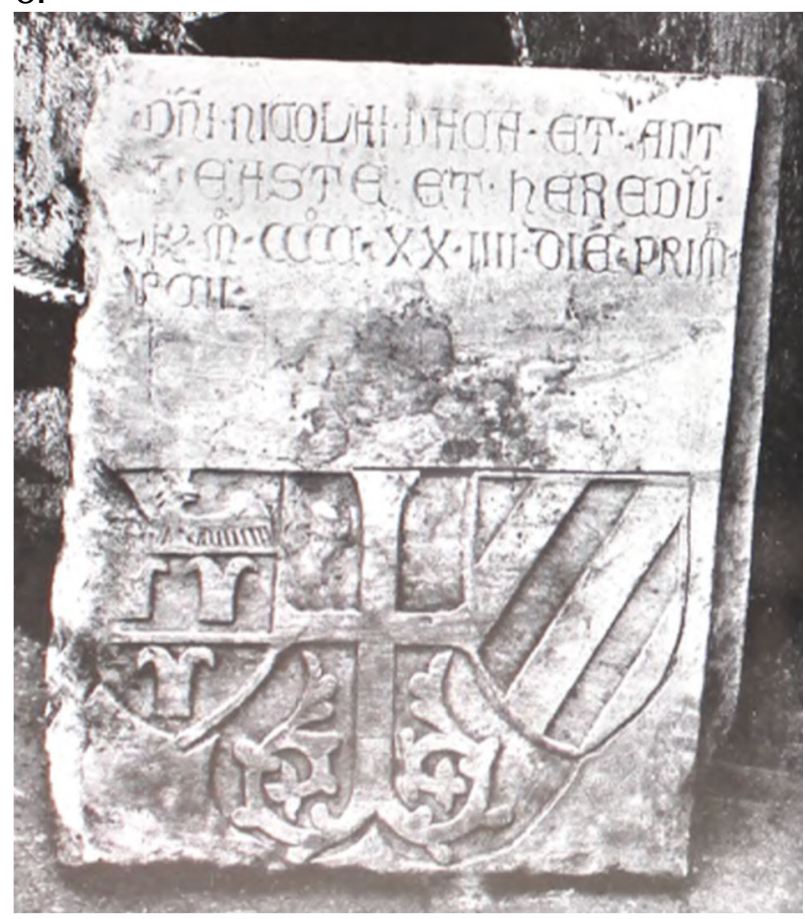

[+ S(epulcrum)] D(omi)ni Nicolai De Vaca et Ant/[onii] de Aste et heredu $(m) /[s u]$ oru $(m)$ MCCCCXXIIII die prima / [mar]cii 
IV THE EPIGRAPHY OF SMALL FINDS 



\section{Epigraphical finds from Amorion: A View from the Excavations Nikos Tsivikis}

The systematic excavations of Amorion, which have taken place since 1989, offer a unique insight into the life of an early and, even more revealingly, of a middle Byzantine provincial city. Three distinct Byzantine strata are clearly visible in the archaeological record, and their distinctive characteristics can be easily detected in the material remains on the site.

First of these belongs to the early Byzantine period (4th- $7^{\text {th }}$ c.), when Amorion had the status of a city, and was the seat of a bishop. It falls within the regular norms of an inland medium-sized urban settlement of the period. Adorned during these centuries with large building projects, impressive basilicas and defensive fortifications, and with the walls built, according to a tradition, by emperor Zeno, Amorion verifies the intensity of late antique urban development. The description of Amorion in the Life of St. Theodore of Sykeon depicts accurately the character of the city in the $7^{\text {th }}$ century. Inscriptions from this period cover many different categories: building donations, liturgical texts inscribed on church furnishings, commemorative texts cut into tombstones and various boundary texts. Moreover, careful recording of the epigraphic material has yielded a sizeable corpus of personal writing, mainly in the form of graffiti on pottery sherds.

The city changed radically after the $7^{\text {th }}$ century. It moved decisively towards what could be called a true medieval urban center. The period from the $7^{\text {th }}$ to the middle of the $9^{\text {th }}$ centuries, which, according to the chronology of Amorion corresponds to the Byzantine Early Medieval period, is richly represented in the archaeology of the city. This can be explained by a series of reasons. First of all, by the fact that in the empire-wide crisis following the $7^{\text {th }}$ century and in the subsequent new organization of the Byzantine state into the system of themata, Amorium probably became the administrative centre (and the provincial capital?) of the thema of Anatolikon, one of the most important in Asia Minor. This led to the growth of the city and also to a considerable rise of local provincial elites in the social pyramid of Byzantium, with the best example being the Amorian imperial dynasty that ruled the Empire for much of the $9^{\text {th }}$ century. Consequently, Amorion found itself in the center of the Byzantine-Arab clashes of the $7^{\text {th }}-9^{\text {th }}$ centuries, with a number of military events taking place at the walls of the city or around it, with the most important being the siege and destruction of the city in August of 838 by the armies of the Caliph Al-Mutassim. This violent event left a most discernable mark on the archaeological record of the city that the excavation has located in many trenches, thus offering a well stratified wealth of finds trapped in the fire and devastation. A large number of inscriptions on different surfaces were retrieved from the destruction layer offering insight in the lively epigraphic habit of what once was considered the Dark Ages of Byzantium.

Byzantine Amorion experienced a third distinct phase: middle Byzantine ( $9^{\text {th }}-11^{\text {th }} \mathrm{c}$.). Almost immediately after its destruction by the Caliphate, Amorion was largely rebuilt. It continued to be the administrative centre of the thema of Anatolikon. The earlier phases of the renovation of middle Byzantine Amorion in the mid-9th century can be connected with the last emperor of the Amorian dynasty, Michael III, who claimed his origin from the provincial city. But it was during the $10^{\text {th }}$ and $11^{\text {th }}$ centuries that the new middle Byzantine city of Amorion came to its full form with important building and artistic 
projects. This phase also came to an abrupt end. Soon after the Byzantine defeat at Manzikert in 1071, Amorion was deserted, probably as a result of the Seljuk attacks in the area, although there is little historical knowledge about the exact circumstances. The middle Byzantine renovation of Amorion offers an epigraphical wealth with many inscriptions connected, but not limited only, to this building activity.

Among the numerous finds in Amorium, a considerable number of inscriptions has been retrieved, giving us an idea of the wealth of epigraphical material in the city, and of the new tendencies in the epigraphical habit. In what follows, several examples typical of different categories of inscriptions from Amorium will be discussed with an aim to highlight the realities of Byzantine epigraphy inside an archaeological context.

1) Inscribed plinth of a column base connected with the cult of St. Konon and mentioning a local group of prominent citizens, the $\sigma \pi o v \delta \alpha i$ io $\left(6^{\text {th }} \mathrm{c}\right.$.) [AmInv T146A]

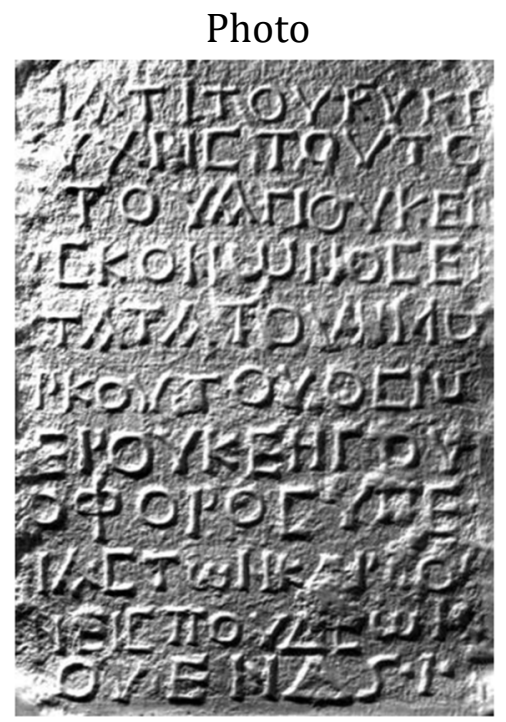

Text

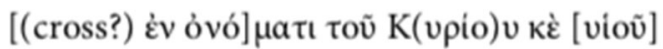

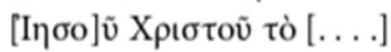

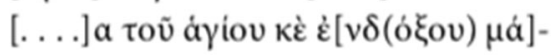

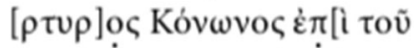

[....] $\dot{\alpha}<<\alpha>\operatorname{\tau ov} \dot{\eta} \mu \dot{\tilde{\omega}}[v \dot{\varepsilon} \pi t-]$

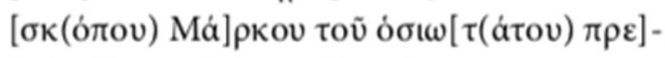

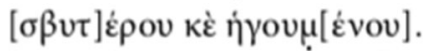

[X

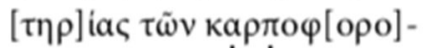

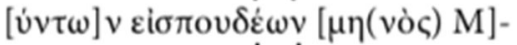

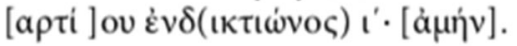


Translation

Translation: In the name of the Lord and of his son Jesus Christ; the ... of the celebrated saint and martyr Konon, in the time of our most .... . bishop [and?] Markos, the most holy presbyter and abbot. Christophoros on behalf of the salvation of the contributing spoudaioi, in the month of March, tenth year of indiction; amen.

\section{Bibliography}

Lightfoot, Chr., Drew-Bear, Th. and Tsivikis, N. (2017) Amorium Reports 5: A Catalogue of Roman and Byzantine Stone Inscriptions from Amorium and its Territory, together with Graffiti, Stamps and Miscellanea, Istanbul, no. 134.

Ballance, M. (1992), An inscription of the Later Roman Empire period in the church, in Harrison, R. M., Ballance, M. and Mango, C. (eds), Amorium excavations 1991. The fourth preliminary report, Anatolian Studies 42, 207-222: 211.

Nowakowski, P. Cult of Saints, http://csla.history.ox.ac.uk/record.php?recid=E01006 
2) Inscribed pottery sherd (graffiti) with a personal note (5 $5^{\text {th }}-6^{\text {th }}$ c.) [AmInv. SF8354]

Photo

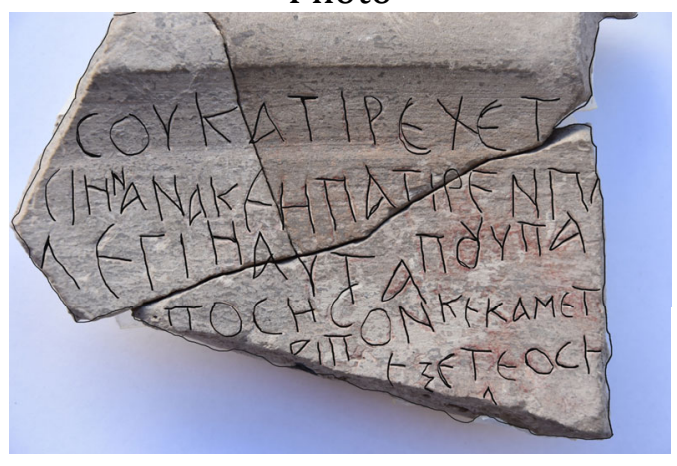

Text and Restoration

...]COYKATIPEXET[...

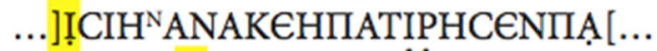

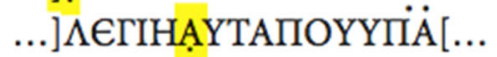

...]ПОСНС[...

...]P̈IחONK€KAM€T[...

...] $] \Xi \Xi \mathrm{T} € \mathrm{OCH}[\ldots$ $\ldots] \Lambda[\ldots$

Text:

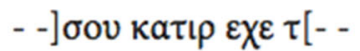

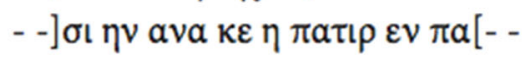

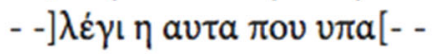

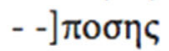

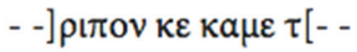

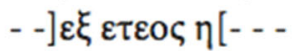

Corrected and restored text:

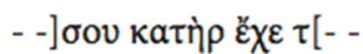

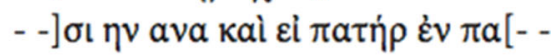

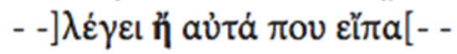

- -]лоons

- -]púrov кaì кáje $\tau[-$ -

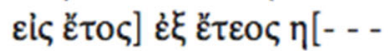

Bibliography

Lightfoot, Chr., Drew-Bear, Th. and Tsivikis, N. (2017) Amorium Reports 5: A Catalogue of Roman and Byzantine Stone Inscriptions from Amorium and its Territory, together with Graffiti, Stamps and Miscellanea, Istanbul, no. G23. 
3) Pottery sherd with prayer inscription (graffiti) (6 $6^{\text {th }} 7^{\text {th }}$ c.) [AmInv. 974.412]

Photo

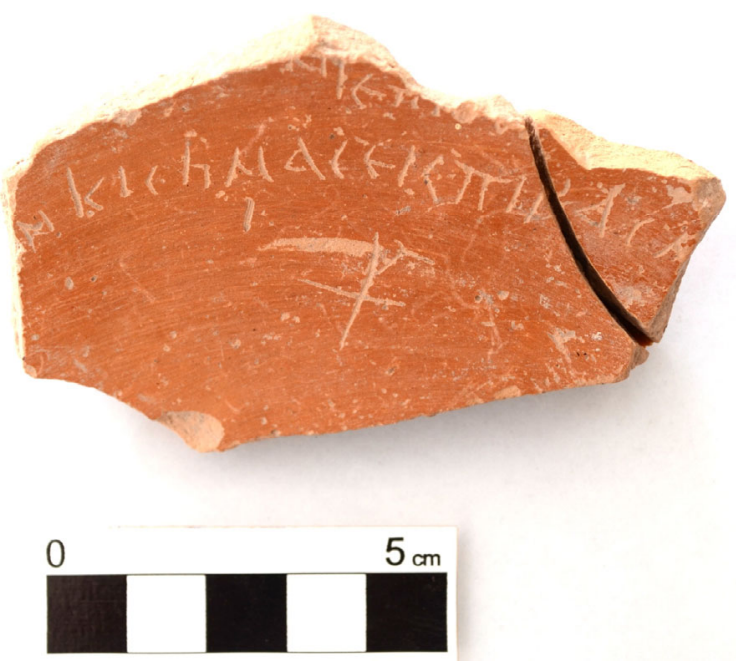

Text

...] N T E II O Y C $[\ldots$

...] N K I C H M A C E I C П I P A C M [...

$+$

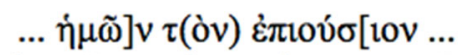

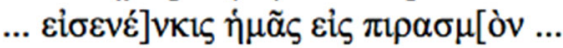

Cross

Unpublished 
4) Inscribed roof tile (838 destruction layer) [AmInv. B1067]

Photo/drawing

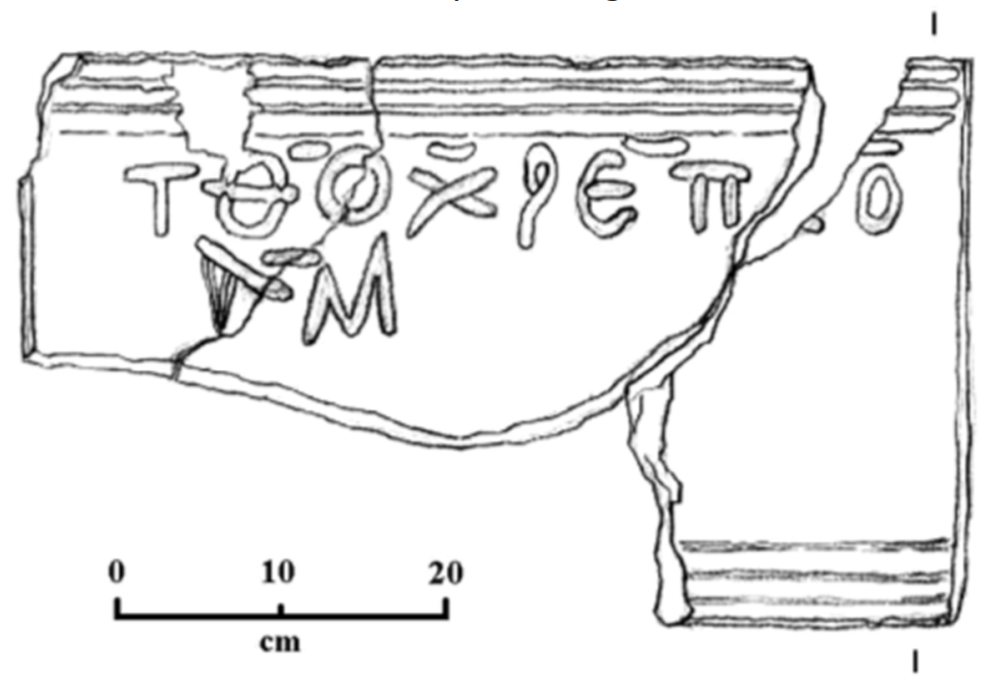

Text

Т๑ХРЕПО

OYAM

$\tau(o v ?) \Theta(\varepsilon o) v X \rho(เ \sigma \tau o v ?) \varepsilon \pi \circ\{\lfloor\eta\}[\sigma \varepsilon]$ ? or $\varepsilon \pi \mathrm{\imath}(?)$

OYAM

or better

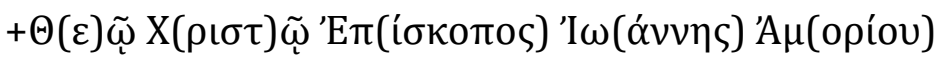

Bibliography

Ivison, E. (2012) Excavation at the Lower City Enclosure, 1996-2008, in Lightfoot, C. S. and Ivison, E. A. (eds), Amorium Reports 3: The Lower City Enclosure, Istanbul, 115. 
5) Byzantine burnished ware jug sherds with kufiq Arabic inscription (838 destruction layer)

Photo/drawing

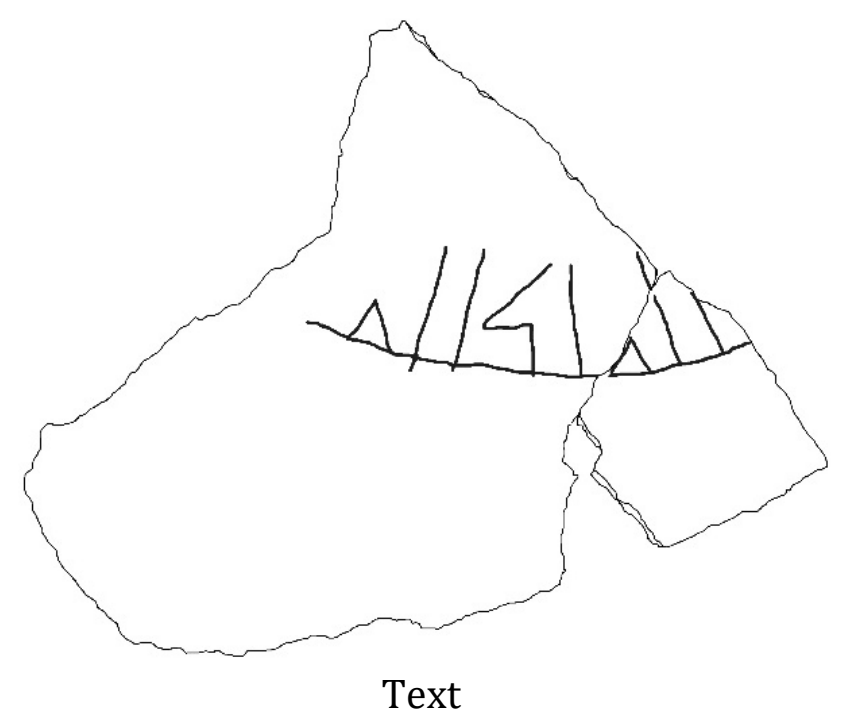

ALMLK LLH al-mulk li-llah

\section{Translation: Sovereignty is God's}

\section{Bibliography}

Lightfoot, Chr., Drew-Bear, Th. and Tsivikis, N. (2017) Amorium Reports 5: A Catalogue of Roman and Byzantine Stone Inscriptions from Amorium and its Territory, together with Graffiti, Stamps and Miscellanea, Istanbul, no. G24. 
6) Semicircular sarcophagus lid with inscription (10 $10^{\text {th }}-11^{\text {th }}$ c.)

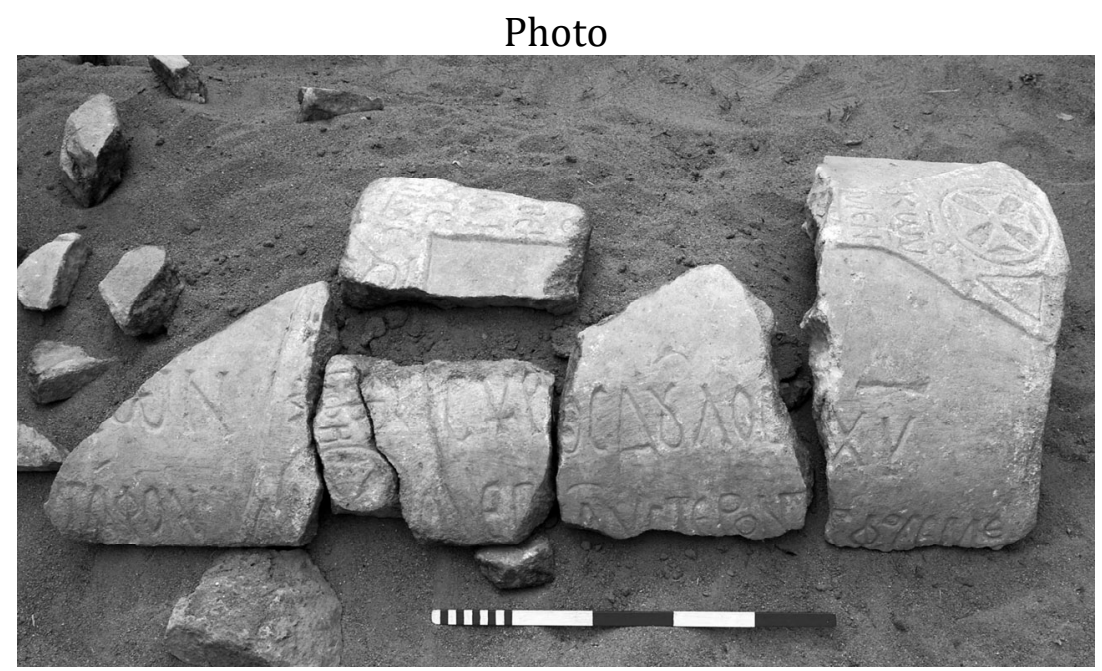

Drawing

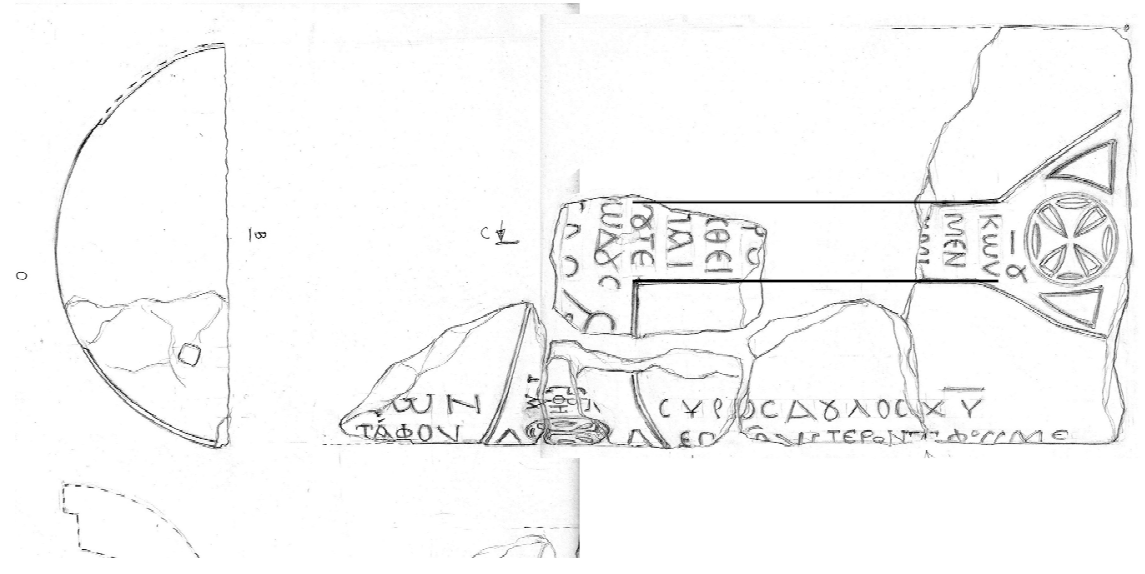

Text on side

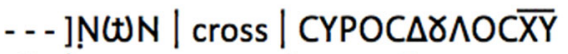

-.--]TÁфON | arm |EП[--]ÂYCTEPONTAфOCEME

Text on cross

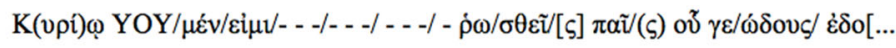

Translation:

To the Lord... YOY/MEN/ẸIM!̣!/- - - / - - - - - - / -having empowered the Child, whose earthly...

Bibliography

Lightfoot, Chr., Drew-Bear, Th. and Tsivikis, N. (2017) Amorium Reports 5: A Catalogue of Roman and Byzantine Stone Inscriptions from Amorium and its Territory, together with Graffiti, Stamps and Miscellanea, Istanbul, 73-78. 


\section{The Epigraphy of Small Finds from the Theodosian Harbor/Yenikapi Excavation: Some Examples \\ NiKOS TSIVIKIS}

Byzantine epigraphic material transcends the commonly discussed categories of monumental epigraphy. It also involves a large number of inscribed small-scale items. These can include objects of everyday use as well as extremely valuable and unique artifacts. They all can also convey different levels of social situations spanning the marking of small objects by official and imperial authorities at the most formal level and inscribing items of everyday use by craftsmen or common people, whose own level of literacy was very low. This variety also applies to the nature of texts that can range from eloquent epigrams to simple personal notes. This epigraphic evidence is often very difficult to discern among the endless archaeological material coming from modern excavations; it is even more difficult to include it in official epigraphic corpora. Not to mention the limitations set by the state of evidence itself: as the majority of informal inscriptions were etched or painted on organic matter, they seldom survive the test of time (and soil).

The excavations of the Theodosian Harbor of Constantinople (mod. Yenikapi, Istanbul) have offered a unique wealth of such inscribed items. Although most of this material is still in the process of documentation and has not yet been published, two extant exhibition catalogues allow us to take a first glance at these objects and their accompanying texts.

In this essay, I present four items from the Yenikapi excavation, each exemplifying a larger group of inscribed small finds from an archaeological record. These can often be items that carry coterminous inscriptions conveying an additional message to / information on the user/wearer. These 'small-finds', as they are categorized in the archaeological record jargon, besides their obvious materiality reveal a vibrant world of words and texts beyond the official epigraphic habit. They offer a wealth of information on Byzantine society and its members, but also on occasional writing, very often only of contemporary and ephemeral relevance, closely linked to the moment of its production.

\section{1) Inscribed golden ring ( $\left.6^{\text {th }} c.\right)$}

A $5^{\text {th }} / 6^{\text {th }}$-century golden ring found buried in the Theodosian harbor features an inscription invoking the Lord to protect the wearer, who is also explicitly named. Such items are very common in the archaeological record of early Byzantine sites, and they are often made of humbler material. Gold rings are much more exceptional, and, as such, they also testify to the wealth of certain individuals residing in the capital city. This is exactly the reasoning behind naming the individual wearing this protective ring, rather than using the generic formula ('the one wearing') as is mostly the case (Kizıltan Zeynep et al). So, the gold ring from Yenikapi was destined for a specific person, a member of the Constantinopolitan elite, who, as we are informed in the inscription, is called Undila(s). This proper noun is obviously non-Greek: it designates a person (male or female) of Gothic or Germanic ethnic origin. We know from the Prosopography of the Late Roman Empire of a $6^{\text {th }}$-century Gothic commander by the name of Unilas (PLRE vol. IIIB 1392, 
mentioned by Procopius, De Bellis 5.16). This provides a clue for the identification of the person from the Yenikapi ring.

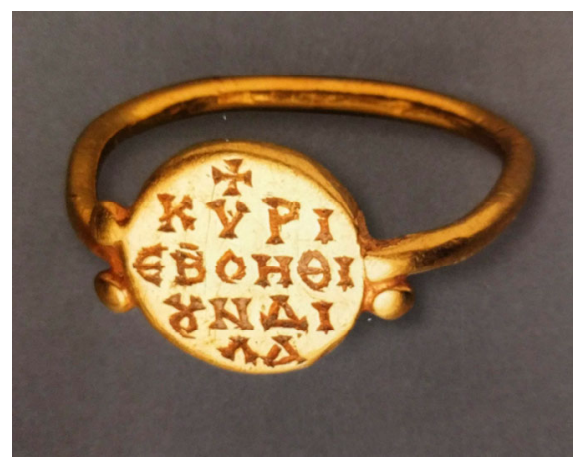

The ring from Yenikapi with a circular discoid bezel carrying a Greek inscription in five lines.

\author{
Text \\ $+|\mathrm{K} Y \mathrm{PI}| \mathrm{E} \mathrm{BOH \Theta I} \mid$ OYN $\Delta \mathrm{I} \Lambda \mathrm{A}$

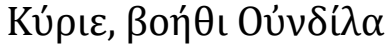

Bibliography

Zeynep, K. et al. (eds) Stories from the hidden harbor: shipwrecks of Yenikapı, Istanbul 2013, no. 78, 13.

For a catalogue of bronze rings with generic name references, see: Yangaki, A. (2012), A Byzantine ring from ancient Messene bearing the inscription ' $\mathrm{K}(\mathrm{YPI}) \mathrm{E}<\mathrm{B}>\mathrm{OH} \Theta \mathrm{H}$ ANA' - A contribution to a group of rings with the same inscription, in Sioumpara, E. and

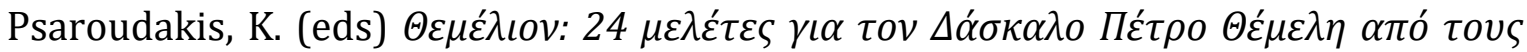

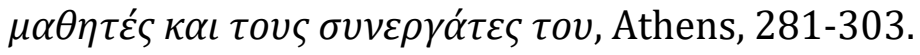

2) Inscribed wooden shoe $\left(5^{\text {th }}-7^{\text {th }}\right.$ c.)

The second example shows again a utilitarian item inscribed with a personalised message. A much humbler than the gold ring discussed above, it is just a wooden shoe sole of a female sandal or shoe. It has been loosely dated to the time between the $5^{\text {th }}$ and the $7^{\text {th }}$ centuries. The sole features a skilfully executed inscription around the edge of the sole invoking wellbeing of the shoe wearer and an enjoyable use. The inscription is accompanied by the depiction of a pair of birds and some floral motives. The whole composition is strikingly decorative, but it is difficult to say if it featured on the lower or the upper side of an actual shoe, or even, if it was a votive/token symbolizing a shoe. Also, the text is generic enough, not referring to a special owner but rather to a $K v \rho \alpha ́ \alpha \alpha \lambda \eta$, a Fair Lady, suggesting that the wooden item could also be part of "mass" production to be used by/for the fair ladies of early Byzantine Constantinople. Writing on shoes seem to have had a considerable tradition in the Roman and post-Roman world, although surviving examples are very scarce, mainly because these texts would have been written on perishable materials such as leather.

It is uncertain if the inscribed shoe from the Theodosian Harbour attests to a unique practice or a distinct identity of the wearer. There is a small corpus of evidence of female 
Roman $\left(2^{\text {nd }} / 3^{\text {rd }}\right.$ c.) shoe remains or clay replicas, all inscribed with short texts on their soles with the hobnails mentioning the word $\alpha$ ko $\alpha o v \theta(\varepsilon) \iota$ (follow me). These have been interpreted as shoes of prostitutes communicating an enticing message to possible clients (G. W. Elderkin). On the other hand, the writing of wishes for wearers on the soles of shoes brings to mind some anthropological parallels, such as Christian weddings whereby brides would wear special shoes with custom-made texts, or write them themselves. It is interesting to note that writing on leather, usually on shoe soles, is also attested in some early Islamic sources. (S. Mirza)

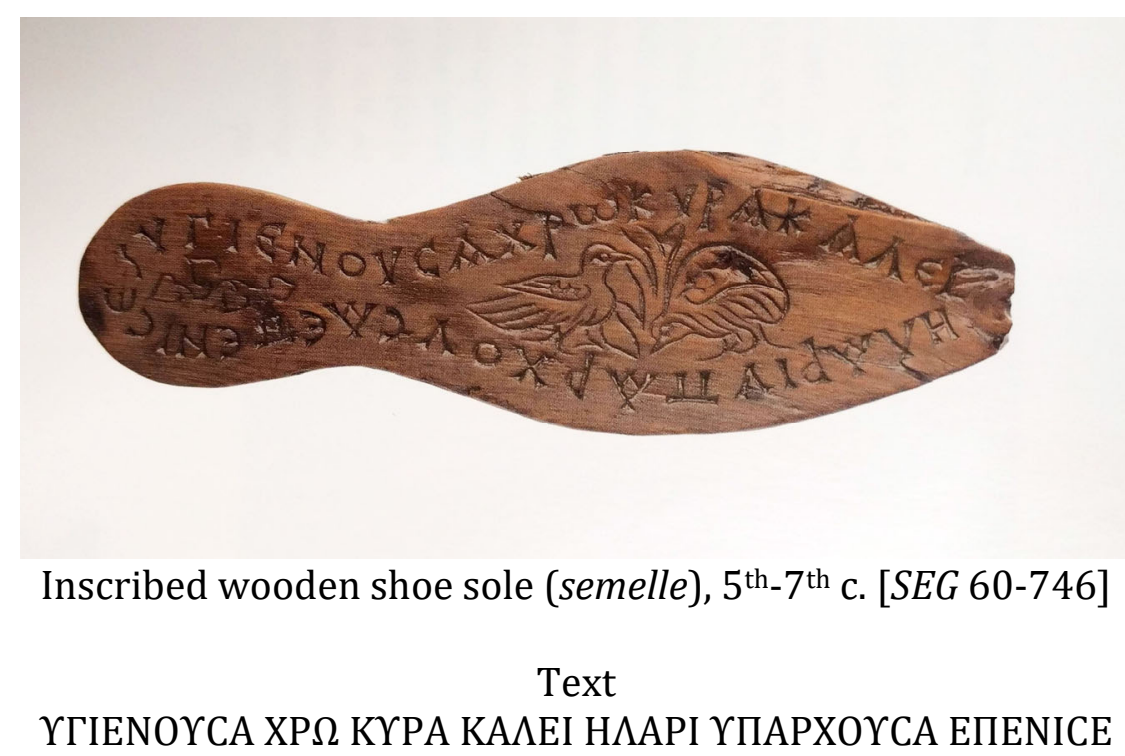

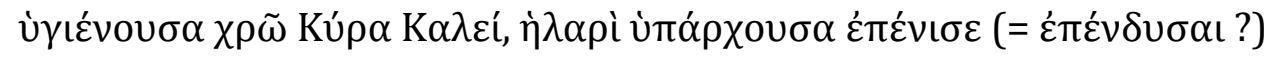

Translation

May you use (this) in good health, Kyra Kale, be happy in wearing (it)

Bibliography

Feissel, D. (2013) Bulletin Épigraphique, in Revue des Études Grecques 126, no. 511.

Karamani, A. (ed.) (2007) Gün Işığında Istanbul'un Yılı: Marmaray, Metro, Sultanahmet Kazıları, Istanbul, 277, no. Y39.

Elderkin, G. W. (1941) The Hero on a Sandal, Hesperia 10, 385, fig. 2.

Mirza, S. (2017) Shoes, Writing: Unspeaking Writing in the Material Culture of Pre-Islamic Arabia and Early Islam, West 86th: A Journal of Decorative Arts, Design History, and Material Culture 24.2, 159-160: https://www.west86th.bgc.bard.edu/articles/shoeswriting/

3) Inscribed jug (graffiti) $\left(6^{\text {th }}-7^{\text {th }}\right.$ c.)

Our third example provides completely different epigraphic evidence: it is a small $6^{\text {th }}$ or $7^{\text {th }}$-century jug, with an inscription and a sketch of a human individual scratched onto it. It is almost certain that the graffiti were incised into the pot at some point during its use. Although the text cannot be fully transcribed from the photographs of the catalogue, it 
might contain an acclamation, marking both the ownership of the jug and also containing a humorous element. The inscription's beginning might be the wish $\beta i \beta \alpha \varsigma$, a Hellenization of the Latin vivas (may you live!), which is not an uncommon feature in simple epigraphic formulas of the Greek-speaking world, echoing the Hellenization of the Latin acclamation

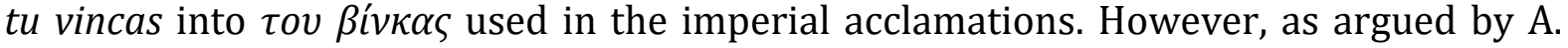
Rhoby, BAPH $\Lambda \mathrm{H}$ at the beginning could also mean 'vessel' (cf. $\beta \alpha \rho$ í $\lambda \lambda$ เov, which is attested in later texts). Although the rest of the text is not completely legible, we can recognize

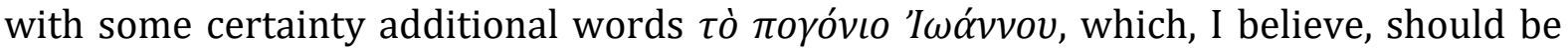
translated as the beard of Ioannes. It might be that this text humors the owner Ioannes by mentioning his trademark beard. The same person is probably depicted in the rough sketch below, which shows an outline of a male human form with special attention given to his pointy beard and his reproductive organs. Besides the personal and humorous character of the graffiti, it is worth noting that a section of the text in the lower left section seems to have been deliberately erased, showing the ephemeral nature of these texts that can be constantly written and re-written or corrected.

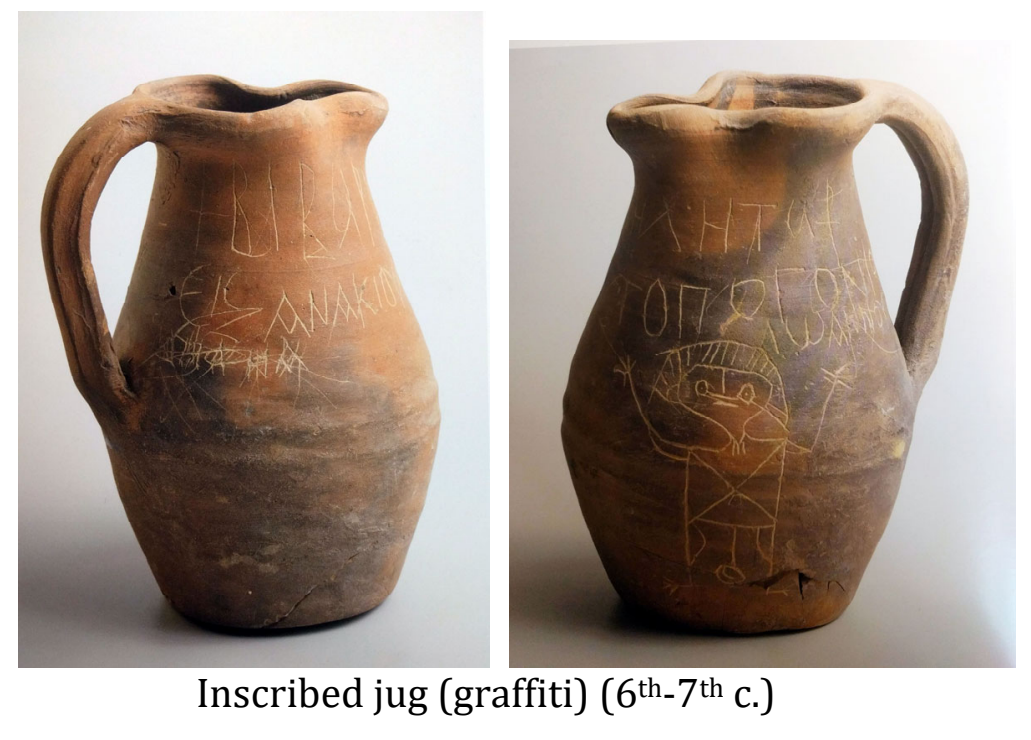

Text

+BIBAPH $\Lambda$ HTOYchristogram

EILANAKIOYTOПOГONIO

[rasura] I RANNOY

Bibliography

Zeynep, K. et al. (eds) Stories from the hidden harbor: shipwrecks of Yenikapı, Istanbul 2013, 111-112, no. 51.

4) A (middle Byzantine?) inscribed roof tile with a personal note listing names of at

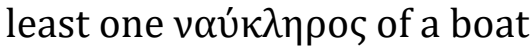

The fourth example belongs to a generic and quite common Byzantine epigraphic category of graffiti on easily available media like bricks or roof-tiles. These surfaces commonly carry all kind of different messages, and are not rare to find in any excavations

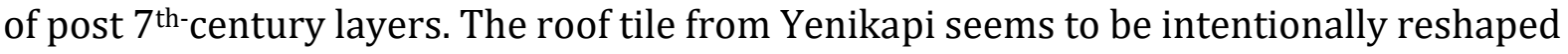


into a smaller square; it dates probably to the middle Byzantine period, and it features four lines of incised Greek text. The inscription poses the usual problems due to the informal and unusual nature of such graffiti material. It contains a list of names, probably of individuals engaged in some sea-fearing or harbor-based occupations. Among the names we read that of a Nikephoros, son of Karelos, whose patronymic opens a window to the multi-ethnic environment of Constantinople and its ports. Karelos (or Karilos) is a Gaulish name, more commonly found in the Latin-speaking provinces of the western Merovingian world. (B. Fourlas ) One of the persons from the list is a $v \alpha(v) \kappa \lambda \iota \rho o \varsigma$, a ship owner, a captain or a merchant of a ship, possibly one of the people named in the same text, and perhaps himself active in the Constantinopolitan port of Theodosius.

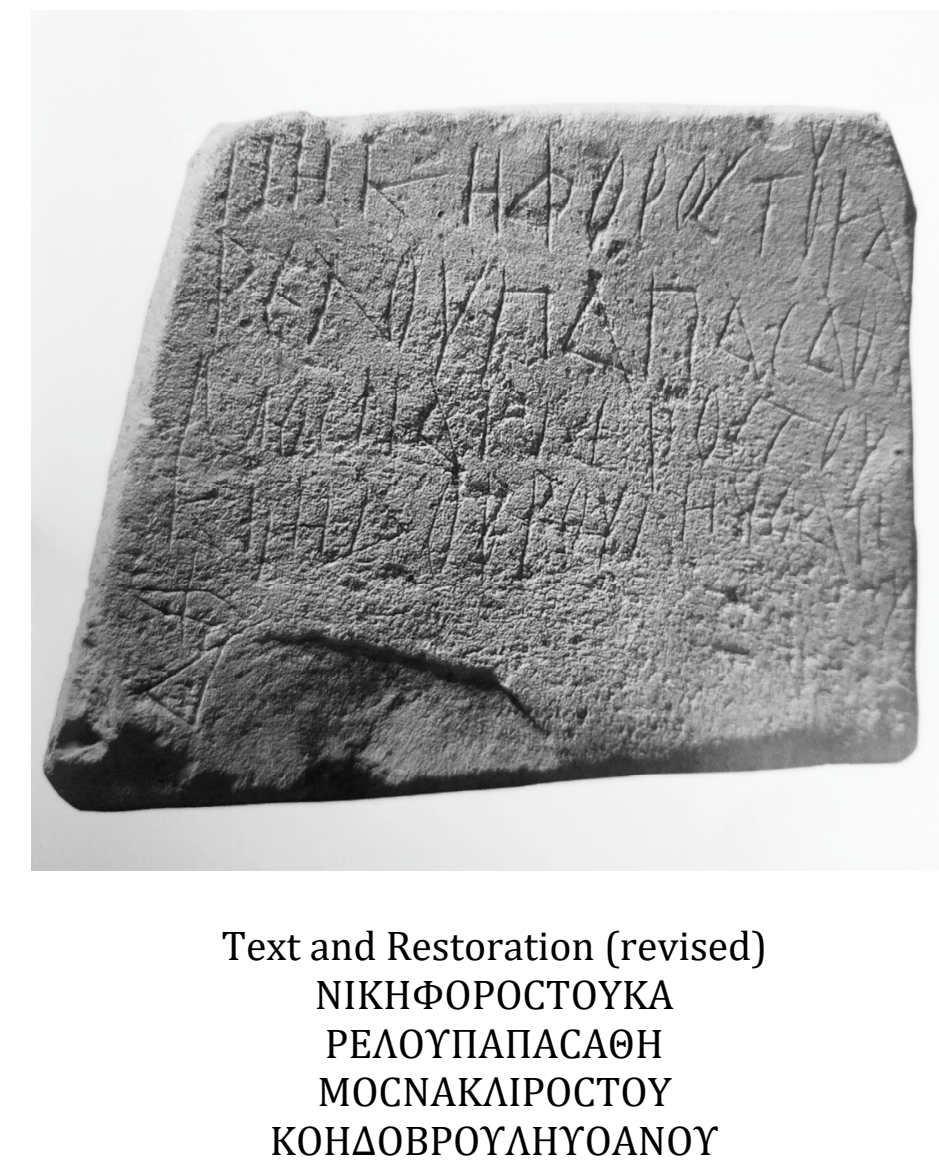

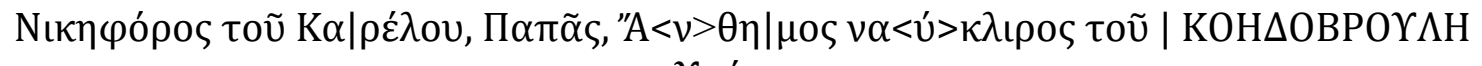
Yoóvou

Bibliography

Karamani, A. (ed.) (2007) Gün Işığında Istanbul'un Yılı: Marmaray, Metro, Sultanahmet Kazıları, Istanbul, 267, no. Y26.

See, also: Fourlas, B. (2019) Early Byzantine Church Offered for the Eternal Rest of Framarich and Karilos: Evidence 'of the Army of Heroic Men' Raised by Tiberius II Constantine? In Eders, S. et al. (eds) East and West in the Early Middle Ages: the Merovingian Kingdoms in Mediterranean Perspective, Cambridge, 93-94. 



\section{Byzantine Amulets in the Eastern Mediterranean and Constantinople \\ DeNIZ Sever GeORgousAKIS}

Amulets are small objects intended to provide protection against evil, diseases, and dangers in life. A wide variety of sources such as hagiographical, canonical, ecclesiastical and historical mention amulets. They refer to amulets using the following Greek words:

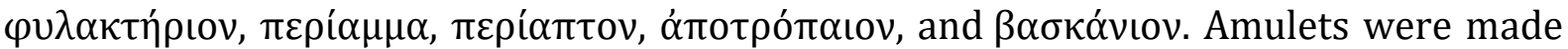
from different materials such as metal, ivory, steatite, wood, and gemstones. They were often small artifacts worn on the body as pendants, rings, and ornaments for garments. According to some middle Byzantine hagiographical sources, certain cultic objects such as crosses, pilgrim tokens and flasks could be used as protective amulets. Whether belonging to the secular sphere or to the domain of Christianity, amulets are almost always decorated with images and/or inscriptions. The images and inscriptions on these objects had an important protective function, because they conveyed to the supernatural their owners' wishes and fears. Late antique amulets feature culturally-syncretic motifs, pagan images, and magical spells. At the same time, they bear Christian symbols, prayers, psalms, and invocations. The inscriptions on the objects often included orthographical inaccuracies.

The images of a rider spearing a demon, a human figure, or a snake lying beneath a horse were represented on numerous objects, such as medallions, rings, armbands and textiles dating back to Late Antiquity. The figure of a rider spearing an enemy is common to various cultures in the Mediterranean. The Thracian Horseman spearing a boar was an especially popular heroic figure in the Balkans during the Hellenistic and Roman periods.

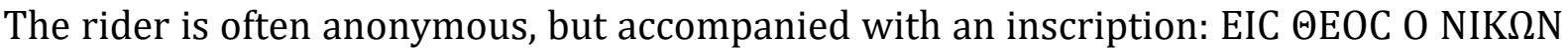
TA KAKA (One God who overcomes evil). At times, inscriptions on amulets name the rider as Solomon. They also refer to the magical seal ring of King Solomon, which gave him the power to subdue demons. Often the image of the rider is accompanied by the motif of an eye attacked by wild animals such as lions, birds, snakes, and scorpions. This amuletic representation was used to repel the Evil Eye, an age-old superstition based on the belief that the eyes of certain individuals have a powerful glance that can harm the well-being of people and animals, and obliterate possessions.

In the fourth century, there was a strong effort to curb the practice of wearing amulets in Christian society. Canonical sources and ecclesiastical writings of the Church Fathers forbade the use of any objects associated with magical practices. However, the existence of a well-known group of amulets, collectively known as hystera amulets, from the Middle Byzantine period shows a continuous and widespread usage of amulets in later centuries. These amulets were produced in the Mediterranean and Eastern Europe, and they bear the image of a head surrounded by serpents and/or a magical inscription. The standard

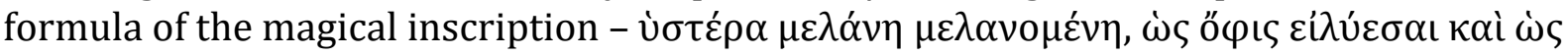

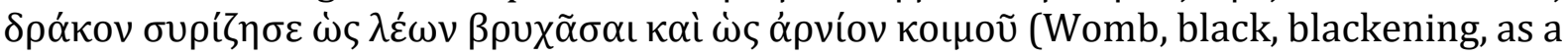
snake you coil and as a serpent you hiss and as a lion you roar, and lie down as a lamb!) is directed to the womb (hystera in Greek). These amulets were thought to treat medical conditions related to the womb, childbirth, and stomach. Their inscriptions might slightly differ but their meaning and the practice of addressing of the womb are consistent.

The amulets included in this essay represent a selection of types commonly found in the Mediterranean. The main categories of amulets have been exhaustively studied and 
published (please, see the selected bibliography). However, local variations of these objects, which combine a wide range of images and inscriptions, require further research. Some production centers are known. For instance, the amulets with the image of the rider and inscription 'One God who overcomes evil' are thought to be from Syria and Palestine due to the high number of objects and molds found in these regions. However, this type of amulets is also found in Anatolia. Considering the prevalence of the hystera amulets in Anatolia, Greece, Italy, and Russia, it is impossible to argue for one production center. It also has to be borne in mind that the molds for these amulets were light in weight, and that portable objects were traded between smiths and jewelers across regions. However, thanks to the amulets, which have been discovered in the Yenikapı Excavations, we know that the hystera amulets were sold and used in Constantinople. In Turkey, the majority of amulets come from private collections, while some have been acquired by public museums. Consequently, archaeological data on amulets are sparse. There are three collections, which house various amulets in Istanbul: the Istanbul Archaeological Museums, the Rezan Has Museum, and the Haluk Perk Collection.

\section{Selected Bibliography}

Alexander, Ph. S. (2003) Contextualizing the demonology of the Testament of Solomon, in Lange, A. (ed) Die Dämonen: Die Dämonologie der alttestamentlich-jüdischen und frühchristlichen Literatur im Kontext ihrer Umwelt, Tübingen, 613-635.

Aubert, J.-J. (1989) Threatened Wombs: Aspects of Ancient Uterine Magic, Greek, Roman and Byzantine Studies 30, no. 3, 421-49.

Aune, David E. (1980) Magic in Early Christianity, in Temporini, H. and Haase, W. (eds) Aufstieg und Niedergang der römischen Welt, Berlin and New York, 1507-1557.

Bonner, C. (1950) Studies in Magical Amulets: Chiefly Graeco-Egyptian, Ann Arbor.

De Bruyn, T. (2017) Making Amulets Christian: Artefacts, Scribes and Contexts, Oxford.

Duling, D. C. (1983) Testament of Solomon, in Charlesworth, J. H. (ed) The Old Testament Pseudepigrapha, vol. 1: Acocalyptic Literature and Testaments, New York, 935-987.

Elliot, J. H. (2015) Beware the Evil Eye, Vol. 1: The Evil Eye in the Bible and the Ancient World-Introduction, Mesopotamia, and Egypt, Eugene.

Faraone, Chr. A. (2011) Magical and Medical Approaches to the Wandering Womb in the Ancient Greek World, Classical Antiquity 30.1, 1-32.

- (1991) The Agnostic Context of Early Greek Binding-Spells, in Faraone, C. A. and Obbink, D. (eds) Magika Hiera, New York, 3-32.

Foskolou, V. (2014) The Magic of the Written Word: The Evidence of Inscriptions on Byzantine Magical Amulets, Deltion of the Christian Archaeological Society 35, 329-348.

- (2005) The Virgin, the Christ-Child and the Evil Eye, in Vasilaki M. (ed) Images of the Mother of God: Perceptions of the Theotokos in Byzantium, Aldershot, 251-262.

Roberts, A. et al. (1994) Ante-nicene Fathers, vol. VII: The Writings of the Fathers Down to A.D. 325, Peabody.

Grabar, A. (1974) Amulettes Byzantines du Moyen Age, in Tardieu, M. (ed) Mélanges d'histoire des religions offerts à Henri-Charles Puech, Paris, 531-541.

Greenfield, R. (1989) Saint Sisinnios, the Archangel Michael and the Female Demon Gylou: The Typology of the Greek Literary Stories, Byzantina 15, 83-142.

Laurent, V. (1936) Amulettes byzantines et formulaires magiques, Byzantinische Zeitschrift 36.2, 300-315.

Maguire, H. (1995) Byzantine Magic, Washington, D.C. 
- (1997) Magic and money in the early Middle Ages, Speculum 72.4, 1037-1054.

Patera, M. (2010) Exorcismes et phylactères byzantins: écrire, énoncer les noms du démon, Cahiers mondes anciens 1: https://journals.openedition.org/mondesanciens/139

Pitarakis, B. (ed) (2015) Life Is Short, Art Long - The Art of Healing in Byzantium, Istanbul.

- (2014) Magie, Santé, Piété Privée, in Spieser J.-M. and Dasen, V. (eds) Les savoirs magiques et leur transmission de l'antiquité à la Renaissance, Florence, 371-396.

- (2012) Bizans'ta Büyü, Sağlığı Koruma Ve Kötülüğü Kovma Sanatı, Istanbul Araștırmaları Yıllığı 1, 15-30.

Schaff, Ph. (1988) Saint Chrysostom, Homilies on Galatians, Ephesians, Philippians, Colossians, Thessalonians, Timothy, Titus, and Philemon, Edinburgh.

Schlumberger, G.L. (1892) Amulettes byzantins anciens destinés à combattre les maléfices et les maladies, Revue des Études Grecques 5, no. 17, 73-93 (= Idem [1895], Mélanges d'archéologie byzantine: monnaies, médailles, méreaux, jetons, amulettes, bulles d'or et de plomb, poids de verre et de bronze, ivoires, objets d'orfèvrerie, bagues, reliquaires, etc., Paris, 117-140).

Sever Georgousakis, D. (2017) Profane and Private: Sacred and Profane Elements on Late Antique and Middle Byzantine Amulets, Codex Aquilarensis 33, 13-26.

- (2017) Rezan Has Müzesi'nden Yayımlanmamış Üç Muska ve Erken Bizans Dönemi'nden "Hipotetik” Büyü Kitabı", Arkeoloji ve Sanat 156, 223-228.

Spier, J. (1993) Medieval Byzantine Magical Amulets and Their Tradition, Journal of the Warburg and Courtauld Institutes 56, 25-62.

- (2014) An Antique Magical Book Used for Making Sixth-Century Byzantine Amulets? In Dasen, V. and Spieser, J.-M. (eds) Les saviors magiques et leur transmission de l'Antiquité à la Renaissance, Florence, 43-66.

Vakaloudi, A. D. (2000) Deisidaimonia and the Role of the Apotropaic Magic Amulets in the Early Byzantine Empire, Byzantion 70, 182-210.

Vikan, G. (2010) Early Byzantine Pilgrimage Art, Vol. 5, Washington, D.C.

- (1991) Two Byzantine Amuletic Armbands and the Group to Which They Belong, The Journal of the Walters Art Gallery, 33-51.

- (1984) Art, Medicine, and Magic in Early Byzantium, Dumbarton Oaks Papers 38, 6586.

Zalesskaya, N. (1976) Amulettes byzantines magiques et leurs liens avec la littérature apocryphe, in Actes du XIVe Congrès international des études byzantines, Bucarest, 6-12 septembre, 1971, vol. 3, Bucarest, 243-247. 


\section{Examples:}

1. Copper alloy amulet, 5 th-6th c., 4,2 x 2,1 cm, the British Museum, London.

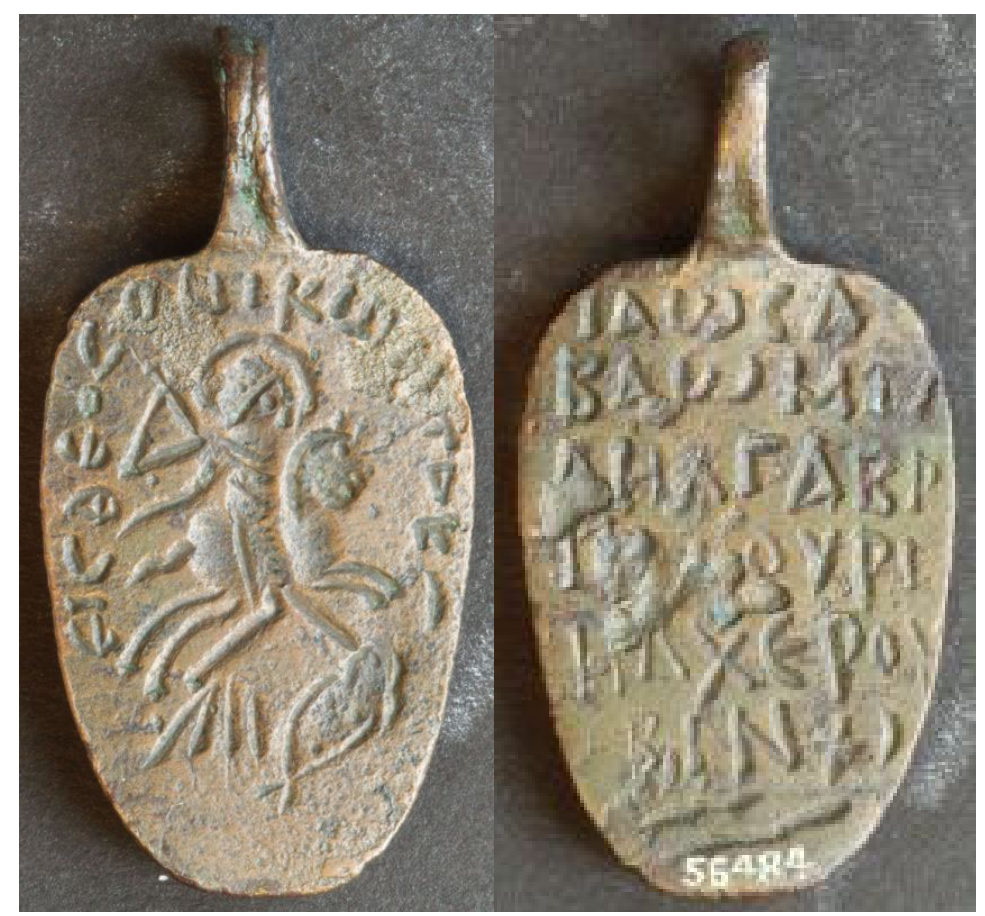

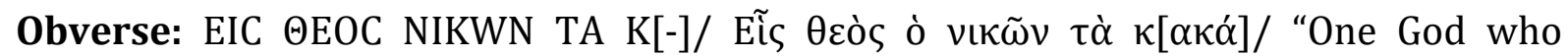
overcomes evil"

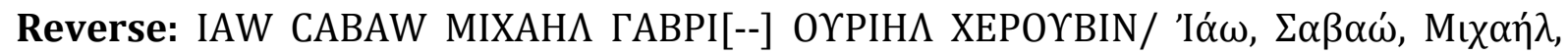

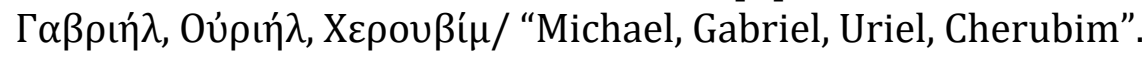

2. Copper alloy amulet, 6th-7th c., 4,4 cm, the Rezan Has Museum, Istanbul.

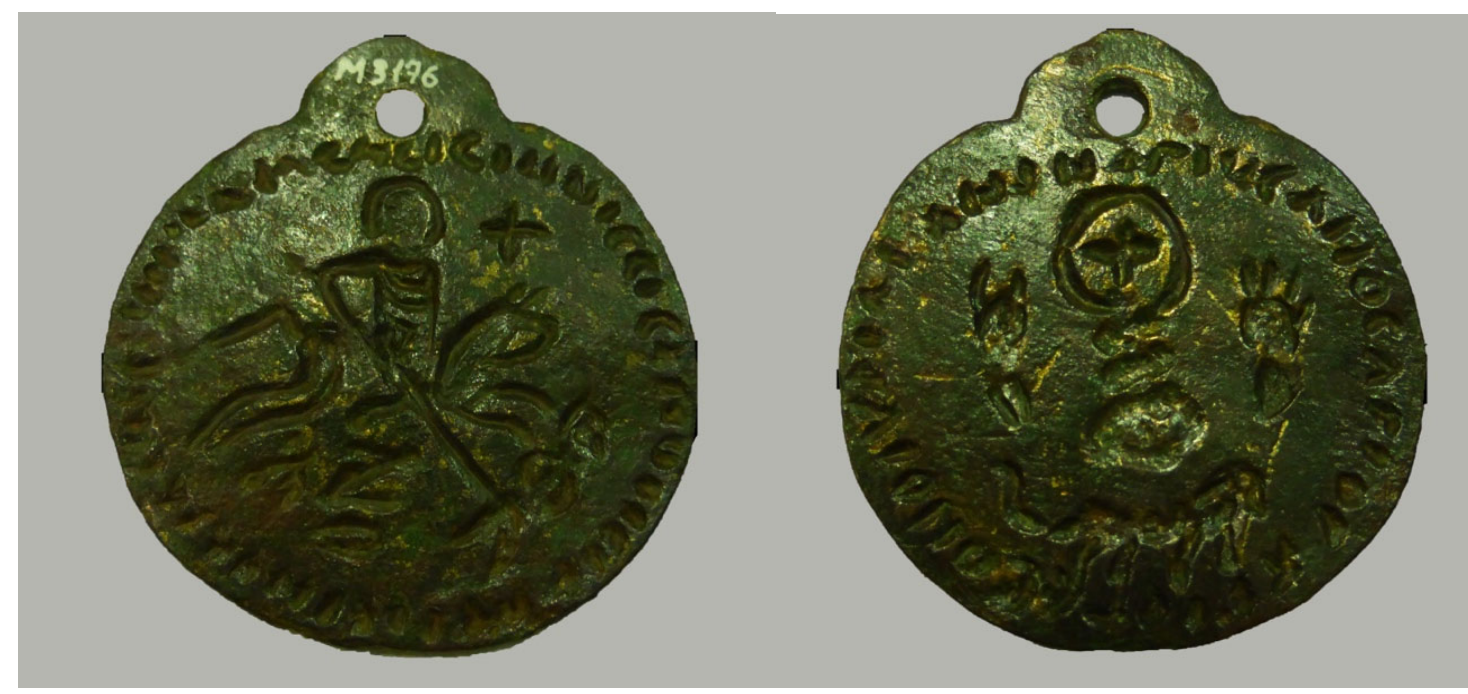

Obverse: CICINNICCOC[- $] /$ ı ]/ "St. Sisinios [ -]".

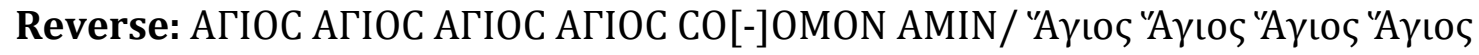

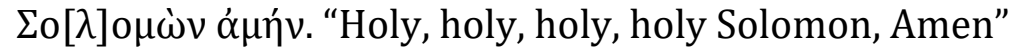


3. Lead amulet, 10 th-12th c., 4,6 cm, the Rezan Has Museum, Istanbul.

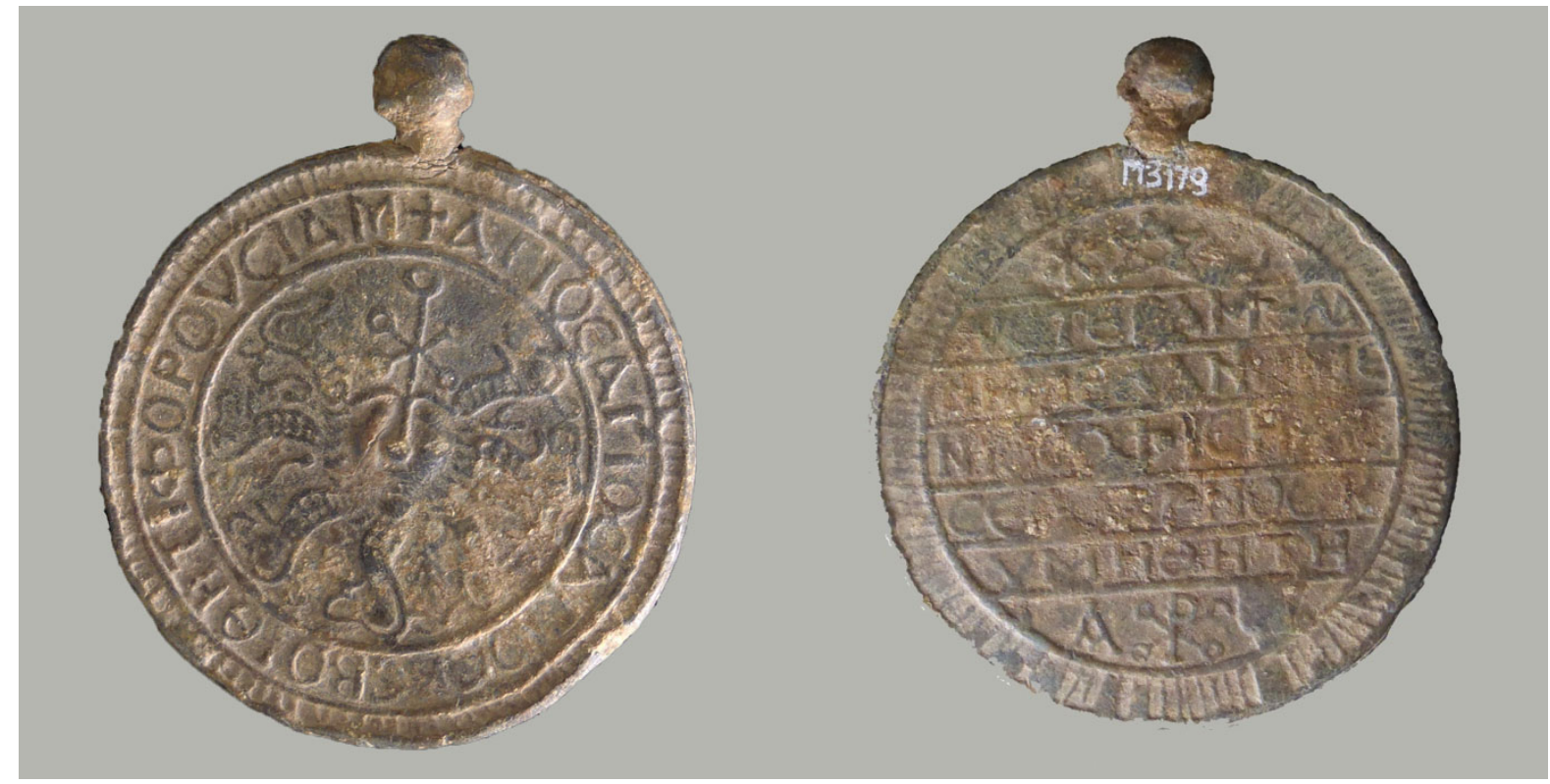

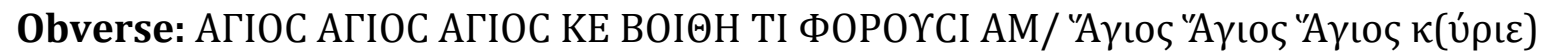

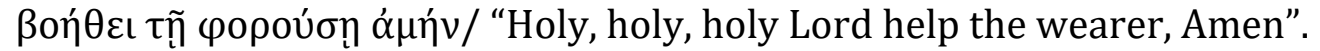

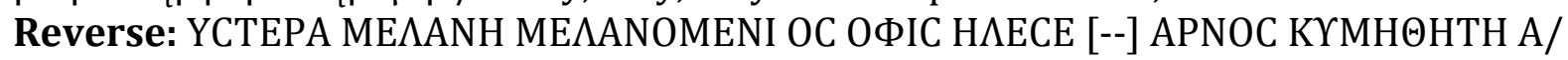

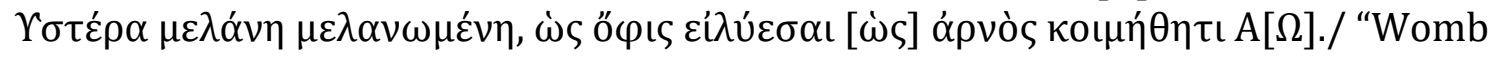
black blackening as a snake you coil, as a lamb lie down." 



\section{THE EPIGRAPHY OF THE SEA AND LAND WALLS}





\section{Map of the Walls of Constantinople}

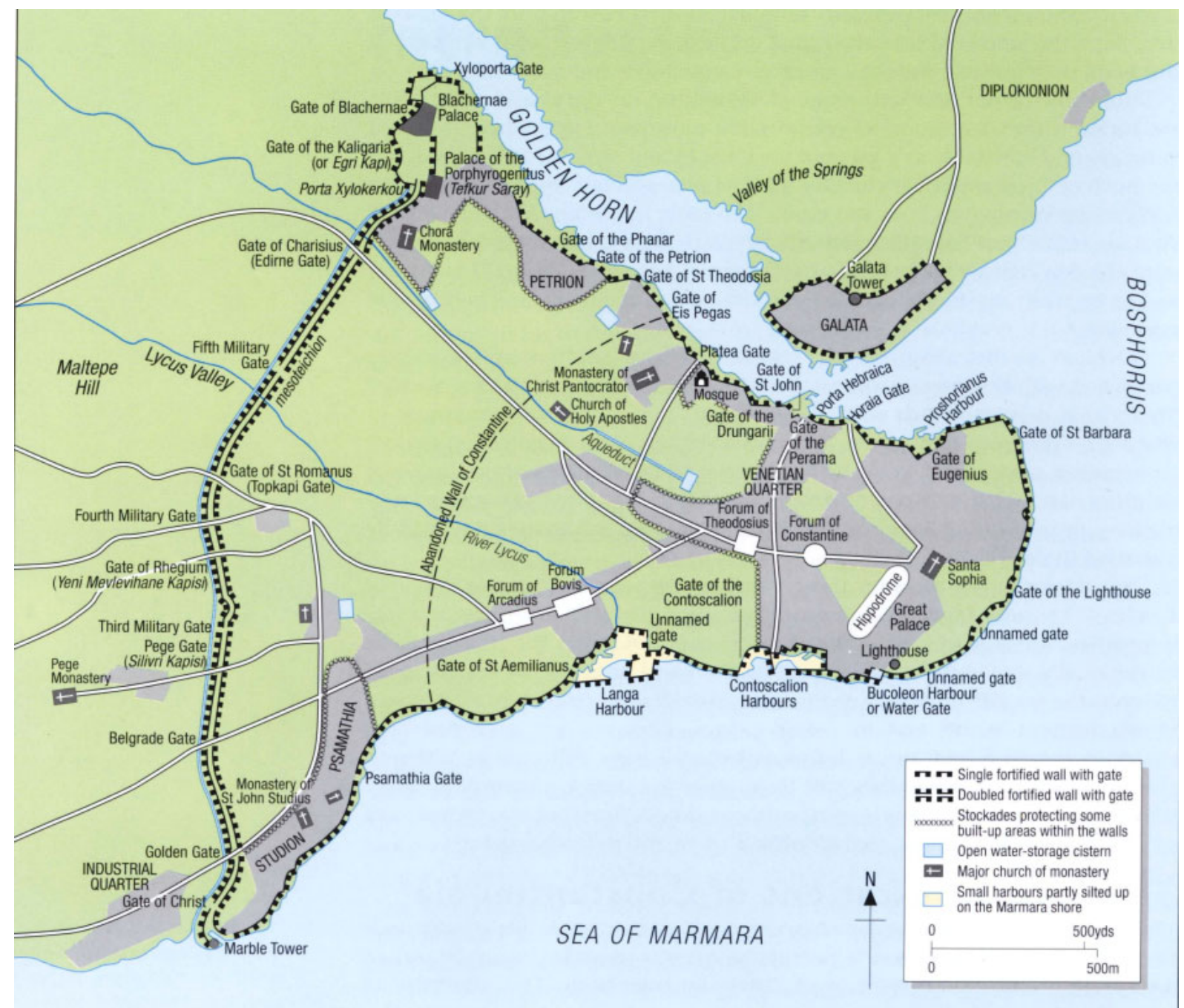

Map of Constantinople showing the line of the Theodosian walls and the sea walls. The course of the walls of Constantine the Great is shown as a dotted line (C) Osprey Publishing Limited) 



\title{
20. The Land Walls of Constantinople: An Introduction
}

\author{
ROMAN SHLIAKHTIN
}

Throughout the thousand years of Byzantine history, Constantinople was a formidable fortress that persisted and survived several major sieges and assaults. Stretching for more than twelve kilometres, the Walls of Constantinople remained a significant landmark in the capital of the Byzantine Empire from the beginning up until the very end of its existence.

The first walls of Constantinople did not have much to do with the surviving fortifications. Constantine the Great began the construction of the wall of the new capital that stretched from the Marmara Sea to the Golden Horn some two kilometres to the east from present-day fortifications. Constantine's wall, the specific course of which is debatable, was finished in the reign of his son, Constantine II (337-361). It consisted of a single wall with towers, and it survived in some form at least until the end of the eleventh century. In the fifth century, the increasing threat of incursion from the West and the growing population of the imperial capital motivated emperors to construct a new fortification of the Land Walls.

Built in reigns of the emperors Arcadius (395-408) and Theodosius II (408-450), the double Land Wall (also called the Theodosian Walls) was a significant construction that demanded considerable building efforts. Stretching from the Golden Gate in the south to the hill of the Gates of Adrianople in the north including nine gates and more than 60 towers, the new walls effectively controlled all approaches to the city from the west. This string of fortifications had three main components. The first line of defence was visual. Constructed with alternating belts of red bricks and white limestone, the Land Walls occupied several controlling points of the cityscape and were visible from afar. The height and position of some towers on the major hills allowed sentries to observe indirect approaches to the city and inform city-dwellers about any potential threat.

If assailants decided to storm the impressive chain of fortifications, they had to meet with several obstacles on the way. The first obstacle was the moat more than $2 \mathrm{~m}$ deep, extant in at least some parts of the walled perimeter. It is not clear whether the moat in Byzantine time had any water in it. After moving through the ditch or the ground in front of the walls, assailants had to climb the outer, lower wall, fortified by rectangular and ushape towers with arrow slits. If assailants managed to climb the lower wall, they had to fight their way through the space between the two walls under fire from the towers of both the inner and the outer wall. This combination of defences made the Theodosian Walls nearly impregnable.

For most of the Byzantine period, enemies of the empire and internal rebels preferred to storm the city using the advantage of the low ground of the Blachernai. Initially, the Blachernai was a suburb of Constantinople located on a hill that probably had its own wall. Below it, at the Golden Horn, was a flat ground as well as a church. This low ground was the site of the Avar-Bulgarian attack of 626. After the attack, the emperor fortified the Blachernai and gradually joined these fortifications with the main walls. After the earthquakes of the eighth century, the emperors of the Isaurian dynasty (717-802) restored and enlarged the towers to the north of Yeni Melvevikapi (the Rhegion Gate) (Fig. 1). In the time of the Amorian dynasty, a Byzantine rebel Thomas the Slav attacked the Blachernai (821). The reigning emperor, Michael II, repelled the rebel and fortified the junctions of the Golden Horn Walls and the Land Walls by a group of impressive towers called Pteron - all adorned with brick inscriptions of the emperors, who constructed 
them. In the twelfth century, the dynasties of the Komnenoi and the Angeloi fortified the wall near the imperial palace of the Blachernai. Manuel I Komnenos (1143-1180) built a formidable new wall that included into the city the perimeter of the growing district around the Blachernai palace. This wall was strengthened with polygonal towers, which controlled the lowland next to the Golden Horn (Fig. 2).

During the sieges of 1203 and 1204, the Land Walls did not see much fighting, because the Crusaders preferred to storm the more accessible walls along the Golden Horn. In the time of the Latin Empire (1201-1261), the Land Walls fell into disrepair. After the restoration of Byzantine power in 1261, Michael VIII rebuilt some sections of the walls, and his son Constantine IX constructed the Palace of the Porphyrogennetos, known also as the Tekfur Seray (Fig. 3), at the junction of the Theodosian Walls and the Walls of Manuel I.

From 1400, the city was preparing for an Ottoman siege. The preparations helped the Byzantines to survive the onslaught of 1422, and to hold on for a month and a half against the overwhelming odds in 1453. It is still not clear where the Ottomans managed to break the walls, with the most likely place being the northern slope of the Lycos valley, in the region of the so-called 'Fifth Military Gate' (Hucum Kapisi).

After the siege of 1453, the Land Walls remained an essential part of the Ottoman capital. In the later Ottoman centuries, the city authorities restored some sections of the walls. The extent of this restoration remains unclear. Still, it is likely that the Ottoman engineers altered some of the original constructions of the Land Walls (such as, for example, the Yedikule castle, and parts of the wall in the vicinity of the Edirne Kapi). In the late Ottoman centuries, the city government allowed some towers in the walls to be used as drinking-houses and small workshops. Finally, in the twentieth century, the Land Walls were altered during the urbanization of Istanbul as well as being restored (in some parts) by Turkish restoration teams. An example of such work is the restoration of the towers in the vicinity of the Mermerkule done by Zeynep Ahunbay and her team. Since 2010, Istanbul City Administration has cleared old buildings adjacent to the Land Walls, and turned them into public spaces, such as playgrounds and tea gardens. These alterations provided better access to certain sections of the walls to visitors and scholars alike. At the same time, the quality of the restoration of some towers remains questionable.

The present state of research on the walls is problematic at best. The lack of systematic archaeological work and the linguistic barrier between local scholars and the international scholarly community makes the situation more complicated. The Byzantine names of many gates are not yet known. A recent debate about the exact location of a major landmark - the Gate of St Romanos - between Hanak and Philippides on the one side and the Effenbergers on the other demonstrates the complexity of the unsolved questions concerning the history of the Land Walls. The situation with the so-called Sea Walls of Constantinople is even more complicated. While the Land Walls still survive and can be further explored, many parts of the walls along the Golden Horn and the Sea of Marmara have disappeared. The main difficulty with the Sea Walls lies in our uncertainty about their origins, while further study is also very much needed to establish a detailed chronology and history of this remarkable monument. The current work of Nisa Semiz promises to reveal some of the intricacies and to further our knowledge of the Sea Walls in the nearest future.

The epigraphy of the Constantinopolitan Land and Sea Walls forms an essential part of the socio-historical fabric that define the Byzantine, pre-modern, and modern perception of the existing fortifications. While their towers and bastions dominated the space of New 
Rome conveying the glory of Byzantium to travellers from afar, the inscriptions communicated the message of imperial might to a more educated audience, who could read their texts from the distance, at which they were legible. Some of these inscriptions survive in situ or in museum collections; some others can be found only in the publications of earlier scholars. Their detailed analysis follows hereafter, in the essays by Nicholas Melvani (see Chapter 21) and Efthymios Rizos (see Chapter 23).

\section{Selected Bibliography}

Ahunbay, M. and Z. (2000) Recent Work on the Land Walls of Istanbul: Tower 2 to Tower 5, Dumbarton Oaks Papers 54, 227-239.

Asutay-Effenberger, N. (2003) Die Entdeckung des Romanos-Tores an den Landmauern von Konstantinopel, Byzantinische Zeitschrift 96, 1-4.

- (2007) Die Landmauer von Konstantinopel-İstanbul. Historisch-topographische und baugeschichtliche Untersuchungen, Berlin and New York.

Downey, G. (1955) Earthquakes in Constantinople and Vicinity, Speculum 30, 595-600.

Loaëc, A. (2017) Les inscriptions en lettres de briques du rempart terrestre de Constantinople-Istanbul : un aperçu des événements de 740-743/744, In-scription. Revue en ligne d'études épigraphiques 2:

http://in-scription.edel.univ-poitiers.fr/index.php?id=237

Mango, C. (1951) The Byzantine Inscriptions of Constantinople: A Bibliographical Survey, American Journal of Archeology 55, 52-66.

Meyer-Plath, B. and Schneider, A. M. (1943) Die Landmauer von Konstantinopel, Zweiter Teil: Aufnahme, Beschreibung und Geschichte, Berlin 1943.

Öztürk, H. S. (2016) Konstantinopolis (İstanbul) Sur ve Kule Yazıtları / Inscriptions from the Walls and Towers of Constantinople, İstanbul Araştırmaları Yıllı̆̆ 5, 1-34.

Philippides, M. and Hanak, W. K. (2011) The Siege and the Fall of Constantinople in 1453: Historiography, Topography, and Military Studies, Farnham.

Semiz, N. (2014) İstanbul Deniz Surları ve Korunması İçin Öneriler [The Sea Walls of Istanbul and Proposals for their Conservation], PhD Dissertation, Istanbul Technical University, Faculty of Architecture.

Talbot, A.-M. (1993) The Restoration of Constantinople under Michael VIII, Dumbarton Oaks Papers 47, 243-261.

Turnbull, St. (2004) The Walls of Constantinople, AD 324-1453, Oxford and Long Island City.

Van Millingen, A. (1899) Byzantine Constantinople: The Walls of the City and Adjoining Historical Sites, London. 


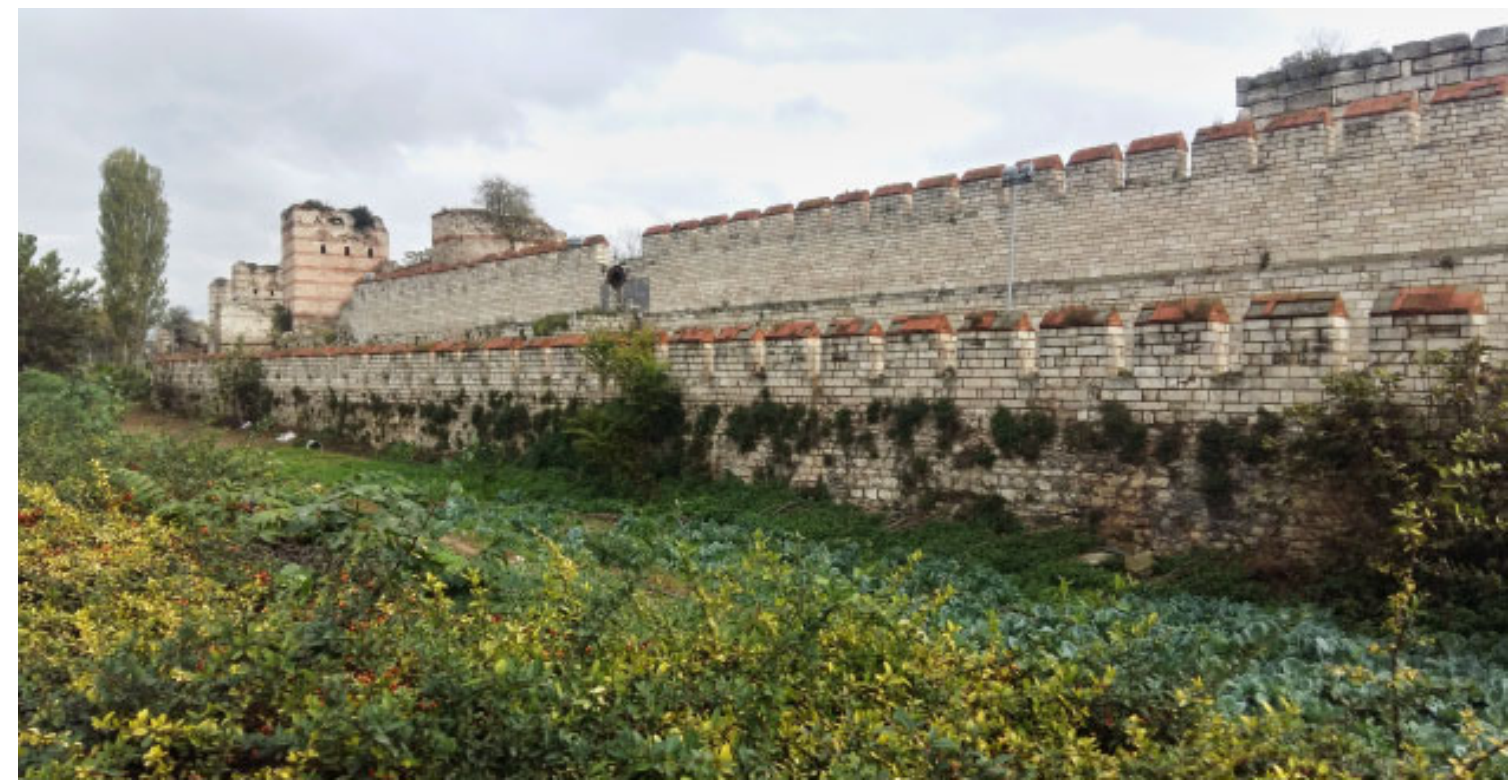

Fig. 1 Land walls, north of the Rhegion Gate (C) https://grandeflanerie.com/portfolio/byzantineistanbul/2/)

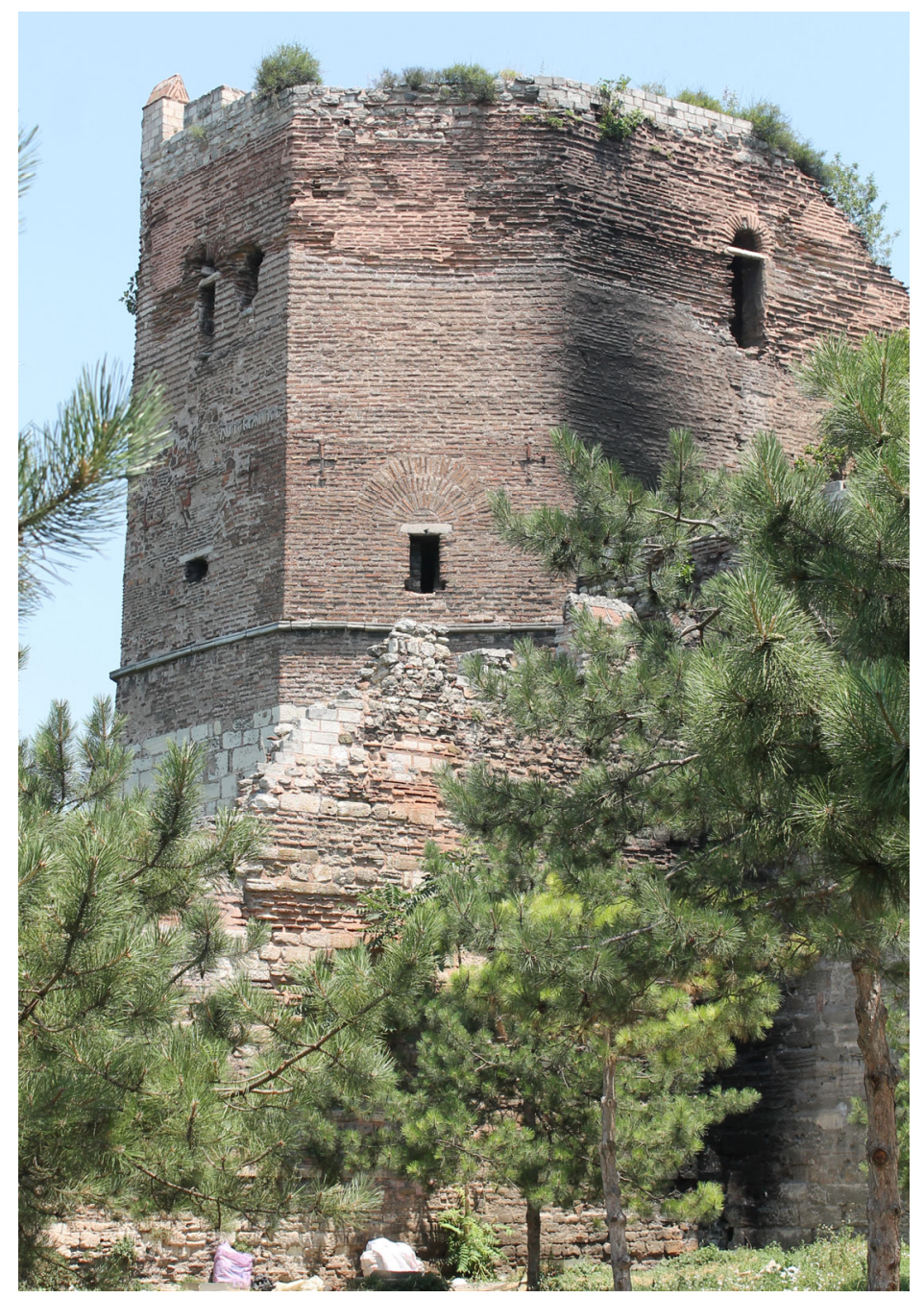

Fig. 2 The Blachernai, Polygonal Tower (C) Andreas Rhoby) 


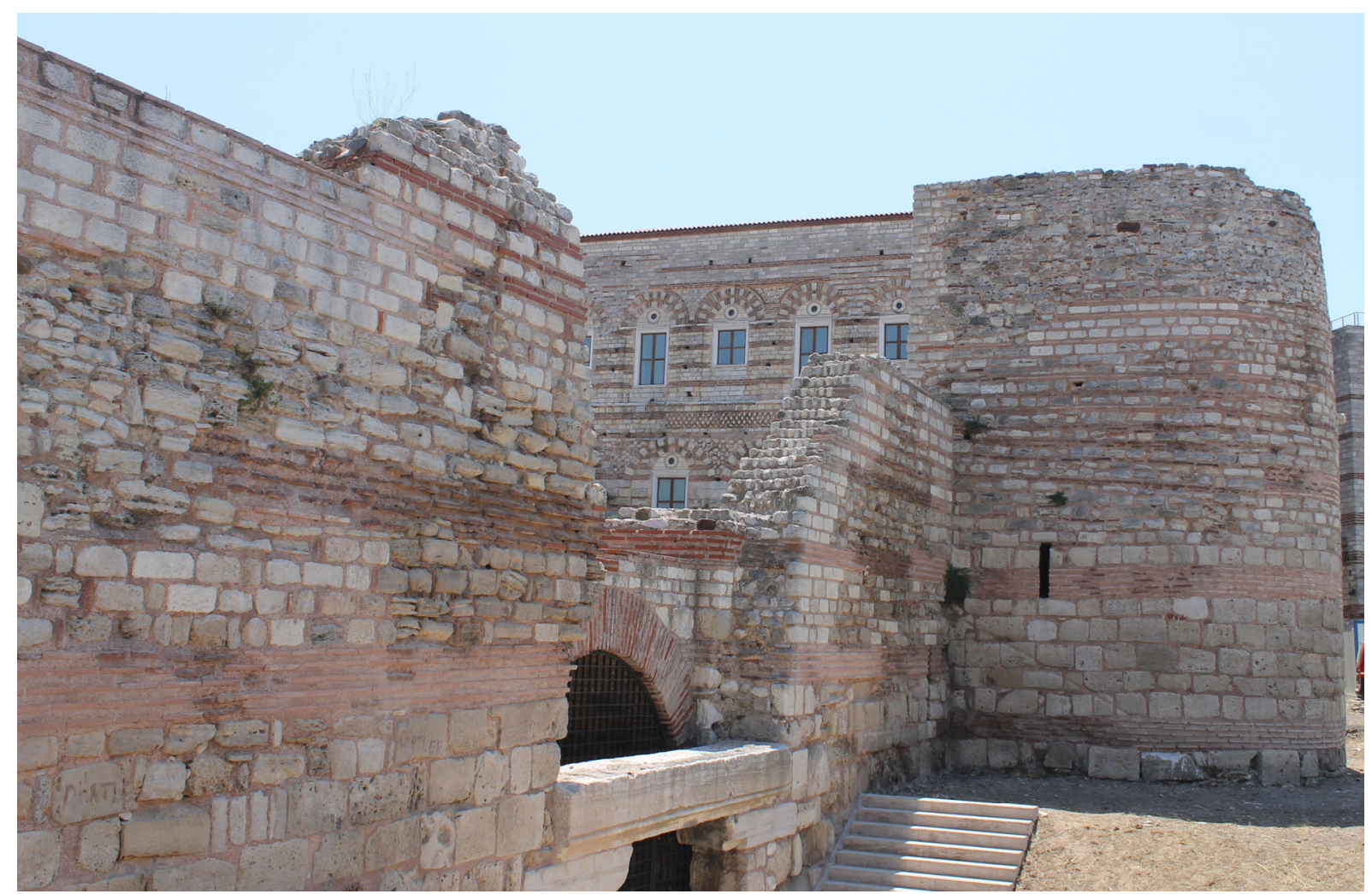

Fig. 3 Tekfur Seray (C) Andreas Rhoby) 



\section{The Epigraphy of the Land Walls of Constantinople NicHOLAS MELVANI}

The study of the inscriptions from the Land Walls of Constantinople is a difficult task: although more than a hundred epigraphic texts are still preserved in situ, some are stored in museums, detached from their original setting, whereas several others have disappeared and are known only through literary sources or 19th-century copies; moreover, the information contained in the inscriptions is often ambiguous and defies dating, especially in cases where only the names and titles of emperors are mentioned. The early 5th-century fortifications were maintained and repaired throughout the city's Byzantine history, and inscriptions in Greek and Latin mentioning these repairs, with the names of the emperors who commissioned them, are found in various parts, especially on the gates and towers along the wall circuit, including the outer wall. As a rule, the texts are prominently displayed facing viewers standing outside the city.

The date of the Latin inscription once adorning the Golden Gate is disputed, since it could refer to either Theodosius I or Theodosius II, and it may even pre-date the erection of the Land Walls. The earliest group of Greek inscriptions dates from the extensive repairs carried out in 447/448 under Theodosios II (recorded by the inscriptions at Belgradkapı and Yeni Mevlevihanekapı) after a series of earthquakes that had damaged large parts of the original structure. (See Chapter 14 by Andreas Rhoby)

The next large-scale campaign attested by inscriptions on towers dating from the reigns of the Isaurian Emperors Leo III and Constantine V (numerous inscriptions between Towers 18 and 63) in the wake of the earthquake of the year 740: these inscriptions were made of bricks inserted into the masonry, unlike the more common practice of incising texts on marble or limestone slabs and cornices. Similar inscriptions mentioning repairs by the imperial administration date from the $9^{\text {th }}$ and $10^{\text {th }}$ centuries.

The inscriptions referring to the campaign of John VIII Palaiologos, dating between 1433 and 1444 (most of them on various towers of the outer wall), constitute an important body of evidence concerning the Land Walls in the $15^{\text {th }}$ century and attest to the efforts of the last emperors to strengthen the defenses of the city against the imminent threat of the Ottomans. Their texts are incised on marble slabs and highlighted with inlaid led fillings. (See Chapter 11 by Matthew Kinloch)

The extension of the walls between the Blachernai and the Golden Horn, which is attributed to the Emperors Heraclius I and Leo V in the sources, preserves inscriptions only from the reigns of Michael II and Theophilos, and later. Remarkably, the portion of the walls known as the "Wall of Manuel Komnenos" bears no inscriptions from the reign of Manuel I. Rather, it displays a verse inscription of Isaac II Angelos. This composition is noteworthy for its minuscule script and its unusual 15-syllable meter.

In short, the texts of the inscriptions, which cover over 1000 years of history and range from short acclamations to elaborate epigrams, are an important source for the study of the construction phases of the Land Walls, of military history and technology, of imperial ideology, as well as of crucial events (such as sieges, earthquakes, various activities of state officials) in the history of Constantinople and the Byzantine Empire. 


\section{Selected Bibliogaphy}

Asutay-Effenberger, N. (2003) Die Entdeckung des Romanos-Tores an den Landmauern von Konstantinopel, Byzantinische Zeitschrift 96, 1-4.

- (2007), Die Landmauer von Konstantinopel-İstanbul. Historisch-topographische und baugeschichtliche Untersuchungen, Berlin and New York.

Bardill, J. (1999) The Golden Gate in Constantinople: A Triumphal Arch of Theodosius I, American Journal of Archaeology 103, 671-696.

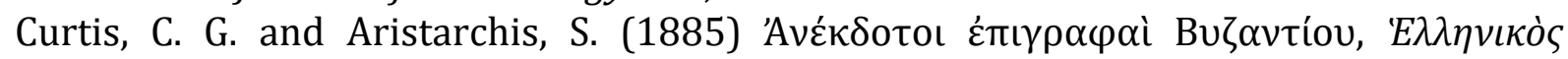

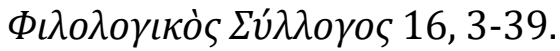

Feissel, D. (1995) Inscriptions chrétiennes et byzantines, Revue des Études Grecques 108, 562-574.

Foss, Cl. (1984) Anomalous Imperial Inscriptions of the Walls of Constantinople, in Studies presented to Sterling Dow on his eightieth birthday, Durham, NC, 77-87.

Kresten, O. (1994) Leon III. und die Landmauern von Konstantinopel. Zur Datierung von

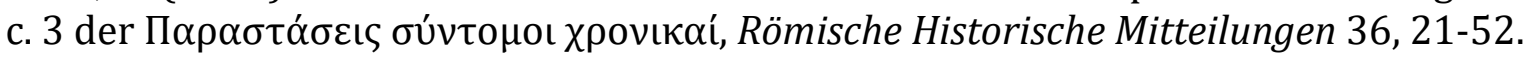

Lebek, W. D. (1995) Die Landmauer von Konstantinopel und ein neues Bauepigramm, Epigraphica Anatolica 25, 107-153.

Loaëc, A. (2017) Les inscriptions en lettres de briques du rempart terrestre de Constantinople-Istanbul: un aperçu des événements de 740-743/744, In-scription. Revue en ligne d'études épigraphiques 2 :

http://in-scription.edel.univ-poitiers.fr/index.php?id=237

Mamboury, E. and Demangel, R. (1936) Une inscription datée sur une tour byzantine de Constantinople, Bulletin de correspondance hellénique 60, 208-213.

Mango, C. (1951) The Byzantine Inscriptions of Constantinople: A Bibliographical Survey, American Journal of Archeology 55, 52-66.

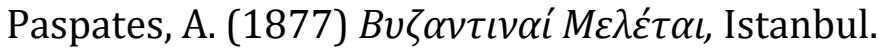

Philippides, M. (2016) Venice, Genoa, and John VIII Palaeologus' Renovation of the Fortifications of Constantinople, Greek, Roman and Byzantine Studies 56, 377-397.

Rhoby, A. (2014) Byzantinische Epigrame auf Stein (= Byzantinische Epigramme in inschriftlicher Überlieferung, vol. 3), Vienna.

Schreiner, P. (1971) Eine unbekannte Beschreibung der Pammakaristoskirche (Fethiye Camii) und weitere Texte zur Topographie Konstantinopels, Dumbarton Oaks Papers 25, 217-248.

Meyer-Plath, B. and Schneider, A. M. (1943) Die Landmauer von Konstantinopel, Zweiter Teil: Aufnahme, Beschreibung und Geschichte, Berlin 1943.

Ševčenko, I. (1970) The Inscription of Justin II's Time on the Mevlevihane (Rhesion) Gate at Istanbul, Zbornik radova Srpske akademije nauka 12, 1-8.

\section{A Selection of Inscriptions from the Land Walls of Constantinople}

TOWER 1 (Figs. 1-2)

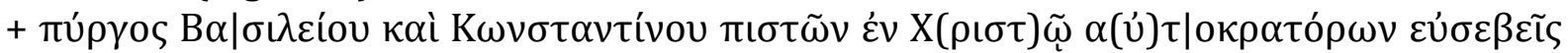
$\beta \alpha \sigma \iota \lambda \varepsilon \tilde{\imath}^{\prime} \mathrm{P} \omega \mu \varepsilon \dot{\varepsilon} \omega \nu+$

TOWER 4 (Figs. 3-4)

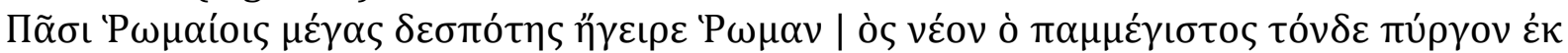
$\beta \alpha ́ \theta \rho \omega(v)$ 


\section{TOWER 5}

$\left.\Lambda \varepsilon^{\prime} \omega \nu\right] \kappa \alpha i ̀ ~ K \omega \nu \sigma\left[\tau \alpha \nu \tau \tilde{v}{ }^{\prime}\right.$

\section{TOWER 18}

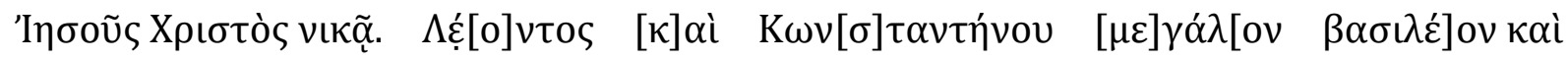

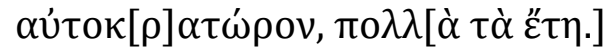

\section{TOWER 25}

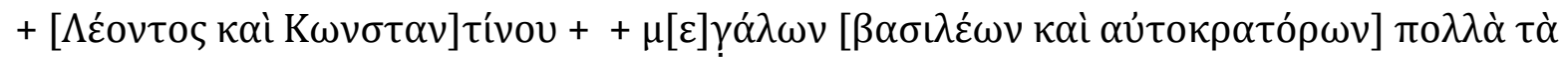
हैंๆ +

\section{TOWER 35}

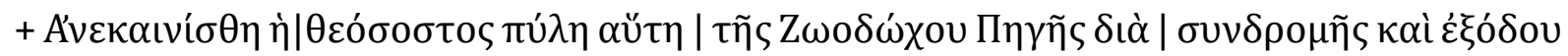

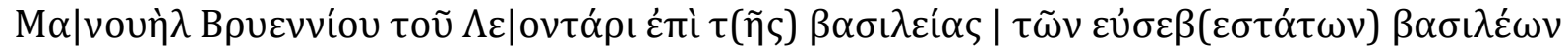

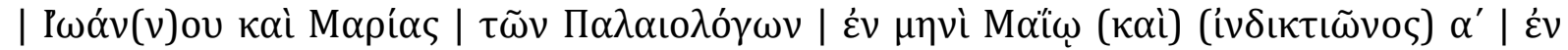
$\varepsilon^{\prime \prime}(\tau \varepsilon l), \varsigma \rtimes \mu \varsigma^{\prime}$

TOWER 36 (fig. 5)

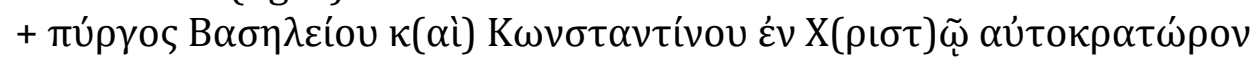

TOWER 37 (fig. 6)

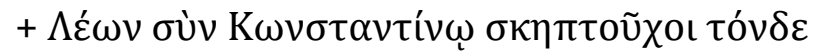

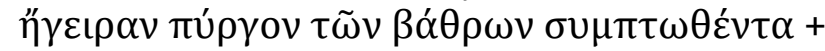

\section{TOWER 40}

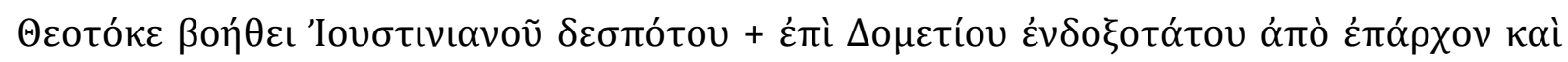

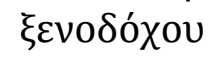

\section{TOWER 45}

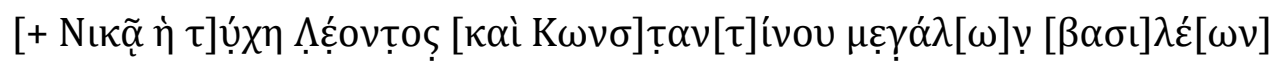

\section{TOWER 47}

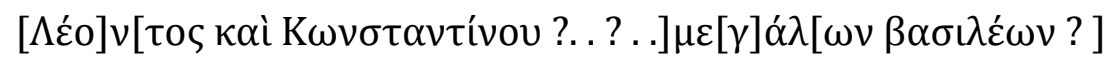

\section{TOWER 48}

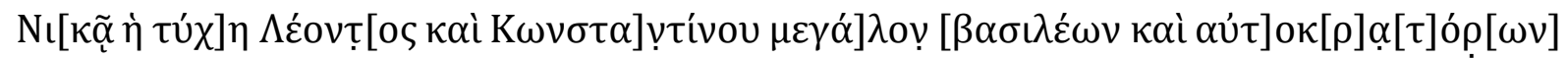

TOWER 50 (fig. 7)

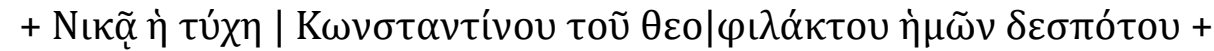

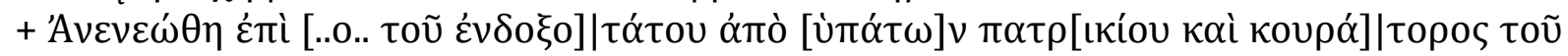

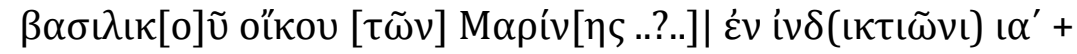

\section{YENI MEVLEVIHANE KAPISI (BETWEEN TOWERS 50-51) (fig. 8)}

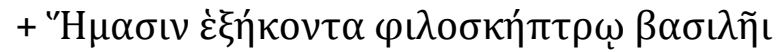

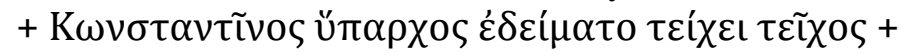

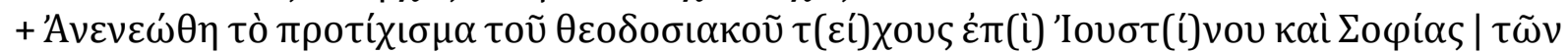

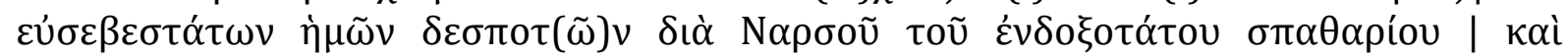

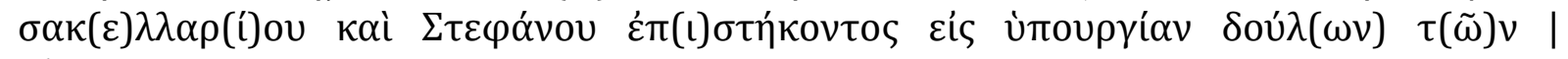

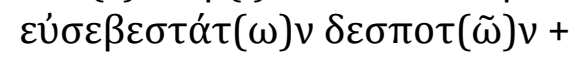




\section{TOWER 54}

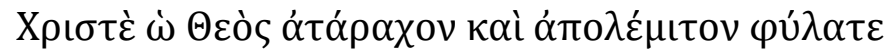

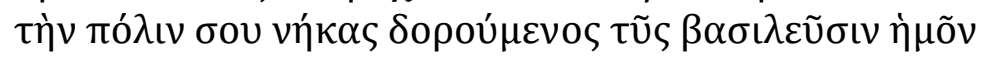

\section{TOWER 55}

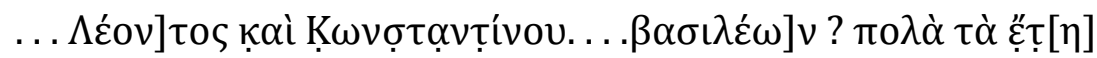

\section{TOWER 56}

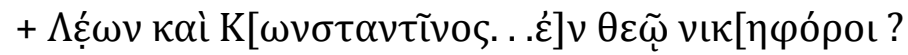

TOWER 57 (fig. 9)

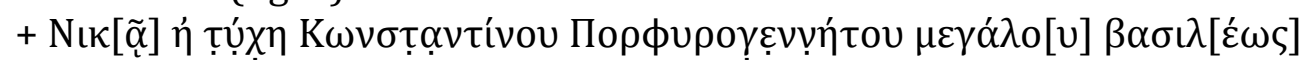

\section{TOWER 59-60}

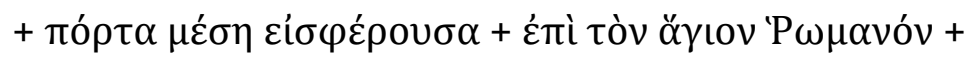

\section{TOWER 63}

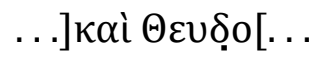

\section{OUTER WALL, TOWER 34a}

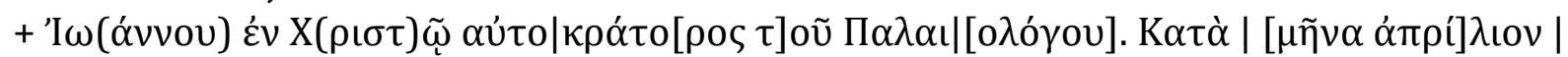
, $\gg \mu \theta^{\prime} \mid \varepsilon^{\prime \prime}$ Tous

\section{BLACHERNAI SECTION, CURTAIN WALL BETWEEN TOWERS 12 AND 13}

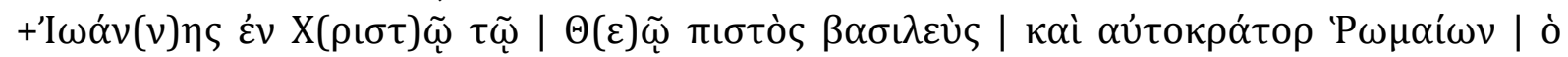

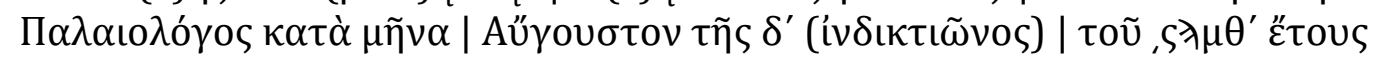

BLACHERNAI SECTION, TOWER 13 (fig. 10)

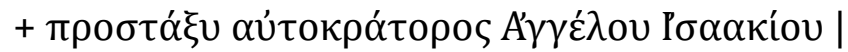

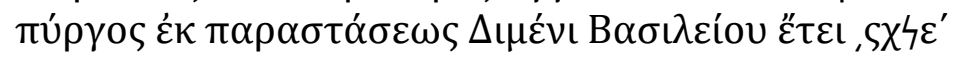

WALL OF LEO V, SOUTH BASTION (fig. 11)

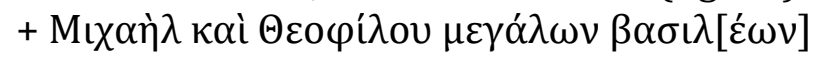

$+\varepsilon ้ \tau\left(\right.$ ous),$\varsigma \tau \lambda^{\prime}+$

PTERON, TOWER 19 (figs. 12-13)

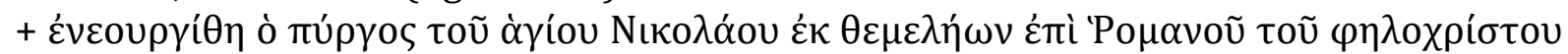
$\delta \varepsilon \sigma \pi \omega ́$ tou + 


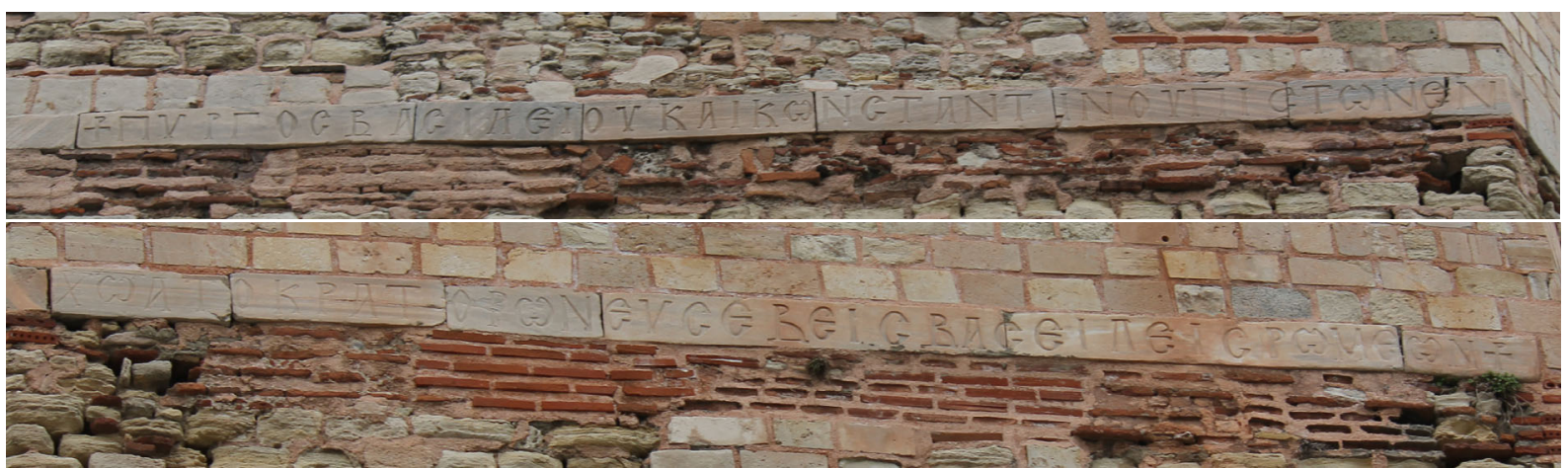

Figs. 1-2 Inscription on Tower 1 (C) Andreas Rhoby)

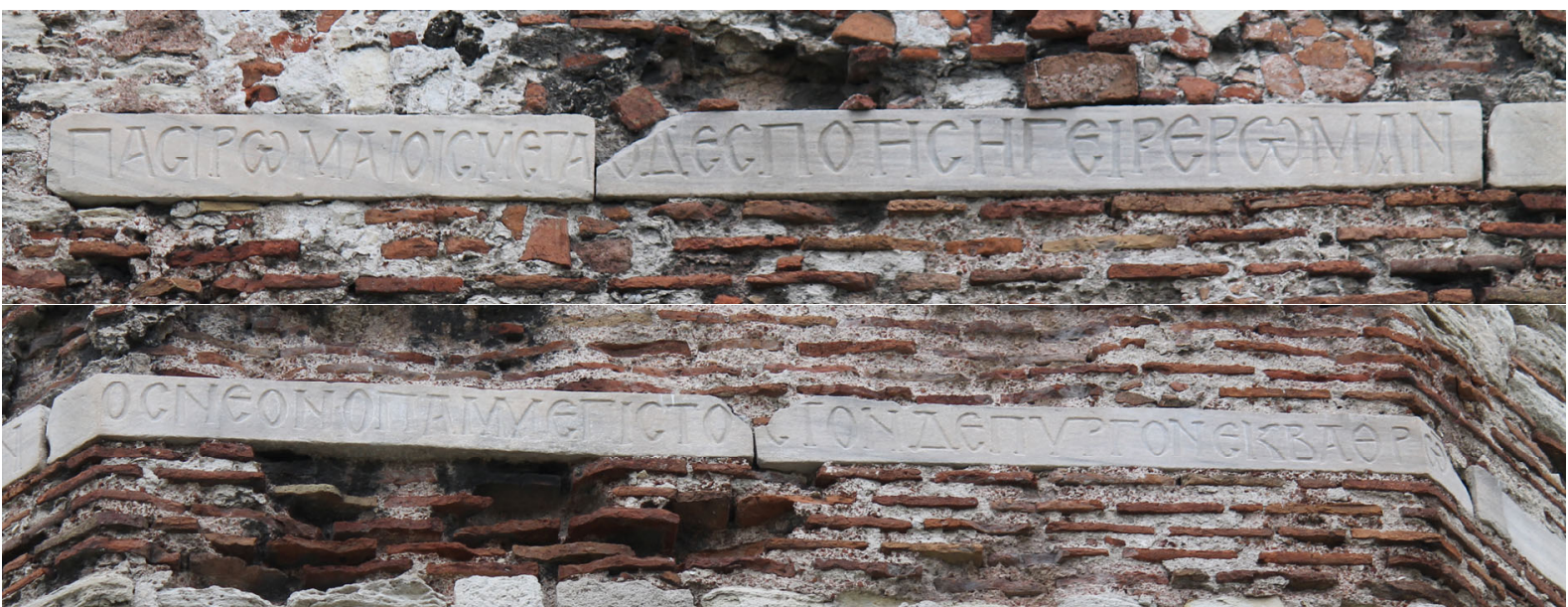

Figs. 3-4 Inscription on Tower 4 (ㄷ Andreas Rhoby)

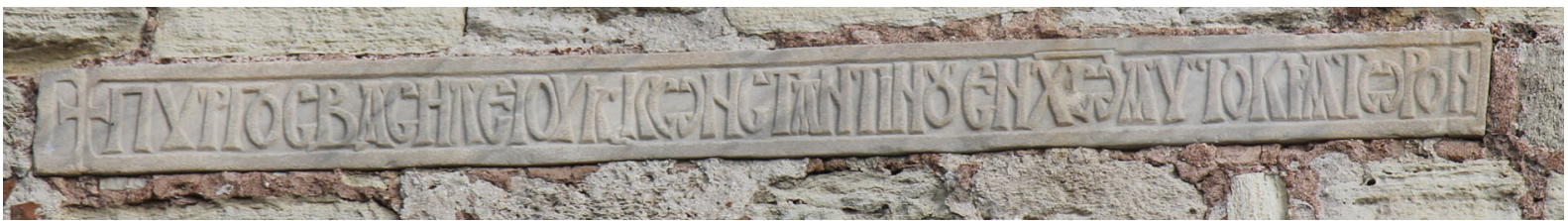

Fig. 5 Inscription on Tower 36 (C) Andreas Rhoby)

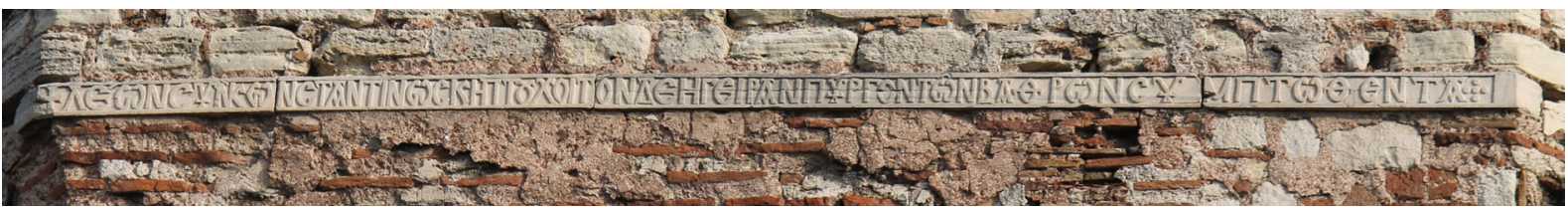

Fig. 6 Inscription on Tower 37 (C) Andreas Rhoby) 


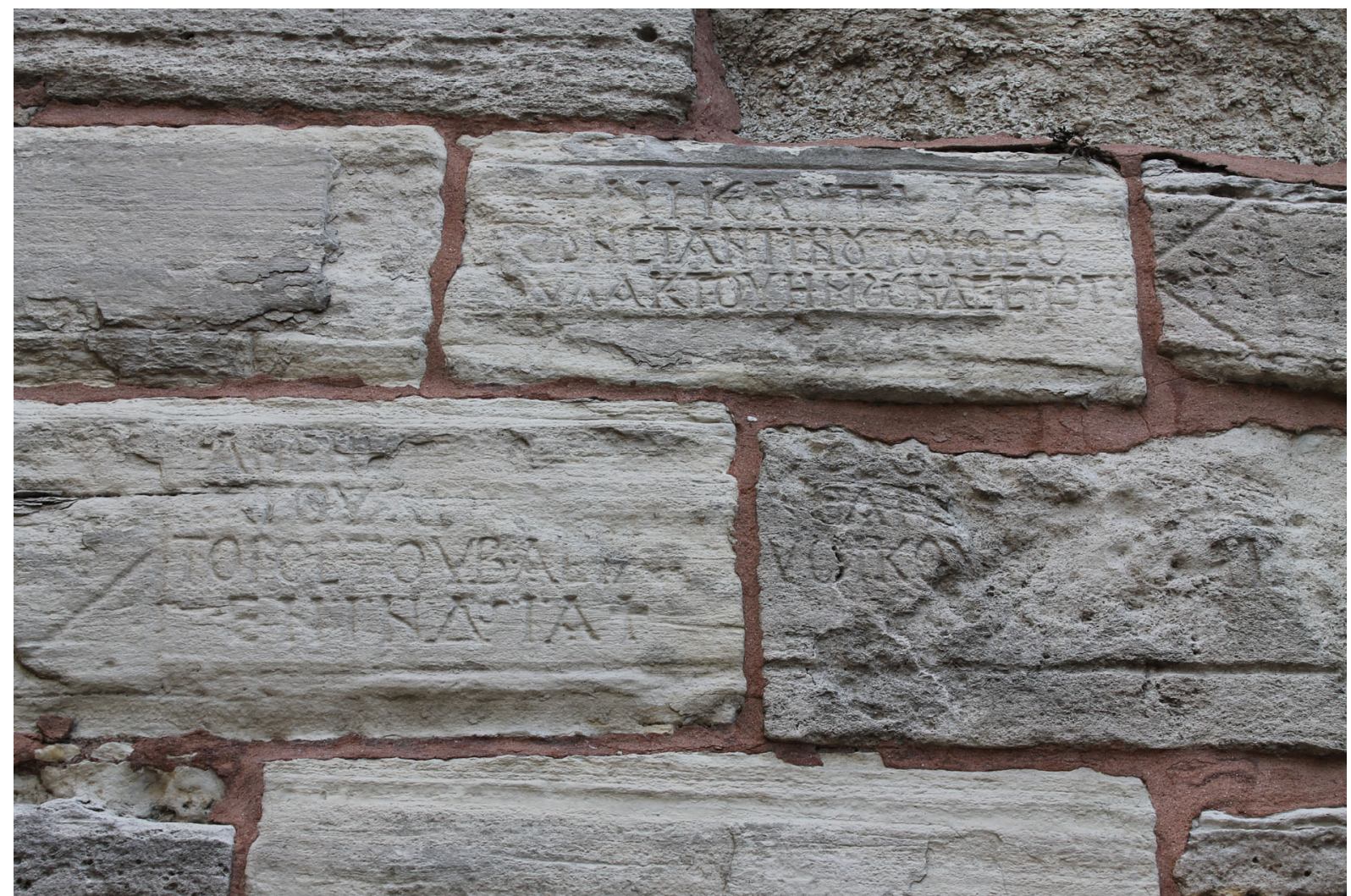

Fig. 7 Inscriptions on Tower 50 () Andreas Rhoby)

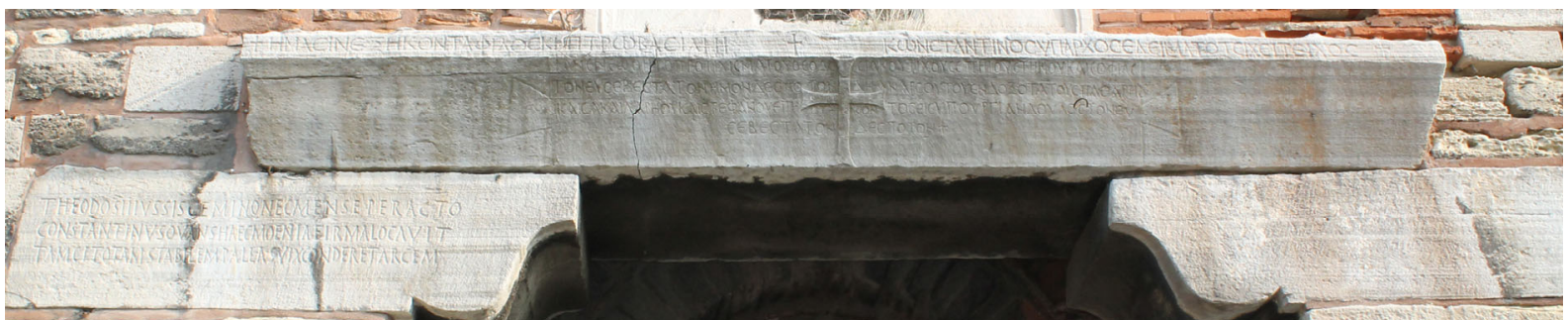

Fig. 8 Inscriptions on the Yeni Mevlevihane Kapısı (C) Andreas Rhoby)

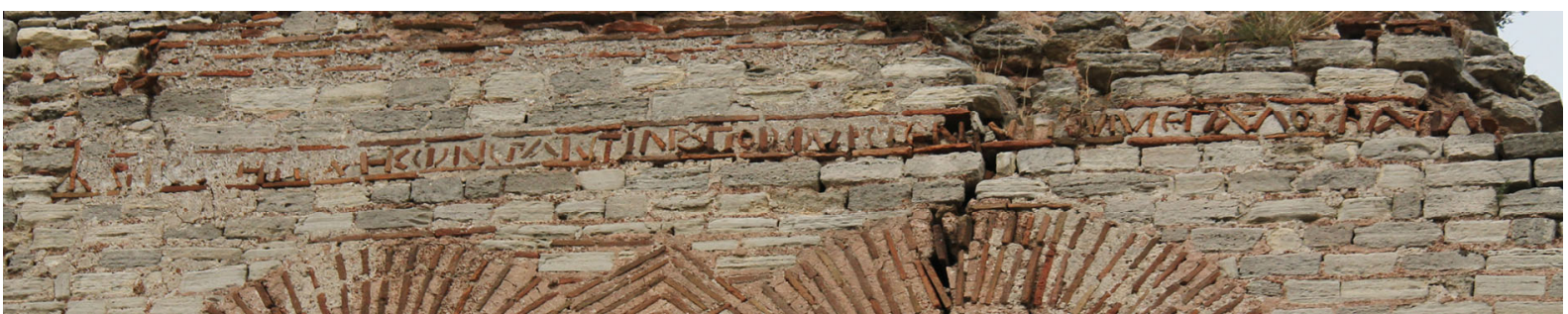

Fig. 9 Inscription on Tower 57 (C) Andreas Rhoby) 


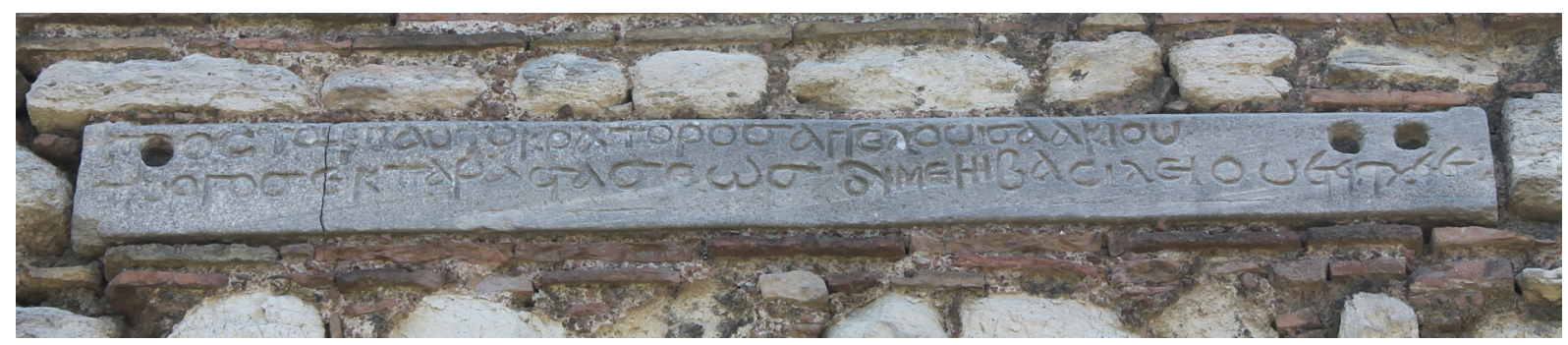

Fig. 10 Inscription on Tower 13, Blachernai Section (C) Andreas Rhoby)

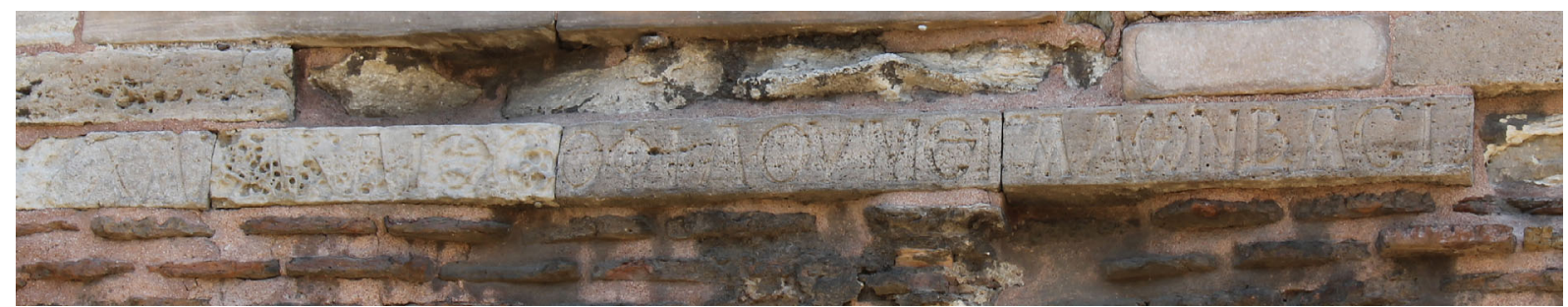

Fig. 11 Inscription on Wall of Leo V, South Bastion (C) Andreas Rhoby)

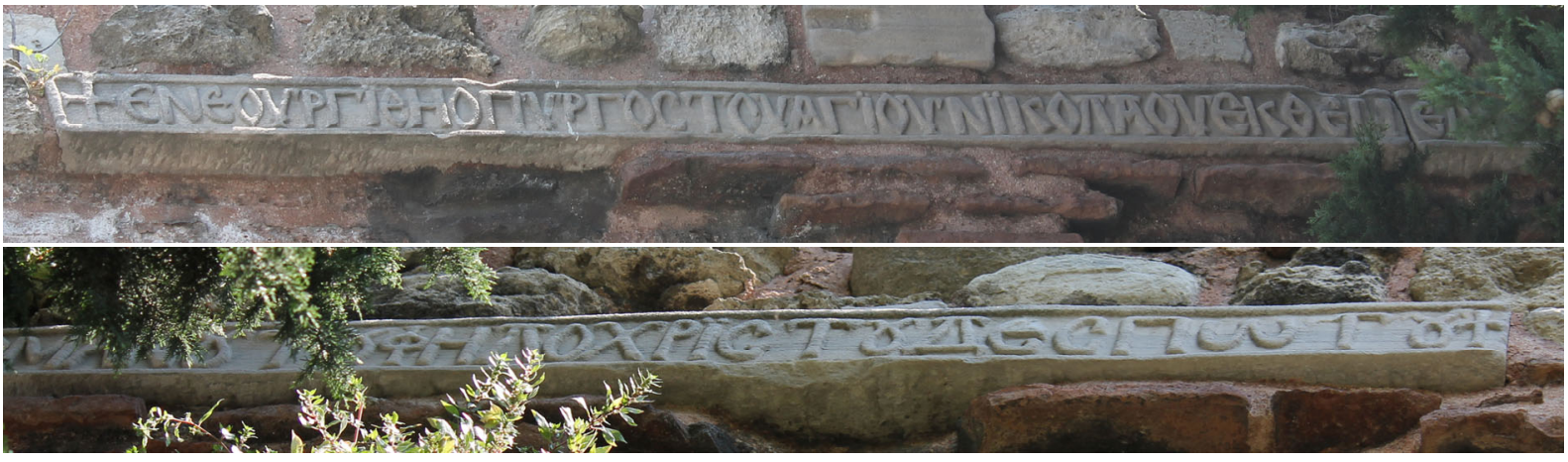

Figs. 12-13 Inscription on Pteron, Tower 19 (C) Andreas Rhoby) 



\section{The Walls Project \\ ROMAN SHLIAKHTIN}

The "Istanbul Walls" project is a unique scientific enterprise funded by Koç University and the Stavros Niarchos Foundation. It aims to represent the archeological heritage of Byzantine and Ottoman Istanbul in digital space, and to make it available to the broader audience in Turkey and abroad. The project unites all types of sources that describe the Walls, and to integrate their data into a new open-source digital platform.

The project prepares a detailed inventory of all preserved parts of the walls, and it has been carried out in several stages. The aim of the first stage (2015-2017) was to record the present-day state of the Wall. A team of photographers created large sets of images that represent the current state of the Byzantine and Ottoman monuments around the Walls. The photographers covered every tower of the Land Walls scaling the walls at several places and negotiating access with local inhabitants. This stage allowed the participants in the project to produce a unique database of high quality images of the Land Walls, and of the buildings around it.

During the second stage of the project (2017-2019), a team of archaeologists and historians from Koç University visited the Walls once a week. They described each construction on the ground, including walls, towers and gates. The technical description revealed many details that were not present in earlier studies of the walls, while the specialists in Byzantine and Ottoman history gathered data about the Walls from all types of sources, including obscure Russian travelogues and unpublished notes from the Ottoman archives. Combining the information from these sources with the data collected in situ, the participants of the project were able to trace some likely Ottoman interventions, and create a catalog of all different types of masonry present in the Land Walls.

At the same time, the project has encountered difficulties in using new methods to study Istabul walls. In 2018, a license was obrained to launch a drone in the vicinity of the walls, which allowed the scholars to observe parts of the Land Walls near Hagios Romanos from above. The use of the viewshed analysis provided an insight into the visual control available to the defenders of the walls at several essential points, including the Yedikule Castle, the terrace in the vicinity of the Blachernai Palace, and the towers in the vicinity of the Gate of Adrianople.

At the present stage, the contributors to the project are working to integrate the data into an online geospatial platform. The prototype version with texts and objects was launched at the Fifth International Sevgi Gönül Byzantine Studies Symposium in Istanbul, in May 2019. The final product of the project will be a website based on the deep map of the city. The website will allow any user to navigate the walls before, during, or after their visit to Istanbul. The system of hashtags will allow the users to choose points of interest ("Gates of Constantinople," "Ottoman Renovations of the Walls," "Inscriptions"), and to plan their trip. Professional users will be able to get the full set of information on any particular item (i.e. a wall, a tower, or a gate) including the photos, descriptions of architectural features, and references to the sources. Thus, the project will draw a broader audience to the Walls as well as providing scholars with a new set of digital tools to explore the past of Istanbul. 



\title{
23. The Epigraphy of The Sea Walls (Including the Marmara Sea and the Golden Horn)
}

\author{
EFTHYMIOS RIZOS
}

The seafront fortifications had a much longer and more complicated structural history than the Land Walls, in as much as their origins in part went back to the pre-Constantinian ramparts of Byzantium. They are conventionally divided into two sections, one running along the Golden Horn Walls (the Blachernai to Sarayburnu) and the other along the Marmara Sea (Sarayburnu to Mermerkule).

The calm and shallow waters of the Golden Horn invited human settlement much earlier than the deep and tempestuous shore of the Sea of Marmara. Consequently, a broad zone of houses was formed along the outer façade of the Golden Horn Walls already in Byzantine times. This continued into the Ottoman period, when the Sea Walls were rendered defensively obsolete, and, as a result, the Golden Horn Walls were quickly consumed by the living city. Thus, they survive in a fragmentary state, mainly between Ayvansaray and Unkapanı. By contrast, the Marmara Sea Walls were less affected by the development of the city. They stood in long stretches directly on the sea shore until the beginning of the development of the city in the $19^{\text {th }}$ and late $20^{\text {th }}$ centuries, when the construction of the railways and the coastal motorway radically altered their appearance. The best preserved section of the seafront fortification remains the stretch between Sarayburnu and the Boukoleon Palace, mainly because it formed part of the Ottoman palace fortifications, and was thus protected from human interventions.

The phase sequence of the Sea Walls is complex, and its interpretation is additionally impeded by the bad and fragmentary state of preservation, and by the lack of a comprehensive study. These problems apply also to the study of inscriptions. The epigraphic material of the Sea Walls has not been recorded as a corpus - unlike that of the Land Walls - and the great majority of the inscriptions seen in the past have since been lost.

It is usually assumed that the Sea Walls incorporated stretches of the preConstantinian (i.e. Hellenistic and Roman) and Constantinian constructions, but these are not positively attested through epigraphy. Possible remnants of masonry can be seen behind the church of Hagios Demetrios Kanaves in Balat (the walls of Regio XIV of the Notitia Urbis?), and within the substructure of the so-called Church of Christos Philanthropos in Sarayburnu. In 439, the Emperor Theodosius II ordered the construction of the maritime fortifications between the Theodosian and Constantinian Walls, which was undertaken by the Urban Prefect Cyrus of Panopolis, whereas the Praetorian Prefect Constantine repaired the walls after the great earthquake of 446 (recorded by a lost inscription on a gate near Yenikapı).

The only extant late antique inscription of the Sea Walls is found on a gate next to the church of Saints Sergios and Bacchos. Possibly belonging to the sixth century, it was a biblical text combining verses from the Psalms and Habakkuk. The gate still stands, but the inscription has suffered extensive damage in recent years, and it has been partly lost (text 1, fig. 1).

The rest of the inscriptions visible on the Sea Walls mainly belong to the Middle and Late Byzantine periods, recording an almost continuous sequence of maintenance works from Theophilus (829-842) to Basil II (976-1025) or Constantine VIII (1025-1028). 
The author of the Patria (2.109) remembers two major renovations of the Sea Walls, under Tiberios II Apsimaros (698-705) and Theophilos (829-842), but it is only the latter that has left a visible trace in the epigraphic record (texts 2-5). In their greatest number, the extant imperial dedicatory inscriptions belong to Theophilos and Michael III (829842). Theophilos' rebuilding project was probably the most extensive, and certainly most ambitious in the way of epigraphic commemoration. During the Summer Programme in September 2018, we viewed his inscriptions on the towers flanking the Değirmen Kapısı and the İncili Kyöşk (texts 2-6) and one in Fener (text 17). These include a long invocation, requesting Christ's protection for the wall, in a formulation, which may echo acclamations used during the dedication of the wall (text 2).

Focused repairs are recorded under Michael III (842-867) (text 6), Leo VI (886-912) (texts 7-8), Basil II (text 10), and Manuel Komnenos (text 11).

The inscription of the impressive Marble Gate, which was uncovered in 1919 by Ernst Mamboury immediately west of the Boukoleon palace, probably belongs to the $10^{\text {th }}$ or $11^{\text {th }}$ century, and refers to the Emperors Constantine VII Porphyrogennetos (913-959) or Constantine VIII (960-1028). It had a Greek inscription of three lines set in a tabula ansata, written on the marble lintel, which spanned the arch of the gate-way. Only a piece of the central part was found, but Mamboury restored the block and placed it back onto the gate, However, since then, it has been removed, and it is now kept in the Archaeological Museum (text 9).

Names of lower-ranking officials involved in the maintenance of the circuit were relatively rare in middle Byzantine inscriptions (Bardas the Domestic of the Schools being the only case; text 6 ; also, see Chapter 10 by Mirela Ivanova), but became more numerous in the Palaeologan period, when the maintenance of the Wall was independently funded by individual aristocrats, who were commemorated without a reference to the reigning emperor (Manuel Phakrases Kantakouzenos, Loukas Notaras, George Branković of Serbia; texts 13-15, see Chapter 12 by Ida Toth).

Besides their defensive function, the Sea Walls were also associated with non-military buildings, such as the ecclesiastical complex, which stood over the substructure known as the 'Monastery of Christ Philanthropos' (probably an inaccurate identification), and which preserves a mostly illegible dedicatory inscription made of bricks (text 16).

Any epigraphic survey of this material needs to be holistic, taking into consideration the distinct phases and history of the Sea Walls, the different modes and agents of epigraphic communication, and the continuing changes in the rules and conventions of Byzantine epigraphy.

\section{Selected Bibliography}

Asutay-Effenberger, N. (2007) Die Landmauer von Konstantinopel-İstanbul. Historischtopographische und baugeschichtliche Untersuchungen, Berlin and New York.

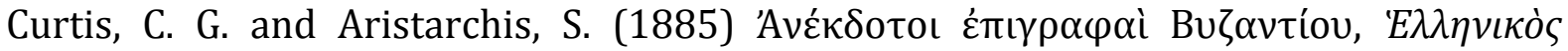

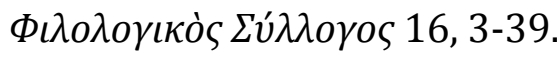

Demangel, R. and Mamboury, E. (1939) Le quartier des Manganes et la première région de Constantinople, Paris.

Dirimtekin, F. (1956) Fetihten önce Haliç surları, Istanbul.

Dirimtekin, F. (1953) Fetihden önce Marmara surları, Istanbul.

Felle, A. E. (2006) Biblia Epigraphica, Bari. 
Mango, C. (1951) The Byzantine Inscriptions of Constantinople: a Bibliographical Survey, American Journal of Archaeology 55, 52-66.

Mango, C. (1995) Ancient Spolia in the Great Palace of Constantinople, in Byzantine East, Latin West. Art-Historical Studies in Honor of Kurt Weitzmann, Princeton, NJ.

Müller-Wiener, W. (1977) Bildlexikon zur Topographie Istanbuls, Tübingen, 301-319.

Rhoby, A. (2014) Byzantinische Epigrame auf Stein (= Byzantinische Epigramme in inschriftlicher Überlieferung, vol. 3), Vienna.

Schneider, A. M. (1950) Mauer und Tore am Goldenen Horn in Konstantinopel, Nachrichten von der Akademie der Wissenschaften in Göttingen, philologisch-historische Klasse, no. 5., 65-107.

Van Millingen, A. (1899) Byzantine Constantinople: the Walls of the City and Adjoining Historical Sites, London.

\section{A Selection of Inscriptions on the Marmara Sea Side (between Sarayburnu and Kumkapı)}

\section{Sixth-century (?) inscription}

1. Late antique biblical inscription, on the gate next to Saints Sergios and Bacchos (Felle 2006, no. 511) (fig. 1):

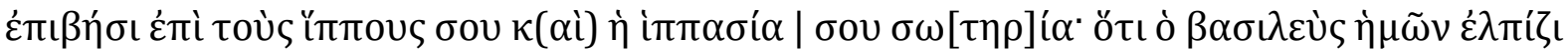

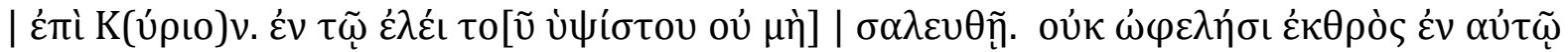

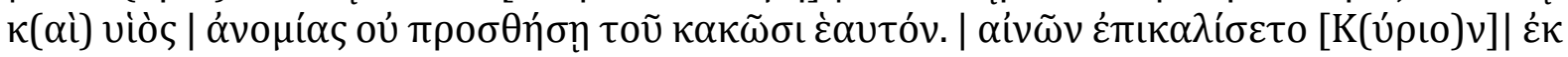

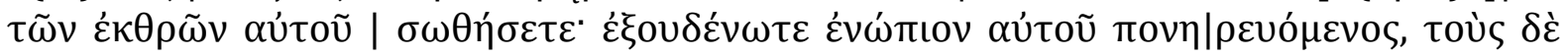

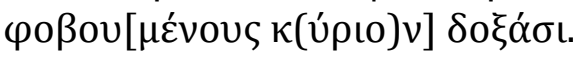

\section{Michael II (820-829), Theophilos (829-842), Michael III (842-867) (joint reigns 822-829, 840-842)}

2. Curtain wall north of Değirmen Kapısı (fig. 2):

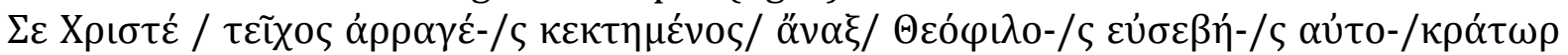

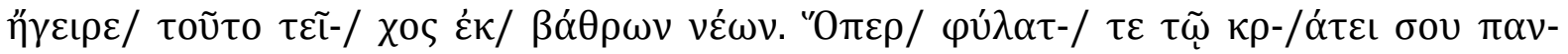

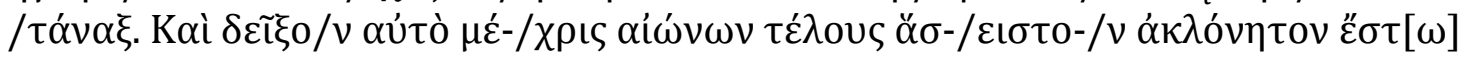

3. First tower north of Değirmen Kapısı (fig. 3):

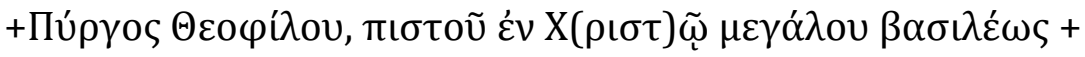

4. First tower south of Değirmen Kapısı (fig. 4):

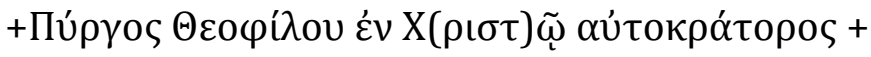

5. Extant inscription on the Seventh tower south of the Değirmen Kapısı, together with a later inscription of Leo VI (text 8) (fig. 5). During a rebuilding of the tower both inscriptions seem to have been disturbed and placed back onto the façade, though in a partially incorrect order, resulting in a syntactically disorderly reading:

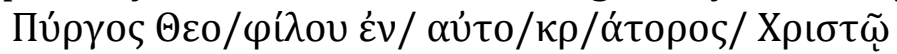

\section{Michael III and Bardas (858-866)}

6. Inscription in three slabs, from the vicinity of the İncili Köşk, now in Istanbul Archaeological Museum (Rhoby 2014, no. TR61) (fig. 6):

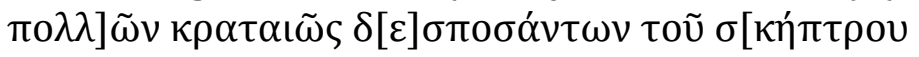




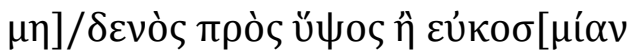

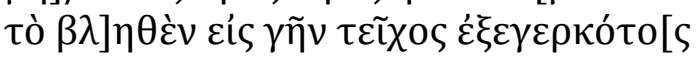

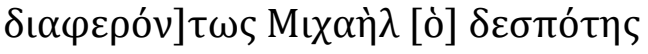

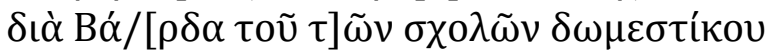

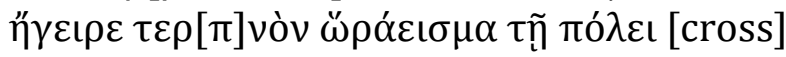

\section{Leo VI (886-912) and Alexander III (912-913) (joint reign 886-908, with Constantine VII 908-912)}

7. Extant inscription on the Seventh tower south of the Değirmen Kapısı, over an earlier inscription of Theophilos (see above, text 5, and below, fig. 5). During a rebuilding of the tower both inscriptions seem to have been disturbed and reintegrated into the façade, though in a partially incorrect order, resulting in a syntactically disorderly reading:

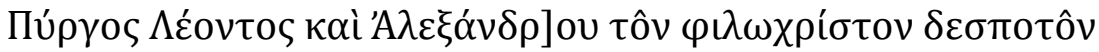

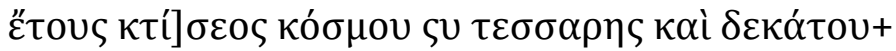

$(\mathrm{AM} 6414=\mathrm{AD} 905 / 6)$

8. Lost inscription from Kumkapı (Kontoskalion):

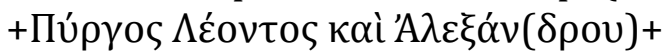

Constantine VII Porphyrogennetos (913-959) or Constantine VIII (960-1028)

9. Inscription of Constantine VII Porphyrogennetos (913-959) or Constantine VIII (9601028), next to the Boukoleon palace. Now in the Museum (Rhoby 2014, no. TR59) (figs. 7-8).

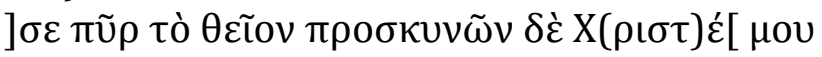

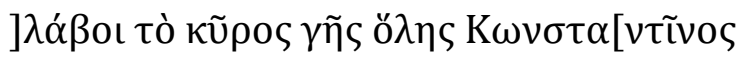

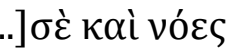

\section{Basil II in 1024}

10. Lost inscription west of Ahır Kapısı:

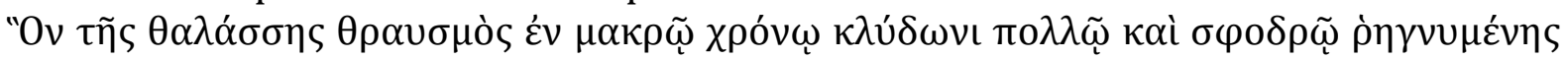

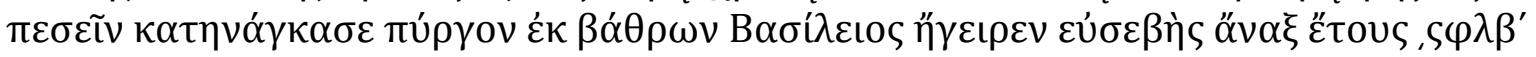

$(\mathrm{AM} 6532=\mathrm{AD} 1023 / 1024)$

\section{Manuel Komnenos in 1163.}

11. Tower near Narlı Kapı:

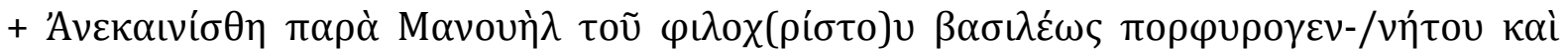

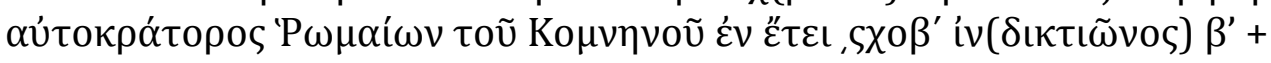
AM $6672=$ AD 1164

\section{Andronikos II Palaiologos (1282-1328)}

12. Lost slab featuring coat of arms and monograms, near Kumkapı

Manuel Phakrases Kantakouzenos, protostrator of John VI Kantakouzenos (13471354).

13. Lost inscription from a tower north of Cubalı Kapısı:

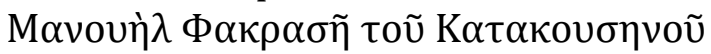




\section{Loukas Notaras (1302-1453)}

14. Lost inscription, between Catladı Kapı and Ahır Kapısı:

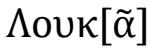

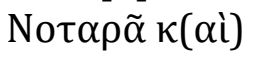

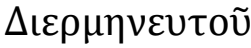

\section{George Branković of Serbia (1427-1456)}

15. From the walls between Kumkapı and Yeni Kapı (now at the Museum) (fig. 9):

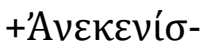

$\theta \eta v$ oũ̃os

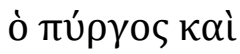

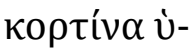

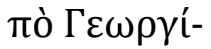

ou $\delta \varepsilon \sigma \pi o ́ \tau o u$

$\sum \varepsilon \rho \beta i ́ \alpha \varsigma \ldots+$

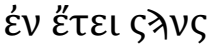

$(\mathrm{AM} 6956=\mathrm{AD} 1448)$

Brick inscription on the façade of the so-called Philanthropos monastery

16. Mostly illegible (fig. 10)

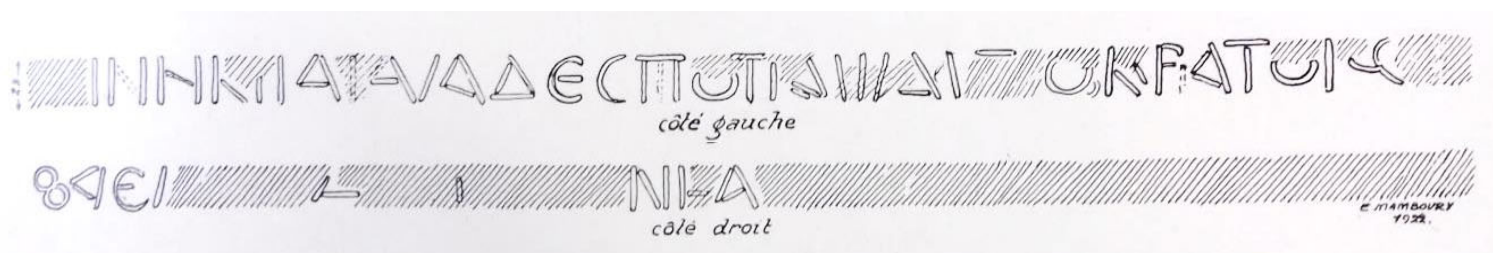

\section{A selection of inscriptions on the Golden Horn side (from Blachernae to Fener)}

\section{Inscriptions of Theophilus and Michael}

17. Eleven fragmentary inscriptions of Theophilus and Michael were recorded between Blachernae and the Fener Gate, most of which have disappeared. One is still extant and can be seen on the third tower west of Fener Kapısı, opposite the Women's Library Foundation (Kadın Eserleri Kütüphanesi) on Murselpasa Cad.

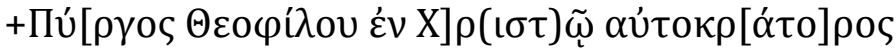

\section{Invocation (?) of Saint Pantoleon}

18. Lost inscription from the 3rd tower east of the Kiliomene Gate

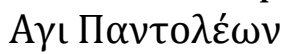

\section{Monogram}

19. Lost slab from the Courtyard of the Koca Mustafa Camii Cross monogram ГА[В]PIH $\Lambda$ (?) 


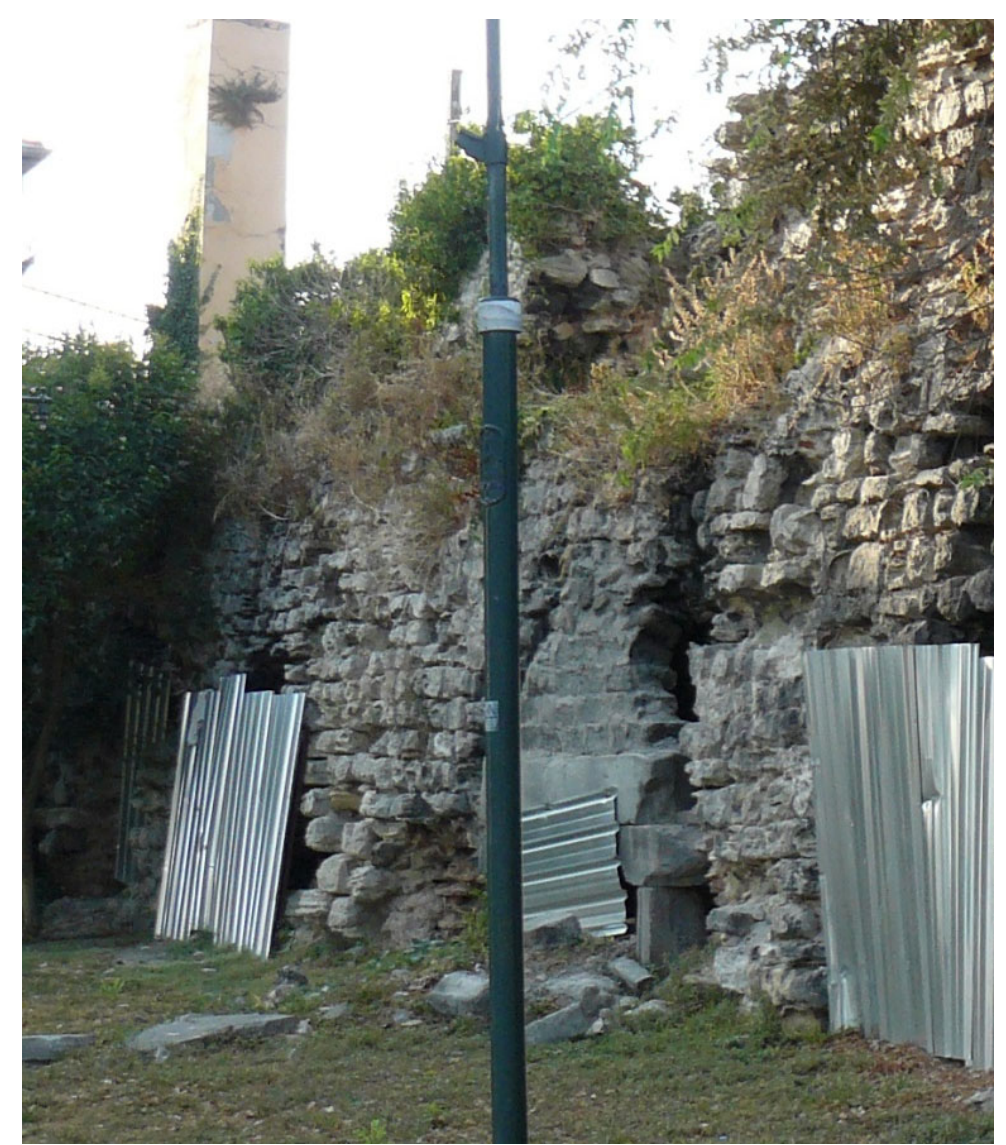

Fig. 1 Late antique biblical inscription, on the gate next to Saints Sergios and Bacchos (C) Efthymios Rizos)

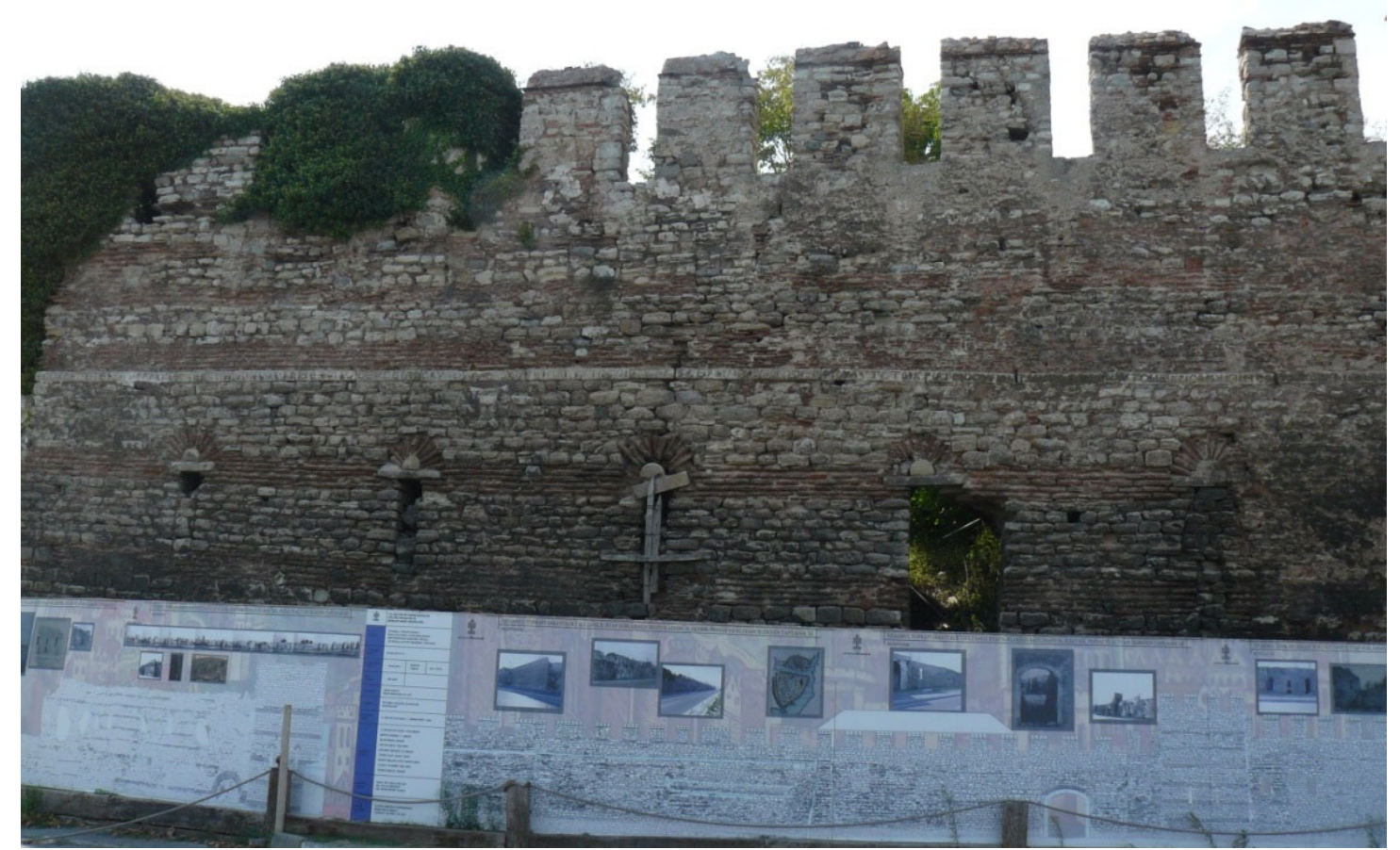

Fig. 2 Curtain wall north of Değirmen Kapısı (C Efthymios Rizos) 


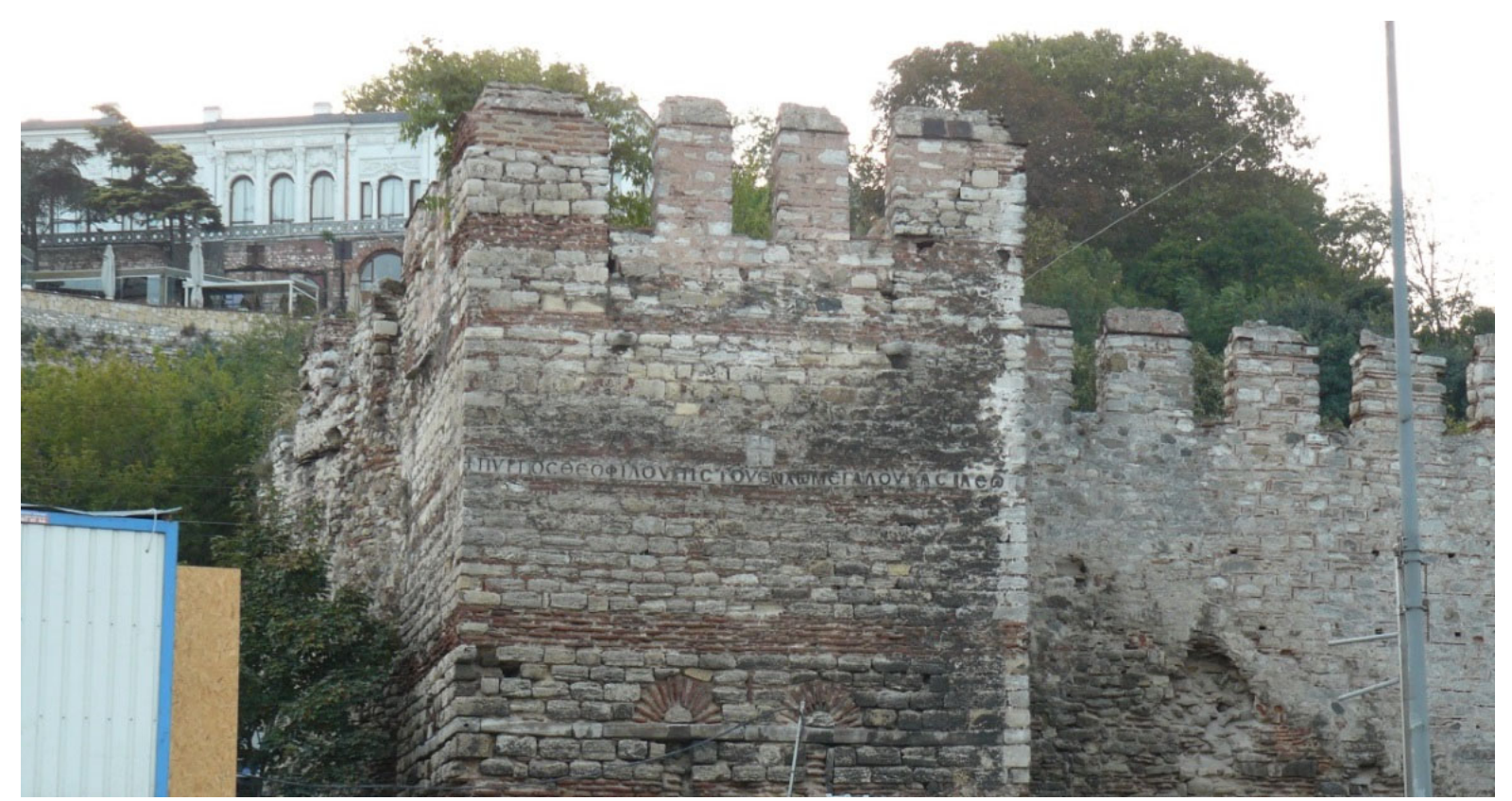

Fig. 3 First tower north of Değirmen Kapısı (@ Efthymios Rizos)

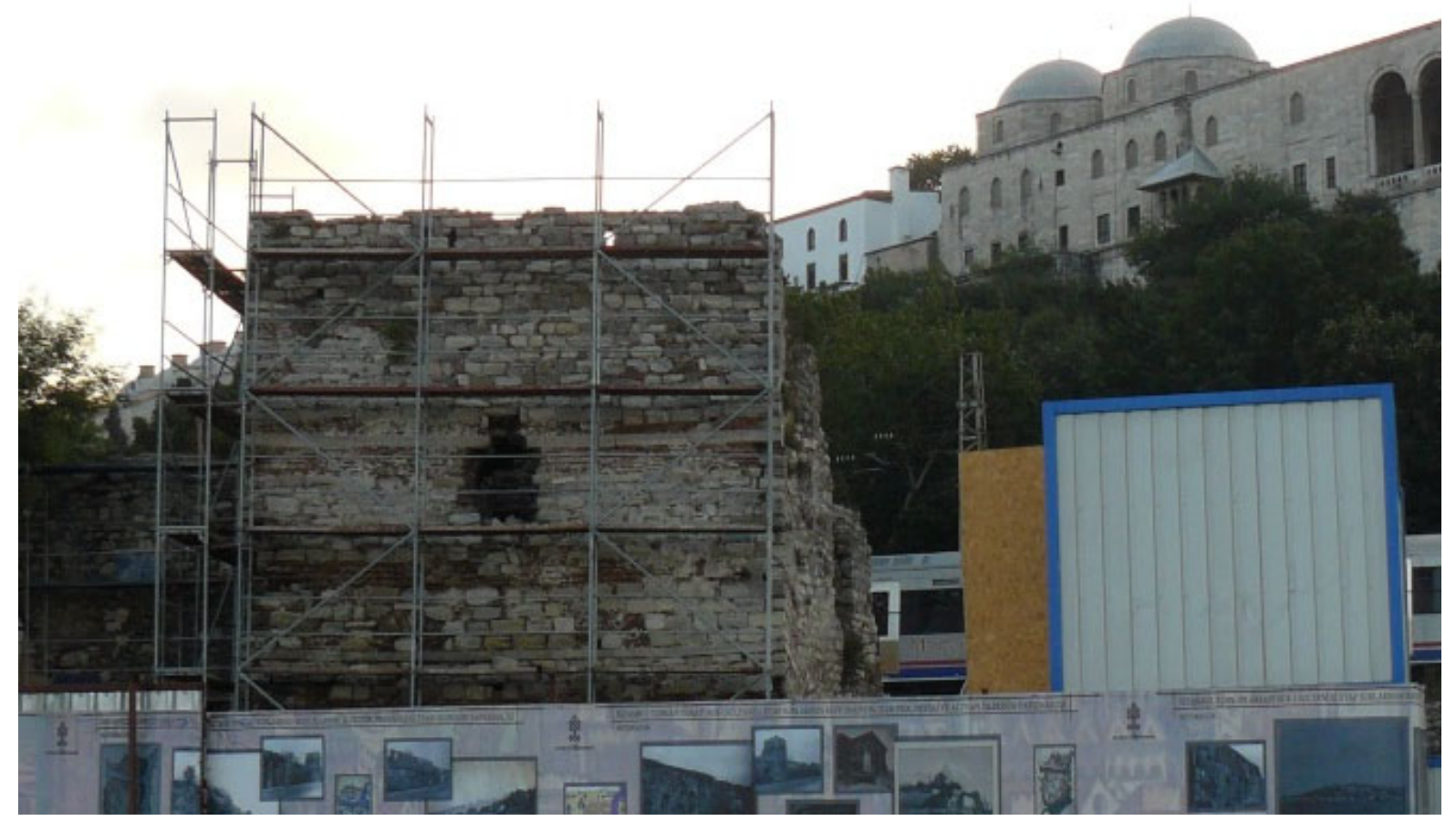

Fig. 4 First tower south of Değirmen Kapısı (@ Efthymios Rizos) 


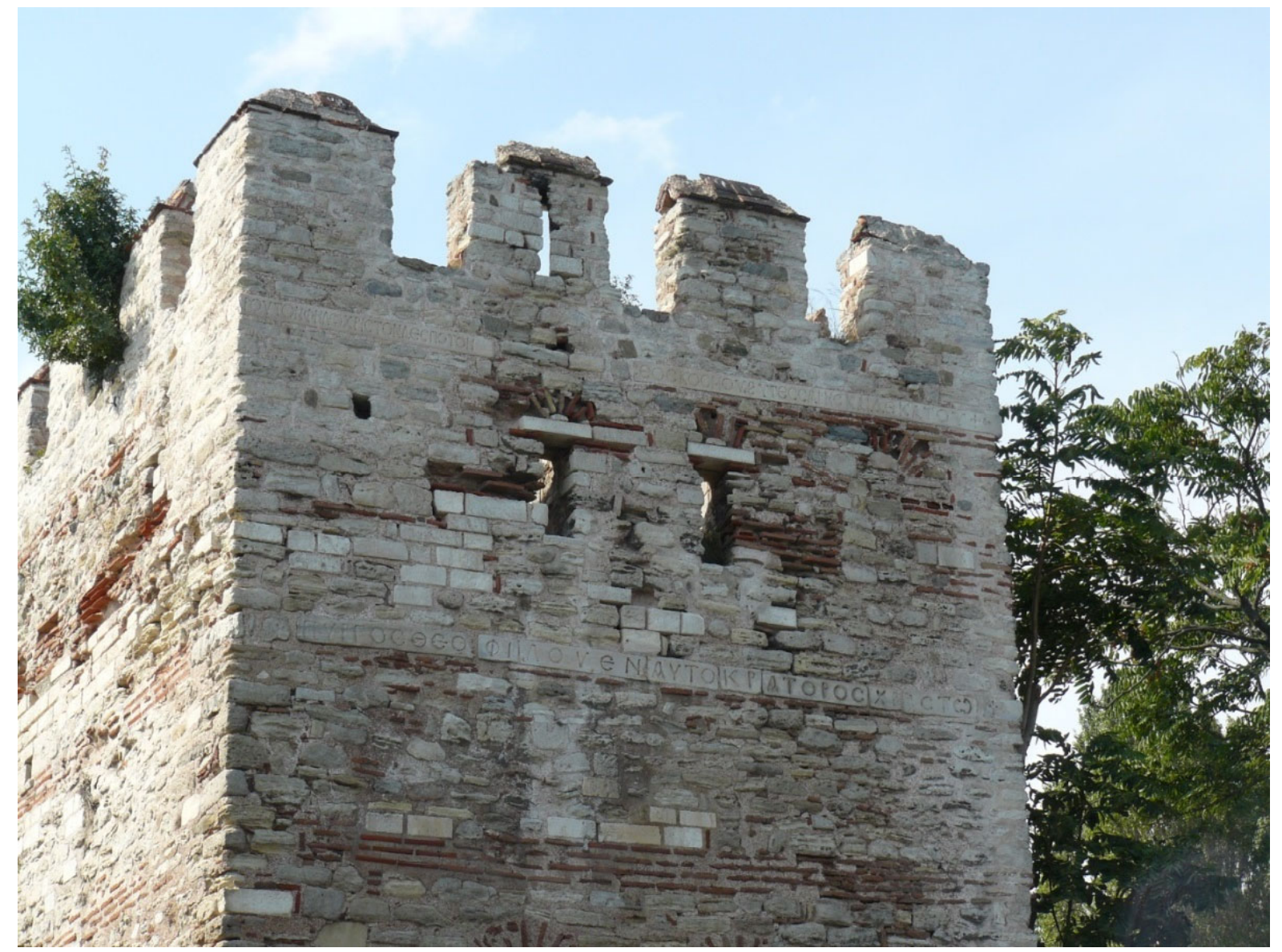

Fig. 5 Seventh tower south of the Değirmen Kapısı (C) Efthymios Rizos)

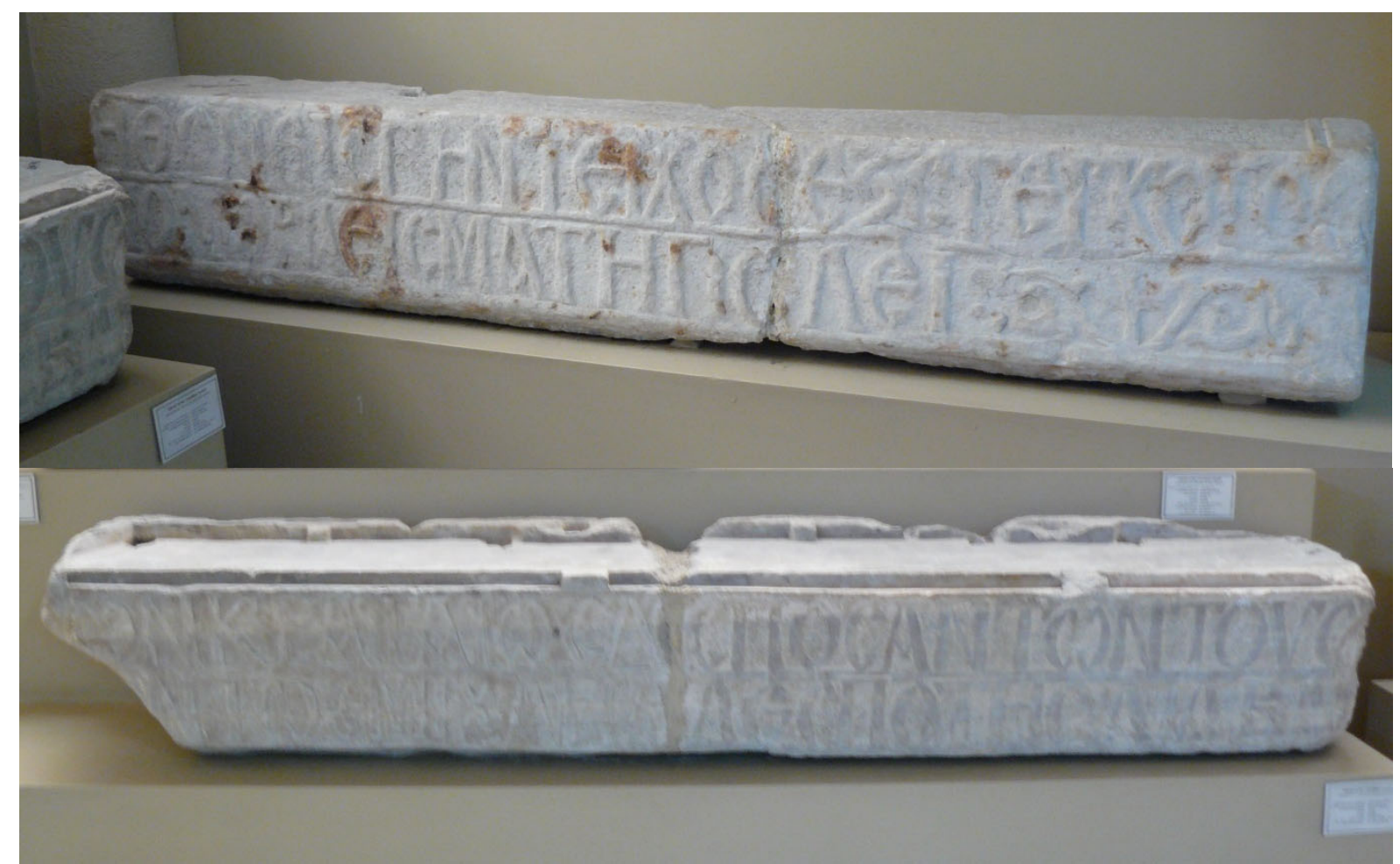

Fig. 6 Inscription in three slabs, from the vicinity of the İncili Köşk, now in Istanbul Archaeological Museum (C) Efthymios Rizos) 


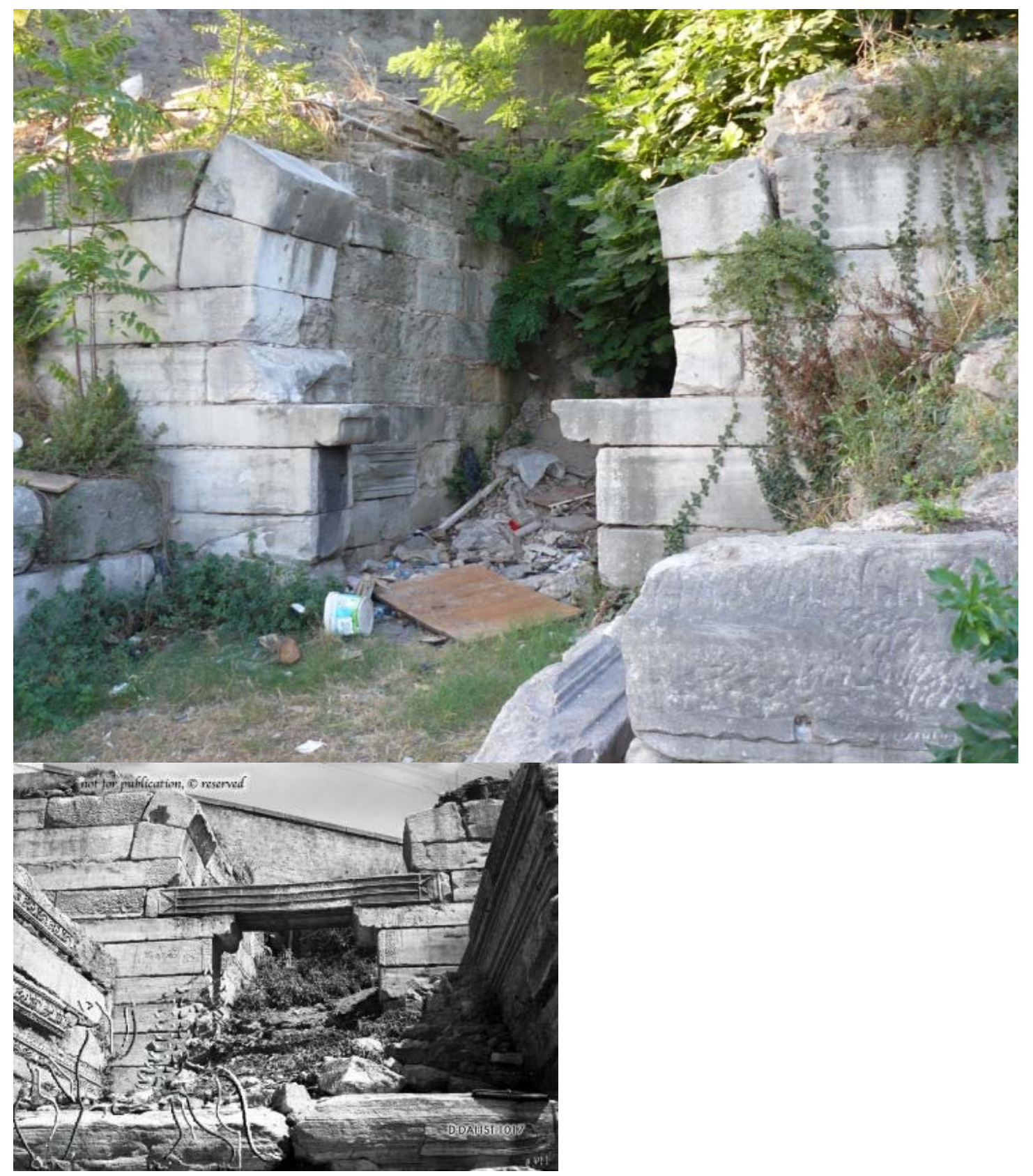

Fig. 7 Gate by the Boukoleon palace, with broken inscription in tabula ansata. State on $5 / 9 / 2018$, and the old restoration of the block by Mamboury (C) DAI Istanbul archive) 


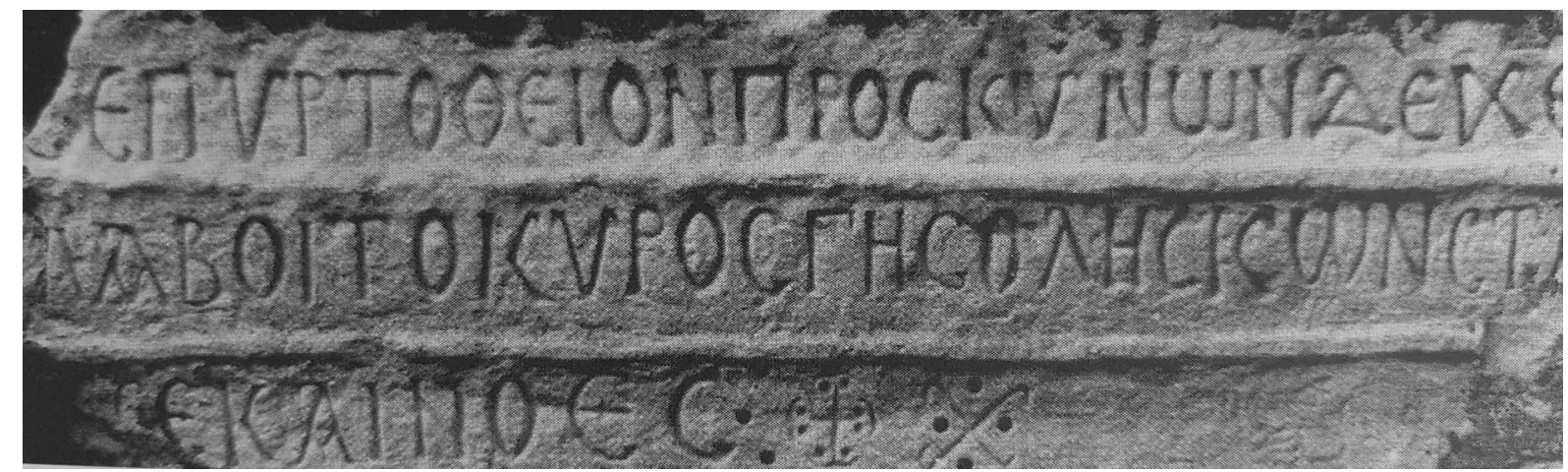

Fig. 8 Inscription of Constantine VII or Constantine VIII, now in Istanbul Archaeological Museum (C) Mango (1995), 648 and fig. 6)

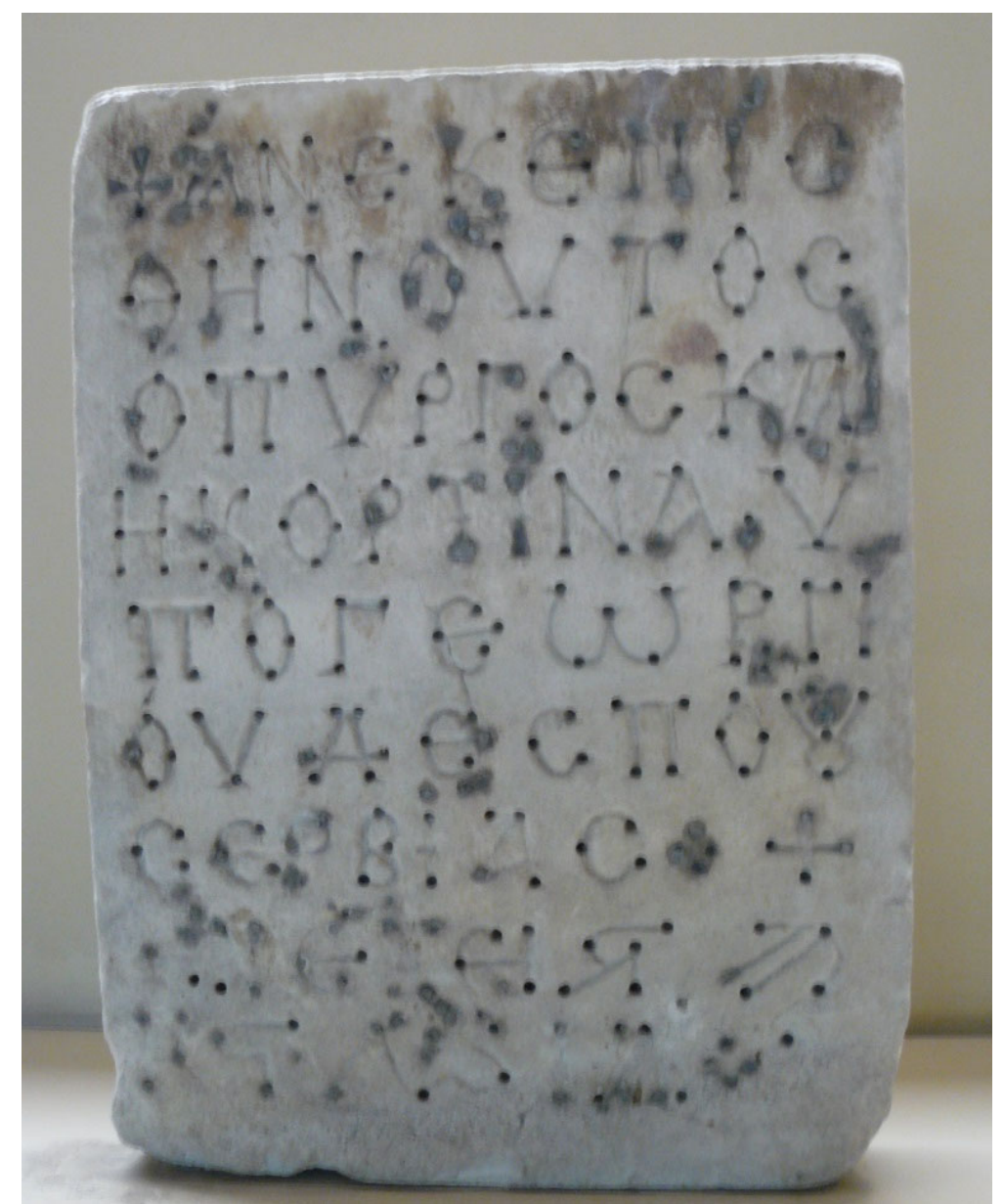

Fig. 9 Inscription from the walls between Kumkapı and Yeni Kapı, now at the Istanbul Archaeological Museum (C) Efthymios Rizos) 


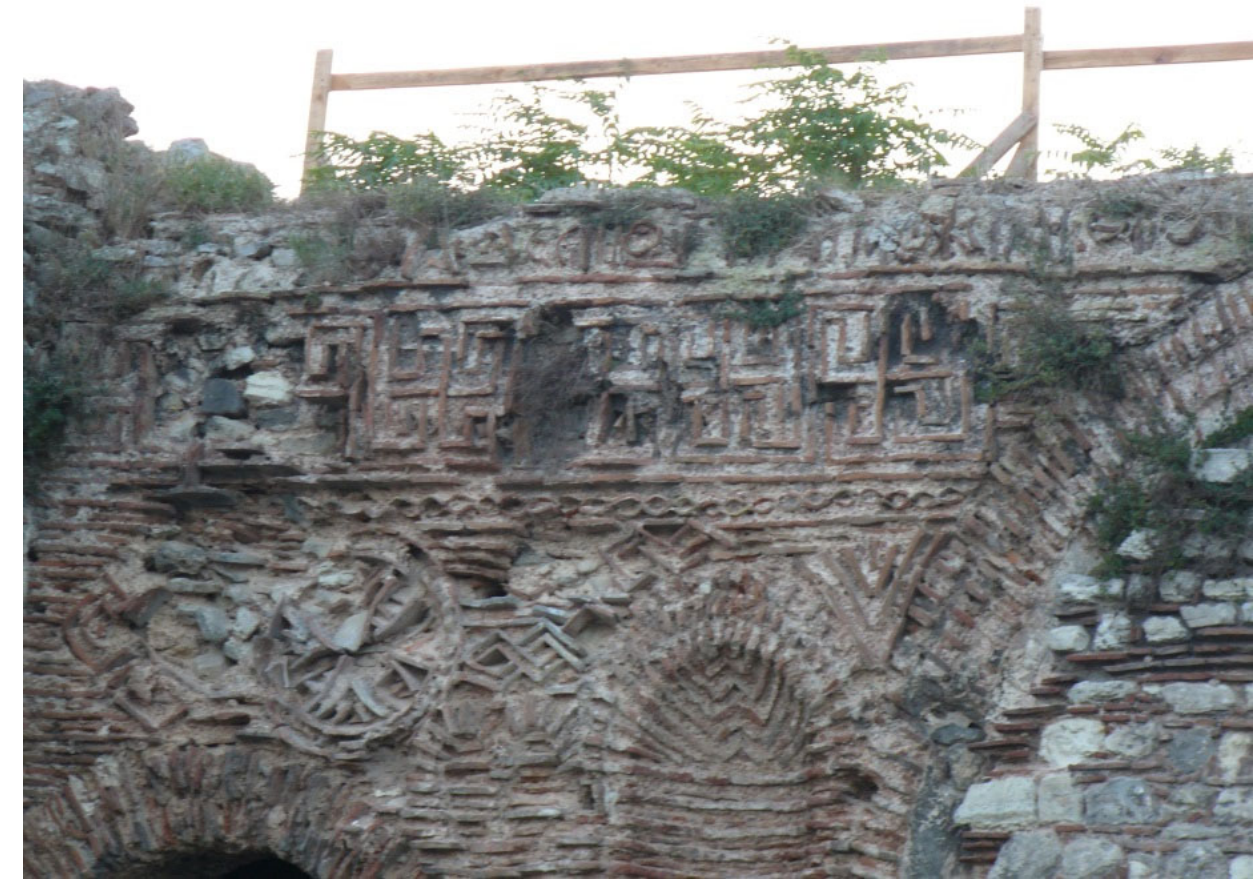

Fig. 10 Brick inscription on the façade of the so-called Philanthropos monastery (C) Efthymios Rizos) 



\section{INSCRIPTIONS IN THE LIPS, ST EUPHEMIA, AND THE CHORA}





\section{The Dedicatory Inscription of the Lips Monastery}

ANDREAS RHOBY

The Lips Monastery (Mone tou Libos, today Molla Fenari Isa Camii) (Fig. 1), situated southwest of the present-day Fatih Camii, was founded in the time of the Emperor Leo VI (886-912). The exact date is unknown, because the chronology given by Ps.-Symeon Magistros, which refers to the year 907/8, is doubtful. The katholikon of the monastery is the earliest surviving dated example of the cross-in-square type in Constantinople.

Between the years 1281 and 1303 Theodora, the widow of the Emperor Michael VIII Palaiologos, restored the complex. She also added a second church to the south of the existing tenth-century church, and dedicated it St John the Baptist. She was also buried in this church. By and large, the churches of the Lips Monastery were used as burial ground. In their narthexes and naves, they contain 29 burials, along with four ossuaries, which date to the middle and late Byzantine period. Thus, the Lips Monastery provides the most extraordinary example of burials within the church space in Constantinople.

The founder of the nunnery was Constantine Lips, a high military official in the imperial army in the time of Leo VI. He is mentioned in the inscription, which is attached to the outer marble cornices of the three central apses of the church (Fig. 2). Holes in the recesses (Figs. 3-6) indicate that the letters made of lead or some other shining metal were originally attached, which must have made the inscription visible (and probably legible) from the ground. It has been argued that the tombs in the church founded by Constantine Lips belonged to him and his family members and/or to the distinguished members of the monastic community.

The inscription of Constantine Lips is not fully preserved. Both the beginning and the end are missing, and there is also a lacuna in the center of the inscription (Figs. 3-6). However, it is easily recognizable that the inscription was composed in verse. In contrast to most of the Byzantine metrical inscriptions, the longer portion of the preserved inscription is not in dodecasyllables but in dactylic hexameters. Sections of the text immediately preceding and following the four hexameters in the middle show that these parts were written in twelve-syllable verse. The mixture of meters is not very common in Byzantium, but extant epigraphic evidence testifies to a tradition, which has its origin in antiquity. In addition, some Byzantine poets are known to have experimented with different verse formats writing poems, which consisted of various metrical schemata.

From the hexameter epigram (Figs. 3-5) we learn that the church was consecrated to the Mother of God Panachrantos. The holy patroness is addressed directly ( $\pi \alpha v \alpha$ ó $\chi \alpha \nu \tau \varepsilon$ ), and asked to secure a place in heaven for Constantine in return for his effort of founding the monastery.

Foteini Spingou suggests that there originally were seven epigrams: the hexameter poem seems to have been a central feature. This can be inferred by the fact that it invokes the Mother of God Panachrantos, the patroness of the church, and that it uses hexameters. In Byzantium, from the middle Byzantine period onwards, hexameters were most often employed to call attention to something of high importance. Three dodecasyllabic epigrams, consisting of two verses each, might have respectively preceeded, and followed after, the hexameter epigram. While the hexameters are attached to the outer cornices of the central apse, the six dodecasyllabic epigrams might have originally been inscribed on the cornices of the church's six chapels. Two of these are situated next to the main church, while the four other chapels are located adjacent to the upper church. It is not known to whom these chapels were consecrated.

The hexameters are of very good quality, which indicates that a professional poet, who worked on commission for the imperial househould and the aristocracy, was the author 
of the verses. He also seems to have been aware of an epigram in the Greek Anthology, which refers to the apses of the Blachernae church that were likewise consecrated to the

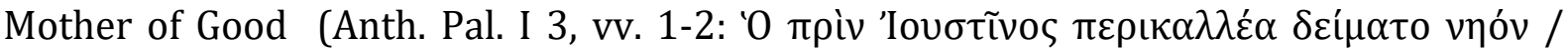

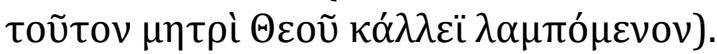

The preserved sections of the Lips epigram run as follows (ed. by Rhoby 2014, no. TR79, transl. by Spingou 2012, 16):

$. . \dot{c}] \kappa \pi o ́ \theta o u$.

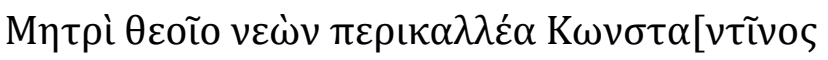
..]ov ő $\lambda \beta$ เov है $\rho \gamma o v$

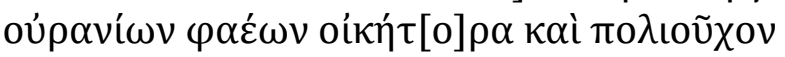

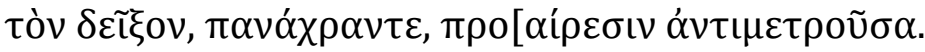

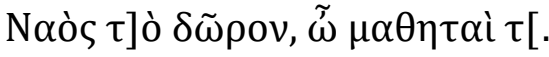
...].

[...] from affection. Constantine (offers) to the mother of God a gorgeous church [...] blessed deed; measuring his (pious) disposition, show him, oh Panachrade (most pure Lady), to be an inhabitant and citizen of the heavenly splendour (Paradise). My gift is a church, o Disciples (of Chist) [...]

\section{Selected Bibliography}

James, L. (2007) 'And Shall These Mute Stones Speak', in James, L. (ed) Art and Text in Byzantine Culture, Cambridge, 191-194.

Macridy, Th. (1964) The Monastery of Lips (Fenari Isa Camii) at Istanbul. With Contributions by A. H. S. Megaw, C. Mango, and E. J. W. Hawkins, Dumbarton Oaks Papers 18, 249-315

Marinis, V. (2004) The Monastery tou Libos. Architecture, Sculpture, and Liturgical Planning in Middle and Late Byzantine Constaninople. PhD thesis, Urbana, IL.

- (2009) Tombs and Burials in the Monastery tou Libos in Constantinople, Dumbarton Oaks Papers 63, 147-166.

- (2015) The original form of the Theotokos tou Libos reconsidered in Petridis, P. and

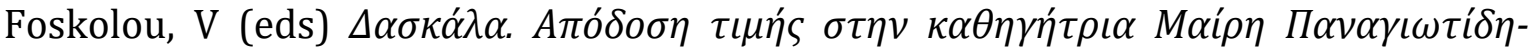

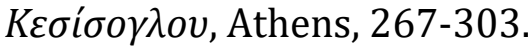

Rhoby, A. (2014) Byzantinische Epigramme auf Stein (= Byzantinische Epigramme in inschriftlicher Überlieferung, vol. 3), Vienna, 673-676 (no. TR 79).

Spingou, F. (2012) Revisiting Lips Monastery. The Inscription at the Theotokos Church once again, The Byzantinist 2, 16-19. 


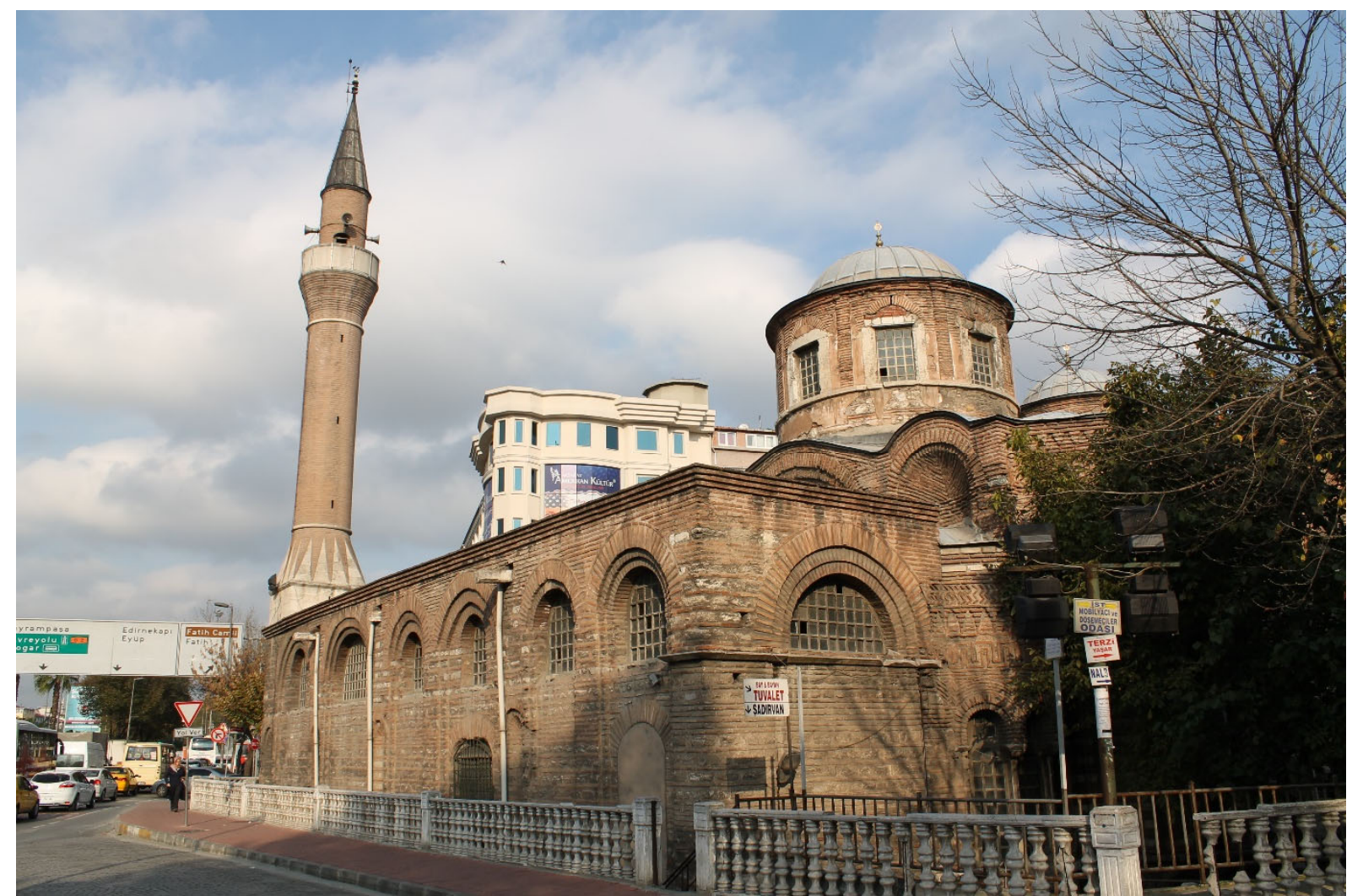

Fig. 1 The Lips Monastery (Molla Fenari Isa Cami) (C Andreas Rhoby)

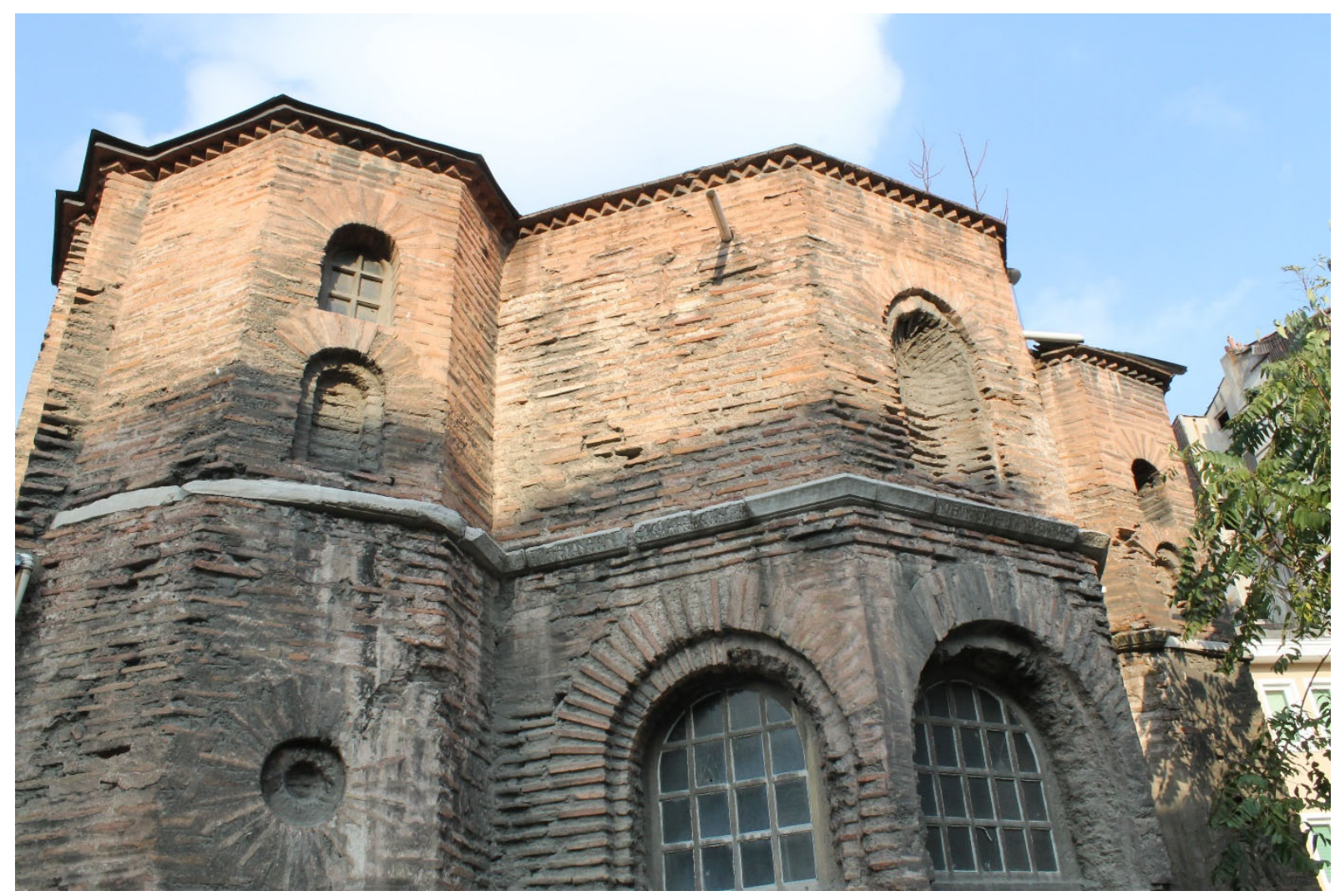

Fig. 2 The outer cornices (C) Andreas Rhoby) 

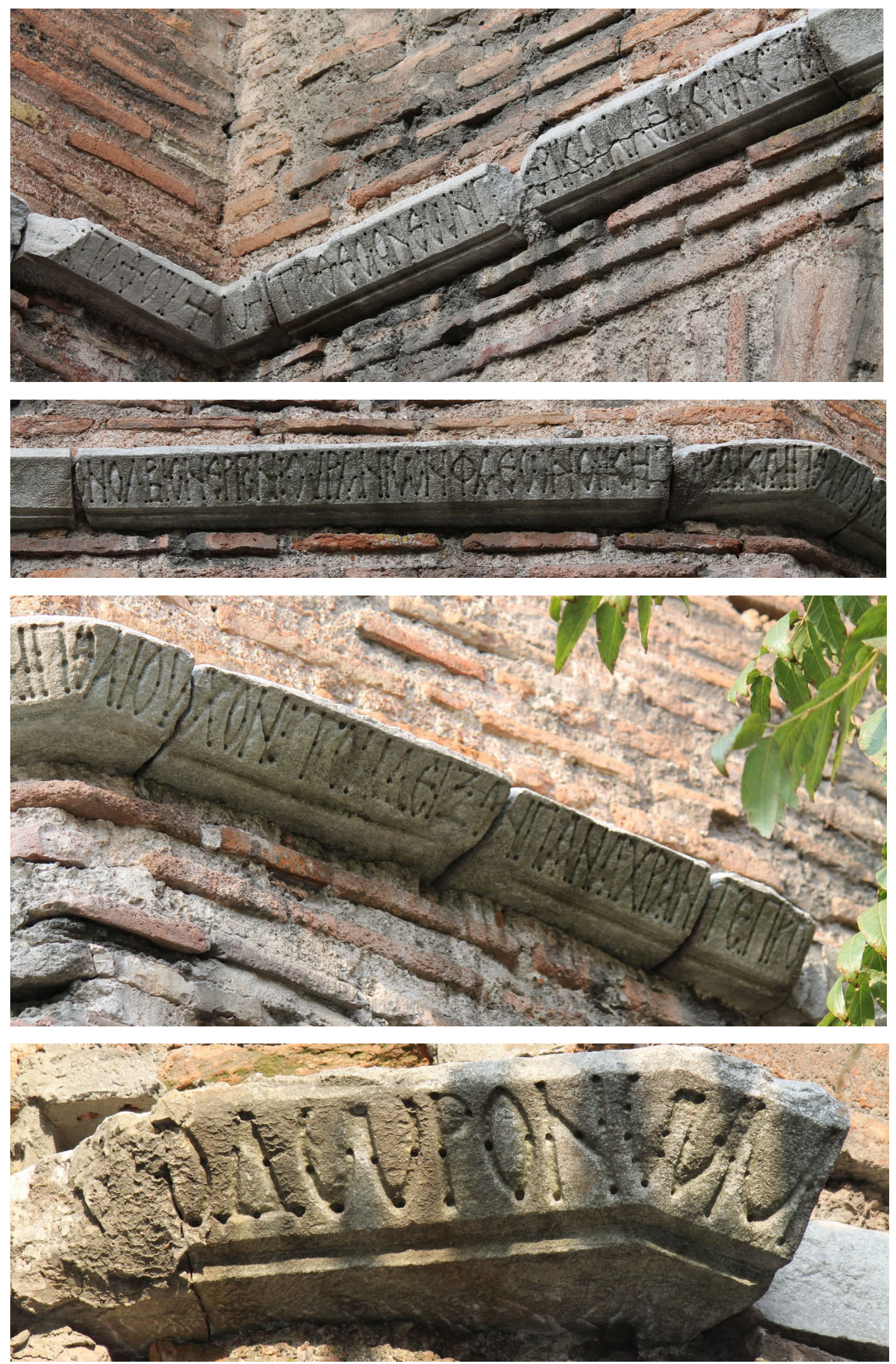

Figs. 3-6 The inscriptions (C) Andreas Rhoby) 


\section{The Church of Saint Euphemia \\ IVANA JEVTIĆ}

The church of Saint Euphemia at the Hippodrome was originally a hexagonal reception hall of the fifth-century Palace of Antiochos. It was transformed into a church in the $6^{\text {th }}$ century.

In the aftermath of the Persian attacks, which had reached the original location of the tomb and martyrion of Saint Euphemia in Chalcedon in the second and the third decades of the $7^{\text {th }}$ century, the saint's relics were moved and enshrined in the church at the Hippodrome that served as the residence of the metropolitans of Chalcedon in the Byzantine capital. Richly decorated and restored more than once throughout its history, the building preserves a rare iconographic cycle depicting the life and martyrdom of Saint Euphemia, dated on stylistic grounds to 1280-1290 (see, fig. 1). The relationship between the pictorial and textual elements in this visualized hagiographic narrative is especially noteworthy.

The cycle is located in the west niche of the church. It consists of fourteen scenes. It starts with the birth of Saint Euphemia, continues with her martyrdom, and culminates in her funeral. It includes the representations of the Miracle of Blood and Miracle of the Chalcedon Council. The cycle is arranged across two registers with the episodes framed by red vertical lines and floral/geometric horizontal bands. Naumann and Belting have recorded the inscriptions in the last seven episodes. The present state of preservation prevents us from knowing whether inscriptions featured in other scenes of the cycle. Judging by the evidence visible today, the letters are neatly executed and painted in white against the dark background. The inscriptions are long: for example, in Scene Eight showing Saint Euphemia in the pond with sea creatures, the text runs across seven lines. In Scene Nine, with Saint Euphemia in the wolf pit, six lines of explicatory text are placed in the upper register, between the two figures. They read as follows (see, fig. 2):

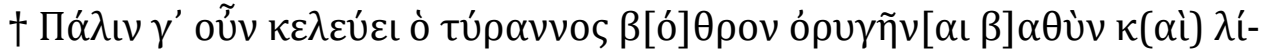

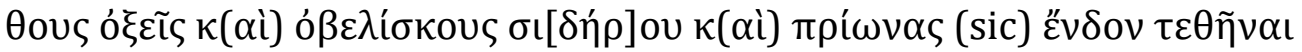

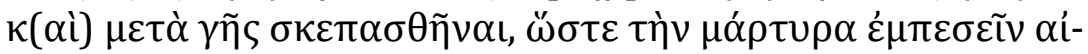

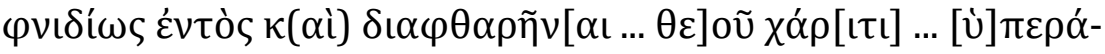

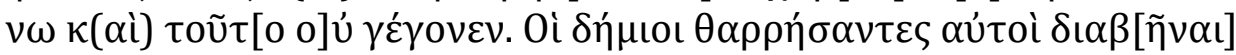

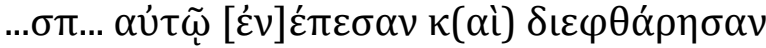

Placed at the eye level, the inscriptions in the church of St Euphemia closely match the iconography. They guide the viewer through this rarely depicted hagiographic story, in which the images and their texts share the task of communicating the visual narrative. By its overall presentation as well as the use of iconographic and verbal means, the cycle of Saint Euphemia closely resembles the objects like the Genoese Pallio. Such an analogy would support the dating of the cycle to the late thirteenth century. During their site visit, the participants of the Summer Programme raised the questions of artistic models and textual sources, and they put forward convincing arguments for reassigning the cycle to the mid-fourteenth century.

The cycle has received little scholarly attention since the publication by Naumann and Belting because the material has not been available for study. Currently, the monument is undergoing extensive restoration in the framework of the project "Cleaning, Conservation and Environmental Arrangement of the Church of St Euphemia at Sultan Ahmet, Istanbul 
Project," which has been funded by the Vehbi Koç Foundation since 2012. Together with the initiative to open the site to the public as part of the Turkish Islamic Arts Museum, this project will certainly re-establish the church of St Euphemia and its fresco cycle as an important Constantinopolitan landmark.

\section{Selected Bibliography}

Akyürek E. (1998) Bizanslılar, Azizleri ve Khalkedon'lu (Kadıköy) Azize Euphemia, Sanat Dünyamız 69/70, 175-189.

Akyürek E. (2002) Khalkkhedon'lu (Kadiköy) Azize Euphemia ve Sultanahmet'teki Kilisesi, Istanbul.

Bardill J. (1997) The Palace of Lausus and Nearby Monuments in Constantinople: A Topographical Study, American Journal of Archaeology 101, 67-95.

Castelli E. (2000) Asterius of Amasea: Ekphrasis on the Holy Martyr Euphemia, in Valantasis R. (ed) Religions of Late Antiquity in Practice, Princeton, 464-468.

Mango C. (1991), Euphemia, Church of Saint, in Oxford Dictionary of Byzantium, New York and Oxford, 747.

Mango C. (1999) The Relics of St. Euphemia and the Synaxarion of Constantinople, Bolletino della Badia Greca di Grottaferrata 53, 79-87.

Majeska G. (1984) Russian Travelers to Constantinople in the Fourteenth and Fifteenth Centuries, Washington, DC, 258-260.

Mathews Th. (1971) The Early Churches of Constantinople: Architecture and Liturgy, University of Pennsylvania, 61-67.

Müller-Wiener W. (1977) Bildlexikon zur Topographie Istanbuls: Byzantion, Konstantinupolis, Istanbul, Tübingen, 122-125.

Naumann R. and Belting H. (1966) Die Euphemiakirche am Hippodrom zu Istanbul und ihre Fresken, Berlin.

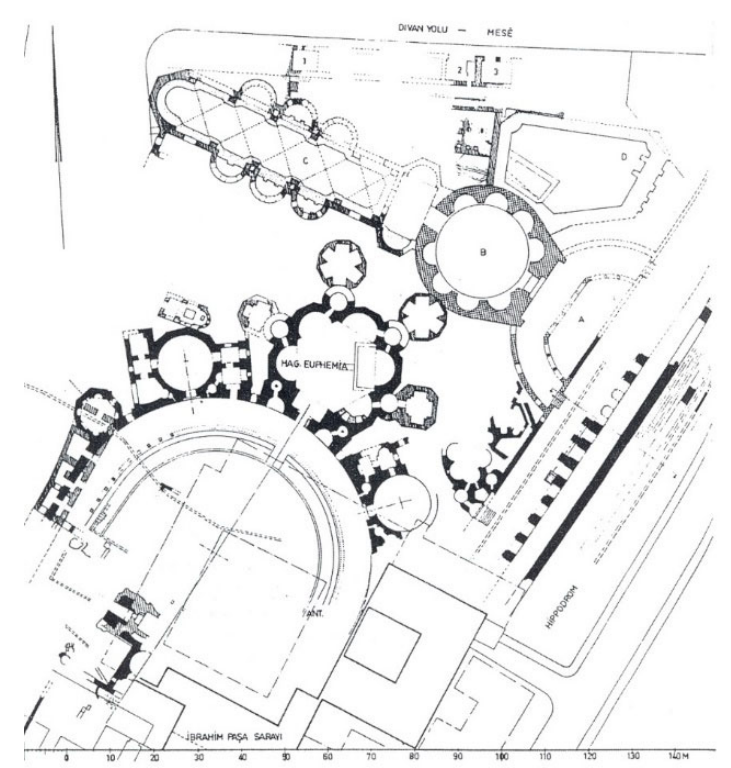

After Müller-Wiener 1977, 124

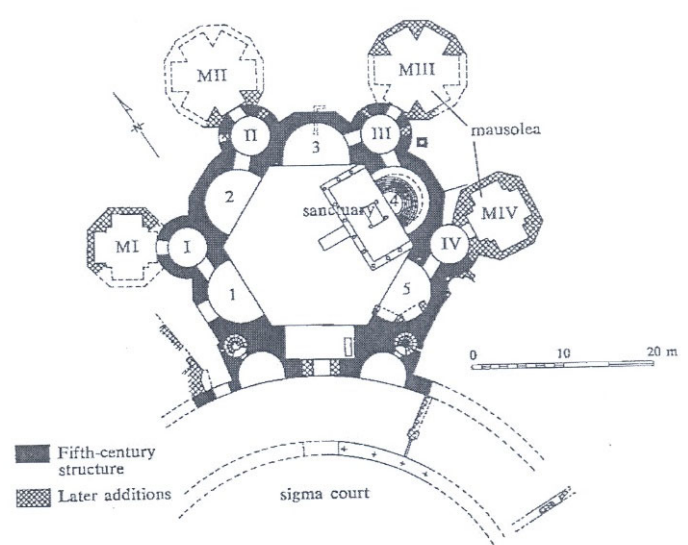

After Mathews 1971, fig. 30 


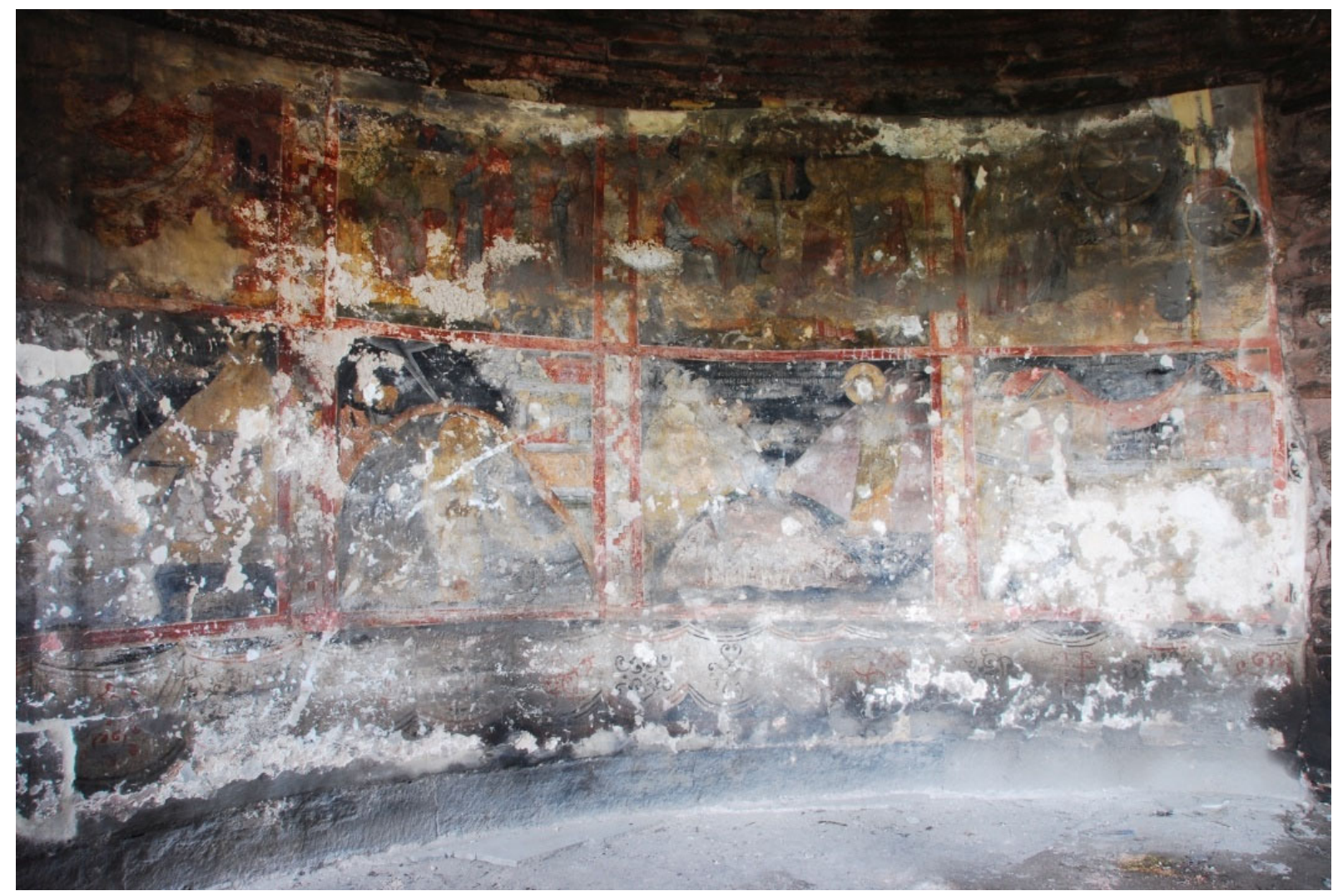

Fig. 1 Church of Saint Euphemia: The Fresco Cycle in the West Niche (C) Barış Altan)

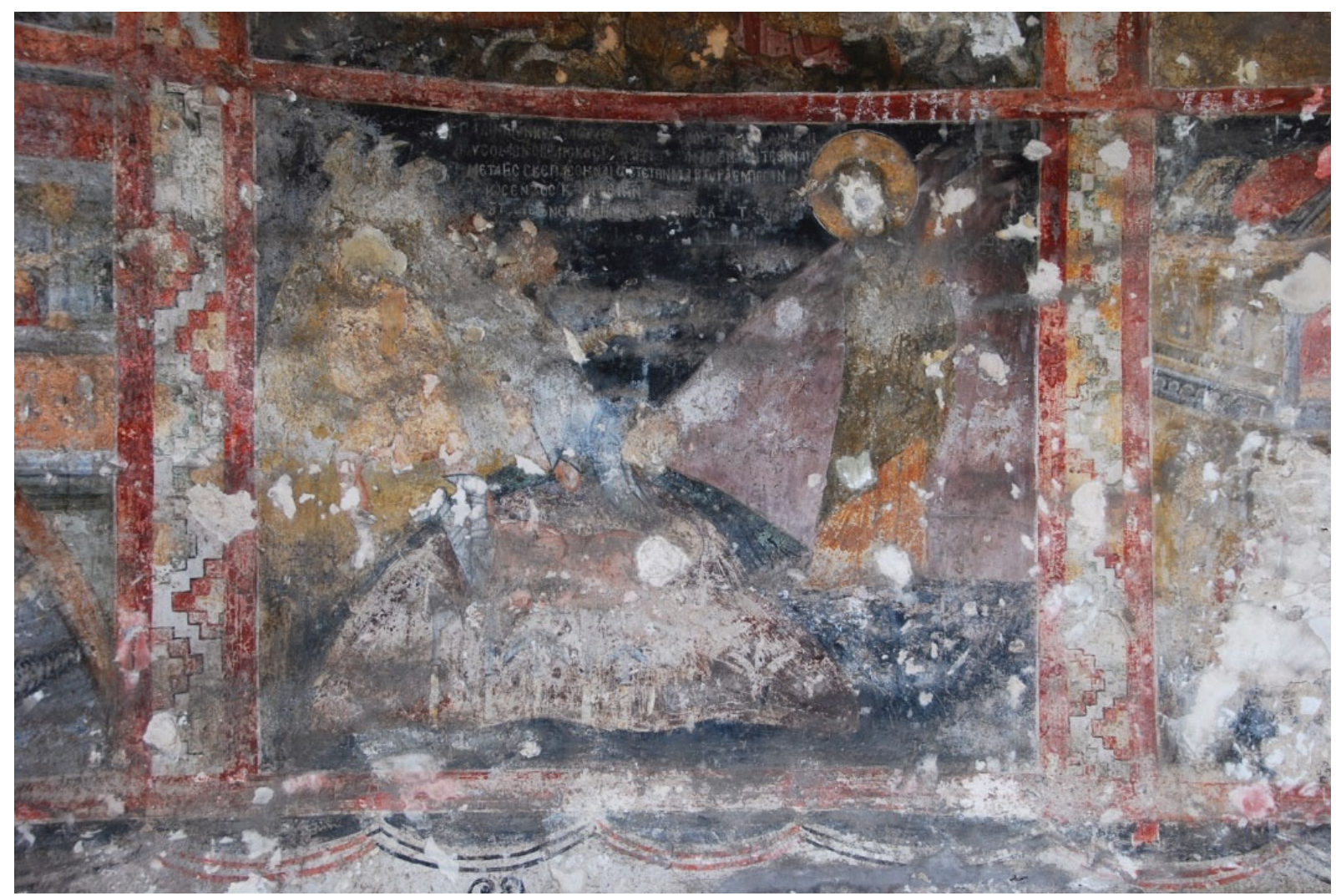

Fig. 2 Church of Saint Euphemia, Scene Nine: The Miracle in the Wolf Pit (C) Barış Altan) 



\section{Remarks on Donor and other Narrative Inscriptions of the Chora Monastery \\ NECTARIOS ZARRAS}

The first part of the essay is an attempt to interpret the donor inscriptions in the inner narthex of the Chora Monastery by examining the views of Theodore Metochites as expressed in his literary oeuvre. Metochites' writings testify to the importance of the monastery for his life and his spiritual development, as well as his views on the offices he held. They also offer significant insights into the content and meaning of Chora's inscriptions. On the basis of information drawn from Metochites' writings, the interpretation of the ktetor inscriptions can be summarized in the following basic questions. What is the meaning of the titles accompanying the names of the donors? What do the inscriptions and portraits tell us about the way in which Metochites perceives the building through his triple role of a senior dignitary, an erudite scholar and a patron? The dedicatory inscriptions in the inner narthex reflect the ideological background of Byzantine patronage. These are best interpreted against the backdrop of the authentic evidence provided by Metochites himself (see, below: 'Excerpts from Metochites' writings supporting the interpretation of inscriptions').

The second part examines the inscriptions through the narrative compositions of the Ministry Cycle, which adorn the domical vaults of the bays in the outer narthex, such as the representations of John Bearing Witness to Christ and The Temptations of Christ, in the second bay of the outer narthex. The inscriptions are harmoniously interwoven with the decorative elements of the composition, and they constitute an integral part of the illustration of the gospel narration, which successfully utilizes every part of the architectural surface. The function of the inscriptions is complex, because they promote the development of the story in three different ways: through the monologue of John the Forerunner, through the Christ's dialogue with Satan, and the narrative passages of the gospel text.

\section{Inscriptions}

Inner narthex, above the entrance to the naos (Underwood 1966, 42; Ousterhout 2017, 31) (fig. 2)

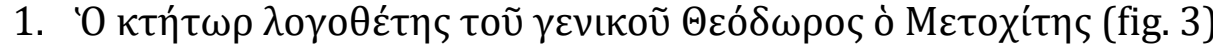
The founder and Minister of the Treasury Theodore Metochites

Inner narthex, south bay, Deesis mosaic (Underwood 1966, 44; Ousterhout 2017, 23, 27-29)

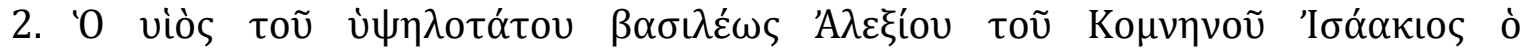

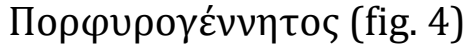

Son of the most exalted emperor Alexios, Isaak the Porphyrogennetos

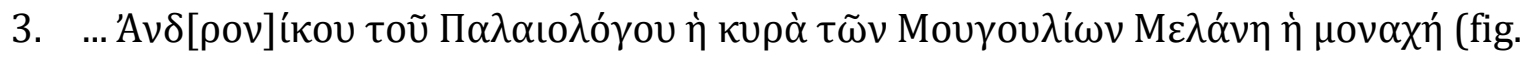
5) ... of Andronikos Palaiologos the Lady of the Mongols the nun Melane 
Outer narthex, second bay (Underwood 1966, 112)

Scene: John Bearing Witness to Christ (fig. 6)

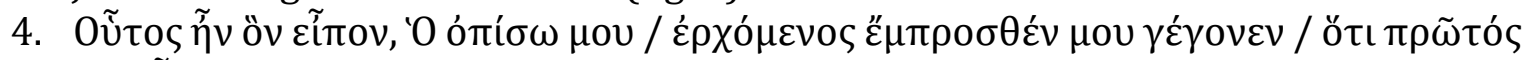

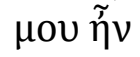

This was he of whom I spoke, He that cometh after me is preferred before me: for he was before me.

Scene: The First Temptation of Christ (Underwood 1966, 114)

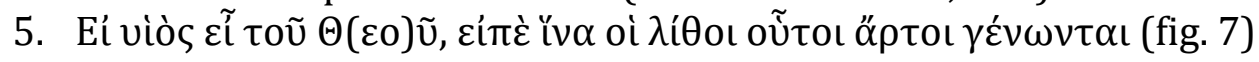

If thou be the Son of God, command that these stones be made bread

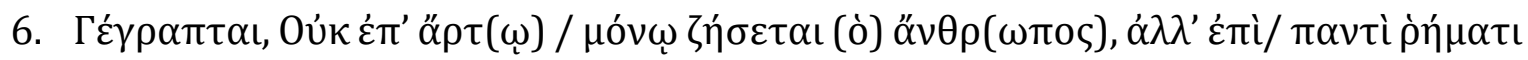

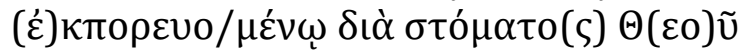

It is written, Man shall not live by bread alone, but by every word that proceedeth out of the mouth of God

Scene: The Second Temptation of Christ (Underwood 1966, 115)

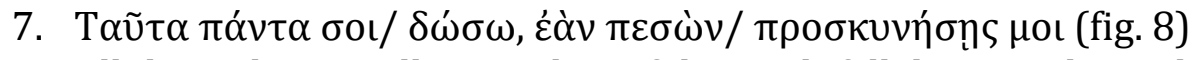
All these things will I give thee, if thou wilt fall down and worship me

8. ' $\Upsilon \pi \alpha \gamma \varepsilon$ ó $\pi i ́ \sigma \omega \mu \nu \mathrm{ov} \Sigma \alpha \tau \alpha \nu \tilde{\alpha}$ Get thee behind me, Satan

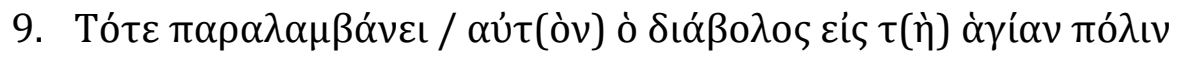
Then the devil taketh him up into the holy city

Scene: The Third Temptation of Christ (Underwood 1966, 115)

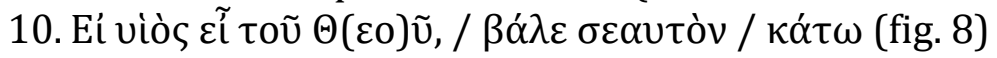
If thou be the Son of God, cast thyself down

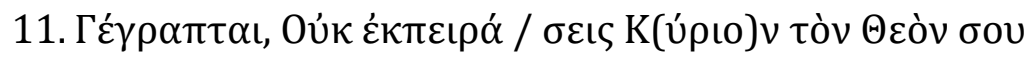
It is written .... Thou shalt not tempt the Lord thy God.

\section{Excerpts from Metochites' writings supporting the interpretation of inscriptions}

A) Now, Time which carries off all good things in its current had all but consigned this monastery to ruin. But the emperor desired to raise it up and restore it as it had been formerly; and he urged me on to this work with force - desirous as I myself was -to oversee this offering in all ways most pleasing unto God, this exceeding delightful favor to the emperor and gain for our soul and imperishable renown through all ages, if only I could shore up firmly and make it in all ways more secure than before -as indeed it now is- and thereby bring before God and before the emperor such an immense and right glorious gift. Featherstone 2011, 225; Ousterhout 2017, 31.

B) But I founded this monastery of yours, my queen, mother of my God, as a safe, neighboring haven that protects me from all tempests, so that I may be able to take refuge here, saving myself from all sorts of bad weather I come across in my life, and from pirates 
who wish the death of both my soul and my body ... So fulfill this wish of mine as well and become a refuge (chora) for the most beloved products of mine (books), saving them, since you inhabit the most beautiful Monastery of Chora, which I built as an excellent, calm retreat for your sake, protecting you from the storms and troubles of this life always; ... as a safe haven (chora) which protects them from all envious destruction.

Theodore Metochites, Poems, ed. Polemis 2017, 134-135.

C) God is the source of all good things, giving to everything the gift of its existence and proper conduct, in a way that is fitting to it, so that everyone may contemplate it with his mind admiringly, filling his heart with pleasure for the immense gifts bestowed upon all creatures by the powerful, acting without pause grace of the immortal God and by his beneficial mind ... However, all these were taken from us because of the envy of mischievous Satan, who fell (Is. 14, 13-14) from the place of light to deep darkness because of his insolence ... he became our implacable enemy for all time, prompting sinful thoughts in our minds; he never wearies of doing this ... Therefore, pain, groaning tears and every kind of misery, unutterable wailing, painful childbirth, illness that bring us near death, and every disaster imaginable flow upon us without pause. As a result of that original sin we became the laughing-stock of the evil one, full of all miseries.

Theodore Metochites, Poems, ed. Polemis 2017, 51, 54-55.

D) But even if my fears are not to be realized, thanks to an unexpected miracle of the Lord, who is accustomed to intervene in our affairs in a miraculous, totally unexpected way, still my anxious thoughts wear me out like a worm destroying my bones (Prov. 14,30) ... I resemble a man who is fatally ill and breathes his last: he expects that he will be among the dead soon, since there is no possibility for anyone to escape death and to come back to life; that has been our common lot since men were created and have lived on the earth and since the sun began to turn around it.

Theodore Metochites, Poems, ed. Polemis 2017, 267.

E) 0 Lord Christ, if Thou hast verily decreed that this State should be blotted out of Thy book, to disappear forthwith completely, there is no other reason for this than the multitude of our sins; by which we, much transgressing, have moved Thee to such great anger against us, contrary to Thy nature ...Propitious, be Thou once again propitious toward us remembering Thy nature, remembering Thy miracles of old, which Thou wroughtest in Thy love of mankind, deeds ever glorious ineffable, unfathomable.

Featherstone 2000, 31.

F) For there is a certain malign influence which seems to creep in, persuading [men] to allow the buildings constructed long ago to fall into ruin, so that as the memory of their builders flows away and dies altogether with the buildings, the new structures remain, clearly proclaiming the memory of the one who established them, amid the deep silence of the rest.

Ousterhout 2017, 57. 



\section{Funerary Inscriptions at the Chora Monastery: Display, Function, and Meaning BRAD HOSTETLER}

The Chora Monastery preserves eight funerary monuments in the parekklesion and narthices (Tombs A-H; fig. 1). These arcosolia were installed at different times over the course of the fourteenth and fifteenth centuries by the Chora's founder, Theodore Metochites, and by members of the imperial family and aristocracy, after the mosaic and fresco programs of the monastery had been completed. Each arcosolium once housed a sarcophagus at the base, and was decorated with images and inscriptions in mosaic, fresco, and marble. The epigraphic material at these eight tombs includes naming inscriptions, monograms, and a 24-verse metrical inscription.

Scholarship has treated these inscriptions primarily as conveyors of historical and biographical information, largely overlooking how they function within their visual and material contexts. I focus on three tombs to discuss different ways in which the inscriptions worked within these spaces.

At the tomb of Michael Tornikes (Tomb D), the deictic nature of the naming inscriptions that accompany the monastic portraits help us consider the interconnected nature of Tornikes's representation in his epigram, in his lunette portrait, in his monastic portrait and in the tomb below (figs. 9, 10).

At Tomb E, the inscribed scrolls of hymnographers Ss Kosmas and John in the soffit serve as visual and verbal prompts to commemorate the Palaiologoi family interred at this tomb (figs. 11, 12).

At the tomb of Demetrios Angelos Doukas Palaiologos (Tomb $\mathrm{H}$ ), the presence and absence of identifying inscriptions for the saints depicted on the figural capitals serve to emphasize the devotional link between Demetrios and his namesake saint (figs. 13, 14).

These three examples show some of the complex ways in which the Chora's funerary inscriptions served as both visual and verbal creators of space, performance, and identity.

Parekklesion, south wall, Tomb D: Michael Tornikes (Underwood 1966, 276-280; Rhoby 2014, 643-650, no. TR68) (fig. 9)

Marble arch, verse inscription

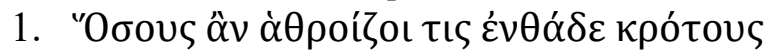

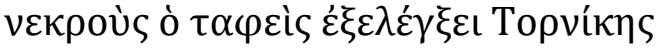



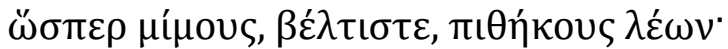

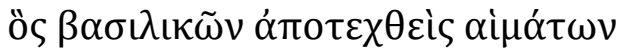

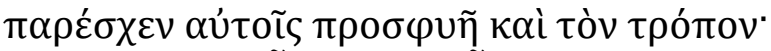

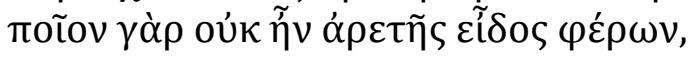

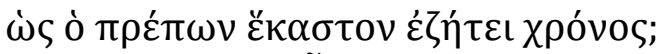

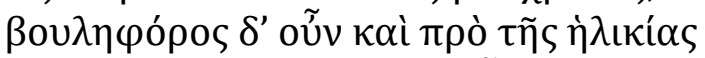

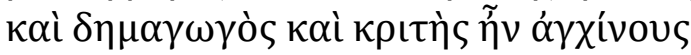

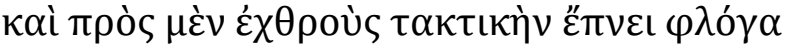

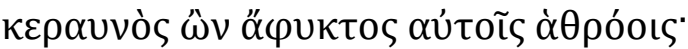

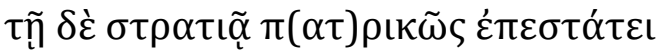




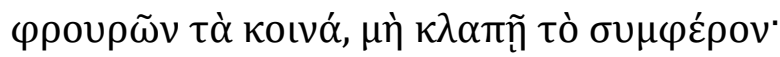

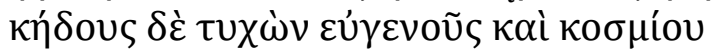

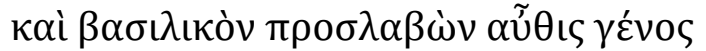

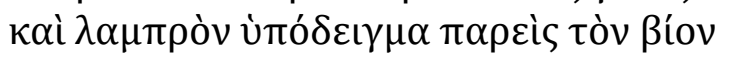

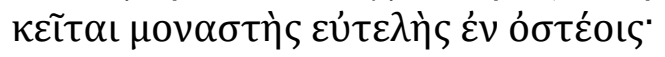

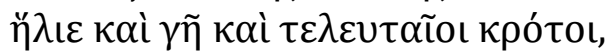

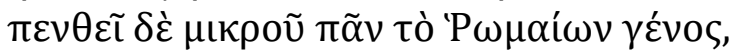

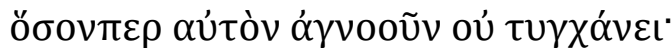

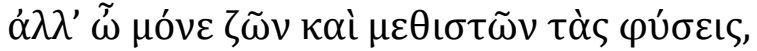

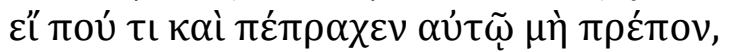

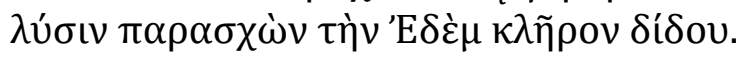

However many applauses one may collect here (on earth),

the buried Tornikes, the triple-best or Grand Marshall,

will convict them dead

just as a lion, 0 dear friend, does so to mimicking apes.

He who was born of imperial blood

also showed a way of life that was fitting to it.

For what form of virtue did he not possess,

as the appropriate time required in each case?

He was also a counsellor before (mature) age

and a popular leader and astute judge,

and against enemies he breathed a tactical flame,

being an inescapable thunderbolt on this crowded mass.

He presided over the army like a father

guarding the common good so that the useful would not be robbed.

Attaining a noble and befitting marriage,

and again obtaining imperial lineage,

and leaving this life as a radiant example,

he lies as a simple monk among the bones.

0 sun, 0 earth, 0 final applauses,

nearly the entire Roman race is in mourning,

as far as he is not unknown.

But $\mathrm{O}$ only living one and transformer of natures,

even if he did something not fitting to him,

granting him pardon, give him Eden as his inheritance.

Jambs, monastic portraits (fig. 10)

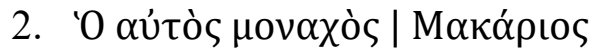

the same person, the monk Makarios

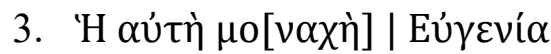

the same person, the nun Eugenia 
Outer narthex, fifth bay, Tomb E: Irene Raoulaina Palaiologina (Underwood 1966, 280-88) (fig. 11)

Jambs, monastic portraits

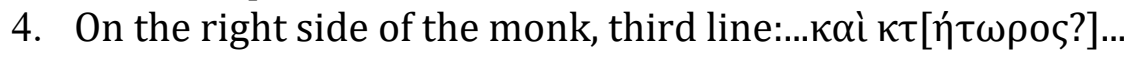

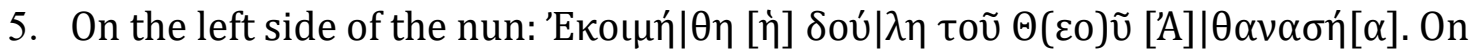

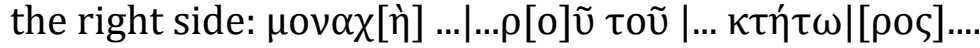

Here sleeps the servant of God, Athanasia the nun ... of ... founder ....

Soffit, saints (fig. 12)

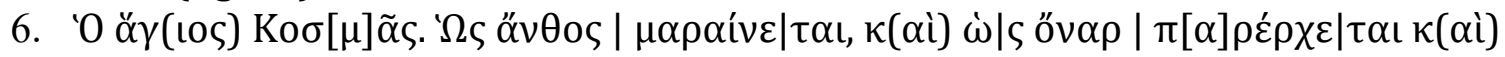
$\delta \iota \mid[\alpha \lambda]$ $\varepsilon \tau \alpha \iota|[\pi \tilde{\alpha} \varsigma] \stackrel{\alpha}{\alpha} \theta \rho| \omega \pi \mathrm{o}(\varsigma)$.

St. Cosmas. Every man fades as a flower, and passes as a dream, and is dissolved.

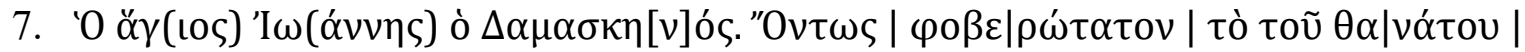
$\mu v \sigma \tau i \mid \rho เ o v$.

St. John the Damascene. Verily, most fearful is the mystery of death.

Inner narthex, first bay, Tomb H: Demetrios Angelos Doukas Palaiologos (Underwood 1966, 295-299; Rhoby 2009, 395-397, no. M8) (fig. 13)

Back wall, inscription next to the Virgin

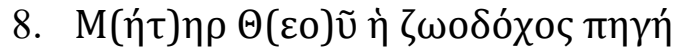

Mother of God, the life-containing source

Soffit, inscription next to Christ

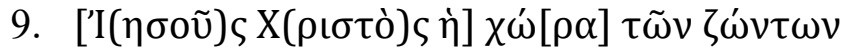
Jesus Christ, the dwelling-place of the living

Back wall, inscription next to the partial figure on the left side

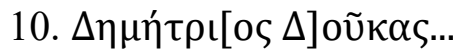

Demetrios Doukas

Back wall, verse inscription below the image of the Virgin

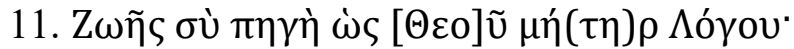

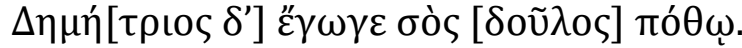

You are the source of life as the Mother of God, the Logos.

And I am Demetrius your servant with love.

East capital, east face (original location: west capital, east face) (fig. 14)

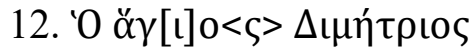

St. Demetrios 



\section{6-27. Consolidated Bibliography by N. Zarras and B. Hostetler}

Brooks, S.T. (2002) Commemoration of the Dead: Late Byzantine Tomb Decoration (MidThirteenth to Mid-Fifteenth Centuries), unpublished PhD thesis, New York University.

- (2004), The History and Significance of Tomb Monuments at the Chora Monastery, in Klein, H. and Ousterhout, R. G. (eds) Restoring Byzantium: The Kariye Camii in Istanbul and the Byzantine Institute Restoration, New York, 23-31.

- (2004) Sculpture and the Late Byzantine Tomb, in Evans, H. (ed) Byzantium: Faith and Power (1261-1557), New York, 95-103.

- (2006), Poetry and Female Patronage in Late Byzantine Tomb Decoration: Two Epigrams by Manuel Philes, Dumbarton Oaks Papers 60, 223-248.

Drpić, I. (2016) Epigram, Art, and Devotion in Later Byzantium, Cambridge.

Featherstone, J. M. and Ševčenko, I. (1981) Two Poems by Theodore Metochites, The Greek Orthodox Theological Review 16, 1-46.

Featherstone, J. M. (2000) Theodore Metochites's Poems "To Himself", ed. and transl., Vienna.

Featherstone, J. M. (2011) Metochites's Poems and the Chora, in Klein, H., Ousterhout, R. G. and Pitarakis, B. (eds) The Kariye Camii Reconsidered, Istanbul, 215-239.

Hinterberger, M. (2001) Studien zu Theodoros Metochites, Jahrbuch der Österreichischen Byzantinistik 51, 285-319.

Hjort, Ø. (1979) The Sculpture of Kariye Camii, Dumbarton Oaks Papers 33, 199-289.

Mango, C. (1959) The Brazen House: A Study of the Vestibule of the Imperial Palace in Constantinople, Copenhagen.

Magdalino, P. (2011) Theodore Metochites, the Chora and Constantinople”, in Klein, H., Ousterhout, R. G. and Pitarkis, B. (eds) The Kariye Camii Reconsidered, Istanbul, 169187.

Melvani, N. (2013) Late Byzantine Sculpture, Turnhout.

Nelson, R. (1999) Taxation with Representation: Visual Narrative and the Political Field at the Kariye Camii, Art History 22, 56-82.

- (1999) The Chora and the Great Church: Intervisuality in Fourteenth-Century Constantinople, Byzantine and Modern Greek Studies 23, 67-101.

Ousterhout, R. (1995) The Virgin of the Chora, in Ousterhout, R. and Brubaker, L. (eds) The Sacred Image East and West, Urbana and Chicago, 91-109.

- (1995) Temporal Structuring in the Chora Parekklesion, Gesta 34, 63-76.

- (2002) The Art of the Kariye Camii, London.

- (2017) Finding a Place in History: The Chora Monastery and its Patrons, Nicosia.

Polemis, I. (2017), Th. Metochites, Poems, ed. and transl., Turnhout.

Rhoby, A. (2009-2018) Byzantinische Epigramme in inschriftlicher Überlieferung, vol. 1-4, Vienna. [specifically, vol. 1 (2009) and vol. 3 (2014)]

Schroeder R. (2009) Prayer and Penance in the South Bay of the Chora Esonarthex, Gesta 48.1, 37-53.

Ševčenko, N. (2012) The Portrait of Theodore Metochites at Chora, in Spieser, J.-M. and Yota, É. (eds) Donations et donateurs dans le monde byzantine, Paris, 189-201.

Talbot, A.-M. (1999) Epigrams in Context: Metrical Inscriptions on Art and Architecture of the Palaiologan Era, Dumbarton Oaks Papers 53, 75-90.

Tanoulas, T. (2013) X $\Omega$ PA: Christian Aspects of a Platonic Concept, Deltion tes Christianikes Archaeologikes Etaireias 34, 405-416. 
Teteriatnikov, N. (1995) The Place of the Nun Melania (the Lady of the Mongols) in the Deesis program of the Inner Narthex of Chora, Cahiers Archéologiques 43, 163-184.

- (1996) The Dedication of the Chora Monastery in the Time of Andronikos II Palaiologos, Byzantion 66, 188-207.

Treu, M. (1895) Dichtungen des Großlogotheten Theodoros Metochites, Potsdam.

Underwood, P. A. (1955) The Deesis Mosaic in the Kariye Camii at Instanbul, in Weitzmann, K. (ed) Late Classical and Medieval Studies in Honor of A. M. Friend, Princeton, 254-260.

- (1966-1975), The Kariye Djami, 1-4, Princeton. 
26-27. Figures of the contributions by N. Zarras and B. Hostetler

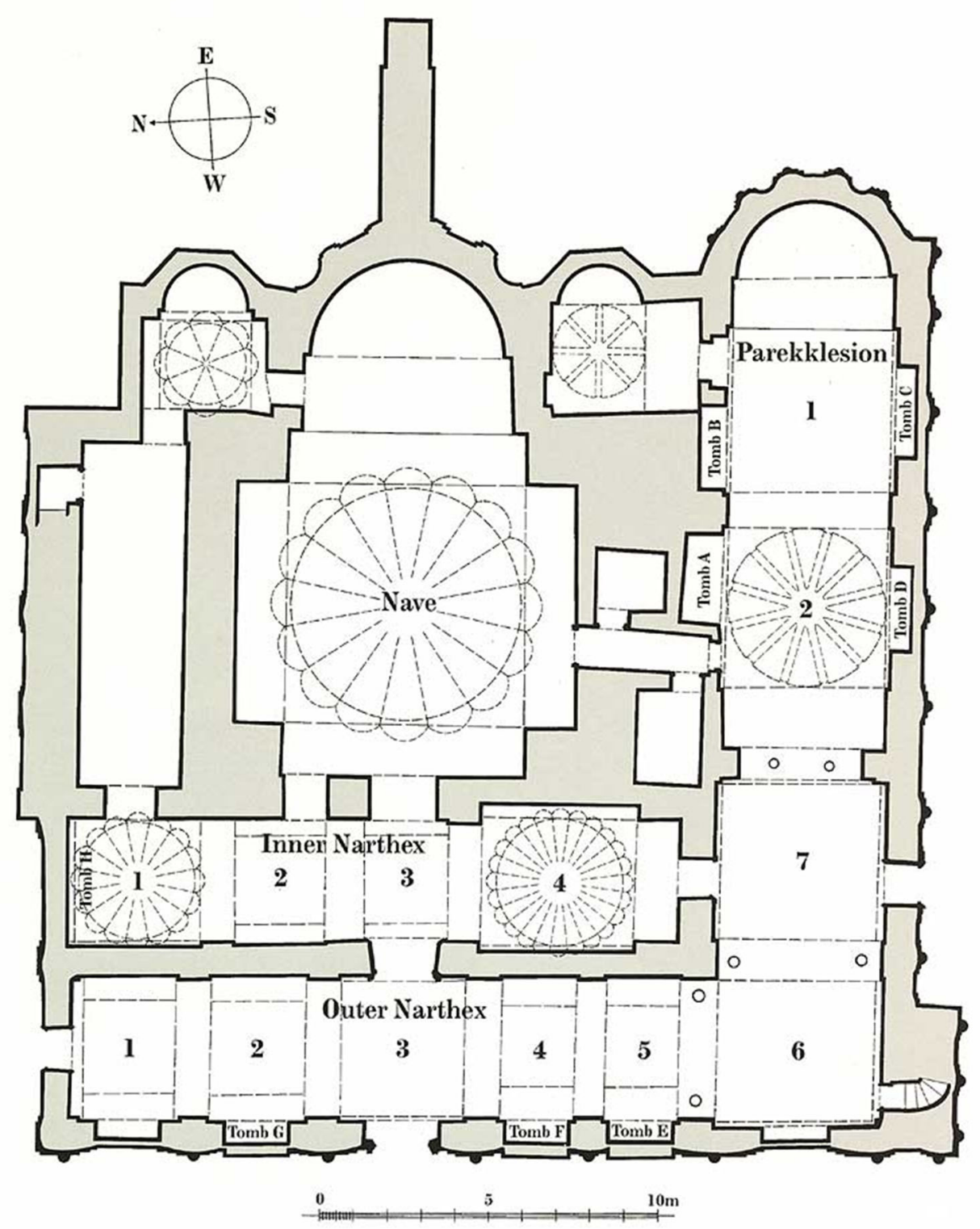

Fig. 1 Plan of the Chora Monastery (C) M. and I. D. Wallach Art Gallery, Columbia Univ., http://www.columbia.edu/cu/wallach/exhibitions/Byzantium/html/building_images. html) 


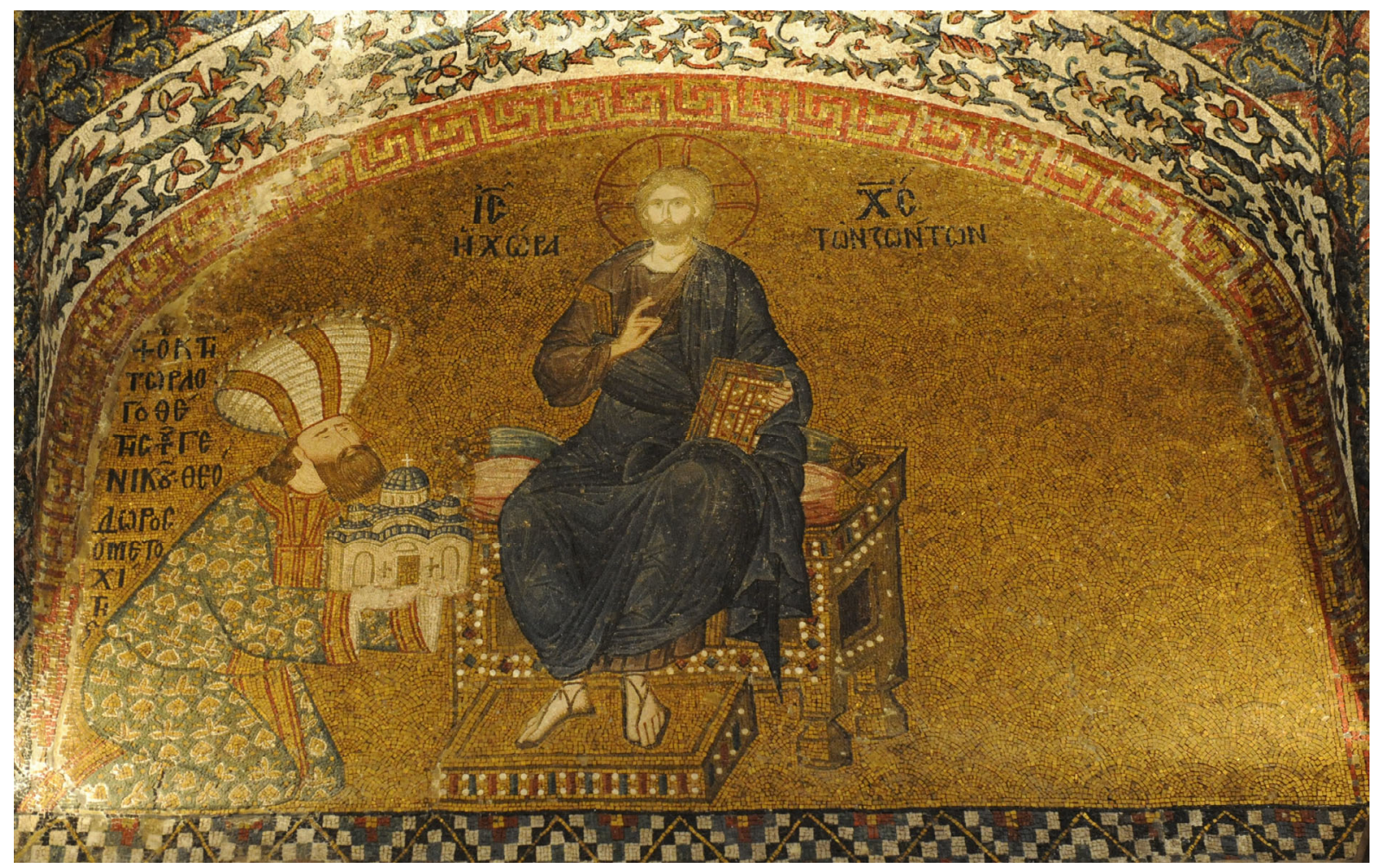

Fig. 2. Inner narthex. The founder and Minister of the Treasury Theodore Metochites (C) Nektarios Zarras)

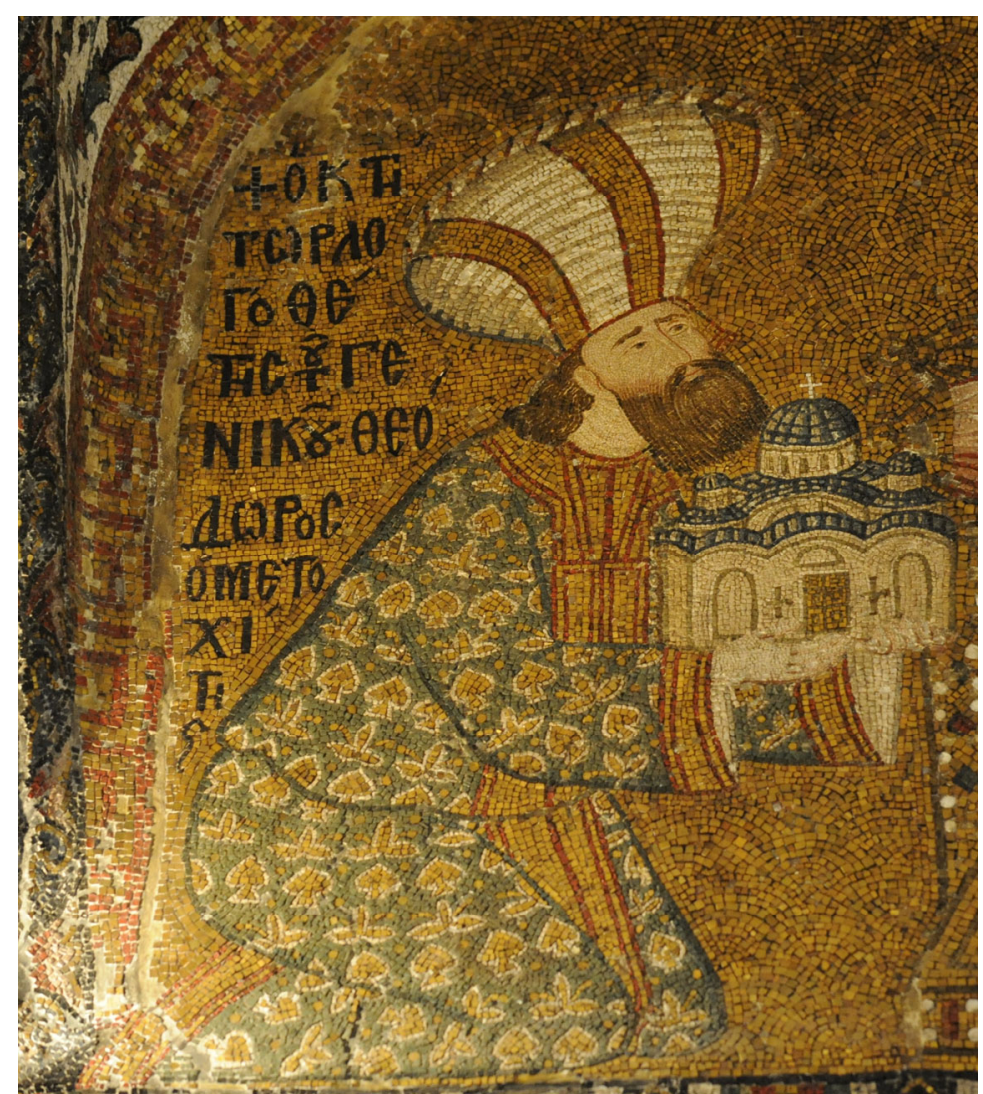

Fig. 3. Theodore Metochites and the patron inscription (ㄷ Nektarios Zarras) 


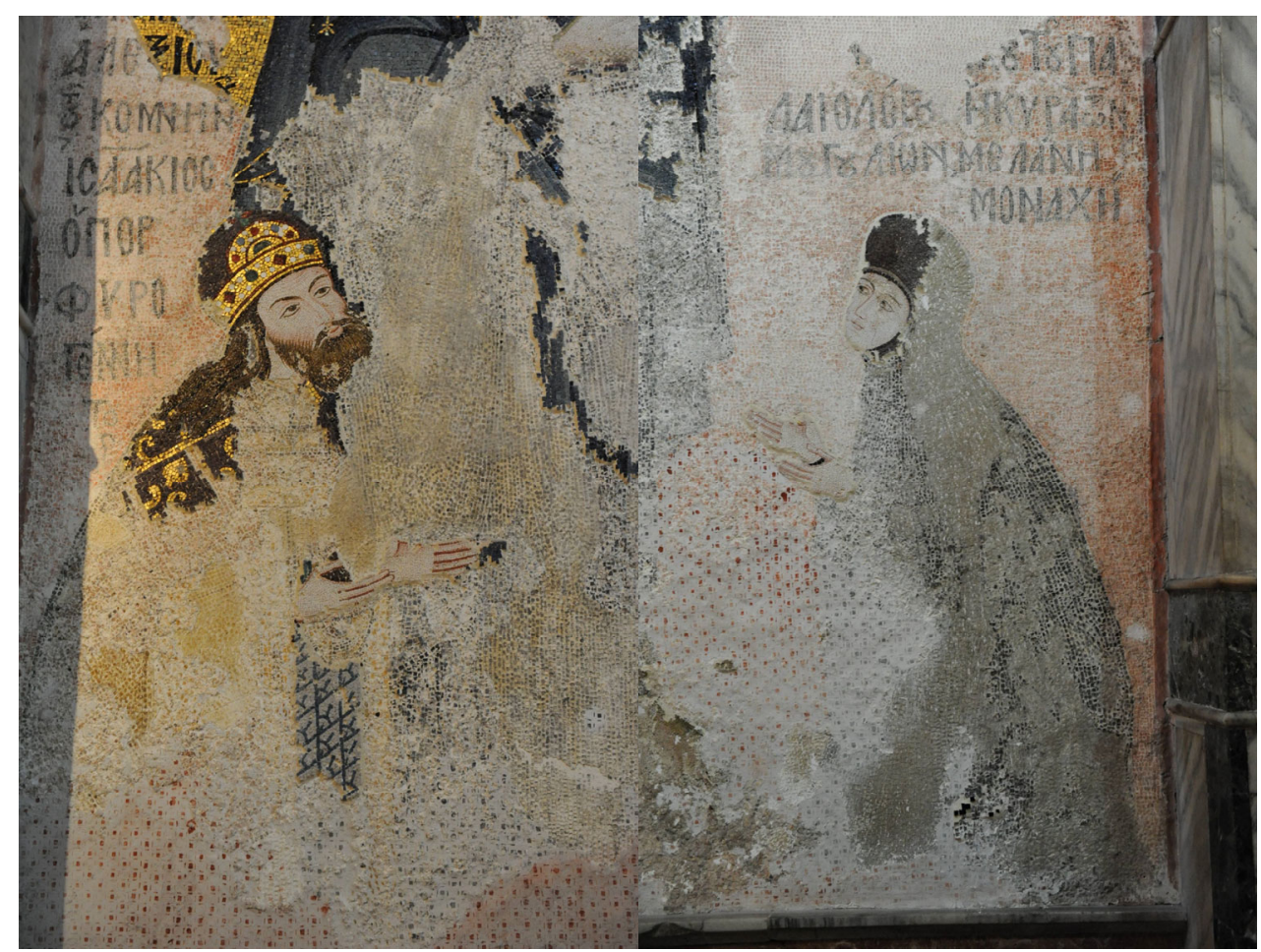

Figs. 4-5 Inner narthex. Deesis mosaic. The sevastokrator Isaakios Komnenos and the nun Melane (@ Nektarios Zarras)

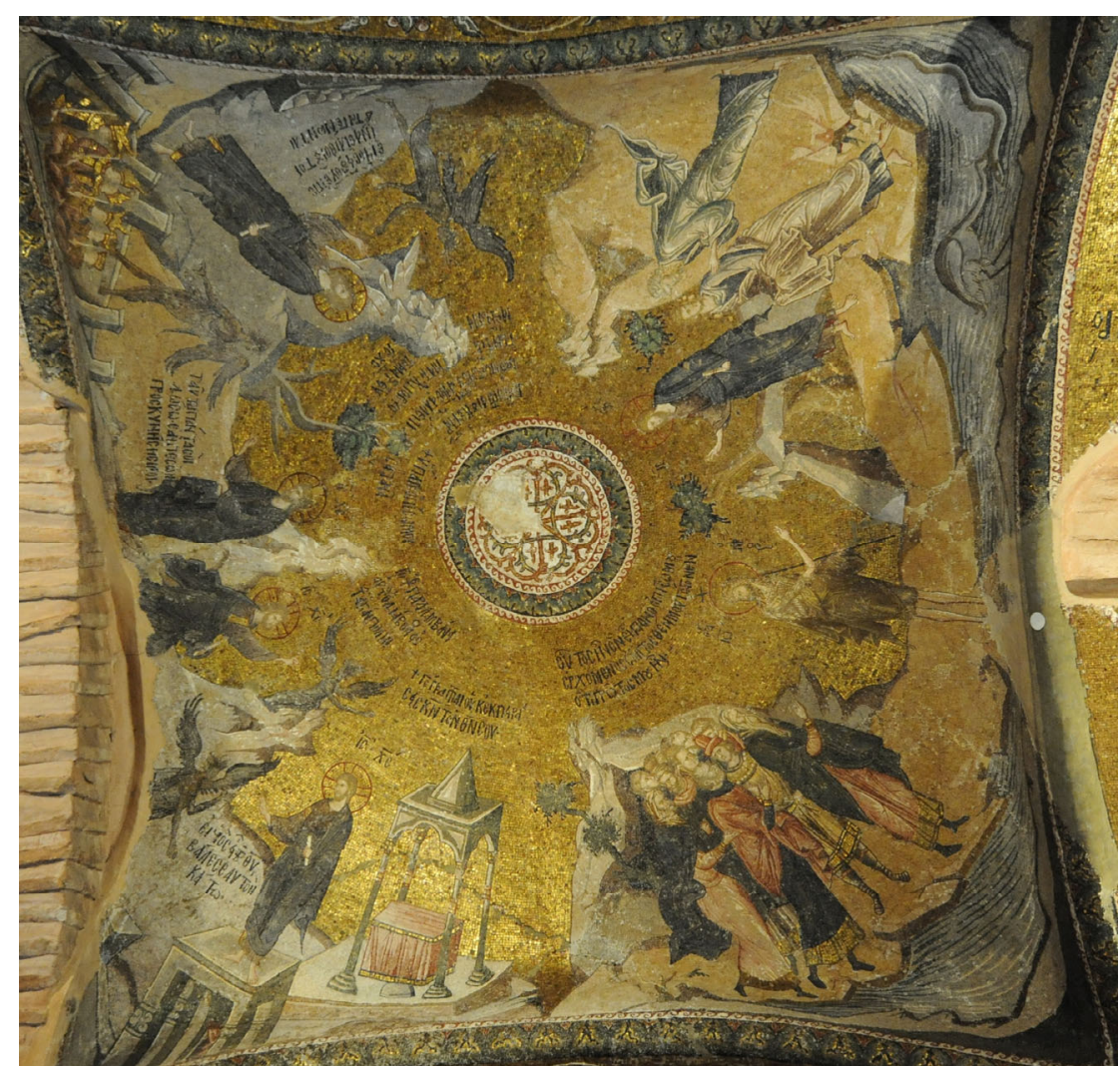

Fig. 6 Outer narthex, second bay. John the Forerunner bears witness to Christ and the Temptations of Christ (C) Nektarios Zarras) 


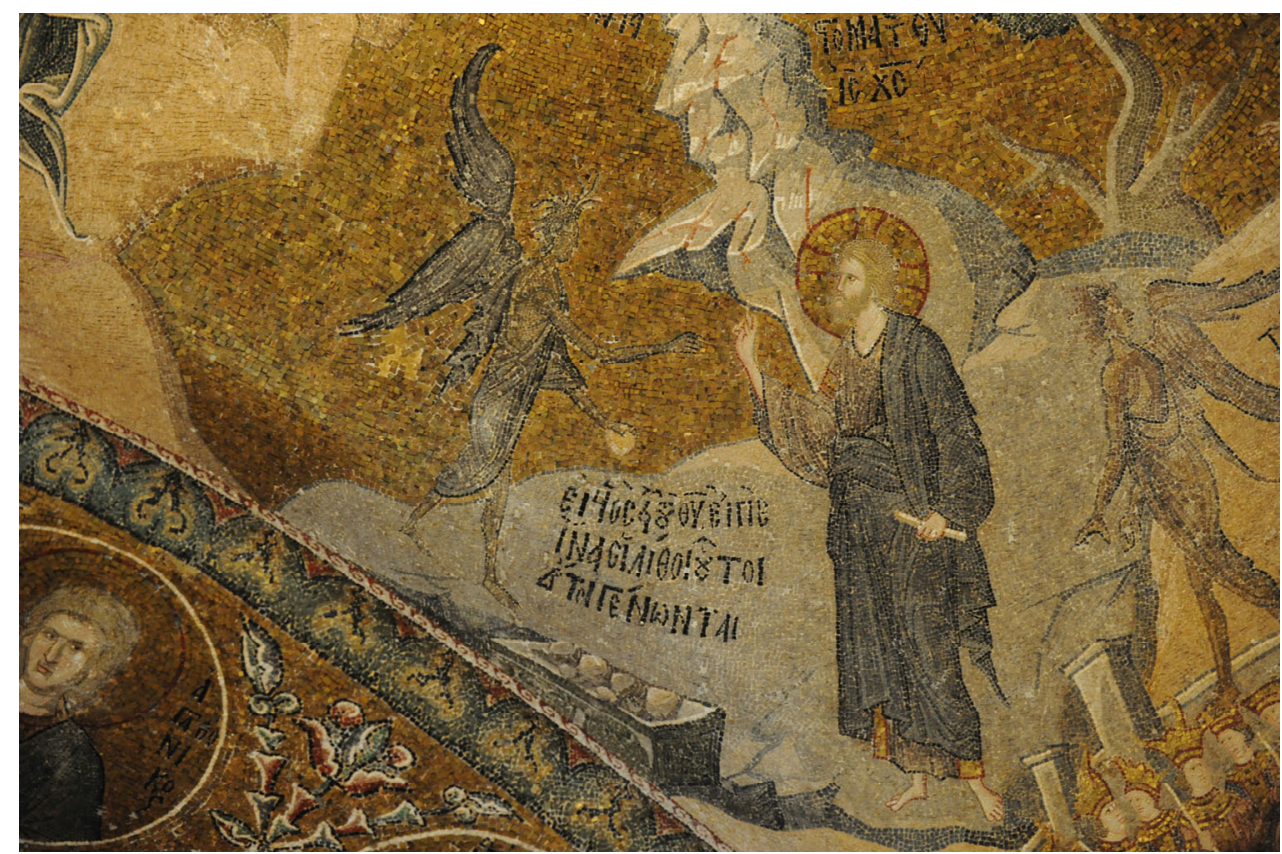

Fig. 7 The First Temptation of Christ (C) Nektarios Zarras)

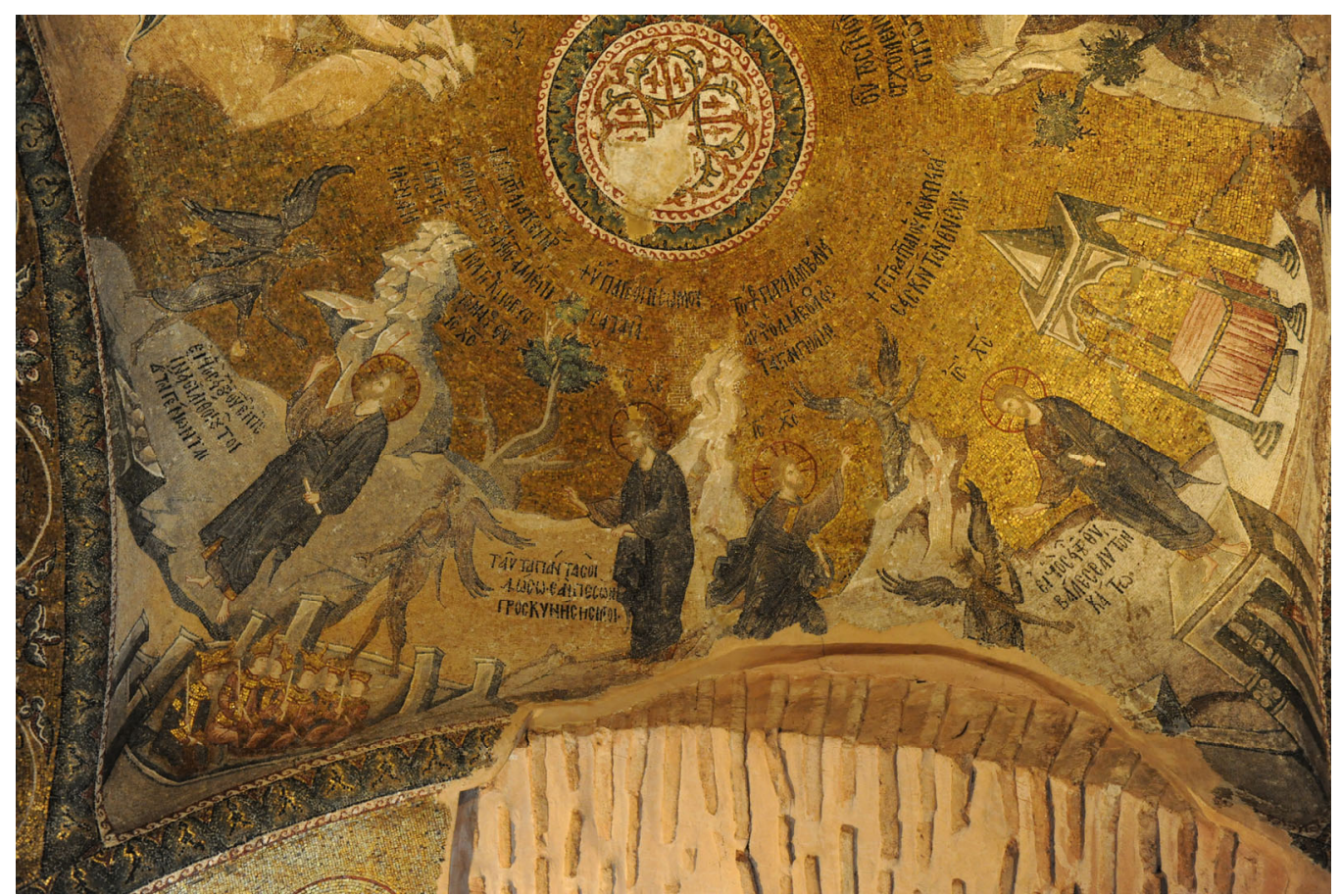

Fig. 8 The Second and the Third Temptation of Christ (C) Nektarios Zarras) 


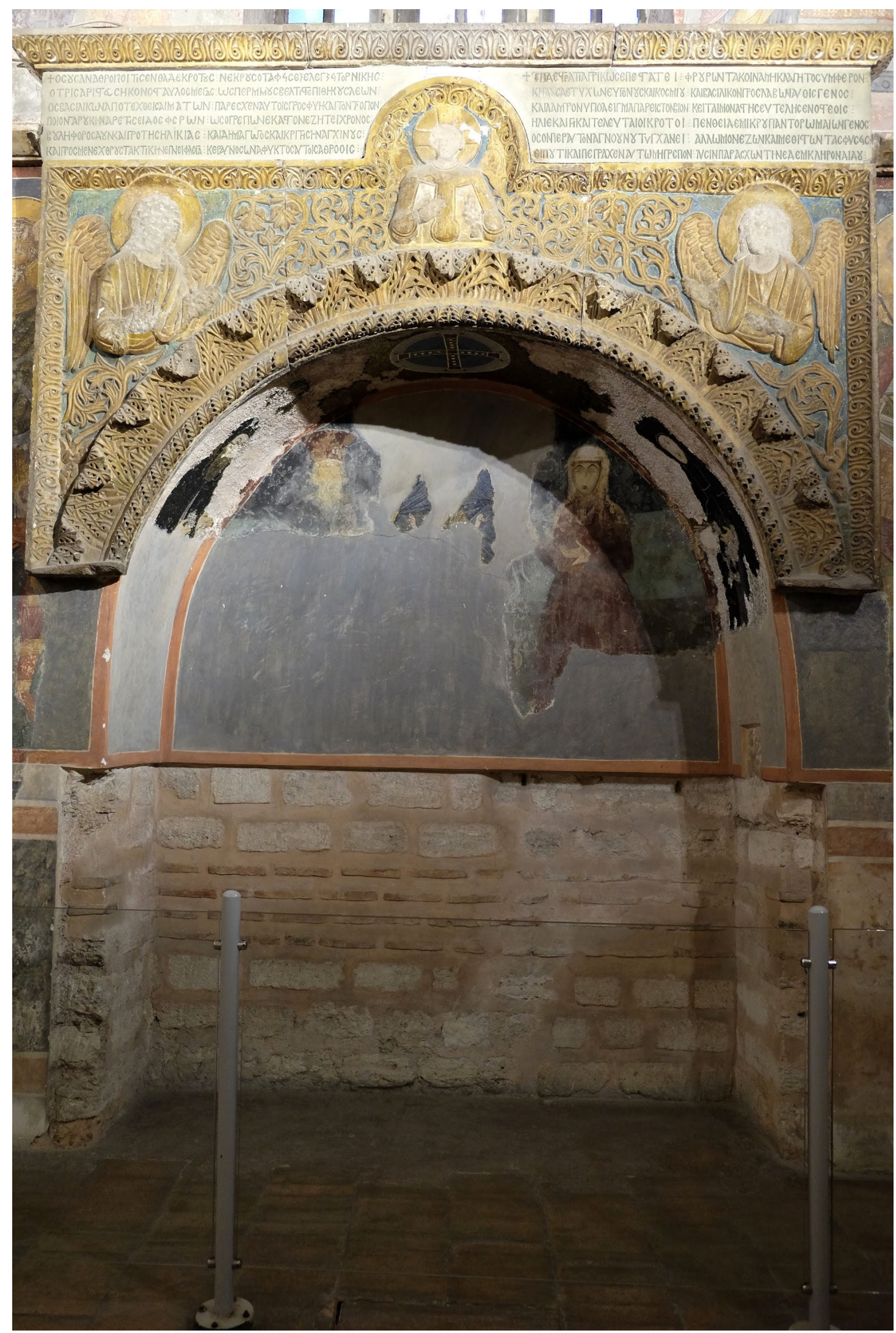

Fig. 9 Tomb of Michael Tornikes (Tomb D) in the parekklesion of the Chora Monastery, ca. 1328 (C) Brad Hostetler) 

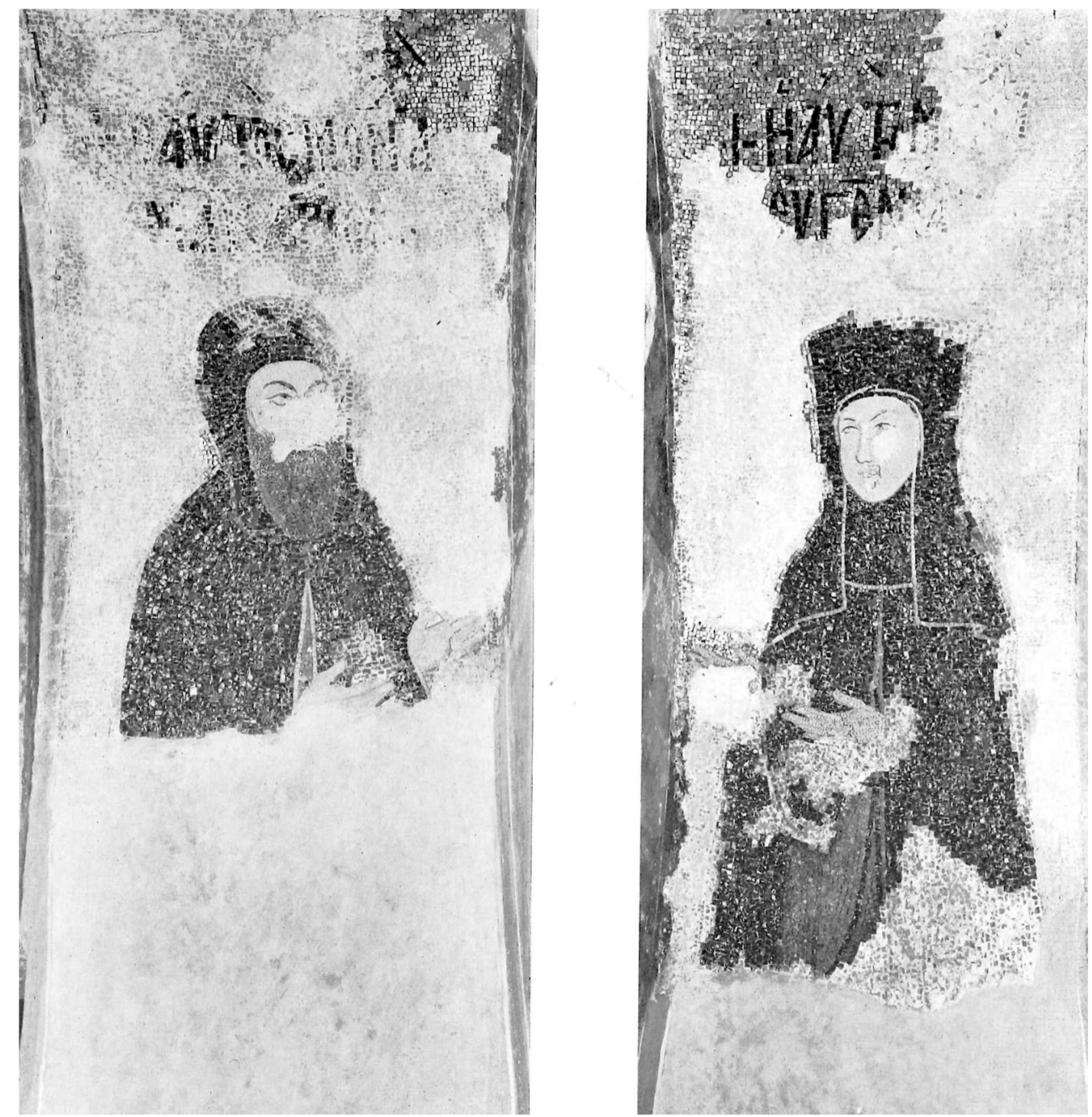

Fig. 10. Portraits of Michael Tornikes and his wife with inscriptions that identify them by their monastic names, Makarios and Eugenia. Tomb D in the parekklesion of the Chora Monastery, ca. 1328. (after Underwood 1961-1975). 


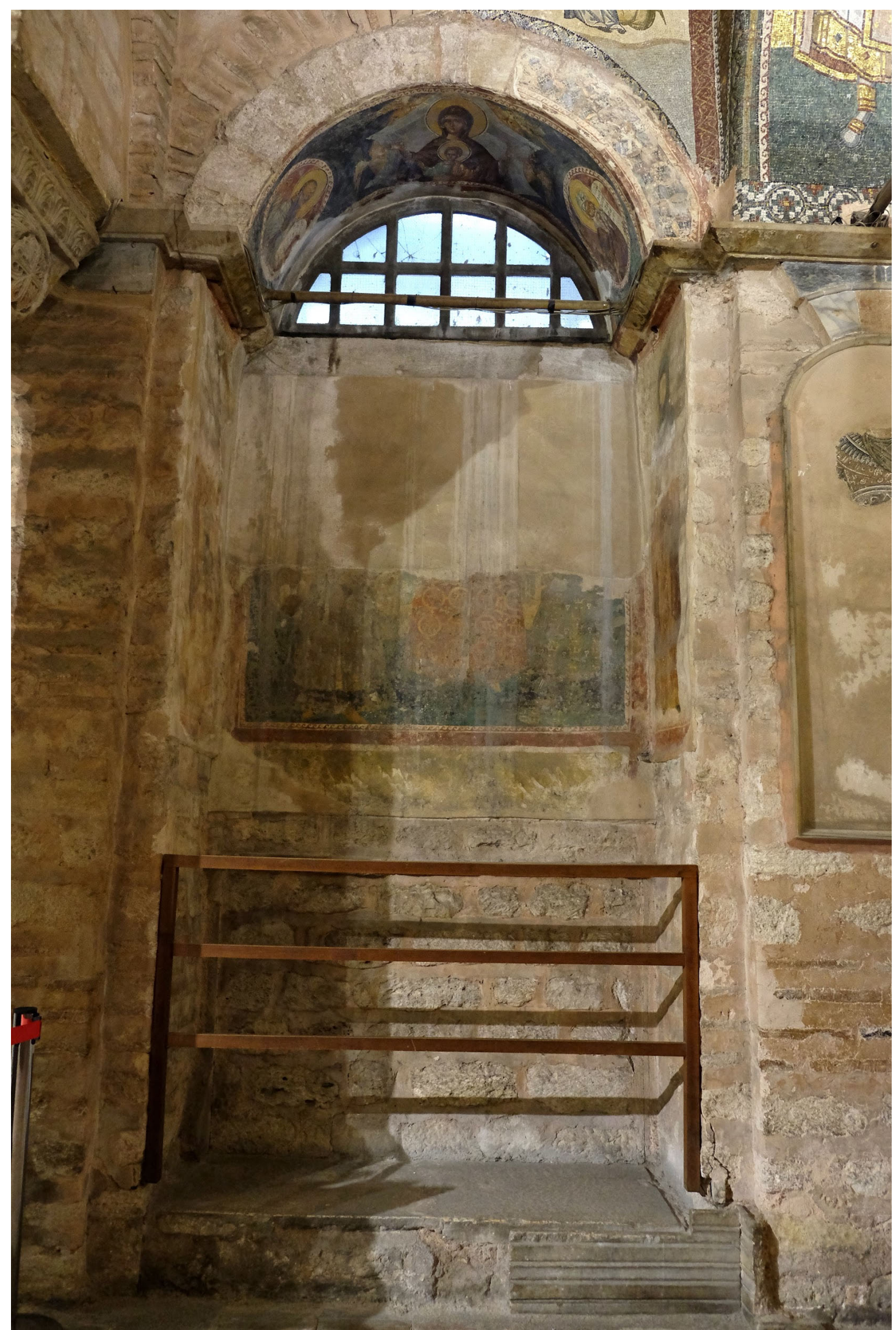

Fig. 11 Tomb E in the outer narthex of the Chora Monastery, 1325-1350 (C) Brad Hostetler) 


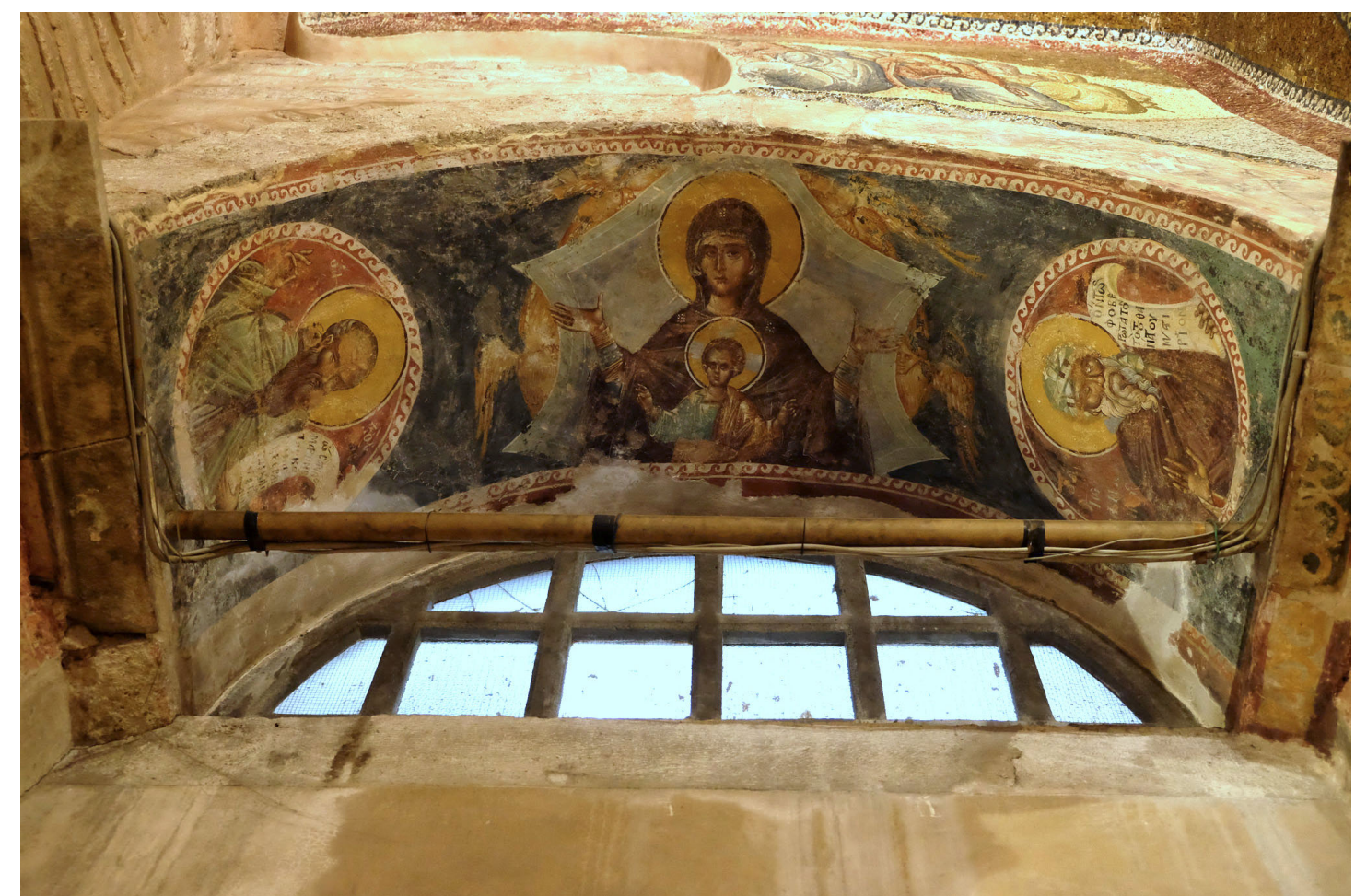

Fig. 12 Mother of God and Christ flanked by St. Kosmas the Hymnographer and St. John the Damascene. In the soffit of Tomb E in the outer narthex of the Chora Monastery, 1325-1350 (@ Brad Hostetler). 


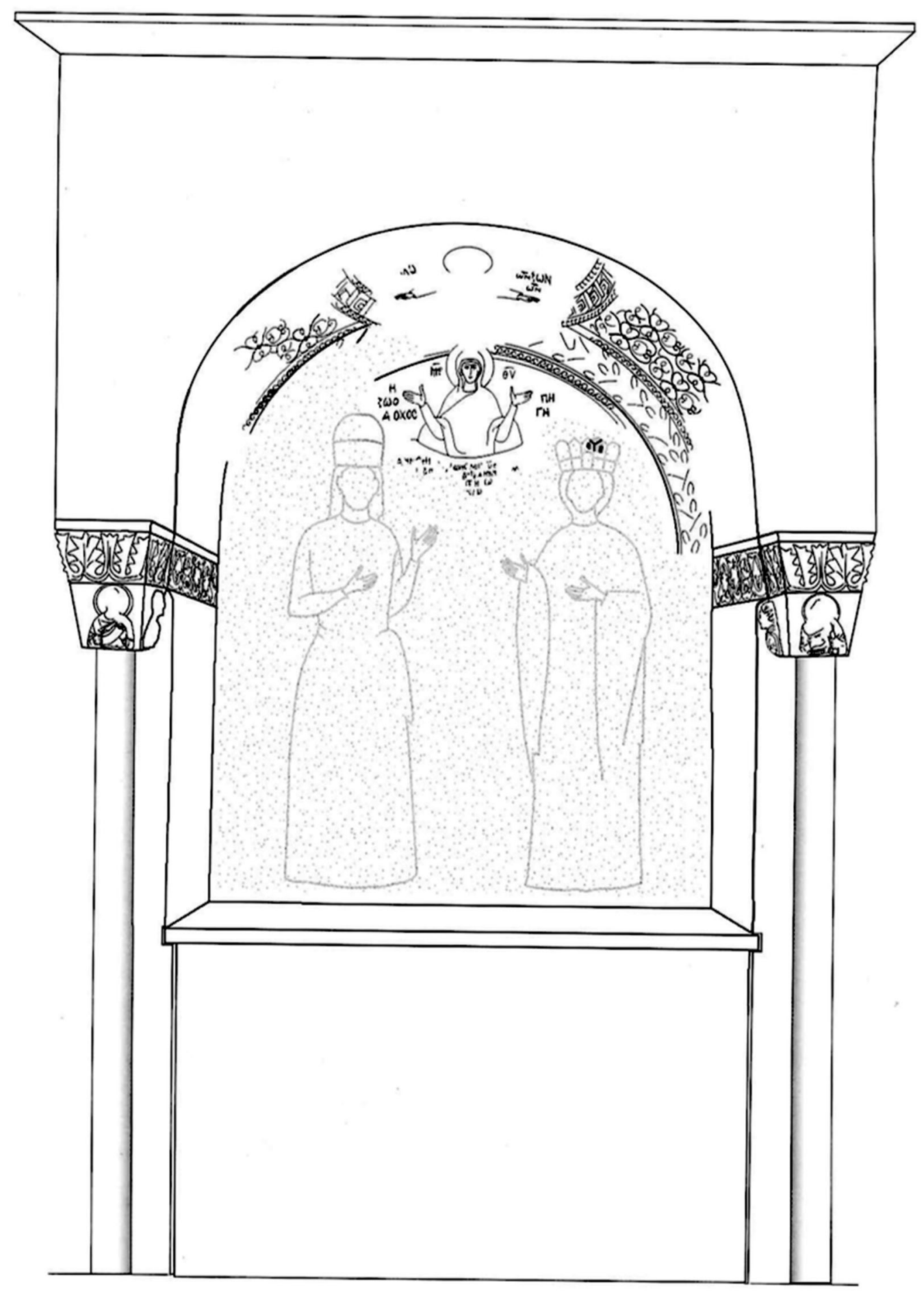

Fig. 13. Photo and reconstruction of Tomb D in the inner narthex of the Chora Monastery, ca. 1340 (after Underwood 1966-1975. Reconstruction: Brooks 2004). 


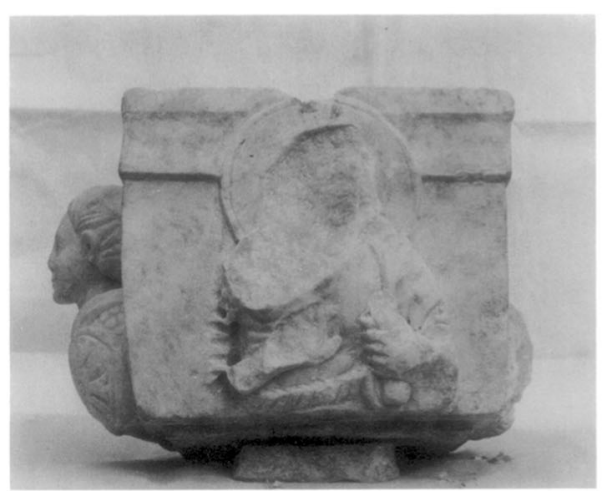

77. Front

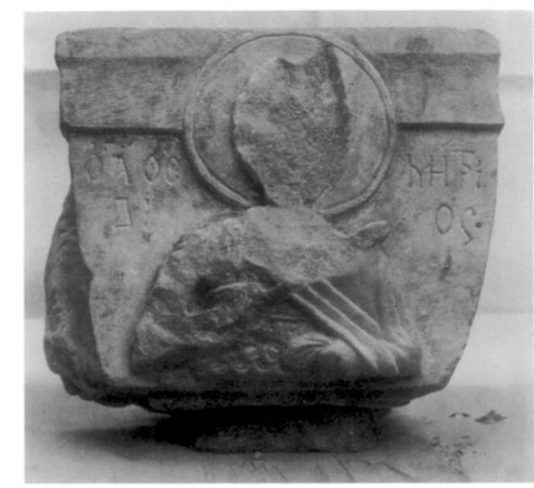

78. East Side, St. Demetrius

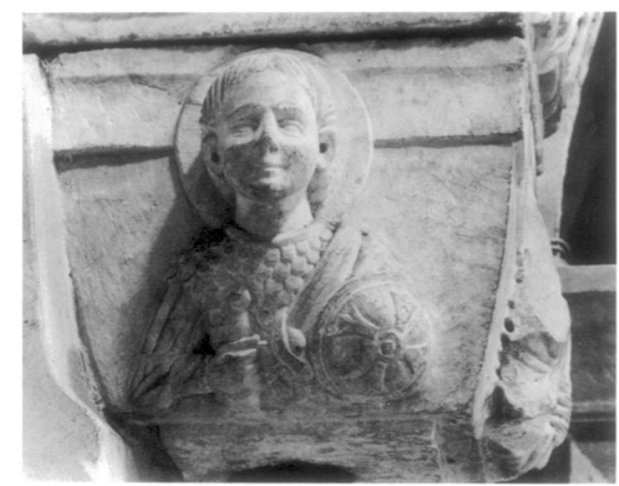

79. West Side, Warrior Saint

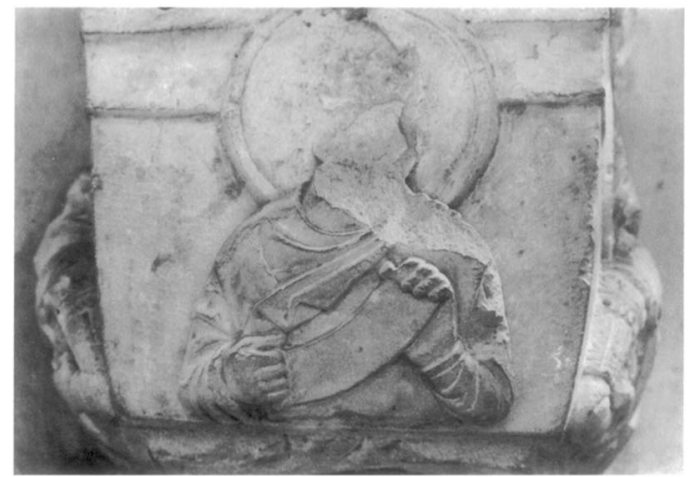

80. Front

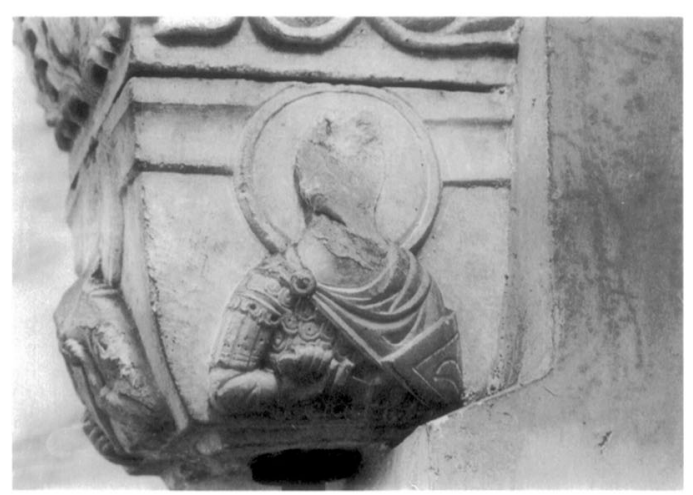

81. East Side

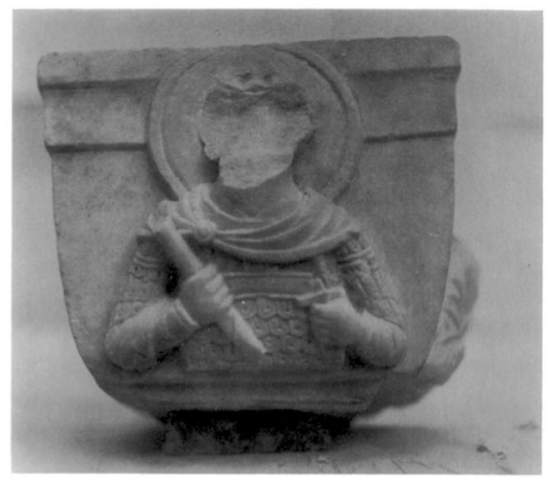

82. West Side

Fig. 14 Details of the figural capitals of Tomb D in the inner narthex of the Chora Monastery, ca. 1340 (after Hjort 1979). 


\section{Some remarks on post-Byzantine/ Ottoman history of the Chora Monastery \\ FILIZ YAȘAR}

Today, the Kariye Museum incorporates the remains of the Chora Monastery, a large building complex, which stood outside the Walls of Constantinople, thus giving the building its name (Greek 'chora' and Arabic 'kariye' both translate as 'countryside', 'land'). The history of the Chora Monastery, whose exact construction date is unknown, goes back to the sixth century. Its architecture, mosaics and fresco decoration, its inscriptions, and elaborate iconographic programmes all make the Chora one of the most remarkable monuments of the Byzantine period.

The conquest of Istanbul in 1453 initiated the Ottoman phase in the history of the monastery. The current scholarly debates regarding this period of Chora's history focus on two basic issues: the amount of damage that the monastery sustained during the siege, and the continuity in the use of the Chora as a Christian church.

Historical records show that the church was converted into a mosque by the Grand Vizier Hadim Ali Pasa (Atik Ali Pasha) during the reign of Bayezid II (1481-1521), probably at some point between 1495 and 1511. A minaret, a minbar, and a mihrab were added after the conversion. During the same period, a madrasah (a Muslim theological school) was attached to the complex. In the following years, some additional buildings, such as a school, a soup kitchen, a fountain and a shrine were constructed in its surroundings, while the main building was repaired several times. During the later Ottoman period, the former monastic complex fell into ruin. The former church, now a mosque, had its inscriptions and mosaics covered over with plaster. In 1948, the Byzantine Institute of America and the Dumbarton Oaks Center for Byzantine Studies sponsored a restoration programme, which uncovered rich decorative, iconographic and epigraphic remains of the Byzantine church that are still visible today. Since 1958, the building has had the status of a museum.

The Chora is one of the emblematic monuments of Istanbul, whose significance rests on its extraordinary historical and artistic value. It is an important symbol of the history and culture of both the Byzantine and the Ottoman Empires.

\section{Selected bibliography}

Akşit, I. (2010) Chora Bizans'ın Işıldayan Eseri Kariye Müzesi, İstanbul.

Atas, Z. (2011) The art and architecture of Chora Monastery in comparison with its East European and Italian contemporaries, in The Sustainable City, VII, 2: https://www.witpress.com/Secure/elibrary/papers/SC12/SC12101FU2.pdf

Dirimtekin, F. (1966) The historical monument of Kariye, İstanbul.

Eyice, S. (1987) Kariye Mosque Church of Chora Monastery, İstanbul.

Eyice, S. (1994) Kariye Cami, in Dünden Bugüne İstanbul Ansiklopedisi, vol. 4, İstanbul. Gülersoy, Ç. (1986) Kariye (Chora), İstanbul.

Oates, D. (1960) A Summary Report on the Excavations of the Byzantine Institute in the Kariye Camii 1957 and 1958, Dumbarton Oaks Papers 14, 223-231. 
Ongen, S., and Aysal, N. (2016), Kariye Müzesi (Chora Manastırı) Kullanılan Dekor Taș Türleri Ve Bunların Kaynak Alanları, in Kârgir Yapılarda Koruma Ve Onarım Semineri. Istanbul, 136-164.

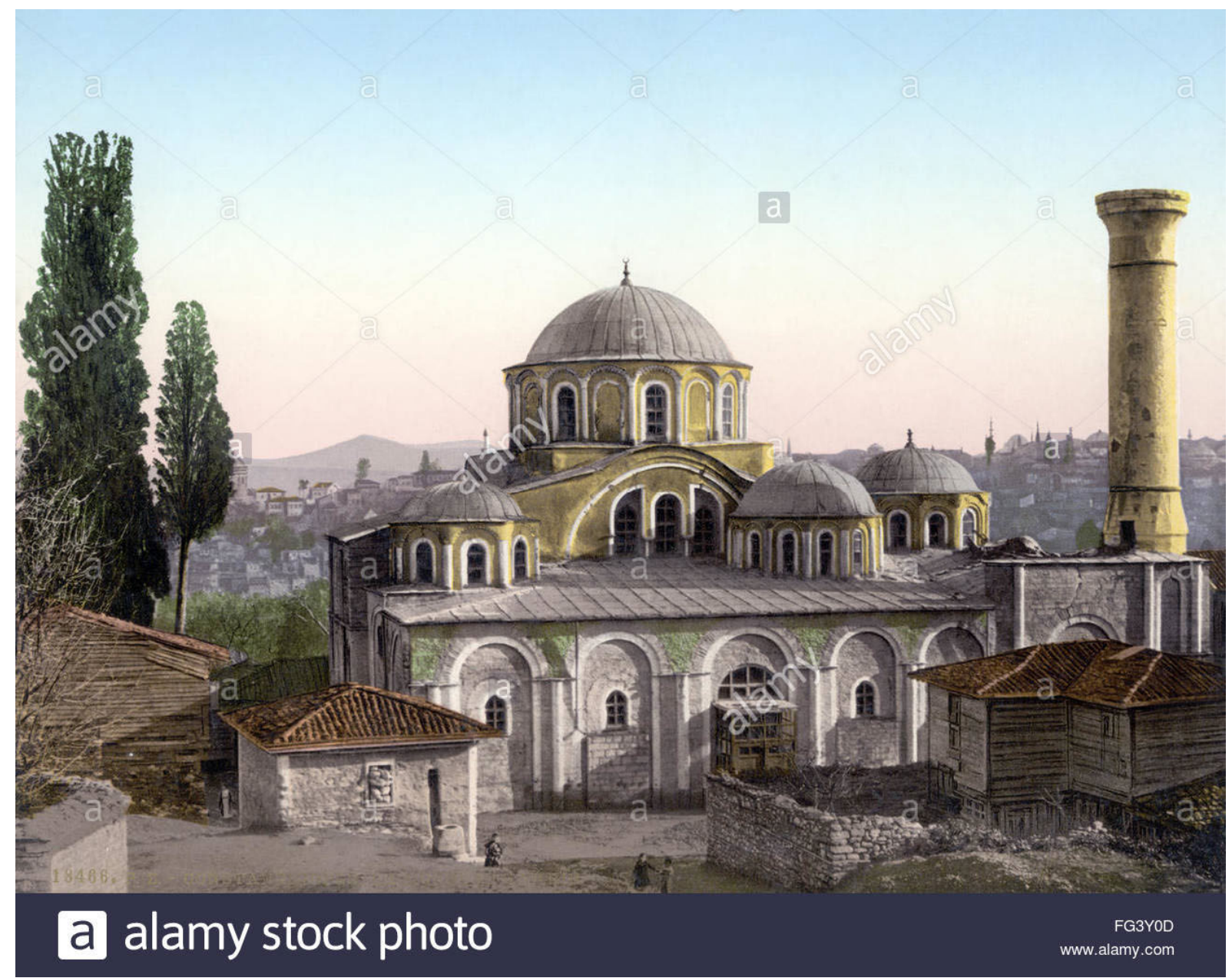

Fig. 1 The Kariye Camii in Constantinople, Ottoman Empire. Photochrome, c. 1895 
VII THE EPIGRAPHY OF ST SOPHIA 



\section{Architecture and Epigraphy in St Sophia GEORGIOS PALLIS}

When the Great Church of Hagia Sophia was founded, inscriptions were being widely used in church architecture and decoration alike. In the two near-contemporary monuments of the imperial capital, St Polyeuktos (524-527) and Sts Sergius and Bacchus (527-536), long epigrams were placed in prominent positions as part of the buildings' sculptural decoration thus showcasing a high level of contemporary appreciation for the monumental display of the inscribed word. Quite remarkably, this practice was not followed in the new Church of Saint Sophia, in which epigraphy was limited only to the imperial monograms, not counting ubiquitous masons' marks.

It was after the end of the iconoclastic controversy that inscriptions appeared in the interior of the church simultaneously with the embellishment of the building with holy images. Epigrams executed in the medium of mosaic were added to the apse of the sanctuary's semidome and to the north and south tympana; their form and scale were in harmony with the architectural space allowing the faithful standing on the ground level to read them. Henceforth, every figure or scene depicted in any church interior had to be accompanied by an inscriptions as a mark of their identity. During the following centuries up to the Palaiologan era, almost all inscriptions that were added in Saint Sophia were parts of mosaic representations depicting holy figures or imperial images.

In the Great Church of Hagia Sophia, epigraphy functioned more as an essential supplement to the mosaic representations and less as an independent element adapted into its architectural space, despite the building's advantages and the thriving epigraphic habits in the period of its creation.

\section{Selected Bibliography}

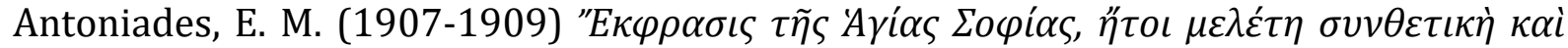

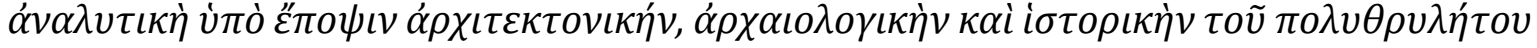

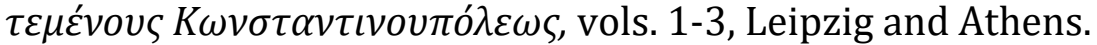

Cormack, R. and Hawkins, E. J. W. (1977) The Mosaics of St. Sophia at Istanbul: The Rooms above the Southwest Vestibule and Ramp, Dumbarton Oaks Papers 31, 175-251.

Guiglia Guidobaldi, A. and Barsanti, C. (2004) Santa Sofia di Constantinopoli. L'arredo marmoreo della grande chiesa giustinianea, Città del Vaticano.

Guiglia Guidobaldi, A. and Barsanti, C. (2009) Le porte e gli arredi architettonici in bronzo della Santa Sofia di Costantinopoli, in Iacobini, A. (ed) Le porte del paradiso. Arte e tecnologia bizantina tra Italia e Mediterraneo, Rome, 81-123.

Mango, C. (1951) The Byzantine Inscriptions of Constantinople: A Bibliographical Survey, American Journal of Archaeology 55, 52-66.

Mango, C. (1962) Materials for the Study of the Mosaics of St Sophia at Istanbul, Washington, D.C.

Mango, C. (1963) The Conciliar Edict of 1166, Dumbarton Oaks Papers 17, 315-330.

Mango, C. and Hawkins, E. J. W. (1965) The Apse Mosaics of St. Sophia at Istanbul. Report on Work Carried out in 1964, Dumbarton Oaks Papers 19, 115-151.

Mango, C. and Hawkins, E. J. W. (1972) The Mosaics of St. Sophia at Istanbul. The Church Fathers in the North Tympanum, Dumbarton Oaks Papers 26, 3-41. 
Mercati, S. G. (1922) Sulle iscrizioni di Santa Sofia, Bessarione 26, 200-218 (= Idem (1970), Collectanea Byzantina, vol. 2, Bari, 276-295).

Niewöhner, Ph. and Teteriatnikov, N. (2014) The South Vestibule of Hagia Sophia at Istanbul. The Ornamental Mosaics and the Private Door of the Patriarchate, Dumbarton

Oaks Papers 68, 117-156.

Rhoby, A. (2009) Byzantinische Epigramme auf Fresken und Mosaiken (= Byzantinische Epigramme in inschriftlicher Überlieferung, vol. 1), Vienna, 397-402, nos. M9-14, figs. 110-111.

Teteriatnikov, N. B. (2004-2005) Hagia Sophia, Constantinople: Religious Images and their Functional Context after Iconoclasm, Zograf 30, 9-19.

Teteriatnikov, N. B. (2017) Justinianic Mosaics of Hagia Sophia and Their Aftermath, Washington, D.C.

Architecture and Epigraphy in St Sophia:

A Selection of Inscriptions

1. Lost inscription over the 'Horologion Gate' (of uncertain date)

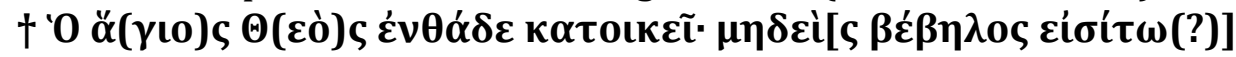

The holy God lives here; let no one profane come inside.

2. On the bronze doors of the south vestibule (841)

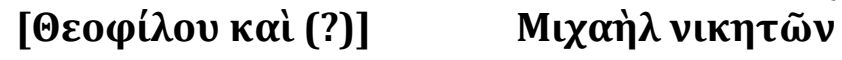

Of Theophilos and Michael the victorious

3. Epigram surrounding the conch of the main apse (ca. 867) (See, also Chapter 30 by Maria Lidova)

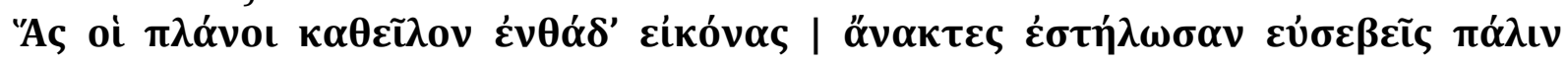
(Anthol. Pal. I 1)

The images, which the impostors had formerly cast down here, pious emperors have again set up. (Translated by C. Mango)

4. Epigrams on the north tympanum (last quarter of the 9th c.)

a. Above the upper row of windows:

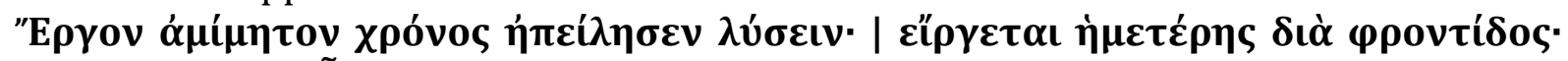

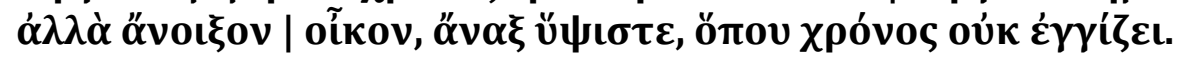

Time has threatened to destroy this inimitable work; it has been hindered by our solicitude; do Thou open Thy house, 0 most high Lord, which time toucheth not. (Translated by C. Mango)

b. Between the two rows of windows

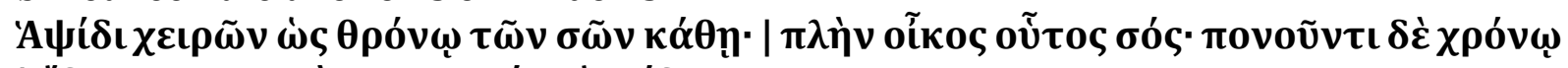

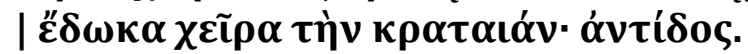

Thou sittest as on a throne on the vault wrought by Thy hands; but this is Thy house; it has been suffering from age, so I proferred to it a mighty hand; do thou repay me. (Translated by C. Mango) 
5. Epigrams on the south tympanum (last quarter of the 9th c.)

a. Above upper row of windows:

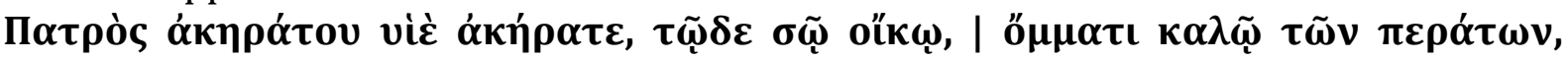

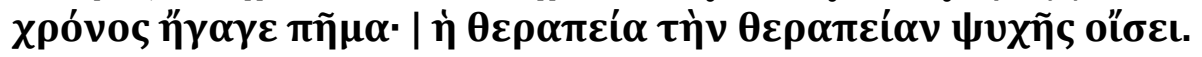

0 incorruptible Son of incorruptible Father, unto this Thy house -the beautiful eye of the universe- time has brought misfortune; Its cure will provide spiritual salvation. (Translated by C. Mango)

b. Between the two rows of windows

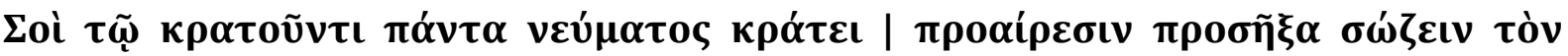

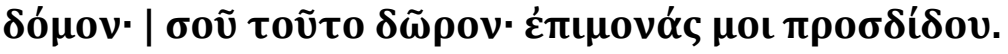

To Thee who rulest everything by the power of Thy nod, I have offered my purpose of preserving this house; this is thy gift; grand me steadfastness. (Translated by C. Mango)

6. Inscribed brick, Archaeological Museum of Istanbul (10th c.)

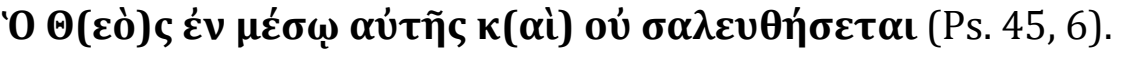

God is in her midst and she shall not be moved 



\section{Hagia Sophia: \\ Word and Image in Byzantine Church Decoration \\ MARIA LIDOVA}

This contribution examines the role of inscriptions in the mosaic decoration of the main church of the Byzantine Empire. It considers two principal types of epigraphical record the dedicatory text around the apse and the short captions accompanying the images of saints and emperors. Discussing and contextualizing this material help highlight some common features, as well as distinct traits of the epigraphical evidence found in the mosaic decoration of Hagia Sophia.

Today, the Church of St Sophia in Istanbul preserves a modest amount of epigraphic evidence. However, it must be remembered that much of the original material is missing, and that various kinds of written texts once decorated numerous liturgical objects, textiles (in particular altar cloths), codices, painted images, etc. Within this rich array of epigraphical record one inscription stood out due to its location and visibility - the text decorating the profile of the apse and surrounding the image of the Mother of God (see Chapter 29 by Georgios Pallis). Beyond doubt, this representation - the Virgin seated on a luxurious throne with Jesus on her lap flanked by two angels standing in the bema - was destined to become the most important and determining visual element of the whole space. As it is well known, this mosaic was created in the ninth century. It was inaugurated on the 29 March 867. Such an imposing image of the Virgin placed in the apse was a political statement with profound ecclesiastic and theological implications, heralding to the public the definitive end of Iconoclasm (843). However, its appearance radically changed the visual dynamics within the church space making the mosaic above the altar the focal point of attention. The reasons behind the production of this image are given in two surviving testimonies. One is included in the text of the sermon by Patriarch Photius (858-867/877-886), pronounced on the occasion of the revelation of the new decoration of Hagia Sophia in the presence of Emperors Michael III and Basil I. The other was integrated into the image, and it was transmitted via the inscription that ran around the apse on the outer rim of the arch, circumscribing the perimeter of the bema space. It read as follows:

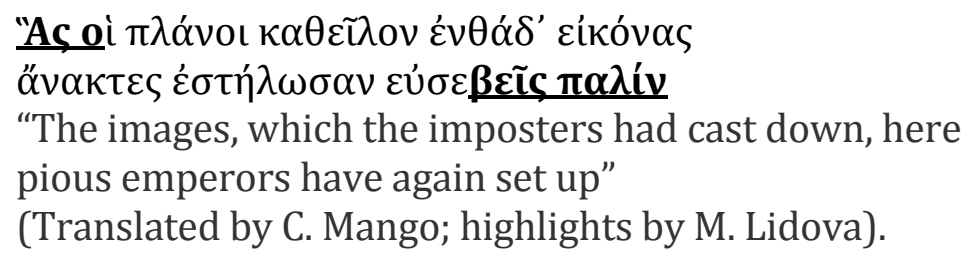

Only the beginning and the end of the original text survive (marked above in bold letters). Brad Hostetler has recently reconstructed the possible locations of the missing words of the

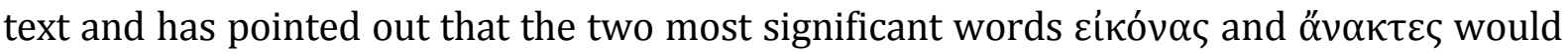
have been inscribed along the upper edge, and would have appeared on the main axis along with the image of the Virgin (see, fig. 1). 


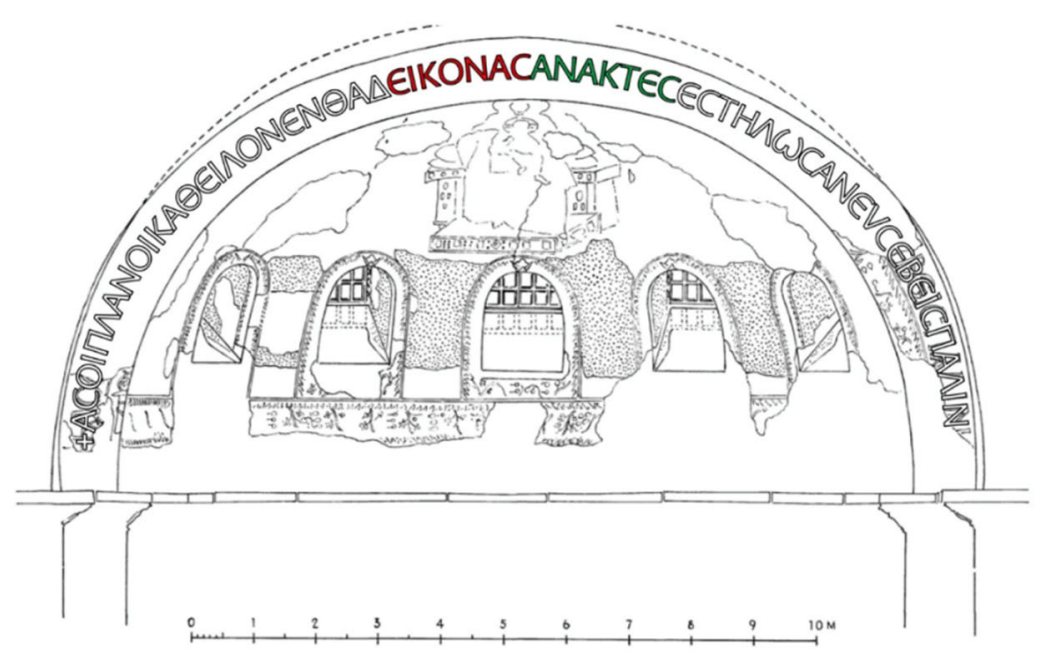

Fig. 1 Hagia Sophia, bema. Reconstruction of the inscription by Brad Hostetler using the elevation drawing from Mango and Hawkins 1965, 150.

(https://bradhostetler.com/2018/01/01/the-apse-inscription-at-hagia-sophia/)

There is some elusiveness about this inscription, since it does not make it entirely clear what images are referred to in the text. It remains unsure whether the poem was intended as a general statement of the revival of image veneration or a direct reference to the representation of the Virgin in Hagia Sophia; or, perhaps, both.

Although formally falling into the category of dedicatory texts, this inscription is very unusual in its verbal formula and message, which is overly general and at the same time far more politically charged than was customary for texts placed in the apse. Cyril Mango compares this text to the inscription that, according to the 'unknown writer', Empress Irene (752-803) placed around the image of Christ in Chalke after she had it restored:

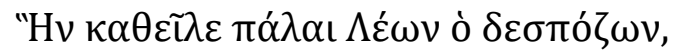

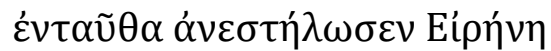

"[The image] which Leo the emperor had formerly cast down, Irene has re-erected here"

(Translated by C. Mango)

If we accept Mango's suggestion, then the Chalke case becomes a very important precedent for the inscription in Hagia Sophia as it testifies to a particular epigraphic formula that may have been used in connection with the reinstatement of the veneration of images. The main difference, however, lies in the absence of specific names in the inscription of Hagia Sophia's apse. The vagueness could have been intentional in order to avoid political disputes and to praise all the rulers, who had attempted to restore religious images, or, perhaps, this wording was self-explanatory at the time. It is also important to bear in mind the proximity of the Chalke Gate to the Church of Hagia Sophia. Furthermore, we know that at some point a copy of the image of Christ Chalkites was made on the inner wall of the façade of the Sophia Church, facing the image of the Virgin in the apse. This created a direct connection between the images, and reflected the intentional pairing of the two icons that became the markers of the beginning and the end of Iconoclasm, not least, perhaps, through the spatial dialogue of texts.

In the absence of a comprehensive study on early Byzantine Greek inscriptions placed in the apse, it would be helpful, in my view, to use as an analogy early medieval Latin texts 
decorating the conches of the apses in the Western Empire. This approach has the potential of advancing our knowledge on the uses of text in monumental church decorations, on the role of donors in the creation and choice of inscriptions, and on the complex relationship between the word and figural representation. The earliest attestations of inscriptions appearing in relation to a conch decoration goes back to the time of Constantine and to the church of St Peter in Rome. Another inscription was apparently made in connection with the earliest figurative decoration representing the scene most commonly identified as Traditio legis, commissioned by Constantine's son Constantius (337-361).

Considering the great religious significance of the imagery selected for the apse, it would be reasonable to expect the text to complement, or comment on, the image, as it is the case, for example, with the vaulted niche decorated with mosaics in the catacombs of Domitilla in Rome (4th century). There, we find an image of bearded Christ, within a sphere of light, flanked by the representations of Peter and Paul, and surrounded by an inlaid inscription:

Qui filius diceris et pater inveniris.

"You who are called Son are found to be the Father as well"

However, when it comes to church decorations and mosaics made in the apse above the altar, in the absolute majority of cases both in the East and West we see dedicatory texts, commemorating patronage by emperors, churchmen or lay donors.

Extant evidence indicates that this practice changed only in the eighth century when a new set of texts started to be used in connection with the apse mosaic decorations produced in the Greek-speaking territories during the period of Iconoclasm. Biblical quotations and verses from the Book of Psalms began to dominate the church space not only with its dogmatic message, but also visually, accentuating the graphic qualities of non-figurative representations, and foremost of the sign of the cross. In addition to the Church of St Irene in Constantinople, these features are visible in the apse decoration of the Church of St Sophia in Thessaloniki, as well as in the programme that once decorated the Church of the Dormition in Nicaea (for an image, see: https://thevcs.org/forever-andever/womb-morning). The dating of the church in Nicaea is still under debate, but if the evolution of the apse inscription in early Byzantine art outlined here is correct, the evidence of Nicaea, whose mosaic programme includes quotations from Psalms 110, 93 and 97, might suggest that such a choice of inscribed text was an eighth-century innovation. Be it as it may, a taste for scriptural texts apparently predated by at least a century the appearance of the inscription in the apse of Constantinople's Hagia Sophia, whose dedicatory nature (at least in form and intent, if not entirely verbatim) could be seen as a further attempt of the victorious iconophiles to break away from the iconoclastic tradition of the preceding centuries, and to revive the epigraphic habits of the distant past. It must also be noted that in the early Byzantine period the use of Biblical texts and dedicatory inscriptions in the conch of the apse - as far as the mosaic medium is concerned - seem to be mutually excluding. This, however, does not pertain to inscriptions appearing on scrolls but only to texts used as frames in a monumental context.

Inscriptions produced in the apses of Greek churches tend to differ from their Latin counterparts in several significant respects. (See, fig. 2) It is common for Greek texts to follow the profile of the arch running above the sanctuary, which required special skills on the part of the mosaicists, who had to place the letters evenly along the curvature of 
the arch. In the West, Latin texts appear predominantly in the lower part of the conch forming a band in the semicircular wall of the apse. Latin dedicatory inscriptions tend to be much longer, and they provide more detail, referencing both the mosaic medium and the represented images. The display of these texts resembles ancient Roman imperial constitutions inscribed in prominent locations for everyone to read. The Byzantine Greeks, on the other hand, showed preference for one-line statements.

However, the major difference was in the use of color. In Hagia Sophia, the inscription was executed in dark blue glass, which created the impression of dark, almost black, letters against the golden background. This approach is different from the early medieval monuments in Rome where preference was given to the golden or white color of the letters appearing against a dark blue background. Remarkably, the preference for one or the other chromatic solution was persistent for each tradition. Constantinople would continue to use dark letters on golden background in later centuries, while Rome has generally produced the examples of the white-and-gold lettering in apse inscriptions. The only exception is the Church of Hosios David with the fifth-century apse, in which two lines of a Greek inscription were inlaid using silver letters against a red background, but it is worth remembering that Thessaloniki was under the jurisdiction of the Pope of Rome until the eighth century. Whether or not this variability in practice and color choice reflects two distinct traditions remains a matter for debate, but the differences in the visual effects obtained in each case are worthy of note.

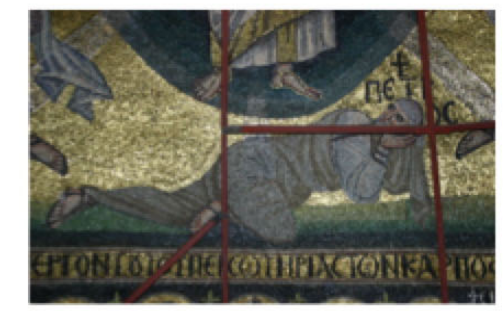

Apse inscription, sixth century, basilica of St. Catherine's monastery at Sinai

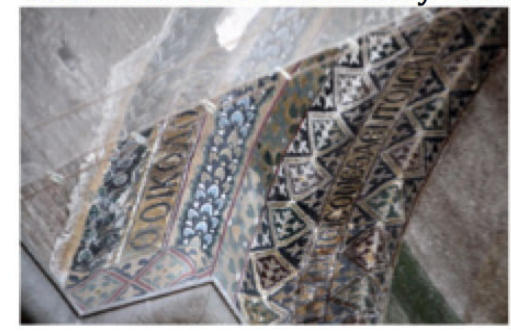

Apse inscription, eighth century St. Irene church, Istanbul

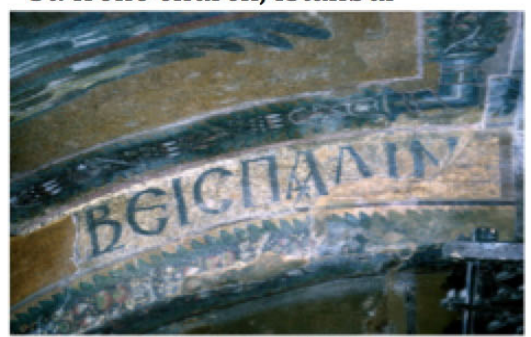

Apse inscription, ninth century St. Sophia church, Istanbul (DO image collection and fieldwork archives)

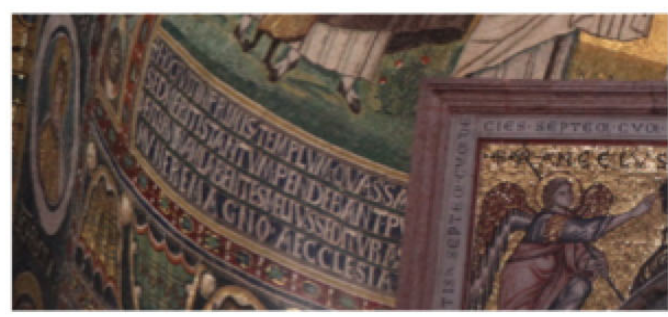

Apse inscription, sixth century, basilica of Eufrasius, Poreč

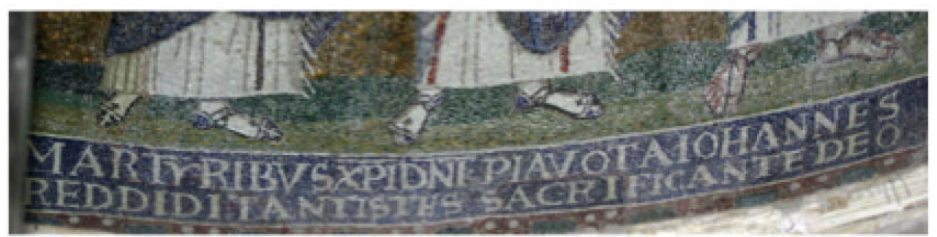

Apse inscription, seventh century, chapel of St. Venantius, Lateran baptistery, Rome

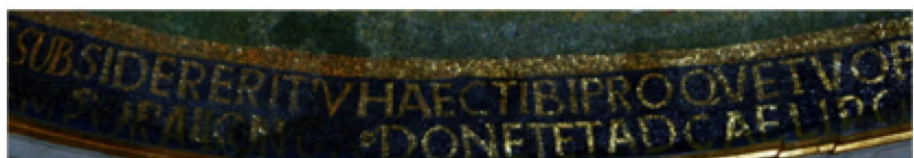

Apse inscription, ninth century, San Marco al Campidoglio, Rome

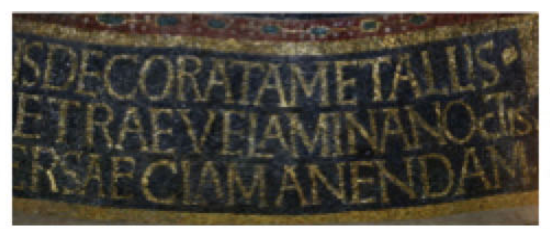

Apse inscription, ninth century, Santa Maria in Domnica church, Rome

Fig. 2 (C) Maria Lidova) 
Another category of inscriptions in Hagia Sophia includes various captions and identifying labels surrounding figural representations in the church. These accompanying texts are often taken for granted, but looking at this material beyond its literal meaning can provide insightful information. Scholars have long been puzzled by the fact that both the apse and the lunette above the imperial entrance in Hagia Sophia are deprived of any letter signs and indications, especially considering that the scene in the narthex contains the representation of a prostrated emperor. (See, figure 3) This state of evidence was of concern in the Middle Ages, when, perhaps in the $11^{\text {th }}$ century, an unknown mosaicist modified the mosaic by adding the name of Jesus Christ (IC XP). (See, figure 3, detail) The tendency to reduce identification markers and keep certain anonymity in relation to the images was apparently intentional in Hagia Sophia, and it does not seem to have been unique in the Byzantine world.

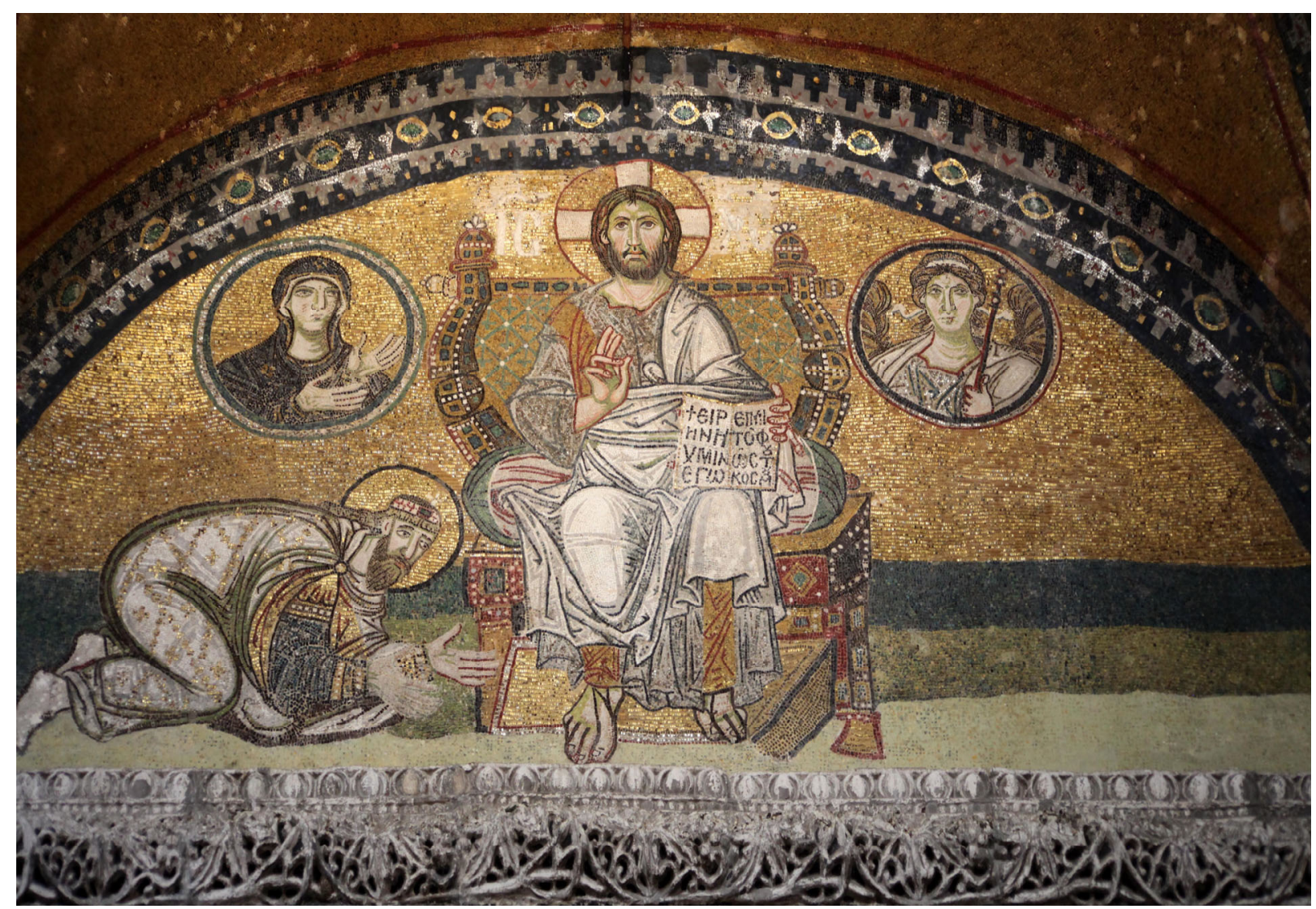

Fig. 3 Lunette above the Imperial Door, Hagia Sophia (ㄷ Maria Lidova) 


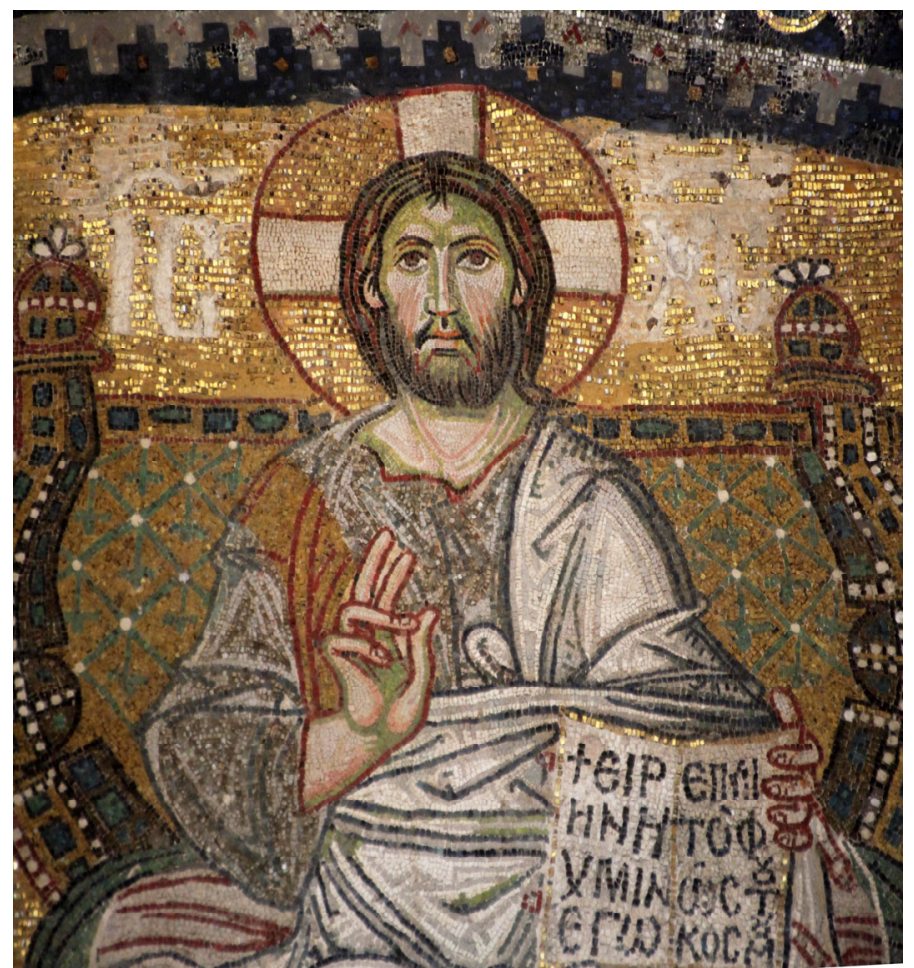

Fig. 3 detail: Lunette above the Imperial Door, Hagia Sophia ( Maria Lidova)

Another set of mosaics in the lunettes along the naos of St Sophia represents a group of standing bishops (among them a few patriarchs). When listing these churchmen, Mango identifies them as St Basil, St Gregory, St John Chrysostom, St Ignatius etc. However, the prefix hagios is absent in all surviving instances. This is noteworthy: the presence or absence of this prefix, in my view, was never random. (See, fig. 4)

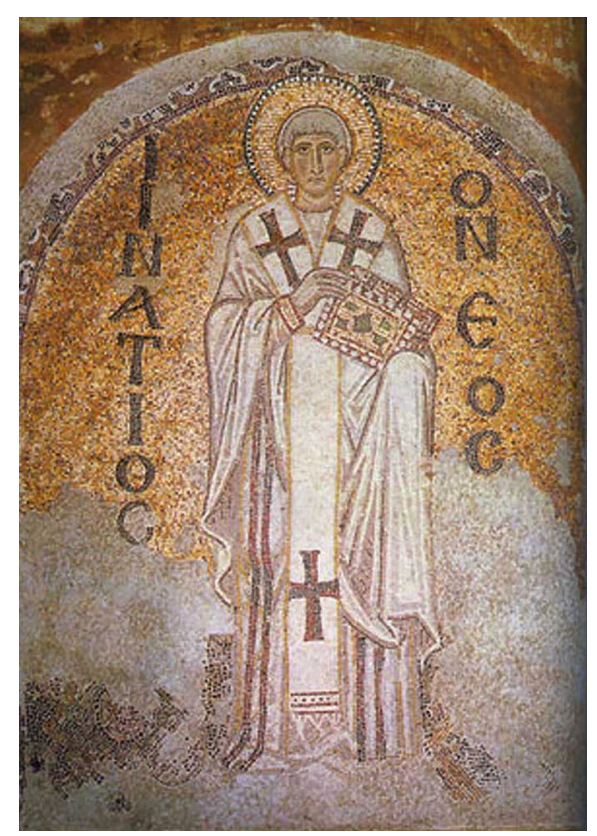

Fig. 4 St Ignatius, Hagia Sophia (C) Maria Lidova)

As I have argued elsewhere, in the earliest surviving epigraphic evidence, martyrs are simply defined by names without any prefix. At a certain point in the end of the fourthearly fifth century, the captions were all expanded to include an indication of status, or 
the word 'saint'. Therefore, the absence of this prefix on the images of bishops created in the ninth century in St Sophia may serve as an indication that they were represented mainly in their historic role as bishops and theologians rather than as saints, recipients of prayers and images of veneration. However, the tendency to omit hagios in certain cases is not uncommon for the ninth century and systematic research is needed before any definitive conclusions can be made.

The captions appearing in connection with imperial representations in the south galleries are well studied and they do not need to be treated here in detail. Nonetheless, the interplay of colors between the black and red lettering used for official titles and inscription on the scroll remains intriguing. Besides, these texts present a unique testimony to the practice of modification and subsequent re-elaboration of epigraphical records. This practice goes hand in hand with partial interventions in the mosaic representations in order to change the identity of a figure or slightly alter the original meaning of the scene. Similar cases of pictorial and textual reworkings are attested throughout the centuries and deserve to be studied comparatively and at length.

The use of epigraphy in the church of St Sophia offers a wide range of examples that can be studied from different perspectives and be successfully employed in comparative analyses. The observations put forward in this summary arise from an oral presentation given at the Summer Programme of Byzantine Epigraphy in September 2018. They are merely an invitation for further investigation of this fascinating material.

\section{Selected Bibliography}

Boston, K. (2003) The Power of Inscriptions and the Trouble with Texts, in Eastmond, A. and James, L. (eds) Icon and Word, Aldershot, 35-57.

Cormack, R. (1985) Writing in God. Byzantine Society and Its Icons, London, 141-178 (Chapter 4 - After Iconoclasm: The Illusion of Tradition).

Leatherbury, S. V. (2016) Reading and Seeing Faith in Byzantium: The Sinai Inscription as Verbal and Visual "Text”, Gesta 55/2, 133-156.

Liverani, P. (2014) Chi parla a chi? Epigrafia monumentale e immagine pubblica in epoca tardoantica, in Birk, S., Kristensen, M. and Poulsen, B. (eds) Using Images in Late Antiquity, Oxford, 3-32.

Mango, C. (1959) The Brazen House: A Study of the Vestibule of the Imperial Palace of Constantinople, København.

Mango, C. (1962) Materials for the Study of the Mosaics of St. Sophia at Istanbul, Washington.

Mango, C. and Hawkins, E. J. W. (1965) The Apse Mosaics of St. Sophia at Istanbul. Report on work carried out in 1964, Dumbarton Oaks Papers 19, 115-151.

Mango, C. and Hawkins, E. J. W. (1972) The Mosaics of St. Sophia at Istanbul. The Church Fathers in the North Tympanum, Dumbarton Oaks Papers 26, 3-41.

Maguire, H. Eufrasius and Friends: On Names and their Absence in Byzantine Art, in James, L. (ed) Art and Text in Byzantine Culture, Cambridge, 139-160.

Maranci, C. (2014-2015) "Holiness Befits Your House" (Ps. 92 [93]: 5): A Preliminary Report on the Apse Inscription at Mren, Revue des Études Arméniennes 36, 243-263.

Rhoby, A. (2009) Byzantinische Epigramme auf Fresken und Mosaiken (= Byzantinische Epigramme in inschriftlicher Überlieferung, vol. 1), Vienna, 397-402. 
Teteriatnikov, N. (fortcoming) Absence of Nomina Sacra in Post-Iconoclastic Images of Christ and the Virgin: Mosaics of Hagia Sophia, Constantinople, in Olsen Lam, A. R. and Schroeder, R. (eds) The Eloquence of Art. Essays in Honour of Henry Maguire, London.

Thunø, E. (2017) The Power and Display of Writing: From Damasus to the Early Medieval Popes, in Zimmermann, N., Michalsky, T., Weinfurter, S. and Wieczirek, A. (eds) Die Päpste und Rom zwischen Spätantike und Mittelalter, Berlin, 95-114.

Thunø, E. (2015) The Apse Mosaic in Early Medieval Rome. Time, Network, and Repetition, Cambridge, 13-62.

Thunø, E. (2011) Inscription and Divine Presence: Golden Letters in the Early Medieval Apse, Word \& Image 27, 279-291.

Whittemore, Th. (1933-1938) The Mosaics of St. Sophia at Istanbul, Paris. 


\section{The Conciliar Edict of 1166 in Hagia Sophia ALEX RODRIGUEZ SUAREZ}

The plaster casts on display in the narthex of St Sophia (figs. 1-3) are copies of the five inscribed slabs made of Proconnesian marble, which survive reused in the Mausoleum of the Sultan Suleiman the Magnificent (d. 1566) (figs. 4-5). The slabs feature a long inscription reproducing parts of the edict of a church council convened in Constantinople, in 1166, by the Emperor Manuel I Komnenos (1143-1180).

This epigraph has a long and well-attested history. Although the inscription survives incomplete, the full text of the edict has been transmitted in several manuscripts. Also, written sources provide information about the subsequent fortunes of this monument. For instance, John Kinnamos testifies that the inscription was put up in the interior of Hagia Sophia, on the left-hand side. Through an epigram written by Theodore Balsamon, we learn that the Emperor Isaac II Angelos set up images of the Apostles Peter and Paul on either side of the inscription. Later sources tell us that the marble slabs remained on display for more than a century after the Ottoman conquest of the Byzantine capital in 1453 , and that they were removed from their original location only after the death of Sultan Suleiman.

Measuring $4.11 \mathrm{~m}$ in height and $4.62 \mathrm{~m}$ in width, the edict is the longest extant Byzantine lapidary inscription. The original epigraph had a double-border frame, which was most probably inspired by an ancient design. The first four lines of the text are inscribed in larger letters (about $8 \mathrm{~cm}$ ) (see, fig. 2), and they include the heading of the document; the rest of the inscription occupies forty-nine lines, and it is carved in somewhat smaller letters (about $6 \mathrm{~cm}$.). The letters do not only vary in size, but also in style: the script gradually becomes ever more cursive and contracted, giving the impression that the stonemason ran out of space in the process of carving the inscription (see, fig. 3).

\section{Selected Bibliography}

Petit, L. (1904) Documents inédits sur le concile de 1166 et ses derniers adversaires, Vizantijskij Vremennik 11, 465-493.

Classen, P. (1955) Das Konzil von Konstantinopel 1166 und die Lateiner, Byzantinische Zeitschrift 48, 339-368.

Dondaine, A. (1958) Hugues Ethérien et le concile de Constantinople de 1166, Historisches Jahrbuch 77, 473-483.

Dirimtekin, F. (1962) Marble slabs inscribed with the acts of the synod of 1166 assembled by the emperor Manuel Comnenus, Ayasofya Müzesi Yilliğı 4, 43-46.

Mango, C. (1963), The conciliar edict of 1166, Dumbarton Oaks Papers 17, 315-330.

Perocco, D. (ed.) (2008) Marc'Antonio Pigafetta, Itinerario da Vienna a Costantinopoli, Padua, 133-134.

Rhoby, A. (2018) The Poetry of Theodore Balsamon. Form and Function, in Rhoby, A. and Zagklas, N. (eds) Middle and Late Byzantine Poetry. Texts and Contexts, Turnhout, 111145: 122 and 136-138 (on Theodore Balsamon's epigram on the conciliar edict inscription) 


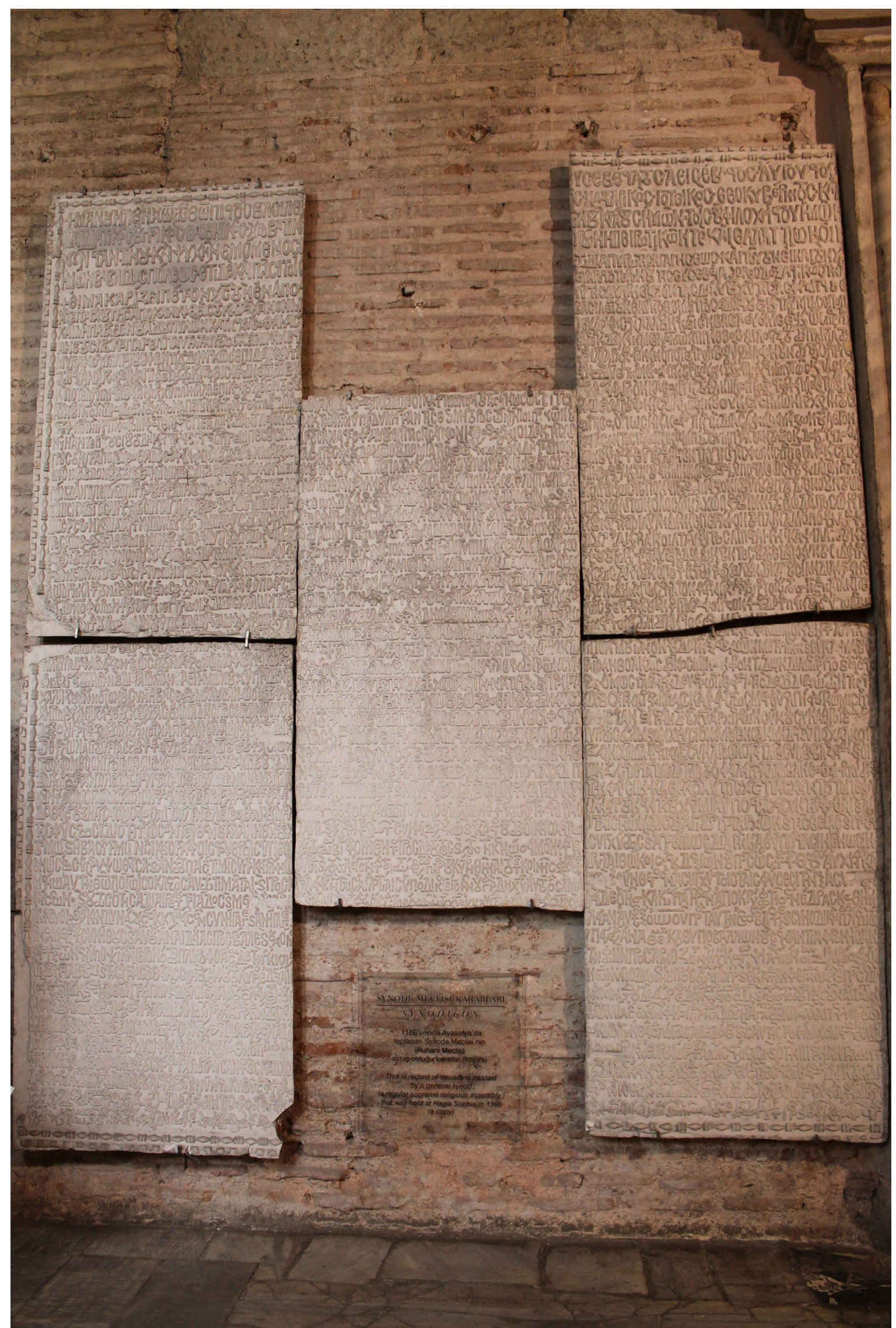

Fig. 1 Plaster casts of the Conciliar Edict of 1166 on display in the narthex of St Sophia (C) Andreas Rhoby) 


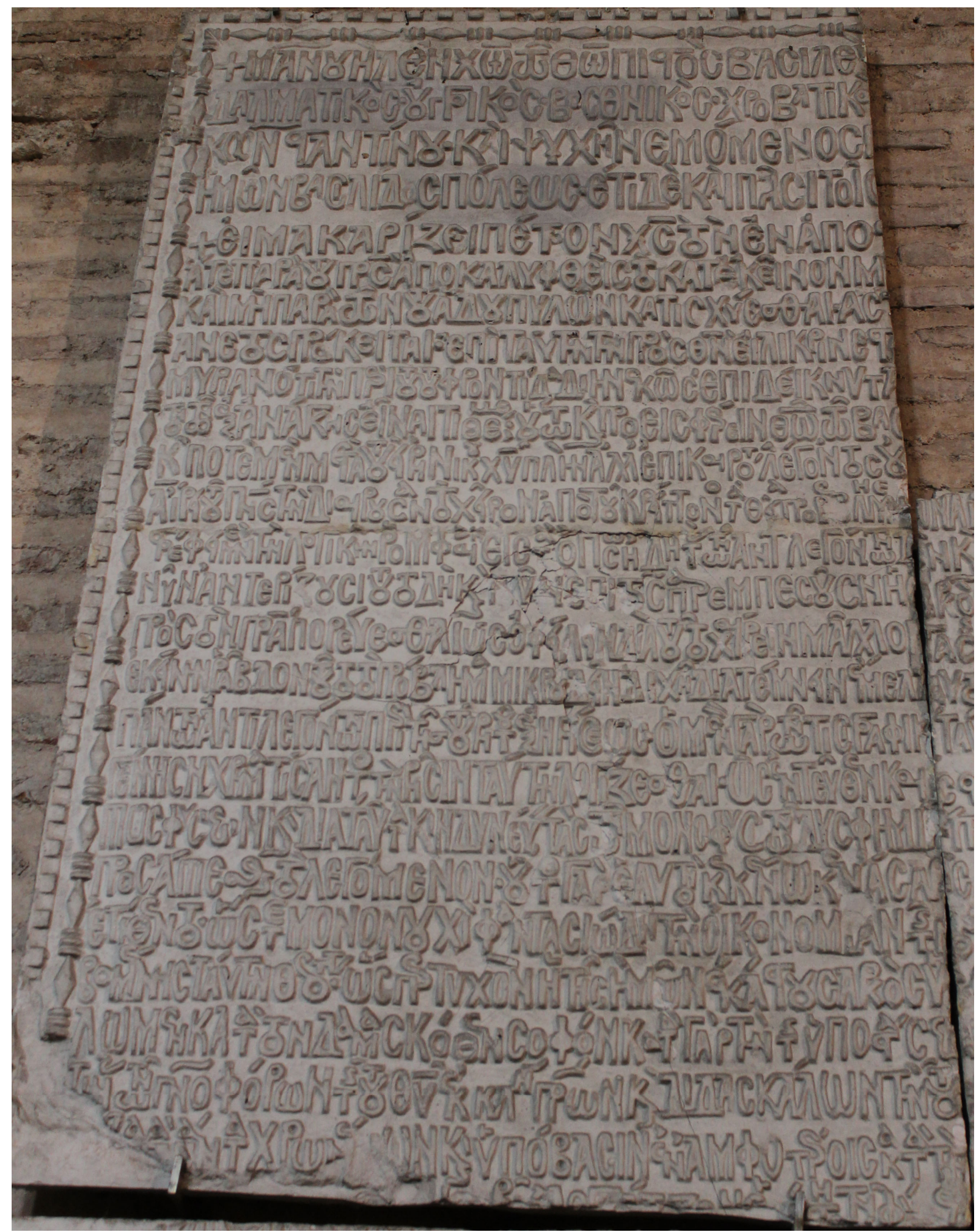

Fig. 2 Detail of the plaster cast of the Conciliar Edict of 1166 showing the beginning of the inscription (C) Andreas Rhoby) 


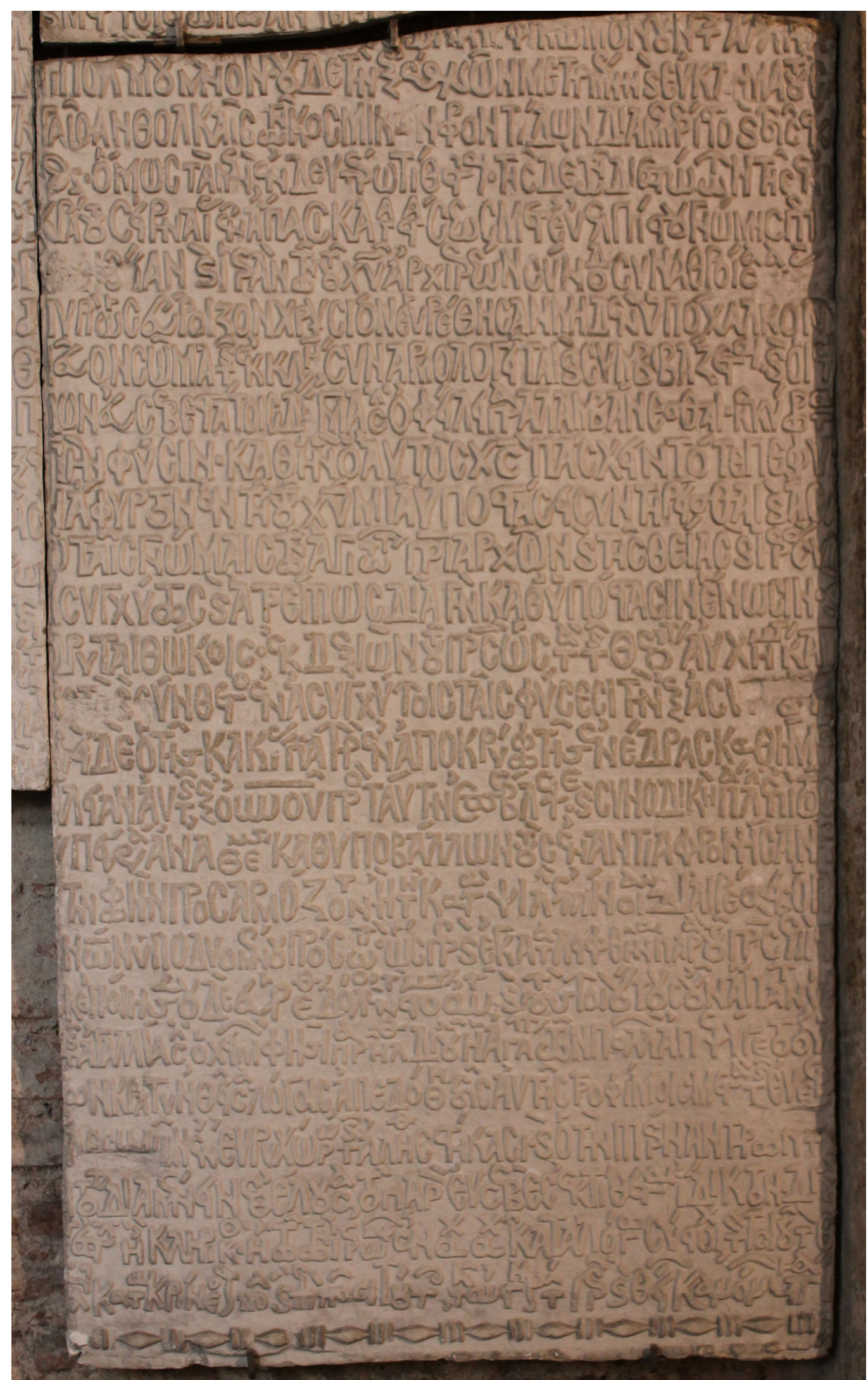

Fig. 3 Detail of the plaster cast of the Conciliar Edict of 1166 showing the end of the inscription (@ Andreas Rhoby) 


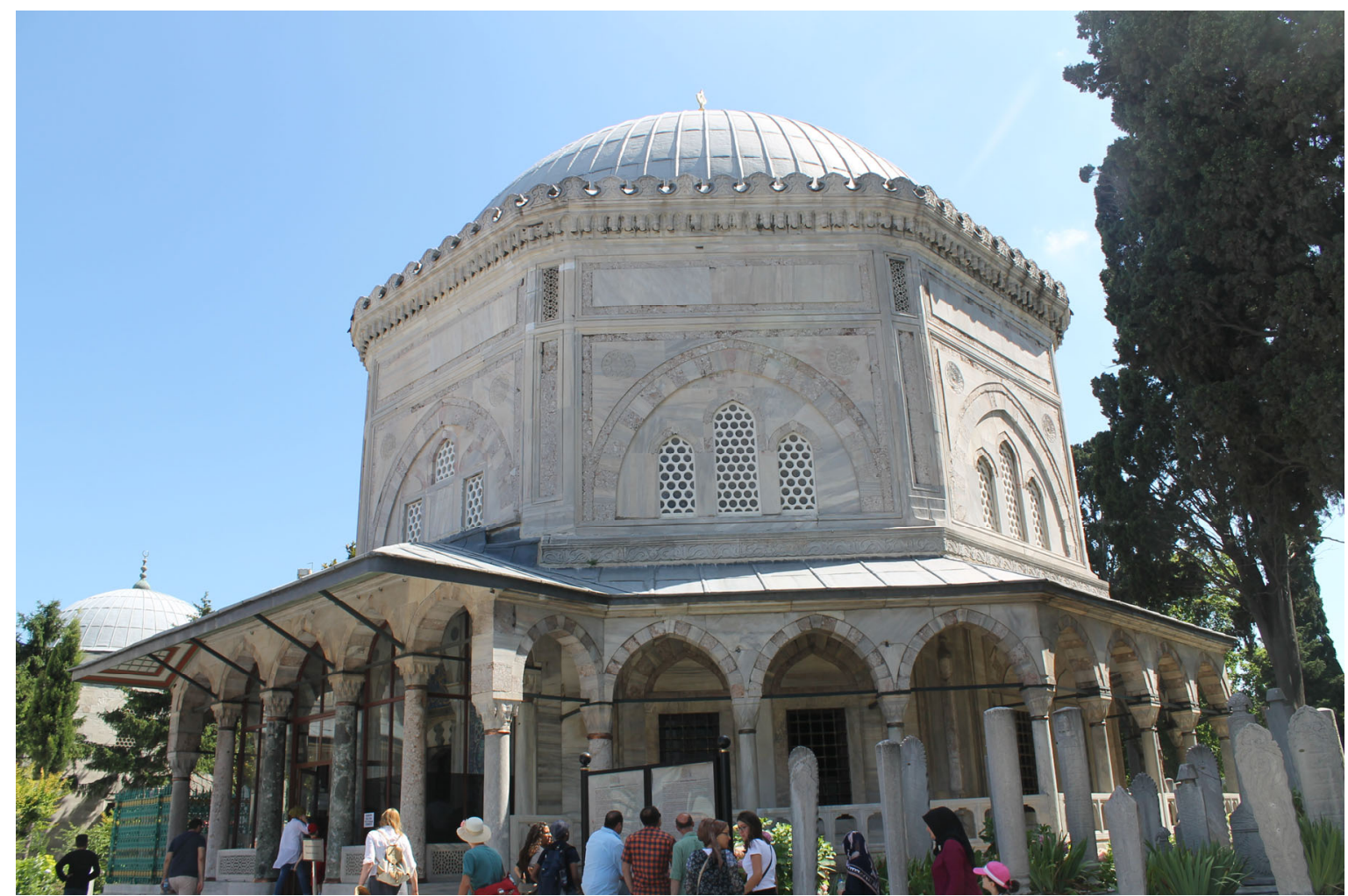

Fig. 4 Mausoleum of the Sultan Suleiman the Magnificent (C) Andreas Rhoby)

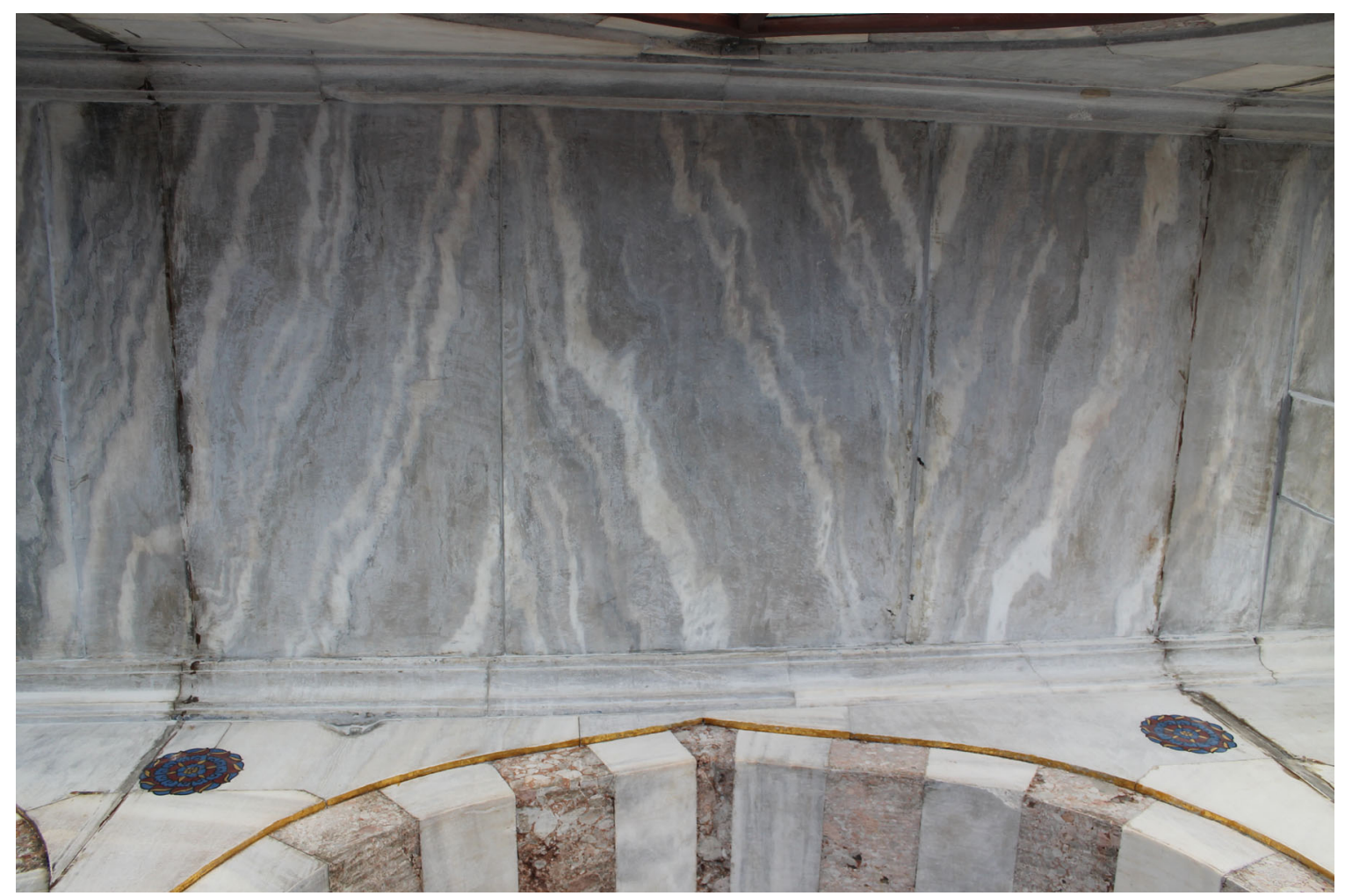

Fig. 5 Vestibule of the Mausoleum of the Sultan Suleiman the Magnificent: the reverse sides of the original inscription of the Conciliar Edict of 1166 (C) Andreas Rhoby) 



\title{
32. Graffiti in St Sophia \\ IDA Toth, MARIA XENAKI, and ANDREAS RHOBY
}

\begin{abstract}
'Astonishingly—although many scholars have studied Hagia Sophia over the years-the building has never been completely documented. New discoveries may yet be made.' (R. Ousterhout, Smithsonian Magazine, December 2008)
\end{abstract}

The habit of inscribing graffiti is arguably the most productive and least studied medieval epigraphic practice. Many contexts yield graffiti material: worship, everyday life, trade, travelling. Graffiti are found in public spaces, residential quarters, on the items of domestic and personal use, in commercial areas, on merchandise, building material, etc. (See Chapters 17 and 18 by Nikos Tsivikis) In the setting of religious architecture, the custom of informal writing on stone, plaster, wood, and ceramic should be considered an integral part of worship rituals. Often, such inscriptions consist of signatures recording the names of the faithful (be they present or absent, alive or deceased), but they can also include invocations, liturgical texts, and even requests to the reader to pray on behalf of the writer.

Although some attempts have been made to define this epigraphic category, modern scholars have yet to acknowledge that Byzantine evidence shows no clear distinction between graffiti and formal epigraphy. In her forthcoming study of the Parthenon material (to be published as a separate volume in the editions of the École française d'Athènes), Maria Xenaki has excluded the term 'graffiti' altogether on the grounds that 'official' and 'non-official' inscriptions feature the same categories of texts: obits, invocations, liturgical texts, names and ex-votos.

St Sophia graffiti are in a poor state of preservation: although many still survive in situ, many more have been removed during the building's cleaning and restoration works. Some are visible in the narthices, naos, ramps and, most abundantly, in both galleries. Others can be found in areas inaccessible to the general public, such as the southeastern portal, the skeuophylakion, the northeastern ramp and the dome.

In terms of content, St Sophia graffiti material includes: names (some written as

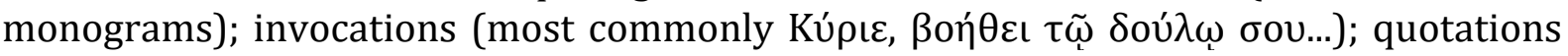
from scriptural or liturgical texts; figural/iconographic representations; cultic symbols (crosses, tetragrams). Some are in languages other than Greek: Latin, Scandinavian (Runic), Slavonic, Arabic, Ottoman (figs. 1-5).

Studying St Sophia graffiti presents many challenges: such epigraphs are poorly preserved, difficult to date, and they vary considerably in the techniques and quality of execution as well as in visibility, legibility, and accessibility. Legacy records such as Robert L. Van Nice Fieldwork Records and Papers, and some other nineteenth- and early twentieth-century scholarship provide significant supplementary information in the form of drawings, tracings, and photographs. This valuable material deserves further research, so that the graffiti of St Sophia can be re-evaluated in their original context and included in the study of this monument as a whole. 


\section{Selected Bibliography}

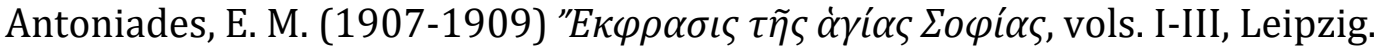

Curtis, C. G. (1869-1891) Broken Bits of Byzantium, vols. I-II, Istanbul.

Evdokimova, A. (2015) Greek graffiti in St. Sophia of Constantinople in the archive of Robert van Nice (D0, Washington), in Rhoby, A. (ed) Inscriptions in Byzantium and Beyond: Methods - Projects - Case Studies, Vienna, 167-177.

Guidobaldi, A. G. and Barsanti, C. (eds) (2004), Santa Sofia di Costantinopoli. L'arredo marmoreo della Grande Chiesa giustinianea, Vatican City, 651-734.

Kalavrezou-Maxeiner, I. and Obolensky, D. (1981) A Church Slavonic Graffito in Hagia Sophia, Istanbul, Harvard Ukrainian Studies 5/1, 5-10.

Mango, C. (1951) The Byzantine Inscriptions of Constantinople: A Bibliographical Survey, American Journal of Archaeology 55/1, 59.

Mango, C. (1962) Materials for the Study of the Mosaics of St. Sophia at Istanbul, Washington, DC.

Mango, C. (1977) L'origine de la minuscule', in La paléographie grecque et byzantine. Colloque international organisé sous les auspices du Centre national de la recherche scientifique, Paris 21-25 octobre 1974, Paris, 176 (18 graffiti in the Dome of St. Sophia)

Robert L. Van Nice Fieldwork Records and Papers, ca. 1936-1989, Collection MS.BZ.012, DO Image Collection and Fieldwork Archive:

http://atom.doaks.org/atom/index.php/robert-l-van-nice-records-and-fieldworkpapers-ca-1936-1989 

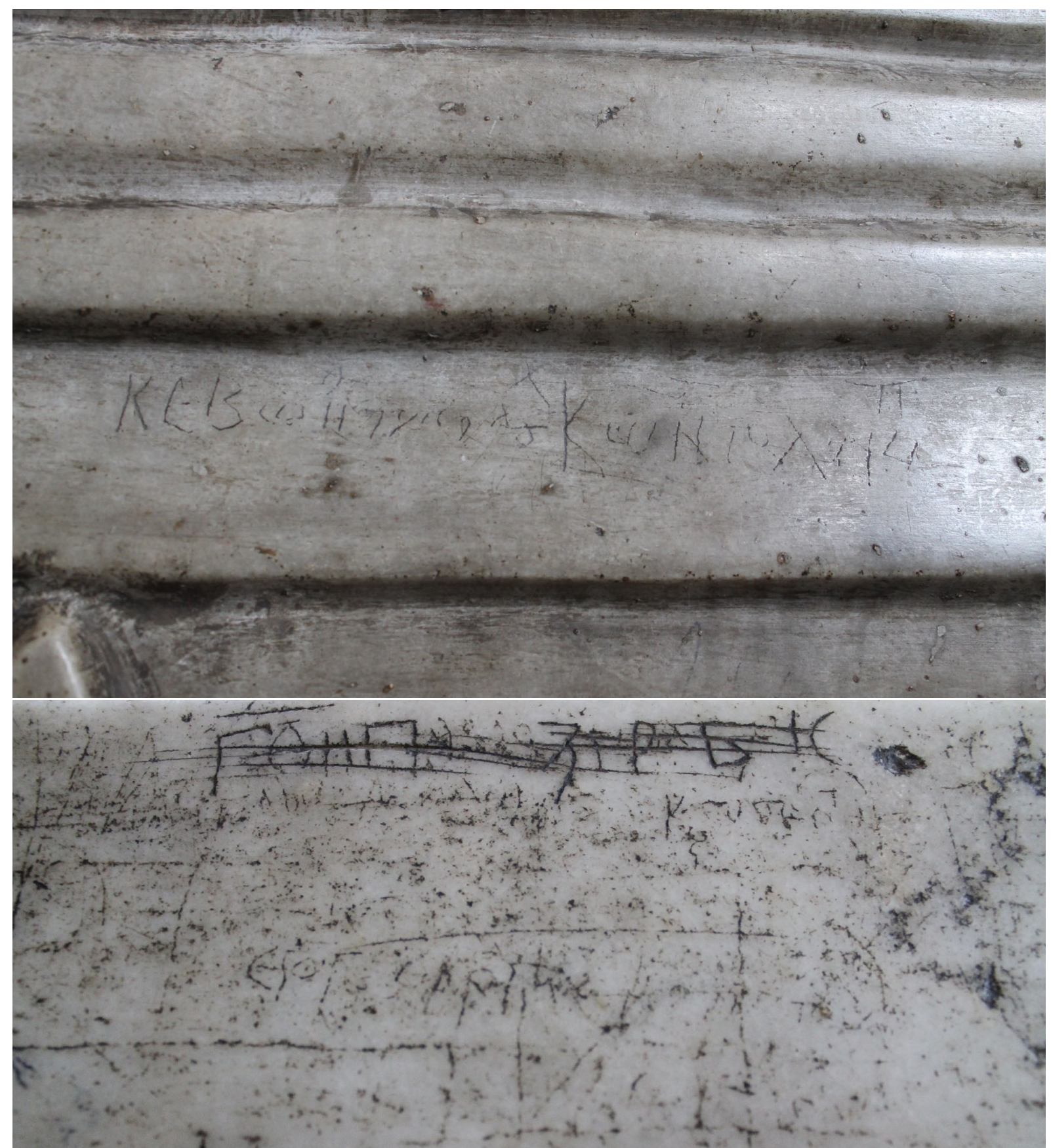

Figs. 1-2 Graffiti in the south gallery (C) Andreas Rhoby) 


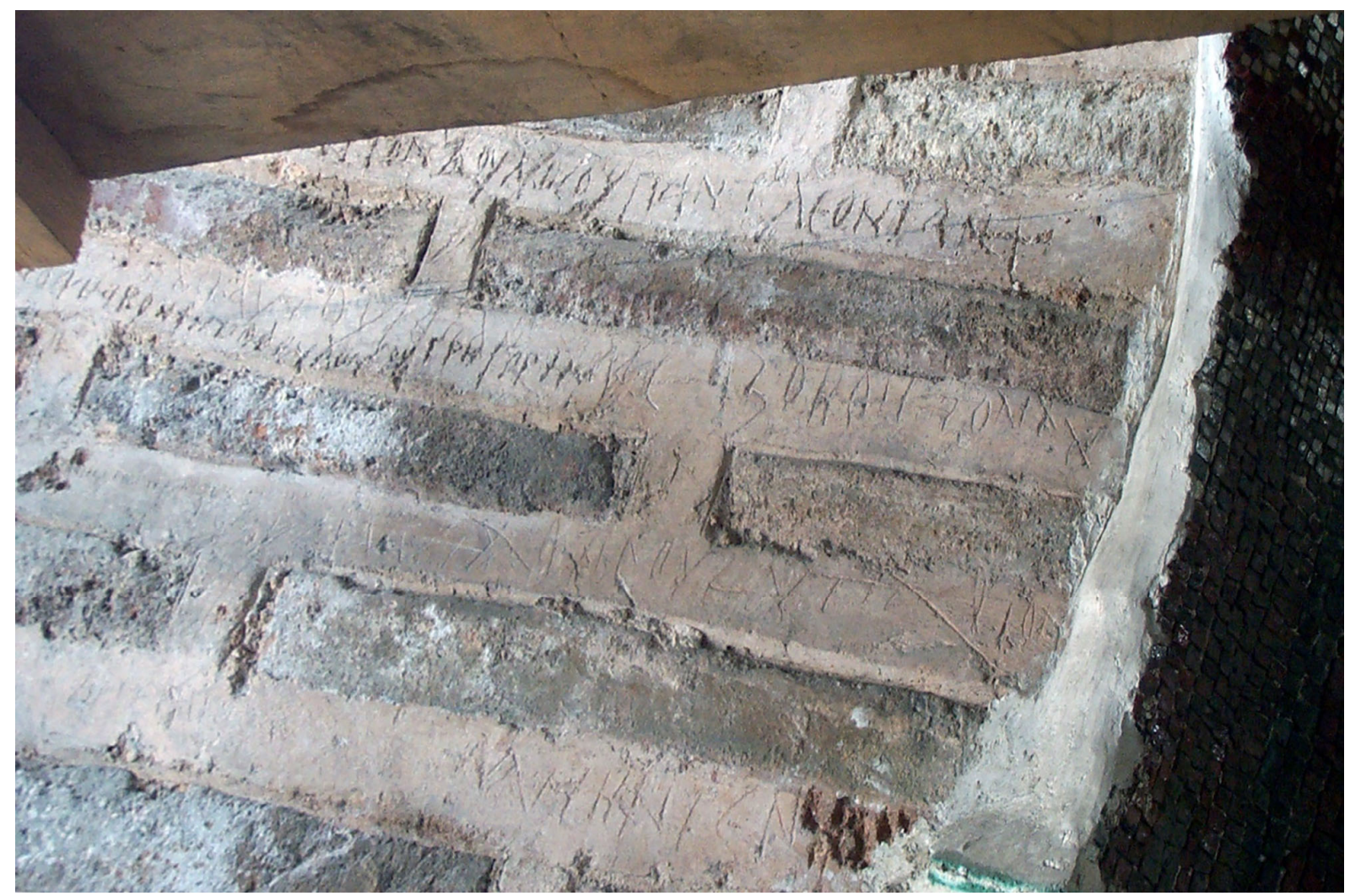

Fig. 3 Graffiti in the dome (C) Robert Ousterhout)

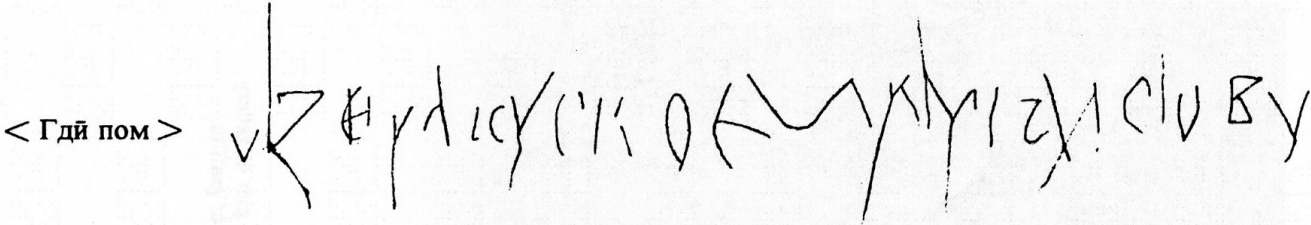

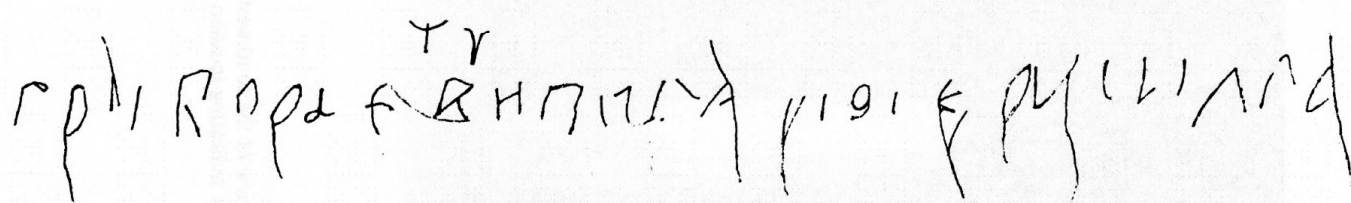

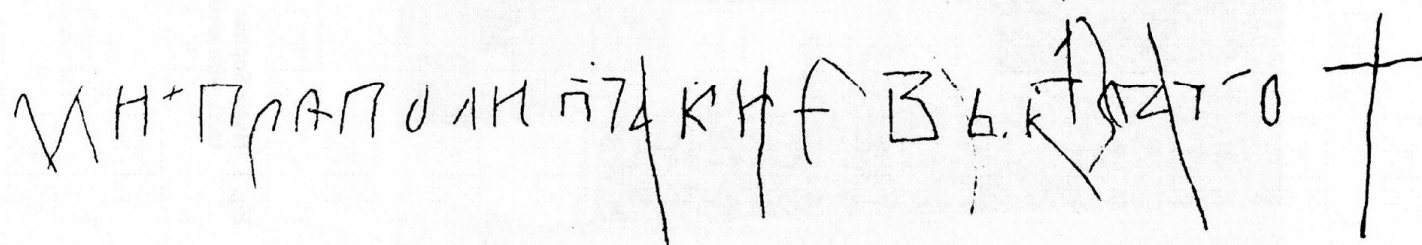

Fig. 2. Tracing of the graffito. [On the column, it is written in one continuous line.]

Fig. 4 Church Slavonic graffito (after Kalavrezou-Maxeiner and Obolensky 1981) 


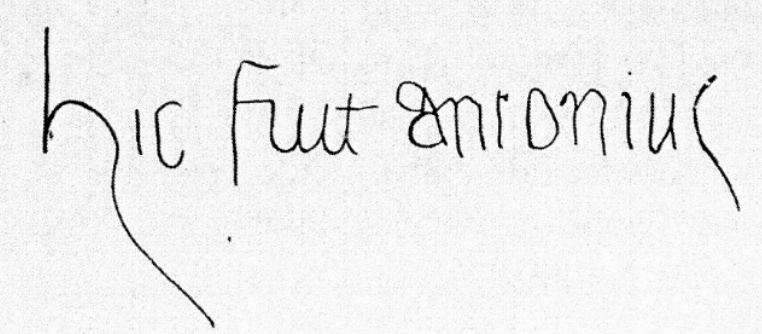

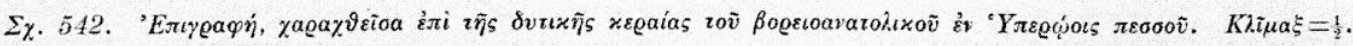

Fig. 5 Latin graffito (after Antoniadis 1908, 358)

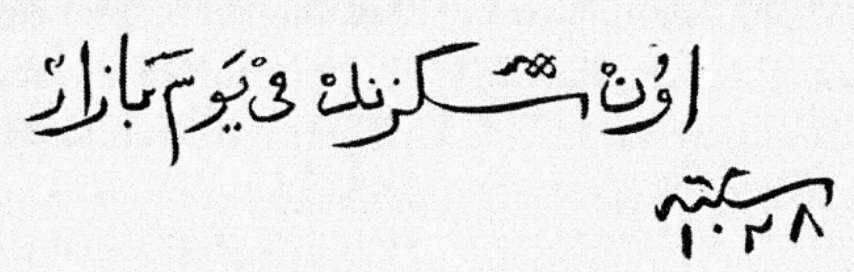

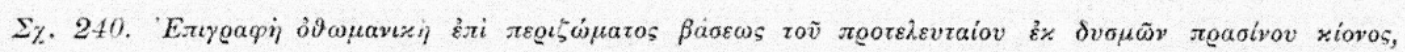

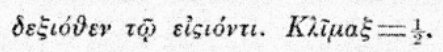

Fig. 6 Ottoman graffito (after Antoniadis 1908, 41) 



\section{THE LONGUE DURÉE: THE PAMMAKARISTOS AND THE ECUMENICAL PATRIARCHATE}





\section{The Architecture of the Church of the Theotokos Pammakaristos in Constantinople \\ MERIÇ T. ÖZTÜRK}

The Monastery of Theotokos Pammakaristos, which had a long construction history, gained prominence during the age of the Palaiologoi. After 1453, it served as the seat of the Ecumenical Patriarchate for more than a century, before it was converted into a mosque, which continues to be in use until the present day (see, fig. 1). The building has also had the status of a museum ever since the completion of the extensive restoration campaign in 1940.

The architecture of the building presents a complex picture. Due to the later additions and changes made to the original structure, the ground plan (fig. 2), such as it had initially been conceived, is not quite obvious. According to Mango and Hawkins, the architectural history of the building has at least four distinct phases:

1. The main church to the north;

2. The parekklesion (the south church, a four-column chapel); (fig. 3)

3. The perambulatory enclosing the south, west, and north sides of the building;

4. Turkish alterations.

In the past, scholars proposed several dates for the construction of the church. The current interpretation of the construction history of the building still very much relies on the studies published during the $60 \mathrm{~s}$ and $70 \mathrm{~s}$. These are still valid, although in part due to the absence of any new epigraphic, historical or archaeological evidence. Against some suggestions of the mid-eleventh century dating based on the evidence of the recessed brickwork, Mango and Hawkins concluded, albeit without specifying a date, that the building was most certainly Komnenian.

More reliable evidence is provided by epigraphy. According to an epigram in a manuscript dated to 1761 and preserved in the library of the Greek Theological College on the island of Halki, the patronage of the building is ascribed to a certain John Komnenos and his wife Anna Doukaina. This evidence was noted by Siderides at the beginning of the twentieth century. Since the manuscript disappeared after the earthquake in 1894, we have to rely on Siderides' testimony; moreover, another manuscript, dating to the sixteenth century, today in Vienna - as pointed out by Hunger and Kresten - contains the same epigram but mentions no location. Mango and Hawkins claim that Siderides was wrong in attributing the erection of the building to John Komnenos, who, incidentally, was the father of the emperor Alexios I Komnenos. They based their arguments on a document, which is today kept at Trinity College (Cambridge) as well as on the fact that Anna Dalassena, the mother of Alexios I, was not a member of the Doukas family.

A dedicatory inscription, which is said to have been inscribed on the cornice of the bema reads the follows:

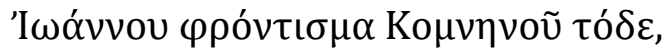

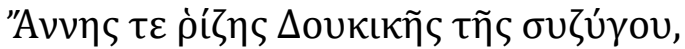

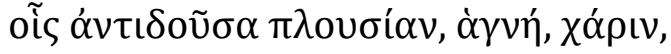

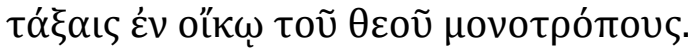


"This is the foundation of John Komnenos and his consort Anna of the stock of Doukas. Reward them, 0 Pure One, with ample grace by ordaining them as monastics in the house of God."

The architectural plan of the main church, which is dedicated to the Theotokos he Pammakaristos (Mother-of-God the All-blessed), is of a cross-in-square type. The naos was 'ambulatory' in shape, that is, it had a central square covered by the dome and it was enclosed by a u-shaped vaulted space with two lateral aisles and a passage to the west.

The extant remains of the Komnenian structure are difficult to understand. Best preserved are the central square and the dome; there survive other remains, namely, some small sections of the south wall and the outer wall of the narthex with four concave niches flanking the entrance doors. It seems that the north and west walls were removed when the perambulatory was added. Later on, probably during the Ottoman period, the apse wall was entirely destroyed. As to the architectural decorations, some parts survive: a small section of mosaic vegetal decoration, some mosaic fragments inside the windows of the south façade and in the narthex. Several remains of the pavement can also be seen featuring marble and opus sectile.

Although the building may have suffered during the period of Latin rule, we do not exactly know to what extent it might have been damaged. It underwent extensive repair works as well as being extended after it came into the possession of the protostrator Michael Glabas Tarchaneiotes. The epigrams by Manuel Philes indicate that Maria, Michael's widow, built and decorated parts of the parekklesion after his death. These also included his tomb. (See also, Ivan Drpić, Chapter 34) The parekklesion was built during the reign of the Emperor Andronikos II (1282-1328), probably shortly after 1310, possibly in 1315 . The northern part of the perambulatory might have been constructed in the intervening period between the construction of the main church and the parekklesion.

The parekklesion retains the original cross-in-square design. It has its own narthex and a gynecaeum. Rather than being a side-chapel, it serves as an independent church. It was raised to the same height as the main church, which gives it a vertical appearance especially visible in its relatively narrow and elongated interior.

The parekklesion also included burials. Various members of the Glabas family were buried in the narthex. Mango and Hawkins make note of the two arcosolia in the east wall, where a fragment of mosaic decoration is still visible. A third arcosolium in the west wall is located to the north of the entrance door of the narthex. Moreover, on the northern wall of the naos, a broad niche was revealed after a restoration. If it served as an arcosolium, as Mango suggests, it must have belonged to Manuel Glabas himself. Numerous, albeit fragmentary, remains indicate that the interior was richly decorated throughout.

\section{Selected Bibliography (in a chronological order)}

van Millingen, A. (1912, reprint 1974) Byzantine Churches in Constantinople, London. Ogan, A. (1949) Aya Maria Pammakaristos Fethiye Camii, Belleten 50, 271-308.

Mango, C. and Hawkins, E. J. W. (1964), Report on Field Work in Istanbul and Cyprus, 1962-1963, Dumbarton Oaks Papers 18, 319-340.

Schreiner, P. (1971) Eine unbekannte Beschreibung der Pammakaristoskirche (Fethiye Camii) und weitere Texte zur Topographie Konstantinopels, Dumbarton Oaks Papers 25, 217-248. 
Mathews, T.F. (1976) The Byzantine Churches of Istanbul. A Photographic Survey, University Park and London.

Restle, M. (1976) Istanbul, Bursa, Edirne, Iznik. Baudenkmäler und Museen, Stuttgart, 128133.

Belting, H., Mango, C. and Mouriki, D. (1978) The Mosaics and Frescoes of St. Mary Pammakaristos, Washington, D.C.

Ousterhout, R. (1999) Master Builders of Byzantium, Princeton.

Rhoby, A. (2009) Byzantinische Epigramme auf Stein (= Byzantinische Epigramme in inschriftlicher Überlieferung, vol. 3), Vienna, no. TR70.

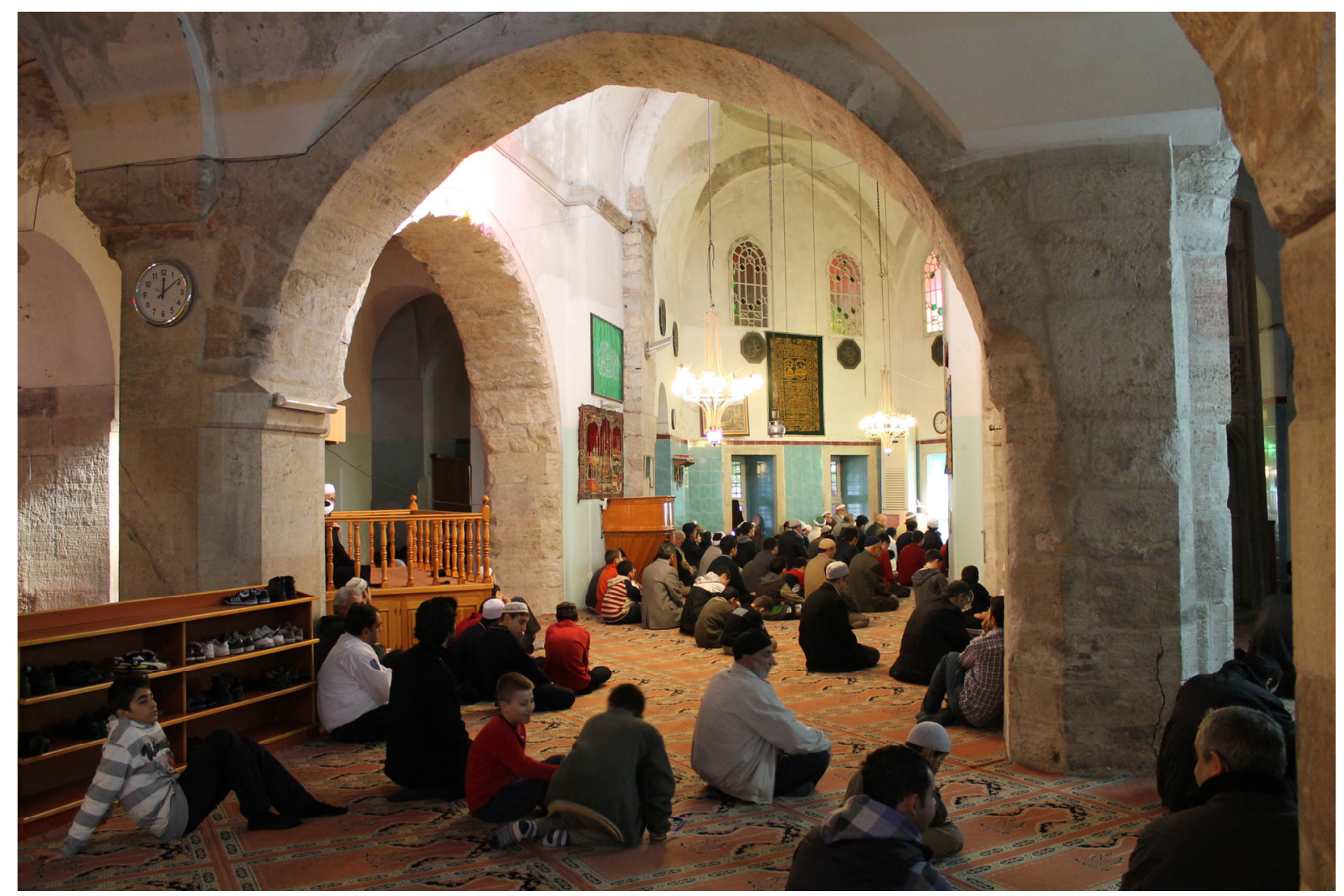

Fig. 1 Interior of the Fethiye Camii (C) Andreas Rhoby) 


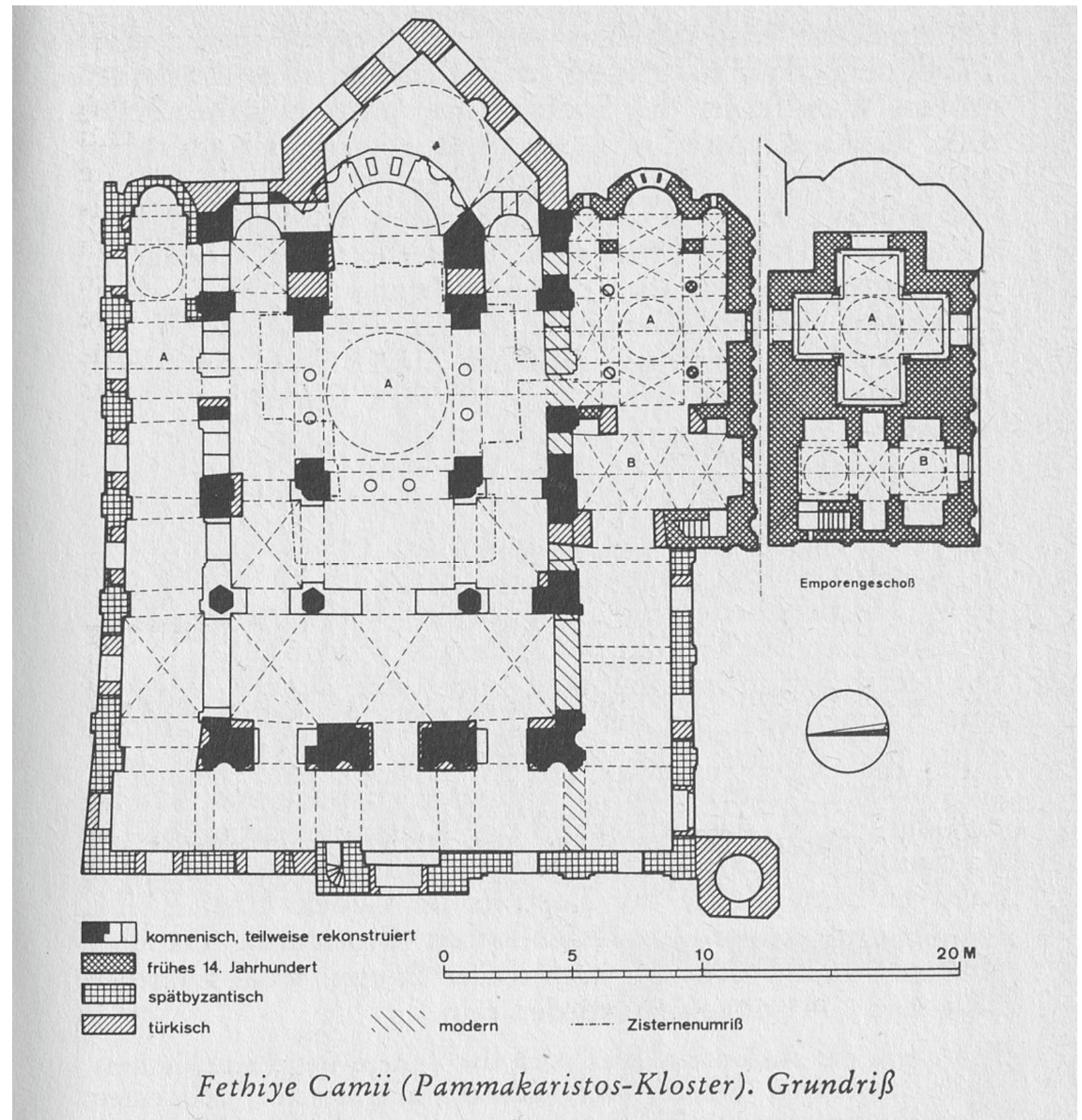

Fig. 2 Ground plan of the Pammakaristos Church (after Restle 1976, 131) 


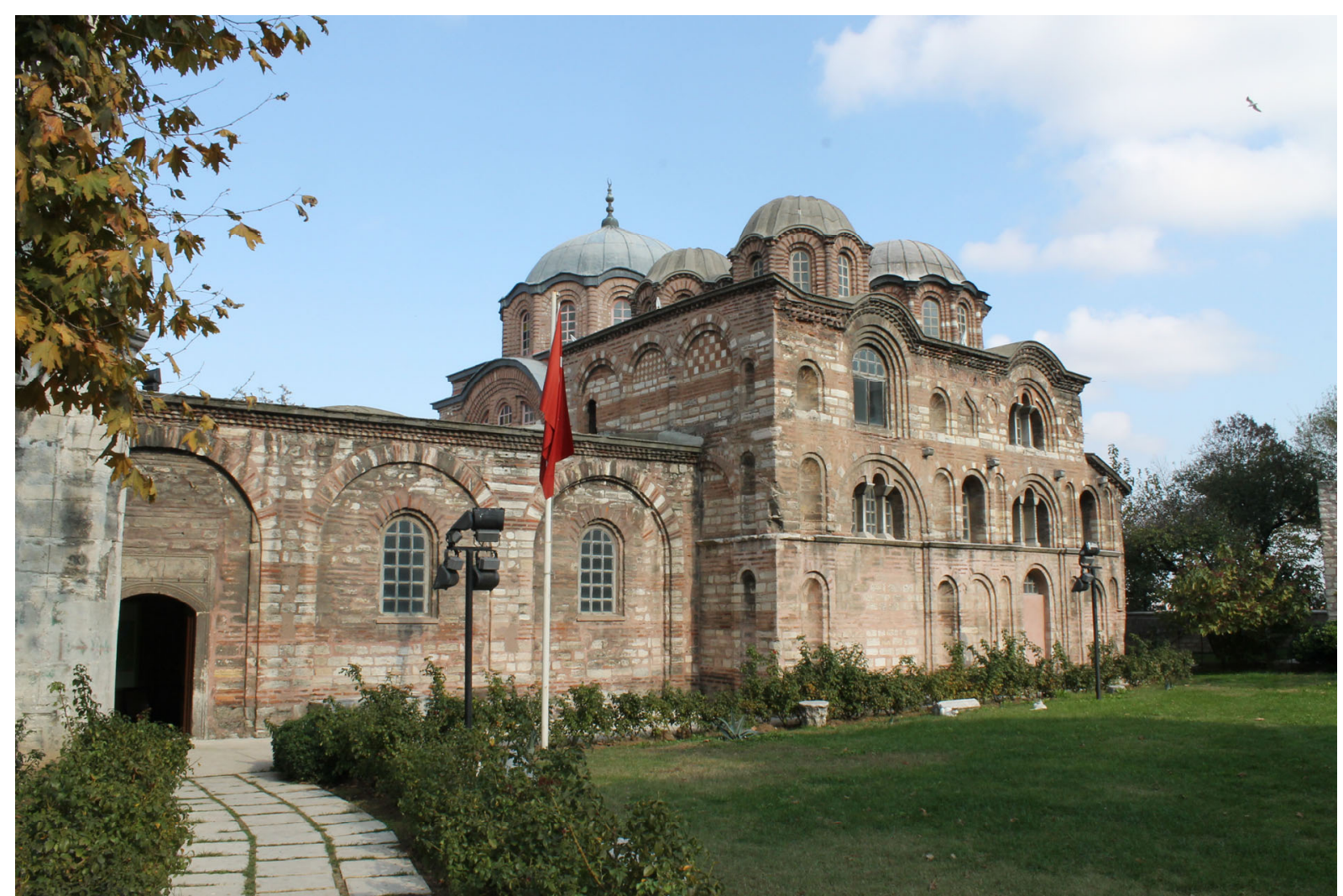

Fig. 3 The Parekklesion of the Pammakaristos Church () Andreas Rhoby) 



\section{The South Parekklēsion of the Church of the Theotokos Pammakaristos (Fethiye Camii): Inscriptions IVAN DRPIĆ}

The Monastery of the Theotokos Pammakaristos (see, Meriç T. Öztürk, Chapter 33), located on Istanbul's fifth hill, is an eleventh- or twelfth-century foundation, which appears to have suffered damage and neglect during the Latin rule of Constantinople (1204-1261). In the decades following the recapture of the city by the Byzantines, the monastery was restored by the prōtostratōr Michael Doukas Glabas Tarchaneiotes and his wife Maria (PLP 27504 and 27511 [= 4202]). Under the patronage of this aristocratic couple, a parekklēsion, most likely dedicated to Christ, was added to the south flank of the monastery's katholikon (fig. 1). This elegant domed structure of the cross-in-square type, preceded by a narthex, served as the prōtostratōr's mausoleum. At the time of Glabas' death sometime between 1305 and 1308, the building was still unfinished. It received its mosaic decoration, as well as a set of metrical inscriptions, or epigrams, at the behest of the prōtostratōr's widow Maria, who, in the meantime, had taken the veil under the name of Martha.

The marble cornice running around the west and south façades of the parekklēsion features an epigram composed by Manuel Philes, the most prolific and sought-after poet of the early Palaiologan period, who wrote numerous pieces of occasional poetry for the prōtostratōr and his wife (no. I below; see Manuelis Philae carmina: ex codicibus Escurialensibus, Florentinis, Parisinis et Vaticanis, ed. E. Miller, vol. 1 [Paris, 1855], pp. 117118 [no. E CCXXIII]). This exterior inscription is essentially an epitaph, a funerary poem in which Maria-Martha pours out her grief in a direct address to her deceased husband. (See, also Chapter 35 by Ariel Fein) Two further epigrams-which, too, probably came from Philes' pen-are displayed inside the parekklēsion. One unfolds along the two marble cornices girding the nave (no. II). The text, painted in gold on a blue background, is badly damaged. It takes the form of a prayer to Christ voiced on behalf of Glabas. The other epigram, lettered in mosaic, surrounds the figure of Christ Hyperagathos, which graces the conch of the parekklēsion's sanctuary apse (no. III). This text serves a dedicatory role; it identifies the parekklēsion as a gift offered to Christ by Maria-Martha for the salvation of her husband. A final element of the parekklēsion's epigraphic program is the heavily abbreviated monogrammatic inscription made of tiles embedded in mortar, which can be seen on the south façade of the parekklēsion, below the eaves (no. IV). Perhaps also metrical, the inscription records the prōtostratōr's name.

Overall, the south parekklēsion of the Pammakaristos church exemplifies how élite Byzantines strategically deployed monumental epigraphy-and epigrammatic poetry in particular-to commemorate acts of religious patronage, proclaim their piety and munificence, and assert their identity, social status, and cultural ascendancy. What makes the parekklēsion's inscriptional décor particularly notable is the care with which the graphic, material, and spatial elements of the displayed epigrams were stressed and sometimes purposefully manipulated to enhance the impact of these texts. 


\section{Selected Bibliography}

van Millingen, A. (1912) Byzantine Churches in Constantinople, London, 157-160.

Hallensleben, H. (1963-1964) Untersuchungen zur Baugeschichte der ehemaligen Pammakaristoskirche, der heutigen Fethiye camii in Istanbul, Istanbuler Mitteilungen 13-14, 128-193.

Megaw, A. H. S. (1963) Notes on Recent Work of the Byzantine Institute in Istanbul, Dumbarton Oaks Papers 17, 333-371, at 367-371.

Belting, H., Mango, C. and Mouriki, D. (1978) The Mosaics and Frescoes of St. Mary Pammakaristos (Fethiye Camii) at Istanbul, Washington, DC.

Kidonopoulos, V. (1994) Bauten in Konstantinopel 1204-1328: Verfall und Zerstörung, Restaurierung, Umbau und Neubau von Profan- und Sakralbauten, Wiesbaden, 80-86.

Papalexandrou, A. (2001) Text in Context: Eloquent Monuments and the Byzantine Beholder, Word \& Image 17/3, 259-83, at 269-271, 276-277.

Effenberger, A. (2006-2007) Zur Restaurierungstätigkeit des Michael Dukas Glabas Tarchaneiotes im Pammakaristoskloster und zur Erbauungszeit des Parekklesions, Zograf 31, 79-94.

Rhoby, A. (2009 and 2014) Byzantinische Epigramme in inschriftlicher Überlieferung, vol. 1, Byzantinische Epigramme auf Fresken und Mosaiken, Vienna, 307-310 (no. 215), 402403 (no. M15); vol. 3, Byzantinische Epigramme auf Stein: nebst Addenda zu den Bänden 1 und 2, Vienna, 657-668 (no. TR73-TR77).

Marinis, V. (2014) Architecture and Ritual in the Churches of Constantinople: Ninth to Fifteenth Centuries, New York, 191-198 (no. XXIV).

Drpić, I. (2016) Chrysepes Stichourgia: The Byzantine Epigram as Aesthetic Object, in Bedos-Rezak, B. and Hamburger, J. F. (eds) (2016) Sign and Design: Script as Image in Cross-Cultural Perspective (300-1600 CE), Washington, DC, 51-69, at 52-54.

Drpić, I. (2016) Epigram, Art, and Devotion in Later Byzantium, Cambridge and New York, 203-214.

\section{Metrical inscription carved along the marble cornice on the exterior of the parekklēsion (figs. 2-4)}

Ed. Rhoby 2014, no. TR76.

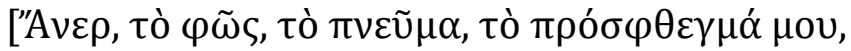

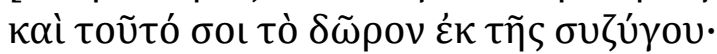

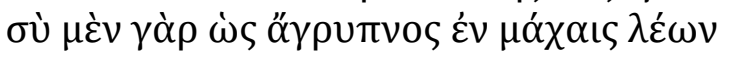

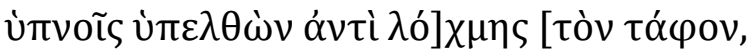

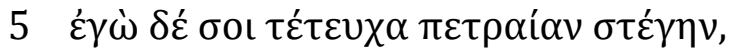

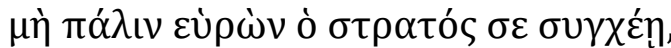

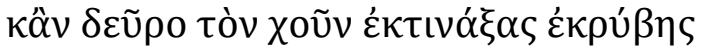

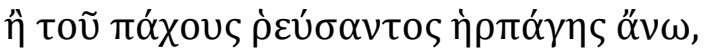

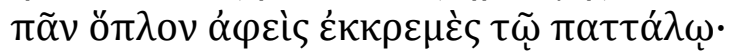

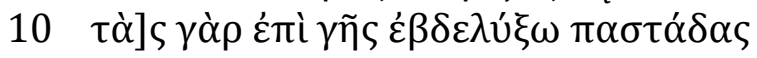

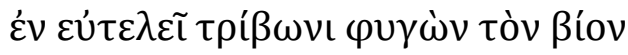

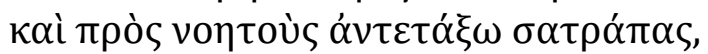

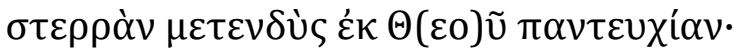

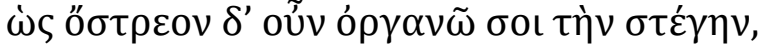




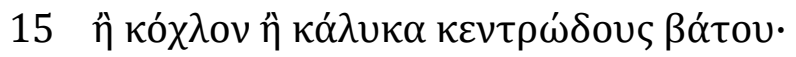

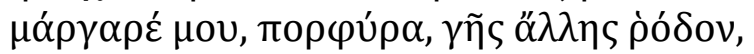

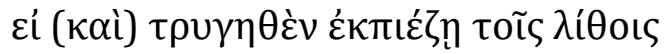

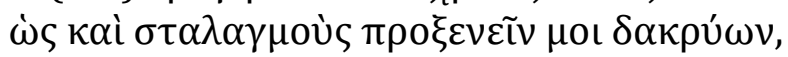

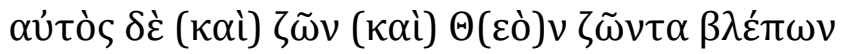

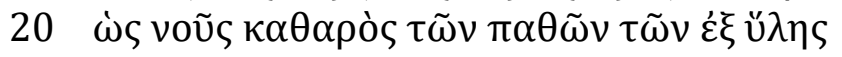

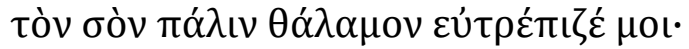

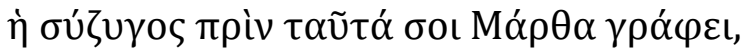

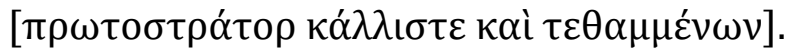

\section{Metrical inscription painted along the lower and upper cornices in the parekklēsion's nave (figs. 5-6)}

Ed. Rhoby 2009, no. 215.

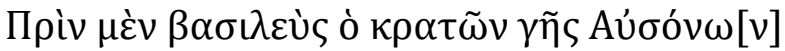

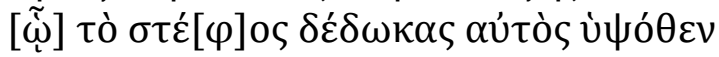

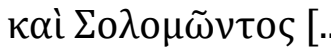

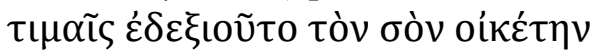

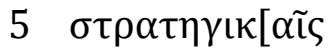
...]

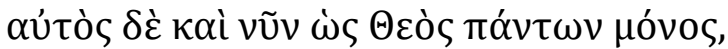
$\tilde{\omega} \Sigma \tilde{\omega} \tau \varepsilon \rho, \tilde{\omega} \varphi \tilde{\omega} \varsigma, \tilde{\omega} \gamma \lambda \cup \kappa \alpha \sigma \mu \varepsilon \dot{\varepsilon}, \Delta \varepsilon \sigma \pi o ́ \tau \alpha$,

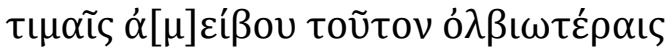

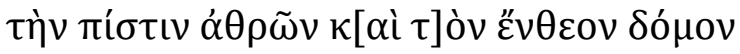

10 öv $\alpha \dot{v} \tau \grave{\lambda} \lambda \varepsilon \pi \tau \tilde{\omega}[v$

15

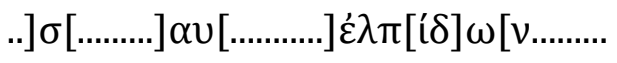

$\tau \tilde{\omega}] \nu \sigma \tilde{\omega} v \pi \rho \grave{s} \grave{\eta}[\mu \tilde{\alpha} \varsigma] \delta \omega \rho \varepsilon \tilde{\omega} \nu \sigma \omega[\tau \eta \rho i ́ \omega v]$

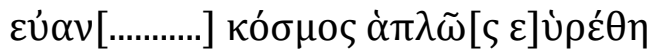

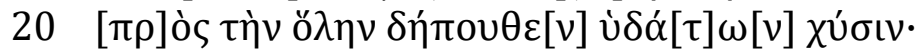

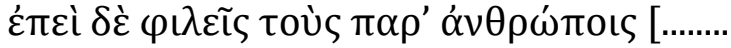

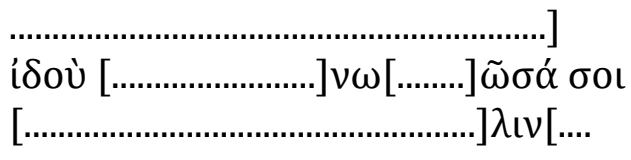

25 
III. Metrical mosaic inscription surrounding the figure of Christ Hyperagathos in the parekklēsion's apse (fig. 7)

Ed. Rhoby 2009, no. M15.

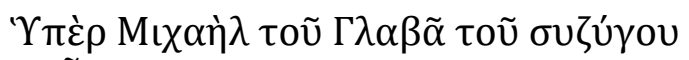

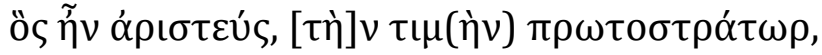

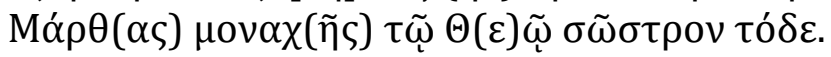

\section{Metrical (?) tile inscription on the exterior of the parekklēsion (fig. 8)}

Ed. Rhoby 2014, no. TR77.

$\mathrm{M}(\mathrm{l}) \chi(\alpha \grave{\eta} \lambda) \Delta \mathrm{oú} \kappa(\alpha \varsigma) \Gamma \lambda \alpha \beta(\tilde{\alpha} \varsigma) \mathrm{T} \alpha \rho \chi \alpha \nu(\varepsilon \mathrm{l}) \omega ́ \tau(\eta \varsigma)$

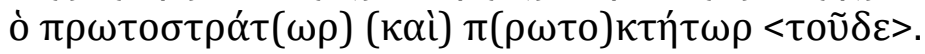

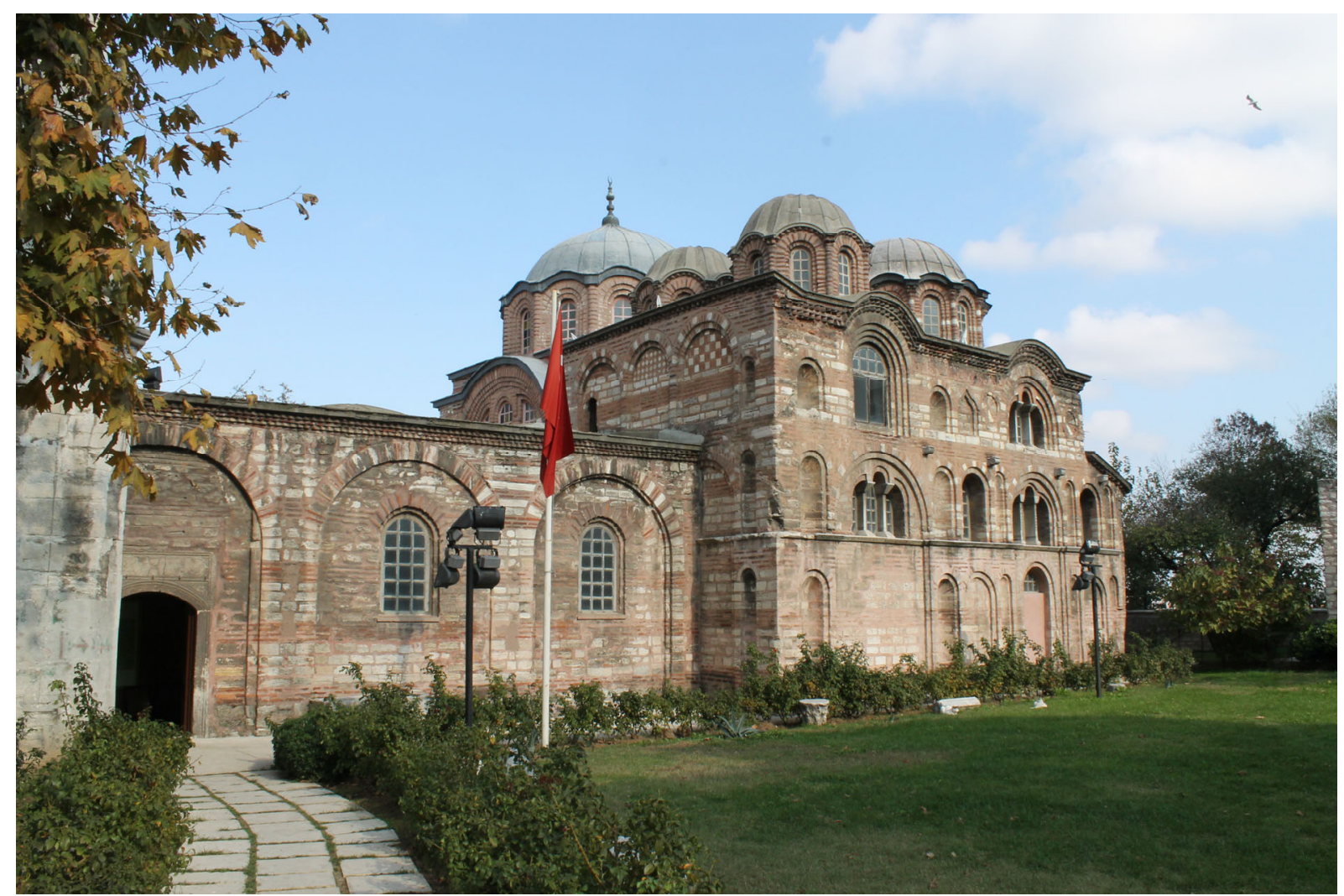

Fig. 1 The Parekklesion of the Pammakaristos Church (C) Andreas Rhoby) 


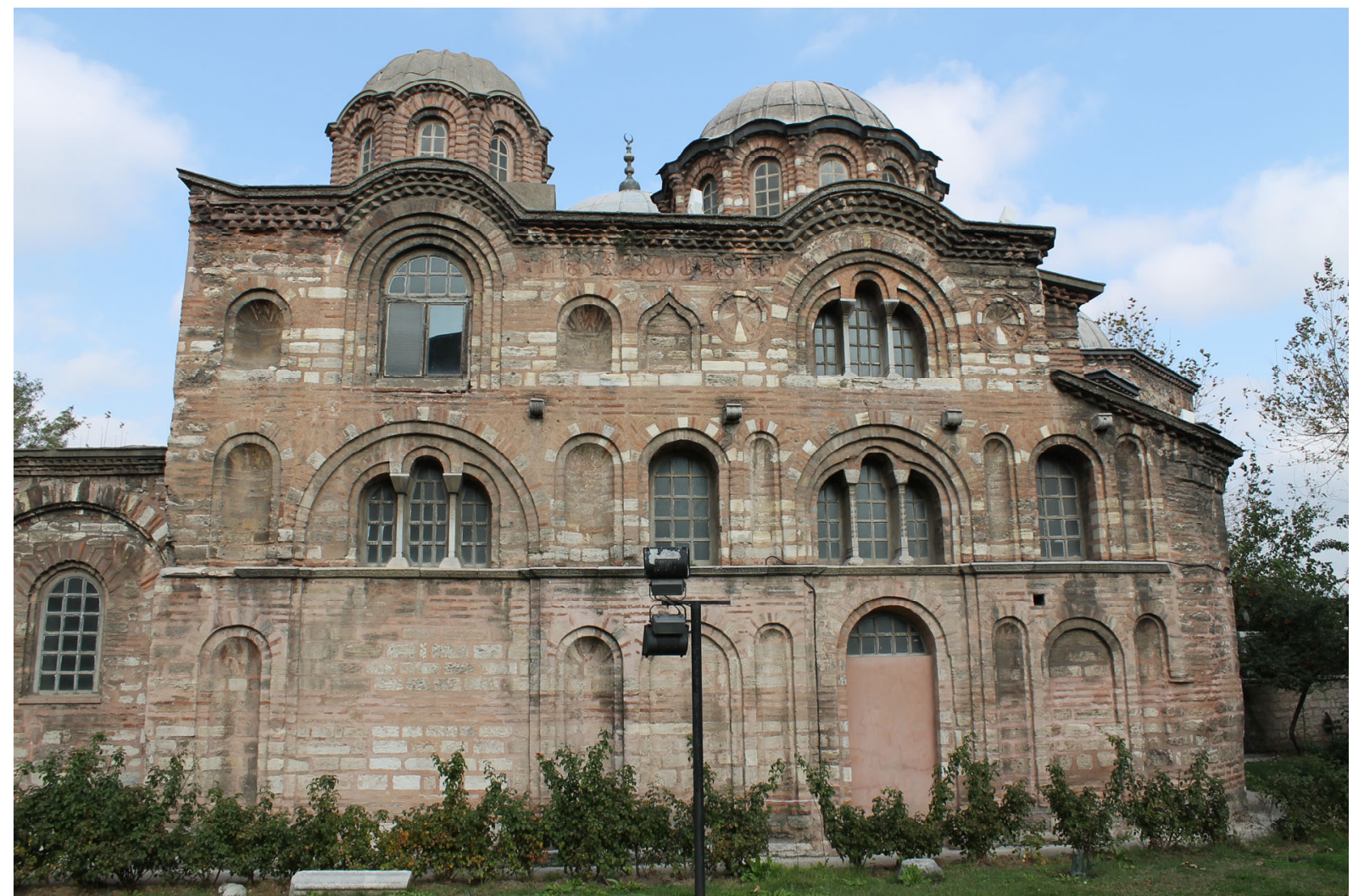

Fig. 2 The Parekklesion of the Pammakaristos Church, inscription no. I on the outer cornice (C) Andreas Rhoby)

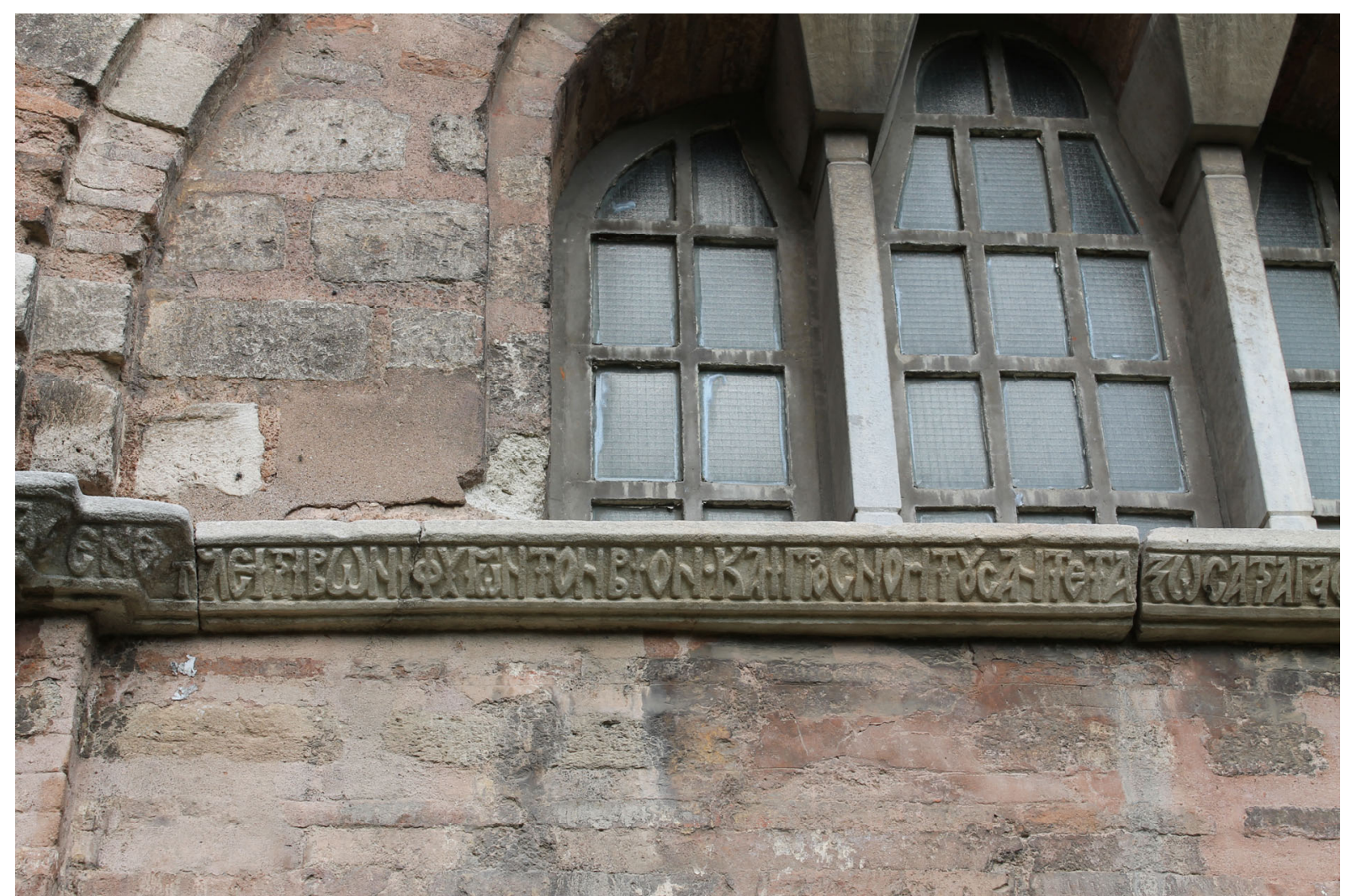

Fig. 3 Detail of fig. 2 (C) Andreas Rhoby) 


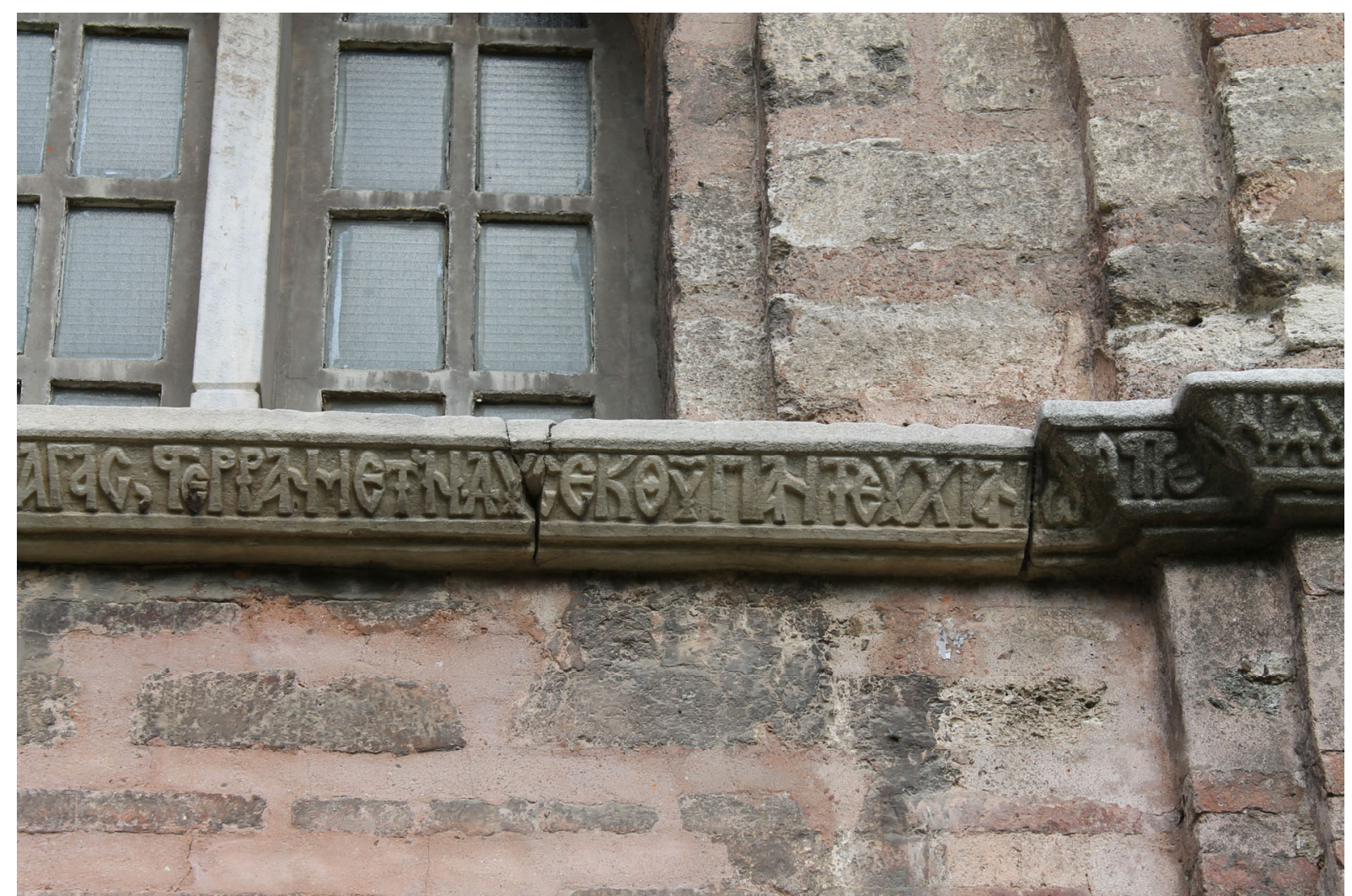

Fig. 4 Detail of fig. 2 (C) Andreas Rhoby)

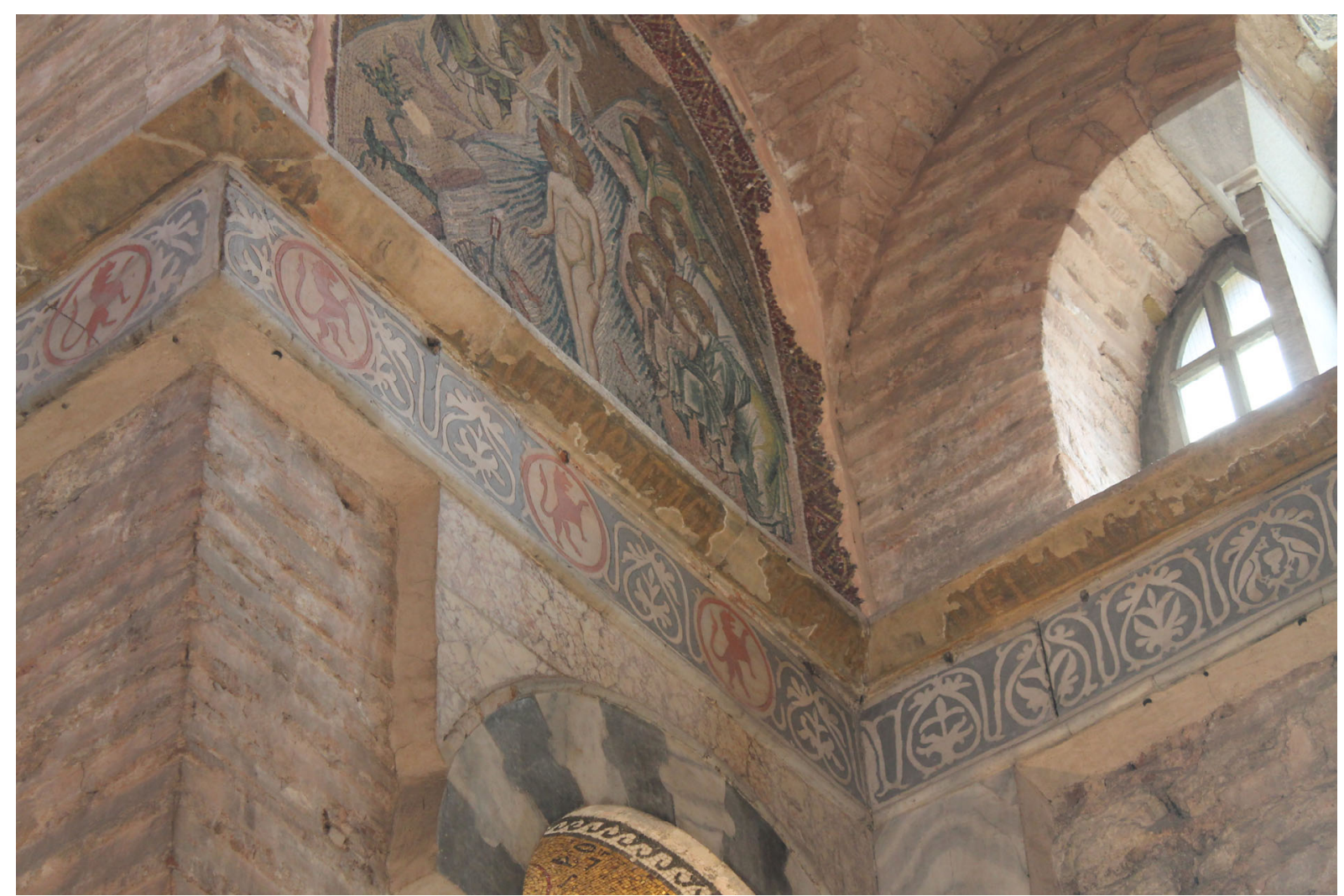

Fig. 5 The Parekklesion of the Pammakaristos Church, inscription no. II painted along the lower and upper cornices in the parekklēsion's nave, detail (C) Andreas Rhoby) 


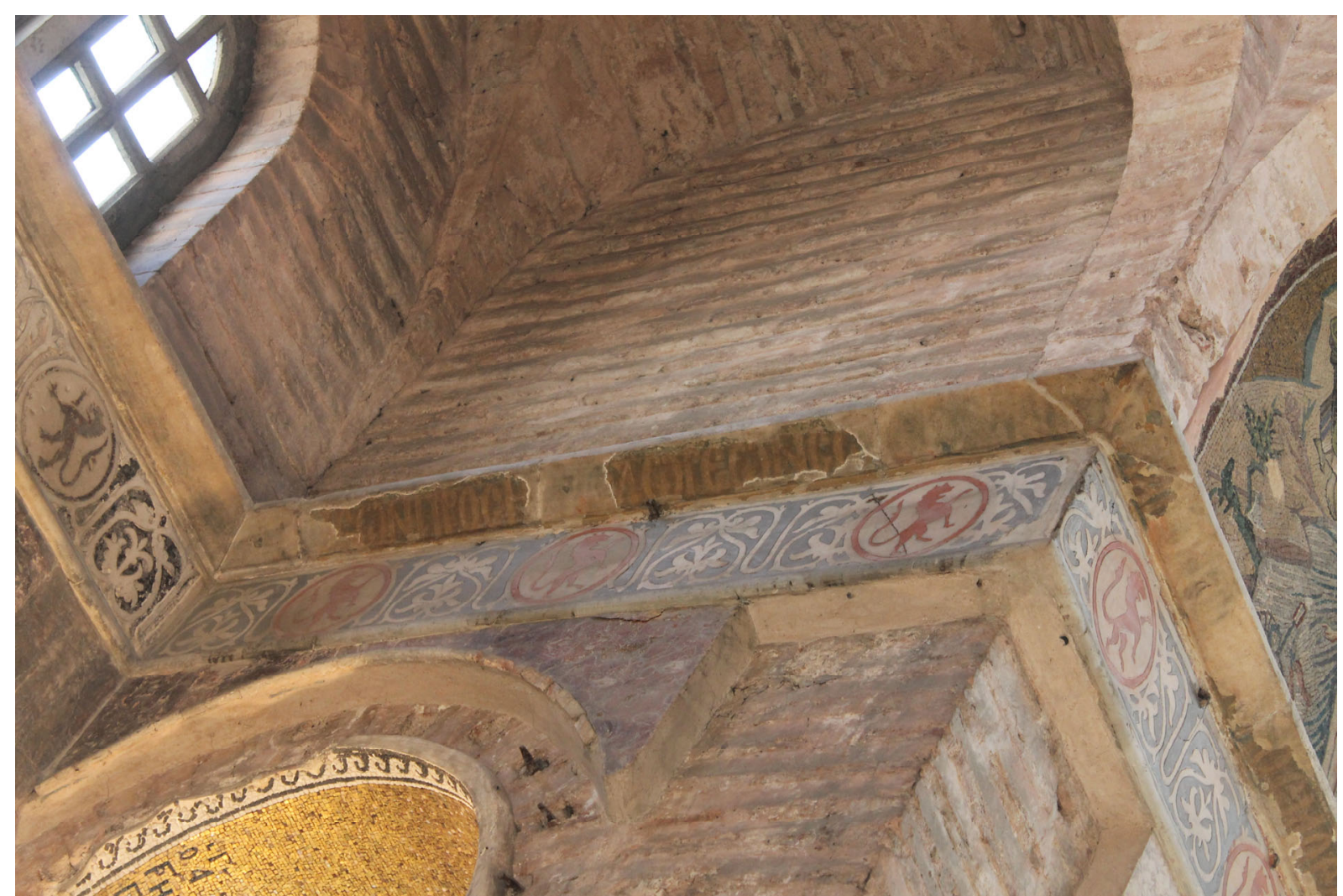

Fig. 6 The Parekklesion of the Pammakaristos Church, inscription no. II painted along the lower and upper cornices in the parekklēsion's nave, detail (C) Andreas Rhoby)

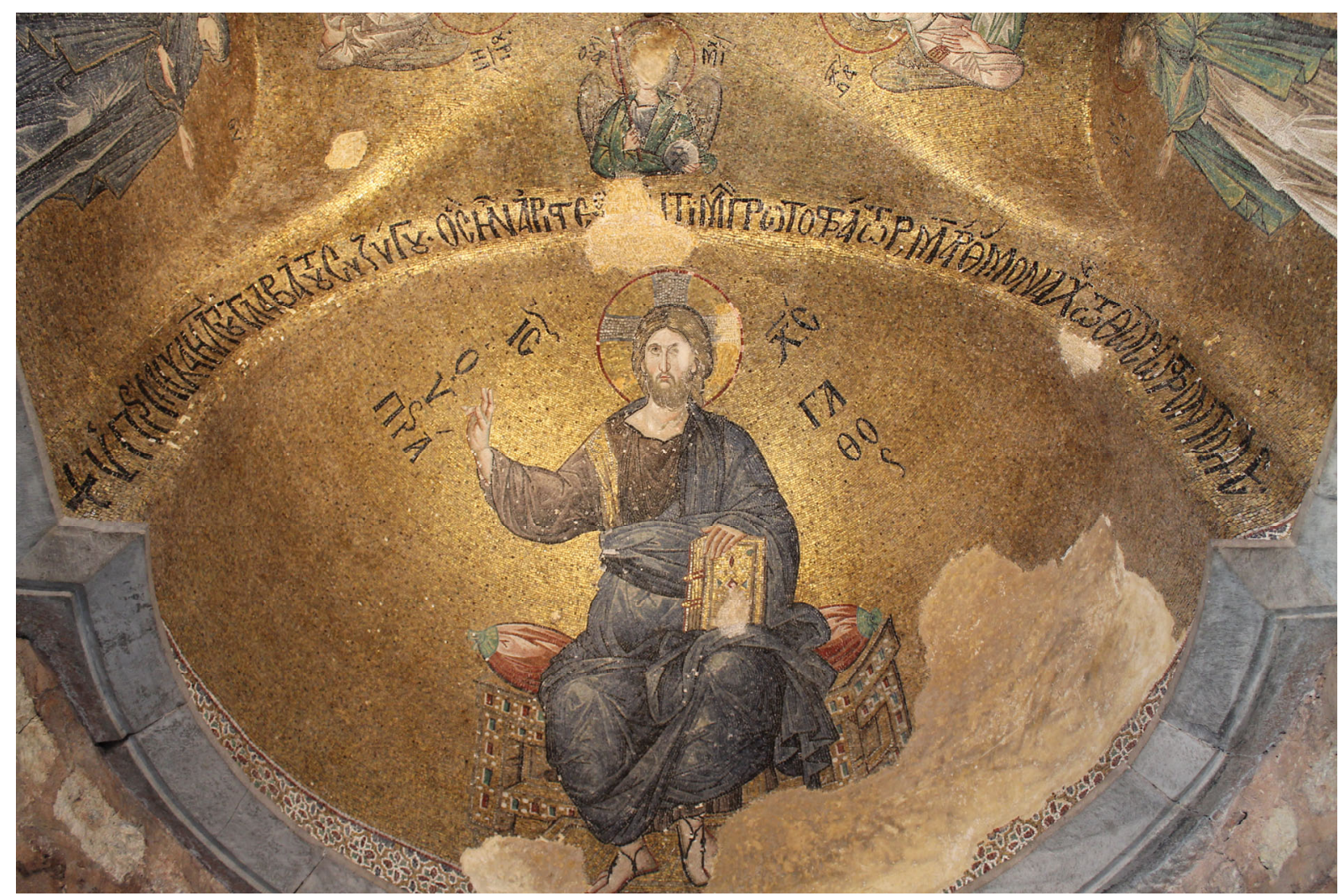

Fig. 7 The Parekklesion of the Pammakaristos Church, inscription no. III surrounding the figure of Christ Hyperagathos in the parekklēsion's apse (C) Andreas Rhoby) 


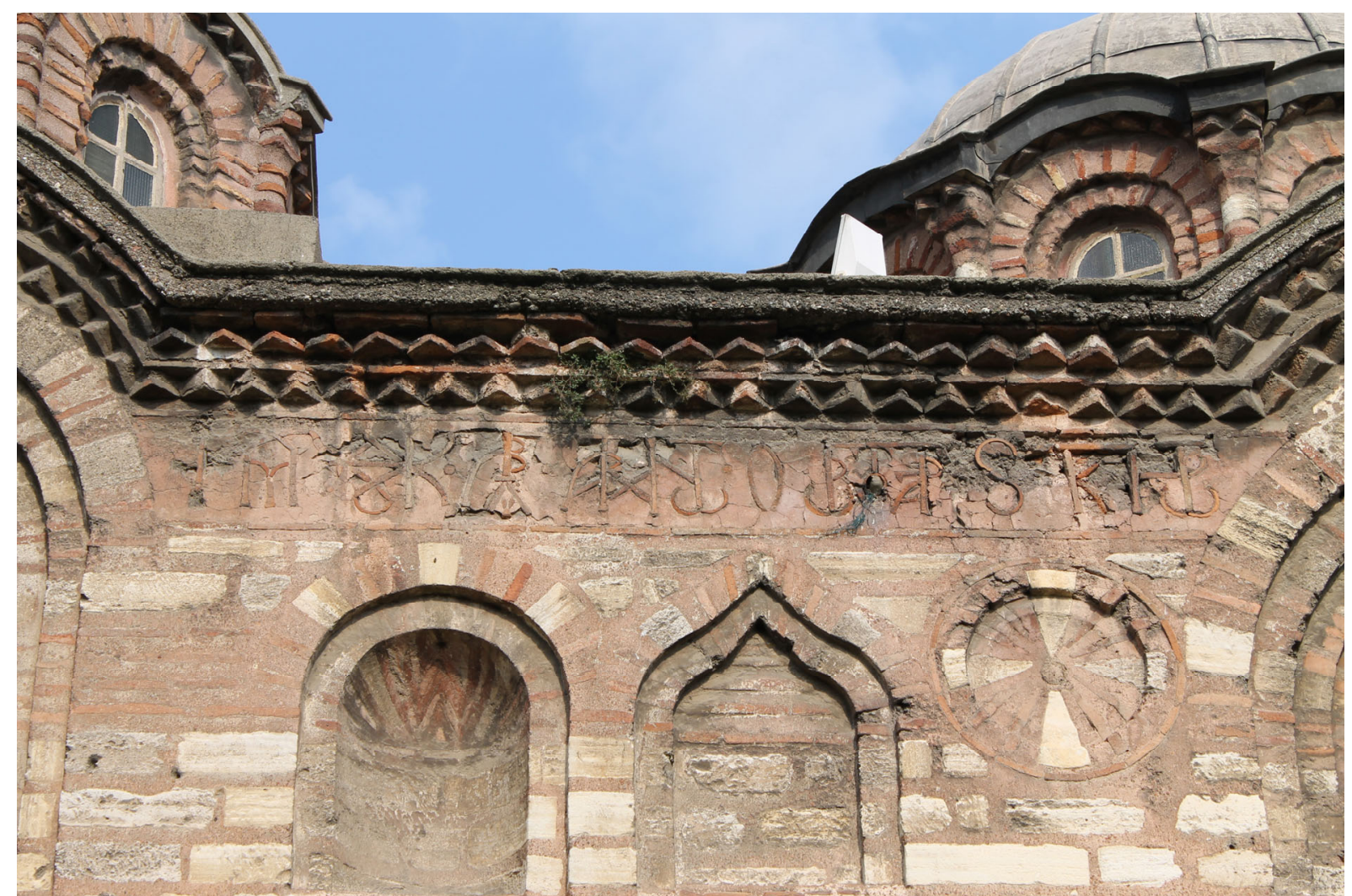

Fig. 8 The Parekklesion of the Pammakaristos Church, tile inscription no. IV on the exterior of the parekklēsion (C) Andreas Rhoby) 


\section{The Post-Byzantine and Ottoman Afterlives of the Pammakaristos (Fethiye Camii) Parekklesion: Epigraphy ARIEL FEIN}

The continuous use of the Pammakaristos (Fethiye Camii) as a church and later as a mosque through the Byzantine, Post-Byzantine, and Ottoman periods offers a unique opportunity to consider the afterlife of its epigraphy. The following discussion focuses on the shifting display and reception of the fourteenth-century marble cornice running around the west and south facades of the parekklesion. The cornice features a funerary epigram in which the patroness Maria mourns the death of her husband, patron Michael Doukas Glabas Tarchaneiotes. (See also, Ivan Drpić, Chapter 34) By the late fourteenth or early fifteenth century, the construction of the south arm of the perambulatory obscured the first five verses of the cornice inscription. Moreover, the perambulatory altered the visitors approach to the church, obstructing their view of the cornice inscription (Fig. 1A/B). For those still electing to circumambulate the church towards the parekklesion, the inscription's legibility remained largely unaltered; its text could be reasonably understood as Maria mourning the death of her husband, connections could be drawn with the epigraphy of the interior, and the inscription still facilitated movement around the church, albeit not to the same extent. However, the abrupt beginning of the epigram, in medias res - possibly even mid-word distorted its reading, not merely erasing part of the text, but also part of the memory it was intended to conjure.

In the sixteenth century, when the Pammakaristos served as the seat of the Ecumenical Patriarchate, the church's epigraphy received renewed interest both from within the Greek community and from foreigners. Among these visitors were members of the German Lutheran Church, for whom the Greek Orthodox Church appeared as a possible resource and ally amidst the controversy between the Reformation and the Catholic Church. In fact, the Lutherans attempted unification with the Greek Orthodox Church during this period, although it ultimately proved unsuccessful. This religious impulse was coupled with a desire by many Lutheran scholars to recover Greek and Christian antiquity; they believed that this heritage was preserved in the artifacts and monuments of Byzantium and the traditions of the Greek Orthodox Church. Lutheran chaplains Stefan Gerlach and Salomon Schweigger traveled through Constantinople on imperial delegations and recorded their impressions of their visits in diaries and correspondence. Their writings described their time at the Pammakaristos; while neither commented directly on the church's epigraphy, they recounted their disillusionment with Istanbul, as they discovered that the monuments of Byzantium's past did not align with their idealized vision of the city.

This same period was marked by an increased antiquarian interest as well as literary production in the Greek community. John Malaxos (16 th $^{\text {th }}$ century), a member of the literary elite, which surrounded the patriarchate, and members of his circle, penned several texts documenting the epigraphy of the Pammakaristos along with some other sites. Peter Schreiner interprets this antiquarianism as a nostalgic effort to collect and preserve a lost 
city. But Malaxos' efforts can also be seen as an active response not only to the new Ottoman overlords but also to the Lutherans' growing preoccupation with Byzantium. By the late sixteenth century, the purpose of the cornice inscription was no longer to preserve the memory of Michael Tarchaneiotes and his wife Maria. Rather, as understood by John Malaxos, it was a powerful reminder of the continuity of the Byzantine Church. In the eyes of the Lutheran visitors and scholars, it provided a potential, but ultimately absent, connection to antiquity.

In 1593-94, the Pammakaristos church underwent further significant alterations to convert the space into a mosque, the Fethiye Camii. In the parekklesion, a qibla wall was added, while the two northern columns were removed to create a wide arch, opening the space between the parekklesion and the North Church. At an unknown date, the walls were plastered up to the dome, obscuring the interior epigraphy entirely. Drawings and photographs from the late nineteenth and early twentieth century attest that in this period, the construction of wooden and stone structures abutting the west façade of the parekklesion further obstructed the exterior cornice inscription. While Ottoman descriptions of the church's epigraphy do not survive, we can speculate that in a city that remained populated by many Byzantine structures and Greek epigraphy, the cornice epigram and preserved domical mosaics, would have called to mind other inscriptions. Not only would they have evoked the conquest of Byzantium but also the ongoing and shifting Ottoman-Greek relationships. The afterlife of the Pammakaristos demonstrates the need to consider the impact that the changes in physical structure, audience, and shifting political climates had on the epigraphy of this historic monument. 


\section{Exterior cornice inscription:}

\section{Ed. Rhoby (2014), no. TR76}

Red - Late $14^{\text {th }}$ /early $15^{\text {th }}$-century alterations

Blue - Ottoman alterations

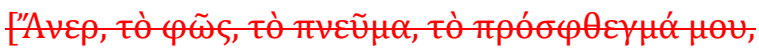

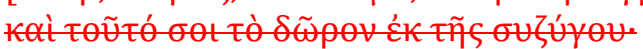

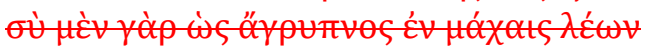

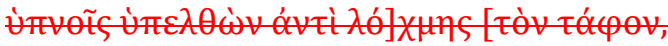

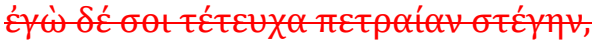

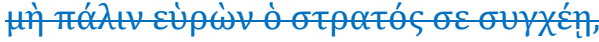

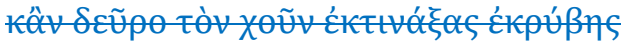

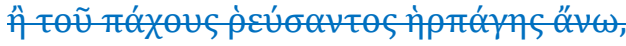

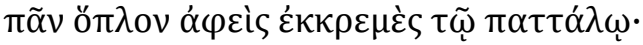

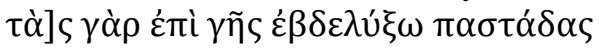

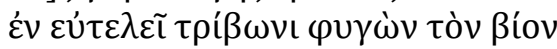

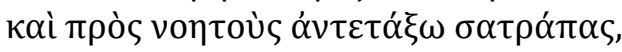

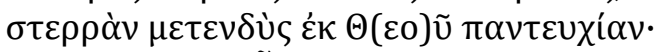

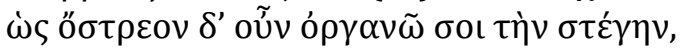

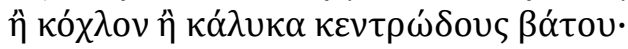

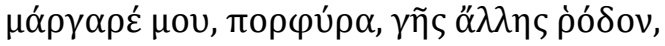

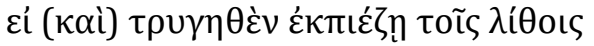

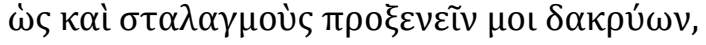

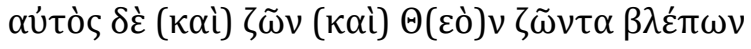

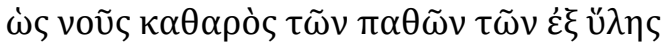

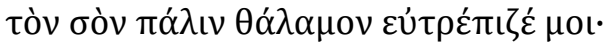

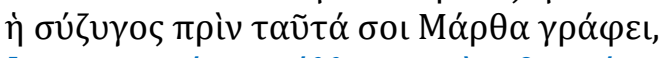

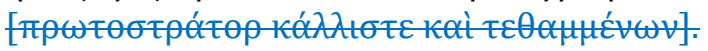
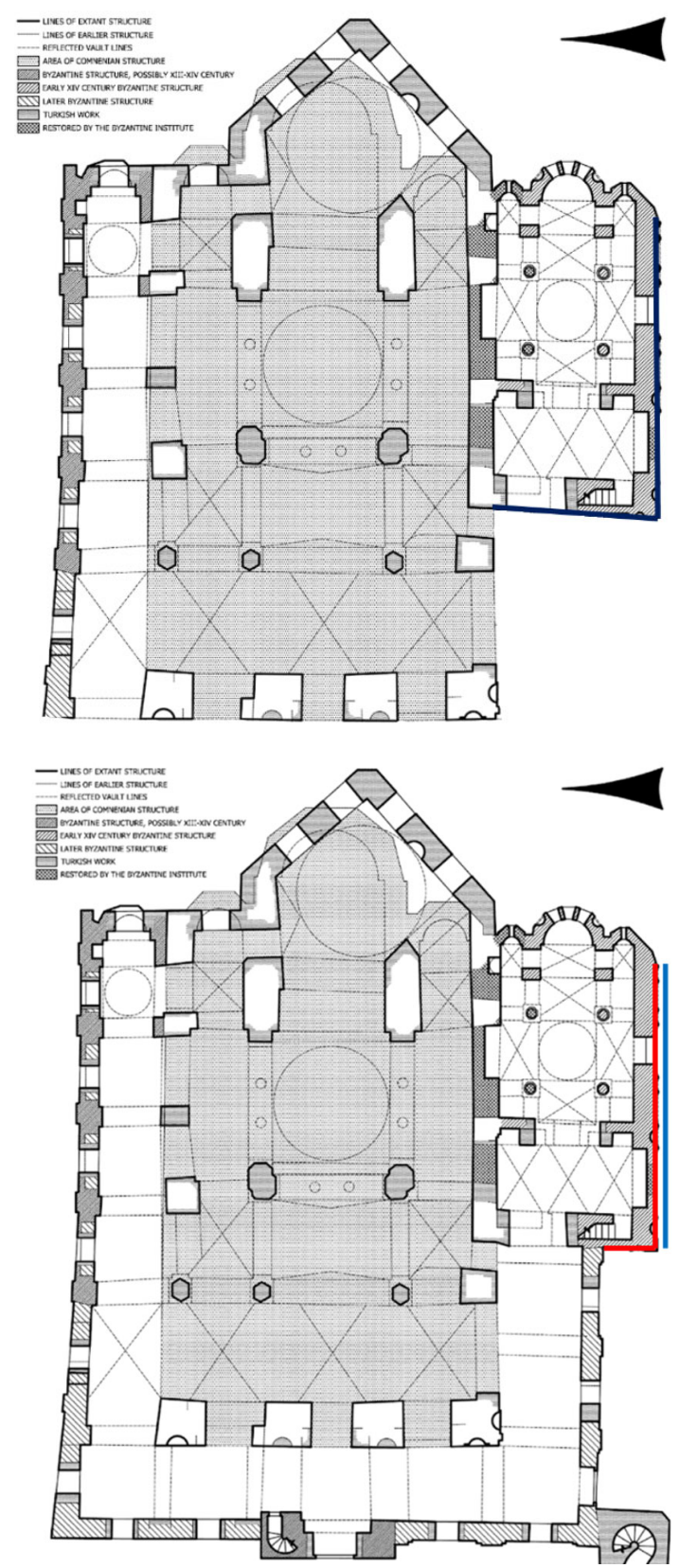

Fig. 1B. Plan after Vasileios Marinis, "Structure, Agency, Ritual, and the Byzantine Church." Fig. 12.9

Red - Late $14^{\text {th }} /$ early $15^{\text {th }}$. century cornice after the construction of the perambulatory

Blue - 19th-century cornice after Ottoman interventions

Fig. 1A. Plan after "Structure, Agency, Byzantine Church," Fig. 12.9

Navy - Original prior to the perambulatory construction of the

\section{Timeline:}

c. 1310
Death of Michael Doukas Glabas Tarchaneiotes Site of detention of the Grand Logothete Gabalas Abbot Niphon of the Pammakaristos appointed metropolitan of Neopatras

Abbot Theophanes of the Pammakaristos promoted to the see of Heracleia 
$1416-1421$

1455

$1455-1577$

1577

$1547-1587$

$1553-1587$

$1587-1588$

$1593-1594$

1640

Turkish rebel Djunaid given refuge by the Byzantine government and quartered in the Pammakaristos

Seat of the Patriarchate moved to the Pammakaristos

Substantial structural alterations conducted by the Patriarchs, see Mango (1978), 26-3

The most extensive restoration program conducted by Patriarch Jeremias II (including a new refectory, kitchen and well, new monastic cells, the second patriarchal kellion, a new gilded templon, four lamps and other vessels of gilded silver, marble revetments in the naos, vestments for the clergy and the patriarchal throne)

John Malaxos compiles the inscriptional heritage of Constantinople, including the epigraphy of the Pammakaristos Church

Gerlach and Schweigger, among others, serve as Lutheran chaplains in Constantinople

Greeks abandoned the Pammakaristos

Grand Vizier Sinan Pasha converted the Pammakaristos to a mosque (Fethiye Camii) in commemoration of his conquests in Hungary Balatkapi fire caused damage to the mosque (extent of damage remains unknown)

$1729,1759,1766-7$ Restorations conducted in the mosque (documented in the Başbakanlık Osmanlı Arşivi)

1845

1936-1938

1955-1960

Restorations conducted under the reign of Sultan Abdulmecid

Repairs conducted by the Vakiflar İdaresi

Repairs conducted by the Byzantine Institute of America (Dumbarton Oaks)

\section{Selected Bibliography}

Primary Literature:

Crusius, M. (1584) Turco-Graeciae libri octo, Basel.

- (1927) Diarium Martini Crusii 1596-1597. Ed. Göz, W. and Congrad, E., Tübingen.

- (1931) Diarium Martini Crusii 1598-1599. Ed. Göz, W. and Congrad, E., Tübingen.

(1674) Stefan Gerlachs des Aelteren Tagebuch, Frankfurt am Main.

Schweigger, S. (1608) Ein neue Reysbeschreibung auß Teutschland nach Konstantinopel und Jerusalem: Darinn die gelegenheit derselben Laender/Staedt/Flecken/geben etc. der inwohnenten Voelcker Art/Sitten/Gebraech/Trachten/Religion und Gottesdienst etc., Nuremberg.

\section{Secondary Literature:}

Ben-Tov, A. (2009) Lutheran Humanists and Greek Antiquity: Melanchthonian Scholarship between Universal History and Pedagogy, Leiden. 
- (2013) Turco-Graecia: German Humanists and the End of Greek Antiquity - Cultural Exchange and Misunderstanding, in Contadini, A. and Norton, C. (eds) The Renaissance and the Ottoman World, Adershot, 181-195.

Effenberger, A. (2007) Zum Datum der Umwandlung der Pammakaristoskirche in die Fethiye Camii, Byzantion, 32-41.

- (2006-2007) Zur Restaurierungstätigkeit des Michael Dukas Glabas Tarchaneiotes im Pammakaristoskloster und zur Erbauungszeit des Parekklesions, Zograf 31, 79-94.

Esmer, M. (2012) Istanbul'daki orta bizans dönemi kilisleri ve çevrelerinin korunmasi için öneriler, PhD Diss., Istanbul Teknik Üniversitesi.

Hallensleben, H (1963-1964) Untersuchungen zur Baugeschichte der ehemaligen Pammakaristoskirche, der heutigen Fethiye camii in Istanbul, Istanbuler Mitteilungen 13$14,128-93$.

Mango, C. (1978) The Monument and its History, in The Mosaics and Frescoes of St. Mary Pammakaristos (Fethiye Camii) at Istanbul, Washington, DC, 3-42.

Mango, C. and Hawkins, E. J. W (1964) Report on Field Work in Istanbul and Cyprus, 19621963, Dumbarton Oaks Papers 18, 319-340, at 319-333.

Megaw, A. H. S. (1963) Notes on Recent Work of the Byzantine Institute in Istanbul, Dumbarton Oaks Papers 17, 333-71, at 367-71.

van Millingen, A. (1912) Byzantine Churches in Constantinople. London, 157-60.

Rhoby, A. (2014) Byzantinische Epigramme auf Stein nebst Addenda zu den Bänden 1 und 2 (= Byzantinische Epigramme in inschriftlicher Überlieferung, vol. 3), Vienna, 657-668 (no. TR73-TR77).

Rhoby, A. and Schreiner, P. (2018) Antiquitates Constantinopolitane im Osmanischen Reich: Johannes Malaxos und seine Aufzeichnungen im Vat. Reg. Gr. 166, Miscellanea Bibliothecae Apostolicae Vaticanae 24, 605-657, at 635-639, 641-642.

Schreiner, P. (1971) Eine unbekannte Beschreibung der Pammakaristoskirche (Fethiye Camii) und weitere Texte zur Topographie Konstantinopels, Dumbarton Oaks Papers 25, 217-248.

- (2001) John Malaxos (16 ${ }^{\text {th }}$ Century) and his Collection of Antiquitates Constantinopolitane, in Necipoğlu, N. (ed) Byzantine Constantinople: Monuments, Topography, and Everyday Life, Leiden, 203-214.

Underwood, P (1956) Notes on the Work of the Byzantine Institute in Istanbul 1954, Dumbarton Oaks Papers 9/10, 291-300, at 298-299.

- (1960) Notes on the Work of the Byzantine Institute in Istanbul: 1957-1959; The Conservation of a Byzantine Fresco Discovered at Etyemez, Istanbul, Dumbarton Oaks Papers 14, 205-222, at 215-219. 



\section{The Ecumenical Patriarchate and Its Inscriptions \\ PINAR SERDAR DinÇER}

\section{The Patriarchal Church}

The Patriarchal Church of St George is located in the Phanar (Greek for 'lantern' or 'lighthouse', probably referring to the old lighthouse situated on the shore of the Golden Horn in the Fatih district of Istanbul). The name 'Phanar' is thought of as being synonymous with the Ecumenical Patriarchate, which includes a church, a patriarchal residence, and offices.

In 1600, during the patriarchate of Matthew II (1596, 1598-1602 and 1603), the patriarchal residence was situated in the small Monastery of St. George at the Diplophanarion. By 1601, the Ecumenical Patriarchate moved to the present location, although its construction continued for a longer time, to be followed by many reconstructions and extensions, which have taken place in the intervening centuries, and continue until the present day.

The building work was carried out under special dispensation by the Ottoman authorities. The first refurbishment and enlargement took place between 1603 and 1614, during the patriarchate of Timothy II. An $18^{\text {th }}$-century source claims that Sultan Ahmed I funded builders and Christian craftsmen in order to restore the Patriarchal Church, which had been damaged by fire between 1603 and 1617. This testimony is supported by a document, which grants permission to Timothy II to enlarge the church, as well as providing evidence of day-to-day interactions between the Christians and the Muslims communities in the capital city.

A close relationship between the Patriarch Jeremiah III and the Sultan Ahmed III facilitated the rebuilding of the church in 1720, after it had been, once again, completely destroyed by fire. It is unclear exactly when this fire had occurred (it must have happened between 1701 and 1720), but we know that much of the Phanar was destroyed, including the area in the immediate vicinity of the Patriarchate.

The church suffered another destruction by fire in 1738. Repair work was undertaken only in 1797, and completed under the Patriarch Gregory VI (1835-1840) in 1836, when the traditional cross-in-square building, was replaced by a basilica with three aisles and a long nave - a structure considered to be more suitable to the needs of the Orthodox community of the time (fig. 1).

The church, such as it stands today, is dominated by a broad neo-classical façade that displays no religious symbols beyond a single cross situated directly under the roofline and the emblem of the Patriarchate placed above the door. This decorative style, further marked by round arches over the three main doors and windows, bears a strong resemblance to early $18^{\text {th }}$-century secular architecture.

The entire building complex of the Ecumenical Patriarchate has great religious, historical, and political significance. In addition to the church, it includes the Patriarchal House, a library, a tower, guesthouses, the Pavilion of the Holy Myron, the Evgenidio Foundation Auditorium and the Constantiniana Houses. Most of these buildings have been rebuilt in the last two centuries. The Patriarchal House itself was completely renovated in the 1980's (fig. 2). 


\section{Selected Bibliography}

Chryssavgis, Fr. J (2009) The Ecumenical Patriarchate: A Brief Guide, New York.

Covel, John (1722) Some Account of the present Greek Church, with Reflections on their present Doctrine and Discipline; particularly in the Eucharist, and the rest of their seven pretended Sacraments, compared with Jac. Coar's Notes upon the Greek Ritual, or

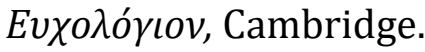

Steeber G. (2012) An Architectural Reflection of Community: a Study of the Patriarchal Churches in Constantinople/Istanbul as a Reflection of the Relationship of Christians and Muslims in the Ottoman Empire, Luther Seminary Digital Commons @ Luther Seminary MA Theses Student Theses.

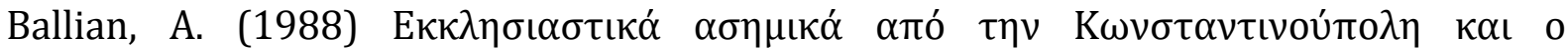

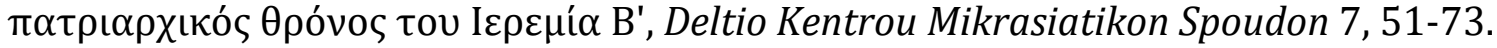

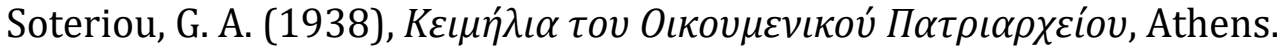

https://www.patriarchate.org/home

https://www.archons.org/home

https://theindex-princeton-edu.uaccess.univie.ac.at/home.action

\section{Inscriptions in the Ecumenical Patriarchate: A Selection}

The Patriarchal Throne (figs. 3-6)

The Patriarchal Throne is one of the most precious artifacts of the Patriarchal Church of St George. Anecdotally, the throne is associated with the renowned Patriarch of Constantinople St John Chrysostom (347-404). An artist inscription at the base of the throne commemorates the craftsmanship of Laurentios of Athens (inscription 1). According to an inscription beneath the eaves of the throne's gables, the Patriarch Jeremiah II bequeathed the throne in 1577 to the Patriarchal Church of the Virgin Pammakaristos (inscription 2).

The throne stands four meters high and is made of walnut wood. It is inlaid with ivory, mother of pearl, and colored wood fashioned in the form of a vine. In the past, it was also decorated with precious stones, but these have since been lost.

According to a third inscription, on one of the gables over its eaves, the throne was damaged between 1652 and 1654, during the tenure of the Patriarch Paisios I (1652-3 and 1654-5), and it was subsequently restored by the Patriarch Iakovos (1679-82) (inscription 3). However, numerous gems as well as two icons, which formerly decorated the throne, were irretrievably lost. These icons represented: a) Christ the Pantokrator, and b) the Descent into the Hades and the Burial of Christ. The latter was described by Malaxos in 1577, but its exact position remains unknown. The present icon on the throne also depicts Christ the Pantokrator; it was a replacement commissioned in the 17th century by the Patriarch Paisios I (inscription 4).

The actual throne of the Ecumenical Patriarch is in fact the synthronon located within the altar space. The prominent throne situated in the middle of the nave is the seat of the abbot. The patriarch, therefore, sits here as head of the monastic brotherhood, of 'the Great Monastery', and he may also invite other, or visiting, hierarchs to officiate from this throne. 
1.

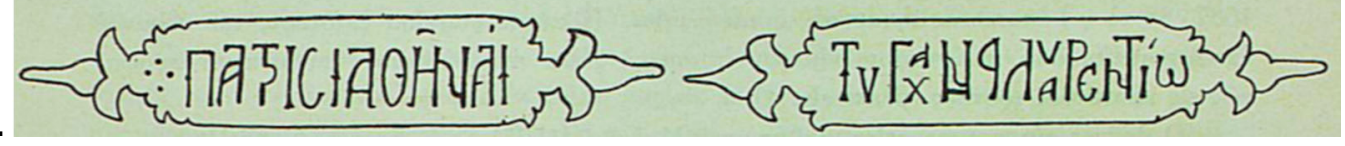

ПАTPIC T'A@HNAI

TҮГХANEI $\Lambda$ AYPENTI $\Omega$

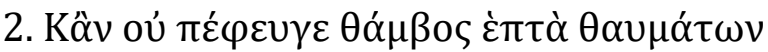

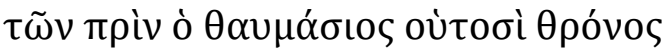

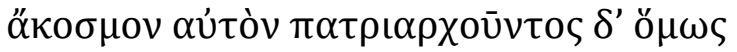

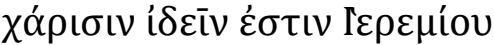

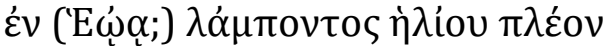

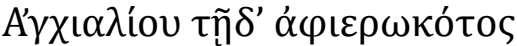

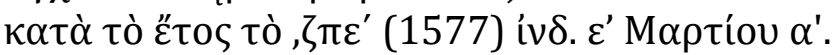

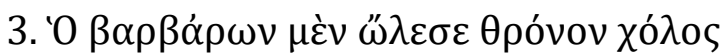

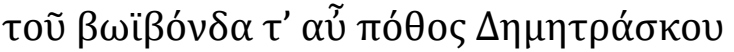

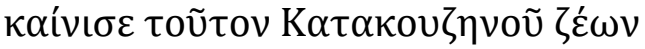

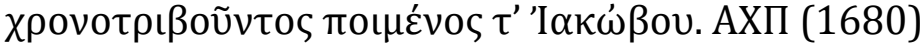

\section{4. $\Delta$ EH $\Sigma \mathrm{I} \Sigma$ ПAÏ $\Sigma$ IOY ПАТPIAPXOҮ}

The Pulpit (Ambo) (figs. 7-10)

A legend attributes the pulpit to the most famous preacher of the early Christian church, St John Chrysostom, who delivered many sermons during his tenure as Patriarch of Constantinople (AD 398-404). Nevertheless, an inscription inside the pulpit states that it was constructed in 1703, during the second tenure of Gabriel III (1702-7). The pulpit, which is wrapped around a column on the left side of the nave, is made of walnut wood and of mother of pearl. It is decorated with the motif of a vine, although in a simpler form than we see on the throne. In general, the craftsmanship is less elaborate than that of the throne.

\section{EN MINH AY-}

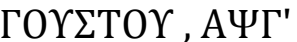

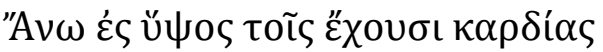

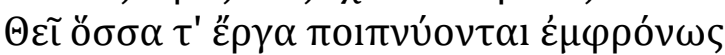

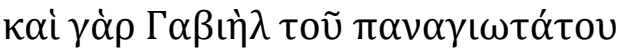

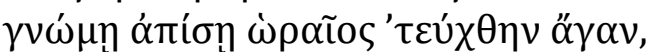

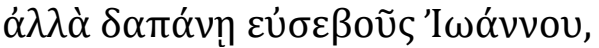

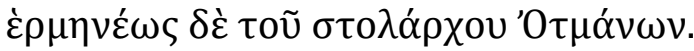

The Icon of St John the Baptist (fig. 11)

The icon of St John the Baptist is displayed on the right side of the nave in the Patriarchal Church. It is thought to have been brought over from the Church of the Virgin Pammakaristos. This mosaic icon have been dated to the eleventh-century thus predating the representations of St John the Baptist found in Haghia Sophia and the Chora Monastery. St John is depicted pointing to the Son of God and bearing a scroll, which reads: 'Behold, the Lamb of God, who takes away the sin of the world':

I $\triangle$ E O AMNO $\Sigma$ TOY $\Theta Y$ O AIPSN THN AMAPTIAN TOY KOSMOY.

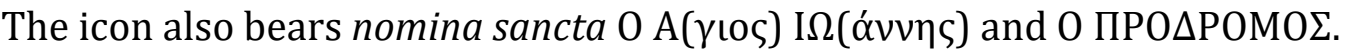


The Plan of the Patriarch's Church at Fanar in Conftantinople.

T A B. 1 .

a.a. The Northex.

B. The Stalls of the Officers of the Church. $\gamma$. A place where fome Reliques of Saints are kept.

8. The Pillar to which Chrift was faften'd, with Rails about it.

$\varepsilon . \varepsilon$. The Stalls of the Metropolites.

$\zeta$. The PatriarchsThrone with Steps up to it.

$\eta$. The Place where the Priefts and Deacons proftrate themfelves before the Patriarch.

$\theta$. Two Stalls for the Princes of Moldavia and Wallacbia when prefent.

s. The Tetrapodium, or fourfooted Table, on which the Picture of the Saint for the day ftand.

x. Đúga airia, or wegaia. The holy or fair Door.

$\lambda$. The Door out of the Church into the Prothefis.

$\mu$. The Prothefis, or ByAltar of Propofition.

\%. A Stone Table on which the ఐegoøogx', or Bread that is offered and the Wine are firft fet.

$\xi$. The $\chi$ wreurngerv, or Sink

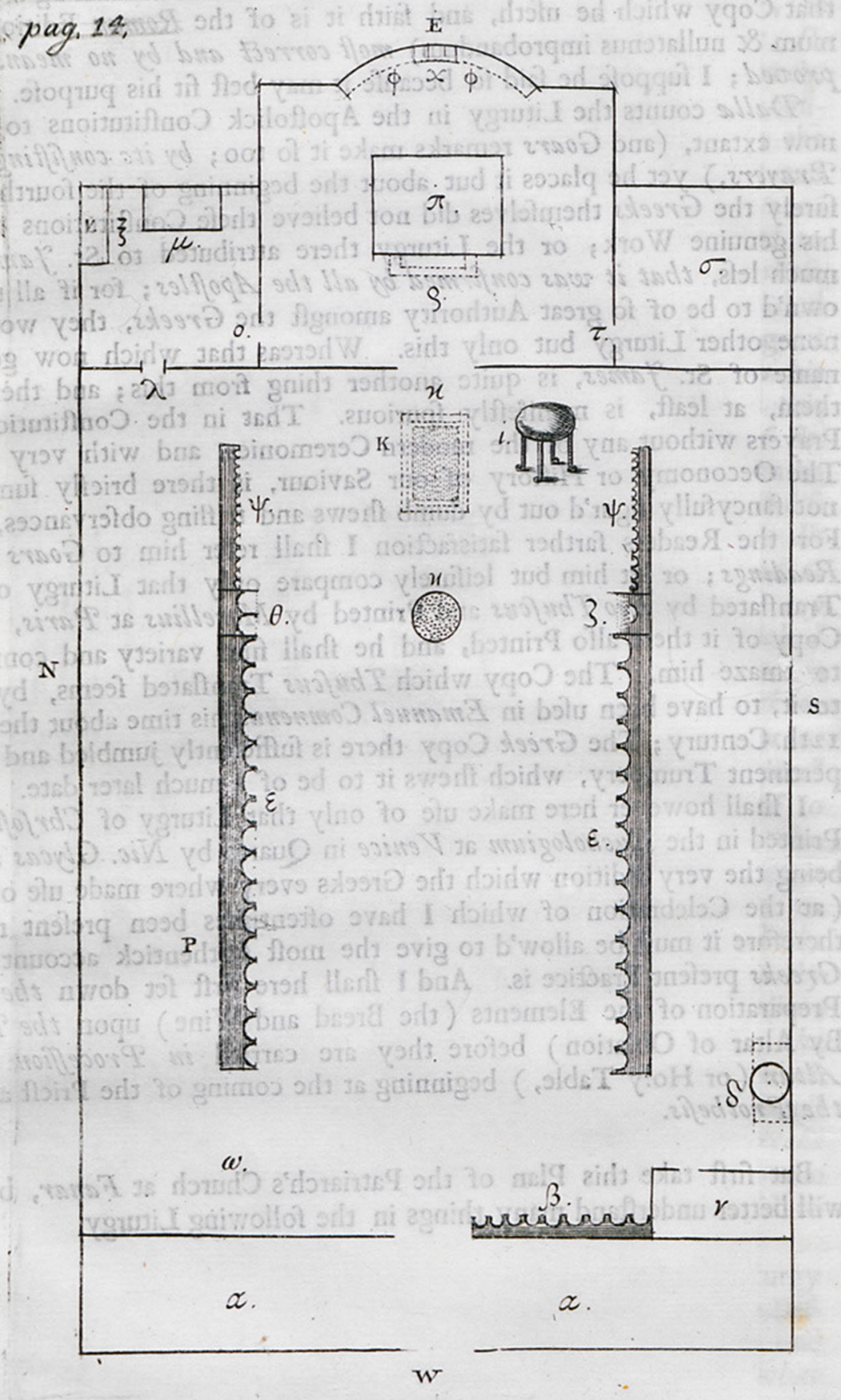
where they calt in the Water after Baptifm, or any thing that is fpoiled.

o. A Door from the Prothefis into the iegareion, or Chancel.

7. 'A ria Teame ${ }^{\prime} \alpha$, the Holy Table.

§. Two Steps where he that confecrates ftands, called xpinis. Goar. Euc. p.r6z. b.

$\sigma$. The oxevoquadixion, where all the Holy Utenfils are kept.

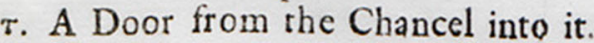

๑.. . A Stone Bench where the Metropo. lites fit, upon many Occafions.

$\chi$. The "'snor Bin $\mu \alpha$, or Patriarch's Throne, which Words often are taken for the whole Chancel; on the Steps up to it the Prieft fets, whilft the Epift. is read.

$\psi . \psi$. The $x o g$ os, or Quire, where the Singers fer.

Fig. 1 Plan of the Patriarchal Church (after Covel 1722) 

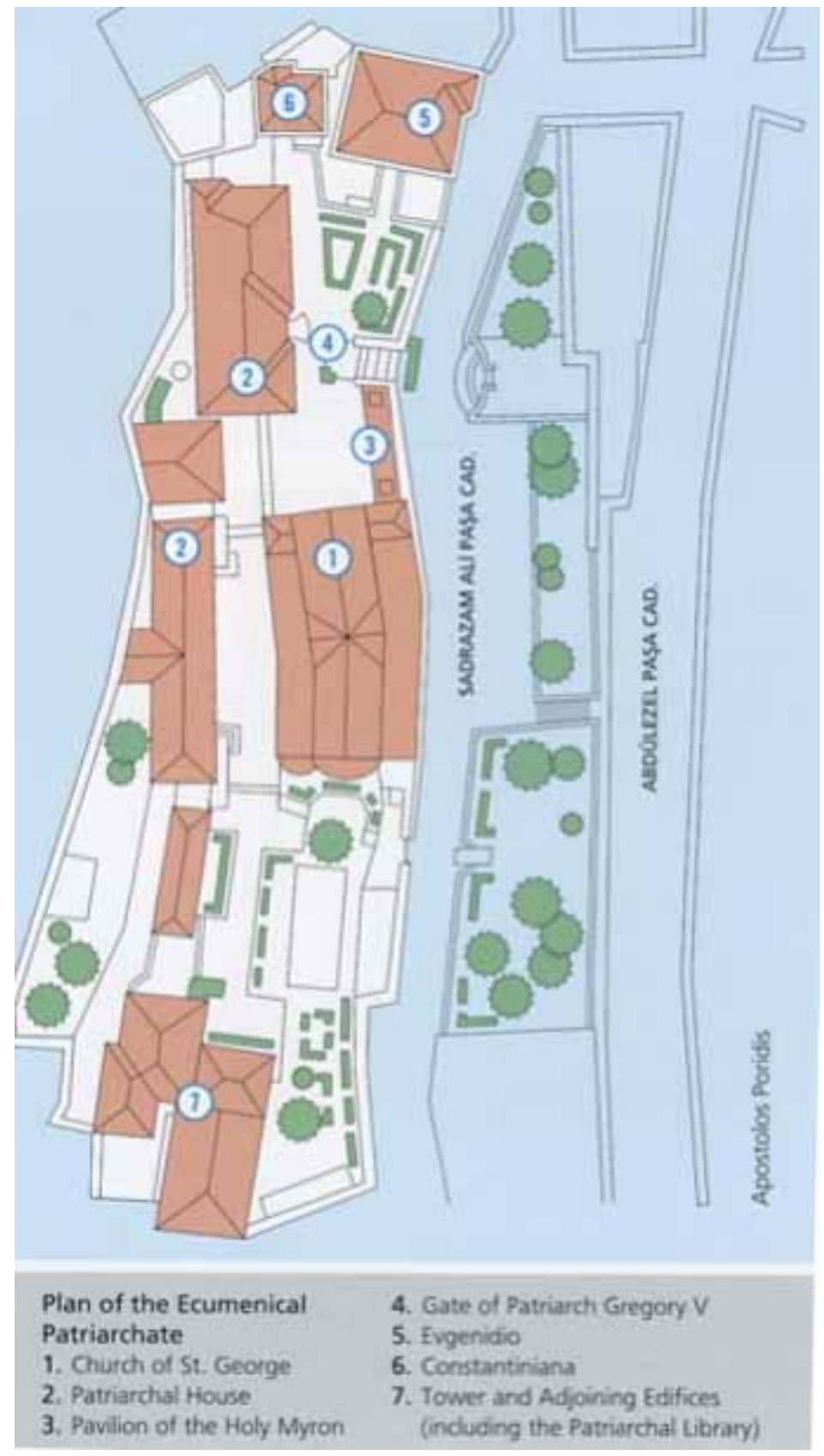

Fig. 2 Plan of the Ecumenical Patriarchate (after Chryssavgis 2009) 


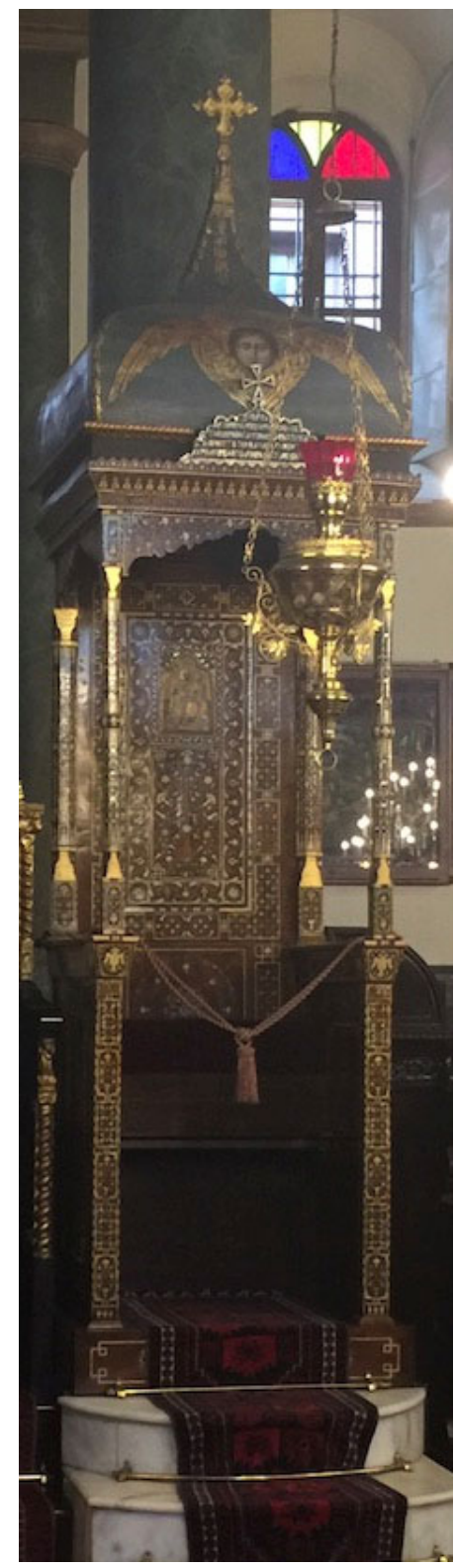

Figs. 3 The Patriarchal Throne (C) Pinar Serdar Dinçer)

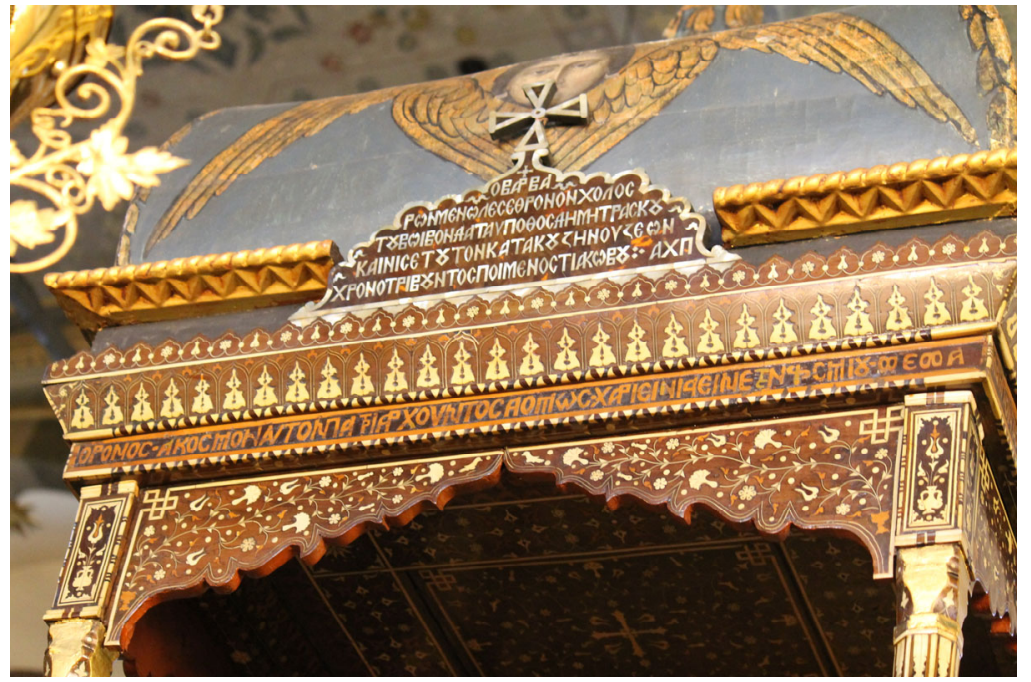

Fig. 4 The Patriarchal Throne (and detail) (C) Andreas Rhoby) 


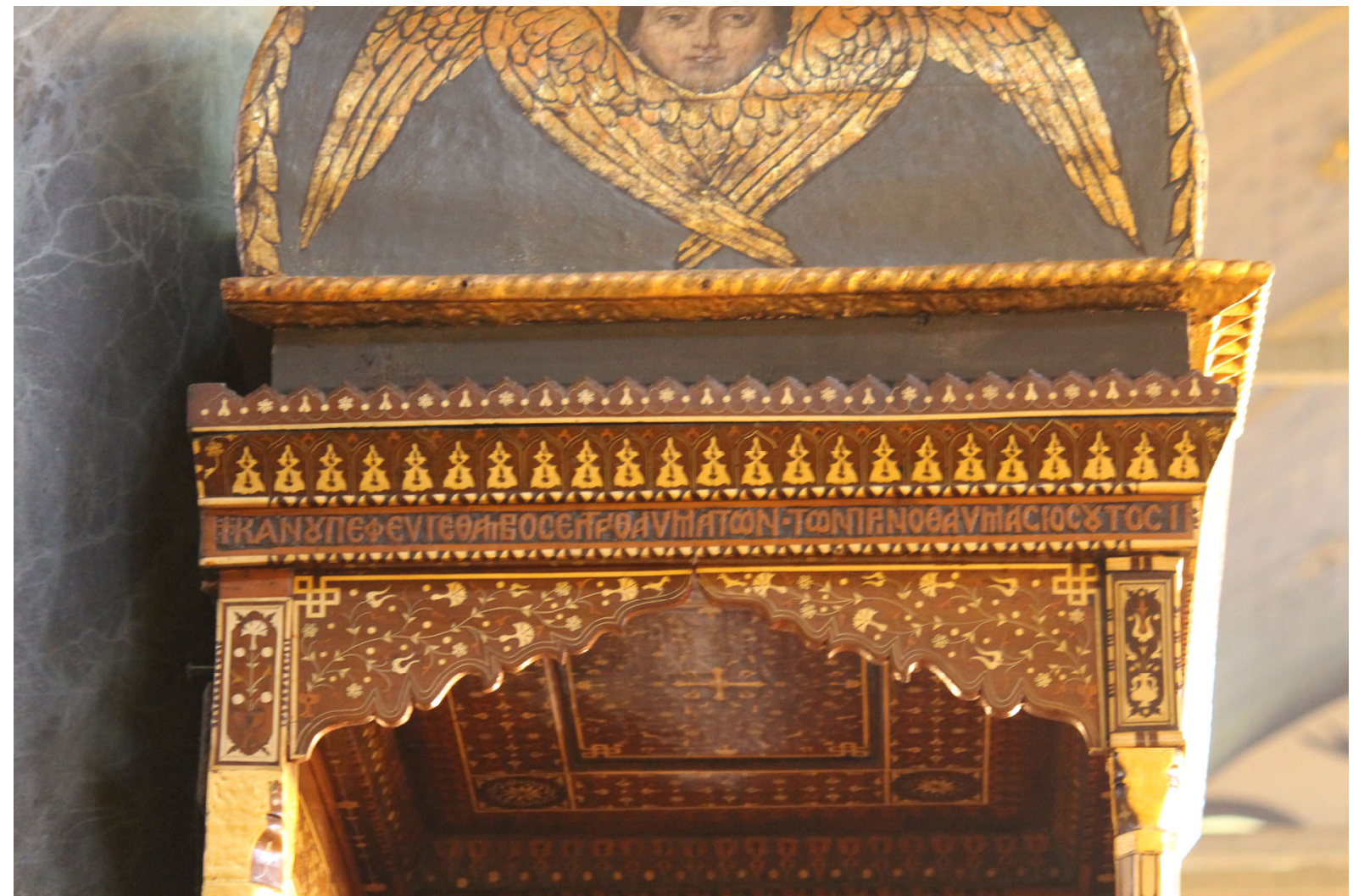

Fig. 5 The Patriarchal Throne (and detail) (C) Andreas Rhoby)

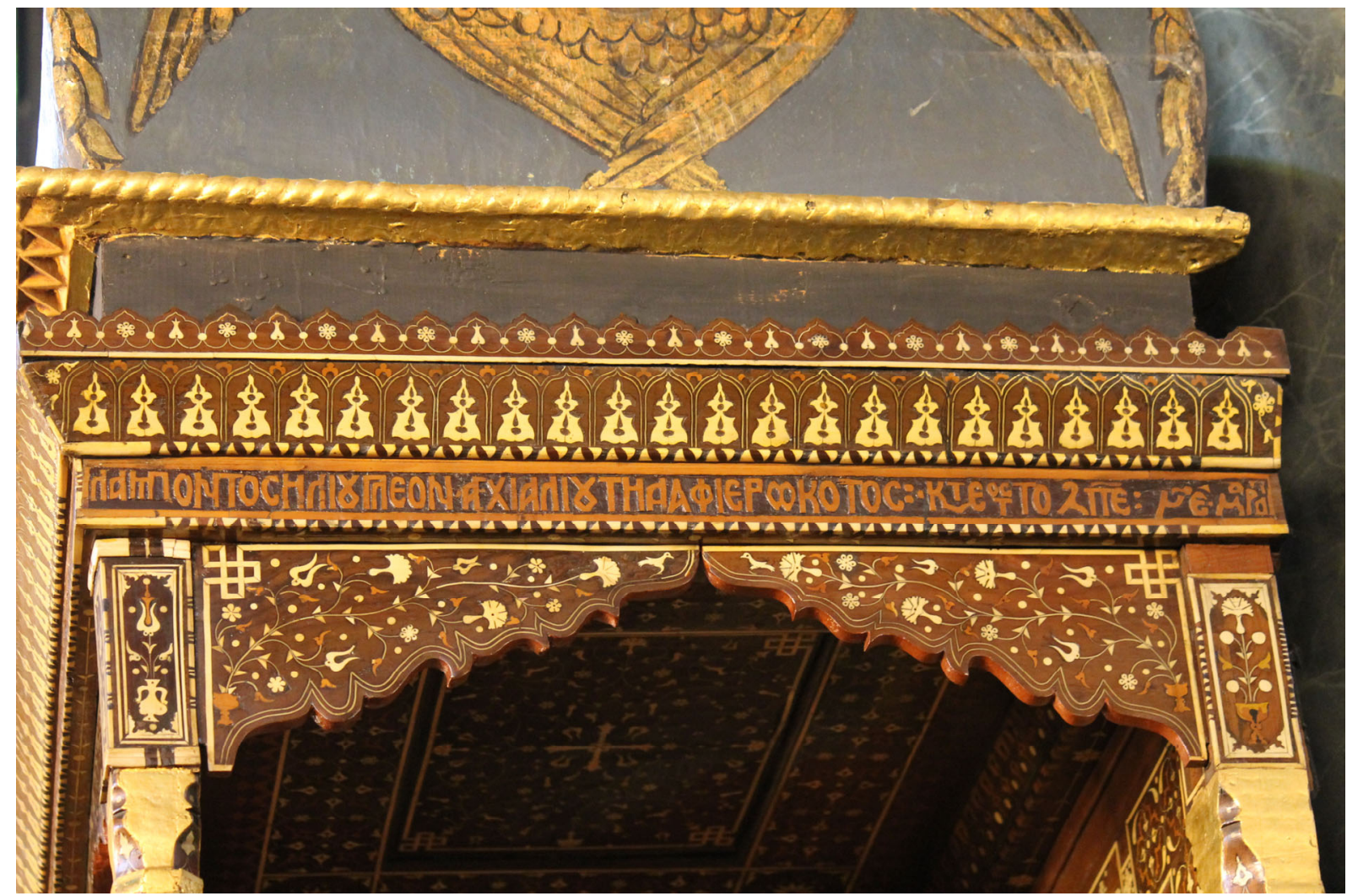

Fig. 6 The Patriarchal Throne (and detail) (C) Andreas Rhoby) 

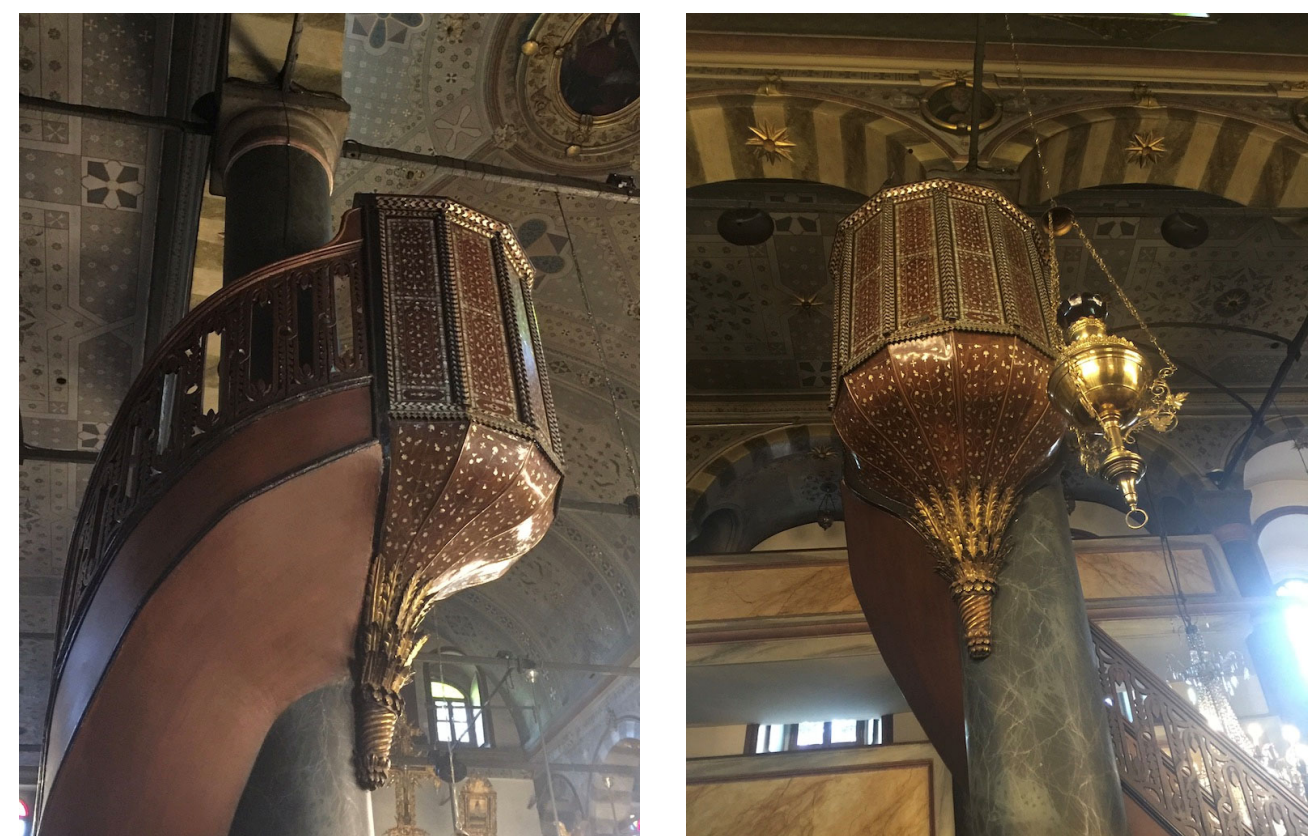

Figs. 7-8 The pulpit (Ambon) (C) Pinar Serdar Dinçer)
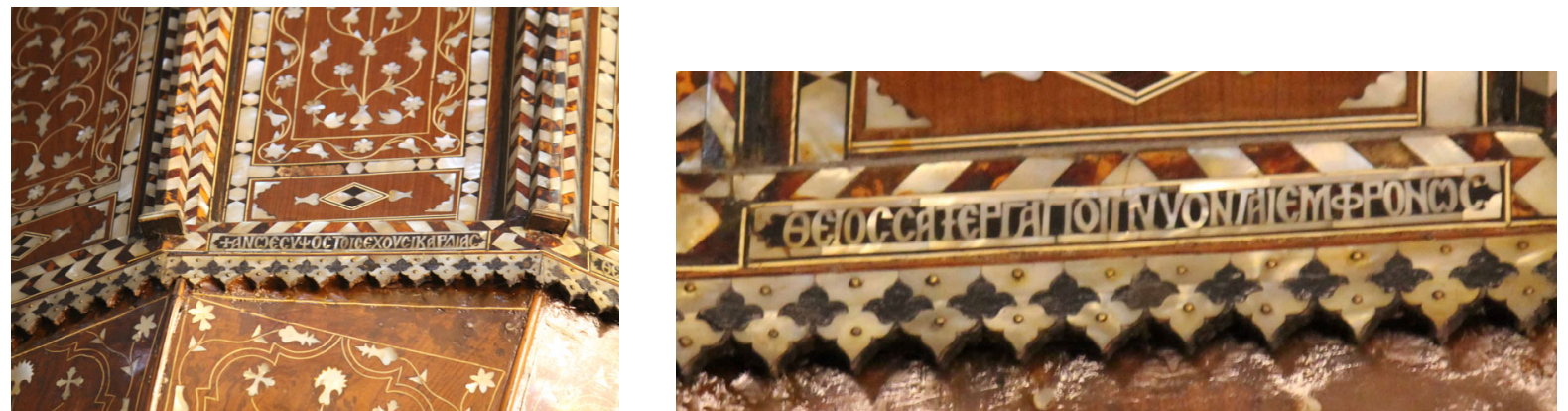

Figs. 9-10 The pulpit (Ambon) (and detail) (C) Andreas Rhoby)

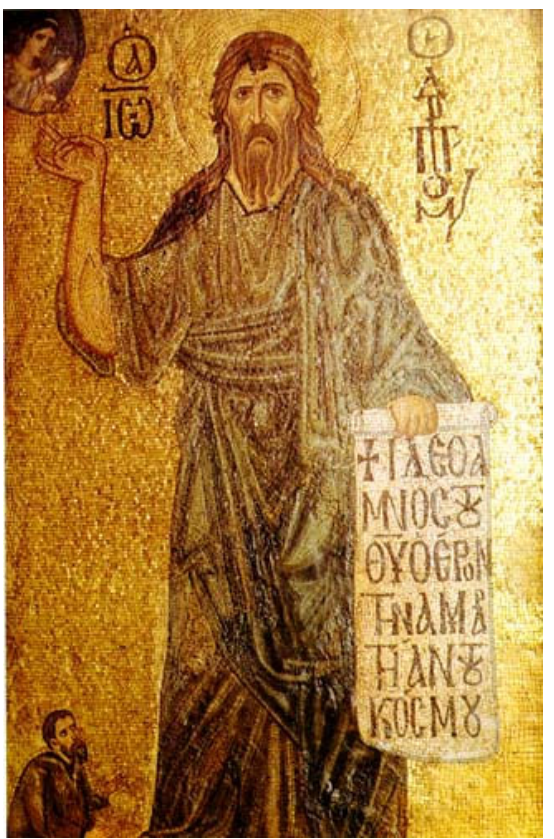

Fig. 11 The Icon of St John the Baptist (https://theindex-princetonedu.uaccess.univie.ac.at/s/view/ViewWorkOfArt.action?id=1C837138-912E-4BB1B334-DF51F0A3F438) 
IX FIELD ARCHAEOLOGY AND EPIGRAPHY 



\section{A Middle Byzantine Patriarchal Monastery and Its Long Durée: The Contribution of Inscribed Finds from the Küçükyalı, Istanbul ALESSANDRA RICCI}

Archaeological remains in the neighborhood of the Küçükyalı, on the Asian side of Istanbul, are tucked between modern apartment buildings, set slightly inland from the Marmara seashore, located at a close proximity to the Prinkipo islands (modern Princes Islands). They cover some 4.500/5.000 sq. meters. In Byzantine times, the area was part of the capital's extended Asian hinterland, and it was set some hundred meters inland from the coast.

The surface remains were the object of attention by Pargoire (Pargoire 1901) and Mamboury (Mamboury 1920), who identified them as the monastery of Satyros built by the eunuch patriarch Ignatios in the second half of the 9th century. Later, Eyice (Eyice 1959a, 1959b) saw in the remains at the Küçükyalı those of the Islamicate palace built by the Emperor Theophilos during the Second Iconoclasm, and known as the Palace of Bryas. In the subsequent decades, the site at the Küçükyalı continued to be identified as the Palace of Bryas.

Notwithstanding the two dissimilar and somewhat contrasting identifications, it is only in recent times that the site has become the object of systematic archaeological fieldwork (Ricci 1998, 2018). The on-site work has been set up in order to address the question of the site's identification. To begin with, archaeological activities took the form of field surveys and non-invasive investigations. Their aim was to document structures that had emerged since the publication of Eyice's work, and to re-assess the data related to the site's identification in light of the new evidence, with the ultimate goal of verifying the potential for archaeological excavations. Since 2014, the fieldwork has developed into a programme of systematic stratigraphical excavations running in parallel with various activities aimed at transforming the area into a public archaeological park (Ricci and Yilmaz 2016).

The identification of the complex with the monastery of Satyros is now grounded in the results of the most recent work at the site (Ricci 2018). Architectural, archaeological and textual evidence-in particular the Vita Ignatii composed by David Niketas Paphlagonalong with the study of material remains confirm that the monastic complex was built during the second half of the $9^{\text {th }}$ century, in the course of the patriarch's second tenure in 877 and before his death in the same year.

Furthermore, the archaeological work has brought to light later phases of life at the complex. These are now connected with evidence from the Typikon of the Pantokrator Monastery stating that Satyros became a dependency of this imperial monastery. Excavations of the monastic katholikon dedicated to St. Michael and the newly discovered necropolar area around its exterior are in progress (Ricci 2019). The church is built on an elevated platform with an underground cistern below the ecclesiastical building that served both as a water reservoir and as a substructure.

Finds from the excavations contribute to a fuller understanding of the site, casting new light on the life of the monastery across many centuries, and on the role of monastic foundations and dependencies in the hinterland of the capital city. Ultimately, they contribute to a more nuanced picture of Byzantine archaeology.

Inscribed material thus far retrieved among the finds from the site is fairly wide, spanning brick stamps, marble cornices, (funerary?) inscriptions, marks on marble 
elements as well as lead seals and coins. While work on this material proceeds, this essay discusses some of the inscribed finds from the site. It presents two categories: brick stamps and inscribed marble cornices.

\section{Brick stamps}

Mamboury was first to document brick stamps at, and around, the site. He mentioned two brick stamps (without illustrations) in an article, in which he also identified the site with the monastery of Satyros (Mamboury 1920). In recent years, Bardill's comprehensive catalogue of Mamboury's documentation of brick stamps has included a total of 11 finds from the Küçükyalı (Bardill 2013). On the basis of Bardill's catalogue, it seems that none of the brick stamps was preserved in a complete form, as all the measurements indicate a fragmentary condition. Furthermore, information about the findspots of the material and its architectural context is limited, making it difficult to establish if many of Mamboury's documented brick stamps were in situ, and, if so, where they were found.

In the course of the most recent field surveys and excavation campaigns, a total of 64 brick stamps have been documented, 14 of these in situ. Among the brick stamps found in situ, 8 have been discovered in the church's walls. The masonry of the church is homogenous, with solid brick and mortar walls, and the bricks measuring ca. $35 \times 30 \mathrm{~cm}$ and 4-5 cm in thickness. The walls are preserved at a height of 1-1.5 meters. Six of the in situ brick stamps have been found in the apse walls of the church (Melle 2004). They are all in a fragmentary condition, and have been discovered inserted in the inner section of the walls' masonry. Among them is a recently published example from the church's apse (Ricci 2017):

On a double line in a tabula $(15.1 \mathrm{~cm})($ Fig. 1)

KYPIAK

OYP (?)

Kyriakou (?)

Presbyterou (?)

Kyriakos is probably the name of an individual, and it is probably followed by a word indicating his rank. A similar Kyriakou Presbyterou brick stamp was found during the excavations of the shore of the Küçükcekmece lake, which was situated in a European suburb of the Byzantine capital (Sayar 2015, 189, fig. 8). Another Presbyter brick stamp was documented by Mamboury at Küçükyalı and published by Bardill (Bardill 2013, 916). It refers to $M \alpha \gamma v[(\mathrm{ou})] \varsigma \pi \rho \varepsilon \sigma \beta[(\mathrm{v} \tau \varepsilon \rho 0 u)] \varsigma$. These brick stamps appear to form a "cohesive" group of material datable to the period between the 5th and 6th centuries (Bardill, Sayar).

These and similar groups of materials have been dated, in several cases, to the periods earlier than the dates of the architectural constructions, of which they were part. Issues addressing the dating of brick stamps found in situ have therefore been raised: e.g. analyses of masonry might help clarify whether brick stamps were used in the original construction or in repairs that followed. Other working hypotheses include the possible stockpiling of bricks after they had been stamped, and their usage at a later time (Bardill 2013, 49-53). Alternatively, they may have been salvaged from other buildings and reused in new constructions. Brick stamps from the Küçükyalı that have been studied thus far appear to have all been re-employed from earlier buildings or possibly retrieved from poorly preserved stockpiles, as many of them were used in their fragmentary condition. With the exception of the stamped bricks from the late Byzantine flooring excavated in the church's bema, all other bricks belong to the first building phase of the complex's masonry, dated to the second half of the 9th century. While stamped bricks appear to have 
been re-employed, the broader question concerns non-stamped bricks utilized for the construction of the monastic katholikon. In fact, they show a uniform size and consistent petrographic qualities. The church, which was of a monumental size for its time of construction, must have required a substantial quantity of bricks for its solid brick masonry. Until recently, it has been suggested that solid brick constructions were uncommon because of their costs, and that the early 10th-century Myrelaion in Constantinople represented a rare surviving example (Ousterhout 2008, 170). The katholikon at the monastery of Satyros is another similar case. As in the case of the Myrelaion, the masonry of the church differs substantially from the masonry of its substructure, which is formed by alternating bands of brick and stone, with the bricks being of a substantially smaller size. The structure at Satyros may predate the Myrelaion also as an example of a building practice that implemented different building techniques in different parts of the construction. A working hypothesis is that the bricks used for the construction of the church at the Küçükyalı might have been re-employed from spoliated buildings, prompting further reflections on the economics of middle Byzantine architecture and on the sustainability of large-sized construction projects (Ricci 2017).

\section{Inscribed marble cornices}

The survey and excavation of the monastic church has allowed us to investigate and document the remains of one of the few Constantinopolitan ecclesiastical buildings securely dated to the $9^{\text {th }}$ century. The initial field survey was aimed at exposing the building's general plan through surface cleaning. The data collected during the field survey oriented research as well as archaeological excavations. At the time of writing, the excavation of the church has not yet been completed (Ricci 2019). However, on the basis of available evidence, it is possible to formulate suggestions about the building's plan, its chronology, and some of its decorative elements.

The building belongs to a group of churches commonly described as cross-domed with a tripartite sanctuary, a central octagonal bay, a (newly discovered) narthex, with the addition of pronounced lateral entrances and the likelihood of an atrium that defined its western end above the cistern. In fact, all surviving architectural features of the katholikon sit above the uncollapsed portions of the underground cistern, which was built simultaneously with the church and the monastic complex at large.

As for the dedication of the building, the Vita Ignatii indicates that the katholikon was dedicated to St. Michael; that the patriarch himself was buried there after his death on 23 October 877; and, finally, that the place of his burial was to the south of the main apse, in a small-sized chapel revetted with marble.

Already during the surface cleaning, fragments of decorated and inscribed marble cornices began to emerge, with larger numbers retrieved during the excavation work. Nine of the retrieved fragments of marble cornices are inscribed. One of them comes from a significant architectural and archaeological context.

The excavation of the northern portions of the church focused on the area to the east of the narthex corresponding to one of the four corner rooms adjoining the massive piers which form the church's central bay. Those to the east functioned as side apses to the bema, with the excavated one taking the form of an apsidal chapel.

The chapel preserves some traces of marble flooring and, on the lower level of the walls, traces of marble slab revetments. In the center of the space, a rectangular floor opening ( 1.60 by $0.80 \mathrm{~m}$. ca.) containes a marble slab with a circular hole for an opening in its fill. The fill has also yielded a decorated marble corner cornice with spade-shaped leaves and the Greek inscription (Figs. 2 and 2a): 
$+\lambda \varepsilon 1 \psi$

$\lambda \varepsilon i ́ \psi \alpha$ vov (?)

(relic?)

The cornice shows the incipit of an inscription whose continuation has not emerged during the excavation of this space. However, other wall cornices have been retrieved in this space, amounting to a total of 23 fragments, all bearing the same measurements and the same decorative pattern of spade-shaped leaves. On some of the fragments, it is possible to detect traces of blue cobalt paint. They all belonged to a continuous marble cornice running around its walls and displaying a consistent decorative pattern. Along with the decoration, the cornice included an inscription, whose length and content remain (for the time being) unclear. The architectural features and the nature of the finds make it likely that this space functioned as a reliquary chapel. A hypothetical elevation drawing of the chapel (Fig. 3) shows how the cornice may have featured in this space (Pedone 2018).

The inscription in the chapel also sheds light on the two similar fragments documented before our project begun. The first, published by Eyice, read "OVIEPO", which was read as "tou ierou" (Eyice 1959; Feissel 1987; Mango 1994, 349). The second fragment, a corner cornice, is known through a drawing recorded by Mamboury and subsequently published by Feissel. Mamboury's drawing shows "EBPU" preceded by a much-eroded letter that,

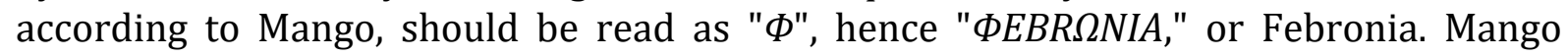
interpreted the name as St Febronia, one of the "women martyrs" to whom, according to

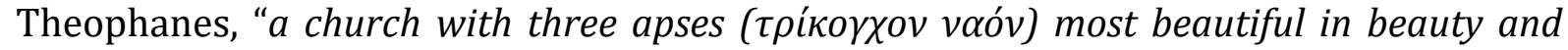
surpassing many others in size, the middle in the name of the Commander-in-chief Michael and each of the two sides in the names of women martyrs" at the Palace of Bryas was dedicated. Mango has therefore concluded that the inscription likely belonged to the triconch church of the palace itself, and hence the site was identified with that of the Emperor Theophilus' Islamicate Palace of Bryas (Mango 1994, 349-350). The question of the plan of the building and the incongruity with a triconch identification of the remains has progressively become apparent as excavation and documentation of the church have progressed. This leaves (if the reading of the inscription proves to be correct) an association of St Febronia with the chapel in the palace. The role of this female saint from Nisibis in Constantinopolitan churches and the transfer of her cult from the East to the West have recently been discussed by Kaplan (Kaplan 2012). Although the existence of the cult of this saint remains somewhat dubious, Kaplan deduces her celebrity on the basis of St Febronia's Passio and Translatio, and some other texts. One of these is the letter no 85 of the iconodule monk Theodore, the abbot of the Studios monastery, in which Theodore mentions that Febronia stands as a model for all other women to resist iconoclasm. It is hard to imagine that an iconoclast emperor such as Theophilos, and his advisors, would have felt motivated to dedicate a section of the Palace of Bryas' chapel to one of Theodore's elected female defenders of iconodule beliefs.

The inscribed cornices from the katholikon at the monastery of Satyros represents a rather early example of this kind of aesthetic and textual display. It is hoped that further archaeological work may help retrieve larger portions of the inscribed cornices and that some further hypothesis about the text might be formulated. At the moment, it is too premature to speculate about the nature of the inscription(s) that decorated the interior of the katholikon, and on whether the exterior of the building may have also featured an inscription, as was the case with buildings from later periods (Drpić 2016). The nature of the epigraph-whether in verse or prose-also remains unclear. On the other hand, our current and ongoing research allows us to propose that the marble cornices interacted 
with the decoration of the church at large, including the walls' marble revetments, likely extending to the cornices and areas with mosaics placed above the cornices. At some point in their functional life, they may have been painted. In the small chapel, the cornices themselves included text and decorative elements that may have alternated to form a visual and aesthetic narrative. This design was intertwined with the functions and rituals of the smaller spaces and with the monumentality of the building as a whole.

\section{Selected Bibliography}

Bardill J. (2004) Brickstamps of Constantinople, 2 vols, Oxford.

Belke, K. (2020), Bithynien und Hellespont (= Tabula Imperii Byzantini, 13), Vienna, 988990 (s.v. Satyros).

Drpić I. (2016) Chrysepes Stichourgia. The Byzantine Epigram as Aesthetic Object, in Bedos-Rezak, B. M. and Hamburger, J. F. (eds), Sign and Design. Script as Image in CrossCultural Perspective (300-1600 CE), Washington, D.C., 51-70.

Eyice S. (1959a) Istanbul'da Abbâsi saraylarinin benzeri olarak yapilan bir bizans saray, Belleten 23, 79-114 (with French resumé).

- (1959b) Contributions a l'histoire de l'art byzantin: quatre édifices inédits ou mal connus, Cahiers Archeologiques 10, 245-250.

Feissel D. (1987) De Chalcédonie à Nicomédie. Quelques inscriptions négligées, Travaux et Mémoires 10, 405-436.

Kaplan M. (2012) Une hôtesse importante de l'église saint-Jean-Baptiste de l'Oxeia à Constantinople: Fébronie, in Sullivan, D., Fisher, E. and Papaioannou, St. (eds), Byzantine Religious Culture. Studies in Honor of Alice-Mary Talbot, Leiden and Boston, 31-52.

Janin R. (1923) La banlieue asiatique de Constantinople. Étude historique et topographique, Echos d'Orient 22, 281-290.

- (1964) Constantinople Byzantine. Développement urbain et répertoire topographique, Paris.

Jordan, R. (2000) Pantokrator: Typikon of Emperor John II Komnenos for the Monastery of Christ Pantokrator Constantinople, in Byzantine Monastic Foundation Documents: A Complete Translation of the Surviving Founders' Typika and Testaments, Washington, D.C., vol. 2, 725-780.

Mamboury E. (1920) Ruines Byzantines de Mara entre Maltépé et Bostandjik, Echos d'Orient 19, 322-330.

Mango C. (1994) Notes d'épigraphie et d'archéologie: Constantinople, Nicée, Travaux et Mémoires 12, 343-358.

Melle C. (2004) I Bolli Laterizi Paleo-bizantini: i Casi di Küçükyalı e Samandira. Tesi di Laurea in Storia dell'Arte Bizantina. Università degli Studi di Lecce (2003-2004), Lecce.

Ousterhout R. (2008) Master Builders of Byzantium, Philadelphia.

Pargoire V. (1901) Les monastères de Saint-Ignace et les cinq petit îlots de l'archipel des Princes, Bulletin de l'Institut archéologique russe de Constantinople 7, 62-78.

Pedone S. (2018), The sculptures from Küçükyalı and their archaeological context, Bizantinistica. Rivista di Studi Bizantini e Slavi 19, 377-390.

Ricci A. (1998) The Road from Baghdad to Byzantium and the case of the Bryas Palace in Istanbul, in Brubaker, L. (ed) Byzantium in the Ninth century. Dead or Alive, Aldershot, 131-150. 
- (2012) Left behind: Small Sized Objects from the Middle Byzantine Monastic Complex of Satyros (Küçükyalı, Istanbul), in Böhlendorf-Aslan, B. and Ricci, A. (eds) Byzantine Small Finds in Archaeological Contexts, Istanbul, 147-162.

- (2017) Infrastruttura, Produzione e Riutilizzo: il cantiere medio Bizantino a Küçükyalı (Istanbul), Arkeoloji ve Sanat 154, 135-146.

- (2018), Rediscovery of the patriarchal monastery of Satyros (Küçükyalı, Istanbul): Architecture, archaeology and hagiography, Bizantinistica. Rivista di Studi Slavi e Bizantini 19, 347-376.

- (2019), The Küçükyalı ArkeoPark (Istanbul), 2016-2018: Excavation, conservation, cultural heritage and public archaeology, Anatolia Antiqua, 28, 255-277.

Ricci A. and Yilmaz A. (2016), Urban Archaeology and Community Engagement: the Küçükyalı ArkeoPark, in Alvarez, M., Yuksel, A. and Go, F. M. (eds) Heritage Tourism Destinations: Preservation, Communication and Development, Wallingford, 41- 62.

Ricci A. and Wohmann R. (2018), Byzantine contexts from the Asian suburbs of Constantinople: preliminary remarks on the ceramics and the archaeology at the Küçükyalı ArkeoPark (Istanbul), in Yenişehirlioğlu, F. (ed), XIth Congress AIECM3 on Medieval and Modern Period Mediterranean Ceramics Proceedings, Ankara, vol. 1, 453458.

Sayar M. (2015), Ziegelstempel von den Ausgrabungen am Nordwestufer des Lagunensees Küçükcekmece, in Rhoby, A. (ed) Inscriptions in Byzantium and Beyond: Methods - Projects - Case Studies, Vienna, 187-194.

Smithies, A. (with notes by Duffy, J. M.) (2013) Vita Ignatii Patriarchae / The Life of Patriarch Ignatius, Washington D.C.

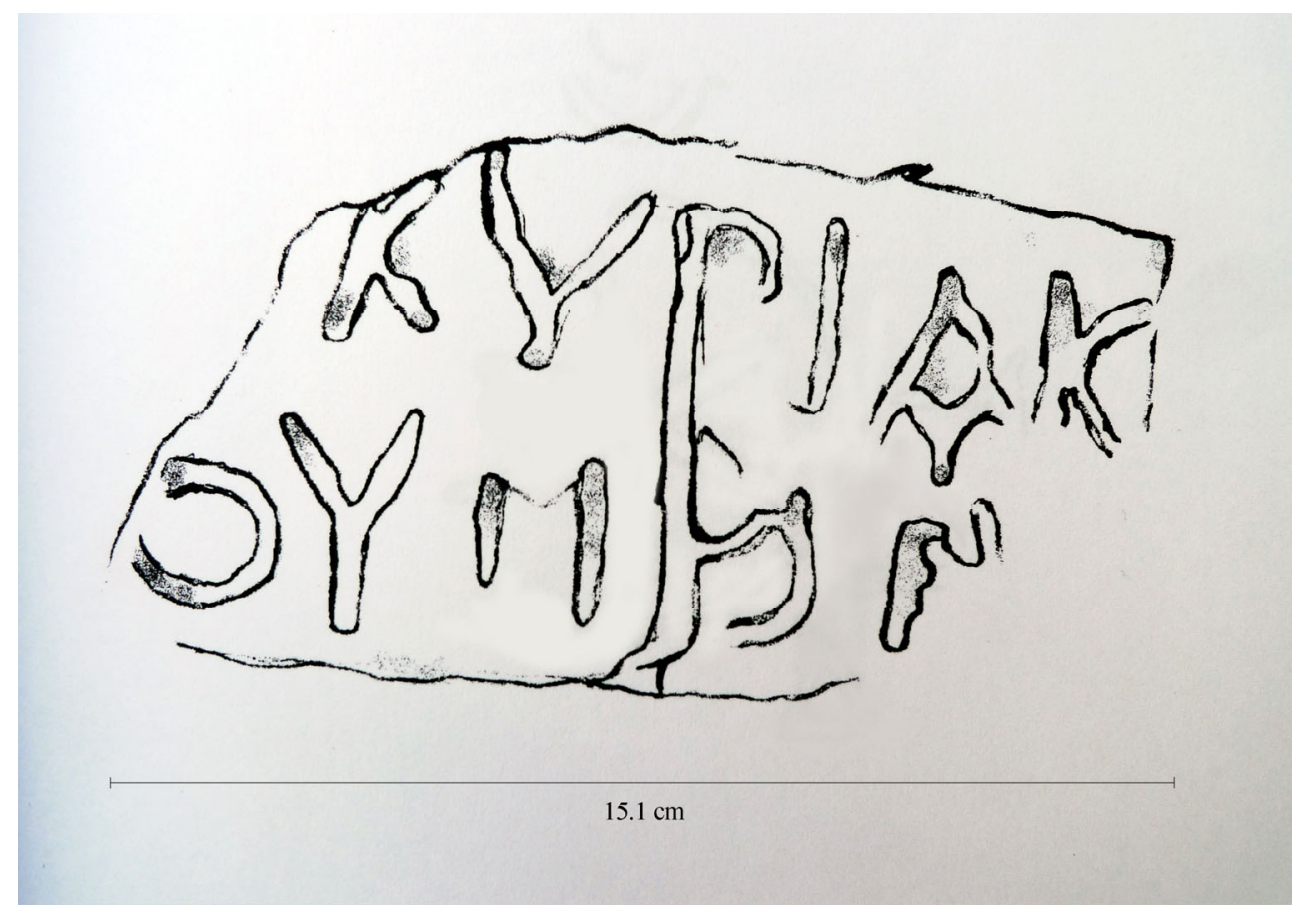

Fig. 1 Brickstamp drawing, in situ, church main apse.

Monastery of Satyros (Küçükyalı, Istanbul) after Melle 2004 and Ricci 2017 


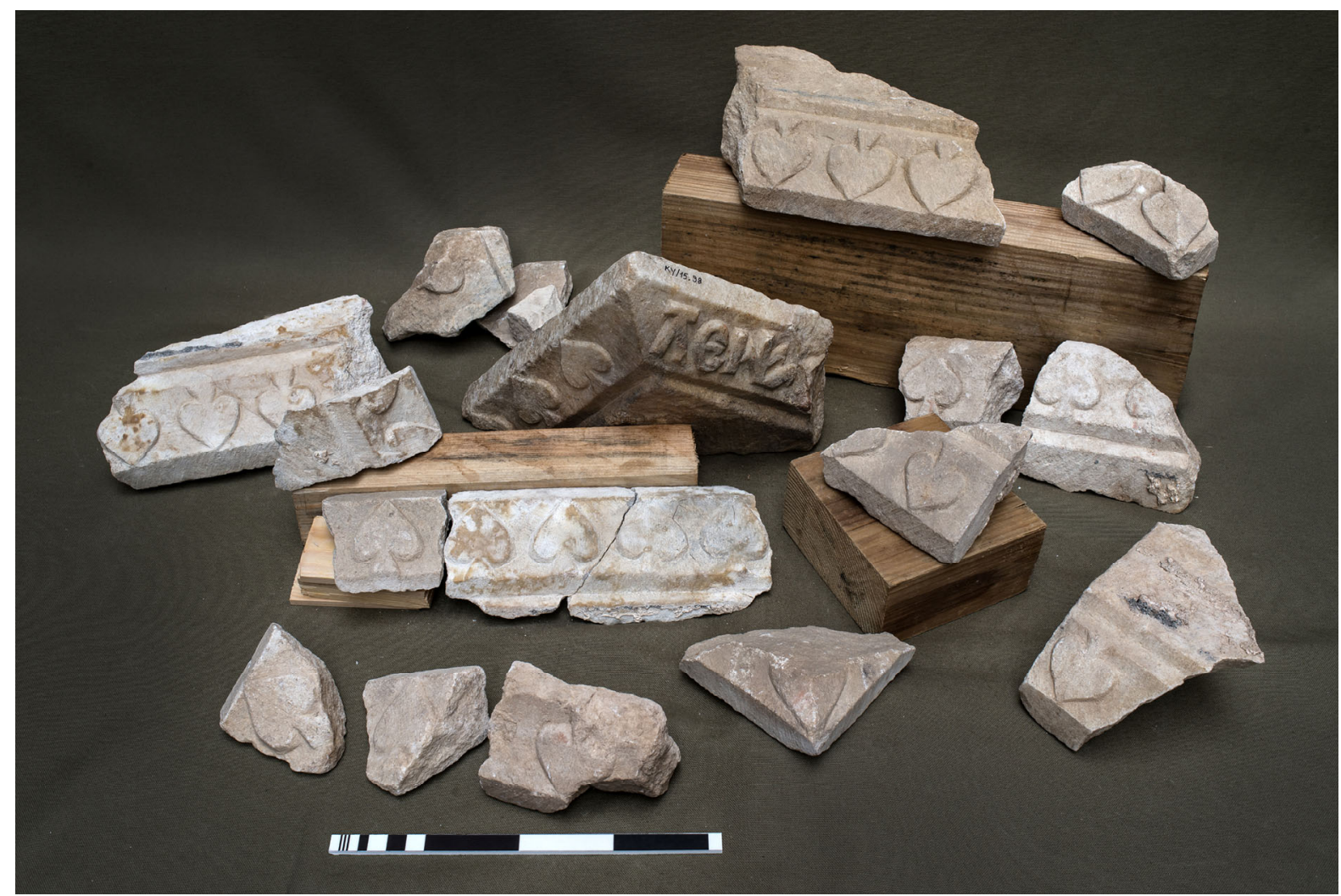

Fig. 2 Marble cornice fragments from the lateral chapel of the church. Monastery of Satyros (Küçükyalı, Istanbul) after Pedone 2018

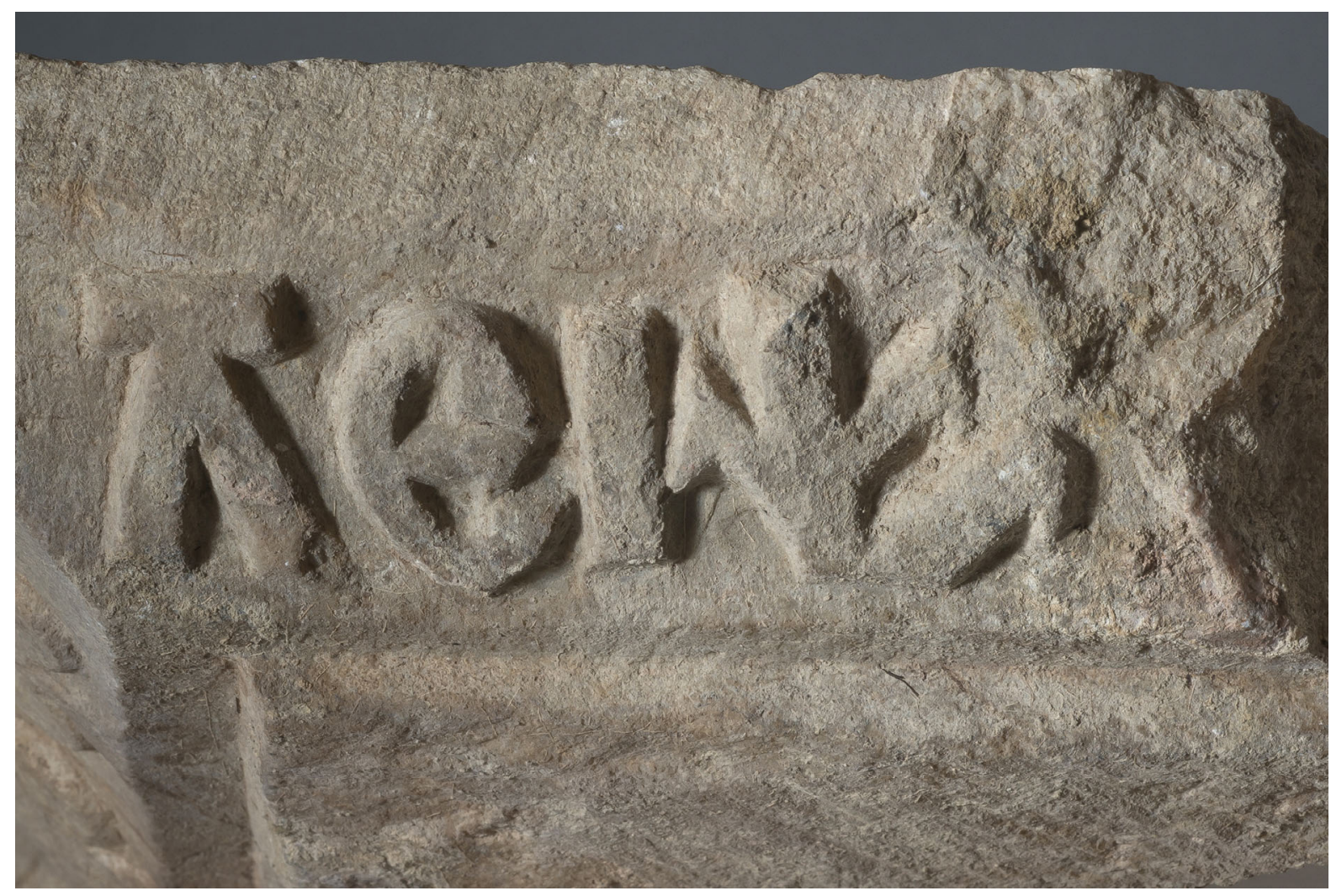

Fig. 2a Enlarged detail of the inscription on the marble cornice. Monastery of Satyros (Küçükyalı, Istanbul) after Pedone 2018 


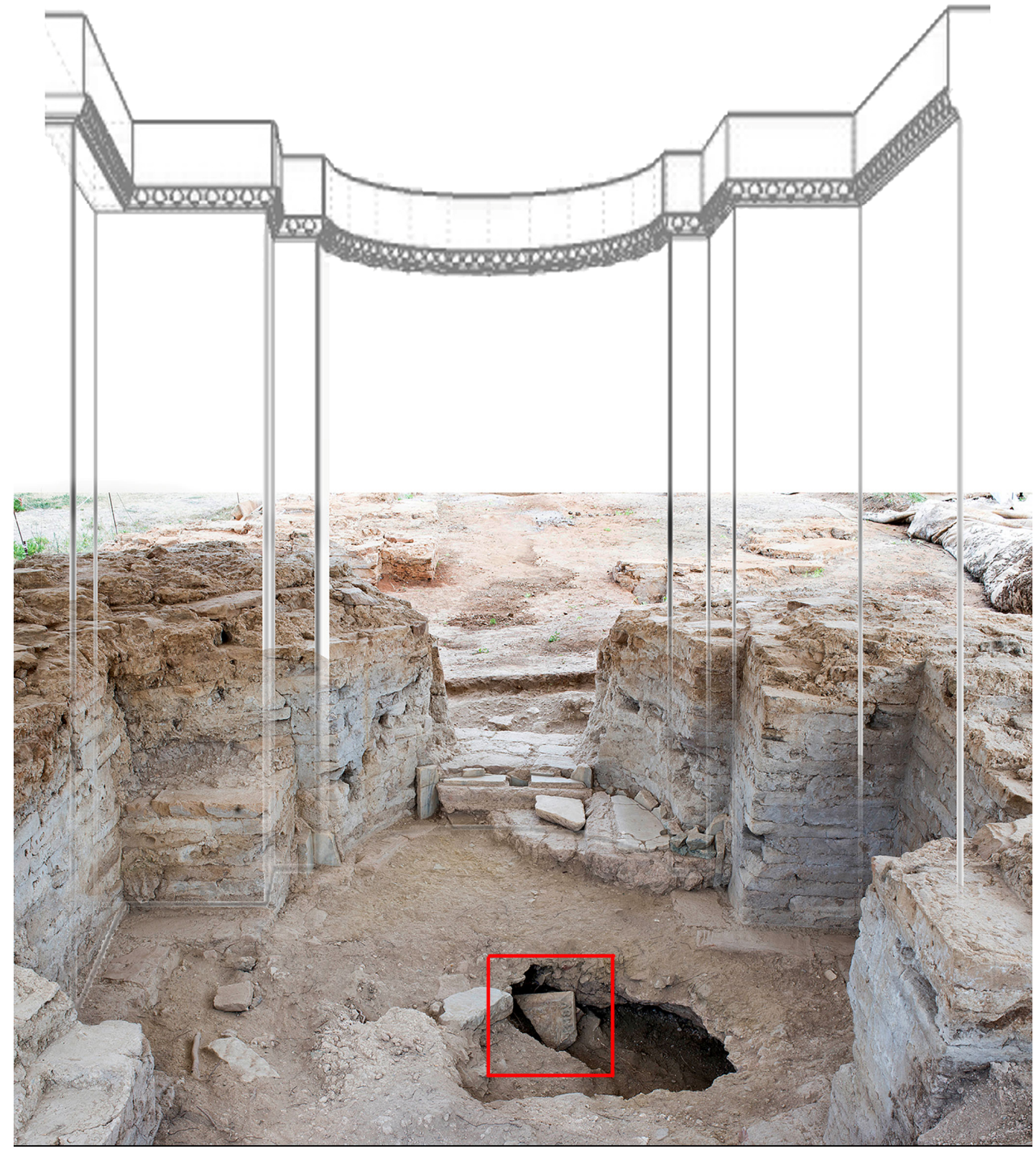

Fig. 3 Hypothetical reconstruction of marble cornices in the lateral chapel. Monastery of Satyros (Küçükyalı, Istanbul) after Pedone 2018 
X PHOTO ARCHIVE: SITE VISITS 



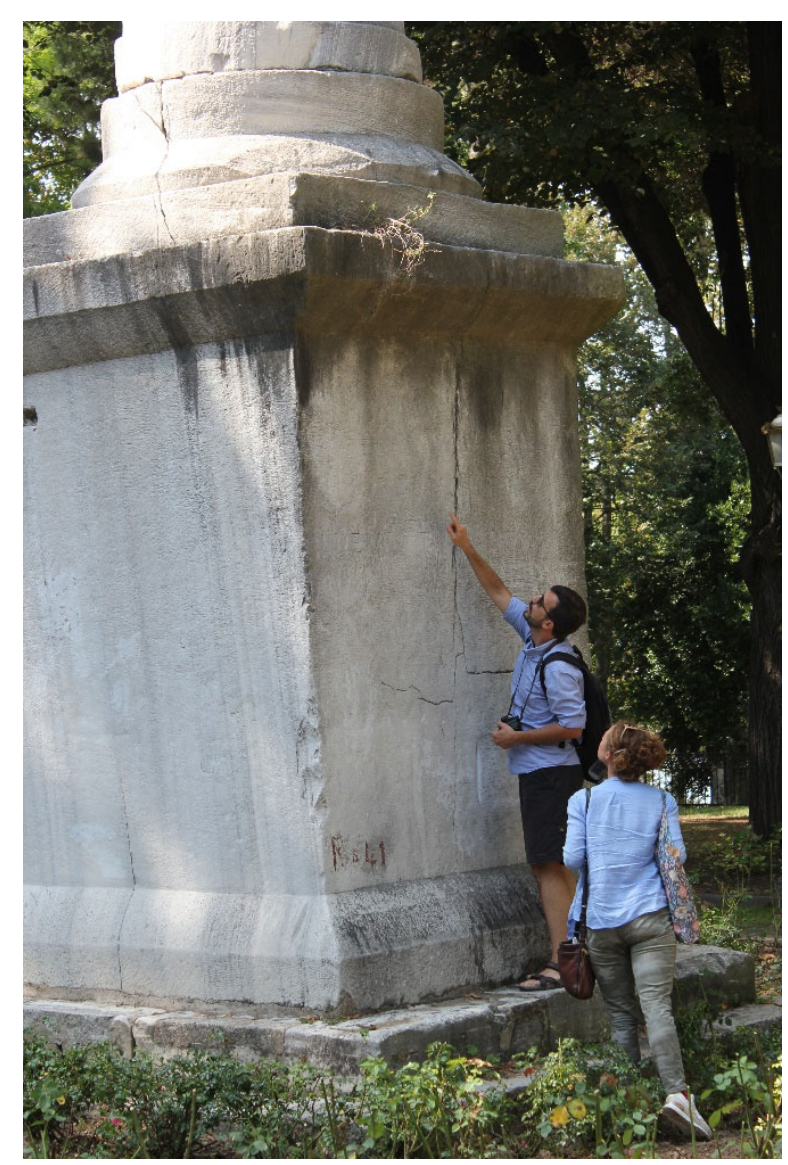

The column of the Goths (C) Ivan Drpić)

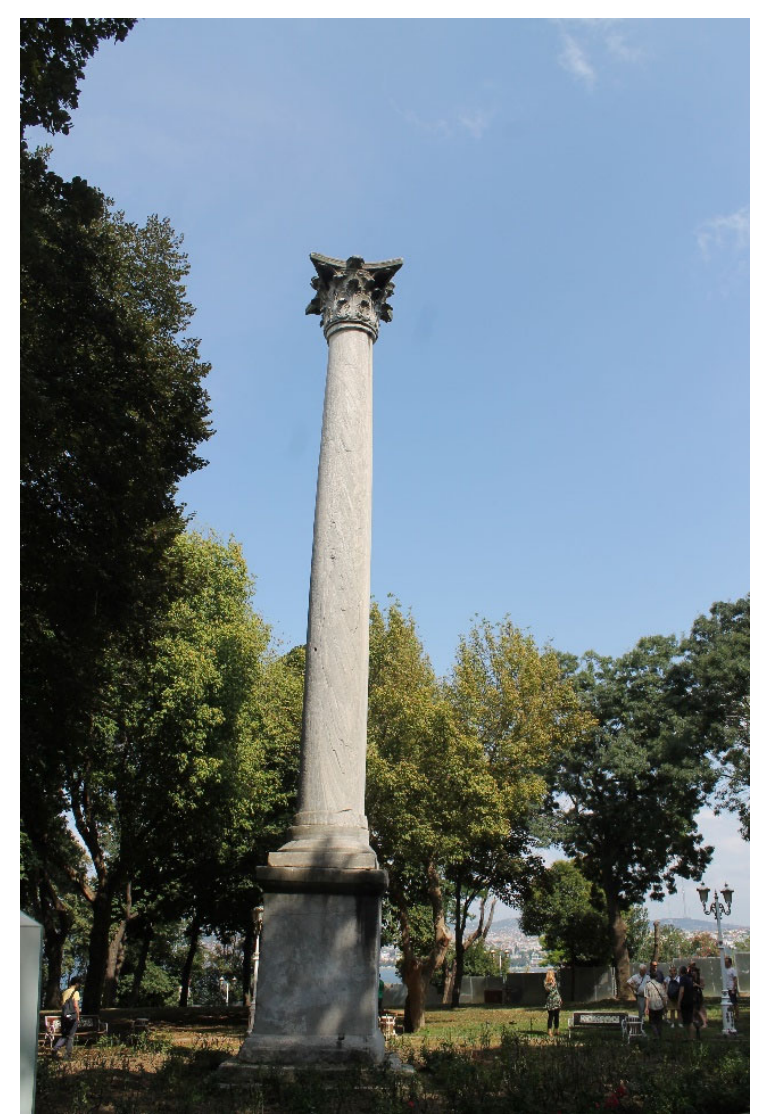

(C) Andreas Rhoby 


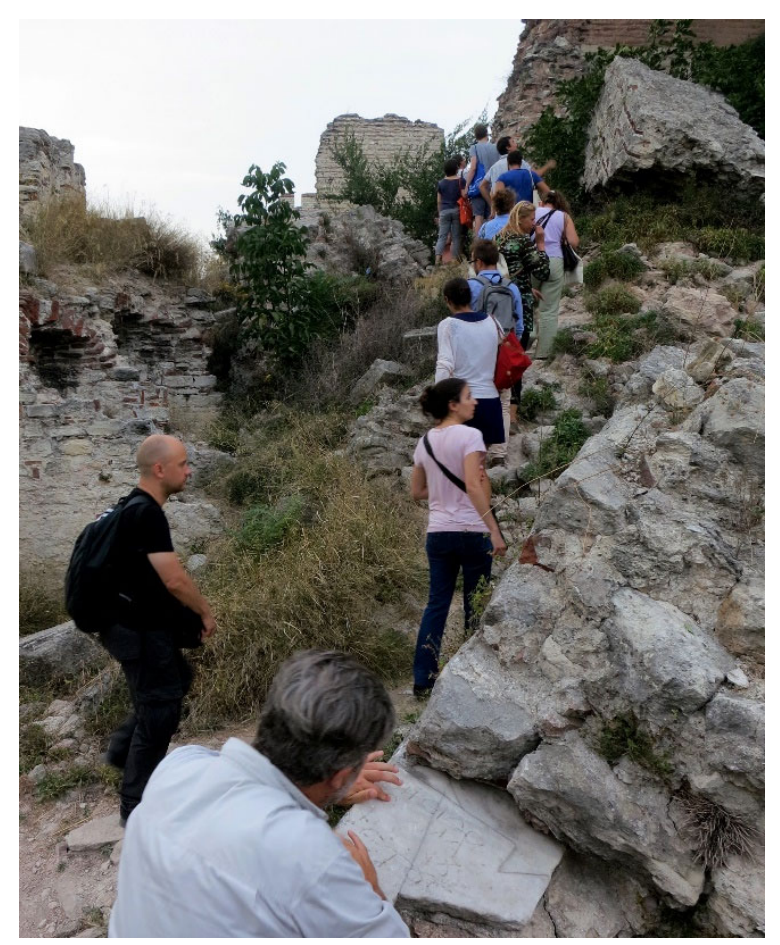

The Land Walls (C Brad Hostetler)

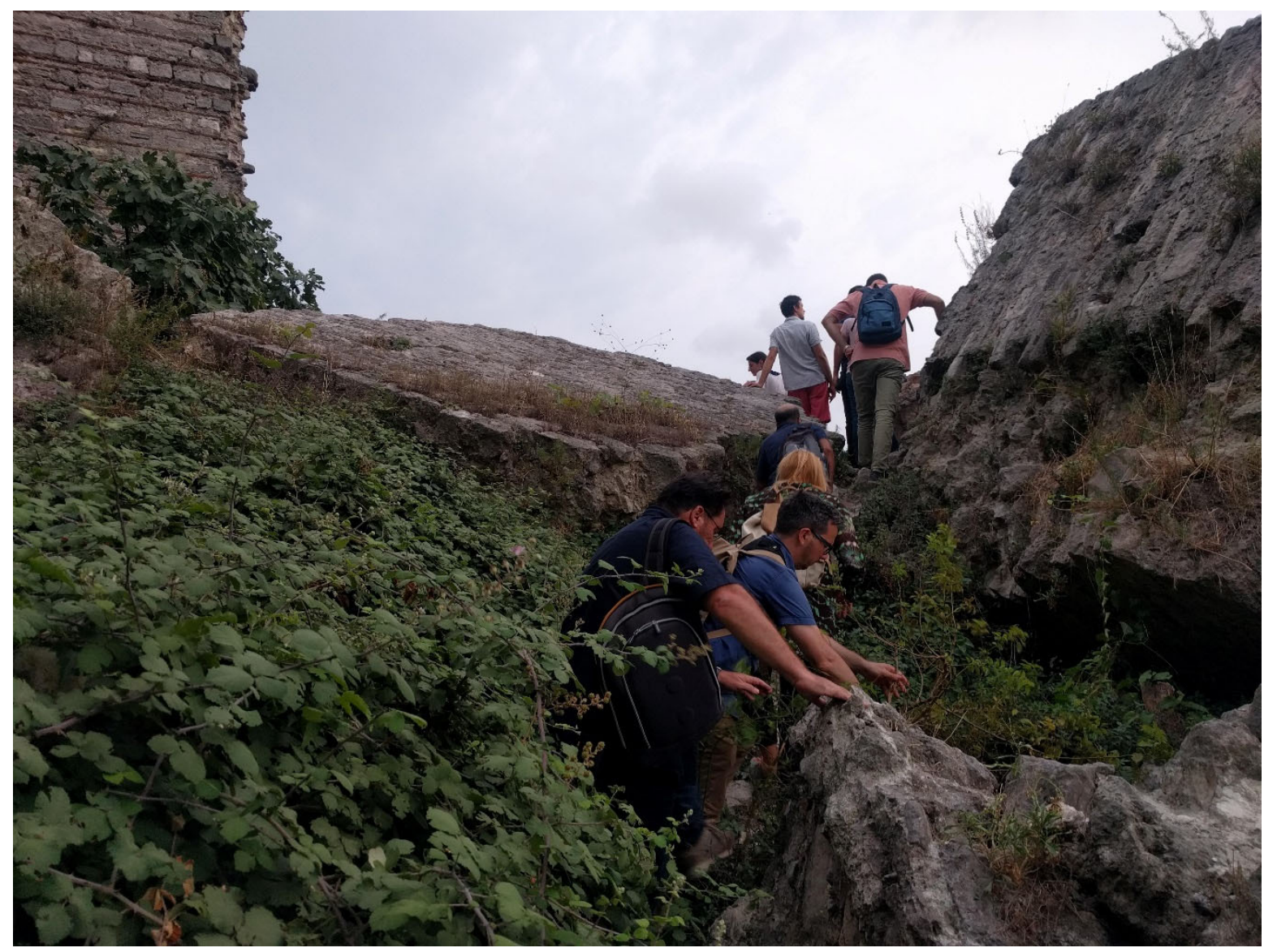

(C) Nikos Tsivikis 


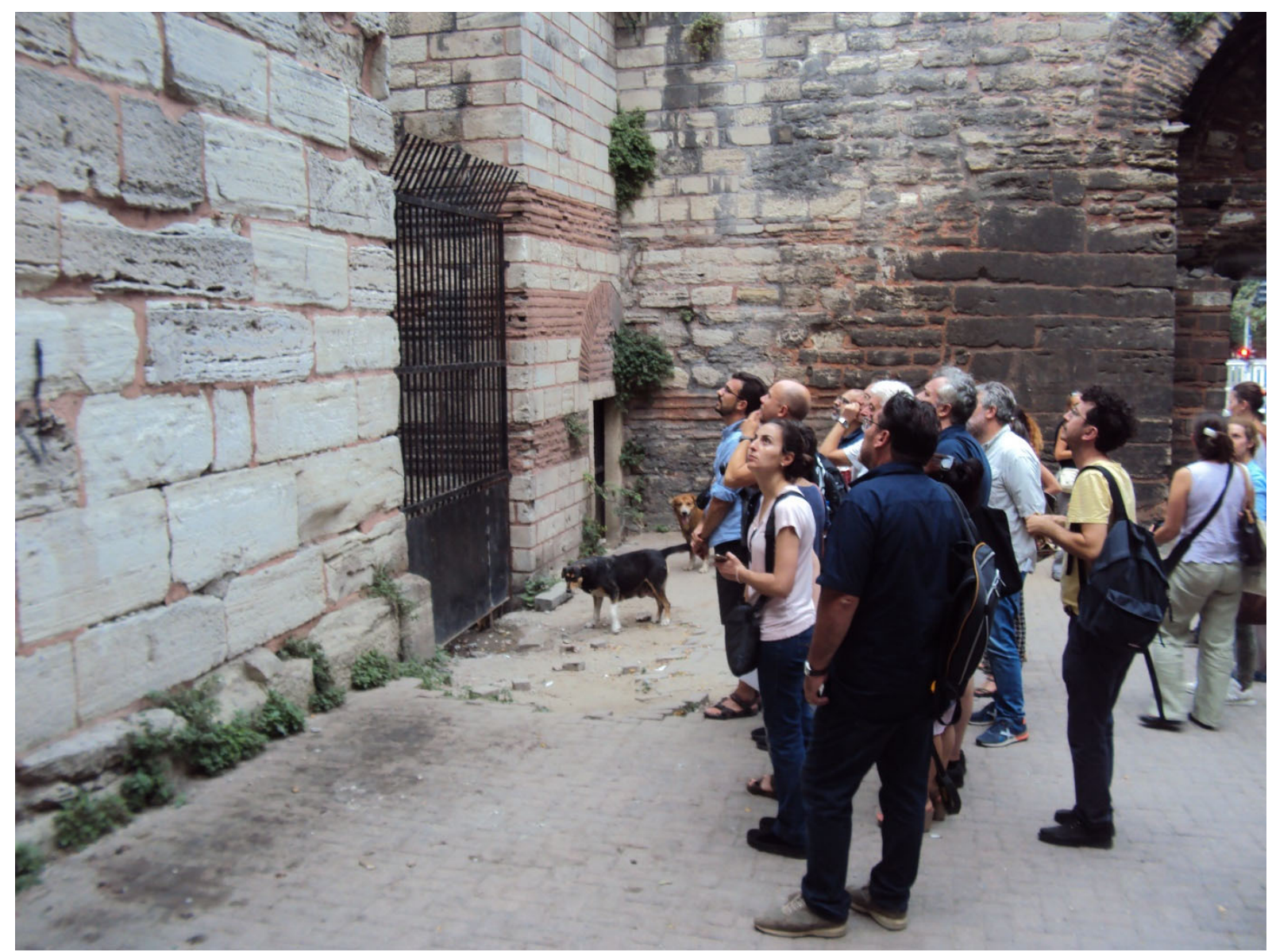

(C) Giorgos Pallis

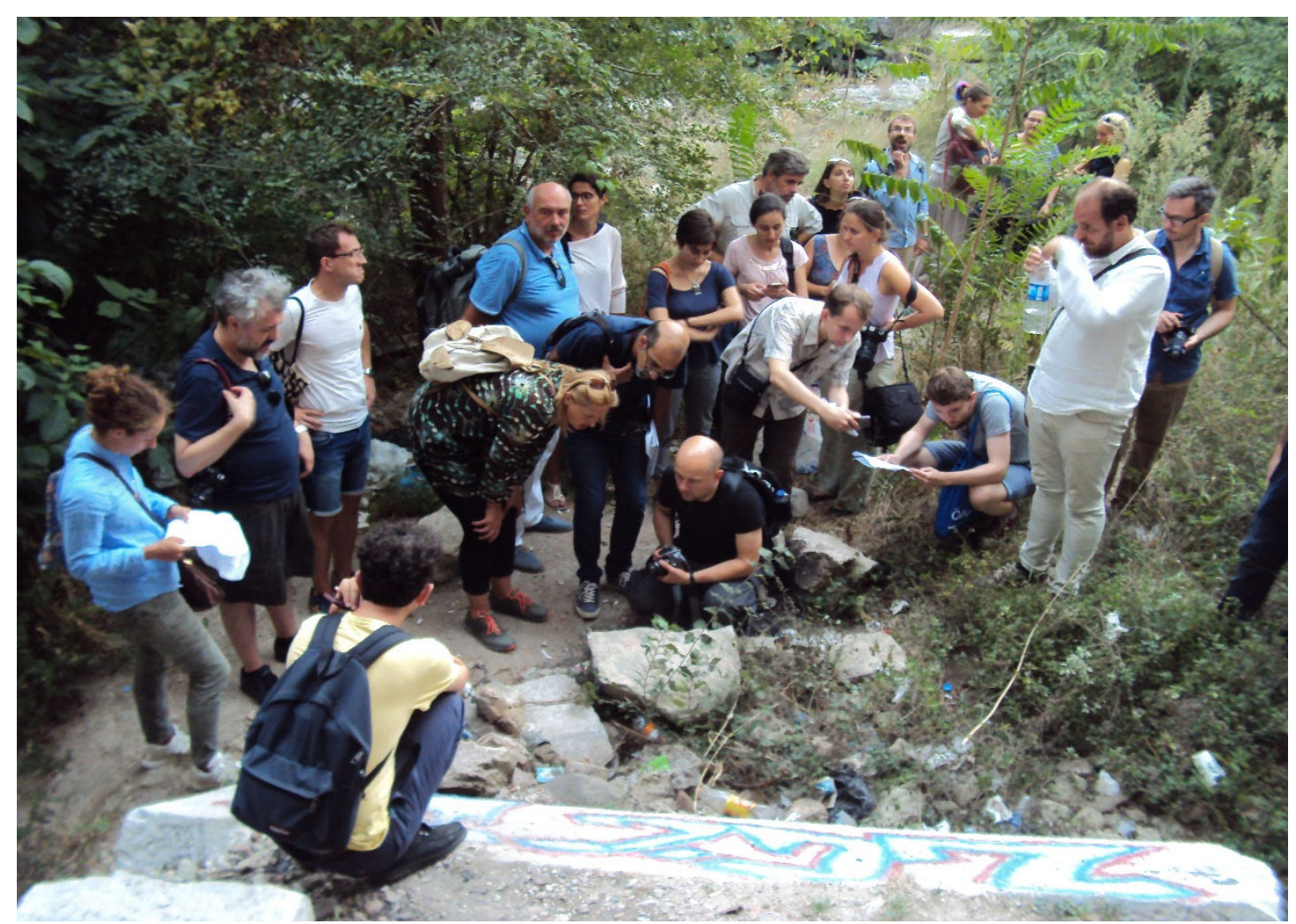

(C) Giorgos Pallis 


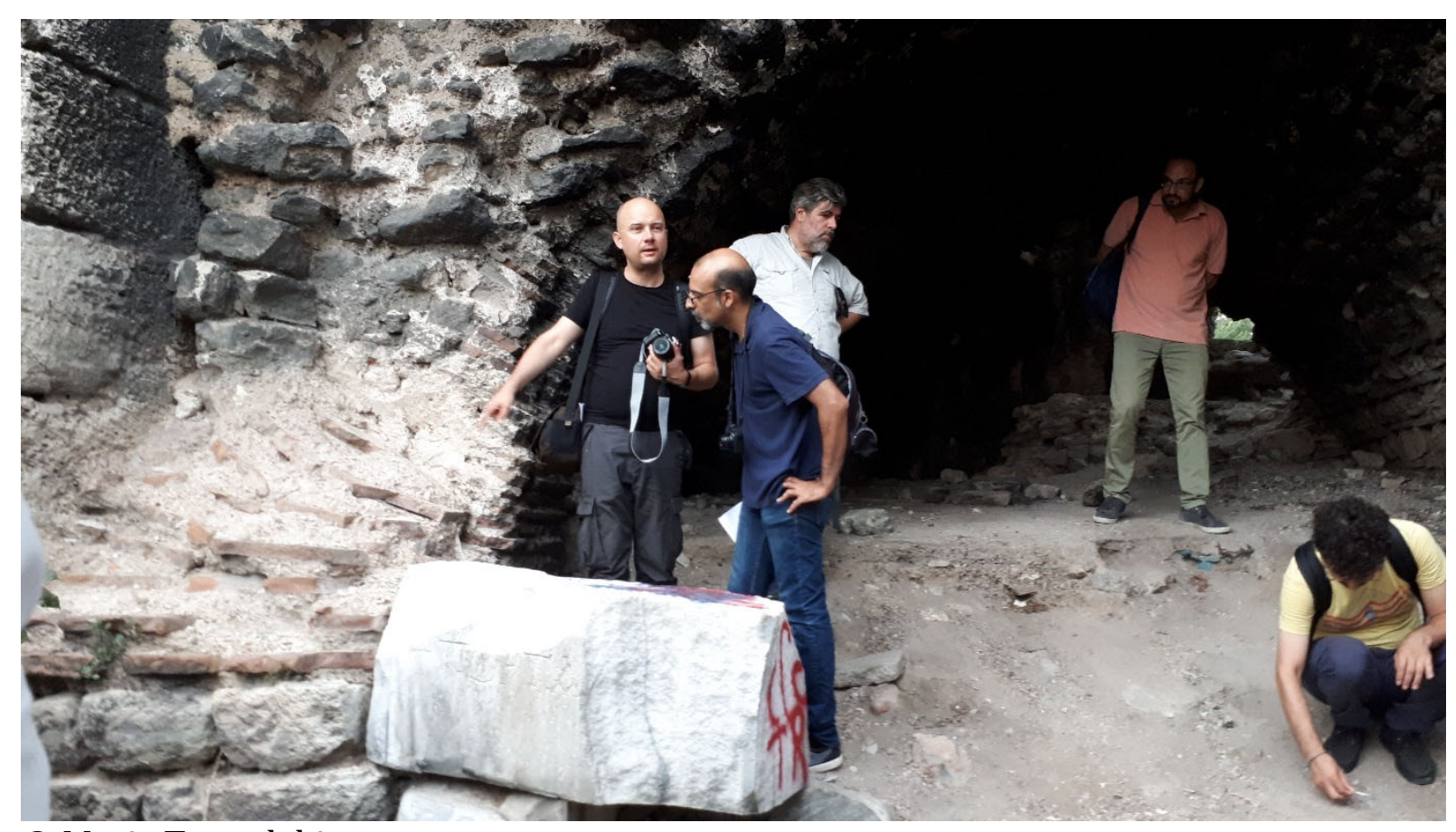

(C) Maria Tomadaki

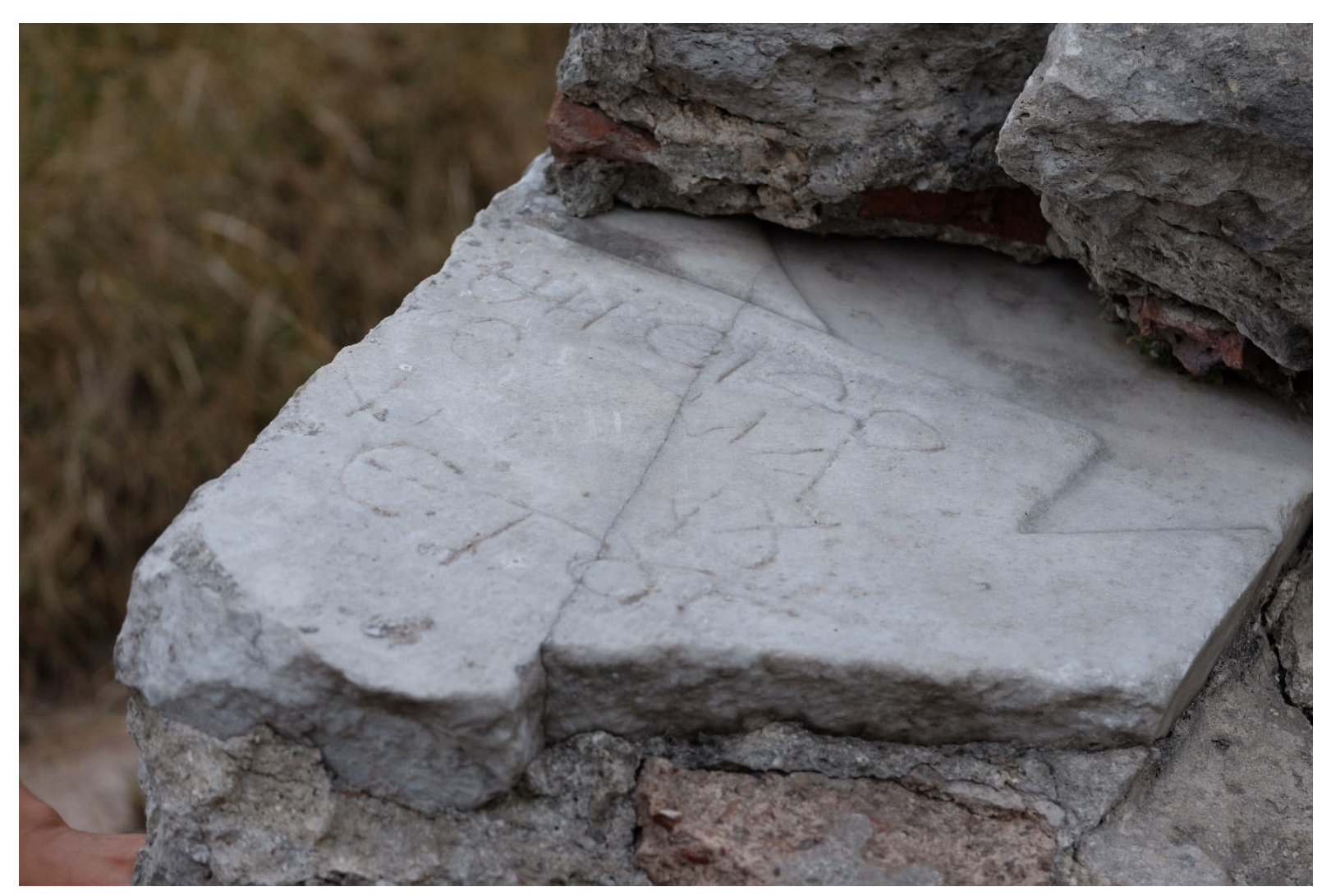

(C) Brad Hostetler 


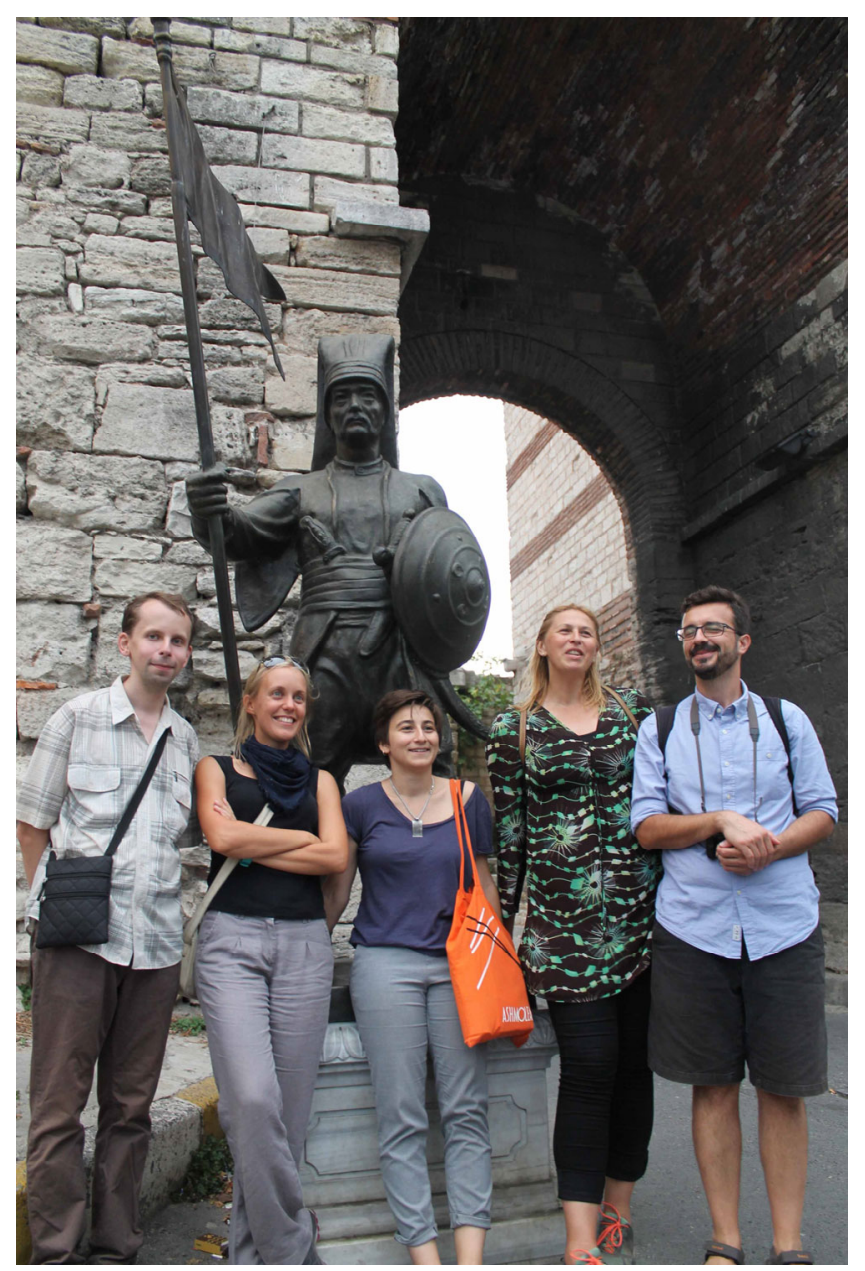

(C) Andreas Rhoby

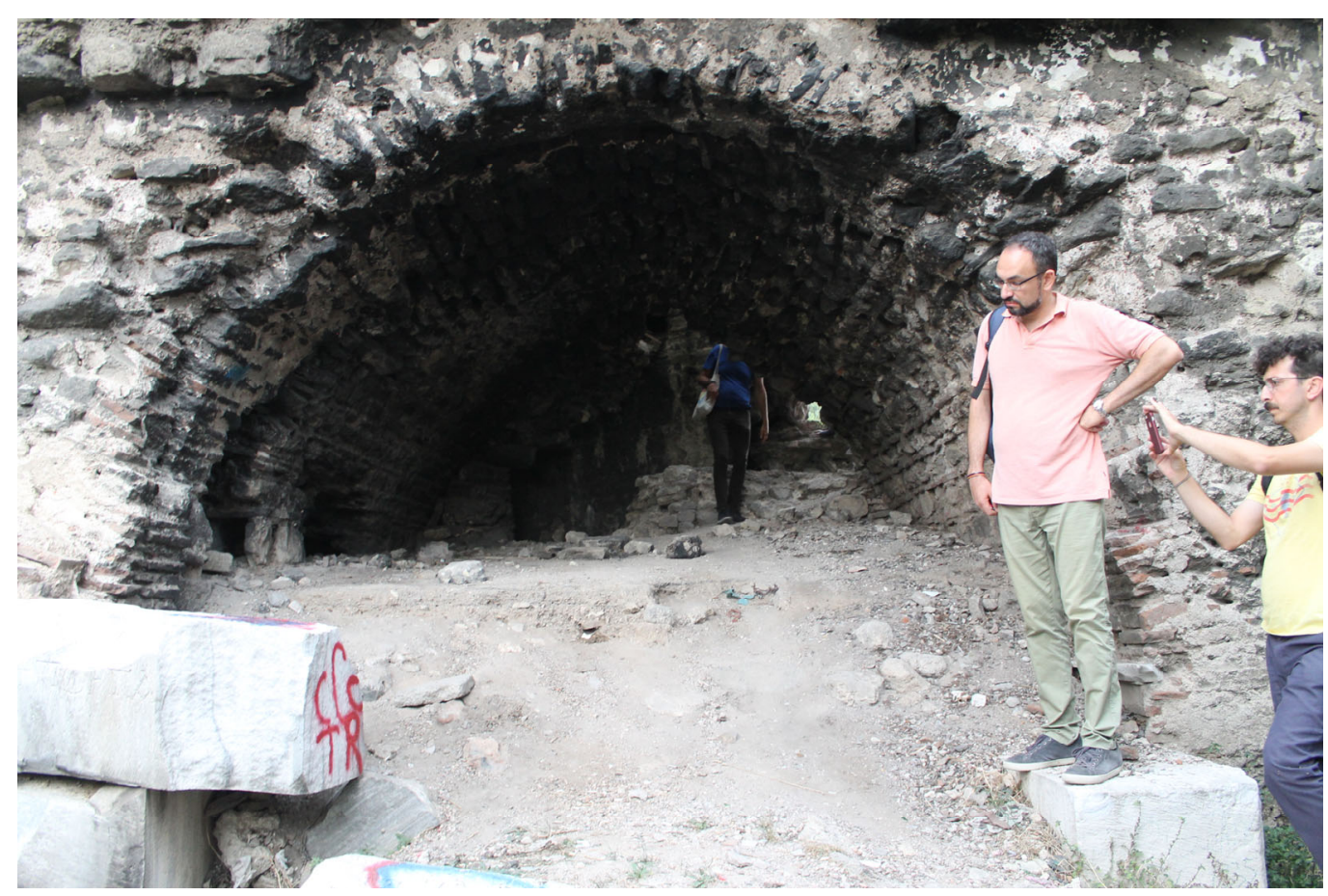

(C) Andreas Rhoby 


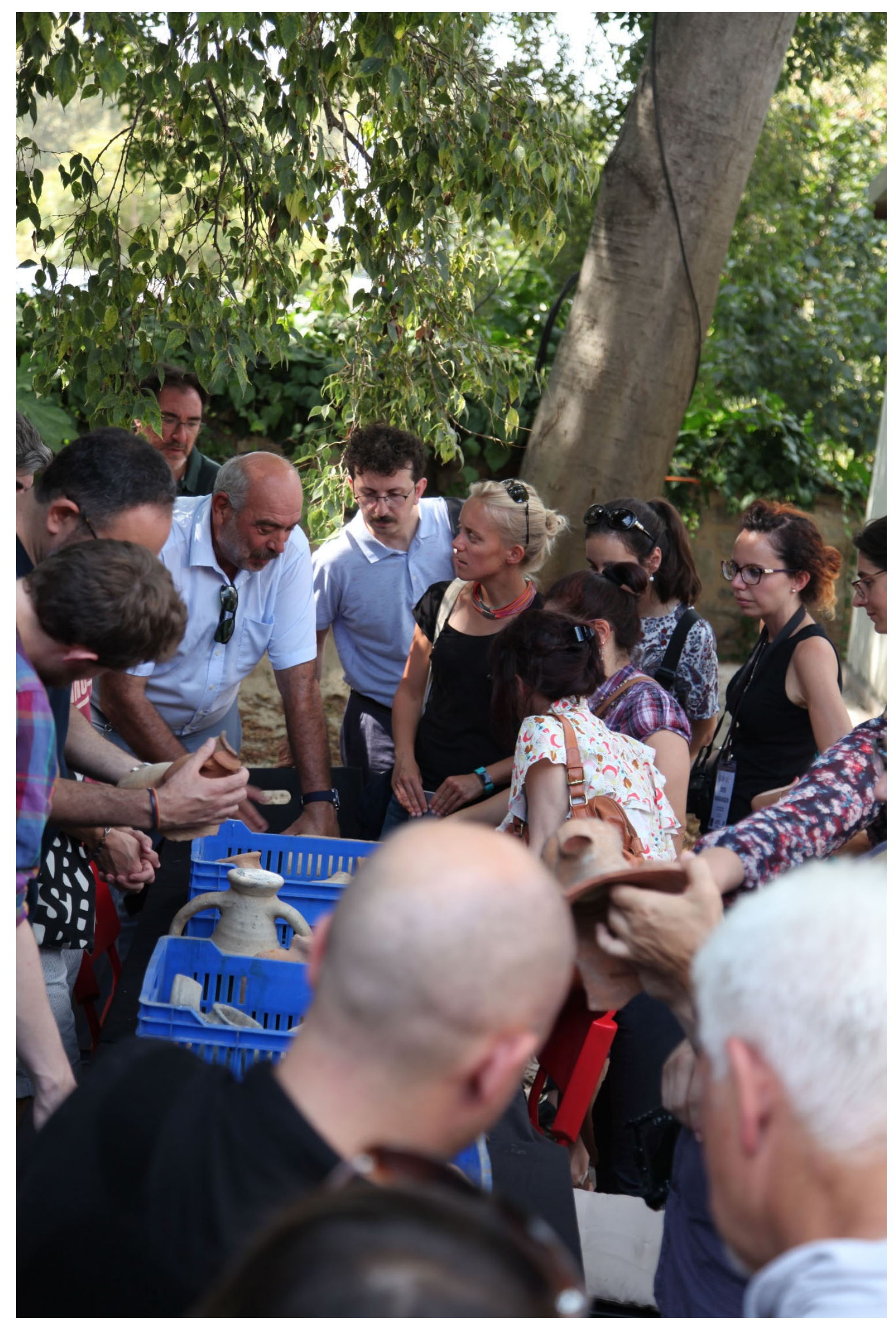

Exploring Yenikapı finds (C) Maria Lidova) 


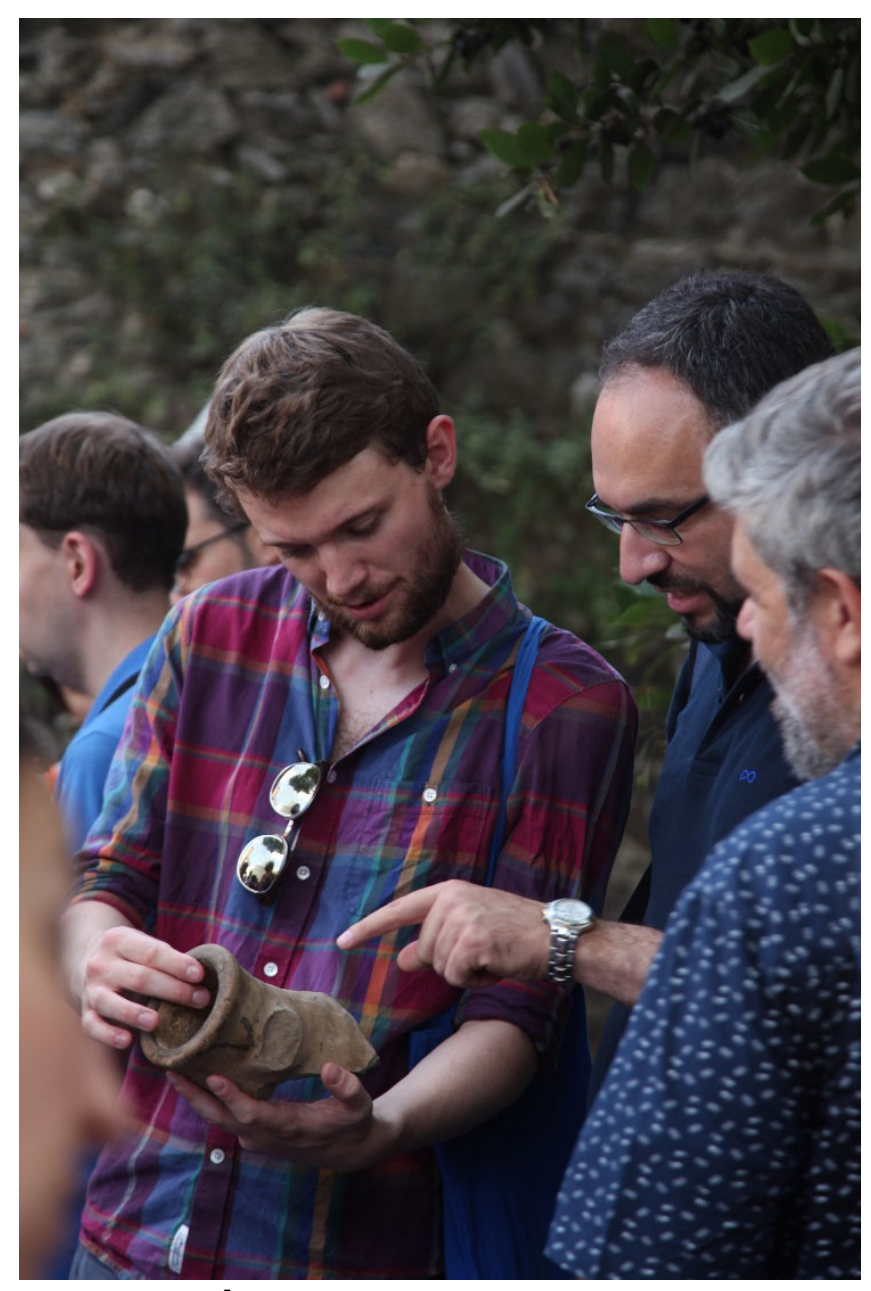

(C) Maria Lidova

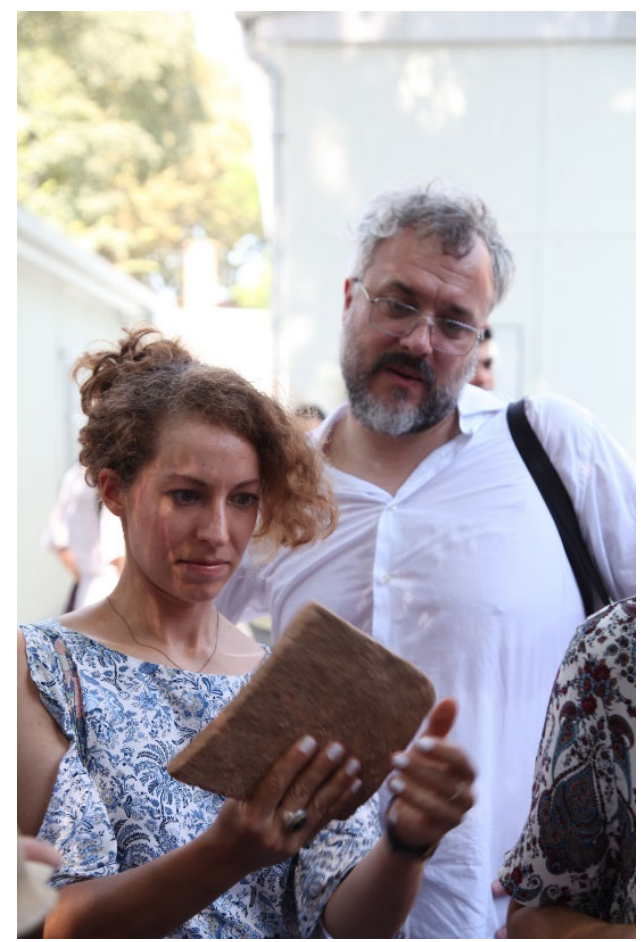

(C) Maria Lidova 


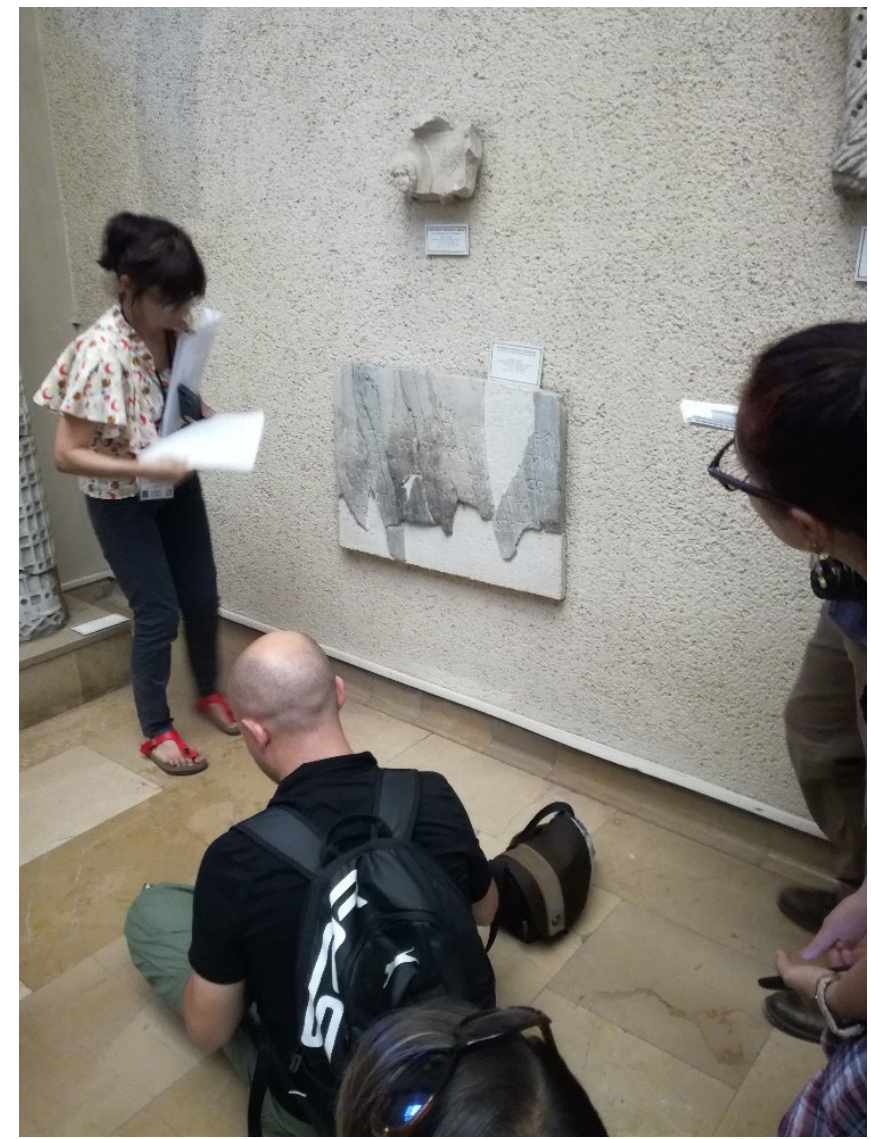

The Archaeological Museum (C) Paweł Nowakowski)

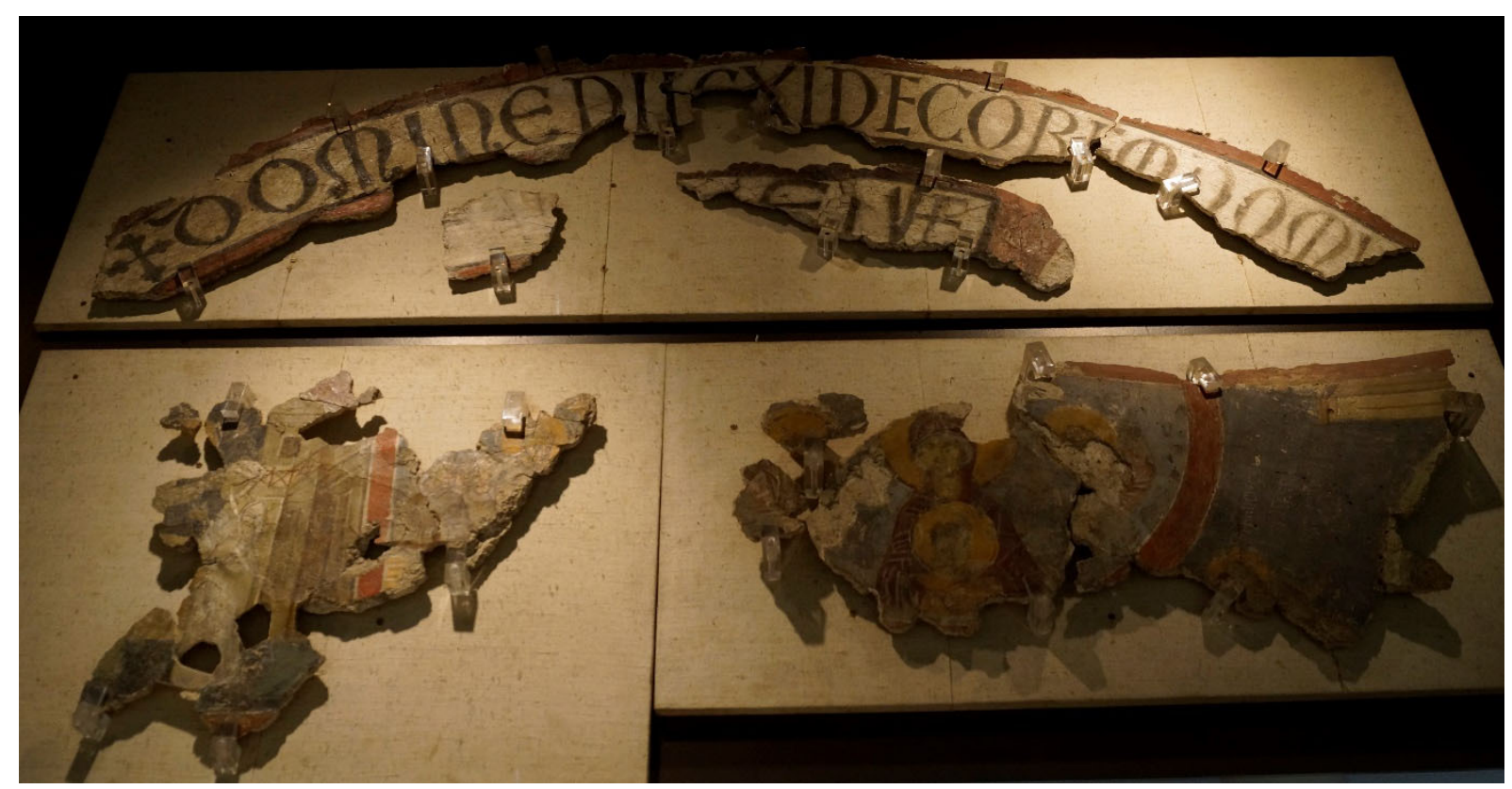

(C) Estelle Ingrand-Varenne 


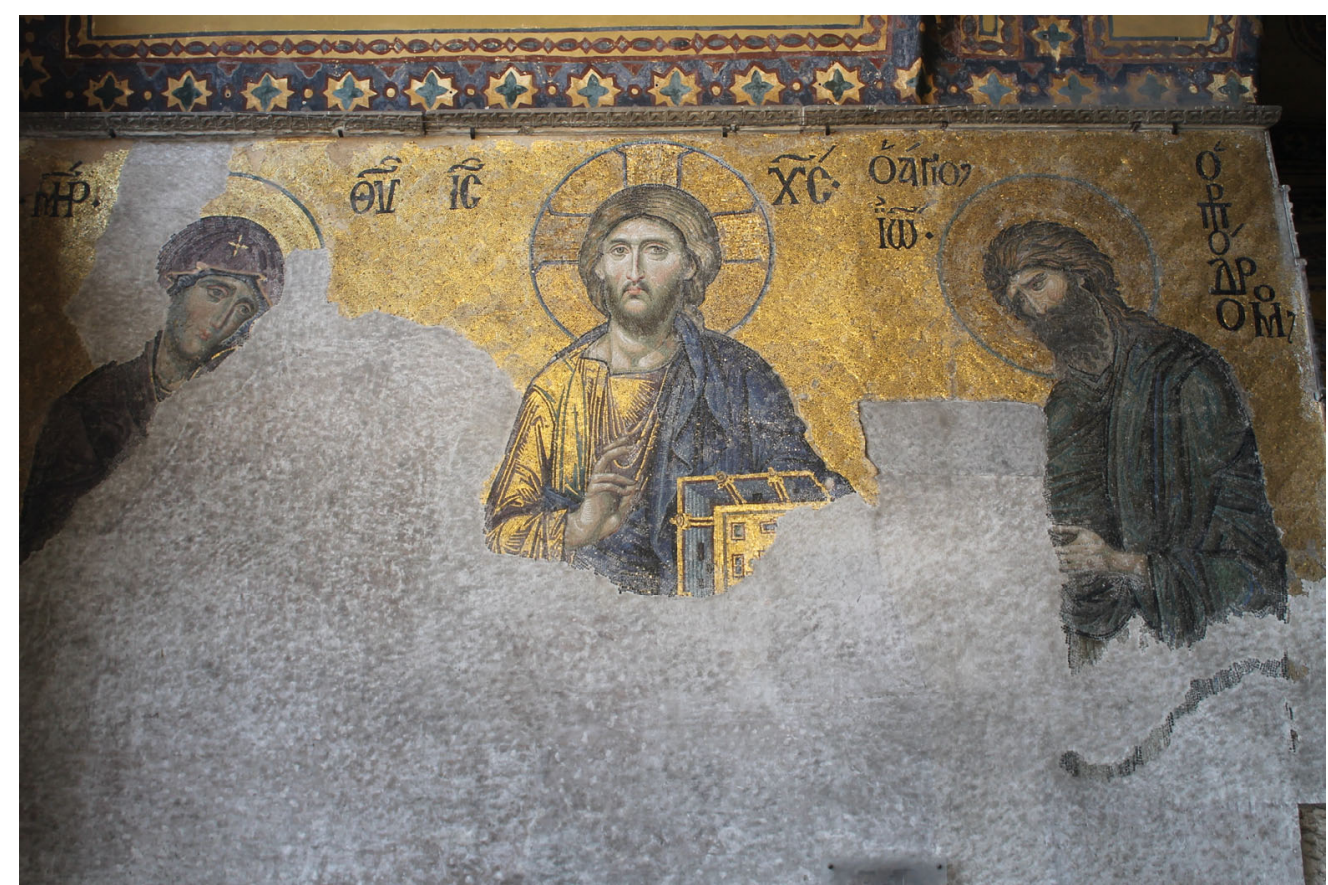

The Hagia Sophia (C) Andreas Rhoby)

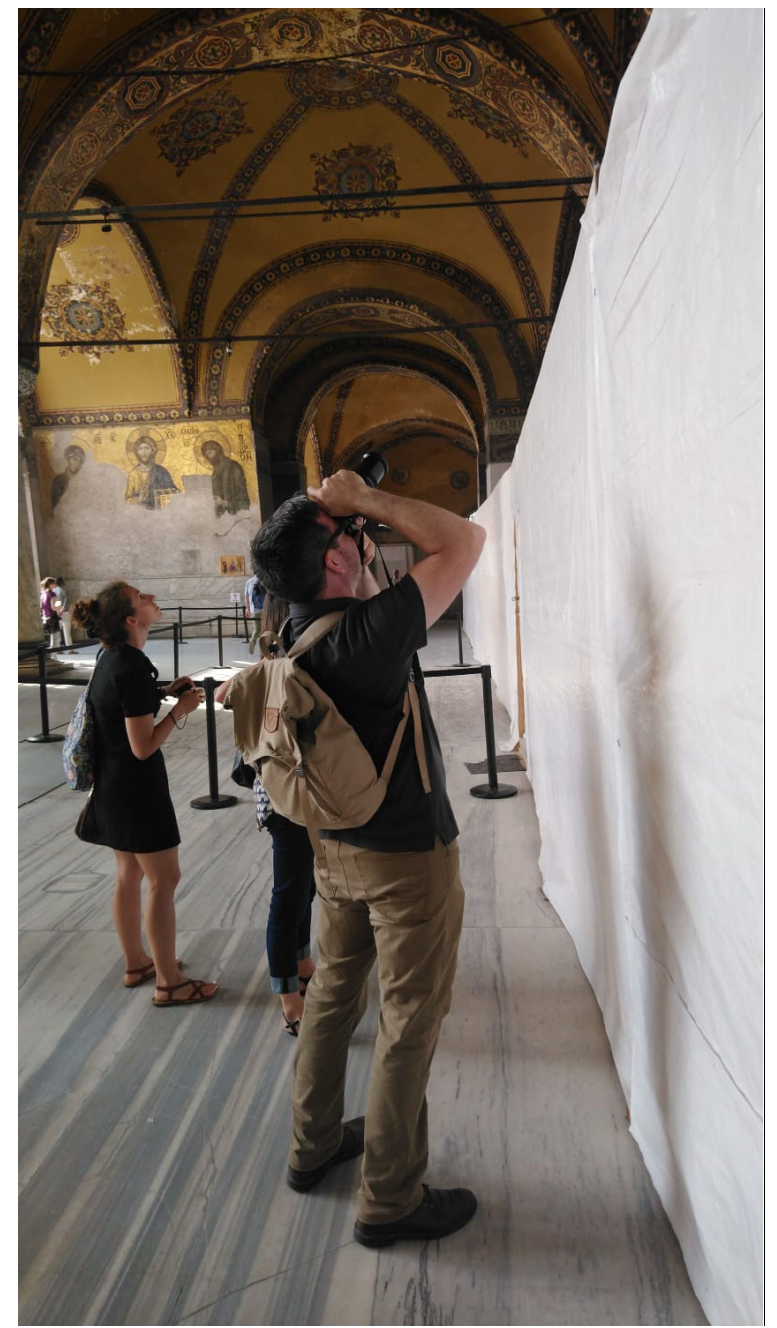

(C) Ida Toth

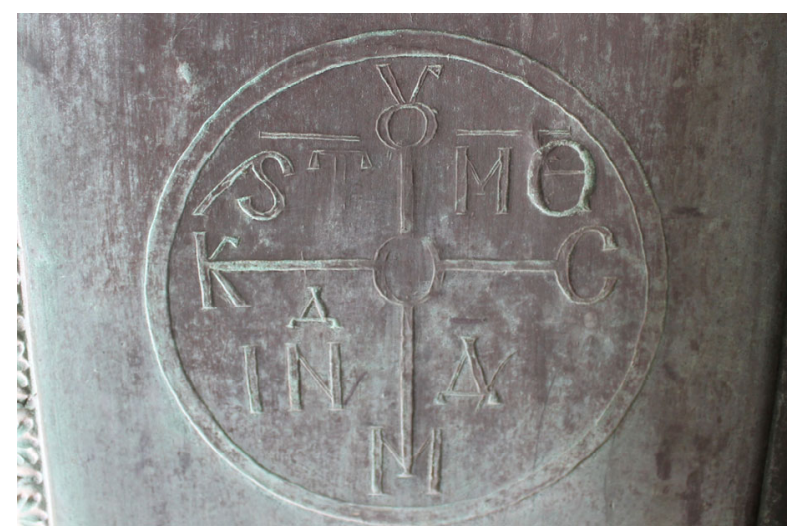

(C) Andreas Rhoby 


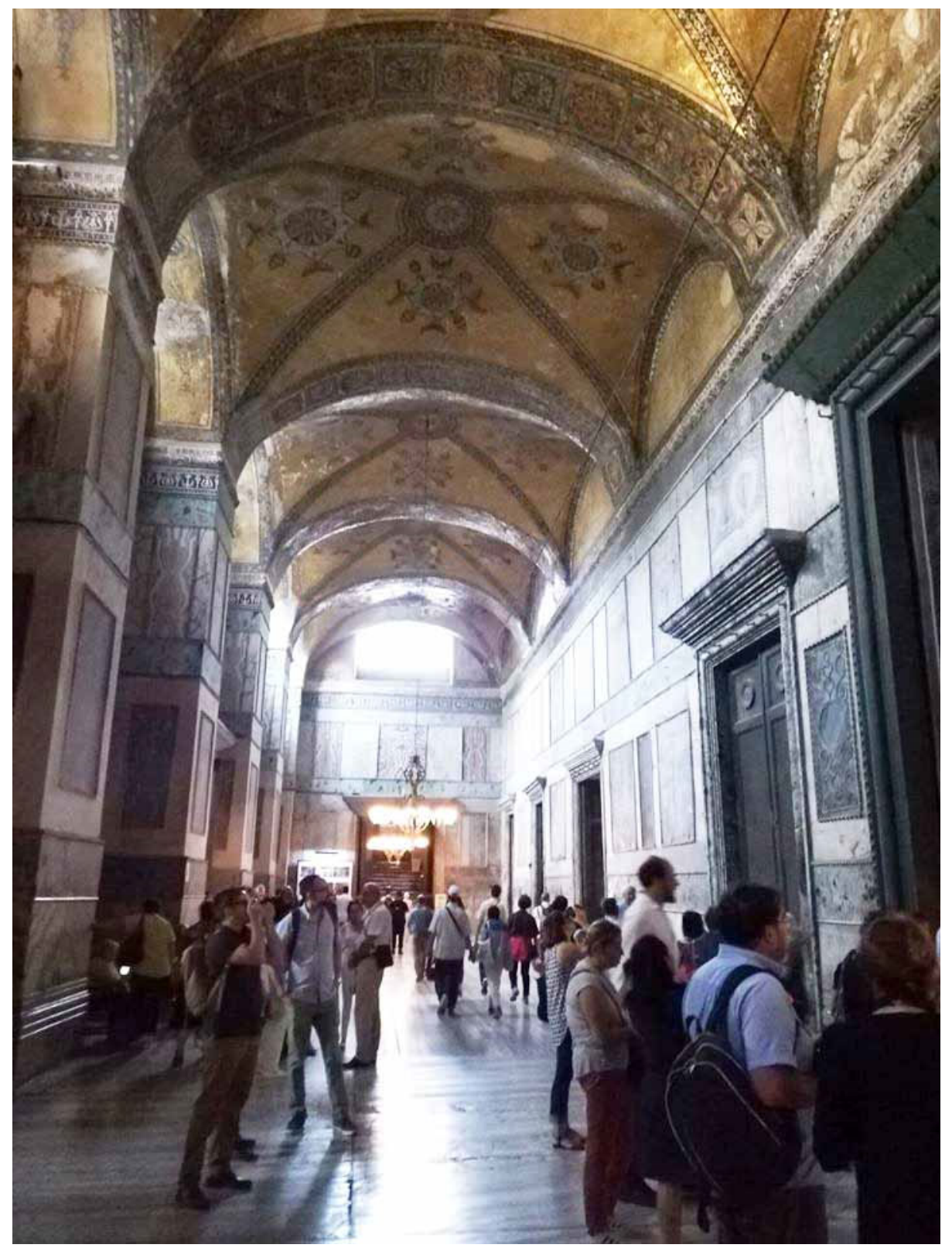

(C) ANAMED

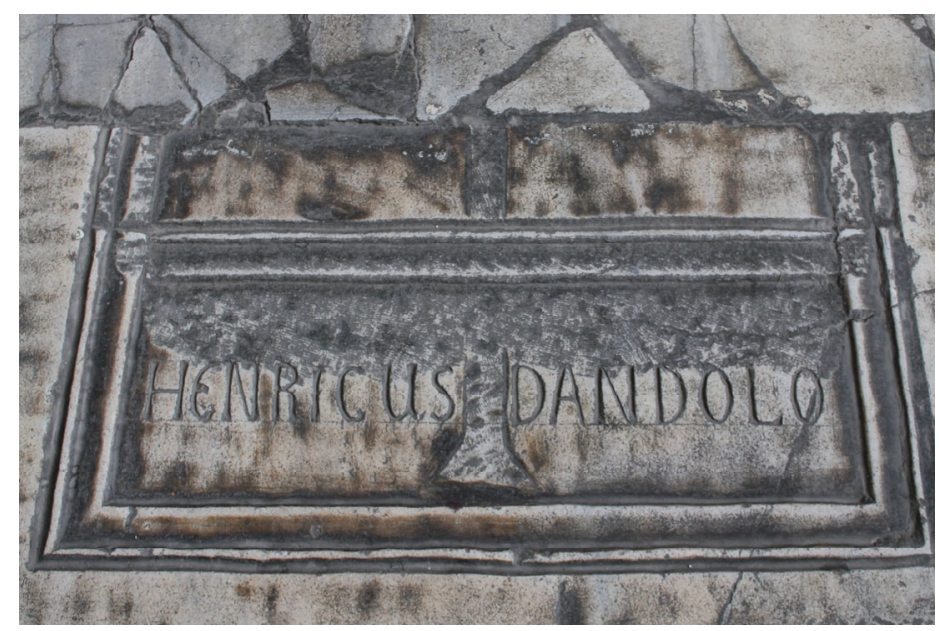

(C) Andreas Rhoby 


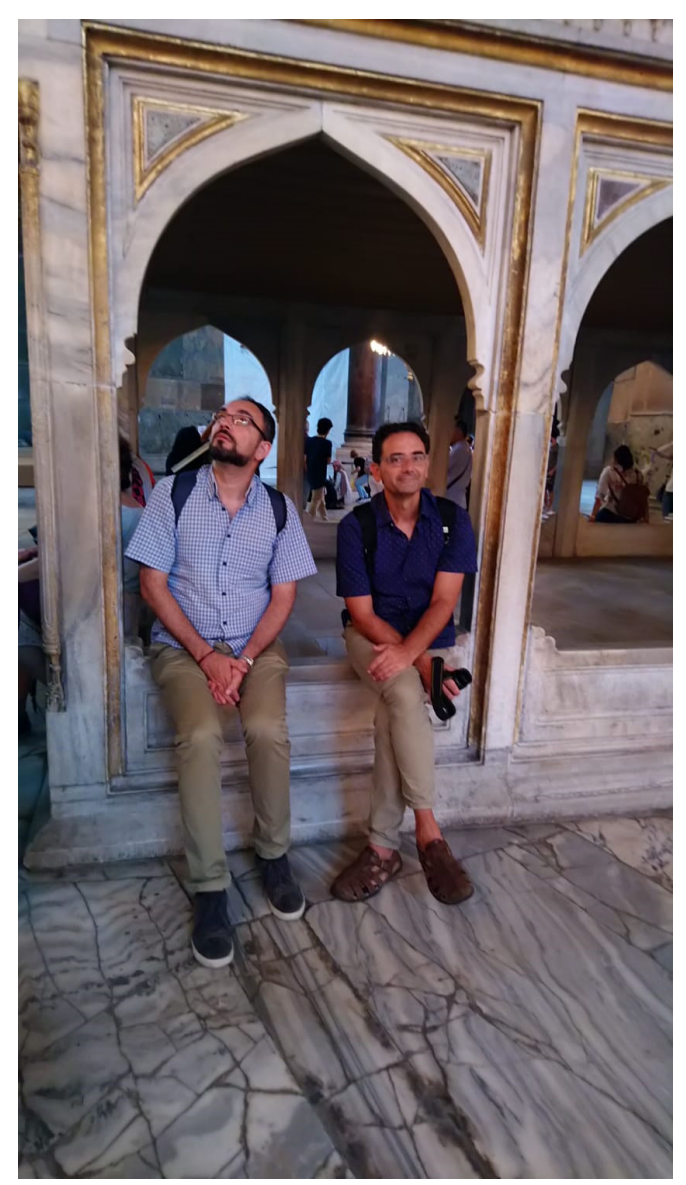

(C) Ida Toth

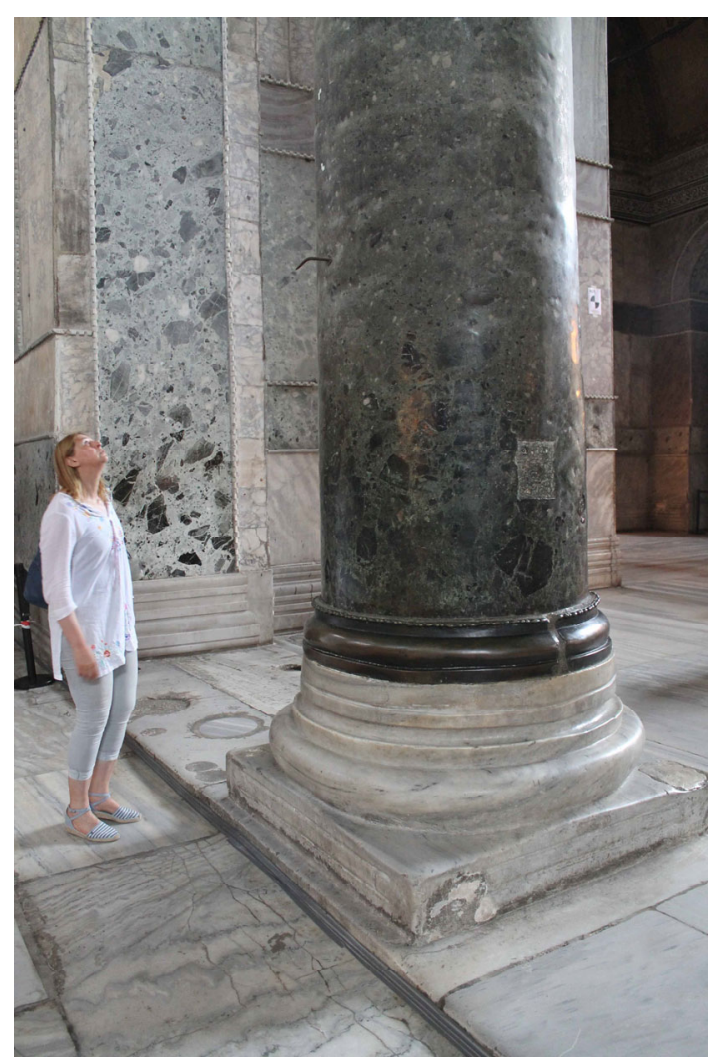

(C) Andreas Rhoby 


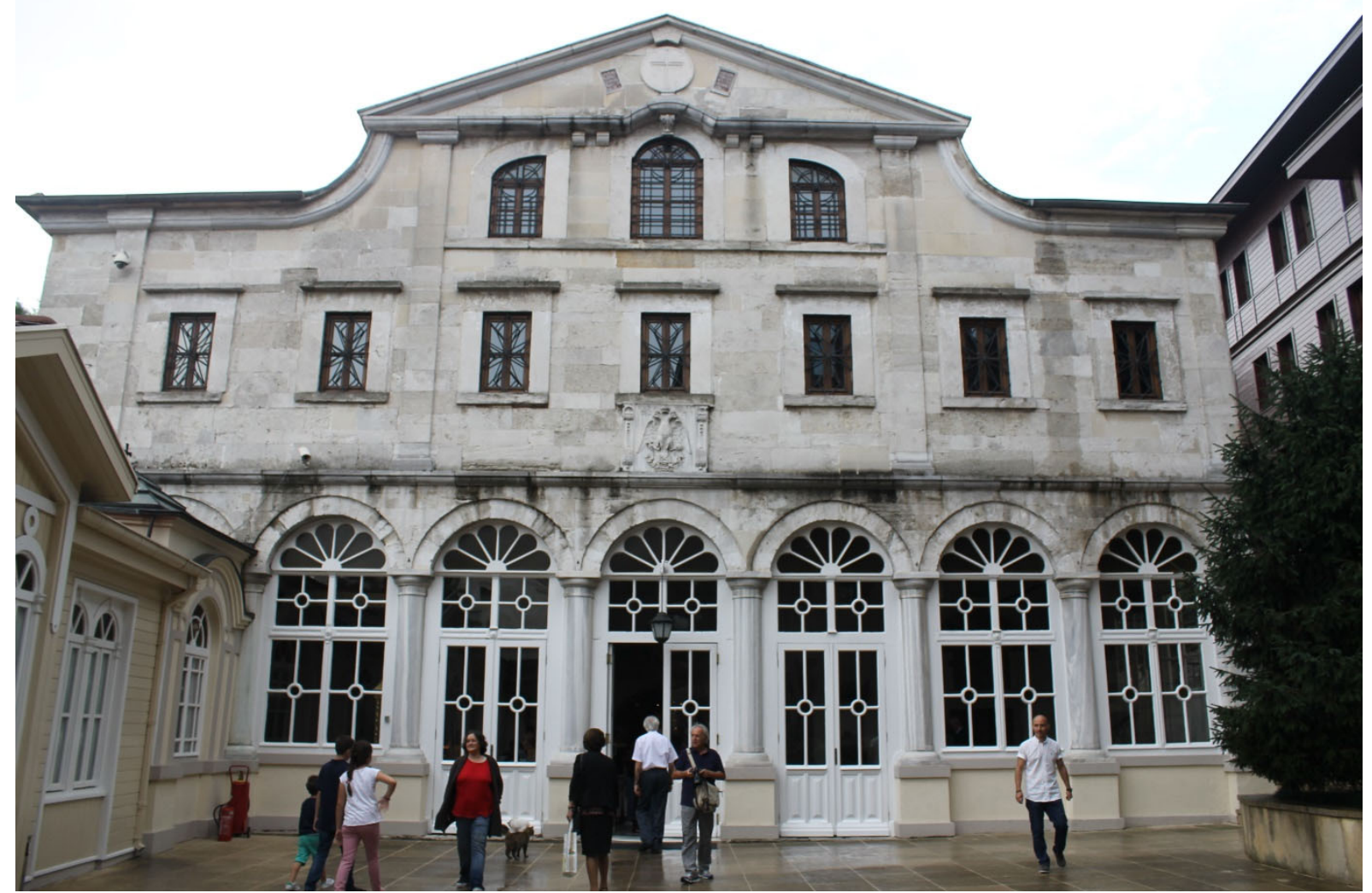

The Greek Orthodox Patriarchate (C) Andreas Rhoby)

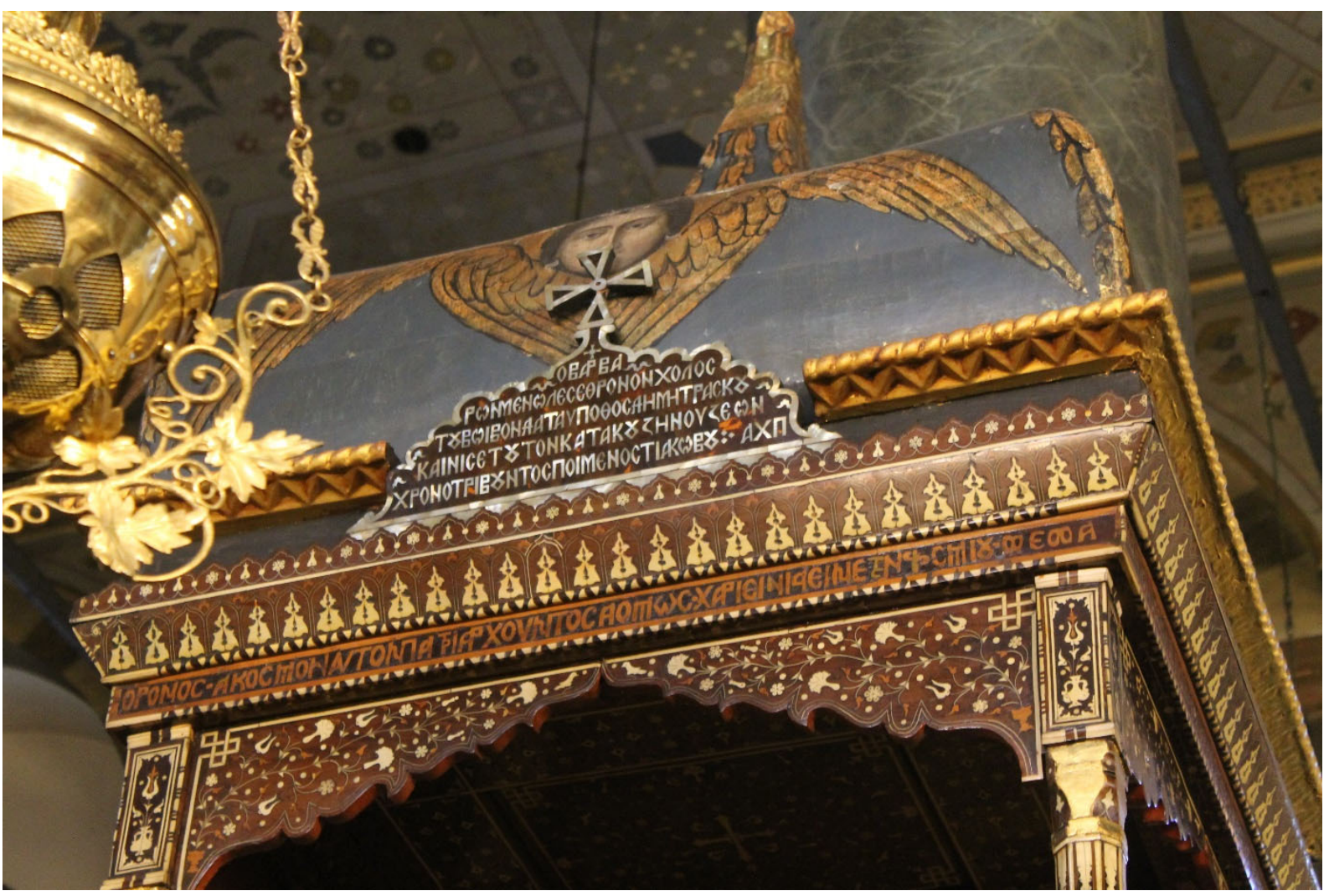

(C) Andreas Rhoby 


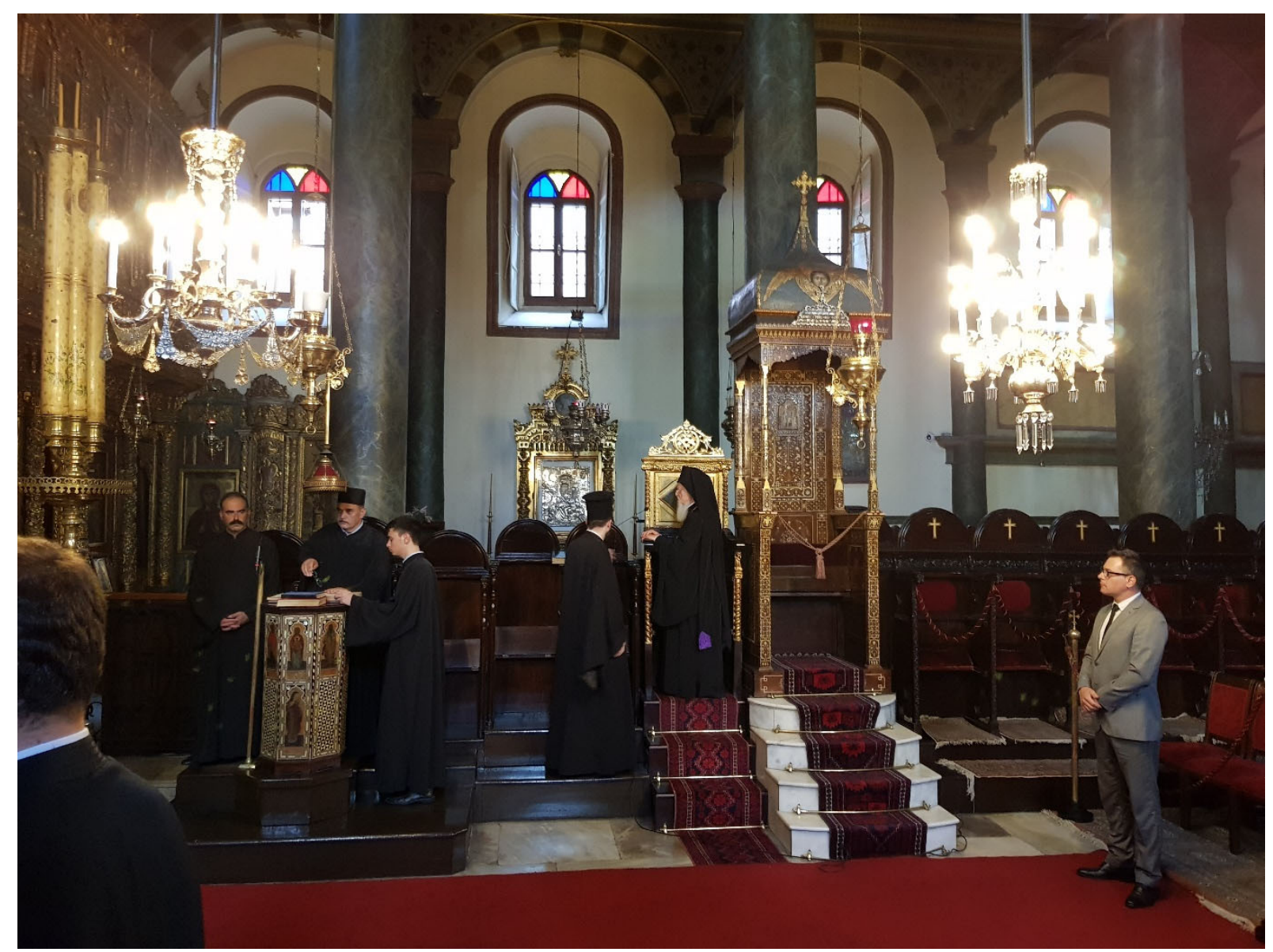

(C) Andreas Rhoby

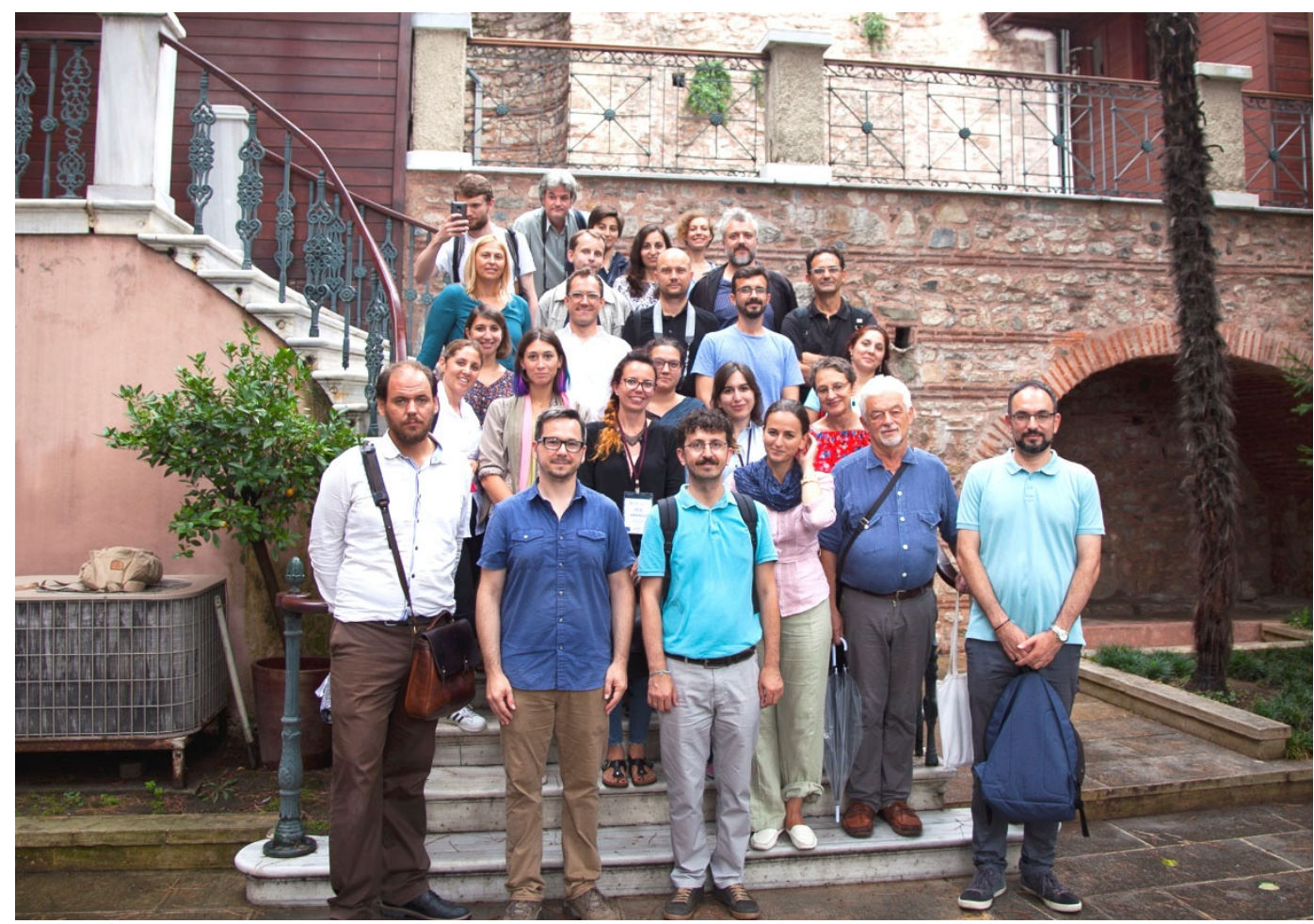

(C) Maria Lidova 


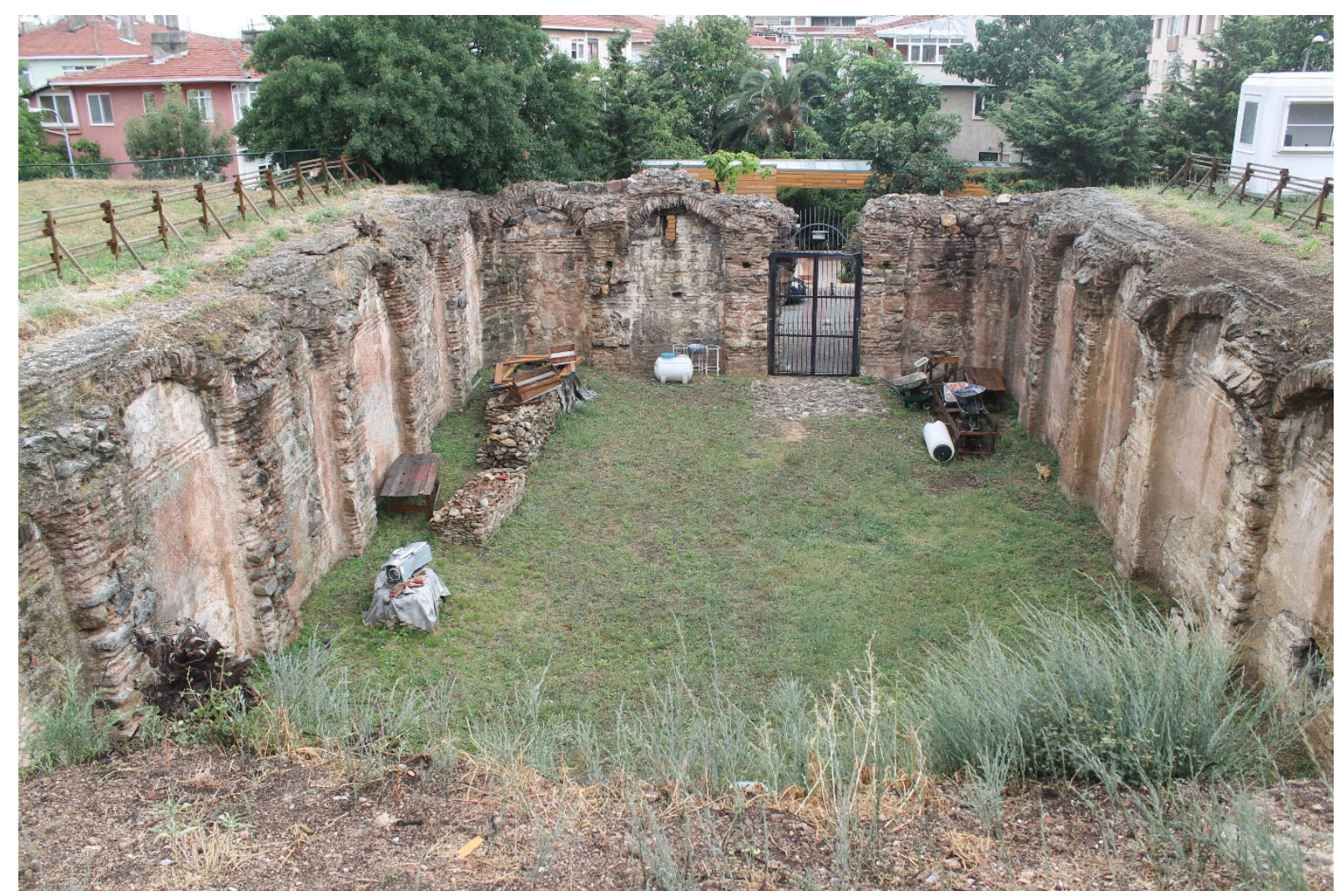

The Küçükyalı Arkeopark (C) Andreas Rhoby)

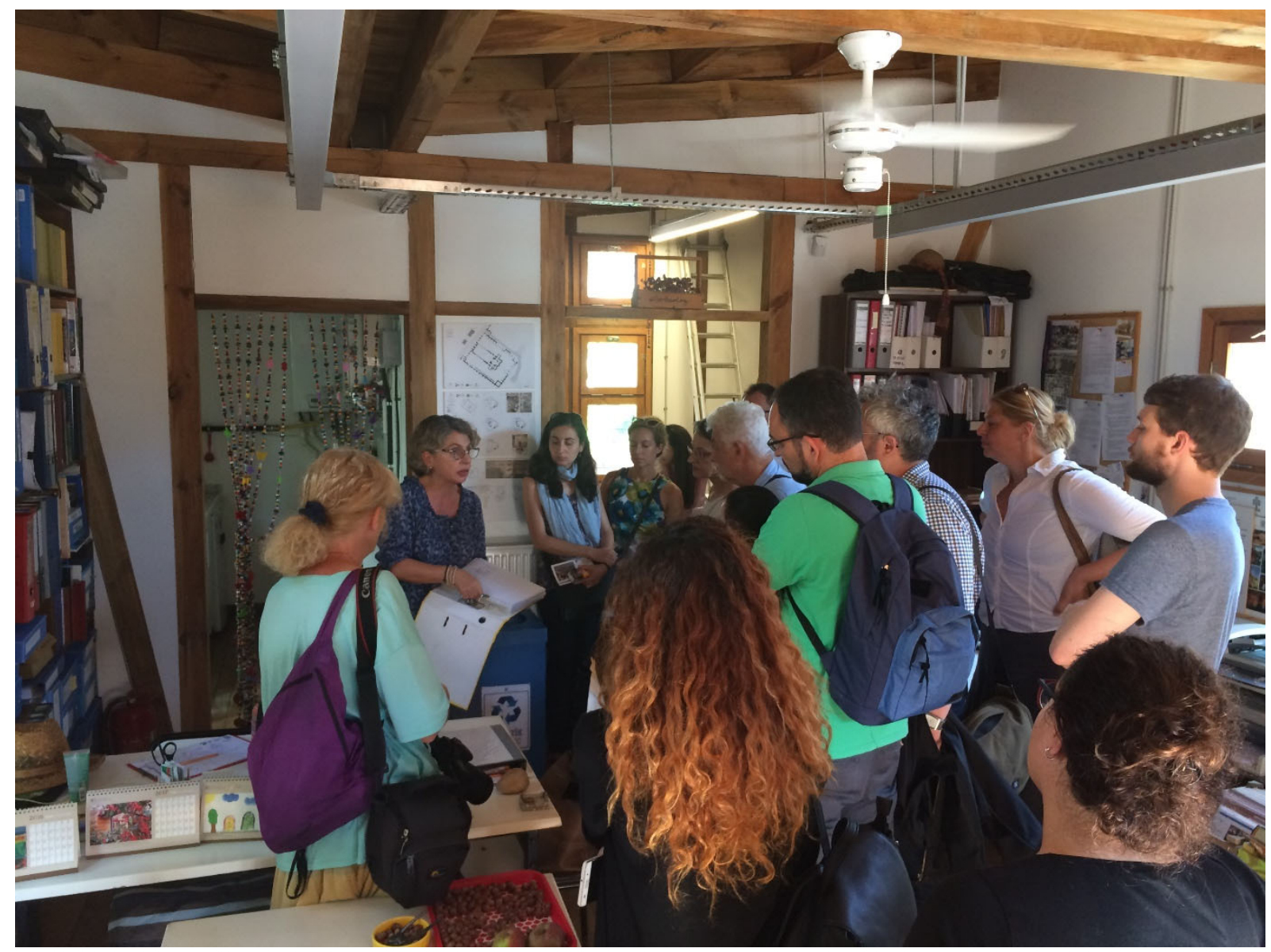

(C) Maria Lidova 